


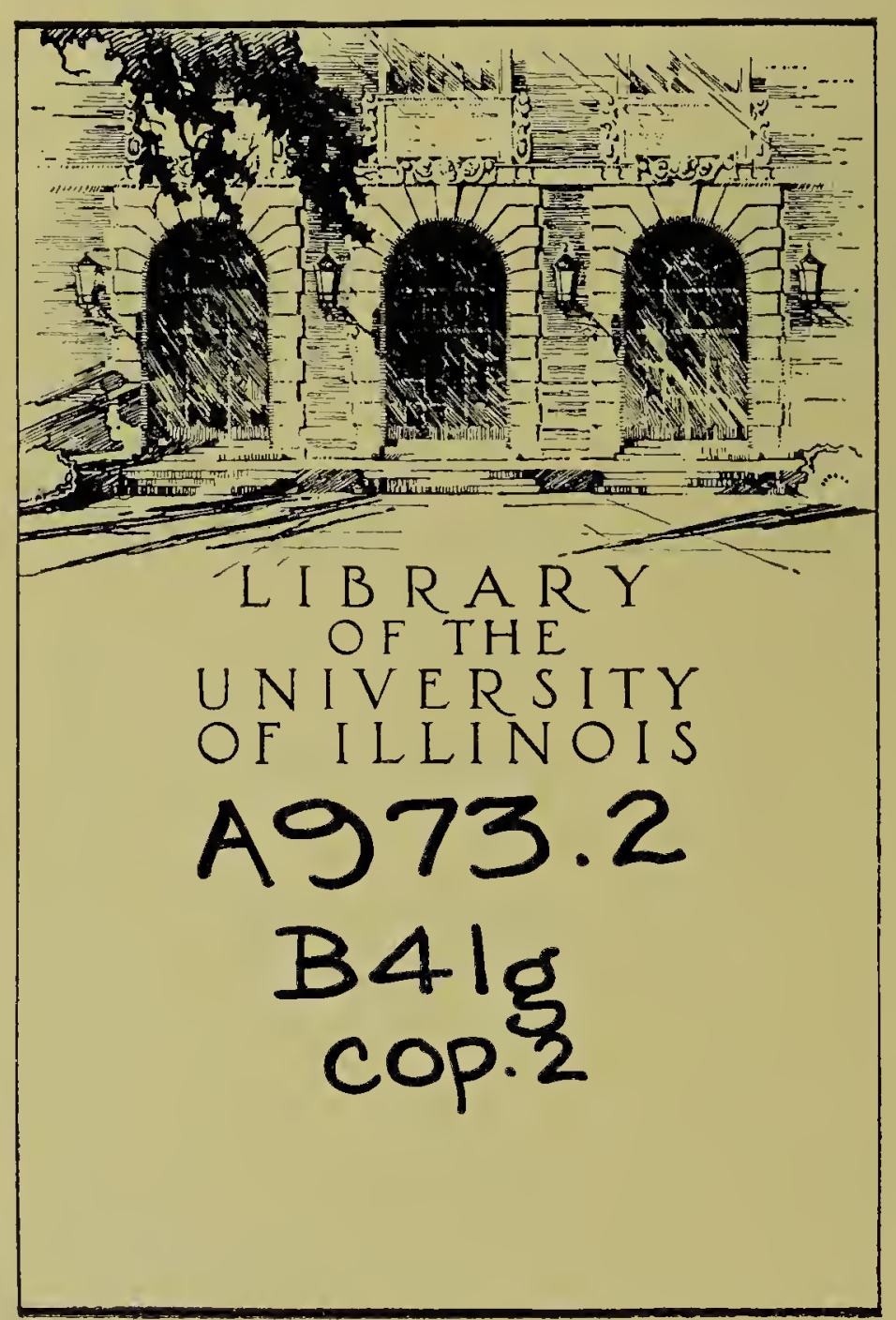


The person charging this material is responsible for its return on or before the Latest Date stamped below.

Theft, mutilation, and underlining of books are reasons for disciplinary action and may result in dismissal from the University.

University of Illinois Library

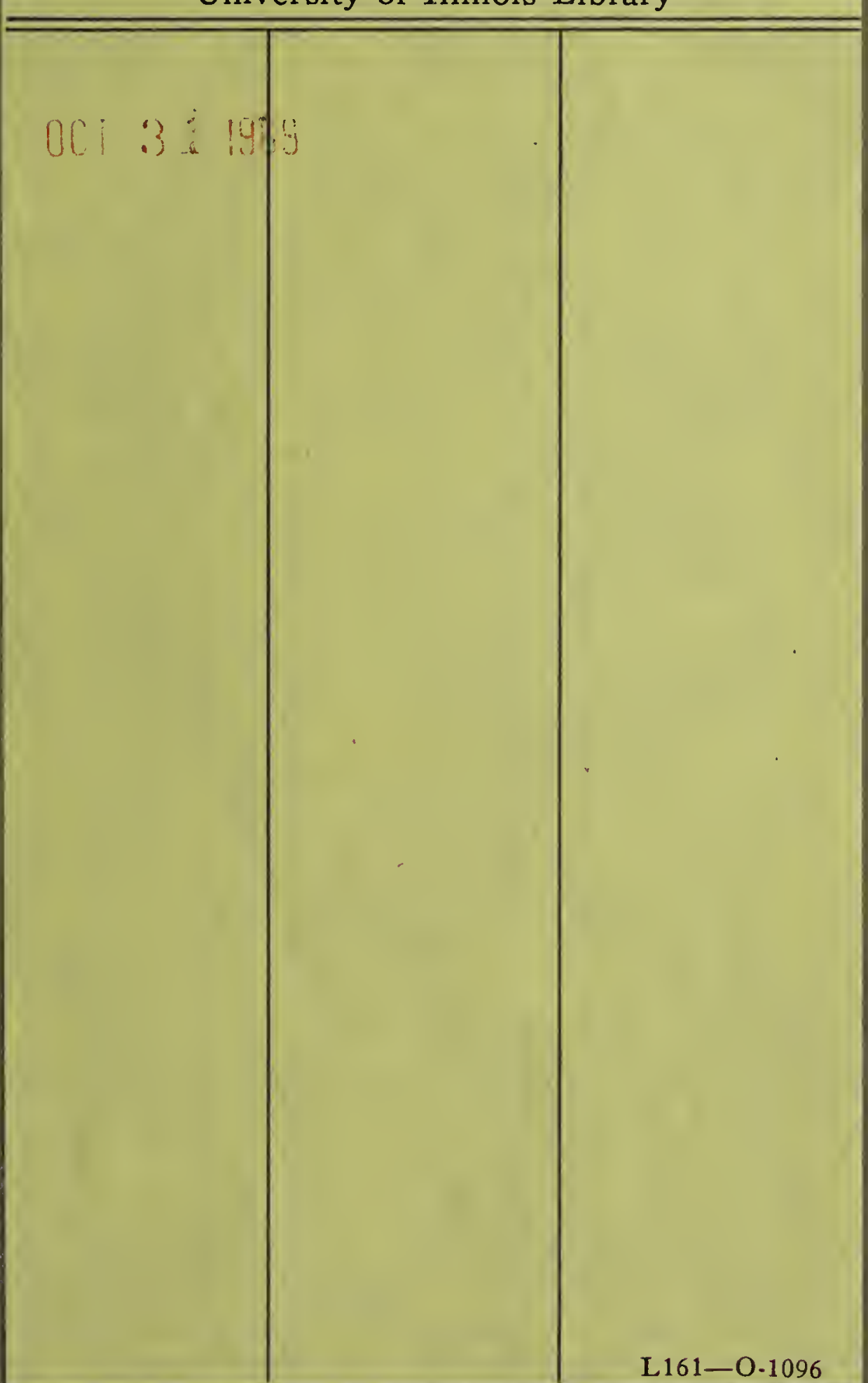





\title{
GUIDE TO BRITISH WEST INDIAN ARCHIVE MATERIALS, IN LONDON AND IN THE ISLANDS, FOR THE HISTORY OF THE UNITED STATES.
}

\author{
BY \\ HERBERT C. BELL \\ DAVID W. PARKER \\ AND OTHERS.
}
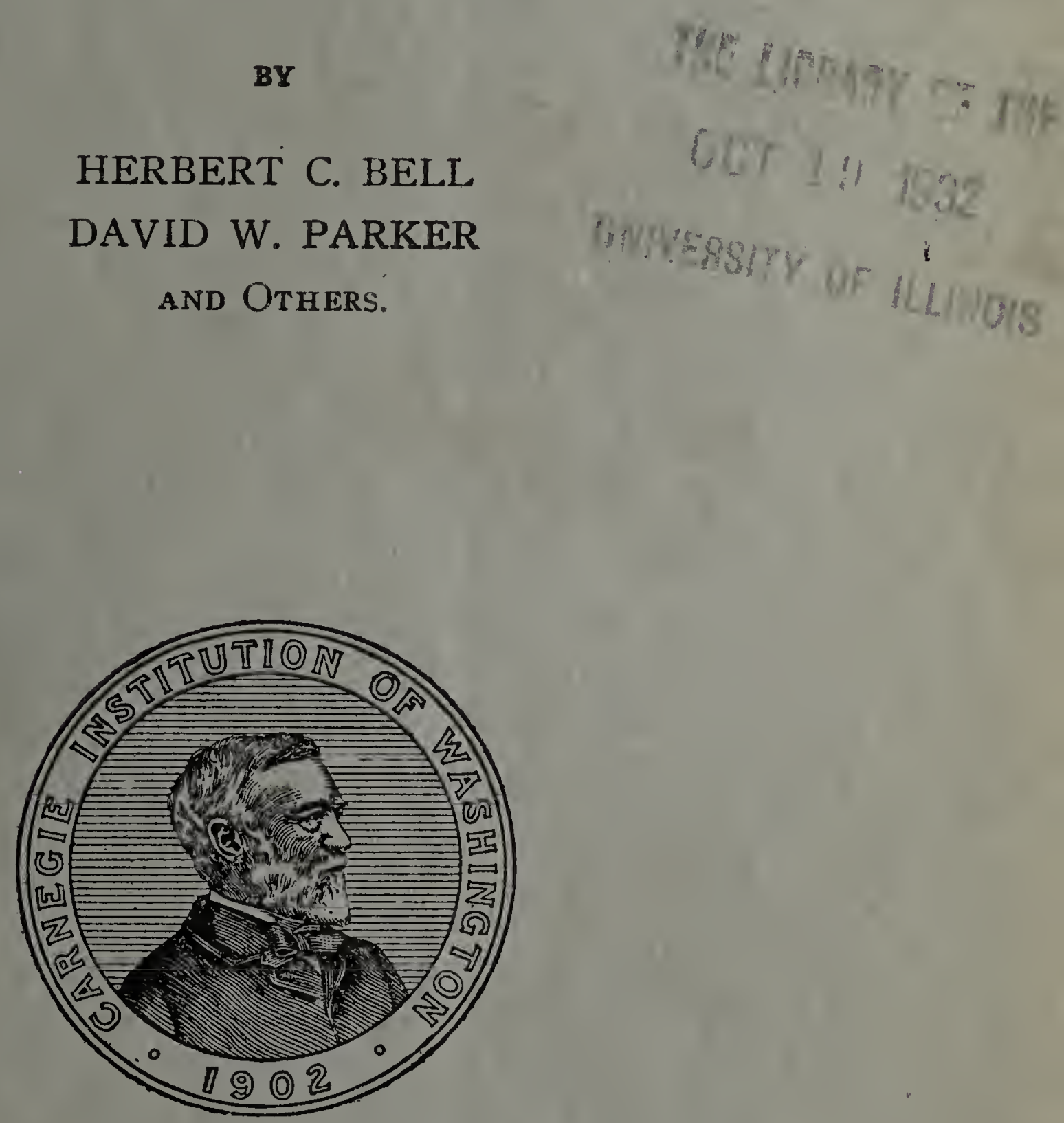

WASHINGTON, D. C.

Published by the Carnegie Institution of Washington 




\section{GUIDE TO BRITISH WEST INDIAN ARCHIVE MATERIALS, IN LONDON AND IN THE ISLANDS, FOR THE HISTORY OF THE UNITED STATES.}

BY

HERBERT C. BELL

DAVID W. PARKER

AND OTHERS.
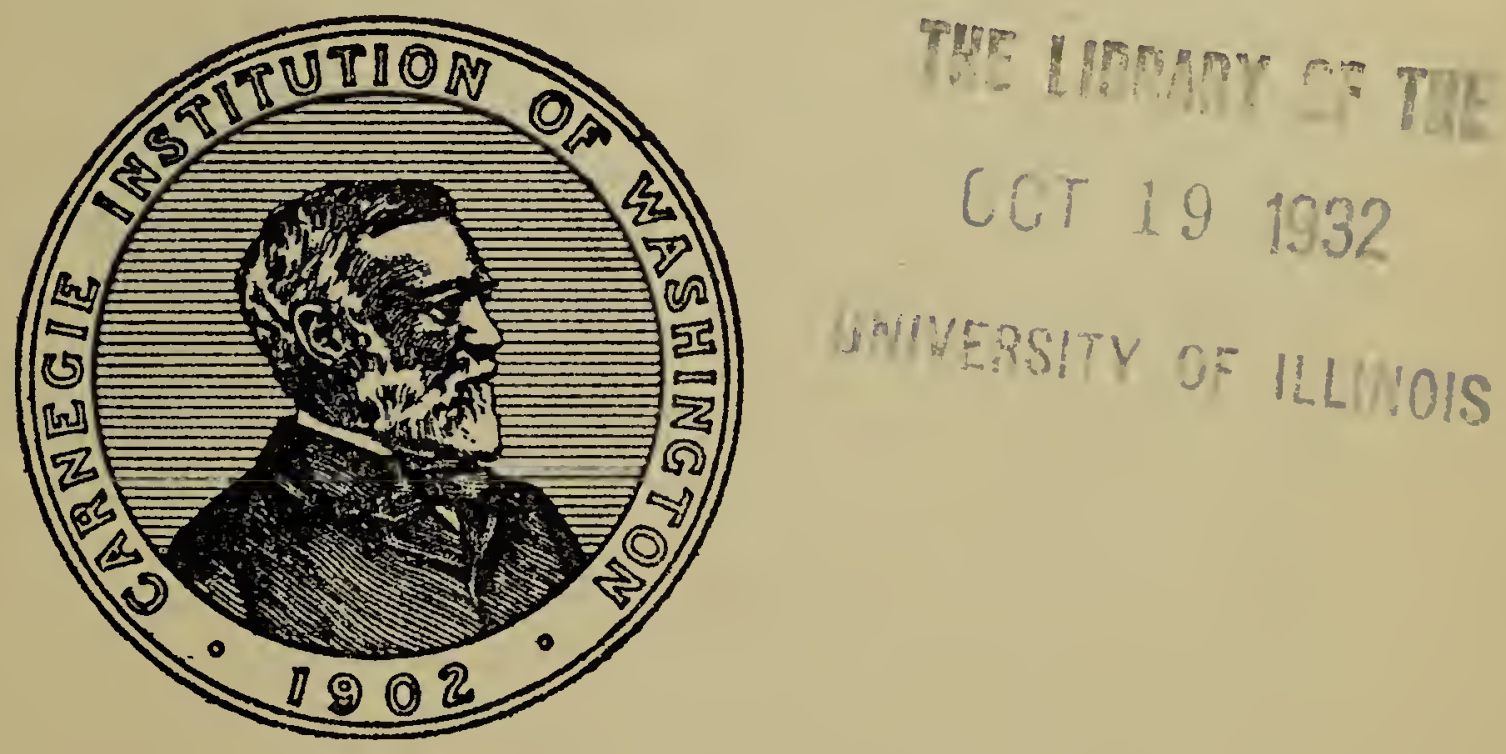

WASHINGTON, D. C.

Published by the Carnegie Institution of Washington 
Carnegie Institution of Washington

Publicatjon No. 372

Papers of the Department of Historical Research

J. Franklin Jameson, Editor

JUDD AND DETWEILER INC.

WABHINGTON, D. C. 


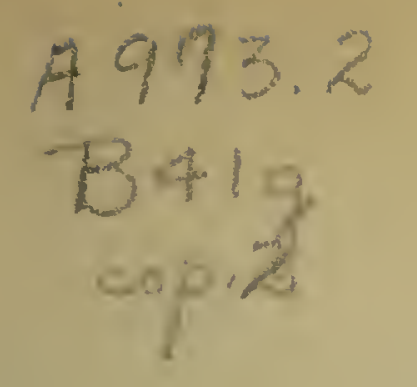

\section{PREFACE.}

Throughout the years immediately preceding the World War, a large part of the work of the historical department of the Carnegie Institution consisted in the preparation and issue of comprehensive guides to the materials for American history preserved in foreign archives. The purpose was to provide investigators with manuals that might save them the expenditures and disappointments attendant upon processes of blind and undirected groping, and at the same time to provide students who could not leave the United States with means of securing copies or arranging for searches to be made by other hands. Naturally, by reason of the relations in which the American colonies stood to the British Empire before the War of Independence and of those which have subsisted between the United States and Great Britain since that event, the largest element in the series of volumes then undertaken is that which relates to the materials for American history in the British archives, to which four volumes have been devoted-two volumes of a Guide to the Materials for American History, to 1783 , in the Public Record Office of Great Britain, by Professor Charles M. Andrews, a Guide to the Manuscript Materials for the History of the United States, to 1783 , in the British Museum, etc., by Drs. Andrews and Davenport, and a Guide to the Materials in London Archives for the History of the United States since 1783, by Drs. Paullin and Paxson; but volumes were also issued which furnished guidance to the American material in the archives of Spain, Germany, Italy, Switzerland, Austria, and Russia, and to the materials for the history of the United States in those of Canada, Mexico, and Cuba. The undertaking of this series of volumes seems to have been justified by the large use which historical scholars have made of those hitherto produced, during the years that have elapsed since their issue.

Fortunately, such guides to the American materials in the national archives of most of the countries whose documents are important to this purpose had been prepared before the fateful days of August I9I4, for the war and the attendant disasters would have made it far more difficult to produce them after that date. Guides to the materials for American history in the national archives of France, the Netherlands, and the Scandinavian countries have however been undertaken, the processes of search and note-taking in them have been completed, except in the case of France, and the resultant reports are in course of preparation.

The present volume undertakes to provide special guidance to a body of widely scattered archival materials, for the history of the British colonial empire in America and of the United States in the period before I8I5. It may be denoted by the general term "British West Indian." Under this term are embraced not only the repositories of public correspondence and records in the British West Indian islands, in the strict sense of that term, and in the Bahamas and Bermuda, but also the West Indian and allied classes-including those of the Bahamas, Bermuda, British Guiana, and British Honduras-in the Colonial Office Papers preserved in the Public Record Office in London. 
These classes have, it is true, been inventoried succinctly in the first volume of Professor Andrews's Guide to the Public Record Office, in the course of his description of the Colonial Office Papers; but the object of the corresponding section of the present volume is to treat them on a much larger scale, with much more abundant listing of individual documents.

This account of the West Indian portions of the Colonial Office Papers constitutes the first part of the present volume, the islands being arranged in alphabetical order as they are in the classification of the Colonial Office Papers themselves. Then follows a brief account of the papers of the West India Committee in London, after which follows, as the second main part of the volume, a body of descriptions, in alphabetical order, of the archives of the individual islands and of what they contain for the history of the English colonies and colonial system in America and of the relations of these islands to the United States down to I8I5 (and, in a few cases, a little later).

The reasons for preparing so considerable a volume upon the West Indian archival materials for American history rest upon two facts. On the one hand, the history of the British Empire in America and of its administration can not be rightly understood except by taking into the student's view not the continental colonies alone, but the whole series of dependencies, continental and insular alike. At times the island colonies, rich and prosperous, were regarded as a more important element in the Empire than those of the continent. There certainly were times when Barbados and Jamaica were thought more valuable in London than Massachusetts or Carolina. A striking illustration of the estimation in which the islands were held lies in the well-known fact that, in the negotiations preceding the treaty of 1763 , the British ministry hesitated for a long time as to whether it were better to give back to France the whole of Canada or to restore to it, as was finally done, the island of Guadeloupe. Students of colonial American history are agreed that its study ought to include much further consideration of the history of the British West Indies than has hitherto been customary. To study the "Old Thirteen" colonies alone is a false method. It is to read into the history of our colonial period a distinction which did not then exist, and in so far to distort and mutilate that history.

In the second place, the commercial relations between the island colonies and those of the mainland form an important part of the economic history of the latter; and even down to 1815, though commercial intercourse after the Revolution was subject to severe restrictions, yet in the commercial, military, and naval fields the history of the islands still remaining under the dominion of Great Britain has many points of contact with that of the new republic. Moreover, it is not to be expected that these now small communities should each be able to put into print the materials for its early history (which some of our richest states have done to but a small extent), or that they should do this in so uniform a manner as to serve the needs of those who wish to study, not a single island, but the Empire as a whole.

The reason for combining in one volume the treatment of the island archives and of the corresponding masses of material in the Public Record Office in London rests mainly upon the fact that the archives in the islands have suffered many losses by reason of wars, hurricanes, earthquakes, fires, pecu- 
liarities of climate, the ravages of insects, and the want of care natural in the custody of small collections, while on the other hand, colonial governors having been required by their instructions to transmit copies of certain series (especially minutes of councils and journals of assemblies) to the home government, some of the most important series are found to be more complete in the Public Record Office than in the islands. The transcripts which arrived in London are in almost all cases still there, while the originals which remained in the islands often perished. Thus the two collections are mutually complementary. Many of the series in the islands are to be found nowhere else, copies of them not having been transmitted to London; there are, as in the case of the continental colonies, many sorts of colonial documents in London that are not to be found in the islands; and some of the most important series are to be found both in London and in the islands, but as a rule are more complete in the former case.

To explain the widely differing chronological limits within which the different sections of the volume are contained, it may be well, without entering too minutely into the intricacies of West Indian history, and especially without regarding those which belong to the years before $1711,{ }^{1}$ to indicate the periods during which the respective islands were in British hands; for other periods their papers must often be sought in French, Dutch, or other archives. It may be said that, aside from partial exceptions lying well before I I I, Antigua, the Bahamas, Barbados, and Bermuda have been continuously under British rule from their first settlement by British subjects until the present time; that Montserrat, Nevis, and St. Kitts were in French hands from $I 782$ to $I 783$, but otherwise always British; and that Grenada and St. Vincent were taken from the French in 1762 , were in British hands from that date to 1779 , in French possession from 1779 to 1783 , and since 1783 continuously British. Dominica was taken from the French in 1761 , and was British from 1761 to 1778 , French from 1778 to 1783 , British since 1783 . St. Lucia, taken from the French in 1762 , was British from 1762 to 1763 , from 1778 to 1783 , from $I 794$ to $I 795$, from $I 796$ to 1802 , and since 1803 . Tobago passed from a sort of neutral status to that of a British colony in 1762 , and was such from 1762 to 1781 , from 1793 to 1802 , and after 1803 . Trinidad was taken from Spain in 1797. Of islands which are not now British, but which figure to some extent in the classification of the Colonial Office Papers, Guadeloupe was taken from the French in 1759 , was restored in 1763 , and was held by Great Britain briefly in 1.794, and at greater length in $1810-1815$. Martinique was in British possession from 1762 to 1763 , from I794 to 1802 , and from 1809 to 1815 ; Curaçao (taken from the Dutch) during part of 1798 and from 1807 to 1814 ; and St. Eustatius (also Dutch) during a part of $178 \mathrm{I}$. It should also be mentioned that from $176 \mathrm{I}$ to 1770 Dominica, from 1762 to 1776 St. Vincent, and from 1762 to 178 I Tobago, were included in the government of Grenada, while from 1671 till after the end of the period included in the scope of this volume there was a general

\footnotetext{
${ }^{1}$ Because the Colonial Office Papers relating to America, of dates prior to July I, I7I I, have been calendared with great thoroughness, often indeed presented at what amounts to full length, in the twenty volumes of the Calendars of State Papers, Colonial, America and West Indies, published by the British government for the Public Record Office.
} 
government of the Leeward Islands, embracing Antigua, Montserrat, Nevis, and St. Kitts. British Guiana was first in British hands in $1781-1782$, and again in $1796-1802$, and was permanently lost by the Dutch in 1803 .

Owing to war-time conditions and other sources of difficulty, the preparation of this volume has extended through a number of years, and it has been prepared by various hands. A beginning was made in 1916, when Mr. Luis M. Pérez, now commercial attaché to the Cuban embassy in Washington, but at that time librarian of the Cuban House of Representatives, went to Jamaica and took notes for an inventory of the various series of public records of that colony. Even before this, Mr. James M. Wright, who in I903 had accompanied the expedition sent out to the Bahama Islands by the Geographical Society of Baltimore and while there had prepared an account of the archives of that colony, as an incident to the preparation of his published history of it, had kindly presented that account afterwards to this Department of the Carnegie Institution. Accordingly, the Department sent no special expedition to these islands. Mr. Wright's account, abbreviated, has been incorporated in the present volume, despite the possibility that some of his statements may not now be exact; efforts to have it brought to date came to unexpected failure, too late for remedy. In the years from I9I9 to I922, Professor Herbert C. Bell carried out in the Public Record Office the examination and description of those West Indian portions of the Colonial Office Papers which are classified as Original Correspondence and Entry-Books, down to the year I775, and also, with Miss Cornelia M. Pierce, secretary of the Department, examined the archives of Bermuda; Miss Lillian M. Penson, now lecturer in history in Birkbeck College, London, prepared a report upon the Original Correspondence and Entry-Books for the period from I775 to I8I5; Miss Edith Moodie, of London, listed, in the form in which they appear in this volume, the West Indian Sessional Papers and printed Acts; and Mr. J. E. Neale took the needful notes from the Shipping Returns. Miss Ruth A. Fisher has also given assistance in London in miscellaneous particulars. Finally, Mr. David W. Parker, formerly chief of the manuscripts room in the Public Archives of Canada, spent the months from September 1924, to January 1925, in a tour of the British islands from Trinidad northward to St. Kitts, examining the archives of all the Lesser British Antilles, and thus completing the work upon the island repositories which had been already carried through in the cases of the Bahamas, Bermuda, and Jamaica. Mr. Parker has also, since his return, prepared the manuscript of the whole volume for publication. That some inequalities and irregularities should appear in a volume prepared by so many different hands and in so many different places was hardly avoidable, but it is hoped that they will be excused.

For aid to the searches made in London thanks are due, and are cordially rendered, to the officials of the Public Record Office, and to Mr. Algernon Aspinall, C.M.G., secretary of the West India Committee. In Jamaica, the investigations of Mr. Pérez were assisted, with the utmost kindness, by Mr. Frank Cundall, secretary and librarian of the Institute of Jamaica, and by his assistant, Miss Morrison, in charge of the library. The inquiries made in Bermuda were greatly helped by Mr. F. G. Gosling, assistant colonial sec- 
retary. Especial thanks are due to the British Ambassador in Washington. Sir Esmé Howard, G.C.M.G.; in preparation for Mr. Parker's expedition, he brought it about through the Foreign Office in London that the Secretary of State for the Colonies sent such instructions to colonial officials as procured for Mr. Parker all possible facilities for his work in each one of the nine islands that he visited. The uniform helpfulness of their governors, administrators, and secretaries is gratefully acknowledged. We also thank Professor Charles $\mathrm{H}$. Hull, of Cornell University, for kindly lending to us a general report on the archives of the British West India islands which he drew up after visiting many of them in the winter of 1905-I906.

February II, 1926. 

TABLE OF CONTENTS.

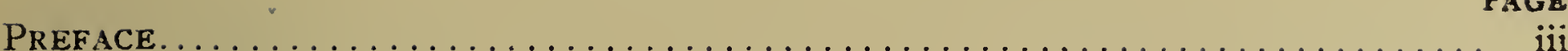

Colonial Office Papers: West Indies, $\ldots \ldots \ldots \ldots \ldots \ldots \ldots \ldots \ldots \ldots \ldots \ldots$

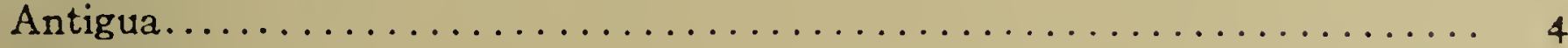

Bahamas................................ I I

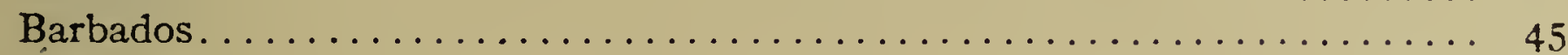

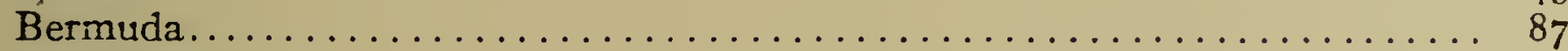

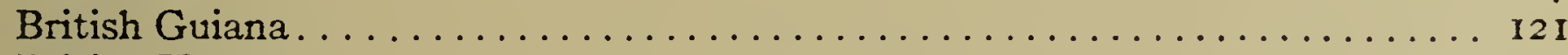

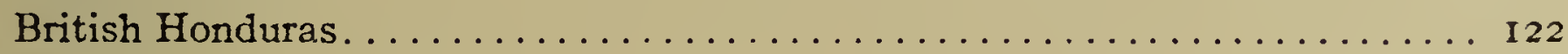

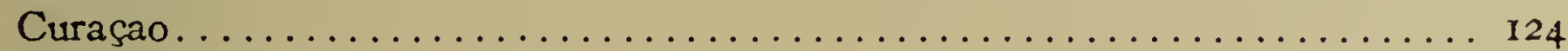

Dóminica.................................. I 24

Grenada....................................... I 35

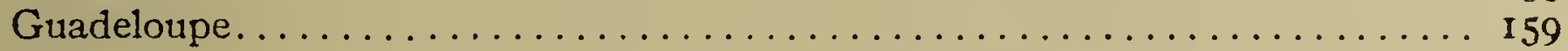

Havana.................................... I59

Jamaica................................... I 59

Leeward Islands. . . . . . . . . . . . . . . . . . . . . . 230

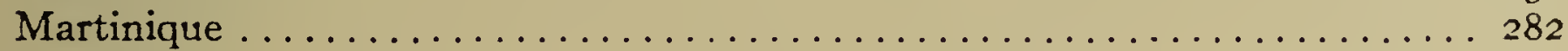

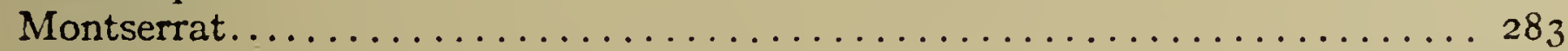

Nevis..................................... 286

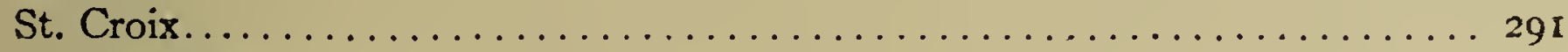

St. Eustatius. . . . . . . . . . . . . . . . . . . . . . . . . . . . 292

St. Kitts. . . . . . . . . . . . . . . . . . . . . . . . . . . . . 292

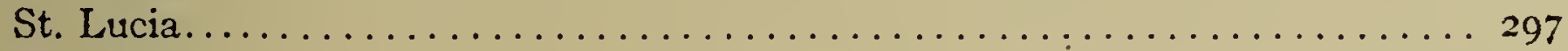

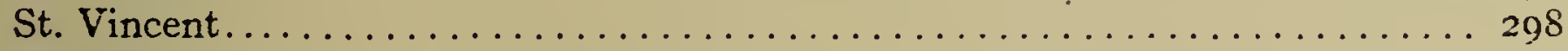

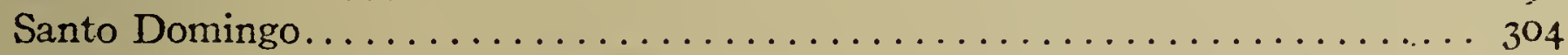

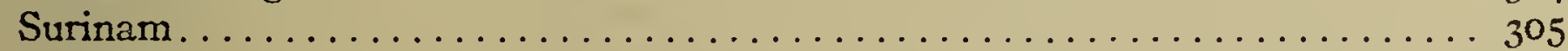

Tobago................................... 306

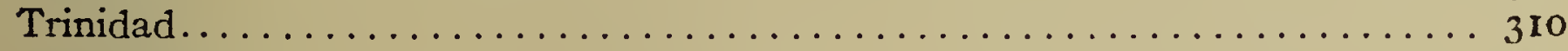

Virgin Islands . . . . . . . . . . . . . . . . . . . . . . . . . .

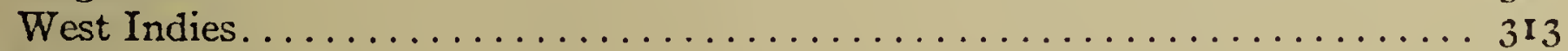

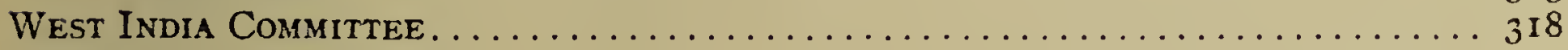

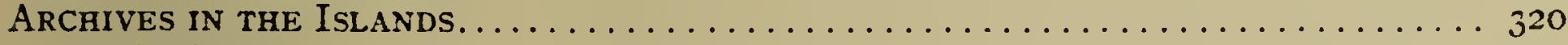

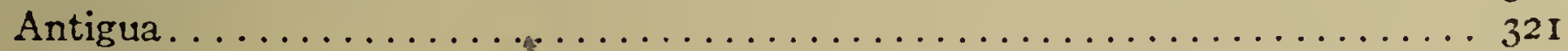

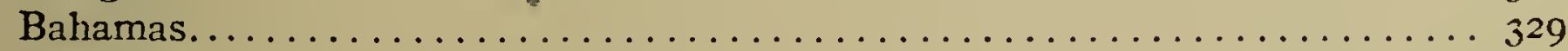

Barbados..................................... 334

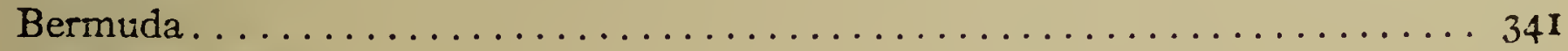

British Guiana. . . . . . . . . . . . . . . . . . . . . . . . . 347

British Honduras. . . . . . . . . . . . . . . . . . . . . . . . . . . . . 348

Dominica...................................... 348

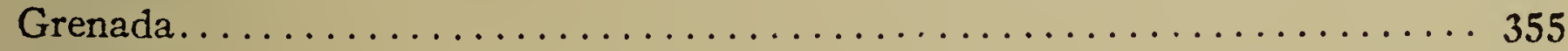

Jamaica . . . . . . . . . . . . . . . . . . . . . . . . . .

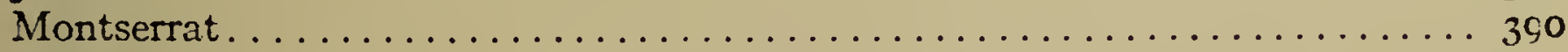

Nevis. . . . . . . . . . . . . . . . . . . . . . . . . . . 39 I

St. Kitts. . . . . . . . . . . . . . . . . . . . . . . . . . . 392

St. Lucia. . . . . . . . . . . . . . . . . . . . . . . . . . . . . . 398

St. Vincent. ................................. 403

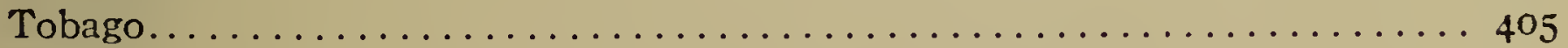

Trinidad..................................... 40.5 



\section{COLONIAL OFFICE PAPERS: WEST INDIES.}

The Colonial Office Papers have already been described by Professor Charles M. Andrews, in volume I. of a Guide to the Materials for American History, to I783, in the Public Record Office of Great Britain (Washington, Carnegie Institution, I9I2). The following section merely treats in greater detail those series which deal with the West Indies and with certain adjacent areas of Central and South America with which the British islands always had close relations. As Professor Andrews's Guide is in the same series of volumes as the one here presented, it seems needless to offer here an extended introduction which would inevitably be constructed along the same or parallel lines. The method adopted is much simpler, namely, frankly to plagiarize some of the parts especially applicable to the present book. A careful perusal of all introductory material in Professor Andrews's first volume, and particularly of pp. 78-8I, 96-1 12, is strongly recommended.

One recent change in the conditions described by Professor Andrews may be noted here, even though it lies beyond the limits of this book. The Colonial Office records are now open to public inspection to the close of I860, instead of 1837 as formerly. "No permits are required for the inspection of volumes consisting of printed Gazettes, Minutes of Legislative Councils, Journals of Houses of Assembly, Colonial Sessional Papers, and other similar Papers which may be presumed to have been made public in the Colonies."

The Colonial Office Papers, as arranged under the recent reclassification, are a mixture of the records of the Board of Trade with those of the Secretary of State, including the old "America and West Indies" series. The archives of the Board of Trade have thus been submerged in an artificial arrangement, and their historical identity has been considerably impaired. ${ }^{2}$

In the present classification of these papers in the Public Record Office, the islands find their places in the alphabetical order of the British colonies, while under each island the papers are, as a rule, arranged in eight classes: (I) original correspondence which came to the Board of Trade; (2) original correspondence which came to the Secretary of State; (3) entry-books of outgoing despatches from the Board of Trade; (4) entry-books of outgoing despatches from the Secretary of State; (5) acts; (6) sessional papers, comprising transcripts of the minutes and journals of the colonial councils and assemblies; (7) shipping returns, or naval office lists; and (8) miscellaneous. This order of arrangement has been followed in the present book. It should, however, be borne in mind that many papers relating to Antigua, Montserrat, Nevis, St. Kitts, and the Virgin Islands are to be found under "Leeward Islands", and that some papers of a general nature are classed under "West Indies".

In the notes which this volume presents respecting papers in the first four of the eight classes named above, the original correspondence and the entrybooks, no data will be found regarding papers earlier than July I, I7II, since all such papers are described, with much greater fullness than would be pos-

${ }^{1}$ M. S. Giuseppi, Guide to the Manuscripts preserved in the Public Record Office, II. iv.

${ }^{2}$ The relation between the designations of volumes or bundles in the old system of classification of Colonial Office papers and in the new can be traced by means of the Key printed in Andrews, op. cit., I. 279-307. The new classification is set forth in List of Colonial Office Records: Public Record Office Lists and Inderes, no. XXXVI. 
sible in this work, in the twenty volumes of the Calendars of State Papers, Colonial, America and West Indies, which have been published by the British government, and of which the twentieth, the last volume thus far published, ends with June 30, I7Ir. The Colonial Office Papers of these four classes have been searched from I7II to I8I5, but a larger scale of treatment has been used for the period from I7II to I775 than for the period from I775 to 1815 . From the time of the American Revolution, one of the two chief reasons for encouraging American study of West Indian history, that which is deduced from the position of the Thirteen Colonies as a part of the British Empire, falls away. The papers of the period from I775 to I8I5 are dealt with on a reduced scale, yet with the intention of including all items relating to the United States.

In the case, on the other hand, of the classes devoted to acts, sessional papers, shipping returns, and miscellaneous papers, the data presented in this volume run from the beginning of such classes to the end of the year 1783 . Although after 1783 the several series dealing with sessional papers and shipping returns were not examined, any records of those characters which were found in the volumes of original correspondence, up to $\mathrm{I}_{\mathrm{SI}}$, were listed. ${ }^{3}$

The Public Record Office also contains several general series in which there is material relating to West Indian along with other colonies, and especial mention should be made of the classes C. O. 323-326 ("Plantations General"), C. O. 388-390 ("Board of Trade, Commercial"), and C. O. 391 ("Board of Trade, Journal") ; but these have been treated with considerable fullness in Professor Andrews's Guide to the Public Record Office, I. 225-267, and have not been included in the scope of the present volume.

\section{ORIGINAL CORRESPONDENCE.}

Duplication of material between the Board of Trade and the office of the Secretary of State for the Southern Department is a subject about which it is very difficult to generalize. It varies widely according to period, subject, and the individual governor. ${ }^{4}$ In general, military affairs and matters of policy lay outside the province of the Board, which concerned itself mainly with colonial administration and trade. A governor might address despatches of the same date to both the Board and the Secretary of State, which would be (a) exact duplicates, or (b) utterly dissimilar, or (c) would vary only as to certain paragraphs. Similarly, enclosures are found in both series; but they are not always the same enclosures. Needless to say, volumes forming a part of the regular series for any colony will show more regularity in form, etc., than those which consist of papers brought together at a later time from different bundles and volumes, but even the regular series show variations sufficient to make generalization difficult.

\section{ENTRY-BOOKS.}

Entry-books sometimes contain orders in Council not found in original correspondence. Many of these books have tables of contents.

\section{ACTS. ${ }^{5}$}

Printed volumes among the acts were examined. Other portions of the lists of acts were compiled from the List of Colonial Office Records.

${ }^{3}$ Between 1784 and 1807 very few sessional papers of the British West Indies are found in their special series; for them one must turn to Correspondence. See List of Colonial Office Records, passim.

${ }^{4}$ See Andrews, op. cit., I. 79-80.

${ }^{5}$ See Andrews, op. cit., I. III. 
SESSIONAL PAPERS.

These series, embracing "minutes of council" (executive), "minutes of council in assembly" (legislative), and journals of assembly, have been treated in the same manner as was done for the mainland colonies in the Annual Report of the American Historical Association for I908, I. 403-509.

SHIPPING RETURNS (NAVAL OFFICE LISTS.) ${ }^{6}$

The headings of the forms employed vary considerably according to date. Returns for vessels entered usually give the following particulars: date of entry; names of ship, master, and owner; tonnage, number of guns and men; when and where built; date and place of registration; class of vessel; whence arrived; destination; when and where bond was given; and character of cargo. Mutatis mutandis outward returns carry the same information, while lists containing both entries and clearances are a merger of the separate returns. While there is general uniformity as to headings, yet it is far from complete. The earlier returns often omit one or more of the heads given in later lists. Attention reeds to be drawn to the confusion in the sequence of returns. The lists compiled for this book overcome this as between one volume and another, but within a single volume returns are often not found in chronological order.

Many volumes contain miscellaneous statistical information. This has been listed according to colony, at the close of shipping returns.

REFERENCE AIDS.

Two typed and bound copies of a "General Catalogue of the Lists, Indexes, Calendars, and other means of reference to the Records of the Public Record Office", are in the Literary Search Room. This "General Catalogue" is not complete, as it does not note the existence of tables of contents in certain volumes.

Index no. I066 3 contains tables of contents of certain volumes relating to the Bahamas, Barbados, Jamaica, and the Leeward Islands. They have been taken from their former locations and placed under one cover.

The earlier registers or "calendars" of Board of Trade correspondence cover the years I703-1759, and comprise vols. I6-5 I of C. O. 326. As regards original correspondence they list all despatches from governors and all important enclosures. The endorsement on each document is copied into the "calendar", and the letter of the bundle and number of the document are added. The arrangement follows exactly that of the papers referred to, and the order is that in which they were dealt with by the Board. In cases where the governor's despatch is accompanied by an abstract the latter is sometimes listed. Where this occurs it is sometimes impossible to determine from the index whether a given entry represents an abstract or a separate letter of that date. This, however, arises merely from the faithful copying of the endorsement. Again, it is difficult in some cases to determine from the index whether a certain document is enclosed or not; and, if so, of what letter it is an enclosure. But in general the enclosures are lettered and numbered in the same manner as the original correspondence. In the case of out-letters the entries correspond in general to marginal notations of the entry-books.

These registers are complete and accurate for the earlier years, but progressive deterioration is shown towards the end. Since the entries give only the most meagre indication of the contents of the documents they could in no case be used as substitutes. On the other hand, in so far as they are complete and accurate, they may make possible some economy of time, in

${ }^{6}$ For naval office lists in general, and for certain complementary returns of shipping between the islands and northern colonies, see Andrews, op. cit., I. I I2, II. 237-239. 
giving a concise statement of the kind of material that a given volume contains.

The secretary or clerk of the Board made abstracts of the governors' despatches, either on the backs of the documents or on separate slips, and arranged these abstracts in alphabetical order. The paragraphs or sections of the letters themselves were frequently lettered A, B, C, etc., and corresponding letters placed on the corresponding sections of the abstracts. In many cases the abstracts were bound and placed among the volumes of a given colony. While showing some inevitable variation in quality, the abstracts of earlier volumes are clear and faithful. The work of dividing letters and abstracts into groups and paragraphs is also conscientiously done. Although the very brevity of the abstracts tends to give them a positiveness of statement which the originals with their usual qualifying phrases do not possess, the abstracts give quite sufficient indications as to the nature of each clocument thus noted.

\section{ANTIGUA. ${ }^{1}$}

C. O. 7 :I. Secretary of State: Original Correspondence. i702-I802.

1. I702-I802. (See Andrews, Guide to the Materials for American History in the Public Record Office, I. I85.)

C. O. 8. Acts. ${ }^{2}$
1. I668-1706. (Includes Nevis.)
2. $1684-1693$.
3. I697-I7I4.
4. I7I $5-1721$.
5. $1722-1727$.
6. I728-I 737 .
7. I738-I 740 .
8. I740-I742.
9. $1742-1746$.
10. I746-I75I.
11. $1752-1755$.
12. $1756-1758$.
13. $1761-1764$.
14. $1764-1767$.
15. I768-I77I.
16. I $769-1787$.
17. I 77 I-I 773 .
18. $1773-1776$.
19. 1778 .
20. I779-1783.

C. O. 9:1-43. Sessional Papers. ${ }^{3}$

1. I704, July I4-Sept. 5. Minutes of council (attested and endorsed as to Oct. 26), pp. 29.

I 706, July I4-1706/7, Jan. I3. Minutes of council, pp. 44. I708, July 27-I709, Apr. 23. “" “" pp. 74 .

I708/9, Mar. I9-I709, Apr. 23 (duplicate of last part of above), pp. 39. I709, June 8-Nov. 2I. Minutes of council ("duplicate", with copy of Daniel Parke's letter to the Board, Nov. 25), pp. 67.

I709, June 8-Nov. 21. Minutes of council (same as above of these dates, but without Parke's letter), pp. 65.

I709/Io, Jan. IO-Mar. I4. Minutes of council, pp. 36 .

I706/7, Jan. 24-I707, May 24. Minutes of council in assembly (headings of this and the two following use the words "Council and Assembly"), C, pp. 75 .

I707, July I8-1707/8, Feb. I7. Minutes of council in assembly, A, pp. 65. I707/8, Mar. I-I708, June I8. " “" " “" B, pp. 78 .

${ }^{1}$ See also Leeward Islands.

${ }^{2}$ See also C. O. $154: 1,2,4$.

${ }^{3}$ For earlier dates see Leeward Islands. 
2. I7IO/I, Jan. 26-I7II, July Io. Journal of assembly, pp. 86.

I7II, July I7-I7II/2, Feb. 6. " " " " pp. 37.

I7II $/ 2$, Feb. 7-I7I2, July $24 . \quad$ “ “ “

I7I2, Aug. 2-Oct. I7. “ " " "

I7I2, Nov. 6-I7I2/3, Jan. 8. “ “ “ “ “

I712/3, Mar. I9-1713, June 19. “ “" “ pp. 23.

I7 IO, Sept. 23-I7Io/I, Jan. 26. Minutes of council in assembly, pp. 54, 36.

I7IO/I, Jan. 29-I7II, June I4. “ “ “ “ “ (headings of this and others which follow read: "Council and Assembly"), pp. 87.

I7 I I, June 2I-July 26. Minutes of council in assembly, pp. 35 .

I7 I I, July 8-i7 I2, July I7. “

I7I I, same as above), pp. 90.

I7I 2 , July I8-26.

Minutes of council in assembly, pp. I3.

I7I2, Oct. I7-I7I2/3, Jan. 7.

I712/3, Mar. 24-I713, June 9. " “ “ “ “ “

I7I2/3, Jan. 3-I7I3, Apr. 24. " " " " " (similar to the two foregoing, büt with Feb. 3, Mar. 4 additional), pp. 36 .

I7I3, July 27. Proceedings of assembly-adjourned till further summons, pp. 7.

I710/I, Feb. 22-Mar. I6. Minutes of council in assembly, pp. 50.

3. I7I3, July $27-1713 / 4, F e b$. I8. Minutes of council in assembly (headings throughout the book read: "Council and Assembly"; the volume itself is lettered "Council and Council in Assembly"), I A, pp. 80.

I7I3/4, Feb. 25-1714/5, Feb. 8. Minutes of council in assembly, $2 \mathrm{~B}$, pp. 82.

I7I4/5, Feb. I5-I7I5, July 8. “ “ “ “ “ pp. 49.

I7I5, Sept. 27-Dec. 23. “ “ “ “ (titlepage and endorsement read: "25 Sept. to 25 Dec."), D, pp. 44.

I7 I5/6, Jan. 2-Feb. 4. Minutes of council in assembly, $4 \mathrm{E}$, pp. Io. I7I5/6, Feb. 7-17i6, Apr. 9. “ “ “ “ “ I7I6, May 3-July 21 . I7I6, Aug I-Nov. 5. I716, Nov. I7-1716/7, Feb. 4 ." I716/7, Feb. 8-1717, Mar. 29 . I7I7, May 28-July 26. I717, Aug. 27-Oct. 25. I7I7, Dec. 20-I7I8, Mar. 31. I718, Apr. I6-Dec. I6. I7I8/9, Jan. 5-1719, Dec. 7.

4. I7 15 , July I3-Sept. 27. I7 $5 / 6$, Feb. I I-I716, Dec. 28. I7I6/7, Jan. 24-I7I7, Mar. 29. I7I7, May 28-Sept. II. I7I7, Oct. I8-I7I8, Mar. 31. I718, Apr. 7-Dec. I6. I7I8/9, Jan. 5-I7I9, Mar. 26. I7 I9, May 4-Dec. 7. I719/20, Mar. Io-24 (no title)

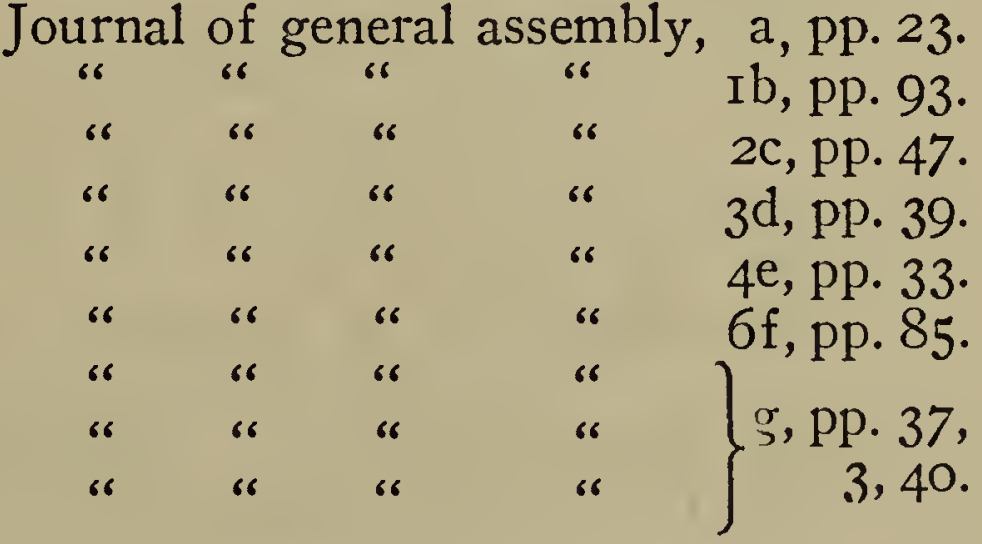


5. I723, May 25-1723/4, Jan. 30. Minutes of council in assembly (or "and Assembly"), A, pp. I3.

I724, Nov. 2I-Dec. II.

I723, Aug. 7-I724, May I2.

I724, Aug. 3-Dec. 23. see C. O. I $55: 6$ ), D 2 , pp. 8 o.

I72I/2, Jan. I-Feb. 24.

I722, Apr. 23-I723, June 28.

I723, July 23-1723/4, Feb. 6.

I $723 / 4$, Feb. I $3-1724$, Nov. 26.

I724, Nov. 27-Dec. 23.

Minutes of council in assembly, B, pp. 22.

" " " " " C I, pp. 84.

(for I725,

Journal of general assembly, E, pp. 64 .

(for I725 and I726 see C. O. I $55: 6$ ).

6. I725/6, Jan. 3-I727, May 30. Minutes of council in assembly (headings read: "Council and Assembly"), pp. 78.

I728, Aug. I9-Oct. I2. Minutes of council (according to title-page and endorsement, but many headings read: "Council and Assembly") ; certified as to Jan. 2, I728/9, no. 2, pp. 4I.

I728/9, Jan. 2-1729, Apr. 29. Minutes of council in assembly (certified as to June 30 ), no. 3 , pp. 54 .

I729, Sept. 24-Nov. 26. Minutes of council in assembly (title page reads: "from June 30"), no. 4, pp. I 5 .

I727, June I6-I728, Aug. I7. Journal of general assembly, no. I, pp. I I3. I728, Aug. 27-Oct. I2. " " " " " no. 2, pp. $5 \mathrm{I}$. I728/9, Jan. 2-I729, Apr. 26. " " " " " no. 3, pp. 56. I727, June I6-Sept. I I. Minutes of council in assembly, A, pp. 37. I727, Dec. II-I728, Aug. I7. " " " " I727, June I6-I728, Aug. I7. Journal of general assembly (same as above, no. I), C, pp. 67. [These last three have been removed here from B. T. Antigua, Correspondence, vol. 6.]

7. I73I, July 26-I732, June 26. Minutes of council (headings read: "Council and Assembly"), pp. 69.

I732, Aug. 9-I733, May 30. Minutes of council, pp. 67.

I733, Oct. 3I-Nov. 29. " " " " " " "

I733/4, Jan. 2I-I734, Apr. 8. " " " " 29.

I729/30, Jan. 26-I733, Sept. 5. Journal of general assembly, pp. 235 .

I733, Nov. I2-29.

I733/4, Jan. 2 I-Mar. I 5 . “

" " " "

I733/4, Mar. I5-I734/5, Mar. 21. " " “" (Mar. I5

is duplicate of the foregoing), pp. 79 .

8. I734, Apr. 27-June I I. Minutes of council (note that there was no meeting on Apr. I 5), pp. 4I.

I734, July 2-Sept. 25. Minutes of council, pp. I6.

I734, Oct. 7-Dec. 20. “ “ " "

I734/5, Jan. 2-I735, July I. " " " " " " " " dorsed "Minutes of Council" but the sittings are headed "Council and Assembly"), pp. 96.

9. I735/6, Jan. I6-1736, Apr. I6. Minutes of council in assembly, pp. 31. I736, Apr. 30-Oct. 27. “ “ " “ “ pp. 36.

I735, July 5-Dec. 20. Minutes of council in assembly (headed: "Council and Assembly"), pp. 32.

I735, June I8-Dec. Io. Journal of general assembly, pp. 45.

I735, Dec. 20-I736, May 20. " “ “ “ 
10. I736, Nov. I-I $736 / 7$, Jan. 31. Minutes of council (includes account of trials of slaves for conspiracy; also reports and lists), pp. I 38 .

11. I736/7, Feb. I-I 738 , May 26. Minutes of council (additional matter on the slave insurrection), pp. I24.

12. 1736 , July 5-Dec. 9. I736, Dec. 20-I737, June 3. I737, July I3-Dec. 9 . I737/8, Feb. I-I738, June I. I738, June I-Nov. 29 . tition), no. 5 , pp. 77. Journal of general assembly, no. I, pp. 54.

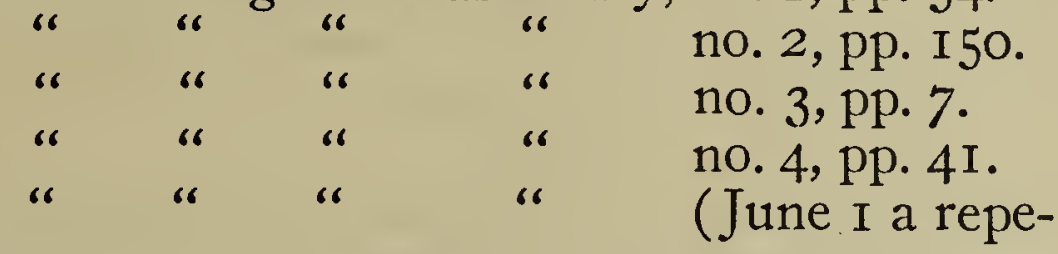

I738/9, Mar. I-I739, May 3I. Journal of general assembly, no. 6, pp. 29. I739, July 23-Dec. I8.

I739, Dec. I8-1740, May 19. repetition), no. $8, \mathrm{pp} .78$.

I740, June 3-Dec. 9. Journal of general assembly, no. 9, pp. 77.

13. "Council and Council in Assembly."

I738, June I-I740/I, Feb. I7. Minutes of council, A, pp. I69.

14. "Council ; Council in Assembly; and Assembly."

I740/I, Feb. 27-I74I, Aug. 24. Minutes of council, B, pp. 26.

I74I, Aug. 28-I74I/2, Feb. I6. “" “" “ C, pp. I8.

I74I/2, Mar. I2-I742, Sept. 6. “ “ “ D, pp. 30.

I740, Dec. 30-I74I, June 22. Journal of general assembly, no. I, pp. 37. I74I, July 2-Dec. I7.

I74I/2, Jan. 26-I742, July 23. “ “ “ “ no. 3, pp. 26.

15. "Council; Council in Assembly ; and Assembly."

I742, Oct. 30-I743, Apr. 28. Minutes of council, A, pp. 24.

I743, May 6-Oct. 3I. “ “ “ “ B, pp. II.

I743, Nov. 9-I744, Apr. 24. “ “ “ C, pp. 28.

I742, July 30-I743, June 2I. Journal of general assembly, D, pp. 45.

I743, Aug. 3-I743/4, Feb. 3. “ “ “ E, pp. 37.

16. I743/4, Feb. 7-I 744/5, Jan. 3I. Journal of general assembly, no. I, pp. 70. I744/5, Feb. 28-I745/6, Jan. 22. “" “" no. 2, pp. 56. I743, Nov. 9-1744, Apr. 24. Minutes of council.

I744, May 8-Oct. I7. Minutes of council (both these endorsed: "in Assembly"), pp. 28, 32.

17. "Council ; Council in Assembly; and Assembly."

I744, Nov. I2-I745/6, Jan. 22. Minutes of council in assembly, pp. 75. I745/6, Jan. 22-I746, July I8.

22 a repetition), pp. 20.

I745/6, Jan. I3-1746, July Io. Journal of general assembly, pp. $3^{8}$.

I746, July I8-Dec. I I.

I746/7, Jan. 27-I747, July 2I. “ “ “ “ pp. 48.

18. I746, July 24-1746/7, Jan. 27. Minutes of council, pp. 20.

I746/7, Feb. I8-I747, Aug. 6. “" “" “p. 35 .

I747, Aug. I4-I747/8, Jan. 28. “" “" “

I747/8, Feb. I6-1748, June I7. “" “" “"

I748, Aug. 25-I749, Aug. 23. " “ “ “

I749/50, Jan. 25-I750, May 3. “ “ “ (endorsed: "Privy Council"), pp. 5 .

I749, Sept. 28-I750, May 3. Minutes of council (papers relating to the suspension of Charles Dunbar), pp. 4I, I5. 
19. "Council in Assembly."

1747, Aug. 14-1748, June 17. Minutes of council (duplicate this period in previous volume), pp. I7, 21. ${ }^{4}$

I748, Aug. 25-I749, Aug. 23. Minutes of council (duplicate this period in previous volume), pp. 39 .

I752, Nov. IO-I753, June I4. Minutes of council, pp. I2.

I753, July 2-1754, Jan. I5. “ “ “ “

I754, Apr. IO-July 3. “ “ “ pp. 5 .

20. I747, Aug. 6-I748, June I7. Journal of general assembly, no. I, pp. 55. I748, Aug. I5-1749, June I. I749, July 25-1750, May 3. I750, May I4-Nov. 8. 1753, Apr. 27-1754, Apr. 26. 1753, Apr. 27-1754, Apr. 26. no. 5$)$, no. 6 , pp. $5 \mathrm{I}$. no. 2 , pp. 35 . no. 3 , pp. 69. no. 4 , pp. II. no. 5 , pp. 50. (duplicate of

21. I754, July I8-Dec. Io. Minutes of council, pp. 8.

I755, Jan. 9-June Io. 1755, June 27-Dec. 4. I756, Jan. 20-June Io. I756, June I6-Dec. 8. I757, Jan. 4-June 21.

22. I754, May 2I-Nov. 5 . I754, Nov. 25-1755, May 20.

I755, May 30-Nov. 25. 1755, Dec. 4-1756, June 2. I756, June Io-Dec. 8. I757, Jan. 4-Aug. I9.

23. I757, July 6-Dec. 5. Minutes of council, pp. 8 . I758, Jan. 3-June 28 . “ “ “ " I758, July 6-Dec. I4. “ “ “ “ “ I759, Jan. 4-June 7. “ “ “ " pp.7.

24. 1759, Aug. 9-Dec. 6. Minutes of council, pp. 5. I760, Jan. Io-June 19. “ “ " pp.9. I757, Sept. 20-I758, July 6. Journal of general assembly, pp. 28. I758, July I3-1759, Jan. 8. “ “ “ “ “ “ I759, Feb. I-Aug. 9. “ “ “ “ “ I759, Aug. I6-I760, Feb. 26. “ “ “ “

25. I760, Mar. 27-Dec. 24. Journal of general assembly, pp. 24. I76I, Jan. 2-July I7. I761, Aug. 20-I762, Feb. I8. I762, Mar. I8-Sept. 9. I762, Sept. 23-1763, May I I. I763, June 4-1764, Jan. I2. I764, Jan. 26-Aug. I6. I764, Sept. 6-1765, Mar. I4

26. I76I, Jan. 2-June 4. I760, July I7-Dec. 24. I761, July 9-Nov. 30 . I762, Mar. I8-Sept. 23. “ “
I762, Oct. 7-1763, May iा. “ “ “ Minutes of council, pp. 7 . I763, June 4-I764, Mar. I. “ “ “

"All very large or double pages to end of Antigua. 
1764, Mar. I5-Aug. 16. Minutes of council, pp. 7. r764, Sept. 6-1765, June 20. “ “" “ pp. II.

27. I762, Mar. I8-Sept. 9. Journal of assembly (duplicate), no. 24, pp. 24. I764, Jan. 26-Aug. I6. " " " " " no. 25, pp. I9. I766, Apr. 3-1767, Mar. 26. “ “ “ “ “ “ I767, Apr. 9-Nov. I2. “ “ “ “ “ “ I768, Feb. 29-June I5. " " " " " to June 30 ), pp. II.

I769, Jan. I2-Aug. 29. Journal of assembly (duplicate; leaves misplaced in binding; adjourned to Sept. 7), no. 33, pp. 24.

I770, Sept. 6-Nov. I. Journal of assembly (incomplete; for continuation see end of vol. 33), pp. 6.

I769, Nov. I-I770, Aug. 23. Journal of assembly (incomplete; see vol. 3I for complete sets of this and the above), no. 35, pp. 7-28.

I77I, Apr. II-I772, Mar. 4. Journal of assembly (duplicate), no. 36, pp. 4I.

I772, Apr. 2-Sept. I4. " " " (incomplete; for the continuation see vol. 33 ; pp. 2 and 3 here are of Sept. I769, but see the correct pages below), p. 22.

I772, Oct. 22-I773, Mar. I8. Journal of assembly (duplicate), no. 39, pp. I4.

I771, Feb. 28. (Fragment: for leaves 7-9 see end of vol. 33), pp. Io-12. I772, Apr. 3. (Pp. 2 and 3 referred to above), pp. 2-3.

I773, Apr. I-Sept. 23. Journal of assembly (duplicate), no. 38, pp. 30. I773, Oct. 2I-I774, Mar. Io. “ “" “ “ no. 40, pp. I7. (See vol. 34 for original sets of nos. 39, 38, and 40.)

28. I764, Sept. 6-1765, Mar. I4. Journal of assembly (duplicate), no. 26, pp. 18.

1765, Mar. 28-1766, Mar. I3. “ “ “ “" no. 27 , pp. 43.

I768, June 30-Dec. $15 . \quad$ “ “ “ pp. $2 \mathrm{I}$.

I778, Oct. 8-r779, Mar. 4. Minutes of council (attested and endorsed, Oct. I, I778, Apr. I, I779), no. 23, pp. 31 .

I780, Nov. I-I78r, Aug. 9. Minutes of council (duplicate), endorsed: "Council in Assembly", no. 24, pp. 63.

I783, Mar. 27-Sept. 24. Minutes of council (endorsed "Council in Assembly"), pp. 4I. Later proceedings continue to 1786 , and at the end of the book are records of a court of chancery, I776-1777, in the case of Joseph de Zubiaur et al., master of the Santa Rita of Bilbao, v. Samuel Redhead of Antigua. Also copies of three acts of July, I776.

29. I766, Apr. 3-1767, Mar. 26. Journal of general assembly, pp. 32. I767, Apr. 9-Nov. I2. 1768, Feb. 29-June 15. I768, June 30-Dec. I5.

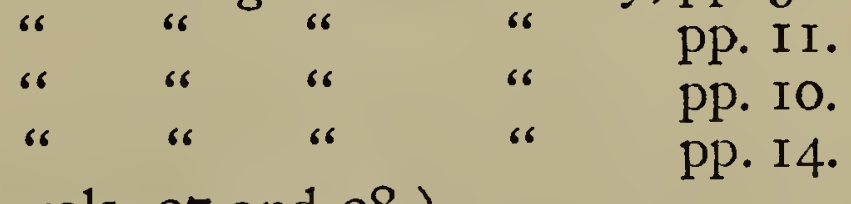

(For duplicates see vols. 27 and 28 .)

30. I767, Feb. 26-1768, June I4. Minutes of council, pp. I8. I768, June I5-1769, Feb. I6. “" “" “ pp.9. I769, Mar. I6-Nov. 23.0 “ “ “ “ I769, Nov. 30-1770, June 7. “ " “ "

31. I769, Jan. I2-Aug. 29. Journal of general assembly, pp. 24. I769, Sept. 7-1770, Aug. 23. “" “ “ pp. 28. 
I770, Sept. 6-i77 I, Feb. 28. Journal of general assembly, pp. I3.

I77 I, Apr. I I-I772, Mar. 4.

32. I770, June I3-Dec. I8.

I77 I, Jan. I7-Sept. 5.

I771, Oct. 3-I772, Mar. 4.

I772, Mar. 4-Sept. 24.

pp. 34 .

I772, Oct. 22-I773, Mar. I8.

I773, Apr. I-Sept. 23.

Ist"), p. 26.

I773, Oct. 2I-I774, Mar. Io.

Minutes of council, pp. I5.

pp. 36.

I774, Apr. 7-Sept. 8. Journal of assembly (duplicate, pp. 20-24 are at the end of the volume, 25 is wanting), no. $37, \mathrm{pp} .24$.

I772, Sept. . -Sept. 24. (Continuation of Ioth item in vol. 27. Cf. also vol. 34. Certified Apr. 2-Sept. 24), pp. 23-28.

I776, Apr. I I-Sept. I2. Journal of general assembly (duplicate), no. 44 , pp. 36 .

I775, Oct. I2-I776, Mar. I4. “ “ “ “ "

I782, Feb. 22-Aug. 22. Minutes of council (duplicate), Pp. 30.

I78I, Aug. I8-I782, Feb. I7. " “ “ “ “ "

I78I, Aug. I8-I782, Feb. I7. “ “ “ “

I782, Feb. 22-Aug. 22. " " " " " " dates), pp. 33 .

I782, Sept. I9-I783, Mar. I3. “ “ “ (same as above of these dates ), pp. 27.

I770, Nov. ..-I77I, Feb. I4. (Fragment: three leaves of assembly journal. See vol. 27, I 2 th item ), pp. 7-9.

34. I772, Apr. 2-Sept. 24. Journal of general assembly, pp. 30.

I772, Oct. 22-I773, Mar. I8. “ “ “ “ “

I773, Apr. I-Sept. 23. “ “ “ “

I773, Oct. 2I-I774, Mar. Io. “ “ " “ "

35. I774, Apr. 7-Sept. 8. Journal of general assembly (cf. vol. 33), pp. 25.

I774, Oct. 6-I775, Apr.6. “ “ “ “ “

I775, May 4-Sept. I4. " " " " "

pp. 33.

I776, Apr. I I-Sept. I2.

pp. 35 .

36. I774, Apr. 7-Sept. 8. Minutes of council, pp. I9.

I774, Oct. 6-I775, Mar. 23. "“" " (attested and endorsed as

Oct. I, I774-Apr. I, I775), pp. 25.

I775, Apr. 6-Sept. I4. Minutes of council (attested and endorsed as Apr. I-Oct. I), pp. 27.

I776, Apr. II-Sept. I2. Minutes of council (attested and endorsed as Apr. I-Oct. I ), Pp. 2 I. 37. I775, May 4-Sept. I4. Journal of general assembly, pp. 33.
I776, Oct. 3-I777, June 26. “

38. I776, Oct. 3-I777, June 26. Journal of general assembly, pp. 70. I778, Mar. 2I-Sept. I7.

39. I776, Oct. 3-I777, Mar. 27. Minutes of council, pp. I9.

I777, Apr. 24-Sept. I8.

I777, Oct. 2-I778, Mar. 26. “ “ “ (attested, and endorsed: "to I April"), pp. 27.

I778, Apr. I3-Sept. 24. Minutes of council, pp. 45.

pp. 52. 
40. "Council in Assembly."

I780, Nov. I-I78I, Aug. 9. Minutes of council (endorsed: "in Assembly"), pp. 62.

I78I, Aug. I8-I782, Feb. I7. “ “ “ (cf. vol. 33), pp. 38.

41. I780, Nov. I-I78I, Jan. I7. Journal of assembly, no. 45, pp. 27.

I781, Feb. 22-Aug. 9. "“" " no. 46 , pp. 37.

I782, Feb. 22-Aug. 22.0 “ “ “ "

I782, Sept. I9-1783, Mar. 13. “ “ “ (attested, and endorsed: "to I9 March"), pp. 74.

I783, Mar. 27-Sept. 24. Journal of assembly, pp. I04.

42. I78I, Feb. 22-Aug. 9. Journal of assembly ( $c f$. vol. 4I ), pp. 40.

I782, Feb. 22-Aug. 22. " " "

I781, Aug. 23-I782, Feb. 17. “" “" pp.60.

I783, Oct. 7-I784, Feb. II. Minutes of council (two copies), pp. 20. (The volume continues to 1788 .)

43. I783, Oct. 7-I784, Apr. I5. Journal of assembly (duplicate), pp. I25.

I782, Sept. 19-1783, Mar. I3. " " " " (same as in vol. $4 \mathrm{I}), \mathrm{pp} .78$.

I784, May I3-Oct. I4.

I783, Oct. 7-I784, Apr. I5. “ “ “ pp. II9.

$1 .^{5}$ Inward:

\section{O. I57:I. Shipping Returns.}

I704, June 6-Sept. 25.

I705, June 25-I706, June 25.

I707, Sept. 25-1708, Sept. 25.

i710/r, Feb. I-17i3, Aug. I.

I7I5, June 25-Dec. 25.

I7I9, Mar. 25-I720, Mar. 25.

Inward, from Great Britain:

I7II, June 25-I7I3, Mar. 25.

Outward:

Dates of the general lists, as well as those for ships clearing for Great Britain and for other British colonies, correspond with those of inward lists.

C. O. io: 4. Miscellaneous.

4. Treasurer's accounts. I7I9-I720. (See Andrews, I. I86.)

BAHAMAS.

C. O. 23:i-it. Board of Trade: Original Correspondence. i7i7-i78o.

1. I7I7-I725.

Paper on deed of surrender of proprietors and its validity. I7I7.

Letters from Gov. Rogers, on formation of council, appointment of officers pending royal confirmation, and other matters connected with establishment of government; on undesirable character of inhabitants, measures for securing settlers from other colonies, extraordinary mortality among inhabitants, activities of pirates, and friendship of inhabitants for pirates. In particular: on capture by pirates of two ships from Carolina, bound, with rice, pitch, tar, and skins, for London; also, on desire of French and Spaniards

${ }^{5}$ Andrews, I. I86, lists these returns under C. O. Io:I (formerly B. T. Antigua 43). 
to secure Eleuthera and Harbor Island. Correspondence with the governor of Hispaniola concerning French claim to the Bahamas enclosed. Plans for developing whale fisheries and supplying Newfoundland and North America with salt. Oct. 31, and Nov. 4, I7I8. "Proceedings of an Assembly of Severall of the Principall Inhabitants of the Bahama Islands at the Citty of Nassau on the Island of Providence August the Ist, I7 I8."

Minutes of council, Aug. 2-Sept. 28, I718.

Deposition on activity of guarda costas at Cuba. I7I8.

Account of collision with Spaniards in lagoon on coast of Florida where Spanish vessels had been wrecked. I7 8.

Account of stores required. I7I8.

Deposition of Richard Taylor of Philadelphia on his experiences with pirates. I7I8.

Papers on defense, including petitions for stores and men.

Letter from Sec. Craggs, enclosing copy of letter from Mr. Gale of South Carolina to Col. Pitt, Nov. 4, I718, on "The designs of the Spaniards and Pirates against the Island of Providence." Jan. 29, I7I $8 / 9$.

Letter from Rogers on danger of Spanish attack. May 27, I719.

Minutes of council, Nov. I4, I7I8-May 26, I7 I9.

Letter from Rogers, on character of inhabitants. So indolent that they are content to live on potatoes, yams, and turtle; and if placed on watch will get drunk or go to sleep. "They pray for nothing but wrecks or the pirates." May 29, I7I9.

Petition of Mr. Buck, in behalf of undertakers for settling Bahama Islands, praying that another independent company of soldiers may be sent; and accompanied by memorial on condition of islands. Dec. 3, I7I9.

Account of expenses of ship Delicia, in service of government at Port Nassau, July, I718-May, I719; showing amounts for wages, provisions, sales, and "liquors expended for supporting the Ship's Company".

Account of trial and condemnation of ten persons for piracy at New Providence. Dec., I7I8.

Letter from Rogers, reporting activities of two war vessels from Cuba against privateers from Jamaica and Bahamas. Undated.

Minutes of council, May I9-July 9, I7I9.

Letter from Craggs, enclosing: (I) anonymous report on state of islands; and (2) extracts of letter from Charleston, S. C., on same. Jan. 21 , I7I9/20.

Memorial from Buck and copartners in answer to foregoing. Feb. 3, I7 $19 / 20$.

Letter from Rogers and council of Bahamas, on capture of Spanish vessels and prisoners, and stating that French have saved the islands by creating a diversion. Jan. I5, I7 $19 / 20$.

Minutes of council, Mar. 3I, I719-Jan. I5, I7 I9/20.

Letter from Rogers on French successes in war, and on conditions in Spanish colonies. Apr. 20, I720.

Letter from Messrs. Farrill and Nicholson to Rogers, from Cuba, sending intelligence on movements of shipping. Apr. 4, r720. Other papers on plans of French and Spaniards.

Letter from Delafaye, secretary to Lords Justices, referring to Lord 
Craven's petition on his title to islands. July 20, I720. Other papers on Craven's title.

Memorial from Buck, on expenses incurred by lessees in settling and defending islands, and on existing conditions. Sept., I720.

Order in Council, for bringing writ of scire facias against charter. Aug. 2, I720.

Three memorials from copartners, on desire to complete settlement of islands. Apr. and May, I72r.

Letter from Rogers: "It is Impossible I can subsist here any Longer on the foot I have been left ever since my Arrivall." Was left with "a few Sick men to encounter Five hundred of the Pirates", and has no support in men, supplies, or warships. Has contracted great debts through having to buy provisions and clothing in North America at extravagant rates and his bills are protested. "This place so secured by my Industry, Indefatigable pains and the forfeiture of my health has since been sold for Fourty Thousand Pounds and my Self by a manager at Home, and Co-partners' Factotem here thought not to Diserve any share of it." Instead he has been very badly used and all expense thrown on him; "but that I have Intire Relyance on the Honour and Justice of my Lord Londonderry, Mr. Wm. Chetwind, and Mr. Docminicque, the only Surviving of the Copartners worth mentioning". Is leaving at once for England to save colony. Feb. 25, I720/21.

Letter from Carteret, referring request of governor, council, and principal inhabitants for calling of assembly. Apr. 28, I722.

Letter from Phenney, stating need of an assembly to raise money for rebuilding of forts, which are in ruins. Dec. 26, I721.

Minutes of council, Dec. I4-I8, 24-29, I72I.

Copy of record of court proceedings in case of $\mathrm{Mr}$. Gohier, relating to capture of seal fish and payment of tenths of oil, at first to proprietors, and now to copartners, lessees from proprietors. I72I.

Account of ordnance stores. I72I.

Memorial of Nicholas Trott, governor of Bahamas 1694-1697, on his claims to lands: these claims being now threatened by lease given to copartners for 21 years from I7I7, I721, or 1722. Contains interesting information on land system.

Letter from Phenney, on need for assembly, establishment of militia, and work on forts. Feb. IO, I721/2.

$I d$., on same matters, rates of local currency, and pirates. Sept. I4, Dec. 24, I722; Mar. 2, I722/3. Enclosures include correspondence with governor of Havana on pirates, description of islands, accounts of receipt and disbursements regarding ordnance, present state of forts; and descriptions of trials of several pirates. Aug. and Oct., I722.

List of families to which Gohier has assigned land in New Providence. I722.

Minutes of council, Dec. 23, I722-June 17, I723.

Various papers on pirates and trade with pirates, the calling of an assembly, and need for ordnance stores.

Public accounts of islands, Apr., I722-Dec., I723.

Answers sent by Phenney to queries of Board. Dec. 24, I723, Dec. 3, I724, Apr. I6, I725.

Treasurer's accounts for 1724 . 
Papers on Spanish depredations. I725.

Copy of commission issued by the governor of Santiago, Cuba, to Spanish guarda costa. I724.

Depositions on piracy. I725.

2. $1726-1731$.

Letters from Gov. Phenney. Jan. 26, 28, I725/6. Encloses: treasurer's account, I725; draft of patent for granting land in Bahamas, I726; answer to queries of Board; list of fees to be taken by various officers; deposition on Spanish depredations; correspondence with the governor of Havana; account of christenings, marriages, and burials; stores on hand and required.

Papers on rumor of approaching war, preparations by Spaniards, and need for better protection.

"Copies of Several proceedings relating to the ill-behaviour of Lieut. Ferrall"; and papers asking for his removal as commander of independent company in Bahamas. Details of condition of troops.

Report of proceedings in trial of Michael Bevan, master of sloop Swansea, which put into the Bahamas to refit while proceeding from Bristol to New York, and was seized and condemned for lack of register and certificate of lading. Case tried by jury in court of common pleas. Appeal allowed to chancery, but heard in council. Feb. and Mar., I72I/2.

Papers on establishment of an assembly, and on eviction of settlers, I72I and I722, supply varied information on conditions.

Letter from Phenney, on quit-rents paid to proprietors. Apr. 20, I727. Encloses: treasurer's account of cash, I726; affidavits on plundering of vessel by Spaniards, I727; answers to customary queries, I726; accounts of ordnance; and accounts of christenings, marriages, and burials, I726-1727.

Id., with answers to customary queries of Board. Mar. I6, I727/8.

Letter from Townshend, on system of land tenure, and misgovernment by Phenney. Copartners have tenure of twenty-one years, of which half is nearly expired; but have power to grant land for ninetynine years. Have spent $\epsilon_{35}, 000$, but much wasted or embezzled. "The Governour ingrosses all the Trade. Mrs. Phenney sells Rum by the Pint and Biscuit by the Half Ryal." Aug. I3, I728.

Other papers on Phenney and his wife. In particular, memorial from Mrs. Vere. "She [Mrs. Phenney] had the Opportunity of keeping the very Life of every body there in her Mercy, who could not have any Provisions or Subsistence whatsoever without paying her own exorbitant prices. . . . The Sd. Governours wife has frequently Brow beated Jurys and Insulted even the Justice on the Bench." She buys produce and goes to England, saying the governor will pay, but he, when applied to, answers that he never meddles in her affairs.

List of men capable of bearing arms in New Providence Island, Eleuthera, and Harbor Island. One hundred and sixteen in all, of whom "seldom above seventy at home at a time".

"To the Honourable Collector Bladen, the Representation of Cuthbert Jackson of London, Mercht., in relation to the Bahama Islands", giving their history. In I7I7 proprietors surrendered civil and military government to the crown, with reservation of quit-rents and royalties. These they leased in the same year to Capt. Woodes 
Rogers for twenty-one years at $£_{50}$ per annum for first seven years, $£$ ioo per annum for second seven years, and $£ 200$ per annum for last seven years. The "old Lessee" had power to grant patents of lands at a yearly rent of $\mathrm{I} d$. per acre and to demand one-tenth of all braziletto, salt, whale oil, wrecks, and ambergris during term of twenty-one years. Rogers, appointed governor, assigned his lease to copartners. Much money was put in, but sunk without adequate return on account of operations of pirates and laziness of inhabitants. Lessees revised partnership, with new partners and capital, in 1720 , but distress continues; and inhabitants have been saved from starvation only by assistance from Carolina. Principal needs now are civil government, abolition of lessees' tenths, and measures to make possible acquisition of firm title to land.

Orders in Council, representations, and other papers issuing from Privy Council and Board on proposal for buying out proprietors. I729.

"Mr. Fane's Report relating to the Exercise of Admiralty Jurisdiction by the Lds. Proprietors of the Bahamas in view of their Charter." May 16, I729. [Printed in Chalmers, Opinions, ed. I858, p. 507.]

Letter from Phenney. Encloses: answers to queries of Board, I729; treasurer's account, 1728; report of christenings, etc., 1728; and account of stores. Mar. Io, I728/9.

Letter from Gov. Rogers, on first meeting of assembly, Sept. 30, I729, and on bringing of independent company of soldiers from Bermuda. Nov. 12, I729. Encloses list of ten acts recently passed.

Letter from five of proprietors, Berkeley, Beaufort, Craven, J. Colleton, and Robert Abdy (as one of the executors and devisees for Sir John Tyrrell, deceased), offering, in response to suggestion from the crown, to sell out for 1,000 guineas each, clear of all fees, and reserving arrears of rent due from lessees or assignees of proprietors' lease. Apr. II, I730.

Letter from Shelton, secretary to proprietors, giving particulars of lease by proprietors to Woodes Rogers, and by him to W. Chetwynd, Adam Cardonnel, and Thomas Pitt, Esqs.; "but the right and interest of the term, is by mean assignments now vested in Sir Charles Wager, Mr. Hide, Mr. Harris, etc." Lease dated Oct. 28, I717, and to operate from Dec. 25, I7I7. Lessee to have right to grant lands for not less than I $d$. sterling per acre. Sept. 9, I730.

Letter from John Hyde, explaining what lessees receive and pay, and price which they will demand to sell out. Apr. 3, I73I.

Plan of Fort Nassau on island of New Providence. I73I.

Letter from Rogers. Continued poverty and difficulties; attempts to promote cotton and sugar planting, and ship-building; plans to supply salt to North American colonies, and to secure settlers from Bermuda and other colonies; poor condition of forts (iron work of which was all sold by Phenney) and of militia; and condition of independent company of troops. Oct., I730.

$I d$., on difficulty with assembly which desires to exclude officers and soldiers who are freeholders from franchise. Feb. I0, I730/I.

Copy of letter from Richard Fitzwilliam to Carkesse. Fitzwilliam, having gone to the Bahamas "to inquire into its Trade and management of Customs", sends general description of colony and its trade. New Providence, June 30, 1729. 
3. $1732-1737$.

Letter from Rogers, on general weakness of island, and necessity that the crown take it over and put an end to discouraging contests on titles to land. Oct. I4, I73I. Encloses: classified statistics on all classes of population, I7I5; public accounts, I730-I73I; and answers to customary queries.

"The Charter of the Bahama Islands", as granted to proprietors, Nov. I, I670.

Copy of lease by proprietors to Woodes Rogers. Oct. 28, I7I7. Other formal papers.

Memorial of Richard Fitzwilliam, appointed governor of the Bahamas, reviewing its history and describing conditions.

Opinion by Fitzwilliam and J. Eden, agent to Gov. Rogers, on ten acts ; in particular, on act to forbid export of planks and other materials for shipbuilding. I730.

Order in Council, directing commissioners of Treasury to complete bargain for purchase of proprietors' and lessees' rights. Aug. 2, I733.

Letter from Fitzwilliam. Threatened negro insurrection; lack of produce for building up commerce; and unwillingness of members of assembly to raise money, "such a sett of head-strong, simple, ungovernable Wretches were never convened in legislative Capacity". Sept. 7, I734.

Various papers on transfer of titles of proprietors and lessees to the crown.

Letters from Fitzwilliam. Weakness, discouragement, and threatened diminution of population; recovery of property from Spanish wrecks; removal or concealment of all but one of acts of assembly after Rogers's death; and attempts to collect tithes of salt and wood for the crown. Dec. 5, I733, Feb. IO, I733/4, July 2, I734, and Mar. II, I734/5.

Id., complaining that he has not received any communication from Board since arrival, and enclosing: list of acts passed at session of assembly commencing Aug. 20, I734; treasurer's accounts, Dec., I733June, I734, and Midsummer-Christmas I734; and list of families, I735: Mar. I I, I734/5.

Id., sending depositions on seizure of vessels by Spaniards without excuse. Aug. 20, I735. Other papers.

$I d$, reporting that soldiers of independent company receive no allowances such as given elsewhere, and are dying for want of medicines and starving on account of price of provisions. Ordnance stores also lacking, and company has only twenty muskets. Duties, including that of I $d$. per bushel on salt exported, have been laid by assembly in place of tenths. Dec. 22, I735.

Id., on seizure of vessel by Spaniards. Dec. 22, I735. Encloses "an Account of the Duty-Laws in Force, etc., in the Bahama Islands". I735.

Memorial of Chaloner Jackson, collector at the Bahamas, complaining that Fitzwilliam interferes with officers of customs, monopolizes trade in colony, and commits various malicious and arbitrary acts. Oct. $7,1736$.

Letters from Fitzwilliam to Board, and to Sir William Strickland and Sir William Yonge, secretaries at war, on distressing condition of 
troops. Describes mutiny due to hardships, attempts of mutineers to escape by sea, their capture, and execution of twelve on charge of piracy. Aug., I734-Mar., I735/6.

Account of royal revenues, Christmas I734 to Christmas I735.

Affidavits on misbehavior of Fitzwilliam in monopolizing all trade by compelling merchants to sell only to him. I736. Memorial of Henry Popple, and address of grand jury in defense of Fitzwilliam, I736. Other papers.

Letter from Burchett, sending copy of instructions to sloop-of-war stationed at the Bahamas. Nov. 5,1736 .

Letter from Fitzwilliam, asking for instructions on escheats and treasure trove; and urging annexation of Turks Islands to the Bahamas as necessary for prevention of illicit trade between British and French colonies, and introduction of French goods. Nov. I2, I736.

Papers on complaints against Capt. Symonds of H. M. S. Shark, showing methods used in recruiting seamen. I736-1737.

4. $1737-1742 .{ }^{1}$

Letter from Fitzwilliam, on weakness of colony. "It will be impossible for me to answer the Ends of my being sent hither without your Lordships' Interposition in Favour of this miserable Place." Mar. 26,1736 .

Treasurer's accounts, Christmas I735 to Christmas I736, so detailed as to give information on population, shipping, etc.

Letter from Fitzwilliam, answering Chaloner Jackson's complaints, and charging that Jackson levies extortionate fees and excuses some persons from paying enumerated duties. Apr. I8, I737. Other papers contain information on security given on bonds, and other phases of enforcement of acts of trade.

Memorial of Henry Popple, agent to Fitzwilliam, on behalf of latter.

Letter from Fitzwilliam, complaining that fear of Spaniards prevents raking of salt; that other colonies, knowing that no salt is to be had, send no provisions; and that population is consequently compelled to subsist on crabs, fish, and wild fruit. Oct. 28, I737.

Treasurer's accounts, Christmas I736 to Midsummer I737.

Letter from Pres. Howell, picturing growth of law and order, and showing that troops are driven by distress to robbing of plantations. Aug. 8, 1738 .

Letter from R. Noden, objecting to revenue act of the Bahamas, laying duties on exports of salt, timber, and tortoises, a tonnage duty of $t_{I} 8$ per ton on shipping entering and clearing, and forfeiture of troo from anyone who rakes salt or cuts certain kinds of timber without license from government. Asserts that this act is aimed directly at people of Bermuda; and describes activities of Bermudians in building sloops, raking salt, and trading with West Indies on return voyages from N. Am. to Bermuda. Aug. I5, I739.

Letters from Pres. Howell, on military weakness of colonies, distress of troops, and panic at approach of hostilities. Feb. 28, 1738/9, and Jan: 9, I739/40.

${ }^{1} \mathrm{~A}$ note inserted at beginning of volume by $\mathrm{Mr}$. Hubert Hall shows that letter from Gov. Tinker, Jan. I3, I742/3, with naval office lists for $1742-1743$, is among prize papers of High Court of Admiralty, but gives no reference to particular volume. C. O. 23:5 contains duplicate of letter dated Jan. $17,1742 / 3$, with which naval office lists and minutes of council were forwarded. 
Treasurer's accounts, Midsummer to Christmas I738, and Midsummer I739 to Christmas I740.

Copies of orders in Council, for sending engineer and stores to the Bahamas. Dec. 27, I739 and Feb. I4, I739/40.

Letters from Gov. Tinker on weakness of colony, preparations and captures by Spaniards. May I2, 29, July I7, Oct. I3, I74I.

Id., on capture by H. M. S. Rose, "stationed with Us", of "a Spanish Snow commanded by Capt. Vandeño, a very famous Corsair of the Havanna, and the same who cut off Capt. Jenkin's Ear; he had with him large English ships laden with tobacco from Maryland, and a schooner with provisions". Begs that more soldiers be sent, the independent company stationed in colony being hardly sufficient in time of peace, and militia always dispersed in search of food. June I3, I742.

Treasurer's accounts, Midsummer to Christmas, I74I.

Letters from Tinker, reporting rumor that Spanish expedition now investing Georgia will, if successful there, attack the Bahamas on return voyage. Has sent to Jamaica for help. Aug. 9, 30, I742.

$I d$., on capture of Spanish "register." ship which has been ransomed for 90,000 pieces of eight. Dec. 7, I742.

List of English prisoners of war exchanged and sent to the Bahamas from Havana. Mar. 4, I742/3. Military and naval officers, merchants, carpenters, bricklayers, seamen, and others.

5. I 743-I754.

Letters from Tinker, on conditions in colony, and state of troops. July. I I, I743 ; Feb. 20, I743/4; July 9, I744; and June 22, I745.

Treasurer's accounts, Christmas I74I to Christmas I742, Christmas I743 to Christmas I745, Midsummer I746 to Midsummer I75I, Christmas I75I to Midsummer I752.

Reports from Fane on 32 acts passed I729-I74I.

Answers to queries of Board of Trade. I745.

Letter from Tinker, on captures of Spanish vessels. June 30, I745. Encloses: letter from viceroy of Peru to viceroy of Santa Fé, on conditions, financial and other, in his government; copies in Spanish and English of report of president of Panamá to King of Spain on condition of towns and forts; and plan of fortifications of Panamá.

Other papers on relations with Spaniards.

List of prizes brought into the Bahamas, Oct. I740-May I747.

Letter from Tinker, on need of guard ship for protection of salt ponds. Apr. Io, I747.

$I d$., on development of wealth and prosperity of the Bahamas during the war, through opening up of trade with $\mathrm{Cuba}$, and increase of revenue from prizes brought in. Describes trade and estimates its value, number of vessels engaged, etc. Apr. 4, I748.

Detailed and seemingly complete list of all prizes brought into and condemned at New Providence from commencement of war to Mar. 25, I748.

Letter from Tinker, outlining history of the Bahamas during the war. Jan. 30, I748/9.

Matthew Lamb's opinions on various acts, including one fixing rates for gold coins. Nov. 2, I748.

Letter from Tinker, on seizures of vessels by Spaniards. July 2, I752.

Answers to queries of Board of Trade. I752.

Letter from Tinker, on French claims to Turks Islands, Sept. 9, I753. 
6. $1754-1759$.

Letter from Tinker, on conditions, military and other, in islands. Jan. 24, I754. Papers on French designs on Turks Islands enclosed.

Treasurer's accounts, Midsummer $175^{2}$ to Michaelmas I753, Midsummer I 754 to Christmas I754.

Accounts of baptisms and burials for one parish, May 26, I750-Dec. 25, 1753 .

State of ordnance stores. 1754 .

Letters from Tinker, on French claims to Turks Islands, and on question whether Turks Islands are dependencies of Bermuda or the Bahamas. I753.

"Description of Turks Islands." I754.

Answers to general queries of Board of Trade. 1755 .

Letters from Tinker, on weakness of islands, need for ordnance stores, and preparations for war. I756-1757. In particular: on embargo which, in pursuance of orders, he has placed on provisions. Apr. 12, 1757 .

Id.: "The Spirit of Privateering has taken possession of these People, and extinguished every other industrial and commercial application in times of war, this is a general rendezvous from the northern colonies for all that set of folks." . . . Feb. 25, 1758.

Important letter from Shirley, on Monte Cristi trade. Mar. 29, I760. Several enclosures.

7. 1760-1768. (No papers for 1765 nor for first seven months of 1766.)

Papers on Monte Cristi trade (principally duplicates of those in C. O. $152: 46)$.

Letter from Shirley, on reasons for removing Samuel Gambier (son of president of council) from council and court of vice-admiralty. Oct. 23, 1760. Encloses declaration of William Mowat, advocate general of the Bahamas, on alleged statements by Gambier that he was being paid by merchants of Philadelphia, engaged in the "Flag of Trucing Trade" with French islands, to do all he could for such vessels as were carried into the Bahamas as prizes, and that he did not consider such trade illegal. Oct. 23, i760. Other papers on Gambier case.

Petition to Shirley from "Sundry Owners of Privateers, Merchants, and Others, Inhabitants of said Bahama Islands", on illegal trade by northern colonies, and protection given it by Gambier. Alleged that Gambier was contracting to send provisions to Monte Cristi. Oct. 12,1760 .

Papers on seizure, and trial in court of vice-admiralty, of the snow Thomas and Waddle, seized by a Jamaica privateer because laden with French sugar, rum, and other produce. Release granted by Daniel Laroche, surrogate of court of vice-admiralty, on grounds that, on purchase, title to goods became British; and that, consequently, no law exists restraining such trade, even after declaration of war. I760. Judgment given in extenso.

Many papers on flags of truce, largely from northern colonies, going to Monte Cristi and other points in Santo Domingo. Wholesale charges of bribery and corruption against governor, judges of admiralty court, and other officials. Further information on the Thomas and Waddle. Among these papers is a copy of certificate granted by 
Shirley, July 22, I760, to flag of truce going to Monte Cristi with seven French prisoners.

"Address of sundry merchants of New Providence and Others, Commanders of or interested in Privateers: . . . the Business of Privateering is the most beneficial and almost the only profitable Trade carried on in these Islands." I760.

Articles of complaint against Shirley by Richard Derby of Salem, owner, and George Crowninshield, master, of ship Ranger, captured after clearing from Monte Cristi for Leghorn, and condemned at New Providence. Also, answer to these articles of complaint by James Bradford, judge of court of admiralty at New Providence. Other papers, showing that the Ranger was former French privateer, sold at Gibraltar, and commissioned as British privateer in I76I.

Letter from Halifax, on French raid on Turks Islands. Aug. Io, I764. Other papers on raid.

Proceedings in trial, in admiralty court, of John Bishop, accused of piracy in seizing Spanish vessel Nuestra Señora de la Soledad. Correspondence with Spaniards on same.

Papers on appointment of agent for Turks Islands.

Proceedings in murder trial in court of oyer and terminer. 1767.

"Heads of Rules and Orders for regulating His Majesty's Ponds on the Turks Islands." I767. "Heads of regulations" made for administration of Turks Islands. I767.

Letter from Shirley on Turks Islands, and on "break up" of Monte Cristi trade. Apr. 19, I767.

8. I768-I $77 \mathrm{I}$.

Apparently nothing of importance not found in C. O. 23:18.

9. I77 I-I779.

Order in Council, for disallowance of act of 1769 for establishing and regulating courts.

Reports of Richard Jackson on acts passed I770-I777, relating to: courts; governor's salary; making of cotton and coffee grown in islands legal tender to receiver general, assessors, and collectors; creation of parishes; governing of negroes, mulattoes, and Indians; education; security given by masters of ships; clearance of vessels to other British colonies; proceedings on attachments entering out of court of judicature; import and export duties; poll tax; and regulation of salt ponds.

Letter from Lieut.-Gov. Gambier, on supplying North America with salt from Turks Islands. June I5, I778.

Id., complaining of false accounts of seizure of Fort Nassau, printed in North American papers and reprinted in London. June I6, I778. Encloses minutes of Council, return of stores at Fort Nassau, etc. Many papers on American attack of Mar., I776, when island of New Providence was taken. Mutual recriminations between Gov. Browne and council, council blaming Browne for indifference to intelligence received, and for easy surrender, and Browne complaining of disaffection in colony, and of open encouragement and entertainment offered to Hopkins and his followers by attorney general, collector, and other persons.

Papers on Browne's refusal, on returning from North America, Dec. I6, I778, to continue licenses for trade with America granted by Pres. Gambier; claiming that, while licenses were ostensibly for 
supply of necessary provisions, they covered in reality illegal trade.

10. $1779-\mathrm{I} 78 \mathrm{o}$.

Many dismissals and replacements of officers involved.

W. Knox to R. Cumberland enclosing letters, etc., from Gov. Browne and others containing references to trade with America. Aug. I8, I780.

Letter from J. Maxwell, no. Io. Encloses "A list of Vessels Captured and Libelled in the Court of Vice-Admiralty in New Providence from the I June I779 to 30 June I780", including 37 American vessels. June 30,1780 .

"A Narrative of the Transactions etc. on the Invasion of the Island of New Providence by the Rebels in I776." Followed by depositions, . etc., on the same subject and also on trade with America during the war.

Letter from W. Knox. Encloses letter from Lord G. Germain to Gov. Browne, relating to rebel attack on the Bahamas. Dec. 2I, I780.

The volume contains also some unnumbered papers at end relating to Gov. Browne's defense, including 2 printed certificates:

(I) for clearing out a vessel from Beaufort, N. Carolina;

(2) a privateering commission signed J. Jay President.

11. I72I-I754.

Abstracts of letters from governors. (Incomplete.)

C. O. 23: 12-62, I52:46. Secretary of State: Original Correspondence. I696-I8I5.

12. I696-I73I.

Letter from Board of Trade on orders received for drafting commission and instructions for Roger Mostyn. Cannot "see how a Commission and Instructions can be properly prepared for a Governor of a Place where there are but twelve dispersed families". Asks that Stanhope receive his Majesty's pleasure on Board's representation of Dec. I4, I7I5, showing unfortunate conditions in colony, need for writ of quo warranto or scire facias, and for proper settlement and fortifications. Mar. 24, I7 I5/6. Copy of representation, Dec. I4, I7I 5, appended.

$I d$., on pirates. Sept. I3, I716. Enclosures: (I) representation on desertion of islands by proprietors, ruin of forts, and departure of population; points out importance of islands, and advises that government be resumed by the crown. Feb. 2, 1708/9. (2) Extract of letter from Spotswood to Board on pirates. July 3, I7i6. (3) Deposition of John Vickers of New Providence on pirates. $I d$., enclosing copy of representation of Board, of same date, on petition of Woodes Rogers for settlement of the Bahamas. Sketches early history of colony, and advises scire facias "in the Court of Chancery on the Patent" or quo warranto in King's Bench. Recommends acceptance of Rogers's proposal to go out in his own ship, spending at least $£_{4}, 000$, and taking out artificers. Suggests that Rogers, who is well recommended by many of best merchants of London and Bristol, be made governor and furnished with soldiers and large guns. July 26, I7 77.

Representation, advising resumption of government of colony by the crown, and sketching previous history. Dec. I4, I7 I5. 
Computation of expense of transporting five hundred Palatines to the Bahamas. I7 I7. Interesting for current prices.

Memorial of sundry merchants, complaining of neglect of colony by proprietors, and recommending Rogers. I 7 I7.

Several letters relating to Rev. Mr. Curphey, who desires to be chaplain of independent company in the Bahamas, and affording information on religious and other social conditions. I722. Also memorial from Phenney, asking that his Majesty give "a Service in Plate with Furniture for the Communion Table", pulpit, desk, etc., as to other colonies.

Papers on Spanish designs, depredations, and piracy. I723-I728.

Two memorials from lessees, showing what they have done in settlement, and requesting help. I723, I724.

"The Case of Capt. Woodes Rogers", picturing conditions in colony. July 15, I726. Petition of Woodes Rogers on same. Aug. 13, I727.

Duplicates of naval office lists: entries and clearances at New Providence, Dec. 26, I727-Mar. 25, I728.

Answers to customary queries. 1727.

13. I7I8-I727.

Letter from Rogers, on use of reformed pirates to catch those unreformed; sending to England for trial of three persons accused of piracy; work on forts; and other preparations against Spaniards. Dec. 24, I7 18.

Id. Character of settlers, French, Palatines, and others, whom he brought to the colony; discovery of conspiracy of settlers to desert island, and flogging of three convicted; neglect of the Bahamas by war vessels at Jamaica; poverty and high prices. Jan. 24, I7I8/9.

Id.; on same matters, and the friendship of inhabitants for pirates. Jan. 30, I718/9.

Id., on Capt. Dennis, who was sent by governor and council of Jamaica to Havana, to demand release of Englishmen held prisoners there and made to work on forts; and who, returning unsuccessful, reports fitting out of Spanish expedition. Feb. Io, I7 $8 / 9$.

Proceedings, on indictment for felony, in court of oyer and terminer and general jail delivery at New Providence.

Minutes of council, Nov. I4, I7 I8-May 26, I7 I9.

Letters from Rogers on pirates; Spanish preparations; poverty and misery of colony; and lack of both protection and direction from home government. I720-I723. (Distinctly more valuable than corresponding letters addressed to Board.)

Copies of correspondence between Phenney and governor of Cuba on piratical acts by Spaniards. Mar., I722/3.

Plan of harbor at New Providence. I723.

Sketch of church now building. I723.

Accounts of trials in admiralty court, convictions, executions, and pardons of persons accused of piracy. I722.

Letters from Phenney on fortifications; relations with Spaniards; and prosperity of the "remaining Palatines" in colony. Aug.-Dec., I723. Encloses: plan of Hogg Island, accounts of ordnance stores, and abstract of treasurer's accounts.

$I d$., on calling of assembly. Many inhabitants are pardoned pirates; but, as few of these have taken up lands, they have not much 
influence in assembly. Suggests that property qualifications for assemblymen and voters be made high. Jan. 2, I723/4.

Engineer's report on the Bahamas. I724.

Form used in grant of land. I724.

Papers on Augustine Blanco and other pirates. 1724.

Letter from Phenney on difficulties of government. "The other Councellors being so frequent at Sea among the Islands following their Employments, We have been sometimes Six Weeks and Two Months without a Number sufficient to make a Quorum." Sends list of persons suitable for appointment to council. "Several of them are very illiterate, which is unavoidable here." Jan. 28, I $725 / 6$.

Letter from governor and council. "The Bahama Society" compel payment of tenths; while, in so far as known, the proprietors turned back tenths for service of colony. Also, inquire how land grants should be made. Jan. 26 , I $725 / 6$.

List of fees appointed to be taken in the colony. I724.

Christenings, marriages, and burials, I72I-I726.

Plan of Fort Nassau.

Naval office lists for New Providence, inwards and outwards, Nov. I3, I 72 I-Mar. 25, I 727.

Minutes of council, Nov. I4, I72I-Feb. I, I726/7.

Accounts of stores, and abstract of treasurer's accounts.

14. I728-I 746 .

Minutes of council, Mar. I0, I726/7-Dec. I6, I727, Jan. 9, I727/8Jan. 2, I728/9, Aug. 25, I729-June I5, I730, Aug. I9, I730-Sept. 28 , I73I.

Naval office lists, inwards and outwards, Sept. 30-Dec. 25, I727, Mar. 26-Sept. 29, I728, Dec. 26, I728-Mar. 25, I729.

Births and burials. I727.

Treasury accounts. I728.

Testimonial sent to Walpole and Newcastle by Hans Sloane, Montagu, Heathcote, Micajah Perry, Alex. Spotswood, E. Vernon, F. Fane, Edward Southwell, Benj. Bennet, Samuel Shute, and others, recommending Rogers for second appointment as governor. Feb. 29, $1727 / 8$.

Numerous papers of various dates, from time of settlement to 1729 , on need for improvements in government of the colony. Memorials from merchants, proprietors, and governors, etc.

Letters from Rogers, on conditions in the colony, and conduct of Phenney. I730.

Minutes of assembly, Sept. 29, I729-Dec. 8, I730.

Papers on Spanish seizures and depredations, conditions of forts and troops, and political troubles in colony.

"Some Particulars of the Bahama Islands humbly proposed by $\mathrm{Mr}$. Edward Walpole...", on produce, trade, etc.

Letters from Fitzwilliam on negro troubles, Spanish wrecks, and mutinies. I732.

Minutes of council, July I7-Sept. 23, Nov. 8-I8, I734; endorsed as covering June 24-Dec. 25, I734.

Minutes of council in assembly, Aug. 20, I734-Jan. 4, I734/5.

"Copy of letter relating to a Rebellion in the Island of Providence." I735 (?). 
"The Case of the Inhabitants of the Bahama Islands" against the governor for engrossing trade, etc. I735.

Anthony Weltden, factor to South Sea Company at Havana, to Gov. Fitzwilliam, on designs of Spaniards. Feb. 6, I736/7.

Letters from Weltden to Gov. Oglethorpe, on Spanish designs against Georgia. In particular, on John Savy, "bailly" of Carolina, who declares himself to be in service of Spaniards and connected with scheme to take Georgia. Jan. I7, Feb. 6, I736/7.

Affidavits on Spanish preparations for war. I737.

Letter from Pres. Howell, sending copies of letters from various Spanish officials giving information on movements of shipping. Dec. 4, I739. Enclosures Spanish.

Francis Humphreys, factor to South Sea Company at Porto Bello and Panama, to Weltden, on preparation of Spaniards for war, movements of shipping, etc. Porto Bello, Sept. 28, I739.

Deposition on capture by Spaniards of the Charming Molly of S. C. I74I.

Letters from Tinker, on operations of continental privateers, and other naval matters. I74I, I742. (Only in part duplicated elsewhere.)

15. I735-1786. (Correspondence of Secretary of State with Board of Trade, forwarding correspondence with governors and other papers.)

List of affidavits and other papers relative to loss of brigantine Rebecca of Newport, Rhode Island, forcibly detained, I732, in his Majesty's service by Gov. Woodes Rogers. I740.

Copy of letter from William Bull, president of council of S. C., to Gov. Tinker, on designs of Spaniards against New Providence. June 29, I74I.

Printed lists of prices current, for provisions, naval stores, tobacco, wine, lumber, and other imports, from West Indian and continental colonies, and other places. Also printed accounts of import and export duties at the Bahamas, Bahama currency, rates of exchange, costs of pilotage and ship-building. Printed at Nassau, Sept.-Nov., I785, July, I786.

Petition of sundry merchants of Bristol recommending Woodes Rogers as person able to cope with pirates. Fifty-nine signatures. No date.

Correspondence with Treasury on Loyalists settled at the Bahamas. I783. Other papers on Loyalists, including petitions and letters from Thomas Ross of Georgia and others.

(For other papers see Andrews, I. I88.)

C. O. I52:46. (Part.) I748-I760. (This volume of original correspondence of Secretary of State with the Leeward Islands includes a number of papers relating to the Bahamas.)

Letter from Gov. Tinker, on importance, weakness, and neglect of islands. Apr. 4, I748.

Adm. Knowles to Tinker, describing taking of Port Louis. Mar. I3, I747/8.

Tinker to Board, on piratical seizures of Spanish vessels by British privateers. "I must say that hitherto the Spanish in these parts have maintained a perfect neutrality, and preserved a due observance of the treaty. . . . I cannot say as much for the procedure of the Dutch and Danes." June 20, I757. Enclosures include letter from governor of Havana. 
Pres. Gambier to Board, on trade of North American vessels with French in Monte Cristi under commissions as privateers. Sept. 30, I7 58 .

Letters from Shirley to Board, on same as foregoing. Mar. 29, Aug. I, I760. Enclosures include deposition of William Taggart of Newport, R. I., Apr. 21, I760, and copy of Spanish let-passes.

C. O. $23: 16$. I762-1767. (No papers for I765 or first seven months of I766.)

Letter from Shirley, on insecure state of colony, and inadvisability of reduction in garrison now being executed. May 29, I764.

Representation from Board of Trade: "Stating His Majesty's Right to the Turks Islands as part of the Lucayos or Bahama Islands", and showing to what extent title has been asserted. Aug. I5, I764.

Letters from Shirley, on French raid on Turks Islands, on the importance of those islands. July 19, 20, Sept. 3, 23, I764.

Halifax to Shirley, pointing out that colonies must put forts in best condition and provide for regular up-keep before requesting ordnance; stating that fleet must always provide principal protection; and reporting that French have disavowed raid on Turks Islands and promised full reparation. Nov. 8, I764.

Other papers on French and Spanish claims to the Bahamas and Turks Islands. Depositions, letters, etc.

Letter from Shirley, describing illegal trade with Hispaniola permitted by his predecessors. Feb. 25, 1765.

Papers on Nuestra Señora de la Soledad and acquittal of Bishop, who seized her, on his trial for piracy.

Memorials and letters, of various dates, by Andrew Symmer, appointed agent for Turks Islands, on their importance.

Treasury accounts, I76I-I764.

Letters relating to "phare", with an iron fleur-de-lis above and "choiseul" in iron letters below, set up at Turks Islands by French, and taken by British. Shirley accedes to D'Estaing's demand for its return after D'Estaing has renounced his claim.

Letter from Shirley, forwarding address of thanks from assembly for repeal of Stamp Act, and asking to have New Providence made a free port. Arguments advanced give much information on trade. Jan. 24, I767.

Shelburne to Shirley, stating that, on account of loss which Shirley has incurred through break-up of independent company of which he was commander, he is now allowed additional salary of $\mathfrak{t}_{3}$ oo, "payable out of H. M. 4 $\frac{\mathrm{T}}{2}$ per cent Duties from the Leeward Islands". June $20,1767$.

Correspondence of Symmer with Shelburne, showing that idea of appointing agent for Turks Islands was not only to give protection, but to encourage French and Spanish trade there, and to procure intelligence of conditions in French and Spanish settlements. According to Symmer this is "the most favorable opportunity to 17. I768. ruin the Monti Christo trade". I767.

Papers on Turks Islands. Letters from Symmer, describing progress of settlements, attempts to improve salt pans, and emphasizing strategic importance of islands. Papers on salt-raking, I767. Correspondence on refusal of Spaniards to deliver fugitive slaves 
from islands, I767. Account of salt shipped from Turks Islands, May I I-Nov. 29, I767. Representation on Turks Islands, May 3, I768.

Memorial from Shirley, on advantages of making New Providence a free port. 1768 (?).

Letters from Symmer, on suppression of Monte Cristi trade by Spanish authorities, and on transfer of part of same to Turks Islands.

18. $1768-1769$.

Letter from Shirley. Decline of colony; lack of staple, and consequently of trade; unfortunate nature of land system; and disastrous condition of local finances leading to removal of inhabitants. Dec. 9, I 768. Encloses answers to customary queries, statement of reasons for establishment of free port at New Providence, and plans of various forts and batteries constructed or projected.

Memorial of Richard Cumberland, agent for the Bahamas, begging for assistance in defense.

Letter from Symmer, describing trade with Turks Islands. North American vessels with cash go directly to Cape St. Nicholas, but those with produce stop at Turks Islands to trade with French there, French having placed heavy restrictions on trade by British vessels. English rice bought and shipped as French from Monte Cristi. Encloses account of goods landed at Turks Islands from North America since Nov. 7, I768. Jan. I7, I769.

Id. Has received orders to submit in all things to governor of the Bahamas and will obey. But "the settlers here are alarmed to the greatest degree for fear they must ... . be Subject to the Legislative Authority of Providence, in which case they are unanimously determined to leave the Islands". Jan. I7, I769.

Address from inhabitants of Turks Islands asking for independent legislature. Mar., I769.

Letter from Shirley, on administration of Turks Islands, and sending copy of instructions given by Shirley and council of the Bahamas to Symmer. Apr. 28, I769. Many other papers on Turks Islands.

Letter from Symmer, on Shirley's decision to extend to Turks Islands all laws of the Bahamas, including those for raising money. This will ruin settlers, extinguish commerce, and depopulate the islands. May Io, I769.

Letter from Shirley, on seizures of British vessels by Spaniards. June I2, I769. Encloses correspondence with governor of Cuba.

Hillsborough to Shirley, on suspension of illegal trade in Turks Islands,

19. I $769-$ I 770 . and Shirley's relations with Symmer. Aug. 4, I 769.

Papers on fortifications and reinforcements.

"Public revenue" of the Bahamas. I768-i769.

Letter from Symmer, on trade at Turks Islands. Jan. 5, I770. Other papers on relations between Shirley and Symmer, and showing amounts collected by Symmer as agent for the crown.

Hillsborough to Shirley, on decision of the crown that Turks Islands are to be part of government of the Bahamas. Fact that inhabitants of Turks Islands have no representation in assembly of the Bahamas makes no difference in legislature. "As the whole body of People belonging to the British Empire are represented by the Commons of Great Britain, so are the inhabitants of the Bahamas, 
in general, represented in the Assembly of that Government." Apr. I4, I770.

Letter from seven settlers and salt-rakers of Turks Islands, "being a Committee Chose by the Inhabitants", expressing apprehension of result of administration of Turks Islands by governor and council of the Bahamas. They and their fathers resorted to Turks Islands for ninety years, mainly from Bermuda. Interference by Shirley and council with local regulations for raking salt will ruin pans. Mar. I0, I770.

Letter from Symmer, complaining that governor and council of the Bahamas seize trading vessels without warning, and attempt to compel all vessels to enter and clear from Turks Islands through New Providence. Mar. 5, I770. Encloses copy of regulations for working salt-ponds adopted in the Bahamas. Mar. 5, I770.

Letter from Shirley, complaining of illegal commerce carried on in Turks Islands, under cover of salt trade, since Symmer's arrival, and of Symmer's refusal to admit Turks Islands as being dependency of the Bahamas. Encloses list of vessels entering Turks Islands from Boston, New York, and other places, Mar. 2-Sept. 25, I 769 , with names of captains, ports from which arriving, detail of cargoes, etc.; and depositions, decrees of court of vice-admiralty, and other papers relating to latter. Feb. I3, I770.

Numerous other papers on Turks Islands, salt trade, and disputes between Shirley and Symmer.

20. $1770-1771$.

Letter from Symmer, reporting success from threats to French and Spanish governors in Santo Domingo, that privilege of loading salt at Turks Islands will be withdrawn if runaway slaves are not restored or paid for. Nov. I2, I770. Correspondence enclosed.

Id., complaining that, largely on account of Shirley, "nothing but Confusion and Oppression prevails here at present", and asking for other employment or increase on his salary of $f_{1}$ oo sterling per year. Complains also of insinuation in letter written him by Shirley, June 20, I770: "while the Nights are dark and the Bar is smooth, you will not want your usual Night Cap". Nov. I2, I770

Hillsborough to Shirley, stating that papers on Symmer's contention have been laid before Board of Trade; and suggesting election of one or two representatives from Turks Islands to sit in assembly of the Bahamas. Feb. II, I77I.

Letter from Shirley, complaining that Capt. Thomas Hodgson, in command of recently arrived reinforcement to garrison, refuses, in defiance of sign manual, to recognize Shirley's authority to command all garrison troops. Jan. 29, r77r. Correspondence enclosed.

Hillsborough to Shirley, confirming him in command of all garrison troops, except in matters of regimental detail. May 4, I77r.

Letter from Symmer, on his service in Turks Islands, and on legality of legislation for Turks Islands by assembly of the Bahamas. Encloses copy of act of the Bahamas intended to apply to Turks Islands. Feb. I9, I77I.

Representation by Board of Trade, on Turks Islands, censuring Symmer for insubordination and for permitting illegal commerce. May 3I, I771. Hillsborough to Symmer sending representation and reprimand. June 8 , I $77 \mathrm{I}$. 
Letter from Shirley, enclosing copy of proceedings in court of admiralty, sitting for trial of piracies, felonies, and robberies committed on high seas, in case of the Matty, bound from Jamaica to Liverpool, which was seized by her crew. May 30, r77I.

$I d$, appealing for assistance in payment of judges and other officials. May 30, I77r. Encloses papers showing their salaries and perquisites.

21. I77I-1772.

Shirley to Hillsborough. Persistent denial of his authority at Turks Islands; continuance of illegal commerce there; embezzlements by Symmer; and reluctance of council of the Bahamas to support him in the use of force to correct these abuses. Also, on unfortunate effects of uncertainty concerning land titles in the Bahamas. Oct. ro, I77I.

Hillsborough to Shirley, reaffirming authority of governor of the Bahamas over Turks Islands, and empowering legislature of the Bahamas to decide what proportion of total taxes shall be paid by inhabitants of Turks Islands. Apr. I, I772.

Letter from Shirley, defending himself against various charges of misgovernment. In particular in cases of John Green and William Taylor, members of assembly. Green's original complaint was against writ of ne exeat, issued to prevent him from leaving island without settling suit brought against him in chancery. Having taxed court of chancery with injustice, he was committed for contempt, Feb., I767. Complained to assembly, but was ordered to make submission on pain of expulsion. Taylor being made a prisoner on an execution issued by admiralty court, delivered to council paper of complaints "so infamous and subversive of government" that he was condemned to six months" imprisonment; but, on intercession of assembly and his personal apology, was restored to marshal of court of admiralty. Many enclosures. May 9, r772.

$I d$, on pirates. May I5, I772. Encloses copy of proceedings in court of admiralty against pirates.

Letter from Symmer, on disorder in Turks Islands through disobedience of salt-rakers to regulations; and on refusal of Shirley to give assistance in suppressing disorders until full submission is made to government of the Bahamas. Oct. 3, I772.

22. $1773-1774$.

Letters from Symmer, complaining that Shirley refuses assistance and exacts high fees; and reporting increasing defiance of regulations on salt-raking by armed vessels from Bermuda. "Their crews had Paste Board Caps in the Grenadier Fashion with the word 'Experiment' printed on the Caps." I772-I773.

Letter from Shirley, sending and endorsing petition from council and assembly. Apr. I7, I773. Encloses petition: through grant of exclusive charter to private adventurers "who have long since abandoned the care of them", inhabitants are debarred from agriculture and land improvement. Revenues formerly secured from turtle fishery and woods, and from import duties levied. Exhaustion of woods and prohibition of import tax on British manufacturers have extinguished revenues. Courts closed because judges cannot be paid. Begs royal bounty for payment of salaries; and 
notes that Georgia became flourishing when charter was revoked and colony taken under royal protection.

Papers on case of John Green, still held in custody. Alleged that no court was held when ne exeat was granted. Other charges against Shirley.

Letter from Shirley. Nov. 6, I773. Enclosed letters from Symmer, on fresh disorders and illegal trade at Turks Islands, and papers on complaints from Bermuda of fees taken at Turks Islands by deputy of collector at the Bahamas.

Dartmouth to Shirley, announcing his promotion to be governor of Dominica as reward for merit. Feb. 5, I774.

Letters from Shirley, on Green's case, and on prosperity of the Bahamas at time of war and decline in time of peace. Nov. 26, 28, I773. Encloses answers to customary queries.

State of Capt. Blackett's company of the I4th Regiment on arrival at New Providence. July 4, I773.

Letter from Shirley, sending acts revised and repassed according to instructions sent him; one containing suspending clause. May I3, I774.

23. $1775^{-1777}$.

Dartmouth to Gov. Browne, ordering that case of Green be disposed of, and Green treated with all leniency possible. Aug. 2, 1775. Joseph Green to Dartmouth, sending John Green's statement of his own case, dated Nov. 30, I774, and including attack on Shirley: "the Governor Selling Soldiers and Selling. Justice publicly, his Officers did as he set them the example . . . smugling was continued as before with his approbation; of this I wrote to the Boston Commissioners". Council was in connivance with governor and for a private man to make accusations "was as much as his life was worth". Aug. 5, I775.

Letter from Browne, reviewing conditions. "The Bahama Islands can never arrive to any state of real advantage to the Crown until the propriety of the Lands can be secured to the Planters." At present inhabitants wander from place to place, cutting timber, selling it abroad, burning land over, raising a couple of crops, and moving on. "The vegetation is so totally destroyed that it can scarcely recover itself in ten years." Suggests that negotiations for buying out proprietors be renewed. Settled conditions of land tenure would also discourage "the abominable practice of wrecking", and illicit trade. May 6, I775. Encloses statements on produce, shipbuilding, fortifications, military stores, etc.

Letter from Gov. Browne, written from Pensacola. Describes conferences with Mr. Gauld, surveying engineer for the district, and engineer Hutchins, and others on situation of "the intended Town of Dartmouth on the Mississippi". June I2, I775.

Letter from Pres. Brown. Has received letter from Gen. Gage, dated Boston, Aug. 29, I775. Gage states that American vessels are fitting out for hostilities against West Indies; and has also heard of plan to seize government property at New Providence "as they have done in many places". Gage has consequently sent two vessels under convoy of man-of-war to remove all artillery and military stores from New Providence, these to be returned when island can be protected. Council of the Bahamas, on considering letter, 
declares that all forts, garrisons, and military stores are under sole direction of commander-in-chief of islands; that compliance with Gage's request would expose island and its commerce to attack; and that "the inhabitants of these Islands have upon all Occasions given every possible proof of their inviolable attachment and loyalty to H. M. Person and Government". Brown consequently notifies Gage, Sept. 29, I775, that he cannot allow military stores to be removed. Nov. 7, 1775 .

Important group of papers on raid on the Bahamas by expedition organized in Philadelphia under leadership of Esek Hopkins. Ships Alfred, Columbus, Cabot, Andrew Doria, Wasp, Fly, and Providence, commanded by Saltonstall, Whipple, Hopkins, Biddle, Hallock, Hacker, and Hazard, carrying I30 guns and I I70 men, participated. All military stores (except some powder sent to St. Augustine by governor on approach of raiders) seized, forts dismantled, and prisoners, including Gov. Browne and Irving, receiver general of North Carolina, carried off. Papers relate not only to raid, but to attitude of people of the Bahamas, to conditions and events observed by Browne in North America, to case of William Taylor (supra), and to operations of American privateers. Among more important are:

Letter from Chief Justice Atwood on failure of Gage to remove supplies before raid, events of the raid, and treachery of people of the Bahamas in notifying North Americans of weakness of colony, and inviting them to raid it. Mar. 22, I776.

Letter from Gov. Browne, on board Alfred, on sending of powder to St. Augustine, and treachery of Bahamians. Mar. I7, I776. Letter from Pres. Brown, describing raid. May 2, I776.

Memorial from William Taylor, describing raid and release of John Green and himself by Hopkins. Also, bringing serious charges against Gov. Shirley. Shirley caused acquittal of two Spanish prizes captured by Taylor's privateer, "who were Carriers to the French before the Spanish War broke out"; the Spaniards selling the cargoes of fine white sugars to governor and judges at very low prices before decision pronounced, on condition that decision should be favorable. Sugars were shipped away "without paying the King's Duties" and the Spanish captains taken into governor's service to bring him sugar, coffee, and wine from French. On return of Spaniards, governor libelled the vessels and pocketed all proceeds. May 20, 1776. Enclosures include statements of accounts, useful for current prices.

Memorial from John Green, complaining that though entirely innocent, he has been persecuted for fourteen years. Nov. 5, I775.

Letter from Taylor, sending copy of commission and instructions issued by Continental Congress to John Adams of privateer Chance, fitted out at Philadelphia; danger incurred by any person informing on co-operation given to North Americans by Bahamians. June $16,1776$.

Letter from Gov. Browne, describing raid, and seizure of Irving as "mandamus councellor of South Carolina". Describes fight of American privateers with the Glasgow, and heavy casualties among American wounded: "I suppose on acct. of the unskill- 
fulness of their Surgeons, and the want of Cloaths and other necessarys at their Hospital". Also, on his exchange "for that rebel who calls himself Lord Stirling"; and on assistance given to rebel privateer outside Providence harbor by James Gould, speaker of assembly, who "mutinied" on Mar. 3, and took eighty of militia with him. Rebels are also "countenanced and encouraged by some of the members of H. M. Council and officers of the Crown and Customs".

$I d$., on his attempts at recruiting men in Connecticut and their scattering in consequence of measures taken by Washington and Trumbull. New York, Nov. Io, I776.

$I d$., on same; on economic and military conditions; and on treatment of British prisoners by Americans. Middletown, Aug. 2, 1776.

24. I $777-\mathrm{I} 78 \mathrm{o}$.

Id., on destruction of rebel stores at Danbury. May 3I, I777.

Letter from Gov. Browne, no. 6, proposing the raising of two battalions of Iooo men each, one "of Connecticut men". Jan. 20, I 778.

$I d$., no. 8, reporting favorable reception by three-fourths of the colony of Connecticut and by "the Jersys" of drafts of bills to enable his Majesty to appoint commissioners. New York, May 4, I778.

Letter from Lieut.-Gov. John Gambier, reporting landing on Jan. 27 of party of marines from a vessel of war belonging to the American Congress; many Americans in the town joined them. Feb. 25, I778.

Id., reporting poor state of defenses. Salt supplied to Americans in large quantities. June 15,1778 .

$I d$., Mar. 7,1778 , enclosing copy of association entered into by inhabitants on Jan. 3I, I 778 , for defense.

Letter from Gov. Browne complaining of establishment of "a Juncto" by disaffected persons headed by the lieutenant governor and reporting landing of five rich cargoes of rebel property without any opposition from proper authorities. Feb. I2, I779.

$I d$., no. IO, . . . "the Lieut. Governor has repeatedly applyed to me, to continue a Licence he has thought proper to grant to the merchants of this place to carry on an open and free Intercourse with the Rebells, under the pretext of procuring Provisions, which request I have flatly refused . . ."; a plan in contemplation by the French to attack the island. New Providence, Jan. I I, I779.

$I d$., nos. I I and I9, reporting continuance of trade with rebels. Jan. I5, Feb. 27, 1779 .

$I d$., no. I3, reporting that the lieutenant governor had issued commissions against the French only.

Letters from J. Gambier and other members of council protesting against representation by Gov. Browne of their conduct during the attack in I776. Feb. 22, Mar. 3I, I779. Letter encloses "A Narrative of the transactions, etc. on the Invasion of New Providence by the Rebels in $1776 . "$

Letter from Gov. Browne, no. I5, referring to invitations issued in public papers to refugees to settle in islands. Apr. 3, I779.

$I d$., no. I6, reporting the seizure of "Young Cezar a remarkable fast sailing Schooner. . . Employed by the disaffected Inhabitants of the Government for the purpose of supplying the wants of the Rebels". June 29, I779. 
Id., no. 18. Encloses tables entitled “. . . Return of American Prisoners at Nassau for the Months January, February, and March"; ditto "for the Months of April, May, and June". Also "Instructions to Thomas Hodgson Esqr to proceed to Charles Town in South Carolina to establish a Cartel for the Exchange of Prisoners"; and "Articles of Agreement for the Exchange of Prisoners of War Between .. Montfort Browne . . and . . John Rutledge . . . Governor . . . of South Carolina etc. etc." July 4, I779.

Id., no. I9, reporting continuance of illicit trade. Sept. 24, I779.

$I d .$, no. 23. Encloses "A List of Prizes Condemned in the Court of ViceAdmiralty for the Bahama Islands since March I778". Feb. 6, I780.

Letter from Gov. John Maxwell, no. 9. French will not attack Turks Islands "as it answers the Americans getting salt, and keeps up an Intercourse for Intelligence". May 3, I780.

Letter from Gov. Maxwell, no. 12. Encloses "A List of Vessels Captured and Libelled at the Court of Vice-Admiralty in New Providence from I June I779-30 June I780". Includes 37 Americans. June 30, i 780 .

25. $1780-1786$.

Letter from Gov. Maxwell, no. I5. "I have been obliged to send the Rebel Prisoners to the first Port not being able to keep or Victual them." Sept. 24, I780.

Id., no. I7. "A small Fleet from the Cape have carried off all the salt from Turks Island." Feb. I, I78I.

Id., no. I8. Reports defenseless state of islands. Mar. I6, I781.

$I d .$, no. 24. Encloses "A List of Prizes . . ." to Apr., I782, including 127 Americans. Apr. I7, I782.

$I d$., reporting successful attack by Spain, Americans supplying the transports. Americans "disappointed . . . exceedingly" because they are not included in the capitulation. May 14, 1782. Encloses terms of capitulation, also letters and papers relating to the attack.

Letter from Brig.-Gen. McArthur, describing position at island of Abaco, "where the Colony of Refugees sent in September last from New York has settled". Quarrels among them. Another small colony from New York (6I persons) settled on Cat Island. "The numbers at Carleton and Marsh's harbour are 658 souls, . . . six hundred souls have been brought here from East Florida at the expense of Government, and about fifty at their own. Two settlements are formed near the south end of Abaco and a good number are going to Exuma." Mar. I, I784.

Letter from Gov. Maxwell, no. 2, enclosing a memorial from Loyalists. They number "about five Hundred Whites and one Thousand Blacks. . . . There are two Classes of Loyalists: the first consists of Farmers, who have set themselves down on the out-Islands with large Families and ten, twenty or one Hundred Slaves. . . . The second Class is composed of the officers Merchants, and People under a certain Description, who hope to return to the American Continent, when they have made their peace there. Nothing can satisfy these People. . . . Flour being very scarce, I have permitted the Americans to supply us.. . some of them have 
attempted to tear down the American Colours". The memorial follows.

Id., no. 3, enclosing address of Loyalists and proclamation against rioting and insulting the American flag. June 4, I784. Encloses "Return of Loyalists who have arrived in the Bahama Islands from North America".

Id., no. 5. July 29, I784. Encloses printed handbill summoning in the name of I4 persons "a General Meeting of the Loyalists from the Continent of North America, at Mr. Johnston's House . . . on Thursday the 29th inst . . ." Nassau, July 26, i 784 .

Id., no. 9. Encloses 18 papers mainly relating to Loyalists. Sept. 29, 1784 .

$I d$., nos. I0, I6, I8, relating to affairs of Loyalists. Oct. 8, Dec. 4, I784; Feb. 2, 1785 .

Letter from Lieut.-Gov. Powell, no. 2, relating to a meeting of Loyalists held on May 9: "it was amongst other things resolved, that the Members of which that meeting was composed were not represented in the present Assembly and of course not bound by any laws the Assembly might pass." . . . May I I, I785. Encloses address from Loyalists.

Draft to Lieut.-Gov. Powell, describing treatment to be given to Loyalist malcontents. July I 8, I785.

Letter from Lieut.-Gov. Powell, no. 8, referring to trade with America "carried on by Smuggling at the Islands of Abaco, Turks Islands, Exuma, Long Island, Cat Island, and Eleuthera, from whence the Goods are brought in small Craft, and sold at noon Day by Auction at this Place". . . . Oct. I6, I785.

Letter from Pres. John Brown, no. I. Encloses memorial from Loyalists; also "Return of the number of Loyalists". . . . Feb. 28, I 786.

Id., no. 2, relating to illicit trade. Apr. I7, I786. Encloses memorials on same subject: there "is scarcely a day but there are American Vessels at some one or other of the Out Islands smuggling Dry Goods and American produce and carrying off the most valuable productions of this Country. .. . And at Turks Island the 26. I $780-1786$. Americans are so daring as to carry away Salt by force".

"A List of Vessels and Cargoes Condemned this present War In the Vice-Admiralty Court of the Bahama Islands up to the eighth day of May I782." Includes I24 "rebell".

Letter from J. Hebburn, President of the Board of American Loyalists. Sept. 20, I784.

"The Memorial of Anthony Stokes . . . Provincial Agent for his Majesty's Bahama Islands." Relates to contraband trade. May I2, I 786.

27. I786-I 788 .

Letters from Pres. J. Brown, nos. I3, I4, I9, and from Gov. Dunmore, no. 7 , enclose:

Minutes of council, Sept. I I, I786-Jan. 3I, I787.

Journal of assembly, Jan. 8, I $787-F e b .2$, I 787.

Minutes of council, Jan. 31, I787-Apr. 25, I787. 
Minutes of council, Oct. $2-26,1787$.

Journal of assembly, Dec. 4, I787-Mar. I3, I 788 .

" "legislative council, Dec. 4, 1787-Mar. 13, I788.

Letter from Gov. Dunmore, no. I, referring to trade with America.

Nov. $28,1787$.

28. $\mathrm{I} 787-\mathrm{I} 788$.

Minutes of privy council. Oct. 26, I787-May 20, I788.

Letter from Gov. Dunmore, no. 9, enclosing papers relating to Loyalists. Aug. 8, r 788 .

Memorandum relating to Loyalists.

29. $1788-1789$.

Letter from Gov. Dunmore, no. II. Encloses minutes of council, June I2-Nov. I3, I788. Dec. 20, I788.

Letter from Zach. Wood, Turks Islands, Jan. I0, 1789. Encloses list of vessels loading salt from Turks Islands under 28 Geo. III., c. 6, Aug. 27, 1788-Jan. 5, 1789.

Letter from Gov. Dunmore, no. I3. Jan. 28, I789. Encloses naval office returns July I-Dec. 3I, I788; also "General Account of the Surveys made of Land for the Loyalists". . . , July 27-Dec. 3I, I788.

Id., no. 26, referring to trade at Turks Islands with American vessels. Sept. 5 , I 789.

30. $1789-1790$.

Journal of assembly. Feb. 5-June 26, I789.

Minutes of council in assembly. Feb. 5-June 26, I789.

" " council, Nov. I3, I788-July I, I789.

Letter from William Miller. Turks Islands, Oct. 7, r789. Encloses "An Account of Salt shipped at Turks Islands from Ist January i788 to 5 th Oct. I 789 ".

Letter from Gov. Dunmore, referring to carrying off of cotton to America. Apr. 5, r790.

Letter from Capt. Murray, reporting that American vessels have almost forsaken Turks Islands. Turks Islands, Apr. 3, r790.

Letter from Gov. Dunmore, no. 4, June I 5, I790. Encloses list of lands granted, Bahama Islands, Apr. 8, I788-Dec. 31, I789.

Id., no. 6. Encloses letter of Aug. 28, r790, reporting prevalence of smuggling by Americans in Exuma and Turks Islands. Sept. I, I790.

Minutes of council in assembly. June 8-July 23, I790.

Journal of assembly. June 8-July 23, I790.

Minutes of council, July 2, I789-June 2I, I790.

31. I790-I792.

Letter from Gov. Dunmore, no. I2. Encloses "Account . . . for Auditing Grants for American Loyalists". . . , Apr. 28, I790March 2, I791. May I6, I791.

Letter from Alexander Murray, referring to smuggling of supplies by Americans. Turks Islands, May 20, I792.

32. I 792-1793.

Letter from Gov. Dunmore, no. 25. Feb. 27, I793. Encloses :

Minutes of legislative council. July 3, I792-Aug. 27, I792.

Journal of assembly. July 3, r792-Aug. 27, I792.

Minutes of council. June 2r, I790-Oct. I 5, I792. 
Id., no. 27, reporting admission of provisions in foreign vessels for six months. May 25, I793.

Id., no. 27 [28?], reporting capture of vessels of the islands by French privateers fitted out at Charleston by Mr. Genet, "Calling himself the French Minister to the American States". June 25, I793.

Id., no. 29, reporting capture of fifty vessels by privateers. July I7, I793. $I d .$, no. $3 \mathrm{I}$, relating to eight vessels captured by privateers fitted out at Charleston by Mr. Genet. July I9, I793.

Id., no. 34, enclosing letters from Mr. Hammond, British minister to the United States, and Mr. Bond, British consul at Philadelphia, giving information of meditated French attack on islands. Sept. I4, I793.

Id., no. 35, on same subject: Genet is "giving every encouragement to people of all Nations to join him ... he is . . . getting a Number of Field Carriages made at New York . . . and . . . the whole Coast of America is lined with his Privateers". Oct. 9, I793.

Id., no. 36, Oct. Iо, I793. Encloses:

Minutes of council in assembly. July I6-Sept. I6, I793.

Journal of assembly. July I6-Sept. 16, I793.

Letter from Col. P. Irving, asking for reinforcements, and complaining of action of America "in suffering her vessels to take out French commissions and to make prizes of British property". May 26, I 793 .

33. I793-I794.

Letters from Gov. Dunmore, nos. 39, 42. Dec. I7, I793, Feb. 5, I794. Enclose :

Minutes of council. Jan. 2I-Sept. 6, I793.

Oct. 7-Dec. 23, I793.

List of prizes. Aug. I-Dec. I7, I793.

$I d$., no. 44, reporting extension of importation in neutral vessels to June 30. Feb. I7, I794.

Id., no. 46. "I am informed . . . that the French have collected a considerable force in the States and are joined by a General Clark, an American, with a Thousand Men, who has renounced his Allegiance to the States; and that they have marched to the Mississippi with a design to attack New Orleans. It is supposed that Monsr. Genet is with them, as he left New York on the arrival of a New Minister from France." Apr. 9, I794.

Id., no. 50, relating to trade with America. June 9, I794.

Letter from Adam Chrystie. June 22, I794. Encloses list of grants of land, June I8, I790-May 3I, I794.

34. I794-I796.

Letter from Gov. Dunmore, no. 4. Mar. 7, I795. Encloses journal of assembly, Sept. 19-29, I794.

Id., no. 8. May I3, I795. Encloses return of council showing Stephen de Lancey, chief justice, absent without leave, said to have left Mar. I8 with intention of going to American States; also minutes of council, Jan. IO, I794-Jan. I4, I795.

Id., no. I9. July 7, I795. Encloses:

Minutes of legislative council. Oct. 6, I795-Mar. I9, I796. 
Journal of assembly. Nov. 3-Dec. 23, I795.

35. I796-I797. Feb. I6-Mar. I9, I796.

Letters from Gov. Dunmore, nos. 2I and unnumbered. July I2, Oct. 22, I796. Enclose :

Minutes of council. Jan. 20, I795-Feb. 24, I796. Mar. Io-Oct. I7, I796.

$I d$., enclosing papers relating to "part the Americans in some of the States have been acting in support of the French". Nov. 12, I796.

Letter from Lieut.-Gov. Forbes. Encloses papers relative to capture of American ship Thomas. Feb. 26, I797.

36. 1797.

Letters from Pres. Robt. Hunt. July 14, Sept. 8, I797. Enclose:

Minutes of council. Oct. IO, I796-July I I, I797.

$$
\text { " " " Aug. 22-28, I797. }
$$

Votes of the . . . House of Assembly . . Nassau . . . (I796). Sept. 19, I794-Mar. 19, I796.

37. 1797-1798.

Letters from Pres. Hunt, nos. 7, 9, Nov. 24, I797, Jan. 27, I798. Enclose:

Minutes of legislative council. Nov. I, I796-May I I, I797.

Journal of assembly. Nov. 7-28, 1798.

Minutes of council in assembly. Nov. $7-28,1798$.

Naval office returns, Exuma. Jan. 5-July 5, I798.

38. I798-I799.

Letter from Gov. Dowdeswell, no. 25. Dec. 9, I798. Encloses naval office returns, Exuma, July 5-Oct. Io, I798.

$I d$., no. 7. "The new Commerce between America and the Spanish Colonies, is no doubt supported by Spanish Capital, in return for which, they notoriously supply them, with every necessary article of naval Warlike stores." Jan. 23, I799.

Draft to Gov. Dowdeswell, no. I I, relating to trade with United States. Apr. 6, I799.

Journal of assembly. Oct. 30-Nov. 30, I798.

Minutes of legislative council. Oct. 30-Nov. 30, I798.

39. I 799-1800.

Letter from Gov. Dowdeswell, no. 7. Feb. 23, I80o. Encloses journal of assembly, Oct. 22-Dec. 2, I799.

Id., no. 21. July 20, I800. Encloses:

Votes of . . House of Assembly . . Nassau . . . ( 1800$)$.

Oct. 22, I799-May 20, I80o.

Minutes of legislative council. Oct. 22-Dec. 2, I799.

Id. July 20, I800. Encloses:

Apr. 30-May 20, 1800.

Naval office returns, Exuma. Jan. 5-Apr. 5, I8oo.

40. I8OI.

$$
\text { Nassau. Mar. 25-June 25, I800. }
$$

Letter from Gov. Dowdeswell, no. 7. Apr. I, I80I. Encloses:

Naval office returns, Nassau. Dec. 25, I8oo-Mar. 25, I8o I.

Exuma. Jan. 5-Apr. 5, I8oI.

Naval office returns, Nassau. Mar. 25-Sept. 25, I8or. 
41. 1802 .

Letter from Pres. Hunt, no. Io. Jan. 28, I802. Encloses:

Minutes of legislative council. Oct. 6-Dec. 24, I8or.

Journal of assembly. Dec. I4-24, I80I.

Letters from Gov. Halkett, nos. 7, 9, I0, I7. Apr. 13, 15, 16, July 23, I802. Enclose:

Naval office returns, Nassau. Sept. 25-Dec. 25, I80I.

" " "Exuma. Oct. 10, I801-Apr. 5, I802.

“" " " Nassau. Jan. 25-Mar. 25, 1802.

" " " Nassau. Apr. 25-June 25, I802.

$I d$., no. I2. June 3, 1802 . Encloses minutes of privy council, Apr. 2, I80I-Jan. 29, I802.

42. 1802 .

Letter from Gov. Halkett, reporting temporary refusal of the inhabitants of Turks Islands to allow export of salt: several American vessels sent away without salt. Sept. 9, I802.

$I d$., relative to affairs of Indians, especially in Florida: Bowles, director general of the Muskogees, issued a proclamation in I799 ordering the departure of all Americans and Spaniards. Oct. I3, I802.

$I d$., no. 21. Encloses memorial relating to port of entry at Crooked Island. Oct. I 5 , I802.

Id., no. 22. Oct. I9, I802. Encloses journal of assembly, Mar. I6May I8, I802.

$I d .$, no. 23. Oct. 19, I802. Encloses:

Naval office returns, Nassau. June 25-Sept. 25, 1802.

“" " Exuma. Apr. 5-Oct. 10, I802.

$I d$., relating to payment of duty on salt at Turks Islands: it falls on the Americans. Dec. 14, I802. Note at end of letter gives amount of salt exported and tax paid, Aug. I7-Nov. I7, I802.

The volume contains also a number of papers relating to Bowles and the Indian nations under his command.

43. 1803 .

Letter from Gov. Halkett, no. I, relative to export of salt from the Bahamas in foreign vessels. Jan. I, I803.

Id., nos. 3, 6, I3, I7. Feb. 4, 20, Apr. 24, July 7, I803. Enclose:

Minutes of legislative council. Mar. I6-Dec. 29, I802.

" " privy council. Jan. 29-Dec. 29, 1802.

Naval office returns, Nassau. Sept. 25, I802-Mar. 25, I803.

" “ " Exuma. Oct. 10, 1802-Apr. 5, I803.

List of grants of town lots to May 4, 1803 .

44. 1803 .

Letters from Gov. Halkett, nos. 22, 25, 28. Aug. I, Oct. 3, Nov. 8, I803.

Enclose:

Minutes of assembly. Nov. 22-Dec. 29, 1802.

Naval office returns, Nassau. Mar. 25-Sept. 25, I8o3.

Papers relating to trade of Turks Islands and tonnage duty imposed there.

45. 1804 .

Letters from Gov. Halkett, nos. 9, I0, I4. Mar. 3I, Apr. 2I, I804.

Enclose :

Naval office returns, Nassau. Sept. 25-Dec. 25, 1803.

" " the Caicos. Oct. II, I803-Jan. 5, I804. 
Naval office returns, Exuma. Oct. Io, I803-Jan. 5, I804.

Journal of assembly. Nov. I5, I803-Jan. I3, I804.

Minutes of legislative council. Nov. I 5, I803-Jan. I3, I804.

Letters from H. M. Dyer, nos. 2 and 6. June I I, July 19, I804. Enclose naval office returns, Nassau, Dec. 25, I803-June 25, I804.

46. $\mathrm{I} 8 \mathrm{O} 4$.

Letter from H. M. Dyer, no. II. Aug. IO, I804. Encloses list of grants of land, May i8, I803-July 24, I804.

Letter from Gov. Cameron, no. 7. Dec. I4, I804. Encloses naval office returns, Nassau, June 25-Sept. 25, 1804.

Id., no. 9, relative to opening of ports for American imports. Dec. I7, 1804 .

47. 1805 .

Letters from Gov. Cameron, nos. I2, I3, 27, 30. Jan. I2, I4, Apr. 22, June I7, I805. Enclose:

Naval office returns, Nassau. Sept. 25, I804-Mar. 25, I805.

Proclamation prohibiting import in foreign vessels of grain, etc. June 7, I805.

Journal of assembly. Nov. I 3, I804-Apr. 5, I805.

Minutes of legislative council. Nov. I 3, I804-Apr. 5, I805.

48. 1805 .

Letters from Gov. Cameron, nos. 39, 47, 3. July I2, Oct. 5, Nov. 9, I805. Enclose :

Naval office returns, Nassau. Mar. 25-Sept. 25, I805.

Proclamation for extending importation of American produce to Jan. 9 .

49. 1806.

Letters from Gov. Cameron, nos. I I and i6. Feb., May 9, I806. Enclose naval office returns, Nassau, Sept. 25, I805-Mar. 25, I8o6.

50. 1806 .

Letters from Gov. Cameron. July I I, Nov. IO, I806. Enclose naval office returns, Nassau, Mar. 25-Sept. 25, I806.

$I d$., reporting issue of proclamation allowing importation of salted beef, etc., in neutral vessels for six months. Dec. I3, I806.

51. 1807.

Letters from Gov. Cameron. Feb. 9, Mar. 12, May II, I807. Enclose:

Naval office returns, Nassau. Sept. 25, I806-Mar. 25, I807.

Returns of exports and imports. I794-I805.

Minutes of legislative council. Oct. 28-Dec. 22, I806.

Id. Encloses letter from collector of customs, Apr. I8, I807, stating that it has been usual to allow exportation of sugar, coffee, and cocoa to America to pay "the King's duty". May I I, I807.

52. 1807 .

Letter from Gov. Cameron. Aug. 8, I807. Encloses naval office returns, Nassau, Mar. 25-June 25, I807.

Id. Sept. I0, I807. Encloses letter from J. Hamilton, Norfolk, Va., relating to U. S. proclamation of July 2 for departure of his

53. 1808 . Majesty's ships-of-war. Aug. 2, I807.

Letter from Gov. Cameron relative to trade of Turks Islands, Jan. 9, I808. Encloses tables of imports from and exports to U. S., Jan. 5, I794-Jan. 5, I795, in British and American vessels respectively. 
54. 1808.

Letter from Gov. Cameron, reporting information that Congress has passed resolution authorizing the President to suspend embargo and non-importation acts when he shall think fit. June I3, I808.

Id. Oct. I I, I808. Encloses Votes of . . . House of Assembly . . .

56. 1809 . Nassau. . . . (1807.) Oct. 27, I807-Feb. 29, I808.

Letter from Pres. Munnings. Aug. 9, 1809. Encloses list of grants of

57. I8 iо. land, Aug. 28, I788-June 29, I809.

59. 1812.

Papers relating to trade of Turks Islands.

Letter from Pres. Munnings, reporting preparations for defense in view of hostile aspect of American affairs. July 20, I812.

Id. Receipt on July 24 of news of declaration of war by U. S. Sept. I4, I8I2.

$I d$. Detention of several vessels under American colors and twelve vessels under Spanish colors bound to the Havana with cargoes supposed to be the property of Americans. Sept. I6, I8I2.

Draft to Gov. Cameron, no. 6, directing every facility to be given to officers placed in charge of American property detained: John Dougan officer for Bahama Islands. Nov. 9, I812.

Letter from Pres. Munnings, describing preparation for war: defenses when U. S. commenced hostilities only one sloop-of-war and a schooner of ten guns. Nov. 26, I8I2.

Letter from Gov. Cameron. Encloses affidavit dealing with seduction of British seamen from their allegiance by U. S. Dec. I2, I8I2.

Papers relating to trade of Turks Islands.

60. I813. (See Palson and Paullin, Guide, etc., p. 284.)

Letter from Gov. Cameron, no. 2, stating that letters of marque against U. S. had not yet been issued. Jan. I I, I8I3.

Id., reporting departure of John Dougan, his work being finished. Mar. 9, I8I3.

$I d$., reporting capture of the Apollo by an American privateer, and her subsequent recapture. Mar. 9, I8I3.

$I d$., enclosing two letters from chiefs of Indian tribes stating that I0,00012,000 Indian warriors are said to be assembled to oppose Americans in the south and to be asking for British aid. Oct. 28, I813.

Id. Encloses documents relative to Indian tribes in America. Nov. $3^{0}$, I8I 3 .

61. I8I4.

Letter from Gov. Cameron, no. I4, acknowledging receipt of despatch no. I7 of Jan. 21, I8I4, relative to "admission of American subjects into the Naval Service" and to American Indians. Apr. I, I8I4.

Id. Encloses "Extracts of letters from Pensacola relating to American and Indian affairs". Apr. I7, I8I4.

$I d$., no. 20 , with enclosures relative to expedition to assistance of Indians. Aug. 6, I8I4.

62. I8I5.

Letter from Gov. Cameron, no. 12, giving information of signature of Treaty of Ghent. Apr. I5, I8I5. 
$I d$., no. I7, relative to sale of American negroes in the Bahamas. May 9, I8I 5 .

Id., no. I8, relative to an inquiry as to an American prisoner of war said to have been on the islands. May 9, I8I5.

Papers relative to sale of American negroes in the islands.

C. O. 24 :I-5, Board of Trade: Entry-Books. I7I7-I784.

C. O. $326: 33$. Index to Board of Trade Correspondence. I7I7-I759.

1. I7I7-I742.

Draft of commission for Woodes Rogers. Nov. 21, I7I7.

Draft of instructions for Woodes Rogers. Brief, but accompanied by copy of instructions given to governor of Jamaica, for his general guidance. Marginal note: "June 3, r73r. Capt. Phenney said at the Board that the Copy of these Jamaica Instns. mentioned in this Article, was of those given to Sr. Nic. Lawes." Rogers is not to call an assembly, but report on proper number to constitute one; and is not to make laws until assembly has been called. Nov. 21, I7I7.

Letter to Addison, sending attorney general's opinion concerning surrender of proprietors. Dec. II, I7I7.

Letter to Craggs, endorsing petition of Gohier, Buck, and other undertakers on sending of soldiers to the Bahamas. Jan. 2, I7 I8/9.

Letter to Rogers, answering his request for confirmation of appointments to council. "I believe you have not considered what the expence will be, it will come to at least $\sum_{9}$ I $5 s$. a head which will be in the whole about $E_{\mathrm{II}} 7$, And, as there is no Person here that I know of authorized and enabled to disperse that Money it will be to no Purpose to recommend them to His Majesty, since the Warrants will lie in the offices for want of Fees, which ought to be paid indeed proportionably by each Person put into the Council as in other Plantations." Jan. I5, I7 I8/9.

Letter to Craggs, on necessity of sending troops, military stores, and warship to the Bahamas without loss of time. Feb. 4, I718/9.

$I d$., on request for reimbursement by copartners, who own ship Delicia which is used as guard-ship by governor pending construction of forts. Also recommending sending of troops and stores, and the extension of settlements in Florida. Dec. 4, I7I9.

Representation on Lord Craven's petition. July 25, I720.

Id., on state of the Bahamas and on what has been done by lessees in sending out artificers and other settlers (including some Spanish prisoners of war), in driving off pirates, in furnishing guard-ships, in fitting out sloops and constructing forts, and in repulsing Spaniards. Sept. 9, I720.

Draft of commission for George Phenney. Introduction alone given, remainder, according to subjoined note, being identical with that of Rogers. June 20, I72I.

Letter to Carteret, with representation on memorial of copartners praying for charter of incorporation. Memorial shows expense and trouble involved by lack of proper incorporation, and need for royal bounty for support of troops and payment of governor's salary. Board, in representation, endorses memorial, but lays down instructions for regulation of capital and dividends of corporation; designed mainly to prevent "stockjobbing and those other inconveniencies" which 
have lately arisen from misapplication of charters. Specifies also amount of shipping to be employed, and facilities to be extended for commerce. Advises that "all powers of government" be retained by the crown. June 30, I72I.

Letter to Phenney, requiring that plans for an assembly be sent. June 26,1723 .

Representation, on calling of assembly. Nov. Io, I726. Other papers.

$I d$., censuring Phenney, and reporting on state of the Bahamas. Oct. I, I728.

Draft of commission for Woodes Rogers. Nov. 29, I728.

Draft of instructions for Woodes Rogers, showing alterations comprised in temporary provisions for election of assembly. May 13, I729.

Report to committee of Council, on value of lands in the Bahamas, and amount which the crown should pay for them. Sept. 8, I730.

Letter to Rogers, on powers and procedure of legislature. "It would be proper that the Proceedings of the Assembly also should resemble those of the Parliament of Great Britain so far as the Circumstances of the Colony and your Instructions will permit. . . . We may observe to you that the Constitution of England owes its preservation very much to the maintaining of an equal Ballance between the branches of the legislature." June 29, I73I.

Representation to lords of committee on purchase of islands. Mar. 9, I73I/2. Other papers on purchase.

Introduction of draft of commission for Fitzwilliam; remainder omitted as identical with that of Rogers. Jan. IO, $1732 / 3$.

Draft of instructions for Fitzwilliam. Mar. 21, I732/3.

Representation recommending purchase of islands. Mar. 7, I732/3.

Letter to Fitzwilliam, stating that his Majesty, in purchasing, will purchase all rights of proprietors including tenths, which governor should therefore collect. Aug. 8, I735.

Representation on complaints of Chaloner Jackson against Fitzwilliam. Mar. 2, I737/8.

Draft of Gov. Tinker's commission. Apr. 2, I740.

Draft of Gov. Tinker's instructions. July 24, I740.

2. $1743-1760$.

Letter to Tinker, on act of 1745 for settling and extending current rates of foreign gold. Points out that act should have had suspending clause, and clause distinctly providing that provision should not restrain his Majesty from settling rates by proclamation or instructions to governor. July I4, I749.

$I d$., on sending of ordnance stores; showing recent policy in this matter, amount sent, etc. June 7, I753. Other papers on military stores and fortifications.

Draft of commission for Shirley. Nov. 7, I758.

Draft of Shirley's instructions, showing no important alterations. Feb. $20,1759$.

3. $176 \mathrm{I}-1774$.

Letter to Admiralty, on Shirley's removal of Samuel Gambier as judge in admiralty court. Mar. Io, I76r.

Draft of Shirley's commission. May 29, I76r.

Draft of Shirley's instructions (including trade instructions). June 23, r $76 \mathrm{r}$. 
Papers on case of ship Ranger.

Letter to Halifax, on British title to Turks Islands. Feb. I 5, I765.

Letter to Shirley, on treatment of Spanish vessels entering the Bahamas in distress. Feb. I5, 1765.

Letter to Conway. Obstacles to settlement of Turks Islands through proprietorship of private persons in the Bahamas; French designs at Santo Domingo for cutting off British commerce; and suggested renewal of negotiations for purchase by the crown of title to lands in the Bahamas. Dec. I0, I765.

Draft of Shirley's commission. Oct. 23, I767.

Draft of Shirley's instructions. Mar. 7, I768.

Representations on Turks Islands : British title; relation to the Bahamas; appointment of Symmer to look after trade; and his attempt to organize civil government. May 4, I768, May 3I, I77 I.

Representation for disallowance of two acts passed I768 and I769, one on establishment and regulation of courts of judicature. Jan. I2, I77I.

Draft of Browne's commission. Feb. 7, I774.

Draft of Browne's instructions (including those on laws of trade). May 5 , I774.

4. I775-1781. Instructions, Commissions, Board of Trade Correspondence.

5. I784. Instructions for Governor Maxwell.

C. O. 326:33. I7I7-I759. Table of contents of Board of Trade original correspondence. Also, list of out-letters and representations of Board of Trade, as appearing in tables of contents of entry-books.

C. O. 24:6-i7. Secretary of State: Entry-Books. i766-i829.

6-7. I767-I78I.

Abstracts and copies of letters from governors and others. Mainly, if not wholly, duplicated in C. O. 23:I7 et seq.

8-13. I 789-1808. Précis of correspondence.

14. I768-I801. Letters from Secretary of State to Board of Trade, governors, agents, and others.

Letter to governor of the Bahamas (pp. 2-I7), referring to position of Loyalists. Sept. 25, I784.

15-16. I784-I8I3. Out-Letters.

Letter to Gov. Halkett (Pp. I $32-133$ ), relative to reception of persons "who had been induced to emigrate to the United States but who have not been admitted to the rights of American citizens". Aug. 30,1803 .

17. I8I3-I829. Out-Letters.

C. O. $25: I-5$. Acts.

1. $1729-174 I$.

4. $1768-1773$.

2. $1743^{-1} 753$.

5. I774-I $78 \mathrm{I}$.

3. $1764-1767$.

C. O. 26:I-9. Sessional Papers.

Minutes of council, and of council in assembly, are in C. O. $26: 1-6$ and 8. A list of them follows: 


\section{O. 26:I-6, 8. Sessional Papers.}

1. I72I, Nov. I4-I72I/2, Mar. 6. Minutes of council, A, pp. I-93.
I721/2, Mar. 8-I723, Aug. 4 .
1723, Aug. 7-1726, May I6.
I726, May I6 $2-1726 / 7$, Feb. I.
1726/7, Mar. Io-1727, Dec. I6.
I727/8, Jan. 9-1728/9, Jan. 2.

$$
\begin{aligned}
& \text { " “ } \text { “ } \text { “ B, Pp. 94-I86. }
\end{aligned}
$$

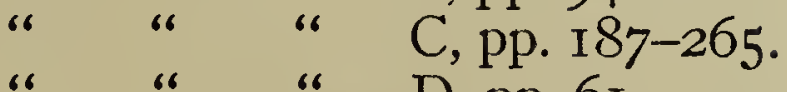

$$
\begin{aligned}
& \text { " " " " } " \text { " } \\
& \text { “ “ “ “ } \text { “ }
\end{aligned}
$$

2. I729, Aug. 25-I730, June I 5. Minutes of council, pp. 25.

I730, Aug. 9-1731, Sept. 28.

I733, Nov. 29 3 -I734, June 21.

I734, July I7-Nov. 28 .

the half-year, pp. 8.

I734/5, Jan. 4 and Mar. I I.

I735, July 5 and Nov. 26.

I735/6, Mar. 8.

I736, July I 3 and Sept. 7.

I736, Dec. 23 and I736/7, Mar. 8, 9.

I737, Mar. 26 and Aug. 20.

I737/8, Jan. 5 .

I738, June I 2 .

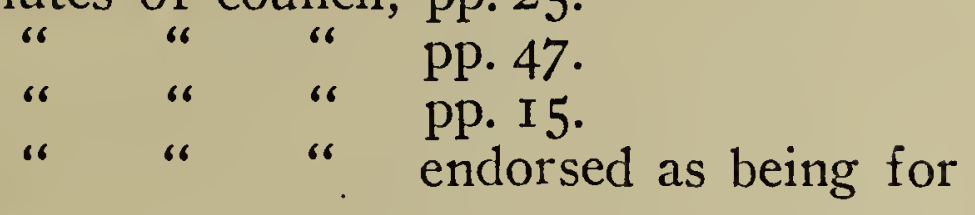

I734, Aug. 20-I734/5, Jan. 4. Minutes of council in assembly, pp. 38.

I736/7, Mar. 8-i6.

pp. 16.

I738, July I-Aug. 5. Minutes of council, endorsed as to Sept. 29, "No Council between Michaelmas and Christmas", pp. 8.

3. I739, July I6.

I739, Nov. I.

I739/40, Jan. 5-Mar. I9.

I740, Apr. 7-June I7.

I740, July 20-Sept. 25.

I740, Oct. 2, 3, 25, and I740/4I, Jan. 9.

Minutes of council, each endorsed as covering the quarter to which they belong; A-F, pp. 2, 2, 5, 8, 9, 4 .

I74I, Apr. 23-I744, Nov. 8. Minutes of council, endorsed as to Dec. 25, $\mathrm{G}, \mathrm{pp} .28$.

I74I, Sept. IO-I74I/2, Mar. I6. Minutes of council in assembly, "a", pp. 44 .

4. I746/7, Feb. I I.

I747, Sept. II.

I $747 / 8$, Mar. I.

I748, July 2 I.

I748/9, Feb. I6.

I749, July 20.

I 749/50, Feb. 22, 27.

I750, Nov. 9, I 3,17 .

I750, Nov. 2 I ; I75I, Jan. Io, Feb. 26, May 9.

I75I, July 9, Aug. 27, Oct. 29, Dec. I7.

I752, Mar. 2-May 29.

I752, July 2-I754, Jan. 8.

I754, June I5-Dec. I7.

I755, Aug. 8-I757, July 6.

Minutes of council on these dates, each endorsed as for the half-year to which they belong; nos. I-8, pp. 2, 2, 3 , $2,2,3,4,5$.

${ }^{2}$ Duplicate of previous entry.

- The first after Fitzwilliam's arrival. 
I747/8, Mar. I-I9.

I749, Nov. 27-I750, Mar. 9.

I750, Nov. 9-13.

I753, Jan. 9-20.

I753, June 26-Sept. 25.

5. I764, May 10-22.

I766, Nov. I8-1767, Feb. 3 .

Minutes of council in assembly, pp. I6.

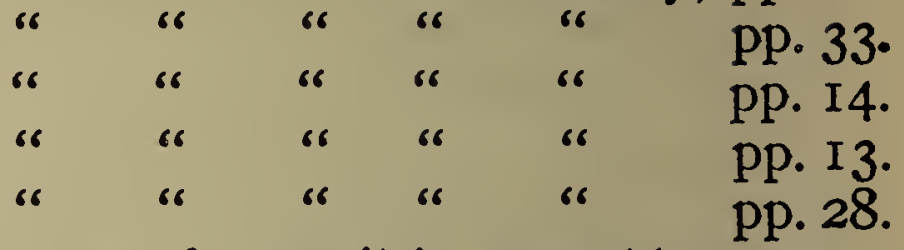

Minutes of council in assembly, pp. II.

pp. 37.

6. I764, May I0-22. Minutes of council in assembly (duplicate of above in $26: 5)$, pp. Iо.

I772, Jan. 2I-Feb. 28. Minutes of council in assembly, pp. 8.

I774, Sept. 23-1775, Feb. 22. Minutes of council, pp. 6.

I775, Mar. 20-1776, Mar. 4.

I776, May 7-I777, Apr. 23.

I779, Nov. Io-I780, Mar. 6.

I780, Mar. 8-May ıo.

I780, July I4-I78I, Mar. 2 I.

I776, Dec. I7-21.

I779, Dec. 2 I-I780, Jan. 6.

I780, Mar. 2I-May I.

I780, Sept. I2-Oct. 4.

I781, Feb. 6-21.

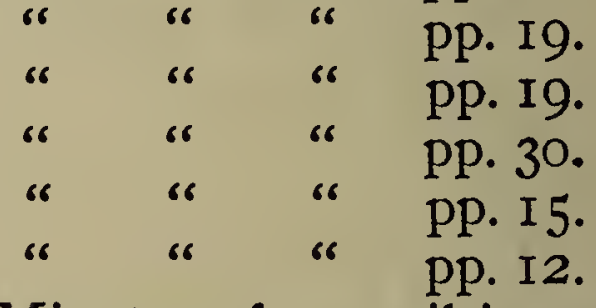

I786, Feb. 23-Apr. 7. Minutes of council, pp. I6.

8. I 768 , Oct. $25-$ Nov. I 5 .

1768, Dec. I3-1769, Mar. I7.

I769, Nov. 2-I770, Oct. II.

I770, Nov. I9-I771, Mar. I2.

I772, Jan. 2I-Feb. 28.

(Duplicate.)

I772, Mar. 3I-Apr. I6.

I773, Jan. I2-Feb. I2.

I775, Dec. 4-I776, Mar. 28.

I773, Aug. 24-I774, Feb. 5 .

I774, Dec. I 2-24.

Minutes of council in assembly, pp. 9.

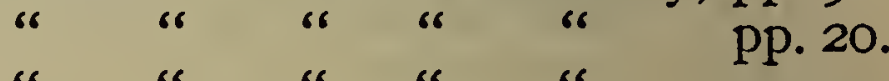

" " " " " $" 4$ pp. 44 .

" " " " " $"$ " $" 12$.

pp. I2.

Minutes of council in assembly, pp. 6 .

“ “

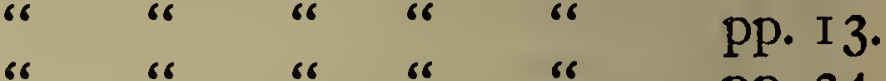

" " $"$ " $"$ " $"$ "

pp. 8 .

It has not been thought needful to list here the journals of the assembly. All that exist from the beginning in I729 to I794, whether found in the Colonial Office Papers or in the island archives in Nassau, have been put into print, in one consecutive series, by the care of the speaker, Mr. Harcourt Malcolm. They are entitled: Votes of the Honourable House of Assembly of the Bahama Islands, and run as follows: I. I729-1753 (Nassau, I9I0); II. I760-I765 (I9I0); III. I766-I770 (I9II); IV. I770-I776 (I9II); V. I779-I786 (I9I2); VI. I787-I790 (I9I3); VII. I79I-I794 (I9I3). With the brief session of Sept. I9-29, I794, contemporary printing began. It is understood that the library of the assembly in Nassau contains a set of these printed journals from I794 till long past the date (I8I5) with which this Guide closes. ${ }^{4}$ The British Museum has the following:

Votes, etc., Sept. I9, I794-Mar. 19, I796 (Nassau, I796).

Apr. 30-Dec. 18, 1800 (ibid., I800-1801).

Oct. 6-Dec. I0, I801 (ibid., I801).

Nov. I3, I804-Jan. I4, I805 (ibid., I805).

Feb. 26-Apr. 5, I805 (ibid., I805).

${ }^{4} V$ otes of the Assembly, I902, p. 173 and appendix; 1906, p. 283. 
And a few, as has been shown on previous pages (pp. 36, 39, ante), are in C. O. $23: 36,39$, and 54 .

12. Inward:

C. O. $27: 12$, I3. Shipping Returns.

I721, Nov. I3-I727, Mar. 25. I 727 , Sept. 30-I 728, June 24. I 728, Dec. 26-I 729, Mar. 25. I 729, June 25-Sept. 29. I729, Dec. 25-I73I, June 24. I733, Dec. 26-1734, June 24.

13. I752/3, Jan. 5-1754/5, Jan. 5 . Outward:

In C. O. 27:I2 the list for Sept. 29-Dec. 25, I728, is present, and that for Dec. 25, I734-Mar. 25, I735, is missing. With these exceptions the lists correspond to the inward returns.

MISCELLANEOUS.

The following papers are with shipping returns:

12. List of ships outward, no cargo stated. Apr. 21, I74I-Mar. 25, I748.

13. Accounts of duties, inward and outward, and of duties collected for the governor's salary, pursuant to act of assembly, giving details of ships and dutiable cargo. June 25-Dec. 25, I755.

Balances of revenue and disbursements. June 25, I755-Dec. 25, I756.

\section{BARBADOS.}

C. O. 28:I3-35. Board of Trade: Original Correspondence. i709-i782.

13. I709-I7I2. (Papers of dates previous to July I, I7II, are listed and described in Cal. St. P. Col., I708-1709, and I7IO-I7II.

Papers on danger to Leeward Islands from the French, and the assistance sent from Barbados; on refusal of island to provide for prisoners; and on the responsibility of the British men-of-war for capture of British merchant shipping. I7II, I7I2.

List of prizes taken into Martinique, July, I I Io-May, I7II, giving ports of origin in the continental colonies and elsewhere.

Letter from Gov. Lowther on capture and ransom of Surinam. Dec. 20, I 7 I 2 .

Commission and instructions issued by Gov. Lowther to Brig.-Gen. Maxwell and others to go to Martinique and treat for a truce with the French there. Feb. 2, I7I2/3.

Letter from Lowther. Injury sustained by Barbados from disregard shown by Leeward Islands for royal orders concerning fees and value of foreign coins ; support of religion and other matters. Dec. 20, I7I I.

Numerous papers on seizure of ship Oxford, arriving from Ireland, for breaches of laws of trade.

List of French prizes taken, July, I7II-Mar. I7II/2, with some particulars concerning each.

14. I7I2-I7I7.

Letter from Lowther, on his need for more authority on naval matters. May 28, I7I2.

'The return for Dec. 26, 1742-Mar. 24, 1742/3 is among prize papers of the High Court of Admiralty (vide Andrews, Guide, I. 189). As these papers are arranged according to the name of the vessel captured, no attempt was made to find them. 
Accounts of ordnance and other stores, June 2, Aug. I, I7 I2.

Account of christenings and burials, by parishes, giving also the numbers of schoolmasters, June 22, I7 I I-June 22, I 7 I2.

Account of negroes imported, June 22, I7II-June 2, I7I2.

Statistics of inhabitants, by parishes, distinguishing age, sex, and color; also of whites and slaves fit to bear arms; also of horses and plantations. I7 I2.

Account of prizes and seizures dealt with in court of admiralty, June I IJuly I2, I712, with some particulars regarding each.

Memorial of the agent, regarding importation of sugar, rum, and molasses from Surinam into New England, Oct. 6, I7 I3. Letter from Harley, showing evil effects of such traffic. Nov. 4, I7I3.

Letter from Bolingbroke. Complaints from French regarding trade carried on by British vessels at Martinique. July IO, I7I4.

$I d$., on money due officers of ordnance for stores supplied. May 20, I7I4.

Papers on John Colleton's appointment to council.

Letter from Sharpe, president of council, on French claims to St. Lucia and Tobago. Feb. 28, I7I4/5. Also copies of correspondence between governors of Barbados and Martinique on the subject.

Letter from Stanhope, on claims of the crown and assembly in appointment of treasurer. July I I, I7 I5.

Reference of a letter from Lowther to Townshend on appointment of secretary, and his emoluments. Dec. 28, I7I4.

Order in Council for preparation by attorney general and solicitor general of a bill to prohibit such intercourse as that involved in importation of produce of Surinam into New England. Feb. 20, I7I3/4.

Order in Council on committee of Council's three representations: one relates to settlement of the Bahamas and another to trade of African Company. Jan. 2, I7 I5/6.

15. I7 I 5-I720.

Letter from Lowther, on the British and French, British and Spanish, and French and Spanish trade in the West Indies. Cartagena and Porto Bello formerly centres of Spanish trade; but Spaniards are now supplied by French at Panamá and other ports of the South Sea. Oct. 25, I7 I5. Enclosures include correspondence between governors of Barbados and Martinique, and detailed account of negroes imported and exported, Apr. 24, I7I4-Apr. 24, I7 I5.

Letter from Methuen. As treaty of I686 with France still holds good, governors of British colonies must prevent trade with French. Apr. 8, I7 I7.

Memorial from agents of Barbados, asking confirmation of act laying. duties on importation of all foreign sugars, and discussing cost and selling prices of British and French sugars. Read Sept. 27, 1717.

Opinions of solicitor general and Richard West that Spanish vessels cannot legally be permitted to trade with the British islands. Jan. 29, Feb. 4, I719/20. [Printed in Chalmers, Opinions, ed. I858, pp. $566,567$.

Numerous papers concerning illegal trade carried on from Barbados with French and Spanish settlements, and containing accusations of connivance by the governor.

Letters from Lowther on prevalence of piracy and measures for suppressing it. July 20, I7 I7, Nov. 9, I7 I8. 
Accounts of christenings and burials, Apr. 24, I7 I 5-Apr. 24, I7 I6.

Papers relating to attempt of Rev. W. Gordon to set up an ecclesiastical court under a commission from the Bishop of London.

Lists of causes determined and pending in court of error and court of chancery, I7I6-I7I7; in court of chancery and courts of common pleas, I7I7-I7I8; and for all of these courts, I7I8-i7I9. Proceedings in court of grand sessions, I7 I8-17 I9.

Papers relating to fees paid to patent officers. Opinion of attorney general on act to ascertain the payment of bills issued under the Paper Currency Act. I7I7.

Report of Commissioners of Customs to Lords of the Treasury on importation of clayed sugars as muscovado. Mar. 28, I7 I9.

Numerous letters and other papers on British and French titles to St. Lucia and St. Vincent.

Account of poll tax on negroes, raised for repair of fortifications, I7 I 5 .

Letters from Carkesse (for Commissioners of Customs), on laws for farming the $4 \frac{1}{2}$ per cent. Apr. 24, May I6, I720.

16. I7I5-I719. ${ }^{1}$

A large mass of papers on disputes between Gov. Lowther and Alexander Skene, secretary of Barbados. Received Jan. 4, I7I4/5.

Complete returns, by parishes, of all white inhabitants, with the names of all families, number of men, women, boys and girls in each family, and age of each individual. Read Oct. 6, I7 I9.

Minutes of commissioners of contracts, on state of the fortifications in Nov., I7I 5 .

17. $1720-1723$.

Numerous papers concerning quarrels between Cox, president of council, and council, and between Cox and the secretary. In particular, "Minutes of the Hearing before Mr. Worsley upon the complaints against Mr. Cox". June, I723.

Letter from Cox, describing his co-operation with French in taking measures against a pirate. Feb. 4, I720/I.

Letter from W. Gordon, on settlement of St. Lucia, July I4, I720. Petition of Duke of Montagu for grant of St. Lucia and St. Vincent. Jan. II, I72I/2. Other papers relating to those islands and Tobago.

Letters from Lowther and other papers on administration in courts of exchequer and common pleas and on other legal matters at Barbados.

Orders in Council approving drafts of commissions for Viscount Irwin and Lord Belhaven as governors. Feb. 26, I720/I, and May 5, I72I.

Observations by Commissioners of the Customs on instructions to Lord Belhaven, appointed governor of Jamaica, exportation of Irish linens to the plantations, and giving of security by naval officer. June I4, I72I.

Papers on settlement of Tobago.

Letters from Cox and from Gov. Worsley on contraband trade from Martinique and other French colonies with British islands, continental colonies, and Ireland. Aug. 23, Nov. 8, I721 ; Mar. 20, I722/3, July I6, Sept. 24, I723. Other papers.

${ }^{1}$ This volume consists only of the three groups of papers listed, groups apparently judged too bulky to be inserted in their natural places. 
Letter from Horatio Walpole expressing desire of Treasury for opinion of Board on payment to president of the council of one-half the governor's salary. Feb. I3, I721/2.

List of I 5 forfeited bonds. List of fines, forfeitures, and escheats imposed at court of grand sessions in June, I723. List of gunners, matrosses, and ordnance stores in Barbados in I723. Papers relating to disputes between officers of casual revenue. All enclosed in Worsley's letter of Sept. 24, I723.

18. I723-I727.

Letter from Worsley, sending depositions of several persons captured by pirates, and forced into their service. Nov. 24, I723.

Several papers, including letters from Commissioners of the Customs and Richard West, on act laying import duties on "wines and other strong liquors" imported into the island.

Orders in Council on representations of the Board, approving act on affirmation by Quakers. Apr. 6, 30, I723.

Report of Richard West on act providing for issue of bills of credit. May 4, I724. Memorial of merchants in London trading to, and interested in, Barbados against the act. May 6, I724. Order in Council for its disallowance. Aug. 22, I724.

Letter from Worsley on trade of northern colonies with Martinique. June I3, I724.

Letters from Worsley and Newcastle on French and British claims to Tobago. Nov. IO, I724; Jan. 24, I724/5; Apr. I9, I725.

Answers by Worsley to queries on trade, shipping, produce, population, fortifications, revenues, courts, etc., of Barbados, with lists of persons holding the more prominent positions, and account of enforcement of laws of trade. Oct. I8, I724.

Letter from Commissioners of the Customs, with account of $4 \frac{\mathrm{T}}{2}$ per cent. duty, I7I5-I724. Mar. 8, I724/5.

Proceedings in court of escheat, held before Thomas Warren, "his Majestie's Escheator General”, Oct. 8, I725-Jan. I 5, I725/6.

Lists of escheats pronounced in court of grand sessions; business before court of grand sessions in Dec., I725; fees taken in the various offices; and christenings and burials, Jan. I722/3-Jan., I725/6.

Treasurer's accounts showing numbers of negroes imported, etc., Aug., I723-Aug., I725.

Lists of negroes imported I707-I726, in some cases distinguishing those imported by the African Company from those imported by independent traders, and giving particulars regarding each cargo.

Papers on appointments of deputies by patent officers, with specimens of deputations, instructions, and powers of attorney. I727.

19. $1727-1728$.

Letters from Worsley, complaining that assembly does not always present its speaker-elect, omits suspending clause in legislation, attempts to exclude crown officials from assembly, inquires into executive matters, wishes to see accounts before payment, etc. "This part of the World is Infected with the Maxims of the Representatives in New England." Complains also of fees demanded by patent officers. Aug. 4, Oct. I6, Dec. 4, I727. Other papers.

Petition of Duke of Montagu, desiring grant of Tobago instead of St. Lucia, which he proposes to give up. Jan. 23, I727/8. Papers 
relating to activity of French at St. Lucia and St. Vincent. Letter from Newcastle asking for report on the matter. Mar. I5, I727/8.

Treasurer's accounts, showing numbers of slaves imported, Aug., I725Aug., I726.

Letter from Worsley, complaining of capture of ship, laden with sugar for England, by Spanish privateer from Santo Domingo. July 20, I728. Deposition of ship's master enclosed.

20. I728-I729.

Letters from Worsley, describing old and new disputes with assembly, which is erroneously believed in the colony to enjoy powers "analogous to those of the House of Commons", especially in financial matters. Aug. 14, Sept. 13, Dec. I0, I6, I728. Other papers.

Letter from Mr. Lightfoot of Barbados, complaining of governor's choice of persons for grand and petty juries, and sending lists of persons with number of negroes and amount of other property owned by each. Dec. 30, I728.

Papers relating to Tobago and St. Lucia.

State of public debts, Jan. 19, I728/9; statements of various public accounts, I726-1729.

Opinions of Worsley and Fane on act for reducing the rate of interest from to to 8 per cent. Nov. 8, I728; July I7, I729.

21. I729-173I.

Numerous letters from Worsley, and other papers, concerning refusal of inhabitants of most parishes, from I727 on, to pay poll tax on negroes and mills by which governor's additional salary was provided. It is contended by those refusing to pay, and denied by lawofficers of colony and crown, Board and Privy Council, that act instituting tax expired with Worsley's first commission on death of George I. Other questions arise, such as liability incurred by vestrymen and assemblymen in not presenting returns. Attempts of the crown to secure payment of arrears of additional salary claimed by Worsley extend over a number of years. Leader of party refusing payment is Mr. Haggett of council, who, so governor is informed, "Laid the Foundation of the disturbances that happened in New England whilst Col. Shute was there". Enclosures in Worsley's letter of Apr. 24, I730, include detailed accounts of amounts raised by tax in 1729 , lists of all slave-owners in each parish, and lists of all who paid, with numbers of slaves, windmills, and cattle-mills owned by each.

Letters and addresses on failure of Duke of Montagu's settlement at St. Lucia, French activity at St. Lucia and St. Vincent, conferences at Paris concerning these islands and Dominica, agreement for evacuation of all three islands, and possible retention of Tobago and St. Croix.

Minutes of court of chancery, Jan. I728/9-July, I 729.

Various reports on act for reducing rate of interest in Barbados.

Letter from Worsley on refusal of Spaniards at Porto Rico and Hispaniola to give satisfaction for seizure of British vessels; complaints from Worsley of trade carried on with French colonies from Ireland, and with French and Dutch colonies from the northern colonies. July 7, I 730 . 
"Letter from Mr. Vernon, one of the Clerks of the Council dated $23^{d}$ Novr. I730 inclosing Copies of two Petitions from the Traders to the Sugar Islands, complaining that Ireland and the Northern Colonies are supply'd with Sugar etc. from the French and Sugar Plantations; with Copies of three other Petitions in behalf of the Northern Colonies ag't the sd. two Petitions and desiring the Board to be present at the Comittee of Council $2 \mathrm{Ith}$ of Decr. to hear what may be Offer'd on each Side." Text of the five petitions. Letter from Stanyan, one of the clerks of Council, announcing adjournment of meeting until Dec. 25. Letter from Sharpe, agent for Barbados, concerning hearing of two petitions from merchants of Dublin and Liverpool. Jan. 29, I730/1. Other papers.

22. $1730-1732$.

Letter from Worsley on seizure of British vessels for illegal trade at St. Lucia. Mar. 27, I731.

Proceedings of committee of council and assembly on public accounts, Jan. I8-Mar. I2, I730/I, showing amounts collected under certain taxes.

Accounts of collections under excise law and on importation of slaves, Nov., I728-May, I730. (The collections on importation of slaves, of which many accounts are found in succeeding volumes, supply full information of all cargoes of slaves brought to the island.)

Order in Council, referring petition from several merchants trading to Barbados that governor be not in future permitted to accept additional salary voted by assembly. July 27, I73I.

Letter from Worsley, referring to large sums of money raised for soliciting petitions on trade of northern colonies with French islands. Letter from Newcastle referring petitions on the subject from assemblies of Barbados and Antigua. "Observations on and Reasons in answer to the Representations from Barbados, Antigua and St. Christopher's, relating to the Trade between the Northern Colonies and the French and Dutch Settlements." The Case of the British Northern Colonies. Letter from Leheup, agent for Barbados, enclosing "A Reply humbly offered on behalf of the Island of Barbadoes to the Observations on their Petition and to the Address from the Northern Colonies." I730, I73I.

Order in Council permitting merchants and planters concerned in petitions from the sugar colonies to withdraw them as application has been made to Parliament for relief. Apr. 8, r73I.

Letter from Oxenford, assistant inspector general of exports and imports, giving account of sugar imported into and exported from British islands from Christmas, I726, to Christmas, I730. Imports from various British islands and exports to various foreign countries are separately listed. Feb. $8,173 \mathrm{I} / 2$.

Letter from Worsley, describing activity of French at St. Lucia, St. Vincent, Dominica, and Tobago, and enclosing copies of his correspondence with governor of Martinique on British vessels seized at St. Lucia. June 27, r73r.

23. $1732-1733$.

Letters from Newcastle enclosing addresses of House of Lords, on laying before the House, by Board of Trade, of representations from sugar 
colonies on decay of sugar trade and commerce between British and French colonies. Mar. 23, I731/2; Apr. 6, I732.

Letter from Barwick, president of council, on trade carried on at Barbados by French sloops. Oct. 6, I732.

Order in Council referring petition of Dunbar, surveyor general for Barbados, the Leeward Islands, and Bermuda, that he be made a member of council in each of said governments. May 22, I733. Order in Council approving favorable report of Board on Dunbar's petition, and commanding that an additional instruction be sent to each of the three governors to admit Dunbar as "councillor extraordinary" during residence. July 3, I733. Order in Council referring petition from Dunbar that he be made a "councillor in ordinary", since any inferiority of position would hinder him in "preventing the passing of any acts or orders any ways tending to the Prejudice of His Majesty's Revenues". Nov. 23, I733.

Memorial of governor, council, and assembly praying that a British statute, "for the More Easy Recovery of Debts in His Majesty's Plantations and Colonys in America", be not applied to Barbados; reviewing legislation passed there for recovery of debts; and describing conditions with reference to trade and currency. I733.

Letters from Viscount Howe, governor of Barbados, on evacuation of St. Lucia, St. Vincent, and Dominica, publication of his commission in those islands and in Tobago, and seizure of British sloop at Tobago by Spaniards. July I, I733.

Treasurer's accounts and lists of stores. I730-I 732.

Extensive and important papers on attempts to secure payment of arrears of Gov. Worsley's additional salary.

24. $1734-1737$.

Letters from Howe and Fane on act to regulate fees collected by patent officers. Feb. 4, I733/4. Apr. 6, I734. Orders in Council for the disallowance of act and forwarding by governor of table of fees as collected in Queen Anne's time. Feb. 12, 1734/5; Apr. 3, I735.

Papers on requests of island for ordnance stores, and measures taken locally to provide for defence, including order in Council, Apr. 3, I735, directing sending of. stores and providing what proportions of cost shall be borne by home and colonial governments.

Order in Council for appointment of Surveyor General Dunbar as a councillor in ordinary. July II, I734.

Letter from Howe, on declining trade, prosperity, and population of the island, flight of debtors to South Carolina, and seizure of vessels belonging to Barbados and Virginia by Spaniards; suggesting that Spanish vessels be admitted to trade; and that planters be allowed to send "at least their improved sugars" directly to foreign markets. Nov. 7, I734.

Id., pointing out that, while commissions of earlier governors declared that a law should not be in force for more than two years unless confirmed, there is still in force a law of 1676 concerning which no evidence of confirmation is to be found. Nov. 23, 1734. Opinion of Attorney General Blenman of Barbados on this and on several questions relating to early constitutional history of the island. Nov. 20, 1734 . 
Letters, memorials, and depositions of various persons on British and French claims and activities with respect to St. Lucia, St. Vincent, Dominica, and St. Croix; also on attacks on British vessels by Spaniards.

Letter from Dottin, president of council, describing declining prosperity of Barbados and depreciation of its currency; and complaining that the island is asked to spend more on defense than it can afford, because the large proceeds of the $4 \frac{T}{2}$ per cent. tax, which should provide for defense, go largely into pockets of collectors. Oct. 2I, I735.

Id., concerning judicial appeals to Privy Council. June I4, I736.

Papers on the land system.

Further papers on arrears of Worsley's salary.

Accounts of ordnance stores and of population, distinguishing age, sex, and color.

Treasurer's accounts, statements of amounts raised from all sources, and lists of annual expenses of government; also, account of all laws imposing duties and impositions which were in force in Mar., I73I, and of those passed up to 1735 .

25. I737-I742.

Two memorials from John Ashley, "one of the Deputys of the Rt. Honble. Horatio Walpole Esqr. as Surveyor and Auditor General of All His Majesty's Revenues arising in America, late member of His Majesty's Council of the Island of Barbadoes", on decay of sugar trade. The remedies proposed are permission for direct exportation of sugar to foreign markets, measures for relief of debtors and preservation of their estates, and lowering the rate of interest. Among the accompanying papers are: "Settlement and Insolvency Bill as proposed for Barbadoes and An Explanation of the Fall of the said Island", I737; "The Fall of Barbados since the French Edict of 1726 permitting a Direct Exportation of their Clay'd Sugar, and other Produce from their Sugar Plantations to Several Parts of Europe"; a table showing fall from I723 to I734 in yield of the $4 \frac{1}{2}$ per cent. and quantities of produce on which it was levied; Some Observations on a Direct Exportation of Sugar from the British Islands, printed at London, and containing interesting statements and tables; and "The Miserable Case of the British Sugar Plantations", a pamphlet in manuscript signed "Britannicus", also with elaborate tables. Read, July 6, 20, I737.

Four letters from Dottin, president of council, on activity of French at St. Lucia, seizure of British vessel by French, illicit trade carried on by British war vessels, manner in which expenses of court of grand sessions should be defrayed, and reluctance of assembly to insert suspendnig clauses. "The Assembly seldom care to make an act wherein this clause is incerted because it has generally happen'd to lye a long while without being Confirm'd or Disallow'd, An Instance of which is this Clause about four years Since." Dec. I2, I736; May I4, Aug. 20, I737; Jan. 24, I737/8.

$I d$., in answer to Board's circular letter issued pursuant to addresses from both Houses of Parliament on rates of gold and silver coins and issue of paper currency in America. Nov. 9, 1739.

"The British Right to the Islands of St. Vincent, St. Lucia and Dominica," presented to Board by Robert Dinwiddie, Apr. 29, I740. 
Letter from Gov. Byng, on payment for small arms sent out, and also the question whether naval officers can make seizures for breaches of laws of trade on their own account, or merely as assistants to officers of customs, when such seizures are made in ports and within jurisdiction of the governor. May 14, I740.

$I d$., asking for copy of printed laws of Barbados just completed. Aug. I3, I740.

$I d$., on measures taken for defense and the issue of letters of marque. Sept. 20, I740.

Letter from Dottin, president of council, on attempts of assembly to control expenditure. Dec. 30, I740.

Representation of assembly to Board, declaring its intention to discontinue grant of additional salary to governors. Oct. 28, I748. Orders in Council on this subject and on employment of proceeds of the 4/2 per cent. Apr. 15, July 10, I74I. "An Account of the Produce of the four and half $p$ Cent Duty that has arisen from His Majesty's Colonies of Barbados and the Leeward Islands since His Majesty's Accession to the Throne, with the Application thereof."

Letter from Dottin, on act for relief of debtors and state of the island's trade. Apr. 2, I74I.

Treasurer's accounts, and accounts of christenings and burials.

26. $\mathrm{I} 742-\mathrm{I} 745$.

Letters from Robinson to Newcastle, of which the following are the most important:

Trade of Barbados with French settlements, and activities of French at St. Lucia, St. Vincent, Tobago, and Dominica. Nov. 27, I742. Impressment, privateering by British vessels, militia, and need of ordnance. June 25 , I743.

Describing measures taken for defense, and showing that the assembly has agreed to pay for small arms and ammunition. Dec. 3 , I743.

Troubles connected with impressment, plans for defense, and disposal of prisoners of war. May Io, I744.

Impressment, disposal of prisoners of war, and French activities at St. Lucia. July I 5, i744.

Exchange of prisoners of war, military weakness of the island, and trade between Ireland and French colonies. Enclosures include copy of agreement for exchange of prisoners, and depositions on Irish trade. Mar. 24, I744/5.

Arrival of French fleet, and measures taken to protect the island. Enclosures include letters from Commodore Knowles. May 8, I745.

Operations of French at St. Lucia. July 7, I745.

27. $1745^{-1747 .}$

Order in Council for sending of ordnance stores, with lists of stores and prices. Feb. 27, 1745/6.

Numerous letters from Gov. Robinson on quarrels with assembly concerning rights of latter to inquire into executive matters, to compel presence of witnesses and production of documents, and to control finances of the colony. I746 and I747. Enclosures include several numbers of the Barbados Gazette. 
Order in Council, referring letter from Lords of the Admiralty, who propose that commander of war vessels stationed at Barbados and Leeward Islands shall be appointed a member of councils of Barbados and Antigua. Dec. I8, I746.

$I d$., for appointment of Legge as member extraordinary of council during time of his command of his Majesty's ships in those seas. June 3, I747.

Papers on privateering, including transcripts from journal of the captain of a privateer, and giving some information on naval matters.

Lists of magazines, forts, batteries, and stores. I747.

Account of powder collected under gunpowder act, I740-I747.

Account of negroes imported, Oct. I4, I746-Apr. I4, I747.

Letter from Robinson, answering at unusual length the usual queries concerning conditions of all sorts in the island, including information concerning French at Martinique, and enclosing plans of fortifica-

28. 1746 . tions at Barbados. Feb. 20, 1746/7.

"Letter from Sir Thos. Robinson dated the 27 Feb'ry, I745/6. In Answer to I 5 Articles of Complaint against him by some Gentlemen of the Assembly." This letter with accompanying papers occupies the entire volume. Robinson seeks to defend himself against charges of having prevented bills passed by assembly from going to Council, of robbing council of its functions as a branch of the legislature, of misapplying public funds, of levying taxes by using slaves in construction of public works without compensation to their owners, of disobedience to instructions in choice of judges and of members of council, of unreasonable adjournments of assembly, of neglect of duties as chancellor, etc. Papers accompanying Robinson's refutation include: lists of meetings of council, assembly, and court of chancery during his administration, showing where each meeting was held and what persons were present; minutes of council, Mar. I4, I744/5-Feb. I8, I745/6; and journals of assembly, Mar. I4, I744/5-Dec. 24, I745.

29. $\mathrm{I} 748-\mathrm{I} 75 \mathrm{I}$.

A large number of important papers, occupying the greater part of the volume, on St. Lucia, Dominica, St. Vincent, and Tobago. British and French claims to, and settlements on the islands; efforts made to strengthen these claims in I748; agreements for evacuation negotiated by Pulteney and Bladen in 1723 or 1724 , by Lord Waldegrave at a later and unspecified date, by governors of Barbados and Martinique (with respect to Tobago only) in I749, and by British and French governments in I749; and measures taken to execute the agreements of 1749 . Letters, memorials, and representations from Duke of Newcastle, Duke of Bedford, governor, agent, committee of correspondence and council of Barbados, and other persons and bodies. A number of proclamations, orders, and other papers on the same subjects are found as enclosures.

Statistics of population for I 748 ; returns of christenings and burials, I747-I75I; of importation of slaves, I747-I75I; of payments of gunpowder tax, I747-I75I ; and storekeeper's return, I750.

Letter from Gov. Grenville, enclosing replies to Board's customary queries on trade, shipping, population, produce, fortification, courts, revenues, etc., of the island. Feb. 8, 1748/9. 
30. $\mathrm{I} 75 \mathrm{I}-\mathrm{I} 756$.

Papers on evacuation of St. Lucia, Dominica, St. Vincent, and Tobago.

Letter from Gov. Grenville, enclosing his "Observations on His Majesty's General Instructions to Him", and his "Observations on His Majesty's Orders and Instructions relating to the Acts of Trade and Navigation". Dec. I4, I752.

Petition from the provost marshal, on alleged attempts to deprive him and his deputies of fees. Read Feb. 26, I754. Other papers.

Letter from Weekes, president of council, complaining of state of court of exchequer. Sept. I6, I755. Other papers.

Several papers relating to misconduct and removal of Judge Fairchild of court of common pleas.

Accounts of burials and christenings, and of importation of slaves, and storekeeper's accounts. I75I-I756.

31. I756-I759.

Letters from Gov. Pinfold on measures taken for defence.

Statistics of population. "Tis Allow'd on all.Hands That the above is a very imperfect List and fall[s] at Least $\mathrm{I} / 3 \mathrm{~d}$ short of the real Numbr. of Inhabitants which from the Nature and Disposition of the People cannot more exactly be come at." Signed by secretary of the island. 1756.

Accounts of christenings and burials, and of importation of slaves, and storekeeper's accounts. I756-1759. Memorial of provost marshal, complaining of encroachment on his powers and fees by court of chancery. I757. Letter from Pinfold defending court of chancery, and explaining recent act on court of exchequer. May 3I, I758. "The Humble Memorial of the Masters in Chancery." I758.

Petition of merchants and planters residing in Barbados and the Leeward Islands for addition of two packet boats to the four now in operation, in order that they may have time to place their insurance before their ships are captured by the enemy. $175^{8}$.

Letter from Pinfold, complaining that the Dutch carry Irish provisions to French both directly and through St. Eustatius; brigantine fitted out by the island has successfully protected trade with northern colonies. He has published his commission in Tobago, but has been unable to do so in St. Lucia, Dominica, and St. Vincent. Complains that acts of Barbados are in print only up to 1738 . Jan. 7, I758.

32. $1760-1767$.

Letter from Pinfold on trade from Barbados with French through neutral islands.

Accounts of christenings and burials, importation of negroes, payments of powder duty, and treasurer's accounts.

Letter from Pinfold, forwarding replies to customary queries. May 30, I 762 .

Petition from provost marshal, that act "regulating" proceedings of himself and his subordinates be not confirmed. Read June 22, I763. Other papers.

Letters from Pinfold, on misbehavior of John Adams, who armed his negroes to resist provost marshal. May 28, Nov. 12, I764; July 6, I 765 .

Letters from Pinfold, and Bishop of London. Removal of two beneficed clergymen; discussing jurisdiction of Bishop of London in colonies; 
authority of governor over local clergy; farming of ecclesiastical livings; and establishment of ecclesiastical court. Dec., I763-July, I765. Other papers.

Letter from Pinfold, admitting that he has not forwarded lists of vessels inwards and outwards which were called for; but "for many years before my arrival, this had been discontinued, and as I am informed, by the permission of the then Lords Commissioners". June 22, I764. $I d$., on French settlements at Cayenne. Sept. 25, I765. Enclosures.

$I d$., reporting that enforcement of Stamp Act has been "quiet and easy", although "North American correspondents have spared neither Threats nor Entreaties to persuade us to imitate their Outragious and Rebellious Conduct". Feb. 21, I766.

Barbados Mercury, Mar. 22, I766.

33. $1767-1772$.

Letter from Hillsborough on obstruction of justice from insufficient number of councillors in the island. Jan. $27, \mathrm{~s} 768$.

Accounts of negroes imported, powder duty collected, men able to bear arms, and christenings and burials.

Letter from Gov. Spry, on administration of justice in court of common pleas. Sept. 24, Nov. 4, I768. Other papers.

$I d$., reporting loyalty of colony. Sept. 24, I768; July 8, I769; Mar. I, I770; Nov. 29, I77I ; June I, I772.

$I d$., on trade from Barbados with Spaniards, and British depredations on Spanish Main. Refers incidentally to presence in island of two Spanish agents of the Asiento. Aug. 27, Sept. 19, 1769. Other papers.

$I d$., on negro insurrection at Tobago. Dec. 20, I770.

34. I772-I78r.

Richard Jackson's opinion on act for establishing fire companies : involving question whether there had arisen here special circumstances which would justify local legislature in creating corporation. Nov. I6, I772.

Accounts of christenings and burials; slaves imported; gunpowder collected to Aug., I773, and money collected in lieu of gunpowder after that date.

Letter from Pres. Rous on "implied disgrace" to island in decision that Barbados should in future have a lieutenant governor. Jan. 20, I773.

Richard Jackson's opinion that act placing import duty on negroes is "repugnant to the General Principles adopted by the Government with respect to its Colonies". Mar. I4, I764.

Letter from Gov. Hay, on duties of naval officer. May 9, 1776.

Opinion of Richard Jackson that act of assembly for preventing correspondence with king's enemies raises question whether assembly may declare to what cases laws on high treason may extend. Nov. I6, г780.

Letter from Samuel Estwick, agent for Barbados, on new and oppressive fees executed by secretary; and on misuse of the $4 \frac{1}{2}$ per cent. Feb. I4, I78I.

Other papers relating to the $4 \frac{\mathrm{T}}{2}$ per cent. duty. 
35. $\mathrm{I} 78 \mathrm{I}-\mathrm{I} 782$.

Letters from naval officer of Barbados. Aug. I5, Sept. 26, I78r. Encloses lists of entries and clearances. Nov. I I, I780-Aug. Io, I78I.

36. 1705-1753. Abstracts of Board of Trade, Original Correspondence.

C. O. $28: 38-42$. Miscellaneous Papers Accumulated in the Offices of the Secretaries of State. i 702-I803.

38. I702-I7I4.

"Letter from the Commissioners of the Board of Trade to the Earl of Nottingham about an enclosed Representation from the principal Officers of the Ordinance [sic] in relation to the expense of an Engineer, a Store-Keeper, a Master Gunner and seventeen Gunners at Barbadoes with Ordnance Stores there, with a Report on the same." May 24, I7I4. Relates to use of proceeds of $4^{\mathrm{I}} / 2$ per cent. duty for this purpose.

(On cursory examination the other papers in this bundle appear to contain nothing of importance not available elsewhere.)

39. I7 I4-I 728 .

"Report", unsigned and undated, but probably emanating from Board of Trade, on petition of agents of Barbados against establishment of an ecclesiastical court.

Extract of letter from Newcastle to Robert Walpole on French claims to St. Lucia and St. Vincent, giving some information on early history of these islands. May 6, I728.

Texts of two petitions of assembly, complaining of Gov. Worsley. Jan. 4, I $727 / 8$; July 25 , I 728 .

Texts of several acts "as past the Assembly", notably acts to exclude members of that body from certain offices, civil and military, and to regulate election, powers, and proceedings of churchwardens.

(Among the other papers those relating to St. Lucia and Tobago are especially numerous.)

40. I728-I740.

"A particular Account of the Orders past by the Governor and Council for which there is at Present no fund." The orders date from I7I4 to 1728 and are interesting in showing minor expenditures seldom individually listed.

Extracts of letters relating to ill-treatment of British subjects by French at St. Vincent. Letter from F. Freelove to W. Wood, on conditions in St. Lucia, St. Vincent, and Dominica. July I, I729.

Representation of assembly to Board of Trade, describing miserable condition of island in comparison with French and Dutch settlements, and complaining of trade carried on with latter by the northern colonies. Aug. 27, I73I.

Papers on Gov. Worsley's additional salary.

Minutes of committee on public accounts, Jan. I8-Mar. I2, I730/I.

Address of president and council of Barbados to the king, requesting that importation of foreign sugars into Ireland and the plantations be forbidden except on re-exportation from Great Britain, that such produce shall pay, on entering Ireland or the plantations, duties equal to those paid on importation into Great Britain, and that direct exportation of British sugar to foreign countries shall be permitted. Jan. I 5, I $752 / 3$. 
Letter of Board of Trade to Newcastle, relating to employment of proceeds of $4 \frac{\mathrm{I}}{2}$ per cent. for defense of island, with copies of such instructions concerning repair of forts in Barbados and the Leeward Islands as the Board could find in its office. July I3, I732.

MS. tract, "The Sugar Trade with the Incumbrances thereon Laid Open", by "A Barbados Planter," with tables of duties, drawbacks, and various charges on sugar, and of possible profits.

Abstract of representation of Board of Trade on state of Barbados. I735.

"Petition of John Jenkins of Barbadoes, Relating to the Spaniards" Seizure of Two British Sloops at Saint Lucia and St. Croix in Augt. I720 and February I726."

41. I74I-I750.

"Warrant" to the governor to observe treaty of 1674 with Dutch by preventing seizure of Dutch vessels, etc. Apr. I3, I743.

Many papers on St. Lucia, St. Vincent, Dominica, and Tobago, and on French armaments and preparations for war.

42. I752-I 803 .

Memorial to Sec. Robinson from John Maynard of Barbados, praying to be relieved from prosecution for having cut wood at Tobago, and describing conditions in that island. Undated.

Report of attorney general and solicitor general on the "high misdemeanour" of Barbadians who cut wood at Tobago. July 25, I753.

Letter from Capt. Russell on relations of French with Darien Indians. Undated.

Extract of letter from committee of correspondence to the agent, Sharpe, instructing him to urge necessity for action regarding the four neutral islands.

"Further Proposal for annoying the French in America." Unsigned and undated. Relates to the use of expedition about to leave Isle of Wight for the West Indies, and discusses plans for attack on Canada.

"An Account of the Certain Annual Expences of the Government of the Island of Barbadoes in time of Peace paid out of the Treasury." Unsigned and undated.

Return of inhabitants of Barbados, by parishes, distinguishing age, sex, color, and condition, and showing number of schoolmasters in each parish. I783.

Letter from William Selwyn, returning five acts sent him by Lord North, as has been the practice since abolition of Board of Trade, and stating that he has no time to consider them. May 9, I783.

Copy of letter from Gov. Parry to Lord Sydney, discussing trade of the island and desirability of free ports there. June I6, I 785 .

Sir John Jervis to Nepean, on movements of war vessels and convoys, and describing his passage to Barbados. Jan. 7, I794.

Id., from Barbados, enclosing letter from I. Shuttleworth on the fault of Sir John Temple, "the English Consul to the United States", in permitting so many British subjects to be registered in service of U. S. merely because they swear to American birth. Jan. I7, I794.

Sir Charles Grey to Nepean, from Barbados, stating that he is "exerting every nerve to open the campaign as soon as possible". Jan. 7, I794.

Letters from General Bruce and other officers. 
Papers on insurance, showing also prices of shingles and of horses "with provender". I794.

C. O. $28: 43-83$, I52:46, Secretary of State: Original Correspondence.

43. I689-17 I8. I689-1814.

Instructions for two persons empowered by Gov. Lowther to treat with lieutenant general of French islands concerning cartel for exchange of prisoners. I7II.

Letters from Lowther, on movements of enemy ships.

Petition of two factors of the African Company in Barbados to judge of admiralty court there with respect to condemnation of one of the company's ships, which was captured by the enemy and later recaptured without having been taken into a French port.

Letters from Chrn. Lilly to Dartmouth with portions of a journal, regarding a trip to Newfoundland. Feb., I7II/2, Apr., I7I2.

Address to her (?) Majesty from clergy of Barbados, congratulating her on success in war. Undated. Eleven signatures.

Address to his Majesty in favor of Col. Sharpe, signed by many gentlemen and merchants.

List of I8 prizes brought into Carlisle Bay since July, I7II, with some particulars of each. Mar. I7II/I2.

Letters from Lowther, on truce with French in Martinique.

Papers showing organization and procedure of courts in Barbados, and including reports of proceedings of court of chancery and court of grand sessions.

Depositions, reports of examinations, etc., taken by order of Lords Justices on petition of Robert Hales and Thomas Hodges, jr., against $\mathrm{Mr}$. Sutton of the council: valuable in throwing light on social conditions.

44. I72I-I 728 .

Address of assembly to the king on illegal trade between Barbados and French islands. Feb. I6, I720/I.

Instructions for receiver general of casual revenue. Sept. I2, I72I.

Additional instruction to Belhaven on ecclesiastical preferments. Nov., I72I.

Worsley to Carteret, on trade of the northern colonies with French islands, that between Barbados and the foreign settlements, and prosperity of Martinique. Mar. 26, I723.

Papers on designs of French in St. Lucia and St. Vincent, and disputes between British and French subjects over turtle fishing at Tobago. These papers involve discussions on interpretation of treaty of 1686. In particular: Worsley to Newcastle, Nov. I6, I724; Jan. 24, $1724 / 5$.

Papers relating to quarrel between the receiver general of casual revenue, the deputy surveyor and the auditor general of Barbados on the one side, and controller, searchers and waiters on the other, in connection with enforcement of laws of trade. I723.

Worsley to Carteret, on act "to supply the want of Cash for the Payment of Public Debts", and discussing financial position of the colony, and lack of currency. Jan. II, I723/4. 
Worsley to Newcastle, discussing, in connection with case of Hales and Hodges vs. Sutton, social conditions and administration of justice in the island ; and enclosing a "Certificate of Escheats" and proceedings of court of escheats. Apr. 27, I726.

Detailed list of fees taken in the various offices of the island. I726.

Papers relating to status of naval officer, including "deputation" and instructions to deputy naval officer.

Worsley to Newcastle, pointing out that some gentlemen in the island

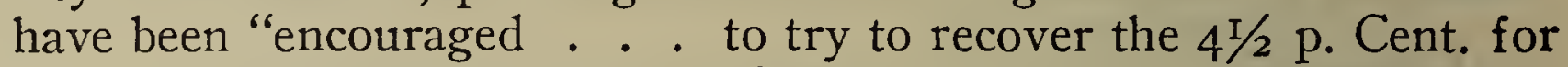
the uses in this Island it was at first granted [sic]" ; requesting that Barbados, like Jamaica, be permitted to place import duties upon alcoholic liquors coming from Great Britain; discussing Bishop of London's jurisdiction; and enclosing letter from the bishop on the suggested ecclesiastical court. Nov. Io, I726.

Id., sending papers on case of Princess Amelia. Apr. I8, May 6, I727. Lists of fines, forfeitures, and escheats. I726.

Proceedings of court of grand sessions. I726.

Draft of letter to Worsley on the rupture with Spain. May, I727.

45. I729-I74I.

Numerous papers on Worsley's appeals for payment of arrears of his additional salary, giving details on incidence of tax from which it was to have been paid and methods of collection. I729, I730.

Letter from Worsley, on trade of British West Indies and continental colonies with foreign colonies. July 7 , I730.

Papers on act for reducing rate of interest in Barbados. I729.

Howe to Newcastle, on "equipage money" and other necessary expenses of a colonial governor. June 24,1732 .

Draft of letter to president of council, on evacuation of St. Lucia, St. Vincent, and Dominica. Jan. I8, I73I/2. Howe to Newcastle, on same subject, with enclosures. Aug. I8, Nov. 22, Dec. 3, I733; Dec. 4, I735. Draft of letter to president of council on the same. Mar. I8, I735/6. Many other papers, I732-I739.

Papers on appointment of deputy clerk and remembrancer to court of exchequer.

Accounts of fortifications and military stores, with letters relating to defense. I729-1738. In particular, abstract of a letter, Howe to Newcastle, Jan. 6, I733/4; and Pres. Dottin to Newcastle, Nov. 4, I738.

"The Case of Francis Whitworth, late Secretary of Barbadoes," and other papers relating to the secretary's office. I733, I736.

Papers on seizures and other "depredations" committed by the Spaniards. I734, I735.

Copies of "Commission of Reprisals" issued by Pres. Dottin against Spaniards, of instructions which accompanied it, of the bond required of person commissioned, and of proclamation issued by Dottin concerning grant of such commissions. I739.

46. $1742-1747$.

Letters from Robinson to Newcastle, in general duplicating Robinson's letters to Board of Trade (C. O. 28:26-27), but presenting notable variations. Besides matters referred to in notes on C. O. 28:26, 27 they deal with: impressment of seamen (June 25, I743; May Io, July I5, I744; March 24, I744/5), removal of chief baron of 
exchequer (Oct. 23, I743); dispute with assembly over control of commissioners of fortifications (May IO, I744); and military operations of French.

Ten numbers of Barbados Gazette for scattered dates in I742, I745, 1746 , and 1747 .

"A List of Mr. Attorney Generals Reports etc Enter'd into the Minutes of Council, Since his last Arrival in the Island upon the 2d of May I744 . . ." I746.

Large map showing fortifications of Barbados.

47. 1746 . A duplicate of C. O. $28: 38$.

48. I741-1747. Duplicate minutes of council and assembly.

49. $1747-1752 .^{2}$

This volume is almost entirely composed of papers relating to St. Lucia, St. Vincent, Dominica, and Tobago, duplicating for the most part those in C. O. $28: 27,29$, and 30 . Of papers not noted elsewhere the following are the most important:

Printed copy of Grenville's proclamation ordering British subjects to leave Tobago; issued pursuant to his agreement with the governor of Martinique for mutual evacuation of the island. Nov. 6, I749.

Grenville's proclamation forbidding British vessels to frequent the four islands. Feb. I8, I750.

Grenville to Bedford, acknowledging receipt of Bedford's letter of Dec. 2I, I749, which contained orders for evacuation of the four islands. Mar. I3, I750.

Grenville's proclamation ordering evacuation of the four islands pursuant to agreement of the two home governments, and announcing that title to the islands is to be settled by commissaries.

C. O. I52:46. I754-I76I. Papers on Barbados contained in this volume of Leeward Islands correspondence. I754-1760.

Letter from Pres. Weekes, stating that, since the French cut logwood at Tobago and have not evacuated the other three islands, public opinion is against punishment of persons going to Tobago. Apr. 9, I754.

Correspondence between Weekes and Dutch governor of Essequibo, on request of governor for military supplies to use against Spaniards, and Weekes's refusal on ground of necessity for maintaining neutrality. Sept.-Oct., I754.

Letter to Weekes from Bompar, explaining that French have seized St. Lucia because British activities on continent make their designs against French colonies only too clear. Martinique, Sept. I5, I755. Weekes's reply. Sept. 24, I755.

Letters from Gov. Pinfold. Naval events; exchange of prisoners; trial of persons accused of ill-treatment of captured Spaniards; publication of his commission in Tobago (St. Lucia, St. Vincent, and Dominica being occupied by French); great fire at Bridgetown; British naval movements; and participation of Barbados in attacks on French. Aug., I756-July, I759.

$I d$., on success in persuading legislature to pass law against intercourse by people of island with enemy, and supplying enemy with provisions and other stores. Also, on his partial success in enforce-

${ }^{2}$ For original correspondence of the Secretaries of State, 1752-1760, see C. O. $152: 46$ (Leeward Islands). 
ment; though French and Dutch get great supplies of provisions from Ireland. Nov. I 5, I760.

C. O. $28: 50.176 \mathrm{I}-\mathrm{I} 767$.

Letters from Pinfold, on military events in island, and in West Indies generally.

Copies of Barbados Gazette, Oct.-Dec., I76I.

Letters from Gov. Pinfold and Pres. Rous, on appointments to council, and on precedence within council. Jan. 27, May 3I, July I9, Aug. 7, I762; July I6, Aug. I9, Sept. 6, I766; Oct. 6, I767.

$I d$., sending "resolutions on the true interest of Great Britain with respect to the Caribbee Islands, as well the old settlements as the neutral islands and the conquests, in which the importance of Martinique is particularly considered"; by a planter of Barbados. May 20, I762.

Correspondence with Pinfold, on ecclesiastical system in island, involving discussion of authority of governor and Bishop of London over beneficed clergymen, farming of livings, and absenteeism of rectors. July 20, Oct. 2, I762; Dec. I 5, I763.

Letter from Pinfold, sending copies of proceedings in council and assembly, showing latter's objections to certain of terms of peace. July $16,176_{3}$.

$I d$., stating that attorney general is ready to resign in case he can secure a reversionary patent of the post for his son. Dec. 24,1763 .

Id., on complaints of Spaniards against piratical acts by English in West Indies, and on suppression of illegal trade in pursuance of his instructions. Nov. I7, I764.

$I d$., sending several lists of various legal instruments employed in courts and by crown officials. Dec. I7, I764.

Id., on French activities at Cayenne. Jan. Io, I765. Encloses depositions.

Printed copy of regulations issued for settlement of Grenada, the Grenadines, Tobago, St. Vincent, and Dominica, showing division into parishes, reservation of public lands, assignment of land grants, etc. Issued at Barbados by John Greg, secretary to commissioners appointed for this purpose. Jan. I9, I765.

Letter from Pinfold, on French at Cayenne; and on brigantine Chance of North Carolina, Thomas Sheppard master, seized on her way to Cayenne with provisions and naval stores. Mar. 23, I765. Enclosures include some papers of the Chance, and letter addressed by John Remsen of Philadelphia to French governor and intendant of Cayenne on contract to furnish provisions, Nov. 22, I764. Other papers on Cayenne, and on trade of North American vessels there.

Copy of Barbados Mercury, Mar., I 766.

Minutes of council. May 27, I766-May 26, I767.

Journal of assembly. Apr. 29, I766-Apr. 28, 1767.

Lists of members of council, showing those present and absent. June I2, I 767 .

Returns of christenings and burials by parishes. 1766 .

Return of negroes imported, May 27, I 766-May 27, I767, showing number in each cargo received, and giving names of consignees.

Account of powder, May 8, I766-May 12, I767. 
51. $1767-1768$.

Address of assembly on obstruction to course of legislature and to administration of justice through absence of members of council and judges from island. Undated. Delivered by Mr. Walker, agent for Barbados, Jan., i768.

Papers on appointments to council.

Letter from Gov. Spry, promising to send collection of laws passed I643-I762, printed at London by Richard Hall, i764. Apr. 8, I768.

Returns of christenings and burials. I 767.

Account of slaves.imported. May 27, I767-Jan. 27, I768.

Several papers on administration of justice in court of common pleas.

Letter from Spry, sending: minutes of council, Feb. II-Aug.- 2, I768; journal of assembly, Feb. I8-Aug. 2, I768; list of members of council ; accounts of population, forts, military stores, and militia;

52. 1769 . and treasurer's return of negroes imported, Jan. 27-Aug. $27,1768$.

Letter from Spry. Depredations of British vessel on Spanish Main. All plunder recovered has been sent to governor and bishop of Porto Rico, and officers of vessel forced to give security for other damage which may have been committed. Sept. I8, I769. Depositions and other enclosures. Hillsborough to attorney and solicitor general, asking what may be done to forestall expected complaints.

Papers on Spanish attempts at encroachment in Guiana. Apr., I769.

Papers on administration of justice in court of common pleas.

Returns of christenings and burials, powder collected, and slaves imported. Aug. II, I768-Feb. II, I769.

Letters from Spry, on loyalty of population.

53. I769-1770.

Letter from Spry, on establishment of lotteries. Oct. 7, I769.

Papers on British depredations on Spanish Main.

54. I770-I772.

Letter from Spry, on negro insurrection at Tobago. Dec. 20, I77o.

$I d$., on military weakness of island: several letters.

Minutes of council. Sept. 4, I770-Aug. 27, I77I.

Journal of assembly. Aug. 7, I770-June I8, I77 I.

Returns of christenings and burials; powder collected; and negroes imported. Aug. II, I770-Aug. II, I772.

Memorial of George Walker, agent for Barbados, asking that vessels of an expedition to be sent to "the southern parts of the globe" for collection of seeds and plants, be directed to touch at Barbados. Island needs intercourse with distant regions of similar climate; but the India Company had obtained instructions to the government of Barbados even to fire upon any of their ships which should presume to touch there upon any pretense, and the instructions had been obeyed literally.

Minutes of court of common pleas for precinct of St. Michael. July I5Sept. I2, I 772.

55. I773-I 774 .

Letter from Hay, on visit to Barbados of Spanish vessel carrying director of the new Spanish Asiento Co., who purchased negroes and flour. Aug. 24, I773.

$I d$., on trade with foreign settlements. June 2, I774.

Id., sending detailed answers to customary queries. Aug. 3I, I774. 
Id., sending copy of acts relating to legal procedure and other matters. Aug. 3I, I774.

Returns of christenings and burials; of collection of powder; and of negroes imported. Aug. II, I772-Aug. II, I773.

56. I 775-I777.

Letter from Hay, reporting that "no bad effect has been felt in the island hitherto from the disturbance in the Northern Colonies", and that "fully as many vessels with provisions and stores have arrived from thence as usual". Also on work of Inspector General Mills in correcting negligence of merchants in not producing certificates to cancel their bonds, and otherwise in providing for enforcement of acts of trade. Apr. 6, I775. Other papers on Mills's operations. $I d$., on provisioning of island. Aug. 29, I775.

Returns of collections under the "mole-head" act, of slaves imported, Aug. I I, I774-Aug. I I, I775, and of burials and christenings.

Letter from Hay, on tranquillity and loyalty of island. "The principal article the Americans want is powder, and I am sensible of the artifices they make use of to get it from any quarter; but in this island there is none. I am informed they carry off a great deal from the Continent in our neighborhood, and in the rivers of Escuebo and Demarara where the Dutch have their settlements, as also from the Dutch and French islands." Apprehended scarcity of provisions and lumber; purchase in West Indies of supplies for troops in North America. Feb. I3, I776.

Id. Passage of address to the crown on scarcity of provisions, and dismissal of Solicitor General Duke for proposing resolution and other objectionable acts. "I could almost wish that no Barristers were allowed to sit in the Assembly, for if they are not well disposed, their studies give them a superiority over the planters." Feb. I5, I776.

Id. Ill feeling and complaints over scarcity of food in island. "All this bustle arises from the pique of the assembly against myself and the Council for giving Capt. Paine leave to buy provisions for Gen. Howe in Boston. . . The assembly themselves were not consulted, who had no right to be consulted." Apr. I3, I776. Encloses letter from Henry Duke protesting against his suspension from office of solicitor general on ground that patent officers may not be suspended "without charge, accusation, or blame", that council did not concur in suspension, and that his behavior in assembly has no connection with his private profession. Feb. I7, I776. Also second memorial from Duke demanding sight of those parts of governor's instructions on which Duke's suspension was based, and threatening law-suits against judges who acquiesced in suspension should this prove to be without sufficient authority. Other papers on this case. Encloses also letter from Hay to Vice-Adm. Young, asking that vessels from French and Dutch islands be permitted to bring provisions to Barbados; and that he convey to island such captured provisions as may not be needed for his Majesty's armed forces. Mar. 24, I776. Young's refusal, Apr. 2, I 776.

Id., on dispute with naval officer concerning latter's duties. May 9, I 776.

Id. Sharp dispute with assembly over right of assembly to address the crown independently of governor and council, and on alleged mis- 
representation by governor to the crown of the true facts as to scarcity of provisions in island. July 25, I776. Enclosures.

Memorial of Walker, agent for Barbados, presenting address from assembly to the crown on scarcity of provisions, and serious consequences ensuing to island. Other papers, showing Hay's insistence that island is sufficiently supplied, and resentment of population at his "malign interposition".

Letter from Hay, on French preparations for war, and assistance to rebels; and on excuse given to French by operation of privateer from Antigua. Feb. 25, I777. Germain's answer, commending Antigua privateer. May 7,1777 .

$I d$., reporting diminution of operations of American privateers and capture of the Oliver Cromwell by Beaver sloop-of-war and the Mosquito by the Ariadne. Particulars on disposal of prisoners. June 3, I777.

Id. Reports capture of seven fishing vessels by American schooner manned chiefly by French sailors. June 15, I777.

Germain to Hay, on disposal of American prisoners. Aug. 9, I777.

Letters from Hay. Economic distress in Barbados; violations of neutrality by French; prosperity of French islands through the war; and disposal of American prisoners. July I2, Aug. 9, 1777 .

$I d$., on privateers commissioned in West Indies and on disposal of American prisoners. July I7, Oct. II, I777.

57. $1777-1780$.

Letter from Gov. Hay, no. 20. Reports embargo laid in French islands on all ships and provisions. Oct. 24, 1777.

Id. Reports news of treaty between France and America. June 4, I778.

58. $\mathrm{I} 78 \mathrm{O}-\mathrm{I} 78 \mathrm{I}$.

Contains references to French and Dutch islands and movements of fleets.

59. I $78 \mathrm{I}-\mathrm{I} 782$.

Letter from Gov. Cunninghame, with enclosures setting forth position of defenses of islands. Dec. 4, I78r.

Minutes of council. May I-Aug. 8, I 782 .

60. I782-1786.

Letter from Gov. Parry, giving results of orders regulating trade with U. S.; these have been strictly enforced. Dec. I6, I783.

Id. Mar. 4, Apr. 28, I784. Encloses lists of entries and clearances, Oct. I, I783-Apr. I, I 784 .

Id. June 23, I784. Encloses minutes of council, Oct. 28, I783-Mar. 16, I 784 .

Id. Dec. 26, I784. Encloses "Account of all the Ships arrived from Canada, Nova Scotia etc". July 2, I783-Dec. 31, I784.

$I d$., relating to trade, representing importance of trade with U. S. Jan. I6, I785.

$I d$., acknowledging receipt of letter with copy of act for continuance of act of 23 Geo. III. regulating trade with U. S.

Id. Encloses proclamation, Aug. 27, I785, relating to trade with U. S. Nov. 9, 1785 .

61. $1786-1788$.

Letter from Gov. Parry. Encloses narrative respecting the ship Columbus, engaged partly in American trade. Oct. 2I, I787. 
62. I788-I 790 .

Minutes of council. July I, I788-May 12, I789. June 2-July 6, i789.

Journal of assembly. Mar. I2-July 6, I789.

Minutes of council. July 2 I-Nov. I7, I789. Nov. 24, I789-July I3, I790.

Journal of assembly. July 21, 1789-Feb. 9, r790.

63. I790-I792.

Minutes of council. July 27, I790-Nov. Io, I79r.

Journal of assembly. Apr. I5-July I2, I 790.

Minutes of council. Jan. 25-July 26, r791.

64. I792-I794.

Minutes of council. Aug. 2, I79I-May 22, I 792.

Journal of assembly. May I7, I791-Apr. I7, I792.

Minutes of council. June 26, I792-July 20, I793.

" " " Sept. I6, I793.

" " "July 23, I793-Feb. I8, I794.

Journal of assembly. July 23, I793-Feb. 18, 1794.

Letter from Sec. Dundas to Gov. Parry. (Secret.) Advises of arrival of cargo for his Majesty's service, possibly in American or some other neutral bottoms. Oct. 2, I793.

Letter from Gov. Parry, notifying the opening of ports of Barbados, owing to urgent necessity. Aug. 3, I793.

65. I794-I799.

Minutes of council. Mar. 2 I-Oct. I4, I794.

66. I800.

Heads of acts passed. May 6, I788-Dec. 21, I795.

Journal of assembly. Feb. 24, 1800.

Minutes of council. June I4-July 22, I 800.

Journal of assembly. Jan. I-Apr. 8, I 800.

Minutes of council. Jan. 2 I-Apr. I8, I800. July 22, I80o-Jan. 22, I80I.

Journal of assembly. June 4-July 22, 1800 .

Letters from Gov. Ricketts to the Duke of Portland and reply to Pres. Bishop relative to admission of American produce. Feb. 4, May 29, July I, I80o.

67. I80I.

Journal of assembly. July 22-Nov. 25, 1800.

Minutes of council. Mar. 27-Apr. 14, I801.

Journal of assembly. Feb. I8-May I2, I8or.

List of entries and clearances. Apr. I-Sept. 30, I80I.

68. 1802 .

Journal of assembly. June 30-Oct. I3, I80I.

Minutes of council. May r2-July 28, I80 I.

Journal of assembly. Nov. IO, r80I-Mar. I I, I802.

Apr. 6-July 6, I802.

List of entries and clearances. Oct. I, I801-June 30, I802.

69. I802.

List of entries and clearances. July I-Sept. 30, I802.

Minutes of council. Apr. 26-Nov. 9, 1802.

Journal of assembly. Nov. 9, 1802 . 
Letter from Lord Seaforth, referring to application of Free Port Act. Oct. 4, I802.

Id. Encloses general report of the state of fortifications, return of militia, return of arms, etc. Dec. 9, 1802 .

70. 1803 .

Journal of assembly. Jan. 25-Feb. I5, 1803.

Apr. 5-June 7, 1803 .

Minutes of council. Dec. 2, I802-June 7, 1803 .

Nov. I-29, 1803 .

List of entries and clearances. Oct. 25, I802-Oct. 3I, I803.

List of acts to which the governor has given assent. Oct. I3, I80IJuly 5,1803 .

71. 1804 .

Journal of assembly. July 5-Aug. 2, 1803.

Minutes of council. Jan. Io-June 5, I 804.

Journal of assembly. Feb. 2I-May 2, I804.

Minutes of council. July $5-$ Sept. 5, 1803.

Journal of assembly. Oct. I8-Nov. 29, I803.

July 3I-Aug. 28, I804.

List of entries and clearances. Nov. I, I803-Jan. 3I, I804.

May I-Oct. 3I, I804.

Letter from Lord Seaforth, on importations from America. Dec. I2, 1804 .

List of entries and clearances. Nov. I, I804-Jan. 3I, I805.

72. 1805 .

Journal of assembly. Oct. I6-Nov. I2, I804.

Minutes of council. (Extracts.) May I8-June I8, I805.

Letters from Lord Seaforth, relative to American intercourse. Feb. I8, Apr. I 5, 1805 .

List of entries and clearances. Feb. I-Apr. 30, 1805.

Letter from Lord Seaforth. Encloses manifest of cargo of American vessel. May 2, I805.

List of entries and clearances. May I-July 3I, 1805 .

Letter from Lord Seaforth, no. 76. Importation from America. Dec. IO, I 805 .

73. 1805 .

Letter from Lord Seaforth, no. 79. Importation from America. Dec. 3I, 1805.

Stephen Cottrell to Edward Cooke. Importation from America. Committee of Privy Council for Trade, Jan. I, I805.

74. 1806.

Journal of assembly. Jan. I5-Mar. I9, I805.

Entries and clearances. Aug. I, I805-Aug. 31, I806.

Letters from J. Spooner, acknowledging receipt of circulars of Sept. 3 and 28 relative to intercourse with the U. S. Nov. 6,28 , 1806.

Entries and clearances. Aug. 3I-Oct. 31, I806.

Letter from W. Fawkener, Committee of Privy Council for Trade, to Sir G. Shee, office of Secretary of State, relating to American intercourse: vessels built by Americans and conveyed to Martinique and Guadeloupe to be fitted out as privateers; "it does not appear to the 
Lords of this Committee that there are any means of preventing the evil . . . ; for unless the American vessels are from their nature and construction evidently contraband of War, they cannot be seized and condemned". June I3, I806.

76. I807.

List of entries and clearances. Nov. I, I806-Apr. 30, I807.

Letter from J. Spooner, acknowledging order in Council of July I, 1807 , on neutral trade. Aug. 22, I807.

List of entries and clearances. May I-Aug. 3I, I807.

Journal of assembly. Jan. I5-Oct. I 5, I805.

77. 1808 .

Letter from J. Spooner, referring to American embargo. Oct. 27, I808.

80. I8II.

"At a Meeting of a Committee of Merchants at the House of James Maxwell Esqr, 7 May I8I r." Contains statistics for fish imports to Barbados in I808-I8I I from Br. W. I., N. Am., and U. S.

Address of inhabitants of Barbados interested in sugar manufacture and trade to Prince Regent. A committee of the House of Commons recommended in I808 that planters might barter sugar with Americans to value of stores received from them. Value of stores from U. S. computed at 25,000 hhds. of sugar.

81. I8I2.

Letter from Gov. Beckwith, referring to recent intelligence of an American embargo. May 9, I8I2.

82. I8I3. (On 8I and 82, see also Palson and Paullin, Guide, p. 285.)

Letter from Gov. Beckwith. Encloses report from Capt. White, Mar. 3, I8I3, of his having maintained a running action with an American cruiser of very superior force from Sat., Feb. I3, to Tues., Feb. I6. Mar. 6, I8I3.

Id. Civil, no. 28. Encloses statement of J. Howe, mate of American brig Hiram of New Haven, on his capture, etc. May 24, I8I3.

Id. Civil, no. 34. Reports extension by proclamation of duties on flour and rice from the U. S. in foreign bottoms, imposed in accordance with order in Council expiring June 30. July I, I8I3.

Id. Confidential. Relates to "a correspondence that has passed between General Henry Lee of Virginia, and myself, on the subject of Peace" ; refers to Gen. Lee's visit about the end of June last. Nov. 26, I8I3. Encloses six papers, including (no. 5) letter from Gen. Lee to Sir George Beckwith: "The three topics of dispute which led to our declaration of War, were orders in Council, the mode of Blockade, and the impressment of our seamen-a fourth seems now edging in, effect of naturalisation." Nov. I6, I8I3. This letter followed by "First Enclosure, containing the Heads of a project for a Treaty".

83. I8I4.

Letter from Gov. Beckwith. Civil, no. 49. Encloses letter dated Washington, Oct. 25, I8I3, on detention of an American merchant; also reply. Jan. $27, \mathrm{I} 8 \mathrm{I} 4$.

Id. Confidential. Return of Gen. Lee from Porto Rico to U. S. Mar. 24, I8I4. 
C. O. 29:I I-19. Board OF TRAdE: Entry-Books. I707-I782.

C. O. 326:34-35. Index to Board of Trade CoRrespondence. I7O3-I759.

12. $1709-1713$.

Papers on office of secretary.

Letter to Lowther, enjoining enforcement of royal proclamations concerning rates at which foreign coins are to be received. May 2, I7I2.

Various papers relating to seizure of the Oxford. May, I7I2.

Letter to Lowther: no persons to be sent as prisoners to England without full proofs of their guilt. Aug. 27, I7I2.

13. I7I3-I7I9.

Letter to Lowther; to have no voice in decision of any case in court of chancery to which he is a party; appeals from court of exchequer must be made to court of chancery, and only after that to Privy Council. July 20, I7I3.

Letter to Bolingbroke, on manner in which expense of furnishing ordnance stores, gunners, an engineer, etc., to Barbados should be met. May 24, I7I4.

Letter to Sharpe: to prevent trade with French colonies. Aug. I9, I7I4. Draft of Gov. Lowther's commission. Nov. I6, I7 I4.

"Copy of a Bill prepared to pass into a patent appointing Mr. Skene Secretary of Barbadoes." Considered Jan. I7, I7I4/5.

Draft of Gov. Lowther's instructions: no important changes. Feb. 22, I 7 I $4 / 5$.

Numerous papers on appointment of John Colleton to the council.

Letter to Lowther, on trade with Spanish and French colonies. Also on trade between French and Spanish settlements at various periods. Has nothing to say to Lowther's suggestion that French colonies be deprived of horses from North America until he can show why this would not cause them to build windmills and make sugar cheaper than ever.

Papers on Mr. Gordon's attempt to set up an ecclesiastical court; in particular a letter to Addison on ecclesiastical preferment in the colonies. Oct. I7, I7I7.

Memorial from agent of Barbados, giving reasons for laying of duties on all foreign sugars entering island; and discussing costs and selling prices of British and foreign sugars. Sept. 25, I7I7.

Letter to Addison on issue of commissions for trial of pirates; and on possible advisability of changing clause relating to impressment in act of 6 Anne. Nov. I9, I7I7.

Letter to attorney yeneral, requesting opinion on "an additional Act to the Act Intitled an Act to ascertain the Payment of such Bills as have been issued pursuant to a late Act of this Island, Entitled an Act to supply the Want of Cash". Nov. 19, I717. Answer of attorney general. Dec. 23, I7I7.

Report from attorney general on act to restrain fees of officers in island. Dec. I6, I7 7 .

Letter to Lowther, on measures taken to suppress pirates, and especially to dislodge them from the Bahamas. Mar. 28, I7 I8.

List of acts passed in I7I4, with remarks on the disposal made of each. Sent to Lowther June 20, I7I8. 
"Letter to Mr. Secretary Craggs with Amendments to be made in the Instructions of the Govr. of Barbadoes." Alterations given in parallel columns with text. Aug. 2r, I7I8.

14. I719-1728.

Correspondence with attorney general, solicitor general, and Richard West, on legality of permitting vessels from Spanish colonies to trade at Barbados. Answer of agents of Barbados to complaints against the governor for permitting such trade. Letter to Craggs suggesting that, while all trade between Barbados and French and Dutch settlements should be forbidden, Spanish vessels should if possible be permitted to trade at the island. Jan., Feb., I719/20.

Letter to Townshend, stating that the Board has no objection to specific inclusion of Tobago in commission of Lord Irwin as governor of Barbados, since Tobago has been tacitly included in former commissions, and specifically included in former instructions. Feb. I5, I720/I. (Irwin appears to have died before his commission was issued, although a draft was prepared on Feb. I, I720/I. The draft of a commission for Lord Belhaven was transmitted Apr. 20, I72I ; but the text is not given, since it "was exactly in the same terms with that since prepar'd for Mr. Worsley"). Belhaven was lost at sea on his way to Barbados.

Letter to Carteret, with representation on Belhaven's memorial concerning right of governors to receive presents from assemblies. Aug. 30, I72I.

Draft of instructions for Belhaven, showing alterations, made, it is stated, to bring instructions into line with those issued to Lawes of Jamaica. The alterations relate to employment of suspending clause, to extension to all persons trading to Africa of "encouragement" formerly given to African Company, to the power of governor and council in removing civil and military officers, and to governor's additional salary. Aug. 9, I72I.

Representation on a number of acts passed I7I4-I720. Aug. I7, I72I. Five letters to Carteret, on settlement of Tobago, and petitions of Duke of Montagu and Mr. Evans for grants of St. Lucia and St. Vincent. Sept., I72 I-Apr., I722.

Draft of Gov. Worsley's commission. Dec. I, I72I.

Letter to Horatio Walpole on the salary which should be paid to a lieutenant governor. Apr. I2, I722.

Draft of Gov. Worsley's instructions, showing alterations designed to make it accord with those of the Duke of Portland as governor of Jamaica. The alterations relate mainly to action on currency bills and on bills providing for votes of money to governors or other persons; also to licensing of clergymen and schoolmasters. The instructions on observance of acts of trade are altered to conform with order in Council issued Oct. 2, I72I, on petition of East India Company. Apr. 26, 1722.

Letter to Worsley, enclosing representations on certain acts, passed I714-I720, which will neither be confirmed nor disallowed for the present. Aug. 30, I722.

Representation for disallowance of act passed in 1723 laying duties on alcoholic liquors imported. Mar., I724. Other papers show act was not disallowed. 
Representation for confirmation of act allowing affirmation by Quakers. Mar. 3I, I724.

Representation for disallowance of act providing for levy on certain kinds of property and issue of bills of credit.

Letter to Newcastle, pointing out that it has always been esteemed the right of the Board to propose suitable persons for appointment to councils in the plantations, citing precedents, and referring to a case in which Newcastle has not respected this right. Aug. 31, I 726.

$I d$., concerning activity of French in St. Vincent and St. Lucia. Feb. 9, I727/8. Representation on grant of Tobago to Duke of Montagu. Feb. 27, I728. Other papers.

Letter to Worsley, on rights of assembly to adjourn from place to place, to inquire into executive matters, and to call for papers in the governor's custody. Apr. 12, I728.

15. I728-1734.

Draft of Gov. Worsley's commission. Apr. I7, I728.

Draft of Gov. Worsley's instructions, with changes defining assembly's powers of adjournment and its obligation to present the speaker for approval. June 27,1728 .

Representation on bill laying duties on importation of alcoholic liquors to raise money for supplies and fortifications, and providing that payment shall be made for supplies only after assembly has inspected them and addressed the governor for payment to be made. Aug., I 728 .

Seven representations on British titles to St. Lucia, St. Vincent, Dominica, and St. Croix, and on evactiation of St. Vincent and Dominica. Dec., I729-Nov., I730. "List of (I8) Papers relating to the Island of St. Lucia, presented to the House of Commons pursuant to their Address of the IIth of February I729/30." Feb. 24, I728/9. Instruction for Gov. Worsley on evacuation of St. Lucia, St. Vincent, and Dominica. Sept. 24, I730. Representation on extracts of two letters from Mr. Finch, his Majesty's envoy at Stockholm, regarding Duke of Courland's offer to sell Tobago to King of Sweden. Sept. 2I, I73I.

List of six papers on trade of northern colonies with French sugar islands, submitted to House of Lords, pursuant to an order of the House dated Apr. I5, I73I. Letter to Newcastle, stating that the Board "must desire your Grace would be pleased to propose to His Majesty that he would graciously recommend the consideration of the Sugar Trade in general to His Parliament". Nov. 9, I73I. List of papers laid before House of Commons on disputes between sugar islands and northern colonies. Feb. 4, 1731/2. Letter to Newcastle on this subject, and concerning laws, manufactures and trade of the plantations. Feb. IO, I73I/2.

Lists of papers laid before House of Commons pursuant to an address of Feb. 14, I73I/2, and before House of Lords pursuant to addresses of Mar. 23, I73I/2 and Apr. 5, I732.

Various papers on perquisites of the governor of Barbados, including representation, Dec. I7, I73I, on petitions of merchants and planters that the governor should no longer be permitted by his instructions to accept an additional salary.

Draft of Gov. Viscount Howe's commission. May 17, I732. 
Report on certain petitions, involving question whether assembly can demand that the governor place accounts before it. May 25, I732.

Representation on means to be employed for enforcing payment of arrears on Gov. Worsley's additional salary. June I3, I732.

Draft of Gov. Viscount Howe's instructions, showing no noticeable alterations. Nov. 29, I732.

Report on Dunbar's first petition to be appointed a councillor in Barbados, the Leeward Islands, and Bermuda, and draft of additional instruction to Howe on the matter. Aug. 8, I733.

16. I734-I747.

Representation for disallowance of act regulating fees. July 9, I734.

Report to committee of Council on scarcity of ordnance stores in West Indies, and on other questions touching defense. July 24, I734.

Letter to Howe, on settlement of Danes at St. Croix under purchase from the French. "It has been thought for some time that this island belonged to the Crown of Great Britain and your Lordship will do an acceptable Service to the Publick if you can collect any proofs to support the King's Title." Sept. 26, I734.

Letter to Pres. Dottin. Trade with foreign settlements; anticipated effects of Sugar Act; and need for importation of foreign cotton. Also, giving permission for passage of an act repealing five acts passed 1672 to $I 717$ and approved, provided that repealing act contains suspending clause. July I8, I 735 .

Several letters on British and French claims to St. Lucia, St. Vincent, and Dominica; in particular, letters to Newcastle, Sept. I6, I735, Apr. 20, I736, and to Gov. Byng, Apr. I, I740.

Representation for disallowance of act assented to by Dottin, on ground that it was not one to which a president could assent, not being "immediately necessary for the Peace and Welfare of the Island". Dec. I7, I736.

Letters to the attorney general and solicitor general for their opinions as to whether the death of a governor would void appointment of a surveyor general made by him; whether issue of a proclamation by president and council for continuance of surveyor general in his office would make such continuance legal; and whether the great seal of the island, and not the governor's seal, should not be affixed to all acts, including proclamations. Feb. $12,17,1736 / 7$.

Draft of Gov. Byng's commission. June 5, I739.

Draft of Gov. Byng's instructions, showing no important alterations. Aug. Io, I739.

Letter to Byng, mentioning that a supplement to the laws of Barbados has been printed by order of Board. Mar. 25, I740.

Representation to committee of Council on governor's additional salary. June I2, I74I.

Draft of Gov. Robinson's commission. Jan. 26, I74I/2.

Draft of Gov. Robinson's instructions, showing important changes in the instructions relating to enforcement of acts of trade. Feb. 2, I74I/2.

Draft of Gov. Grenville's commission. Sept. 22, I746. Introduction only; remainder being identical with that prepared for Robinson.

Draft of Gov. Grenville's instructions. Oct. 23, I746.

Report to committee of Council, recommending that commander of war vessels stationed at Barbados and Leeward Islands be appointed a temporary councillor of Barbados and Antigua. Jan. 21, I746/7. 
17. $1748-1760$.

Letter to Duke of Bedford, stating that, while the Board can find in its books no convention or written agreement for mutual evacuation of St. Lucia, St. Vincent, and Dominica, it "appears" that such evacuation was agreed upon by Lord Waldegrave and the ministers of France in 1730 , and that orders for its execution were sent out by both sovereigns to their governors. July 2I, I748.

Id., concerning developments at Tobago in and since I730. Dec. 7, I748. Letter to Gov. Grenville, outlining history of Tobago to show strength of British claims; and stating that no settlements on the island are to be permitted. Dec. 20, I748.

A number of letters relating to St. Lucia, Dominica, St. Vincent, and Tobago, directing collection of information on the islands by the governor, and forwarding information collected to Bedford and Holdernesse.

Draft of Gov. Pinfold's commission. Feb. 20, I756.

Draft of Gov. Pinfold's instructions, showing no important alterations. Mar. I7, I756.

Letter to Pinfold, sharply criticizing recent act to amend act of I7I8, which regulated court of exchequer. Aug. I, I759.

18. $1760-1772$.

Draft of Gov. Pinfold's commission. Mar. 4, I76r.

Draft of Gov. Pinfold's instructions, showing omission of several articles, which "appeared to us to have become useless", including those relating to sending of proofs of guilt with all prisoners sent to England, and those relating to operation of Habeas Corpus Act. Apr. 28, I76r.

Letters and representations on Pinfold's powers of appointment and removal of clergymen. Mar., Apr., Dec., I764; Sept., I765.

Representation for disallowance of act to render John Adams of Barbados incapable of being elected to assembly, or of filling any office in the island. July 10, I764. Order in Council for disallowance. Dec. 7, 1764. Letter to Pinfold on the subject. Mar. 15, 1765.

Pownall to Charles Lowndes, secretary to Treasury. Board is informed that order in Council directing preparation under great seal of commission to empower governor of Barbados to deprive, after summons and inquiry, clergymen absenting themselves from island without leave, has not yet been issued, "no person appearing to take out the said Order and pay the Fees". Since the largest parish in Barbados is daily suffering, and his Majesty's authority is being brought into contempt, Pownall is directed "to desire you will acquaint the Lds. Commissrs. of the Treasy., that my Lds. Commissrs. of Trade refer it to their Consideration whether it may not be proper to direct their Sollicitor to take out the said Order and pay the Commission it refers to through the several Offices at the Publick expence". Nov. 14,1765 .

Representation on case of Rev. Thomas Harris of Barbados, who is accused of grave misconduct; and asking that his Majesty in Council may contrive a remedy for the need of proper ecclesiastical jurisdiction in the colonies. Nov. 19, I765.

Representation for disallowance of "An Act to impower the Agent to take a Lease of the Office of Provost Marshal General of this Island from the Patentee of the said Office in behalf of the Legislature of 
Barbados, and to make the terms and conditions of such lease binding on the Publick". June 20, I766.

Representation for confirmation of act for governing of negroes, a suspending clause having been inserted in said act. June 26,1767 .

Draft of Gov. Spry's commission. June 26, i 767.

Draft of Gov. Spry's instructions, with no important changes except omission of all reference to St. Vincent, Dominica, and Tobago. July 29, I 767.

Draft of Gov. Hay's commission. Nov. 2, I772.

19. $1773-\mathrm{I} 782$.

Draft of Gov. Hay's instructions, with alterations forbidding him to assent to any acts providing for establishment of lotteries; or for alterations in number of members in assembly, "or inconsistent with Your Majesty's rights; or for making attachments for the recovery of debt on the property of persons who have never lived in the island, otherwise than is allowed by Law in cases of a like nature within this Kingdom". Mar. I8, I773.

Representation, setting forth objections to act for improving the molehead and collecting duties on all tonnage for that purpose. Mar. 3I, I774.

Draft of Gov. Cunningham's commission. Feb. 3, i78o.

Draft of Gov. Cunningham's instructions. Feb. I7, I780.

C. O. 326:34-35. I703-I73I, I73 I-I759. Index to Board of Trade Original Correspondence and Entry-Books. (Accurate.)

C. O. 29:2i-29. Secretary of State: Entry-Books. i767-i8i 3 .

21-22. I767-I782. Letters from governors and presidents to Secretary of State, duplicating letters in C. O. $28: 50-59$.

Letter from Gov. Hay. Secret. American vessels are permitted to come into the port of Martinique with their prizes. Feb. 25, I777.

Id., reporting capture of American privateer. July I2, I777.

23-26. Précis of Correspondence. I789-1791, I793-1797, I801-1807.

27. I768-I80 I.

Letters from Secretary of State to governors, Board of Trade, attorney general, solicitor general, and Admiralty. Drafts of commissions for Hay, Parry, Ricketts. Drafts of two orders in Council on payment of bounty to Barbados. I782, I783.

Letter to Gov. Parry from Lord Sydney, referring to measures proposed by former to prevent trade in West Indies with Americans in French free ports. July 7, I786.

29. I80I-I8I3. Letters from Secretary of State.

Letter to Gov. Seaforth from Lord Camden, no. 6, stating reference to

Treasury of papers relating to exclusion of American produce, etc. Feb. 23, I805.

$$
\text { C. O. 30: I-16. Acts. }
$$

1. Acts, passed in the Island of Barbadoes. From 1643 , to I76?, inclusive; Carefully revised, innumerable Errors corrected; and the whole compared and examined with the original Acts, In the Secretary's Office. By the late Richard Hall Esquire: One of the Representatives in the General Assembly, for the Parish of St. Michael; and one of His Majesty's Justices of the Peace, for the said Island, near thirty years; And since his 
Death continued by his Son, Richard Hall. To which is added, An Index; and Abridgment; With many useful Notes, References and Observations, never before published. And also A List of all the Laws, passed from the Settlement of the Island; which are now become obsolete, expired or have had their effect. (London, Printed for Richard Hall, I764, pp. xi, 526). Advertisement on back with MS. signature "Rich'd Hall"; the volume is superscribed "Fowler Walker" on the title-page.

2. I649-I682.

3. I649-1704.

4. Acts of Assembly Passed in the Island of Barbadoes, from 1648 to I7I8 (London, Printed by J. Baskett, Printer to the King's most Excellent Majesty, And by the Assigns of Thomas Newcomb, and Henry Hills, deceased, I 72I), pp. xxxii, 3I4).

5. $\mathrm{I} 68 \mathrm{I}-\mathrm{I} 692$.

6. I698-I 7 I4.

7. I7I $5-1717$.

8. I7I8-I 724 .

9. $1724-1737$.

10. $1738-1760$.

11. $1761-1767$.

12. $1768-1770$.

13. $1770-1773$.

14. $1773-1779$.

15. $1775-1780$.

16. $1782-1796$.

\section{O. 3 I : I-43. Sessional Pápers.}

1. "Journal of Proceedings of the Governor and Council of Barbadoes from the 29th of May I660 to the 3oth of November I686."

I660, May 28-1664, Mar. 29. Meetings of the governor and council; sometimes with the gentlemen of the assembly. (Copy attested in $\mathrm{I} 684$ as being all business from the year 1660 to Jan., I667, except 1665 and 1666 in which "there is none save only orders for the meeting of field officers"), ff. 89 .

I667, N. S., Feb. I 5-1680, Oct. 20. Proceedings of governor and council, ff. $9 \mathrm{I}-326$.

I680/I, Mar. 7-June 8.

(endorsed: "Orders"), ff. 327-370.

I680/I, Mar. 7-June 8. The same, with some additional matter, ff. 37I410.

I68I, July 5 -Sept. 7.

ff. 4 I I -448 .

I68I, Oct. 4-I68I/2, Feb. 2 I.

ff. $449-5 \mathrm{I} 2$.

I68I/2, Jan. 24-I682, Apr. 29.

(first part same as in the foregoing), ff. $5^{\mathrm{I}} 3^{-}-523$.

Proceedings of governor and council,

I682, June I3-1686, Nov. 30. Proceedings of governor and council (in various small sections, received at different times), ff. 525738.

2. I670, Oct. 2I-I683, Apr. 24. Journal of general assembly. (A continuous copy, certified as made and examined by Geo. Popplewell, Jan. 3, I683/4.)

3. I684, Sept. 30-1685, May 5. Proceedings of assembly, with acts passed, ff. I-23, 29-52.

I685, June 2-Nov. 24. Acts passed and proceedings of assembly (titlepage and endorsement read: "to 5 October"), ff. 53-140. 
I685, Oct. 5-1685/6, Mar. I7. Journal of assembly, ff. I4I-I 58. I686, Aug. 3-1687, July I2. " " " 1688/9, Feb. 19-1690, Aug. 5. “ “ “ "ff. I77-240. 1690, Sept. 2-169I, June I8. Proceedings of assembly (error in date; Wednesday Ioth reads, "adjourned till tomorrow I8th"; with the acts passed), ff. 243-3i 6 .

Copies of five acts passed Oct. 27, I692, ff. 317-327.

I692, July I4. Copy of letter to the governor about present, f. 325 .

I69I, Sept. I. Id., of previous year, f. 329 .

I69I, June I8. Act about laborers (same on p. 3II), f. 33 I.

I69I, Sept. I. Act to defray expenses of agents, f. 337.

1663, July I. Act about general sessions, f. 339 .

I69o, July 8. Id., f. 343. Copy of letter (see p. 329), f. 345 .

I693, July I I-I694, Dec. 24. Proceedings of assembly, ff. 347-427.

4. I686/7, Jan. 25-Mar. 4. Proceedings of council, ff. I-32.

1687, Apr. I9-July I4. “ " “ ff. 33-56.

I687, Sept. 6. Proceedings (passing of accounts), endorsed, "Proceedings of Council in three months ending the seaventeenth of September"), ff. 57-64.

1687, Dec. 6-1687/8, Mar. 20. Proceedings of council, ff. 65-82. 1688, Apr. 19-June I2.

I688, Oct. 2-I688/9, Mar. II.

I69o, May I2-Aug. 5 .

I690, Sept. 2-I690/I, Mar. I7.

I69I, Apr. I5-June I8.

I69I, June I8-169I/2, Feb. 27.

\begin{tabular}{|c|c|c|c|}
\hline & "s & “ & ff $03-126$ \\
\hline & ، & "6 & ff. $127-142$ \\
\hline & 《6 & 6 & ff. $143-178$ \\
\hline & \& & “ & \\
\hline
\end{tabular}

1691, Nov. 25; I691/2, Jan. 28. Proceedings of council of war, with articles of war, ff. 249-272.

I691/2, Jan. 23-June 3. Minutes of council of war, ff. 273-284.

1692, Apr. 12-Aug. 5. Proceedings of governor and council, ff. 285-312. 1692/3, Mar. 2-27. Minutes of council of war, ff. 31 3-336.

I693, Apr. 25-27. “ " “ " " at Martinique, ff. 337368.

1692, Sept. 6-1694, Aug. 7 .

1694, Aug. I7-1694/5, Mar. 23.
ff. 46 I -5 I2.

ff. $369-460$.
1694, Aug. I $7-1694 / 5$, Mar. 23.
ff. $46 \mathrm{I}-512$.

1694, Aug. $17-1694 / 5$, Mar. 23.
ff. $461-512$.

Proceedings of governor and council,

5. I694, Aug. I7-I695, Oct. 29. "Councills Journal, Booke the first." Minutes of council in assembly, ff. I-70.

I695, Nov. 2I-1696, July 2. "Councill's Journal booke the 2d." Minutes of council in assembly, ff. $7 \mathrm{I}-\mathrm{I} \mathrm{I} 6$.

I696, Aug. 7-Nov. 4.

I696, Nov. 10-1696/7, Feb. 3 .

1696/7, Feb. 9-1697, Apr. 29.

I697, May I I-Aug. 5 .

I697, Aug. I7-Nov. 3.

Minutes of council in assembly, ff. II $17-160$.

" " " " " $\quad$ ff. 239-258.

I697, Nov. 23-1697/8, Feb. 22. “ “ “ “ “ ff. 259-286.

I697/8, Feb. I5-1698/9, Feb. Io. Journal of general assembly, ff. 287342.

1697/8, Mar. I-1698, May 17. Minutes of council (in assembly), ff. $343-358$.

I698, July 28-i699, June 5 .

ff. $359-400$. 
I699, Apr. I8-Oct. 3. Journal of assembly (endorsed, "House of Representatives"), ff. 403-426.

I699, June 5-Oct. I7. Minutes of council in assembly, ff. 427-444.

1699, Oct. I 7-1699/I 700, Mar. 7. Journal of assembly (endorsed, "House of Representatives"), ff. 45I-468.

1699, Nov. 23-I700, Apr. 17. Minutes of council in assembly, ff. 473-506. I700, May 7-Oct. 23.

I700, Apr. I7-Sept. 3. Journal of assembly, ff. 555-570.

6. I70I, May 6-Nov. 20.

I7OI, Nov. 20-I7OI/2, Feb. I9.

I701/2, Feb. 24-I702, May I9.

I702, May 20-Aug. 5 .

I702, Aug. 25-Nov. IO.

I702, Aug. 25-Nov. IO. Feb. I6. “ “ " $"$ ff. $255-304$.
I702, Nov. 24-1702/3, Feb.
I700, Nov. 5-1701, May 3. Minutes of council in assembly, ff. 381-4Io.

I700, Oct. 22-I70I, Mar. 29. Journal of assembly, ff. 419-436.

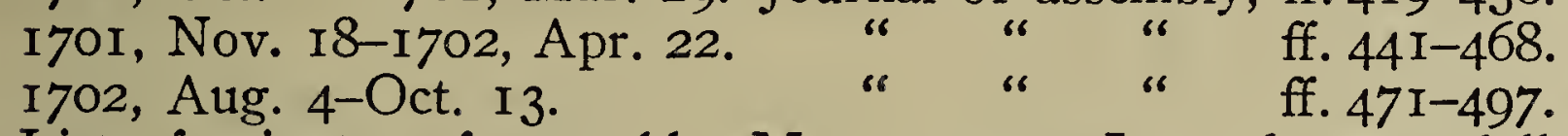

7. List of minutes of assembly, Mar. 4, I70I-Jan. I6, I705, followed by: "Mem. These Minutes are in a Book under the Seal of the Island (referred to the Board by an Order of Council of 23 April I705) containing an Answer to the first Complaints of the Absenting Members of Assembly, and of the Suspended Councillors. Vide in the said Book folio 340. L 56." [This is now C. O. 28:8, the minutes occupying pp. 340-437.]

I702, Oct. 27-1703, May I8.

I703, June 8-July 27.

I703, Aug. 3I-Oct. 25.

I703, Nov. 2-1703/4, Mar. 16.

I703/4, Feb. 8-May I6.

I704, Apr. 4-July 25.

Journal of assembly, ff. I- 57 .

are duplicates), pp. 23.

“ “ “ $"$ ff. $60-86$.

" " " ff. I24-157.

“" " "

" “ " (Apr. 4-May I6

I704, Aug. 23-Sept. I I. Journal of assembly (marked: "A new Assembly"), pp. 25-57.

I704, Aug. 23-Nov. I7. Journal of assembly ("to II September are duplicates"), pp. 75 .

I704, Nov. 28-1705, June 18. Journal of assembly, pp. 89.

I706, Sept. 4-1706/7, Feb. 3. “"“" pp. 40.

Docket only: "Minutes of Assembly 4 June to I I July I705, received from Col. Cleland. Vide Barbadoes Bundle M20." [This is now C. O. $28: 9$, and the minutes occupy II pp.]

8. List of minutes of council and memorandum same as above in vol. 7 , but the folio given is $\mathrm{I} 8 \mathrm{o}$. [Now in C. O. 28:8, the minutes occupying Pp. 180-333.]

I702/3, Feb. 23-May I8. Minutes of council, ff. I-3I.

I703, May II-Sept. 28. “ “ “ “
I703, Sept. I-Dec. 21. ff. $80-$ II 5 .

I703, Oct. 5-Dec. 2I. Minutes of council ("No. I. The Last Three Months' Minutes of the Governour and Councill"), ff. i i6167.

I703/4, Jan. I8-1704, Apr. 8. Minutes of council (title-page as above: "No. 2"), pp. 29. 
I704, Apr. 28-May i6. "No. 3 "), pp. II.

I704, May 26-June 27. I704, June 27-Sept. 6. I704/5, Feb. 20-June 4. I705, July 3-Dec. 20. I706, Sept. 4-Dec. 24. I706, Dec. 27-I706/7, Feb. 9. I706/7, Feb. Io-Mar. 21. I 704, Sept. I I-I 2. I704, Sept. II-I704/5, Jan. 24. I704/5, Feb. 20-I705, June 4.
Minutes of council (title-page as above:

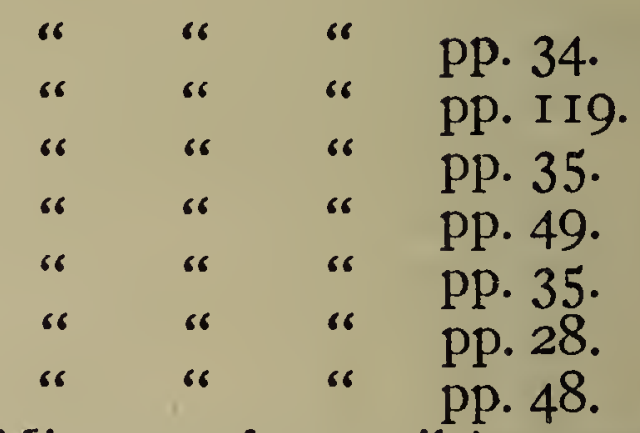

Minutes of council in assembly, pp. I8. pp. 88. pp. 29.

9. I7Io, July I I-Sept. 6. Journal of assembly, pp. I4.

I7IO, July II-Oct. 3I. " “ “ (a repetition to Sept. 6), pp. I9.

I7Io, Oct. 3-I7IO/II, Feb. 6. Journal of assembly (Oct. 3-31, a repetition), pp. Io.

I710, Nov. 29-I7I I, Apr. I7. Journal of assembly, pp. I9.

I7I I, July IO-I7II/2, Mar. II.

I712, Apr. I5-May 7.

I7 I2, May 20-July 22.

I712, Aug. 29-I7I2/3, Jan. I3.

I7I4, May I4-June 29.

I7I4, Aug. 9-Nov. I.

pp. 5 I.

pp. 31 .

pp. 28.

pp. 79.

pp. 27.

pp. 28.

I705 [1706], Mar. II, I9. Proceedings of governor and council relating to an accusation against Downes and Lillington, pp. 8.

I708, May 4-Aug. 30. Minutes of council, pp. I 5.

I708, Aug. 30-Dec. 22. " " " (Aug. 30 a repetition), pp. 39.

I7 Io, May I5-July II. Minutes of council (a loose paper placed within the volume), pp. $3 \mathrm{I}$.

I710, July I I-Sept. 5. Minutes of council (endorsed: "in Assembly"; July II is a repetition), pp. 30 .

I7 Io, Sept. 6-Nov. 28.

I7Io, Dec. I I-I7Io/I, Feb. 20.

I7I0/I, Mar. 6-May 29.

I 71 , June 23-Aug. I5.

I7II, Aug. 25-I7II/I2 Mar. I. " “" "

I7II/2, Mar. IO-I712, Apr. 5. “ “ “ “
I712, Apr. I5-May 21.

I712, July I4-Aug. 3I. Attested copy, dated Sept. I7, of proceedings of council relating to the behavior of the men-of-war when their assistance was required for security of the Leeward Islands, pp. 72.

I712, June 7-Sept. I3. Minutes of council, pp. 88.

I712, Sept. 30-I712/3, Jan. I3. Minutes of council in assembly, pp. 24. I7I2/3, Jan. 20-Mar. 20. " " " " " pp. 54. I7I3, Apr. 28-May I4. Minutes of council (does not say in assembly), pp. $2 \mathrm{I}$.

I713, May I9-Aug. I7. Minutes of council in assembly, pp. 9.

I7I3, Aug. I8-Sept. I4. Minutes of council (does not say in assembly), pp. 47.

I7I3, Sept. 24-I7I3/4, Jan. I3. Minutes of council in assembly, pp. 20. 
I7I4, Apr. 24-July 7. Minutes of council, pp. 30.

I7I4, July I 5-Nov. Io. " " " pp. 56.

10. I707, Aug. 2-Oct. $28 . \quad$ Minutes of council, ff. I-20.

I707, Nov. I-I707/8, Jan. 27. " “" "

I707/8, Feb. I7-I708, Apr. 26 . " " " "

i709, July I2-Nov. 8. " " " " "

I709, Nov. 9-1709/10, Jan. 24. “" " " " $"$ "ff. 9I-IO2.

I709/IO, Feb. I4-I7IO, Apr. 20. “ “ “ “

I7Io, May I5-July II.

I707, Mar. 28-May 7.

I707, May 9-July 28.

Minutes of council in assembly, ff. I69-200.

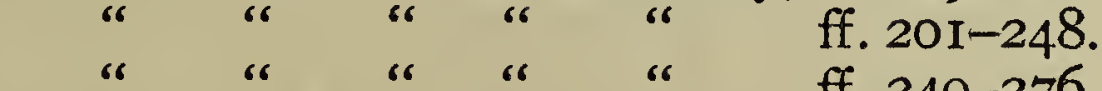

" " " " " " " " " $"$ " $" 249-276$.

I708/9, Jan. 6-i I09, Mar. 29. “
I709, Apr. 6-June I8.

I706/7, Jan. 2I-I707, July 28. Journal of assembly, ff. 329-499.

I707, Aug. 2-Oct. 28. " " " "

I707/8, Feb. I7-I708, May II. “ “ “ “ ff. $54 \mathrm{I}-584$.

I708, May I8-Aug. 24.

I708, Aug. 3I-I708/9, Feb. I 5.

I 708/9, Mar. 22-I709, May 4.

I708/9, Mar. 22-I709, Aug. 24. going), ff. 68I-736.

I709, Aug. 24-Nov. I 5.

I709, Nov. I8-i I09/10, Feb. 28.

I7 Io, Apr. I8-June 7 .

I7I0, May I9-July I I.

going), ff. 8 I I-824.

ff. $585-600$.

ff. $601-660$.

ff. $66 \mathrm{I}-68 \mathrm{o}$.

(part same as fore-

ff. $737-760$.

ff. $761-778$.

ff. 779-8Io.

(part same as fore-

11. Volume bound in calf, lettered: "Barbadoes. Minutes of Council I707 to I7I 3 ", but seems to be a record of certain proceedings relating to the attorney general, Thomas Hodges, with papers quoted, legal opinions, etc. At the end is a narrative précis of the contents. Ff. I-55I, 9 .

12. I7I4, Apr. 24-I7I5, Apr. 6. Minutes of council, A, pp. 78, 58.

I7I5, May I2-Aug. 2. " " " (signed on title-page, "Israel Hudson", with red wax seal), B, pp. 80.

I715, Aug. 3-1716, Dec. I8. Minutes of council, C, pp. I 52.

I7I6/7, Feb. I9-I7I8, Sept. I6. “ “ " (duplicate), D, pp. I39.

13. I7 I5, June 22-Dec. 6. Journal of general assembly (signed on title-page,

"Israel Hudson", with red wax seal), A, pp. 33.

I7I5, Sept. 26-Dec. I7. Journal of assembly (part same as foregoing), B, pp. 56 .

I7I5/6, Jan. 3-I7I8, Apr. 8. Journal of assembly (signed and sealed as above), C, pp. 90.

I7I8, Apr. 8-July 29. Journal of assembly (Apr. 8 repeated), D. pp. 17.

I7I8, Aug. I9-I7I9, May 12. “ “ “ “ $“ \quad$ "

I719, May 5-1720, June 28. " " " (May 5 and I2 repeated; signed and sealed as above), F, pp. 278.

I720, June 30-Oct. I8. Journal of assembly, G, pp. 25.

14. I7I7/8, Feb. I9-I7I8, Sept. 30. Minutes of council (contains various accounts), E, pp. $23 \mathrm{I}$.

I7I8, Sept. 30-I7I9, Apr. 22. Minutes of council (Sept. 30 repeated). F, pp. 257. 
I720, May I0-June 21. Minutes of council (endorsed, "from I6 March"). G, pp. I07.

I 720, June 30-Oct. 25. Minutes of council, H, pp. 46 .

15. I7I9, May I2-1719/20, Mar. I6. Minutes of council (endorsed, "from 22 April I7I9"), pp. II79.

16. I720, Dec. 5-1720/I, Jan. I8. Minutes of council, A, pp. 46. I720/I, Jan. 28-I72I, Apr. 6.

I72I, Apr. I2-Aug. 8.

I721, Sept. 5-6.

I72I, Sept. 9-Oct. 24.

I72I, Oct. 28-Dec. I9.

I 72I, Dec. 22-I 721/2, Feb. 8.

I $722 / 3$, Jan. I9-Feb. 26.

I722/3, Mar. 20-May I7.

I72I, June 7-Aug. 22.

Journal of assembly, c, pp. 37 .

B, pp. I53.

I721, Sept. 5-Dec. 5 .

I722, Aug. 23-I722/3, Feb. 26. “" “" " e, Pp. 25.

I723, Mar. 26-May 28.

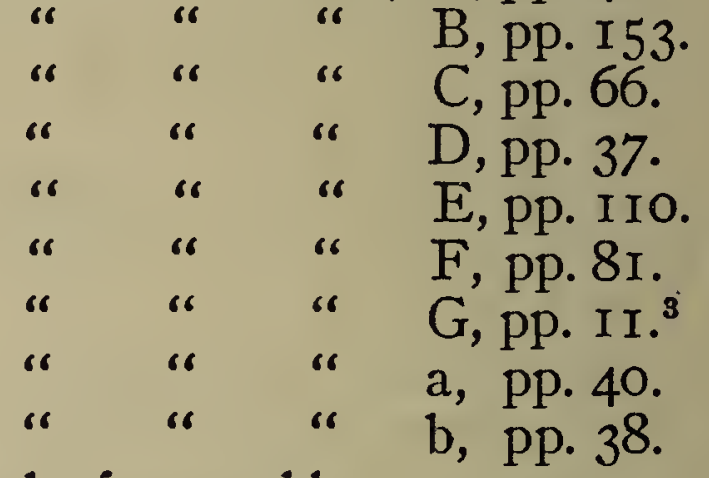

17. I723, May 24-Aug. 7. Minutes of council in assembly, A, pp. 70.

I723, Aug. 8-Nov. 26. Minutes, endorsed: "Council and Council in Assembly", B, pp. 34 .

I723, Dec. 3I-I723/4, Jan. 28. Minutes endorsed as above, C, pp. 26.

I723/4, Feb. 25-I724, Apr. I4. “ “ “ “ D, pp. I4.

I724, May I2-Sept. I. Minutes of council (does not say in assembly), E, pp. 3 I.

I724, Sept. 29-1724/5, Mar. I7. Minutes, endorsed: "Council and Council in Assembly", F, pp. 25.

I725, Apr. I 3-Aug. 3. Minutes of council, endorsed: "in Assembly"; G, pp. 22.

I725, Aug. 3I-I725/6, Feb. I5. Minutes of council, H, pp. 22. I725/6, Mar. I 5-I726, June 8. “ “ “ I, Pp. 20. I726, July 5-I726/7, Mar. 4. “ “ “ K, I726/7, Mar. 2I-I727, July I8. “ “ “ L, pp. 20. I727, Aug. 7-Sept. I 5 . I727, Oct. 24 . M, pp. 26. (a loose paper), pp. 7.

I 727, Nov. 28-i $727 / 8$, Feb. 20. I $727 / 8$, Mar. I9-I 728 , July I3. I728, Aug. 2-I3. sembly"), P, pp. 36. I723, July 30-Sept. I7. Journal of assembly, a, pp. 22. I723, Sept. 24-I723/4, Jan. 9. I723/4, Jan. I6-I724, May 7 . I 724, July 7-Aug. 27. I724, Sept. 24-I724/5, Apr. I3. I725, May II-July 30 . I725/6, Jan. I8-Apr. I2. I726, July 5-Aug. 2. I726, Aug. 30-Nov. 22. I 726, Dec. 20-I727, June 23. I 727 , July I8-Aug. I.

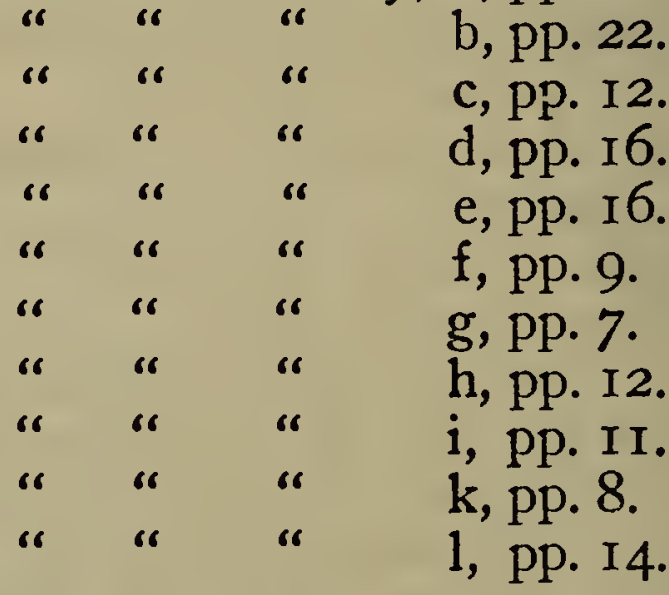

N, pp. 40.

O, pp. 28.

(endorsed: "in As-

The attests to this and the abo impressed on paper over wafer. 
I727, Aug. 8.

I727, Sept. 5 .

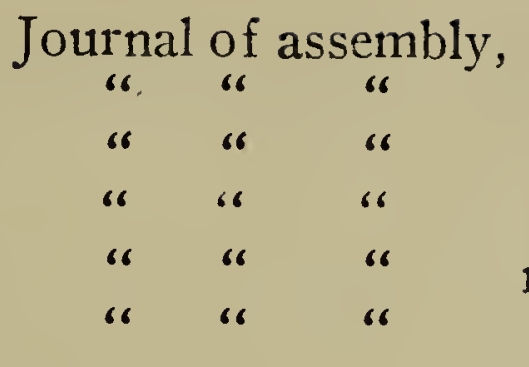

Loose papers,

I727, Sept. I 5 .

I727, Oct. 5 .

I 728 , July I3-3I, Aug. $5,7,8$

I728, Aug. 5/20.

$$
\text { going), n, pp. } 3 \text { r. }
$$

pp. 9, 4, 3, 7 .

18. 1728, Aug. 17. Minutes of council (a loose paper), pp. 22. I728, Aug. 20-Nov. 28.

I728, Dec. I7-1728/9, Feb. I9.

I728/9, Mar. I8-1729, July 8.

Minutes of council, A, pp. 5 .

5-I729/30, Feb. I7 “ " “ “ C, pp. 22

I728, July I3-Sept. I4. Journal of assembly, E, pp. 74.

I728, July I3-Aug. 29 .

F, pp. 53 .

I728, Sept. Io-Dec. 7. G, pp. 16.

I728/9, Jan. I7-I729, May 2. “ “ “ ' (a loose paper),pp.7.

I729, June , 3-July 8.

1729, Nov. 4-I729/30, Mar. I3. “ “ “ I, pp. I9.

19. I $729 / 30$, Mar. I7-I730, Oct. 20. Minutes of council, pp. 35 .

I730, Nov. I7-Dec. 7. sembly), pp. 20.

1730, Dec. 22-173I, Aug. 31.

I73I, Sept. I4-I73I/2, Feb. I5. Minutes (endorsed "of Council and of Council in Assembly"), pp. 85.

I731/2, Mar. 3-1732, May 1o. Minutes of council, pp. 23.

1732 , June 6.

I733, Apr. I2-June 26.

I733, July I0-Oct. 8.
I733, Oct. I7-I733/4, Mar. I3. “ “ “ “ etc.), pp. 108.

20. I733/4, Mar. 20-I735, Apr. 16. Minutes of council, pp. 81.

I735, Apr. 22-Oct. 29.

1735, Nov. I I-I736, Aug. 3I.

fees, etc.), pp. 92 .
I736, Sept. I-I738, July 22. Minutes of council, pp. 82.

(a loose paper), pp. 3 .

pp. 4I.

pp. 39.

contains lists of fees,

1730, Nov. $17-1730 /$ r, Mar. 19. Journal of general assembly, pp. 26.

I730, Nov. 17-1730/1, Feb. 13. Loose paper: Printed votes and proceedings, in separate sheets with continuous pagination. (Printed and sold by David Harry near Broad Street. Same as in above manuscript. Attached is address of council, Dec. 7, and the governor's answer.) Pp. 3 I.

I73I, Apr. 27-I732, Nov. 20. Journal of general assembly, pp. 85 .

I733, Apr. I7-Nov. 6.

1733, Nov. 13-1734, Apr. 6.

1734, Apr. 6-1735, Sept. I6. repeated), pp. 40.

1735, Sept. 23-1736, Oct. 5 .

1736, Oct. 28-1738, Aug. 29.

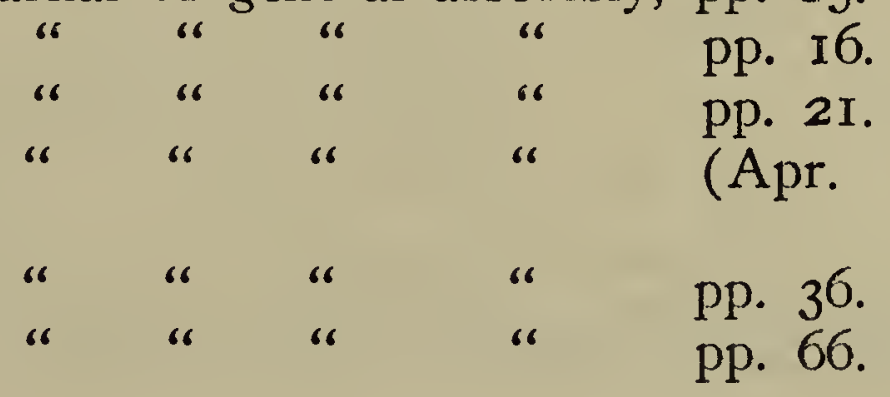


21. I738, Aug. 8-1739, May I5. Minutes of council, A, pp. I6. I739, Oct. 2-I740, Dec. I2. " " " " I740/I, Jan. 20-I743, May Io. " " " " $"$ ", pp. I86. I743, June $7-N o v .22$.

(contains lists of

$$
\text { fees ), D, pp. I05. }
$$

22. I738, Sept. 5-I740, Dec. 23. Journal of general assembly, pp. I2I. I740/I, Jan. 20-I742, July 5. " " " $"$ " I742, July 28-I743, May 5. " " "

23. I743, Nov. 23-I744/5, Mar. I9. Minutes of council, A, pp. I90.

Docket: "The Minutes March I4, I745 to Feb. I8, I746 are annexed as an Appendix to Sir T. Robinson's long letter to the Board 27 Feb. I746 and are bound up with it and make a volume. Bb. 4I." [This is now C. O. $28: 28$, where these council minutes form app. $B$, with pages numbered $I-5 \mathrm{I} 8$.] I745/6, Feb. I9-I746, Aug. I9. Minutes of council, B, pp. I5I.

24. ${ }^{4}$ 746, Sept. 3-1747, Apr. I4. Minutes of council, C, pp. 3 Io.

I743, Aug. 25-Nov. I 5 .

Journal of assembly, no. I, pp. I7.

I743, Nov. 22-I744, Aug. 2I. " " " " no. 2, pp. 52 .

I744, Sept. 2I-I744/5, Feb. 20. " " " " $"$ (continuation on

printed sheets), pp. I7.

As in vol. 23, proceedings of the assembly, Mar. I4-Dec. 24, I745, are with Sir T. Robinson's letter (Bb. 4I). That vol. is now C. O. $28: 28$, and the assembly minutes form app. C, pp. I-64, twenty of these pages being in printed form.

I745, Dec. 26-I746, May 28. Journal of assembly (portions printed, the manuscript continuing on the printed pages), no. 3, pp. 25 .

I746, May 29-I746/7, Mar. I7. Journal of assembly, no. 4, pp. 56.

25. I747, Apr. I4-July 28.

I747, Aug. 4-I748, May Io.

I748, June 7-Dec. I2.

I748/9, Jan. I6-June 6.

I749, July I2-Nov. 8.

Minutes of council, no. I, pp. 87.

I749, Nov. I6-I750, May I5.

26. I747, Apr. 23-June 23.

I747, Nov. 24-I748, May 9.

I748, June 7-Nov. I6.

I748, Nov. 28-I749, July I I.

I749, July I I-Oct. 20.

I749, Nov. I6-I749/50, Mar. 20. " " " " " "

I750, Apr. 24-Nov. 28.

I750, Dec. IO-I75I, Aug. 6.

I75 I, Aug. 20-I752, June 9.

I752, July 7-Nov. 6.

I752, Nov. 29-I753, Mar. 20.

I753, Apr. I7-Nov. 28.

no. 2 , pp. 88.

" " " no. 3, pp. 80.

" 6

"

no. 4 , pp. 94.

" " $"$ no. 5 , pp. 34.

Journal of assembly, A, pp. 22. no. 6 , pp. 53 .

through and marked: "This is to be mad takes in more than the real origl."), M, pp. 25.

I753, Dec. 27-I754, Apr. 2. Journal of assembly, N, pp. 28.

'In Original Correspondence (C. O. 28:48) are sets of council and assembly proceedings, 174I-Mar., 1747, which were sent to the Duke of Newcastle. They duplicate those listed above within the dates mentioned. 
27. I750, July I2-I750/I, Jan. 23. Minutes of council, no. 7, pp. 50. I750/I, Feb. I3-I75I, Aug. 6. " " " " no. 8, pp. 90. I75I, Oct. I-I752, July 8. " " " " $\quad$ " no. 9, pp. 49. I752, Aug. 5-Nov. 7 . I752, Nov. 29-I753, May I4. I753, May I4-Oct. 3I. I 753, Dec. 4-I754, May I4.

28. I754, July 9-I755, May I4. Minutes of council, pp. 66. I755, June 3-1756, June 8. “ “ “ $"$ "

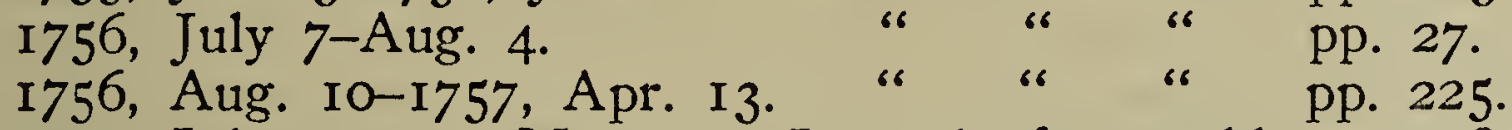

29. I754, July 9-I755, May I3. Journal of assembly, pp. 28. I755, May 27-I756, May 25. " " " " I756, June I-I757, Apr. 28. “ “ “ “ I757, May Io-I758, May 9. “ " “ " “ I758, June 6-I759, July 3. “ “ “ “ I759, July I0-I760, Apr. I5. “ " " "

30. I757, May II-I758, May ro. Minutes of council, pp. I63. I758, June 7-I759, June 6. “ “ “ “

I759, July II-I760, May 6. " " " " (a loose paper), pp. $7 \mathrm{I}$.

31. Volume lettered: "Council in Assembly", but not so stated within. I760, May 28-i76r, May 5. Minutes of council, pp. 84. I76I, June 2-I762, Apr. I3. " " " " I762, May II-I763, May I7. " " " " " " I763, June 4-1764, May 9. “ " " " " I764, June 5-I765, May I4. " " "

32. I760, May 28-i $76 \mathrm{I}$, May 5. Journal of assembly, pp. 37. I76I, June 24-I762, Apr. 27. " " " " I762, May II-I763, Apr. I9. " " " " I763, May 3I-I764, Feb. 2I. “ “" “ " " " I764, May 8-I765, Mar. I8. " “ " " I765, Mar. I8-i766, Apr. I5. “ “" “ (Mar. I8 a repetition ), pp. 32 .

I766, Apr. 29-1767, Apr. 28. “ “ “ “ I767, June 3-1768, Feb. I6. " "

33. I765, July 9-I766, May 27. Minutes of council, pp. I 5I. I765, May 27-1767, May 26. " " “ " $"$ " I767, June 3-I768, Feb. I I. " " "

34. I765, July 9-I766, May 27. Minutes of council (Endorsed: "in Assembly", but seems same as in vol. 33), pp. I 52 .

I765, Mar. I8-i766, Apr. I5. Journal of assembly (duplicate; $c f$. vol. $32)$, pp. 34 .

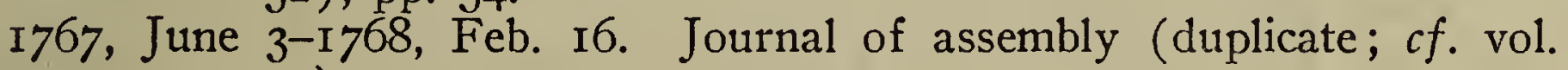
$32)$, pp. 32 .

I77I, Aug. 23-I772, Aug. 3I. Minutes of council (endorsed: "in Assembly"; duplicate; $c f$. vol. 37 ), pp. 97.

I772, Sept. 4-I773, June 8. Minutes of council (duplicate; $c f$. vol. 37), pp. I29.

I773, June 8-July 20. Minutes of council (duplicate; cf. vol. 37), pp. 93.

I773, Aug. 3-I774, July I9. Minutes of council (duplicate ; $c f$. vol. 37), pp. IOO. 
I774, Aug. 9-1775, June 27. Minutes of council (duplicate; $c f$. vol. $3^{8}$ for this and two following), pp. $7 \mathrm{r}$.

I776, July 30-r777, May I3. Minutes of Council (duplicate), pp. 68.

I777, July 8-I779, Apr. I3. “ " " " (duplicate), pp. 264. r779, May I I-1780, Apr. I8. " " " (cf. vol. 40), pp. r 56.

35. I768, Feb. II-Aug. 2.

i768, Aug. 30-1769, Jan. 26. " " "

I769, Feb. I4-Aug. 8.

36. I768, Feb. 18-Aug. 2.

I768, Aug. 30-r769, Apr. I9.

Journal of assembly, pp. 42.

1769, May r6-Aug. 8.

I769, Oct. 3I-I770, Apr. 3 .

I770, May 15 and July 3.

I770, Aug. 7-1771, June I8.

I77I, July I6-r 772 , July 2.

I772, Aug. 4-I773, May 25.

I773, June I5-July 20.

1773, Aug. 3-1774, Apr. I2.

I774, June 23-July I9.

37. I769, Sept. 5-1770, Aug. I3. Minutes of council, pp. 8 I.

I770, Sept. 4-I771, Aug. 5. Minutes of council (certified as ending Aug. 27), pp. 96.

I771, Aug. 23-I772, Aug. 31. Minutes of council (same as in vol. 34, but does not say "in Assembly"), pp. 95.

I772, Sept. 4-I773, June 8. Minutes of council ( $c f$. vol. 34 for this and two following), pp. I25.

I773, June 8-July 20. Minutes of council (June 8 a repetition), pp. 90. I773, Aug. 3-1774, July 19. Minutes of council, pp. roo.

38. I774, Aug. 9-1775, June 27. Minutes of council ( $c f$. vol. 34), pp. 73. I775, July I9-1776, July 9. “" " " "

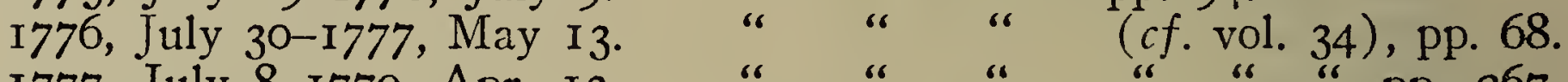

I777, July 8-I779, Apr. 13. “ “ “ “" “pp. 267.

39. I774, Sept. 6-I775, May r6. Journal of assembly (duplicate; a loose paper), pp. 46.

1775, July r9-1776, July 9.

I776, Aug. 22-I777, July 8.

I777, Oct. I-I779, Apr. I3.

I779, May I I-I780, Apr. I8. I08.

Journal of assembly, pp. II7.

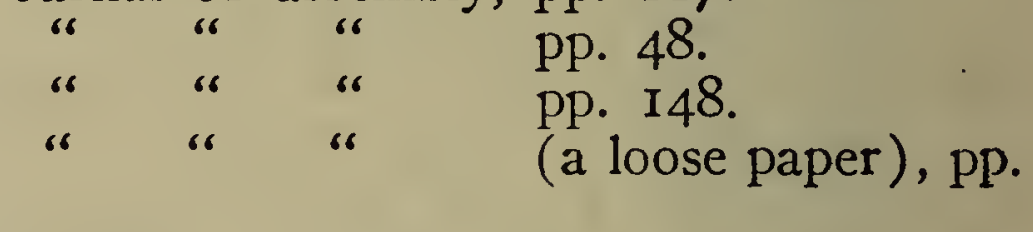

40. I779, Oct. 27. Minutes of council (also in next item), pp. 7. I779, May I I-I780, Apr. I8. Minutes of council, pp. I79. I780, May I7-July I2. I780, July 25-Aug. 22.

pp. 9.

pp. 6r.

41. I780, May I6-Nov. 28. Journal of assembly (with proclamation of Dec. 7 dissolving the house), pp. I50.

I78I, Feb. I4-May I5. Journal of assembly, pp. Iog. I78r, July IO-Oct. $2 . \quad$ " “ " " $"$ " I781, Nov. 28-I782, May I4. " " " " $"$ " I782, July 2-I783, Aug. 5. " " "

I783, Sept. I I. New assembly met, and adjourned to Oct. 28, pp. 6.

42. "Council, and Council in Assembly."

1780, Sept. 5-1781, May 8. Minutes of council in assembly, pp. 88. 
I78I, May I5-Oct. 2.

I78I, Oct. 30-I782, Mar. I9.

I782, Apr. II, 23.

I782, May I-Aug. 8.

Minutes of council.

" 640

(These do not say "in Assembly".) Pp. I $5 \mathrm{I}, \mathrm{I} 23,27,5 \mathrm{I}$.

I782, Sept. 3-I783, Jan. 21. Minutes of council (endorsed "in Assembly"), pp. 85 .

I783, Feb. I8-Aug. I9. Minutes of council, pp. 48.

I783, Sept. I I-I4. Minutes of council (endorsed "in Assembly"), pp. 24. Petitions (two) of Nathaniel Weekes, judge of vice-admiralty, to Gov. Parry, Jan. I 5, Aug. 5, I783, pp. 4.

43. I783, Sept. I I-I 784 , Mar. I6. Journal of assembly, pp. 43.

(The papers continue to later dates.)

C. O. 33:I3-I9, Treas. I :53I-532, $64: 47-49$. Shipping Returns. ${ }^{5}$ INWARD.

C. O. $33: 14$. I680, June Io-I68I, Dec. I7.

13. I68I, Dec. I7-I682, June I7.

14. I68I/2, Jan. I-I683, July I. I682, June I7-Sept. I7.

13. I682, Sept. I8-I682/3, Mar. I7.

14. I682/3, Mar. I7-I685, Sept. Io. I685, Oct. I7-I687, Oct. I7.

OUTWARD.

C. O. 33 :13. I678, Apr. I4-I679, Oct. I4.

14. I678, Oct. I4-I680, Oct. I6.

INWARD AND OUTWARD.

C. O. 33 :13. I687, Dec. 25-I688, June 25 .

I688, Sept. 25-I689, Mar. 25.

I69o, May I3-I69i $/ 2$, Feb. I 3.

I694, Dec. 29-I695, June 24.

I695, Dec. 25-i696, Sept. 29.

I696, Dec. 29-I70I, Sept. 24.

I701, Dec. 25-1702, June 24.

I702, Dec. 25-I703/4, Mar. 24.

14. I 704, Mar. 25-1706, Dec. 24.

I707, Mar. 25-I708, Dec. 24.

I709, Mar. 25-Sept. 24.

Treas. 64:47. I7IO, Dec. 5-I7IO/I, Mar. 24.

C. O. 33:15. I 7I I, June 25-Dec. 24.

I7I2, Mar. 25-I7I2/3, Mar. 24.

I7 I 5, Mar. 25-I7I6, Dec. 25.

I7I7, Mar. 25-I7I8, Sept. 29.

I7I9, June 25-I72I, June 25.

16. I728, June 25-I729, Dec. 25 .

I730, June 25-Sept. 25.

I730, Dec. 25-I73I, June 25.

I733, Apr. I3-Oct. I 3 .

I735, Mar. 25-1738, Mar. 25.

${ }^{5}$ In the earliest returns entrances and clearances are given on separate forms. With Dec. 25, 1687, they merge in a single list; but from Apr. 14, 1747, they again appear separately. 
INWARD.

C. O. 33 :16. I747, Apr. 14-Sept. 25 . I75.2, Sept. 25-1753, Mar. 25.

17. I764, Jan. I-Apr. I.

Treas. 64:48. I772, Dec. 25-I773, Mar. 25.

Treas. 64 :49. I773, Mar. 25-Oct. Io.

48. I773, Oct. IO-I774, Jan. 5 .

49. I774, Jan. 5-I775, Jan. 5 .

48. I775, Jan. 6-1776, Jan. 5.

Treas. I :532. I776, Jan. 6-I777, Jan. 5 .

Treas. $64: 48$. I777, Jan. 5-1778, Jan. 5.

Treas. I :532. I778, Jan. 6-Dec. 25.

Treas. 64:49. I778, Dec. 25-I779, Apr. 5.

48. I779, Apr. 6-July 5.

49. I779, July 6-Oct. Io.

48. I779, Oct. I I-I 780 , Jan. 5 .

Treas. I :531. I780, Nov. I I-I 782, Feb. IO.

C. O. $33: 18$. I 781 , Nov. I I-I 782 , May Io. (This vol. also contains returns for the years $1784-1806$.

OUTWARD.

C. O. 33:16. I747, Apr. I4-Sept. 25 . I752, Sept. 25-I753, Mar. 25.

17. I764, Jan. I-Apr. I.

Treas. 64:49. I772, Dec. 25-I773, Mar. 25.

48. I773, Mar. 25-Oct. Io.

49. I773, Oct. IO-I774, Jan. 5 .

48. I774, Jan. 5-I776, Jan. 5 .

Treas. I :532. I776, Jan. 6-1777, Jan. 5 .

Treas. $64: 49$. I777, Jan. 5-1778, Jan. 5 .

Treas. I :532. I778, Jan. 6-Dec. 25.

Treas. 64:48. I778, Dec. 25-Apr. 5, I779.

49. I779, Apr. 6-July 5 .

48. I779, July 6-Oct. Io.

49. I779, Oct. I I-I780, Jan. 5 .

Treas. I :531. I780, Nov. I I-I782, Feb. IO.

C. O. $33: 18$. I781, Nov. I I-I782, May Io.

19. I 784 , Jan. I-I 786 , July I. I 787 , Oct. I-I 788 , Jan. I.

18. I800, Oct. I-Dec. $3 \mathrm{I}$. I8o I, July I-Sept. 30. I803, Feb. I-I806, Jan. 31.

\section{Miscellaneous.}

C. O. 33:13. Customs receipts. July 3-Dec. I3, I679. They contain similar particulars to the outward returns.

Totals of dutiable goods exported Jan. I-June 30, I682.

Treas. 64:48. Plantation bonds at Barbados. Jan. 5, I775-Jan. 5, I776. (List of bonds. Particulars given are: date of bond, ship, master, surety, penal sum, witness, where bound, observations.)

Treas. I :532. Plantation and European bonds. Dec. 25, I775-Jan. 5, I777. 
Treas. 64:49. Plantation bonds and certificates. Jan. 6, I777-Jan. 5, I778.

Treas. I :532. Plantation bonds and certificates, and European bonds. Jan. 5-Dec. 25, I 778.

C. O. 33:14. List of ships and enumeration of commodities imported, I679I680.

15. Lists of negroes imported. I707-I726; Mar. 25, I708-Mar. 25 , 1726.

19. Christenings and burials. Dec. I, I802-Dec. I, I803. Revenue accounts. May, I803-May, 1804 .

27-30. Court papers and treasurer's accounts. 1723-1737. (See Andrews, I. I9I-I92.)

\section{BERMUDA.}

C. O. 37:9-24. Board of Trade: Original Correspondence. i709-I792.

9. I709-17 6 .

Letter from Lieut.-Gov. Pullein, complaining that Spaniards are seizing and condemning all vessels which carry Spanish money, cacao, salt, or hides. Jan. 9, I7I4/5. Depositions on seizure of three Bermuda vessels, and other papers.

Papers, including "certificate" from Lieut.-Gov. Spotswood and extracts from minutes of council of Virginia, on the Count de Paix, a richly laden vessel which sailed from Santo Domingo for Havre, and after, as is alleged, being purposely run aground, was plundered and broken up by sloops from Bermuda.

10. I716-1723.

Letter from Lieut.-Gov. Pullein, on disputes with assembly, insufficiency of revenue, decline of trade and discontent of inhabitants in Bermuda; and on piracy and illegal trade at the Bahamas. Apr. 22, I7I4.

Several letters from Lieut.-Govs. Bennett and Hope, on pirates by whom "North and South America are infested"; especially around Cape Cod, the Spanish Main, Bahamas, and Turks Islands. I717-1723. Numerous depositions, letters, accounts of trials in admiralty court, and other enclosures.

Letter from Lieut.-Gov. Bennett, on declaration of war and fitting out of privateers. June 8, I7I9.

Account of condition of fortifications. I7I9.

Copy of journal of William Martindale, commander of sloop at Providence, showing activities of British privateers, and especially of two from R. I. which attempted to burn some houses at Harbor Island (Bahamas).

Copies of "the Bermuda Newspaper", consisting of written sheets on pirates and other matters.

Copies of proceedings of admiralty court on: (a) sloop Philippo Quinio of Curaçao, seized by Hopewell privateer (commissioned at Bermuda, I719) for trade with Spaniards; (b) sloop Friendship, late of N. Y. and recaptured from Spaniards; (c) goods taken from sloop Packett Boat of Curaçao, which was seized on charges of carrying Spanish goods and contraband and of conveying intelligence to Spaniards, and was abandoned on account of unseaworthy condition; (d) on goods taken from sloop Catherine of Curaçao, 
seized for trade with Spaniards and carriage of contraband; (e) on sloop Louisa of Martinique, built in Bermuda and seized for trading without papers; and on ship L'Amitié of Dunkirk, seized for supplying arms to Spaniards. I7I9.

Classified account of population. I72I.

"Copy of a Commission from the Receiver General and Sollicitor and Comptroller of the Rights and Perquisites of Admiralty to Robt. Dinwiddie Esqr. constituting him their Agent at Bermuda." I72I.

Proceedings in trial for murder in court of assize, oyer and terminer, and general gaol delivery. I722.

Letter from Lieut.-Gov. Hope, asking for definition of his relations to Dinwiddie, having heard of no such appointment in other plantations. Sept. 9, I722.

Description of Bermuda, forwarded in answer to queries of Board. I722.

Letter from Hope, on quarrel with collectors as to which should receive the king's thirds. Apr. I2, I723.

Accounts of: powder money, I7I6-I723; "the Receiver of the 5 p.Cent upon all dry Goods", I72I-I723; prizes, the crown's thirds of seizures, and duties received on prizes condemned, I707-I72I ; "the King's Slaves", and rent from crown lands, I716-1722; receipts from liquor tax, I7I6-I723; stores in Bermuda, I722.

"Copy of Mr. Strahan's Report upon the Power of collecting Admiralty Dues in Bermuda."

"Copy of Col. Hope, Governor of Bermuda's Case and Mr. West's Report upon his Power to collect Admiralty Dues." I723.

Petition of merchants and traders to Bermuda against act passed there, Nov., I72I, to lay a duty of five per cent on all merchandise.

11. I723-I727.

Letter from Lieut.-Gov. Hope. Illicit trade with foreign colonies, and good understanding which exists between Bermudians and pirates. "The Bermudas Sloops are such Sailors that if they are anything Large the Pyrates never part with them"; but the Bermudians are seldom losers by encounters with pirates. The island revenue misapplied. "For these Twenty Years past . . . the Bulk of this Revenue has been imploy'd in Defending of a Law Suit which one Jones formerly Provost Marshal here has against the late Governor." Strategic importance of the islands. Jan. I4, I723/4.

Storekeeper's account of powder received and expended. I707-I723.

Answers to Board's queries on state of the island. I723.

Hope to Popple, complaining that in two years he has received only two letters from the Board. Jan. I4, I723/4.

Proceedings in admiralty court in trial of sloop George and Elizabeth of S. C., "condemned for illegal Trade in importing Commodities of the Growth of Foreign Plantations from other places than where they were produced and having no proper Certificates, Cocquets or Clearings from the place where Loaded on Board and having been located in an uninhabited island called St. Lucia." I723.

Accounts of "King's Rents", I722; duties on liquors and dry-goods imported, I723-1724; powder-money, I723-I724; and revenues and disbursements in general, I722-1723. 
Reference by Newcastle to Board of petition from Dean Berkeley of Derry and three fellows of Trinity College, Dublin, for patents to erect a college at Bermuda. Feb. I6, I724/5.

Letter from Hope, describing assembly: "it is impracticable to keep them together longer than Three Days, else their Familys wou'd Starve for want of Fish and their Negroes would turn loose. Of the Thirty six Members perhaps most off them can Read and Write." Assembly urges him to pass habeas corpus act, though members do not understand it. Also gives much general information on colony and taste of inhabitants for wandering, illegal trade, and rum punch. Aug. Io, I724.

Proceedings in admiralty court, letter from Hope, and other papers, containing full information on seizure of ship Salamander for importing Indian goods without proper papers, and on condition of admiralty court. I724.

Proceedings in admiralty court in trial of sloop William of Bermuda, which illegally introduced tobacco from Va., was navigated only by two white men and three slaves, and was loaded and cleared by permission of different collectors. I725.

Letter from Hope, defending himself against charges connected with seizure and condemnation of George and Elizabeth of S. C. Nov. 25,1724 .

12. $1727-\mathrm{I} 737$.

Classified account of population. I727.

List of amounts due from individuals under act to raise money for fortifications.

Letter from Lieut.-Gov. Pitt, on seizure of merchant vessels by Spaniards. Apr. 30, I729. Letter from Pitt and council on same, with account of losses recently sustained. Oct. I6, I729. Petition of lieutenant governor, council, and assembly on same, and asking for war vessel and company of soldiers for protection. Oct. 16, I729.

Answers to Board's queries on state of island. 1730 .

Proceedings of admiralty court in trial of pirate. I730.

Order of Lords of Committee of Council referring petition of Noden, agent to Pitt, that $£$ Ioo per annum be secured to Pitt in compensation for recent loss of right to grant licenses for whale-fishing. Apr. I4, I73I. Id., on report of Board of Trade on foregoing, and directing that Pitt ask for said compensation from assembly. July 7, I73I. Other papers.

Letter from Pitt, on foregoing, and on poisoning of whites by negroes. Jan. $27,1730 / \mathrm{I}$.

$I d$., asking for small war vessel and for return to Bermuda of independent company of soldiers now at the Bahamas. Nov. 4, I73 I. Order in Council for return of said company to Bermuda. Dec. 23, I73I.

Proceedings in admiralty court in trial of schooner Rebecca of Boston, seized for illegal introduction of tobacco from $\mathrm{Md}$. ${ }^{\mathrm{I}} 73^{2}$.

Answer to Board's queries on state of island. I733.

Accounts of rents from crown lands, I730; powder money, 1730 ; and duties on liquor and negroes, $1730-1732$.

Letter from Pitt, arguing that opening of whale-fishery has ruined whaling and stopped all exports of oil. May 30, 1734 .

Id., on local trade and manufactures. Oct. Io, I734. 
Answers to Board's queries on state of colony. I735, I736.

Treasurer's accounts of public revenues. I732-1736.

"Answer to the Parliamentary Enquiry relating to all sorts of Taxes or Impositions laid in Bermuda on Trade, Shipping or otherwise." 1735 .

13. $1737-1740$.

Account of powder-duty, I736; and treasurer's accounts, I737.

Letter from Alured Popple, "nominated Gov. of Bermuda", giving, by permission of Board, his observations on Pitt's instructions. Suggests dropping of useless export tax on tobacco; argues that whalefishery should remain unrestricted, and discusses slave trade. "The Inliabitants of Bermuda are known to purchase no Negroes either from the African Company or Others; Many slaves are exported from,-but none imported to Bermuda." Oct. 24, I737.

Memorial of Gov. Alured Popple, complaining that no ordnance stores have been sent since I7OI. I737. Order in Council for sending of stores. Apr. 6, 1738.

Deputy provost marshal's account of public rents received and disbursed, I732-I735. Account of powder-duty received and disbursed, I7361737 .

Letter from Auchinleck, president of council, on reports of Spanish preparations against Georgia. May 8, I738.

Letter from Gov. Popple, on colonial acts placing duties on whales and on all tonnage not English. Former act, soon to expire, placed duty on English as well as on other British tonnage; but, "as no English Vessell has been here since, excepting the Ship in which I came and which was excused paying that Duty", and as no ship is expected before time of expiration of act, begs that act be not disallowed. Argues that Bermuda should be under same surveyor general as Jamaica, Carolina, and the Bahamas. Dinwiddie (who owes his appointment to Walpole) has property in Bermuda, is member of council and should be surveyor general. "Mr. Dunbar since his first Appointment has never been here, to discharge this part of his Duty, and by being one of the Council in ordinary constantly occasions a Vacancy at that Board." Letter also relates to currency situation. Aug. 21, I738. Enclosed is Dinwiddie to Popple, on the currency situation and scheme for introducing British coin. Aug. 17, I738.

Id. Strategic importance of colony and need of ordnance. Sept. 27, I738. Enclosures.

Id., on courts of colony, illicit trade between R. I. and Martinique, restrictions placed by the Bahamas on export of their produce, and relations of Bermuda to Turks Islands. Recent act of the Bahamas forbids, under heavy penalties, exportation of salt, planks, and other articles by persons not of that colony without license from governor; and governor is not restricted as to fees. Bermudians need cedar plank from the Bahamas in building sloops, while "the Ground work of our Trade to America is almost entirely dependent upon our Rakeing Salt at the Turk's Islands. . . . With this Salt they purchase a Cargoe of Provisions from some of the Northern Collonies and these provisions they exchange at some of the Sugar Colonies for European Commodities, Rum, Sugar or what they want, and very frequently Sell their Sloops also and return home to 
Build Another, for the Same Circle of Trade." Question whether Turks Islands belong to the Bahamas, "which comprehend all that Range of Islands which lye North East of Cuba and Hispaniola". Since Bermuda sloops go armed against Spaniards fears trouble from seizures for enforcement of Bahamas' act. May Io, I739.

$I d$., showing that commissions to privateers often interpreted as giving permission to plunder and burn Spanish settlements, and complaining of Virgin Queen of R. I., which plundered and burned Porto Plata in Hispaniola and killed some inhabitants. Describes sending out of island sloops with soldiers from garrison against suspicious craft. "I was obliged to borrow Arms for them, those they have not being fit to fire." Disputes between council and assembly over amendment of bills, and claim of assembly to choice of new speaker at every fourth meeting. Dec. 20, I739.

Information received from Thomas Newton of crew of Virgin Queen. Papers on strategic importance of colony and need for troops, arms, and forts.

Papers on currency situation, with rates at which various coins received. Treasurer's accounts and accounts of powder-money, I737-I739.

Letter from Popple, on instruction from Lords of Admiralty concerning crown's tenth of captures made by privateers. Feb. 28, 1739/40.

14. I740-I744.

Letter from Popple on appearance of Commodore Floyd's squadron, on need for naval protection, arms and troops, and on land tenure. Nov. IO, I740. Other papers on weakness of island, sending of ordnance stores, etc.

Id. The whale-fishery; proceedings taken in case of Dutch sloop seized for trade with Spaniards in contraband; seizures for carriage of contraband executed pursuant to Anglo-Dutch treaty of 1668 ; illicit trade by Bermudians with St. Eustatius and Curaçao; impossibility of enforcement of Sail Cloth Act. Apr. 18, I74I.

List of vessels registered in Bermuda, I738-1740.

Treasurer's accounts, I739-I740.

Letter from Popple: Capt. Davidson, commanding privateer under commission from R. I., has taken a prize back to R. I. in fear of his men being impressed at Jamaica. May 26, I74I. Other papers on Davidson's capture.

Id. Disputes with assembly over custody of records, and assembly's claim to choose its clerk. Dec. 2I, I74I.

Gov. Popple to his brother, William Popple. Assembly's claim to choose clerk, nature and personnel of assembly, use of suspending clause, and illegal trade. Bermuda sloops carry to Dutch islands provisions resold to Spaniards. Many sloops sold at St. Eustatius, and goods taken in part payment. Attempts of northern colonies to sell provisions to Dutch by getting bonds discharged in Bermuda. Had demanded bonds on export of provisions before receiving orders from Board to do this, but cannot force execution of fresh bonds in Bermuda. Attempts of Dutch at St. Eustatius to secure British naturalization. "There is hardly any conveniency but may be bought from the Dutch at about half Prices." Asks William Popple to secure confirmation of certain acts. Dec. 2I, I74I.

Treasurer's accounts, I740-1742, and account of powder-money, I740I74I. 
Proceedings of committee of assembly on public accounts. Oct. 5, 6, I742.

Letters from Popple, on currency situation and circulation of bad Spanish coin, and disputes with council and assembly over finances, trade, and fees of patentees. Oct., I742-Dec., I743.

15. $\mathrm{I} 744-\mathrm{I} 748$.

Ten reports from Fane on 48 acts passed I727-I743.

Papers on land grants and projected wine production.

Letters from Francis Jones, president of council, and from Gov. William Popple, showing how letters were dispatched via New England and Cape Breton, via Carolina or by other routes.

Letter from Gov. William Popple, on governor's additional salary, and seizures of flags of truce. "The French Privateers have orders never to meddle with any English Flags of Truce carrying Prisoners but our Privateers Seize the French . . . and having prov'd the property to be French, The Judges here condemn them . . . being of Opinion that the Flag only protects the Bottom." This will put an end to exchange since governors will not send prisoners for fear they will not be reimbursed, and no private person will do so "Unless he be Allowed to take Effects with him that may Indemnify him". Oct. ro, r747.

Papers on seizure by privateer of cargo of French flag of truce Mary Ann, transporting Dutch prisoners to Curaçao and carrying, by license from French Leeward Islands, cargo of brown sugar for sale at Curaçao. I747.

Letters from Popple, and other papers, on whale fishery and governor's additional salary. I747-1748. Order in Council for additional instruction to allow governor to receive profits of licenses for whalefishing unless assembly grants additional salary. June 30,1748 .

Copy of letter from Pitt to Bedford, on flags of truce, trade with French in time of war, and use of privateers to prevent such trade. May 26, I748.

Treasurer's accounts, $1739-1747$, and account of powder-money, I742I745.

Letters from Popple, on large number of "lawless and profligate" men turned loose in island by cessation of hostilities; and on trial, in admiralty court, of Dutch ships seized by privateers. "The Tryal took up many Days for I am Ashamed to Say the most Scandalous means have been Employed to render her liable to Condemnation, notwithstanding which . . . I Cleared the Vessell and Cargoe and only Condemned the Contraband Goods." His position difficult and even dangerous on account of his attitude toward Dutch vessels. Aug. I5, 30, I748.

16. $\mathrm{I} 748-1749$.

Letter from Popple, on complaints against him regarding use of flags of truce. Oct. IO, I748. Enclosed are: copies of letter from Commissioners of Customs to collector at Bermuda; report of solicitor of customs on seizure of French flag of truce; attested copy of accustomed form of permit to flags of truce; attested account of permits recently granted, and other papers.

Letters from Popple, on governor's additional salary. Sept. I, Oct. ro, I748. 
Deposition of Popple, on disturbances in admiralty court over trial of Dutch ship. I748/9.

Letter from Popple, on council's denial that he can appoint judges, justices, etc., without its advice and consent. Oct. 23, I748. Other papers.

Id., on assembly's demand that joint committee of two houses should tax bills. Feb. 5, Mar. 3, I748/9. Many very long and valuable letters from Popple, discussing trade of colony in all branches. Charges much illicit trade, especially in exchange of provisions for European goods at Curaçao. Officers of customs slack, and frauds in registration, entrance, and clearance common. Governor meets great opposition and other difficulties in attempting to enforce acts of trade. General evasion of Sail Cloth Act of I9 Geo. II. Unscrupulous conduct toward wrecks. I748, I749. Numerous and interesting enclosures, including correspondence of governor with other branches of legislature, instructions to naval officer, etc.

Id., on salt-raking and turtle-fishery. Mar. 3, I748/9.

$I d$. , on governor's additional salary, and enclosing rent-roll of crown lands. Mar. 25, I749.

$I d$, on crown lands, discussing history of same and showing disposition and management of land and slaves taken over from proprietary company. Covers methods of collection, accounts, and evictions. Also, on governor's allowances for slaves, firewood, and transpor. tation between islands. July 8, r749.

Several letters from Popple and other papers on whale-fishery and governor's additional salary. I749.

Answers to queries of Board. I749.

Papers on operation of jury system in Bermuda. I749.

17. I749-I752.

Letter from Popple, on disputes with assembly over appointment of clerk of assembly and custody of records. Nov. I I, I749.

Journal of assembly. Feb. 6, I748/9-Nov. Io, I749.

Letter from Popple. Illegal methods employed in fishing. Feb. 28, I $749 / 50$.

Extracts from letters from Popple to his agent, on threats of personal violence against him. Mar. I749/50.

Opinions of attorney general and solicitor general on jury system in Bermuda. Apr. I3, I750.

Letters from Popple. Quarrel with collector over registration of vessel ; extent of his actual income; disputes with assembly over election of speaker, adjournment, custody of records, appointment of clerk of assembly, and proceedings of governor in admiralty court. I749, I750.

Copy of articles of complaint against Popple, referred to in address and remonstrance of assembly and principal inhabitants to the king; accusing governor of trading with French during war, misusing flags of truce, monopolizing trade, neglecting independent company, recruiting in island, preventing condemnation of prize, refusing to lay accounts before assembly, omitting inspection of sails, and infringing on assembly's rights concerning adjournment and election of speaker. I749. Letter from Popple to his agent, Vincent Mathias, on same. Nov. 2I, I749. List of those who signed same, 
with occupation of each. I749. Address of council, complaining of Popple. I750. Popple's observations on same.

"Two Protests of Masters of Ships on some Violences committed by the Spaniards at Turks Islands." I75I.

List of civil and military officers commissioned by Popple, and of offices vacant. 1752 .

List of fees received by secretary, collector, naval officer, and provost marshal, as established by law. I75I.

Letter from collector to Popple, showing that only one cargo of slaves has been received since I744. Dec. 28 , r750.

Christenings and burials. I743-175I. (Incomplete.)

Accounts of sales of timber. I744-I747.

Account of receipts and disbursements of rents on crown lands, I746I750; and on same for certain districts, I744-I750.

Treasurer's account of duties on importation of liquors. I747-I75I.

18. $1752-1760$.

Jones, president of council, to Popple. French from Santo Domingo have seized Caicos Islands and driven off Bermudian "Caicos fleet". Injury will be done to trade of Jamaica and Bermuda, especially in salt, and to "the quest of wrecks". July 8, i753. Depositions on seizure.

"Observations on the instructions given to His Majesty's Governor of Bermuda", including those on trade, "together with some proposed amendments thereto", by William Popple. (Extensive and interesting.) I754. Order in Council approving draft of new instructions for Popple. I755.

Letter from Popple, on assembly's attempts to secure control of finances. May $5,1756$.

$I d$., on crown lands and tenure of same. May 5, I756. Copy of "schedule" of crown lands, with names of administrative officers, also acreage, rents, etc. Account of receipts, disbursements, and arrears of rent. Letter from Popple, on a bill for sale of crown lands. Nov. 30, 1756. Copies of bills for increasing value of same, and other papers.

Lists of cannon and other military stores "adjudged necessary for the Defence of Bermuda", and of those in the island. 1756.

Classified return of inhabitants. I756.

Letters from Popple, on financial powers of assembly. Jan. I, Apr. 2, I757. Important enclosures, for constitutional history, especially on financial side.

Thomas Smith, collector, to Commissioners of Customs, on his duties.

Letters from Popple, on trade, enforcement of acts of trade, and military weakness of colony. I757, I758. Memorials and other papers.

Copy of paragraph of letter of Col. Henry Tucker to his brother. "Governor Morris of Pensilvania has petition'd the Parliament to grant him an exclusive right of making Salt on the Continent of America for supplying those Colonies . . . I've been using my utmost endeavours to oppose it, and have got New-England, Virginia and Carolina Agents to join me". Mar. 21, I758.

Letter from Popple, on "fish-hawling", and on financial powers of assembly. Sept. I I, I758.

Copy of grand jury's presentment for June assizes. I759. 
Letters from Popple, on sales of crown lands. Oct. 2, I759; Jan. 21, I760. Other papers.

19. $1760-1766$.

Letters from Popple, on sales of crown lands. June 12, I760; Mar. I6, I $76 \mathrm{r}$.

Id. Captures by French privateers and fitting-out of vessels by colony against same. Oct. 6, 176r.

$I d$., on searcher of customs for west end of islands, who "is rather a screen for illicit Trade than a preventive of it". Aug. 12, I76I.

Id. Discovery of negro conspiracy, trials and executions; process of proclaiming martial law; on trials by courts-martial; need for special courts in such cases; and disagreement with council and assembly as to whether governor or legislature should create such courts. Feb. 28, r762.

Id. Use of revenue from crown lands; sale of same; assembly's claim that proceeds of sales should be at disposal of legislature for services of government, and his objections to said claim; and allowances of negroes and firewood to governor. Mar. 31, x762. Statement of sales of crown lands, showing valuations, amounts received, etc.

Classified statistics of population. 1762.

List of civil and military officers. I762.

Letters from Popple, on sales of crown lands. Other papers, showing holdings of tenants in 1747 , sales, and application of revenue from proceeds of sales. 1758-1766.

Letters from Popple to Board and to Lords of Admiralty, on quarrel with collector. Collector insists on receiving and transmitting to receivers general of customs all proceeds of fines, forfeitures, etc., arising in admiralty court from breaches of acts of trade. "Collectors in this part of the world are more esteemed than even Governors." Apr. 29, I763. Copies of extracts from governor's commission as vice-admiral and from collector's instructions.

Letter from Popple. Assembly's desire to control revenue from proceeds of sales of crown lands, its attempt to deprive governor of all connection with agent, and an act to forbid export of cedar timber. "The reason of this Act was to prevent the making the frames of Bermuda Vessels, and sending them in pieces aboard [abroad] by which means the Dutch, French and Spaniards got Bermuda Vessels enough." Aug. 5, 1763.

Papers on Gov. Bruere's action in confining trade to Castle Harbor and St. George's : proclamations, proceedings of committees of council and assembly, petitions and memorials for opening of other ports. In particular, "A true state and description of the Bermuda Islands, shewing the Trade; Ports and Harbours etc" . . : I765.

Proclamation of Bruere on "Licenses for halling Fish". I765.

Letter from Bruere to Pownall. "The Blacks are much too numerous; by too many being kept by Some poor. White Persons, that are not able to maintain them, which obliges many Blacks to have recourse to theft for their Support, which is the reason the inhabitants give for cultivation being quite neglected and the whole a kind of common, and Sheep and Cattle very scarce. No Tobacco, No Sugar Canes." Oct. 22, 1764.

Classified statistics of population. I764. 
Monthly statement on independent company of soldiers at Bermuda, for Nov., 1764 .

Letter from Bruere to Pownall, showing that collector, pursuant to instructions from Halifax, has seized two vessels failing to produce proper certificates for molasses. Dec. 4,1764 .

Account of stores. Mar., I765.

Letters from Bruere, on trade. May 24, July I I, I765. Copy of letter. Bruere to Halifax. Nov. 30, I764.

Letter from Bruere. "The General Assembly have given very little Attendance for some Months past upon Public Business, Being Disgusted at the Stamp Act. . . . The Body of Merchants waited upon me, desiring that their vessels might be allowed to Clear out without taking the Stamp Papers, Saying their Vessells might be burnt or destroyed, by having the Stamp Papers on board, by Refractory People in some of the other Colonies. . . . Some few Stamp papers from the Secretarys office, with Law Business, were taken from the Messenger and destroyed in the Country." May I, I 766.

20. I766-i770.

Letter from Bruere. Dispute with section of assembly as to whether fresh election should have followed his arrival. "One of their Party wrote to New York to know If they were a Lawfull Assembly or not, and they received for answer that they were a legal House of Assembly." Sept. I, I766.

"State of His Majesty's Revenue." Dec., I 766.

Accounts of revenue received or due from sales of crown lands. 1765 , I 766.

Numerous papers on losses sustained by inhabitants through seizure of their vessels by Spaniards at Tortuga, Feb. I8, I766.

Papers on act of assembly to raise money for payment of agent and for expenses of royal troops. I 767 .

Letter from Bruere, on salt-raking at Turks Islands. May Io, I768.

Classified statistics of population. I768.

Letters from Bruere. Disputes with assembly on auditing of accounts, taxing of bills by assembly, payment of members of council and assembly, and resolves of assembly (June 23, 1769): "That it is the undoubted Right and Priviledge of this House to impose Taxes on the Inhabitants of these Islands; and appropriate the Monies arising there from to His Majesty's Use, as it shall occur to them that the Service of His Majesty in these Islands requires . . . that this House will at no Time confer with His Majesty's Council on any Money Matter; or receive from that Board any Amendments or Alterations to any Bill for raising Money." I768-1770.

Letter from Bruere, explaining that, in inserting the words "present in the island" in writs of election, he had in mind a member of the assembly, "William Brigs, master of a Sloop, who is a Virginia man but married at Bermuda, and he was at Sea (or in Virginia) at the time appointed to choose Representatives and hath neither House or land of His own in these Islands and is very Seldom here." Aug. 12, I769.

Text of the excise act passed by assembly, in which two collectors for each parish and a receiver general were appointed. $\mathbf{I} 770$. 
21. $1770-1777$.

Letter from Bruere, discussing three revenue acts recently passed and an act for regular payment of clergy and for regulating seats or pews. Shows churches built by private donations and parochial assessments, and pews assigned "agreeable to the quantum of their respective Assessments for paying their Incumbent and their parochial charges". Discusses rights of ordinary in collation to benefices. June I8, I775.

$I d$., with answers by chief justice to twelve queries on interests of Bermudians in Turks Islands. May 26, I 776.

Memorial of governor, council, and assembly on act of the Bahamas for regulating salt ponds at Turks Islands. July I2, I776. Other papers on claims of Bermuda and the Bahamas to Turks Islands.

22. I779-1782.

Letter from W. Knox to Grey Elliott. Whitehall, Feb. I4, I78I. Encloses petition of merchants, etc., in Bermuda, many of whom were stated to have come from the American colonies "with a View to fit out Privateers and establish a Rendezvous for other Privateers and Prizes". Inhabitants favorable to Americans, with whom they trade. Followed by list of vessels captured.

Letter from Gov. George Bruere, describing illicit trade, and intercourse with rebels. Mar. 26, I78I.

23. $1785-1792$.

Papers and tables relative to condition of Bahama Islands and settlement of Loyalists; also to trade at Turks Islands.

Letter from Gov. Henry Hamilton, no. 3. Mar. II, I789. Encloses naval office returns. July I-Dec. $3 \mathrm{I}$, I788.

24. I7I4-I756. Abstracts of letters of lieutenant governors and governors to Board. (Incomplete and frequently unreliable.)

C. O. 37:26-73. Secretary of State: Original Correspondence. i7o3I8I5.

26. $1703-1745$.

Affidavits on seizure by Spaniards of vessel loaded with salt. $\mathrm{I} 7 \mathrm{r} 3 / 4$. Other papers. I730.

Report of Board of Trade on petition of Dean of Derry and three fellows of Trinity College, Dublin, for patent to found college at Bermuda "for the better propagating of the Gospel among the savage Americans". Mar. 2, I $724 / 5$.

"Thos. Brooke his accot. of the Crown's thirds of Seizures and the Duties received on prizes brought in and condemned here the last French war." Apr. 12, I723.

Extracts from minutes of council, on proceedings against Richard Tucker, secretary and provost marshal, on complaint by Dinwiddie that he had not performed his duties. May-June, I725.

Id., on proceedings concerning George and Elizabeth and Salamander. Feb., r724/5. Other papers, including letters and depositions from S. C.

Copies of letters to Board and secretaries, answers to Board's queries, and addresses and petitions for better protection.

27. $1746-1801$.

Abstract of papers relating to charges brought against Lieut.-Gov. Bennett by Mr. Larkin. Undated. 
Warrant to governor and inhabitants concerning magazine ship Constant Love and conditions under which it is to be operated. Undated.

Draft of warrant for erecting college pursuant to plans of George Berkeley, dean of Derry, and four fellows of Trinity College. Dublin. Undated.

Report to committee of Council disapproving petition for encouragement of production of Madeira wine. Endorsed: "Disapproved". I747. Papers on violent acts of Spaniards at Turks Islands. I752.

Memorial of John Pigott and others on three ships seized by Spaniards. I759.

Papers on complaints against Gov. Bruere. I782, I784.

Drafts of letters to governor on application of interest payable by purchasers of crown lands. I782, 1783.

Memorial of Henry Tucker, agent, on advantages of making Bermuda a free port. Undated.

Military orders and letters. Letters mainly from Maj. Anstruther, commanding at Bermuda, to governor and secretary, on movement of troops, including "the detachment from Rattan". I 783 .

Letter from Traill, collector, to North, on his doubt concerning treatment to be given to vessel arriving from Philadelphia with provisions. May 10, I783.

Gov. Hamilton to Carmarthen. "In these Islands the principal people are very closely connected with the American states by birth, marriage or commercial intercourse. The Chief Justice, the Judge of Admiralty, the Collector of the Customs are natives of America." Feb. 24, I789.

Letters from Maj. Fraser, asking to be appointed governor of Bermuda. I793, I794.

Papers on the alleged persecution of nonconformist ministers. 1800 .

28. I707-1727. (Mainly duplicating or supplementing contents of C. O. $37: 8-$ i r.)

Court-martial proceedings, depositions, and other papers on case of soldiers who conspired to seize Guinea ship anchored at Bermuda. Feb., I709/ro.

Letters from Bennett to Newcastle on designs and movements of French. I7IO-I7I2.

Affidavits on designs of French. I7I2.

Lieut.-Gov. Hope to Carteret, stating that he is sending to the secretary copies of his letters to Board and of most important enclosures. Nov. II, I723.

Numerous papers on the St. James, the Margaret, and the George and

29. I728-1744. Elizabeth.

Lieut.-Gov. Pitt to Delafaye, on a "habeas corpus" act recently passed by assembly and modelled closely on that passed at Barbados in I697. Also, on need for currency smaller than half-royal. Assembly has refused his offer to present act for small currency, "being scared with the idea that they might be Woods halfepence intended for Ireland". Nov. 30, I728.

$I d$., complaining that raising of money is difficult because of poverty caused by depredations of Spanish privateers. Apr. 30, July I , I729.

Pitt to Newcastle, on measures taken for defense. Apr. 30, I729. 
Papers on need for better protection against negroes, pirates, and Spaniards.

Popple to Newcastle, on trade between R. I. and Martinique. Aug. 2I, I738; May Io, 1739 .

Naval office lists of vessels entered and cleared. July, I738-Dec., I740.

List of vessels registered. July, r738-July, I740.

Letter in cipher addressed to officer in Martinique. French.

Papers on seizure of French sloop by Capt. Davidson of R. I.

Popple to William Stone, acknowledging receipt from Lords Justices of extracts from Anglo-Dutch treaty of 1674 and orders to comply with same regarding captured Dutch vessels. May 27, I74I.

Treasurer's accounts. r $741-1742$.

Letters from Popple, on disputes with assembly over custody of records, and assembly's claim to inspection of accounts before payment is made. I74I-I743.

Memorial to Newcastle of William Popple, "Agent of the Independent Company of Foot at Bermuda" (and brother of Gov. Popple) representing that "the said Company has never reced . . . any Supply of small arms during upwards of 40 years they have done Duty in that part of His Majesty's Dominions".

30. $1746-175 \mathrm{I}$.

Gov. Popple to Andrew Stone, on captures and recaptures from French. Aug. 6, 1747.

Many letters from Popple to Newcastle, on disputes with assembly. Numerous enclosures. (See C. O. 37:15-17.)

Decree of admiralty court, condemning French flag of truce. Oct. 12, I747.

Minutes of council, council in assembly, and assembly. I746-1750.

Copy of petition of inhabitants of Bermuda against seizure by privateers and condemnation of flags of truce. 1747.

31. $1762-1767 .^{1}$

Gov. Popple to Egremont, pointing out value of colony, begging for protection against French and slaves, and enclosing address of council and assembly on same. Mar. 3I, I762.

Gov. Bruere to Halifax, describing seizure of Turks Islands by French, and enclosing letters and depositions on same. Sept. I3, I764.

Halifax to Bruere. Demand made by British ambassador to France for restitution of Turks Islands and payment of damages; action of France in disavowing seizure and ordering D'Estaing to restore islands and make reparation; and arrangements to be made between D'Estaing and governor of Jamaica. Sept. 21, I764.

"Weekly State of General Whitmore's Company of the 9th Regiment of Foot." r764.

Letter from Bruere, enclosing list of all legal instruments used in colony. Nov. $27,1764$.

Id., on illicit trade. Nov. 30, I764. Letter from Lieut. Arthur Beard, commanding Bermuda company of 9 th Foot, on same; and enclosing petition of inhabitants of town and parish of St. George's that all vessels be obliged to enter and clear at the Castle or St. George's. Jan. 28 , 1765 .

${ }^{1}$ It seems that no papers in this series for the years $1752-1761$, inclusive, have been preserved. C. O. 37:31 practically begins at 1764 , containing only some half-dozen papers for the two preceding years. 
Letters from Bruere to Halifax and Shelburne, on seizure and condemnation of brig Nerbbury of New England, which sailed from Cape François to Boston with molasses and indigo Sept. 27, I764, i.e., two days before the act on bonding molasses "took place in the colony". Mar. 2, I765; and Mar. 20, I 767.

Petition of council and assembly that proceeds of sales of crown lands be applied to purposes of government in colony, as directed by governor with advice and consent of council. I765.

Bruere to Conway, stating that he has been obliged to confine trade to St. George's by proclamation. Oct. I9, I765.

$I d$. , on seizure by Spaniards of four Bermuda vessels loading salt off Tortuga. Mar. 20, June I0, I 766 . Several depositions.

Shelburne to Bruere, promising that demand for reparation will be pressed. Feb. I9, I767.

Letter from Bruere, reporting receipt by Gov. Lyttelton of reparation money from D'Estaing, and complaining of "factions and beats" in the colony. June 6, I766.

Bruere to Shelburne, on re-establishment of searcher of customs at west end of island and warrant for same. Apr. 28, 1767.

Letter from Gen. Gage, forbidding officer commanding company of 9 th Foot to recognize provincial laws for military government of his Majesty's soldiers or military courts of justice assembled by virtue

32. 1768. of provincial acts. Oct. 14, I767.

Papers on revenue from sale of crown lands, and especially the charge upon it, by warrant of July 26, I765, for governor's salary, said charge to compensate governor for loss of pay as commander of independent company formerly stationed at Bermuda.

Classified statistics of population.

Letter from Bruere. Complains that assembly, by assuming right of taxing all bills, obstructs "the Issuing and Disposing of the Public money for the fixed and Established Contingencys of Government". Reviews fixed charges for payment of various officials, clergymen, members of assembly, and others. Complains of poor collection of taxes. "The Magistrates have Neglected ever since their Uneasiness occasioned by the Stamp Act to put the law in force against Persons that Retail Rum and other Spirituous liquors without license from the Justices of the Peace; and that fund was for some time lost to the Government funds, as they did not Accept of the Stamp paper for law Business but only for those papers wanted to keep their Trade open." July 24, I 768.

List of acts passed I69I-I768 now in force.

Petition of governor, council, and assembly for protection and for redress for French outrage at Turks Islands.

Papers on Turks Islands. Claim of Bermuda to same. Details of French attack. Full description of method employed in collection of salt. Account of seizure, by H. M. S. Scarborough and vessels under her convoy, of salt collected by Capt. Kenneckett of R. I. and 29 other captains of salt vessels. Alleged that vessels under convoy

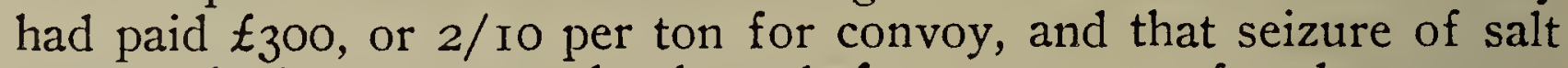
was made because vessels there before convoy refused payment. List of twenty Bermuda vessels from which salt was taken, and other papers showing importance of salt in Bermuda trade. Letter 
of Hillsborough to Lords of Admiralty directing inquiry on action of Scarborough and issue of instructions to his Majesty's vessels in West Indies not to interfere in salt trade.

33. $1768-1769$.

Letter from Bruere, on dispute with assembly over his insertion of words "present in these islands" in writs for election of assemblymen. Dec. 20, I768.

$I d$., on clandestine introduction of foreign rum; and on plundering, by negroes and whites on coast, of vessels in distress. Dec. 28, I 768 .

Papers on action of captain of Scarborough. Letters from Hillsborough, Lords of Admiralty, Vice-Adm. Pye, and others. Alleged that people of Bermuda attempt to monopolize salt at Turks Islands, to great injury of New England fishery and of his Majesty's ships in N. Am. which count on getting salt at Turks Islands for salting provisions; also, that Bermudians ruin ponds by raking prematurely, and that Scarborough was attempting fair division. Vessels from N. Am. meet at Barbados to secure convoy. Orders for non-interference by his Majesty's vessels repeated.

Hillsborough to Bruere, reprimanding him for insertion of words "present in these islands" in writs of election. May I3, I769.

Letter from Bruere, suggesting that despatches would arrive much sooner, especially in winter, if sent by S. C., since "there is so seldom an opportunity to this place from New York". July I4, I769.

34. 1770.

Papers on whale-fishery. Letter from Bruere, Apr. 7, i770. Petition of inhabitants asking for remission of tax payable to governor on each whale taken. Copy of representation of Board of Trade, reviewing history of whale-fishery: transfer of rights from Bermuda Company to the crown, opening of trade in I730 on condition of allowance by assembly to governor, imposition of tax on each whale by legislature to raise governor's allowance, and later failure of assembly to grant allowance. Dec. 5, I770.

Papers on revenue act recently passed by assembly, which appoints two collectors for each parish and a receiver general. Letter from Bruere. May 30, I770. Representation of Board of Trade, endorsing governor's objections. Nov. 2I, I770.

Letter from Bruere, "on the wants and Deficits and Improvements necessary for the better regulation of the Bermuda or Summers Islands", reviewing conditions in colony.

35. ×770-I772.

Many letters from Bruere, and other papers on disputes between governor and assembly on whale-fishery, methods of voting supplies, amounts of supplies voted, appointment of receiver general, taxing of bills, and employment of revenues from sale of crown lands.

Account of receipts and expenditures of money from sale of crown lands. Apr., I770.

Letter from Bruere, on illicit trade, and plundering of wrecks at Turks Islands. Apr. 27, 1772.

Treasurer's account. I772.

36. I772-I777.

Letter from Bruere, complaining of forcible liberation of Bermuda sloop seized for illegal trade by officers of customs. Dec. 5, I772. 
$I d$., complaining of duties exacted at Turks Islands from passing vessels, on authority of Gov. Shirley of the Bahamas. Dec. 31, I772; Jan. 14, I773. Other papers relating also to salt-raking at Turks Islands and to trade of Bermuda with Europe and N. Am.

Papers on continued disputes between governor and assembly.

Answers to' queries of Board of Trade. I773.

"An Estimate of the Annual and contingent Charges of Government upon a Medium." I773.

Classified statistics of population, shipping, and acreage. I774.

Letters from Bruere, on deliberate wrecking and plunder of Industry bound from Limerick to Va. with sixty Irish "servants or convicts". Impossibility of checking such practices in absence of soldiers or war-ships. Apr. 19, I774; Jan. 24, I775.

Id. Difficulties of communication, as shown by fact that last letters, sent via S. C., were opened by committee of inspection there. Aug. 2,1775 .

$I d$. His fear regarding stores, "as there may be but few friends to Government here". Embargo on provisions, though colony oversupplied. Assembly summoned twice but has not met. "The[y] have chosen Delegates here who have petitioned the Congress at Philadelphia to supply them with Indian Corn. And they wait for return of their answer before I suppose they will meet." Can spare provisions to Gage and Howe "but I cannot confide in any Person here at present, they say they may have their Vessel burnt". Will enclose this letter to his private agent or one of his children at school in England "that the Address may not be seen here". July 31, r775.

$I d$., on the breaking open of powder magazine and theft of roo barrels of powder. "It may be supposed that those Barrels left [1o or I2] would not bare removing." $\mathrm{He}$ and "Legislative Body" have offered rewards for discovery of culprits. Lady Catherine of Va., George Ord, master, and Charles Tozen and Savannah Packet of S. C. suspected of having powder but could not be overtaken by custom-house boat. Difficult to send letters home, since "the minds of people are very much poisoned", and "people from Carolina and Philadelphia have corresponded and visited these Islands". Aug. I7, 1775 .

Id. His lack of any confidant, and fear that Bermuda ships will be used against his Majesty's cause. Aug. 20, I775.

$I d$. Intercourse with Dutch islands; abandonment of "lower trades" and service as seamen to negroes, "the White People presuming to be Gentlemen"; obvious deceit in petition to Congress, island being actually overstocked; and difficulty in sending despatches, since "they have prevented any person from hiring or chartering their Vessel to me, either to send to Boston or anywhere else". Sept. 2, I775.

Id. Pursuit and search of vessel hired by him to take despatches and live stock to Gage. Oct. 16, 1775; Feb. 23, 1776.

Id. Removal by H. M. S. Scorpion of thirty pieces of ordnance, to prevent rebels from getting them. Oct. 16, I775.

Rev. Thomas Lyttelton, late of Bermuda, to Germain, asserting loyalty of Pembroke parish and of many in other parishes. Colony would be loyal if provisions assured and small force for protection maintained. London, Jan., 1776. 
Letters from Bruere. Powder sent from Bermuda to rebels at various times; disaffection arising from rebel propaganda, fear of famine and lack of employment; and purchase of Bermuda vessels at the Bahamas for use as rebel privateers. July 14, Aug. 7, I776.

Address of council and assembly to the crown, deploring the unhappy difference between the mother country and her American colonies; denying complicity in sending of powder; and maintaining that petition to Congress was rendered necessary by scarcity of food. July 12 , 1776 .

Letters from Bruere. Pursuit and destruction of sloop arriving from N. Am. by war-ship, and popular feeling against the naval officer commanding. Mar. 4, 24, I777.

$I d$., on resignation of judge of admiralty court, "he having been accustomed to Trade and have connexions in North America". Apr. 22, 1777.

Loyal address of inhabitants of Bermuda. Apr., I777.

Letter from Bruere, on illegal trade in salt and provisions with North Americans, and seizures made in consequence by war-ships. Apr. I9, I777.

Id., on successful coast raid by two privateers from S. C., which destroyed and carried off guns and escaped from H. M. S. Nautilus.

Id. Lack of provisions and unguarded situation of colony. Oct. I4, $24,1777$.

37. $1778-1780$.

Letter from Gov. George Bruere, describing activity of family named Goodrich, of Portsmouth, Va., members of which had arrived in Bermuda and taken up privateering, capturing several American prizes. Jan. 25, 1778.

Id., no. 22. Export of rum and molasses. Mar. I9, I778.

$I d$., no. 36. Arrival of force from N. Y., and appearance of four rebel frigates. Dec. 2, I 779.

Letter from William Brimage, on trade between Bermuda and American colonies: salt obtained by southern colonies, trade carried on with New England through complicity of a custom-house officer in Nova Scotia. Undated.

Letter from Gov. Bruere. Seizure of brigantine Superb, supposed to be brought from S. C. Rice received and sold, "and the Public faith, was pledged for the vessels safety". Apr. 6, 1780. Encloses list of prizes taken by various vessels.

Votes of assembly. Oct. I I, I779-Nov. 25, I780.

38. $1780-1784$.

Letter from Lieut.-Gov. G. Bruere, relative to trade with rebels, in conjunction with St. Eustatius: salt, gunpowder, and drygoods supplied, and over Iooo vessels sold to them, most of them built in Bermuda; trade carried on via Nova Scotia. Dec. 12, I780.

Letter from Henry Tucker to Benjamin Thompson, dealing with trade between America and Bermuda. Feb. 22, I78I.

Letter from Lieut.-Gov. G. Bruere, no. I. Transmits copy of "a wicked association" of Bermudians and Americans, and describes method of trade. Jan. 7, I78I.

$I d$., no. 3. Describes attempt to check trade to America. Feb. 8, I78I. Journal of assembly. Jan. 29-Mar. I6, I78I. 
Letter from Lieut.-Gov. G. Bruere, reporting intrigues with Americans by persons on the island; privateers now being fitted out to attack the rebels. July I 5, I78I.

Id., no. 5. Relates intrigues with Americans. Oct. I7, I78I.

Letter from Gov. Browne, no. I. Refers to Mr. Graham, formerly attorney general of Va. Jan. I2, I782.

Minutes of council in assembly. Nov. I2-Nov. I7, I78I. " of Council. Nov. I6-Dec. 6, I781.

Memorial of William Brimage, late of N. C. June 2I, I782.

Letter from Robert Traill, collector of customs, reporting action of inhabitants in fitting out privateers against Americans. Jan. 4. I783.

Votes and journals of general assembly. Jan. 2I-Mar. 30, I782.

Letter from Gov. Browne, no. 8. Acknowledges receipt of order in Council regulating trade with U. S. Oct. 30, I783.

"Extracts of Letters to Lt. Govr. Bruere": including one from late searcher of his Majesty's customs. "The American Vessles bring us plenty of provisions and enter our ports without restriction they pay their fees and depart without giving bond or clearing." June 28, I 783 .

Letter from Gov. Browne, no. 9. Acknowledges receipt of copy of treaty with U. S. Apr. I5, I783.

39. I778-1784. "Bermuda Miscellaneous Papers."

Minutes of meeting of committee, appointed by inhabitants Sept. 5, 1778 , dealing with "Piratical practice of a certain Bridger Goodrich". 2

List of privateers belonging to Bermuda. Apr. 4, I782-Apr. 4, I783. List of prizes. Apr. 4, I782-Apr. 4, I783.

"Att a General Assembly of the Governor and Company of the State of Connecticut holden at Hartford on the Second Thursday of May Anno Dom. I779": reference to friendship of inhabitants of Bermuda.

Act passed Mar. 30, I782, with suspending clause freeing vessels from obligation to enter and clear at harbor of St. George.

Memorial of Lieut.-Gov. Bruere, setting forth his accusations of trade with enemy. June Io, I784. Followed by number of letters, I776I784, on American intercourse, etc.

Depositions and other papers on American intercourse, etc.

40. I785-I788.

Draft to governor of Bermuda, referring enquiry as to vessel seized on Apr. I2 while trading to "Charles Town". June 28, I785.

Letter from Gov. Browne, no. 6, relative to supply of British registers to citizens of U.S. May I, I785.

$I d$., no. 7 , relative to trade with U. S. June I, I785.

$I d .$, no. Io, notifying appointment as collector for Bermuda of John Green, who came from Philadelphia some twenty years previously. Dec. I6, I785.

Id. Encloses evidence regarding sale of registers. Dec. 29, I785.

Letter from Gov. Browne, no. 36. Acknowledges receipt of act of Parliament and order in Council regulating trade with U. S. Nov. 5, I787.

${ }^{2}$ This is presumably the "wicked Association" referred to in Lieut.-Gov. Bruere's letter no. I of Jan. 7, I78I (C. O. $37: 38$ ). 
Id., nos. 37 and 47. Acknowledges receipt of act of Parliament relating to America and trade with America. Dec. I 5, I787; July I5, I788.

Id., no. 50. July I5, I788. Encloses:

Minutes of privy council. Nov. 6, I787-June 28, I788.

“ " legislative council. Feb. I8-June 28, I788.

Journal " assembly. Feb. 21-June 28, I788.

Letter. from Lieut.-Gov. Henry Hamilton, no. 4. Recommends Bridger Goodrich to seat in council. Oct. I8, I788.

Letter from Bridger Goodrich, describing defense of Bermuda in 1782 . Jan. 3,1785 .

"Extract of a letter from Bermuda January i786. The business as conducted at the Custom House occasions much discontent. We have had 2 or 3 Americans-One from Connecticutt is now at Atwoods Wharf, selling away Corn and Cattle, and I am told pork and Lumber." . . .

41. I789.

Letter from Lieut.-Gov. Henry Hamilton, no. I6. Apr. II, I789.

Encloses:

Journal of assembly. Nov. I0, I788-Jan. I7, I789.

Minutes "legislative council. Nov. IO, I788-Jan. I7, I789.

" “ privy council. Sept. I6, I788-Jan. I6, I789.

Id., no. I7. Reports regulations issued for admission of corn, flour, salted provisions, etc., in foreign vessels. Apr. I I, I789.

Id., no. 20. Aug. I3, I789. Encloses:

Minutes of legislative council. Mar. 23-July I8, I789.

" " privy council. Mar. 3-Aug. I I, I789.

Journal “ assembly. Mar. 23-July I8, I789.

42. I789-I790.

Letter from Lieut.-Gov. Hamilton. Visit of two American merchants, one of whom, Mr. Cooper of Carolina, made enquiries as to attitude of inhabitants to America. "Cooper said he was authorized to such an enquiry, and further asked the Bermudians how they should behave if these Islands were attacked." May 20, I790.

$I d$., no. 8. Encloses memorial on rumored American tonnage bill. June 23 , I790.

Minutes of privy council. Sept. I, I789-July I5, I790.

Journal of assembly. Mar. 22-July I5, I790.

Letter from Lieut.-Gov. Hamilton, no. I I. Acknowledges receipt of act of 28 Geo. III., regulating American trade. July 20, I790.

43. I79I-I792.

Letter from Lieut.-Gov. Hamilton, no. 39, relative to trade with America. July 26, I79r.

Id., Oct. I I, I792. Encloses:

Minutes of legislative council. Mar. 22-July I5, I790.

" " privy council. Nov. 2, I790-Sept. 6, I79r.

" " legislative council. Feb. I5-July I2, I791.

Journal of assembly. Feb. I5-July I2, I79I.

Id., no. 4. Asks for more troops "should any commercial arrangements take place between Great Britain and the United States of America (as intelligence from America seems to indicate)". Dec. I8, I79I. 
Id., no. 7. Reports communication with George Hammond "the Plenipotentiary with the American States" concerning among other matters war with Indians. Jan. 20, 1792. Encloses extract of letter to Hammond, Jan. I3, I792.

Id., no. I9, introducing Bridger Goodrich who had lately been at Norfolk, New York, etc., "where he has observed a great falling off of confidence in all commercial matters, diffidence in the Councils of the Legislature, and even personal disregard for the President of the United States." . . . July 8, I792.

44. I792-I794.

Letter from Gov. Hamilton, no. 30. Encloses copy of letter to Gen. Clarke containing mention of artillery men "with a view to convey to the Americans (should they intercept it) an idea that we have so necessary a force for the defence of the Island, whereas in fact we have neither Bombardier nor Gunner". Feb. 24, I793.

$I d$., no. 37, reporting determination to send a ship to Philadelphia for provisions. May 2, I793.

Id., no. 39. May 20, I793. Encloses:

Minutes of privy council. Apr. I7-Apr. 18, I792.

" "legislative council. Oct. I7, I79I-July 28, I792. Journal “assembly. Oct. I7, I79I-July 28, I792.

$I d$., quoting letter from "Charlestown", Apr. 27, I793, describing action of certain American subjects in fitting out privateers at instigation of French. "It never has been suspected or hinted, that a single American born citizen is directly or indirectly concerned in the Privateers, of the crews more than three fourths are British subjects". May 28, I793.

Id., no. 4I. American countenance of conduct of M. Genet. May 28, I793.

Id., nos. 42,43 , relative to attitude of U. S. June I7, 25, I 793.

$I d$., no. 44. Reports return of sloop sent to Philadelphia. Vessels in future cannot venture on American coasts. July I4, I793.

$I d$., no. 47. Encloses list of vessels fitted out from Bermuda and number of prizes captured. Nov. 21, I793.

Id. Nov. 23, I793. Encloses:

Minutes of legislative council. Mar. I8-June 29, I793.

Journal " privy council. Oct. I 5, I792-Nov. 5, I793.

Journal " assembly. Mar. I8-June 29, I793.

Id., no. 50. American ports are "nearly inaccessible" to English trading vessels owing to French privateers. Dec. IO, I793.

Id., no. 51. Refers to probability of American participation in war. Dec. I2, 1793.

45. $1794-1796$.

Letter from Gov. Hamilton, no. 59. Encloses letter to Sir John Jervis, Mar. 3, I794, reporting information that 92 American vessels were to sail from Bordeaux for America in March and April laden with French goods. Mar. 6, I794.

Id. Quotes information from Norfolk, Va., as to preparations for war. Feb. 4, I794.

Id., nos. 56, 57, 58. Gives information from U. S. May 12, I6, I7, I794.

Id., no. 6I. Capture of prize with Pres. Washington's pass to sail in ballast. June 3, r794. 
Id., no. 62. Encloses copy of permit granted by Washington. June II, 1794 .

$I d$., no. 63. Encloses letter to Capt. Rogers stating that Ioo vessels chartered in ports of U. S. were now nearly loaded with provisions for France. July 20, I794.

Letter from Gov. Crawford, no. I. Jan. I, I795. Encloses letter from Bridger Goodrich, describing capture of twenty neutral vessels by his privateer under instruction of Nov. 6. Cancellation of instruction came too late: "many hundred neutral vessels were taken in a few weeks. . . At the moment there is upwards of 150 sail of American vessels in the different French ports of St. Domingo." Nov. 20, I794. Enclosures relating to American action.

Id., no. 3. Feb. I4, I795. Encloses:

Minutes of privy council. Dec. 20, I793-Nov. 25, I794.

Jan. 24-Feb. 3, I795.

" " legislative council. Apr. 2I-July 3I, I794.

“" “" “ Oct. 8-i I, I794.

Journal “assembly. Apr. 2 I-July 31, I794.

" " " Oct. 8-II, I794.

Jan. I9-3I, I795.

$I d$., no. 5, relating to capture of "a great many American Vessels", and treatment of them. Apr. 27, I795.

Draft, no. 5, to Gov. Crawford, directing "in every case where neutral ships are brought into the Bermudas, to refer them to the cognizance of the Courts of Admiralty". Sept., I795.

Letter from Gov. Crawford, no. 7. Oct. 9, I795. Encloses :

Minutes of privy council. Feb. I4-Sept. I, I795.

" "legislative council. May 4-July 3I, I795.

Journal of assembly. May 4-July 3I, I795.

46. $\mathrm{I} 796-\mathrm{I} 798$.

Letter from J. Bickwood to John King. Encloses letter from John Green, July IO, I794, detailing "the proceedings of His Majesty's Court of Vice-Admiralty in these Islands in American Cases". Jan. 3I, I796.

Letter from Gov. Crawford. Oct. 29, I796. Encloses :

Journal of assembly. Oct. 5, I795-July 23, I796.

Minutes "legislative council. Oct. 5-10, I795.

May 2-July 23, I796.

" " privy council. Oct. 6, I 795-Oct. 4, I796.

Draft to Gov. Beckwith, transmitting copy of letter received from Lords Commissioners of Appeals in Prize Cases, purporting to be written by Mr. Monroe, American minister in France, to Mr. Randolph, American Secretary of State. Such a paper should not be produced in the case; such papers in future if taken on board a vessel should be sent to the governor for transmission to proper destination. Aug. 4, I798.

Letter from Gov. Beckwith, reporting information received from $\mathrm{Mr}$. Liston, our minister at Philadelphia. June I I, I798.

Draft to Gov. Beckwith, no. 6, detailing procedure in appeals in prize cases. Oct. I9, I798. 
47. I798-I799.

Letter from Gov. Beckwith, no. 38. Mar. 2, 1799. Encloses:

Journal of assembly. Mar. 26, I798-Feb. 9, I799.

Minutes “ privy council. Oct. 3, I797-Feb. I3, I798.

Feb. 23, I798-Feb. 8, 1799.

48. I799-1800.

“ " legislative council. Mar. 26, I798-Feb. 9, I799.

Letter from Gov. Beckwith, no. 43. Encloses seven papers relating to "an extensive commercial speculation in the United States... projected by a great Mercantile House in Cadiz". Apr. I7, I799.

$I d$., no. 49. Expresses apprehension at divergency of interpretation by naval commanders on the station and the American government on Art. I8 of treaty with America. June 19, I799.

Id., no. 57. Encloses two papers on opening of ports in Santo Domingo to British and American vessels. Aug. II, I799.

Id., no. 59. Encloses three papers on appeals in prize cases. Oct. 3, I799.

Id., no. 62. Oct. 4, I799. Encloses:

Minutes of legislative council. June IO-July 27, I799.

Journal " assembly. June Io-July 27, I799.

49. I800-I8OI.

Minutes “ privy council. Feb. I9-Sept. 20, I799.

Letter from Gov. Beckwith, no. 92. Sept. 3, I800. Encloses:

Minutes of legislative council. Feb. 24-Aug. 2, 1800.

Journal “ assembly. Feb. 24-Aug. 2, I80o.

50. I8OI.

Minutes " privy council. Oct. 2, I799-Jan. 20, I800.

Letter from Gov. Beckwith, no. II3. Transmits papers on the Indianer "originally an American ship taken by the French . . . sold to an adopted Dane .... in St. Thomas's, and loaded there with a valuable cargo for Philadelphia". Apr. 20, I80I.

$I d$., nos. II6, II7, I2I, I27, I30, I36, on same subject. June I3, I9, July I5, Aug. 21, Oct. 25, Dec. 5, I80I.

Id., no. II8. Transmits extracts of public letters "opened at sea upon the detention of an American Merchantman". Originals sent to Mr. Thornton, British chargé d'affaires in U. S. June 23, I8or. Papers follow, including correspondence of American consul at Algiers with U. S. minister at Madrid.

51. 1802 .

Letter from Gov. Beckwith, no. 7. Feb. 9, 1802. Encloses:

Minutes of legislative council. Sept. 30-Dec. I5, I800. "“" " " Feb. 23-July 25, 1801. “ " "privy council. Aug. 26, I800-Sept. 22, I801.

Journal “ assembly. Sept. 30, I800-July 25, I80I.

Id., nos. 10, 22. Encloses papers on the Indianer. Mar. 2, May 22, I802.

52. 1802 .

Letter from Gov. Beckwith, no. 48. Nov. 24, 1802. Encloses:

Journal of assembly. Apr. 26-July 3I, I802.

Minutes "legislative council. Apr. 26-July 3I, I802. " " privy council. Dec. 29, I80 I-Oct. 5, I802.

53. 1803 .

Letter from Gov. Beckwith, no. 62. June 6, 1803. Encloses:

Account of revenue arising from sale of crown lands, July 6, I796Mar. 22, 1803 . 
Journal of assembly. May 2-July 30, 1803.

Minutes " legislative council. May 2-July 30, 1803 .

54. 1803 .

Naval office returns. Jan. I-June 30 , I803.

Naval office returns. July I-Dec. 3I, I803.

Minutes of privy council. Nov. 26, I802-Mar. 8, I803.

Apr. I2-Nov. 21, 1803 .

Letters from Henry Tucker, nos. 35, 39, reporting capture of ship under

American colors without a register. Nov. 26, Dec. 20, 1803 .

55. 1804 .

Letter from Henry Tucker, no. 12. Reports temporary detention of Spanish dollars shipped on board an American sloop. Dec. 28, I804.

56. 1805 .

Letters from Henry Tucker, nos. 14, 20, relative to admission of American salt provisions. Jan. I7, Apr. I2, I805.

Id., no. I8. Mar. 21, I805. Encloses:

Minutes of privy council. Dec. I9, I803-July 9, I804.

" "legislative council. Apr. 23-July 28, I804.

Journal “ assembly. Apr. 23-July 28, 1804.

Naval office returns. Jan. I-June $30,1804$.

57. 1805 .

Letter from Gov. Francis Gore, no. 8. Encloses affidavit on sloop captured by privateer, master and part of crew being American. Sept. 2I, I 805 .

Naval office returns. Apr. I-Dec. 3I, I805.

Letter (unsigned) to Lord Camden, on "expediency of making Bermuda a free Port, for the admission of American vessels". . . . Mar., 1805 .

58. 1806.

Letter from Gov. Gore. May 22, I806. Encloses:

Journal of assembly. May 20-Sept. 7, I805.

Minutes " legislative council. May 20-Sept. 7, I805.

59. 1806.

Letter from Henry Tucker, no. 3, reporting admission of provisions, etc., in American vessels. June I5, 1806.

Letter from Gov. Hodgson, no. 2. Same subject. Sept. 26, I806.

Naval office returns. July I-Sept. 30, I806.

Letter from Henry Tucker. Dec. I5, 1806. Encloses:

Minutes of legislative council. Apr. 28-May I, I806.

"“ " " June 30-Aug. 9, 1806.

" " privy council. Aug. 24, I804-Apr. 19, I805.

Journal “ assembly. Apr. 28-May I, I806.

60. 1806 . June 30-Aug. 9, I806.

Minutes of privy council. May 7, I805-Feb. 22, I806.

Mar. 4-Sept. 2, I806.

Naval office returns. July I, I804-Mar. 3I, I805.

" " " Jan. I-June 30, I806.

Letter from Gov. Hodgson, no. II, on admission of provisions from America. Dec. 16, I806. Encloses minutes of privy council, Sept. I8-Nov. 21, I806. 
Id., no. I6. Reports illicit trade in "our own vessels" with U. S. Dec. $3 \mathrm{I}, \mathrm{I} 806$.

Naval office returns. Oct. I-Dec. 3I, I806.

61. 1807.

Letter from Gov. Hodgson, no. 22. Reports running ashore of American ship bound for "Charlestown" from Belfast. Had on board twenty Irish emigrants shipped by $\mathrm{Mr}$. Crachen of Belfast who resides there for that purpose. Feb. 5, I807.

Id., no. 25, on admission of American salt provisions. Feb. I4, I807.

Id., no. 30, containing extract of letter from Norfolk, Va., Mar. 16, I807. Mar. 24, 1807.

Id., nos. 37, 49. May I0, July 29, I807. Encloses naval office returns, Jan. I-June 30, I807.

62. 1807 .

Letter from Gov. Hodgson, no. 52. "The Masters of American Vessels frequently endeavour to entice the Soldiers and Sailors to desert from His Majesty's Service." Sept. 2, 1807.

Id., no. 54, relative to admission of provisions. Sept. 20, 1807.

Id., no. 58 and unnumbered. Oct. 9, Oct. 27, 1807. Encloses:

Naval office returns. July I-Sept. 30 , I807.

Minutes of legislative council. Mar. I6-July 31, I807.

Journal " assembly. Mar. I6-July 3I, I807.

Letter from G. Berkeley, representing increase of American trade that

63. I808. would result from making Bermuda a free port. Apr. I2, 1807 .

Draft to Gov. Hodgson, communicating refusal of Bonaparte to agree to demand of American minister at Paris to "revoke or soften decree of blockade against Great Britain". May 7, 1808 .

Letter from Gov. Hodgson, no. 89. Describes factions in assembly. James Tucker "is the remains of the faction which opposed Government so violently during the War with America, and is supposed to be deeply implicated in the transaction of conveying the Powder out of the King's Magazine to the Rebels at Charlestown, in the

64. 1808 . year $1775 "$. May 18 , 1808 .

Letter from Gov. Hodgson, no. II9. Many opponents of government indebted to government for large sums "advanced to satisfy the American Merchants for the Piratical conduct of their Privateers towards the American Trade during the late War". Oct. 3I, I808. Letter from Robert Kennedy. "The Americans still continue to supply us with as much provisions as we require here-notwithstanding the pretended strictness of their Embargo laws." Dec. 7, 1808.

65. 1809.

Letter from Gov. Hodgson, no. I24. Reports passage of American act for rendering embargo more effectual. Act enclosed. Jan. 3I, I809.

Id., no. I27. Describes American affinities of faction in assembly. Feb. 9, 1809.

Draft to Gov. Hodgson, no. I5, notifying grant of pension to an American Loyalist in Bermuda. July 6, 1809.

Letter from Gov. Hodgson, no. I 38 , relative to importation from America. May 3I, I8o9.

Id., no. I42. Factions in assembly and their American predilections. Aug. ro, r8o9. 
66. 1809.

Letter from Gov. Hodgson, no. I48. Refers to position of Americans in

67. I810. colony. Sept. 27 , I809.

Letter from Gov. Hodgson, no. I62, on importation from America. May I8, I8ro.

68. I8II.

Letter from Gov. Cockburn, on trade with America. Oct. 19, I8II.

69. 1812.

Letter from Gov. Cockburn, transmitting act "for levying . . . certain duties on Articles of American produce". Feb. I, I8I2.

Letter from Pres. William Smith. Received news on July I 3 of declaration of war by U. S. Aug. 20, I8I2.

Letter from Gen. Horsford, no. I. Arrival of reinforcements. Sept. I6, I8I2.

Draft to Gen. Horsford, no. 5. "No licence granted by you can authorize any vessel to enter into such of the American Ports as are subjected to Blockade." Feb. 23, I813.

Letter from James Buller to Henry Goulburn. Encloses order in Council authorizing governor of Bermuda to grant licenses under certain conditions for trade with U.S. in foreign ships; also two forms of licenses. Oct. I7, I8I2.

Letter from J. Burrow to Henry Goulburn. Same subject. Nov. I6, I8I2.

70. $18 \mathrm{r} 3$.

Letter from Gen. Horsford, no. I9. Arrival of reinforcements. Mar. 9, I8I3.

$I d$., no. 58. Presence in islands of a person "who has it within his power to procure Specie to any amount, . . . from the United States . . . which he will negotiate at par for Bills on His Majesty's Government". Dec. 30, I8r3.

71. I8I3.

Letter from Thomas Lack to Henry Goulburn, on conditions of American trade. May 3I, I8r 3 .

72. $18 \mathrm{I} 4$.

Letter from Gen. Horsford, no. 6o. Arrival of reinforcements. Jan. 3I, $18 \mathrm{r} 4$.

Id., no. 73. Refers to proclamation by Vice-Adm. Sir Alexander Cochrane "of the extension of the Blockade to all the Ports of the United States". May 23, I8I4.

73. $\mathrm{I} 8 \mathrm{I} 5$.

Letter from Gov. Cockburn, no. I2. Acknowledges receipt of letter of Jan. 28 with directions as to renewal of commercial intercourse with U. S. May I7, I8I5.

Id., no. 22, on disposal of American negroes who joined British during late war. Aug. 23, r815. Enclosures on same subject.

$I d$., no. 25. Refers to capture of packets by enemy during late hostilities. Oct. 26, I8I 5 .

Letter from R. Lushington to Maj.-Gen. Bunbury. Encloses letter from James Till to Victualling Board, Nov. 8, I8I4, describing tax of $2 \mathrm{~T} / 2$ per cent. on foreign vessels imposed by assembly of Bermuda. Jan. 13 , I8I 5 . 
Letter from J. Barnes to Sir H. Bunbury, enclosing letters on reported sale as slaves of American negroes who sought British protection during war. Apr. I7, I8I5.

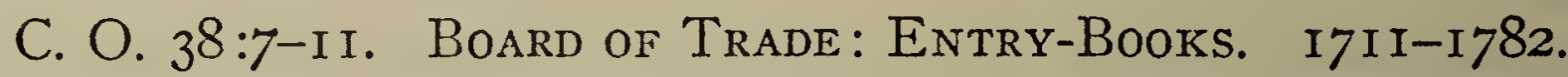

7. I 7 II-I 723 .

Draft of Lieut.-Gov. Pullein's commission. Jan. I3, I7I2/3.

Draft of Pullein's instructions, showing no essential changes. Feb. 2, I 7 I $2 / 3$.

Letter to Dartmouth, with draft of additional instruction forbidding Pullein to receive presents but permitting acceptance of house rent. May I5, I7I3.

Several papers on seizure by Spaniards of vessels carrying Spanish money, cacao, salt, and hides.

Draft of Lieut.-Gov. Bennett's commission. Mar. 4, I7 I4/5.

Draft of Bennett's instructions, showing no important changes. June 30 , I 7 I 5 .

Letter to Craggs, recommending amendments to instructions of the lieutenant governor regarding: procedure in suspension of councillors; use of suspending clause or submission of preliminary draft in cases of acts repealing acts already confirmed; passage of temporary money bills; suspension of patent officers; powers of lieutenant governor as vice-admiral; and acceptance of certificates issued to clergy and schoolmasters by others than the Bishop of London. Aug. 21, I7I8.

Draft of Lieut.-Gov. Hope's commission. Aug. 30, r72I.

Draft of Lieut.-Gov. Hope's instructions, showing alterations to bring commission into accordance with those of Belhaven and Hart; also permitting the acceptance of additional salary, and providing that clergy and schoolmasters secure certificates from the Bishop of London only (pursuant to order in Council of Mar. 26, I72I). Oct. 5, I721.

Letter to Hope, stating that since money raised under recent act placing import duties on British goods is to supply residence for lieutenant governor, Board will not recommend immediate disallowance. Lieutenant governor to seek other means of raising this money. June I4, I722. Representation to Walpole, suggesting confirmation of said act for three years. June 20,1723 .

$I d$., on his dispute with receivers of admiralty, and referring to act passed in last session of Parliament "for the more effectual Suppression of Pyracy". June 27, I723.

8. $1723-1748$.

Letter to Hope, stating Board's objections to act for lessening number of assemblymen and altering method of raising money to pay them. Apr. 2, I 724.

Id. "No Act whatsoever which lays any Duty upon the Importation of European Goods will meet with Approbation at Home."

Representation for disallowance of act laying duties on European goods. June 4 , I 724 .

Id., recommending granting of Dean of Derry's petition, provided college be not allowed to hold more than 1000 acres of land in colony. Mar. 2, I724/5. 
Letter to Hope, stating that no act can be suspended after passage, whether confirmed or not; commending his refusal "to join in the petition for the Habeas Corpus Act"; stating that "it has been thought necessary entirely to put a Stop to Acts that affect in any manner the British Trade"; announcing reversal of decision on the Salamander; and requiring regular accounts of importation of negroes. July 6, I726.

Draft of additional instruction (for all governors) that, in case of judicial appeal to the Privy Council, no execution of decision pronounced in colony to take place unless appellee gives ample security to appellant to make full restitution in case of reversal of decision. July $28,1726$.

Draft of Lieut.-Gov. Pitt's commission. Oct. I7, I726.

Draft of Lieut.-Gov. Pitt's instructions, showing alterations respecting governor's additional salary. May 3, r728.

A. Popple, secretary to Board, to Pitt, stating that commissioners have been appointed to treat with Spaniards on losses occasioned by seizure of British colonial vessels, and directing him to prepare statement and evidence. Dec. IO, I730.

Letters, reports, etc., on whale-fishery and lieutenant governor's additional salary. I73I-I733.

Representation for return of independent company of soldiers from the Bahamas to Bermuda. Dec. 8, I734.

$I d$., for repeal of act passed I73I, placing import duty on all goods not property of inhabitants. Feb. 8, 1731/2.

Draft of additional instruction for admission to council of Dunbar as councillor extraordinary. Aug. 8, I733.

Draft of Gov. Alured Popple's commission. Oct. 25, I737.

Draft of Gov. Alured Popple's instructions, showing no important changes. Mar. 7, I737/8.

Letter to Popple, mentioning Dinwiddie as former collector of customs at Bermuda. Dec. 6, I739.

$I d$., advising that assembly's custom of choosing new speaker every fourth year be allowed to stand, "though dissonant to the Custom of Parliament in England". But the crown's power of approving or rejecting a speaker "is a right from which the Crown has never yet departed in any of her Colonies".

Draft of additional instruction on collection of powder-duty. June I8, I74I.

Letter to Popple . . . "the Right of naming a Clerk to the Assembly is in the Crown, so consequently in you as Governor, and We find upon a like Dispute, which happened in South Carolina in I73I, His Majesty's Governor was directed to name the officer accordingly. ... We are of opinion . . . that all Records ought to be kept in the Secretary's Office as is done in the rest of His Majesty's Colonys." Aug. 10, I742.

Id. "Mr. Dunbar's Removal from the Place of Surveyor General of the Customs does not vacate his Seat as a Councillor in Ordinary". . . . July I2, I744.

Draft of Gov. William Popple's commission. Preamble only. Noted that the rest is identical with commission issued to Alured Popple. Mar. I9, I744/5. 
Draft of Gov. William Popple's instructions, showing changes mainly formal or covered by foregoing additional instructions. Apr. 30, I745.

Report to Lords of Committee of Council on petition for encouragement to project of producing Madeira wine. Apr. 7, I747.

$I d$., on address of assembly on whale-fishery and governor's additional salary. June Io, I748.

Representation, with draft of additional instruction on governor's additional salary; and on action of governor in treating assembly which overstayed adjournment as being dissolved. June 23,1748 .

$I d$., with draft of additional instruction on whale-fishery and governor's additional salary. June 29,- 1749 .

Letter to Popple, on remonstrance of assembly to governor concerning provisions and intelligence carried to enemy by flags of truce, which seldom carried more than one prisoner at a time. I749.

$I d$., on management of public lands. Oct. $26, \mathrm{I} 748$.

9. $\mathrm{I} 749-\mathrm{I} 760$.

Letter to Popple, disapproving of assembly's claim to tax bills and approving council's claim to share in appointment of judges and justices. Feb. I7, I748/9.

Reports to committee of Council, approving governor's claim to nomination of clerk of assembly, and defining parts of three branches of legislature in disposal of public moneys. Feb. 20, Mar. 29, I754. Drafts of additional instructions.

Letter to William Wood, secretary to Commissioners of Customs, on illicit trade. Feb. II, I755.

Draft of new instructions for Popple. May 2, I755.

Letter to Popple, defining rights of assembly in handling and appropriation of supplies voted. July 29,1756 .

Representation on crown lands. May I2, I757.

Report to committee of Council, with draft of additional instructions, on disposal of crown lands. June $6,175^{8}$.

10. I760-1782.

Draft of Gov. Popple's commission. Mar. 4, I76r.

Representation on act to repeal "An Act laying an Imposition on all Jews and reputed Jews trading or merchandizing in these Islands". Mar. I2, I76I.

Draft of Gov. Popple's instructions, showing a number of omissions made pursuant to recent statutes or to additional instructions. May 6, $176 \mathrm{r}$.

Letter to Popple, stating that, while establishment of courts is inherent right of the crown, it is doubtful "whether the single authority of the Crown would have been of sufficient effect and operation in a case of such immediate danger"; and pointing out necessity of regulations and checks on raising of money in colonies. Nov. 24, I762.

Draft of Gov. Bruere's commission. Apr. 4, I764.

Draft of Gov. Bruere's instructions, with merely formal changes. May I8, I764.

Representation on revenue arising from sale of crown lands. Aug. I, I766. 
Report to committee of Council, recommending that Crow Lane be made port of entry and clearance and that searcher be established at Ely's Harbor, provided that assembly makes provision for expense. Sept. 3, I766.

Representation for disallowance of act granting certain taxes, on ground that assembly violates governor's instructions and assumes unwarranted powers in appointing collectors in each parish and receiver general. Nov. 21, I770.

$I d$., on petition of certain inhabitants that the crown will remit tax on each whale caught or will grant other relief. Dec. 5, I770.

Draft of Gov. Browne's commission. Jan. I9, I782.

11. I78I. Governor Browne's instructions.

C. O. $326: 36$. $1703^{-1} 75^{2}$. Index to Board of Trade Original Correspondence * and Entry-Books.

C. O. $3^{8}:$ I3-20. Secretary of State: Entry-Books. I777-I820.

13. $\mathrm{I} 777-\mathrm{I} 78 \mathrm{I}$. In letters.

14. $1789-1807$. Précis of correspondence.

18-20. I 768-1820. Out letters.

20. I $80 \mathrm{I}-\mathrm{I} 820$.

Letter to Gov. Cockburn, no. 6 . Instructions for facilitating export to U. S. in British vessels of British goods upon information of ratification of peace. Jan. 28, I8I5.

$$
\text { C. O. 39:I-9. Acts. }
$$

1. $1690-1702$.

2. Acts of Assembly, made and enacted in the Bermuda or Summer Islands, from I690, to I713-4 (London, Printed by John Baskett, Printer to the King's most Excellent Majesty, And by the Assigns of Thomas Newcomb, and Henry Hills, deceas'd, I7I9, pp. v, 79), with corrections and additions in manuscript. Marked: "N. B. This volume of Bermuda Laws, after having been examin'd by two of their Lawyers, was sent back, with several Corrections and Additions. Rec'd June Ioth, I74I, With Gov. Popple's Letter dated April I8th, I74I."

3. $1698-1766$.

4. $1704-1714$.

5. $1715-1736$.

6. Acts of Assembly, made and enacted in the Bermuda or Summer Islands, Continued to 1736 (London, Printed by John Baskett, Printer to the King's most Excellent Majesty, I737, pp. vi, 8I-I 19, and 27 pp. not numbered). Half title, descriptive: Acts of Assembly passed . . at several Sessions of Assembly from I7I7 to I72I, both inclusive, held by Benj'n Bennett Esq., Lieutenant Governor and Commander in Chief; And at several Sessions of Assembly from I722 to I727, both inclusive, held by John Hope, Esq.; Lieutenant Governor and Commander in Chief; And also' at several Sessions of another Assembly, from 1728 to I736, both inclusive, held by John Pitt, Esq.; Lieutenant Governor and Commander in Chief. With manuscript corrections and additions and

the same N. B. as given above in C. O. $39: 2$.

7. $1738-1760$.

8. $1761-1767$.

9. $1769-1783$. 


\section{O. $40:$ :I-23. Sessional Papers. ${ }^{3}$}

1. I687, Apr. IO-I688, May 2I. Volume bound in calf, containing minutes of council of these dates (ff. I-I9), with other papers, copies of acts, reports, etc. Fully described in Calendar of State Papers, $A$. and $W$. I., I685-1688, no. I779. Referred to by Gov. Robinson as a book of the general matters relating to these islands. Received July 24, I688. With seal.

2. I698, Aug. I7-I699/I700, Jan. 2. Minutes of council (includes report of quarter sessions in July, I699, and some other papers; paged continuously), A, pp. 30 .

I70I, Apr. 28-I707, Dec. I7. Minutes of Council, B, pp. 49.

I708, June 7-I720, June 7. “ “ “ C, pp. I54.

I70I, June 9-1705/6, Jan. 8. Journal of general assembly, D. pp. 99. I705/6, Feb. I2-I707/8, Mar. 2. “" “" “ “ I707/8, Mar. I-I7I4, Apr. I4. “ “ “ “ (Mar. I-2 a repetition), F, pp. 99.

I7I2/3, Mar. 2-I7I7, May I9. Journal of assembly (part same as above), G, pp. 65 .

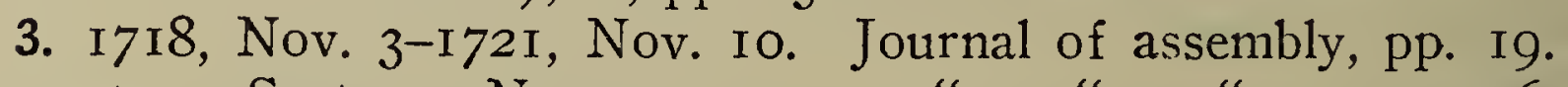

I722, Sept. 25-Nov. I5.

I $722 / 3$, Mar. 4-7.

I723, Sept. 24-26.

I $723 / 4$, Mar. 3 .

I 724 , July $2 \mathrm{I}-23$.

$\begin{array}{llll}\text { “ } & \text { “ } & \text { " } & \text { pp. I6. } \\ \text { “ } & \text { “ } & \text { (loose paper), pp.II. } & \text { (loose paper), pp.5. } \\ \text { “ } & \text { “ } & \text { “ } & \text { pp. } 4 . \\ & \text { “ } & \text { pp. } 7 .\end{array}$

I727/8, Mar. 4-I728, Apr. 5. Journal and votes of assembly, pp. I I.

I728, Nov. I 8-1728/9, Feb. 7. “ “ “ “ “ pp. I6.

I728, Nov. I8-I728/9, Mar. 6 (same as above with addition of Mar. $3^{-6:}$ a loose paper), pp. 23.

I729, Aug. 4-I730, June 24. Journal and votes of assembly, pp. 27.

I730, Nov. 3-I73 I, Apr. 9. “ “ “ “ “ "

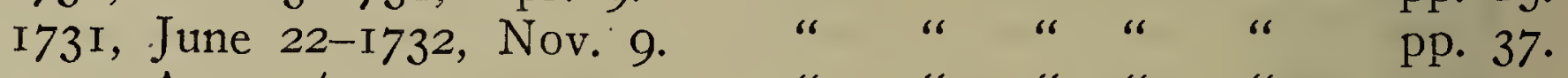

I733, Aug. 7/9.

I733/4, Feb. 5-Mar. 7.

I734, Nov. 5-8.

I735, Nov. I I-I736, Apr. Io.

I736, June 2I-I $736 / 7$, Mar. 2.

4. I720, June 2I-I722, Apr. 3 .

I722, May 8-I723/4, Mar. I6.

I724, July 21.

I727, Nov. 7-I728, Aug. 6.

I728, Sept. 3-I729, Aug. 6.

5. I729, Sept. 9-1736/7, Mar. 2. “ " “ " 7 " Feb. 9-1737, Oct. 25. Minutes of council, pp. 22 .

Minutes of council, pp. 33.

“ “ “ “ “

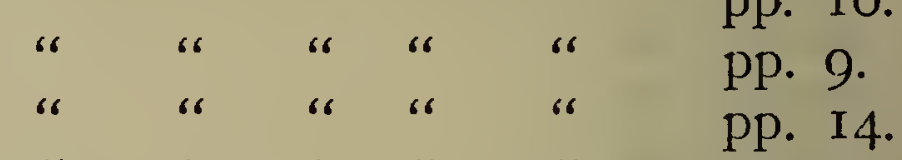

pp. 29.

1737, Nov. I-I738, May 2.

I738, July Io-Aug. II.

I738, Sept. 5-7.

I738, Sept. 5-1739, Nov. Io.

I739, Dec. 4-I740/I, Mar. 5 .

(loose paper), pp. 36 .

pp. I6.

(repeated), pp. 6.

pp. 67.

pp. 64.

${ }^{3}$ Except vol. 6, nearly all these Bermuda sessional papers bear tha seal, impressed on paper over wafer, sometimes on the face, but mostly on the accompanying attest. 
I737, Aug. 9-Sept. 8. Journal of assembly, pp. 2 I.

I 737, Nov. 8, 9.

I737/8, Mar. 7-9.

I738, Aug. 7-rr.

I739, Aug. 7-Nov. Io.

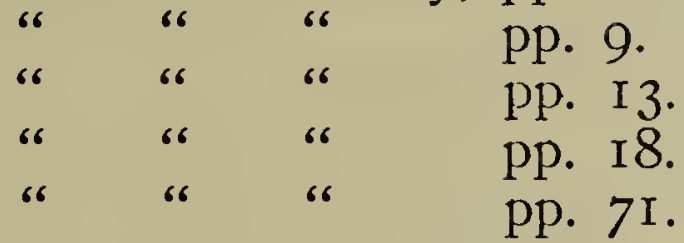

r739, Aug. 7-r740, Oct. 9. Duplicate of previous item, continued r740, May 6-Oct. 9, pp. I I9.

I740/I, Mar. 3-5. Journal of assembly, pp. I8.

6. I742, Apr. 6-Oct. 6. Minutes of council in assembly, pp. I9.

I $742 / 3$, Jan. 4-7.

I742/3, Mar. 8-I743, Apr. 7. “ “ “ “ “ “ $"$ “

I743, Oct. 3-8. " " " " " " " " $"$ "

I744/5, Jan. 7-Mar. 7. “ “

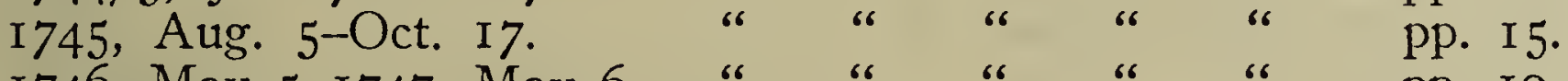

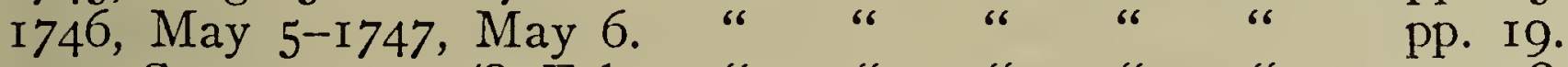

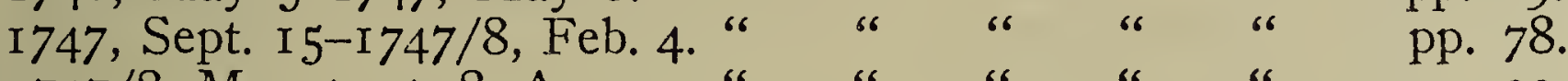

I747/8, Mar. 7-I748, Apr. 30. "

I748, Nov. 7-r748/9, Feb. 7. “
I749, Nov. 6-I 5.

I 749, Nov. 6-I 5 .

I750, May 7-June 23.

I752, Feb. IO-Oct. I7.

I754, Oct. I4-I7.

1755, May 5-r756, Mar. I3.

I 757, Feb. 7-Mar. 25.

1757, Nov. 7-12.

I 758, July 3-Aug. 3 .

I758, Oct. I3-I759, June I4.

I759, July 9-Sept. I9.

I759, Oct. 29-1760, Apr. 26.

7. ${ }^{4} 74 \mathrm{I} / 2$, Feb. 2-I742, Oct. 6.

I742, Nov. 2-I742/3, Jan. 7.

I742/3, Feb. I-I 743, Apr. 7.

I743, May 3-Nov. I.

I744, Sept. 4-I745, June I5.

r745, Aug. 5-r 745/6, Mar. 4.

1746, Aug. 5-1747, May 6.

I747, June 22-Sept. 26.

I747, Sept. 22-I748, Oct. 4.

pp. 44.

pp. 7.

pp. 7.

pp. 69.

pp. 46.

pp. I3.

pp. 26.

pp. 4.

pp. 27.

pp. $5 \mathrm{I}$.

Minutes of council, pp. 22.

pp. 9.

pp. 7.

pp. II.

pp. 20.

pp. 7.

pp. I4.

pp. II. tition ), pp. 49 .

(Sept. 22-26 a repe-

I748, Nov. 8-i748/9, Mar. 23. Minutes of council, pp. 26.

I749, May 2-Nov. 27.

I $749 / 50$, Jan. 2-I750, June 23. " " " " " " $"$ "

I75 r, Nov. I9-1754, Aug. 6. " " " " "

I755, Feb. 27-I756, Mar. I3. " " " " "

I756, Nov. I-r757, Mar. 25. " " " " " "

I757, Aug. 2-Sept. 8. " " " " "

I757, Oct. 4-I758, Mar. I 5. “ " " " " " "

I758, Apr. 4-Aug. I. " " " " " "

I758, Oct. IO-I759, June I4. “ “ “ “

I759, June I4-I760, June 3. " " " " (June I4 a repetition), pp. 27.

"Some of the attests here seem to include the minutes of the council in assembly described in the previous volume. 
8. I 742, Apr. 6-9.

I 742/3, Jan. 4-7.

I742/3, Mar. 8-i743, Apr. 7.

I743, Oct. 3-8.

I747/8, Feb. I-5.

I747/8, Mar. 7-I748, Apr. 30.

I748, Nov. 7-II.

I748/9, Jan. 2-I 3 .

I756, Jan. I2-Mar. I3.

I757, Feb. 7-Mar. 25.

I757, Nov. 7-I2.

I758, July 3-Aug. 3 .

Journal of assembly, pp. I7.

I758, Nov. I3-I759, Sept. I9.

pp. I4.

pp. 4.

pp. I 3.

pp. 28.

pp. 30.

pp. I 4 .

pp. 45 .

pp. 53 .

pp. 67.

pp. 16.

“ " $4 \mathrm{I}$.

9. I760, July 7-I76I, June 27. Votes and proceedings of assembly, pp. 74 . I761, Aug. I7-I762, Jan. 30 .

I762, Mar. I-Apr. Io.

I 762 , July I $4-17$.

I762, Aug. 26-1763, Apr. I 3 .

I763, July 4-I764, Feb. 25.

I764, Apr. 2-Aug. I8.

I 764 , Sept. 24-Nov. 29.

I765, Jan. 7-May 8.

I765, July 8-i766, Mar. 4 .

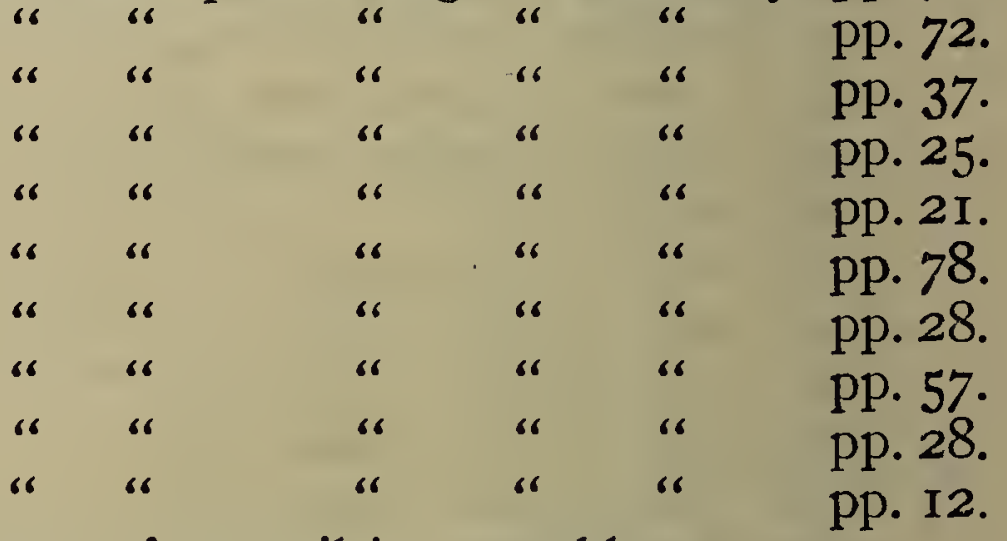

10. I760, May 5-176I, June 27. Minutes of council in assembly, pp. 74 . I76I, Aug. I7-I762, Jan. 30: “ “ “ “ “ I762, March I-Apr. IO. “ “ " “ “ “ “

I762, March 8-I764, Feb. 26. " “ " “ “ (Mar. 8-Apr. Io a repetition; adjourned to Apr. 2, I764), pp. I40.

I764, Aug. I4-I 8 .

I 764 , Nov. 24-29.

Minutes of council in assembly, pp. I4.

I765, Feb. I8-May 8. Minutes of council (in assembly), with memorandum of June IO, pp. I 5 .

I765, June Io-i766, Feb. I4. Minutes of council in assembly, pp. I4.

11. I760, July 8-I76I, June 26. Minutes of council, pp. 36 .

I 761 , July 30-i 762, Mar. 3

I762, Mar. 9-Apr. Iо.

I762, Apr. I9-1764, May I.

I764, Aug. I I-I6.

I764, Oct. I3-Nov. 29.

I765, Feb. I9-May 7.

I 765 , July 9-I 766 , Feb. 4.

I766, Mar. 4-Nov. 4.

I 766, Nov. I I-I 767 , Apr. 7.

I767, May 5-Sept. I9.

I767, Oct. 6-i768, Mar. I.

12. I 766, Mar. 3-Nov. 5 .

I767, Jan. 4-Mar. 2 I.

I767, May 4-Sept. I9.

I767, Dec. I4-I768, Mar. 2 I.

I768, Apr. I I-Oct. I7.
pp. 49.
pp. 8.
pp. $8 \mathrm{I}$.
pp. 5 .
pp. 20.
pp. 9.
pp. 3 I.
pp. 40.
pp. II.
pp. 24.
pp. 34 .

Minutes of council in assembly, pp. 32 .

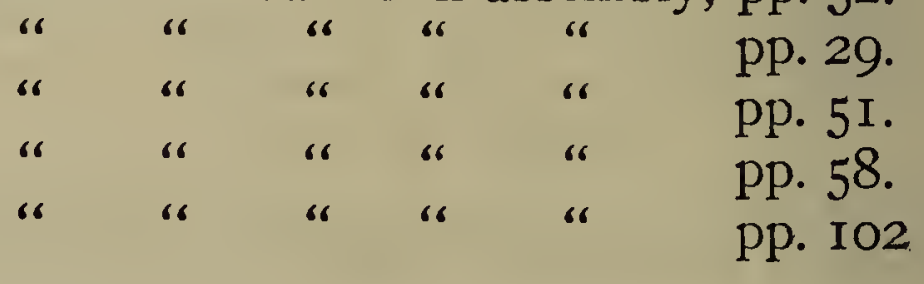


13. I766, Apr. I-Nov. 5. Votes and proceedings of assembly, pp. 28. I767, Jan. 5-Mar. 21. “ “ “ “ “ pp. 26.

(Pinned to the foregoing is a letter dated Mar. I9, I767, from Gov. Bruere to Mr. John Stiles, searcher at the windward of these islands, on his appointment, "which occasioned rancour in the Assembly".)

I767, May 4-Sept. I9.

Votes and proceedings of assembly, pp. 27.

I767, Dec. I4-1 768, Mar. I 5.

I768, Mar. 2I-May I4.

I768, June 20-Oct. I7.

14. I768, Aug. I5-1769, May 6. Minutes of council, pp. I7.

I 769 , June 2I-22.

pp. 4.

I769, Aug. I-1770, Apr. 28. “ “ “

I769, Oct. 2-I770, Apr. 28. Minutes of council in assembly, pp. 88.

I768, Dec. I2-I769, May 23.

I768, Apr. I2-Nov. I. Minutes of council, pp. I4.

pp. 59 .

I769, June I9-23. Minutes of council in assembly, pp. 27.

15. (Volume marked erroneously "Council in Assembly.")

I768, Dec. I2-I769, June 23. Votes and proceedings of assembly, pp. 75.

I769, June 20-23. (Same as in the foregoing), pp. I8.

I769, Oct. 2-I770, Apr. 28. Votes and proceedings of assembly, pp. 92.

1770, Nov. 5-177I, June II. “ " “ “" “" pp. 73.

I771, Nov. 5-1772, Dec. I5. Minutes of council (erroneously endorsed: "Journal of Assembly"), pp. 39.

I773, Feb. I 5-July 23. Votes and proceedings of assembly, pp. 39. I773, Aug. I6-1775, Apr. I. " " “" "

16. I770, Nov. 5-177I, May 4. Minutes of council in assembly, pp. 6I.

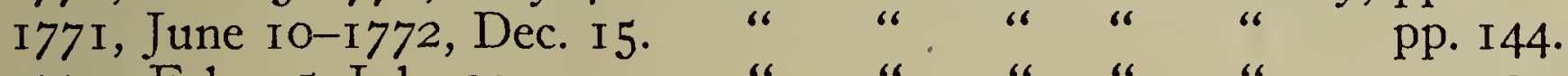

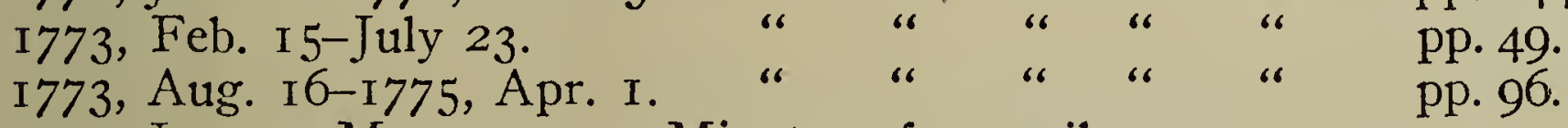

17. I77 I, Jan. I 5-May 4. Minutes of council, no. I, pp. 20. I772, Dec. 16-1775, Mar. 30. “" “" “ " no. 2, pp. 33 . I775, May 4-I776, July Iт. “ “ “ “ I778, Mar. I2-I779, May 21. “ “ “ “
I779, Aug. 5-I781, Apr. I I. “ “ 4 , pp. I4. I779, Oct. I I-I780, May 27. Minutes of council in assembly, no. 6, pp. 98. 1780, Sept. 18-23. “" “" “ no. 7, pp. 20.

18. I780, Oct. 9-178I, Mar. 28. Minutes of council in assembly, no. 8, pp. I20. I781, June I8-Sept. 29. “ “ “ “ “ " pp.70.

I77I, Aug. 5-1772, Dec. I5. Votes and proceedings of assembly, no. 9, pp. 63.

I780, Sept. I8-I78I, Feb. 2. “ “ “ “ “ pp. II 5 .

I78r, Mar. 5-Sept. 29.

I78I, Apr. 2I-Sept. I9. Minutes of council, pp. I3.

19. I775, May I-I776, July I3. Minutes of council in assembly, pp. I25. I776, Oct. I4-I777, Oct. Io. “" " “" “" $"$ " I778, Jan. I2-I779, July 8. “ “ “ “ “

20. I775, May I-1776, July I3. Votes and proceedings of assembly, pp. I I I. I776, Oct. I4-I777, Oct. Io. “" “ “ “" “ I778, Jan. I2-I779, July 8. “ “ “ “ “ “ “ “ I779, Oct. II-I780, May 27. “ “ “ “ “ 
21. I78I, Dec. 3I-I782, May I. Minutes of council, pp. 27.

I782, Jan. 22-Mar. 30. Minutes of council in assembly, pp. I I 5 .

22. I782, Jan. 21-Mar. 30. Proceedings of assembly, pp. I62.

I783, Feb. 3-Apr. 5. Minutes of council in assembly, pp. 82 .

I782, May I4-I783, Apr. 8. Minutes of council, pp. 26.

I783, Feb. 5-Apr. 5. Votes and journal of assembly, pp. I 32.

23. I783, Apr. 29-1784, May 28. Minutes of council, pp. 32.

(The papers in this vol. continue to 1787. )

[The volumes printed by the Bermuda assembly, Ancient Journals of the House of Assembly of Bermuda, from I60I to 1785 (Bermuda, Gregory V. Lee, Queen's Printer, I890, three vols., pp. 2260, and a supplemental vol. IV., London, pr. by Waterlow and Sons, I906, pp. 342), contain many journals not to be found among the transcripts listed above from C. O. 40. The following is a list of these additional originals preserved at Hamilton. The year-dates given in it are to be understood as indicating years beginning Jan. I. Journals indicated by asterisks are to be found in vol. IV., which contains, besides these original journals found after 1890 , also such journals as are to be found in transcript among the sessional papers listed above from C. O. 40 but are not extant in Bermuda.

I696, Sept. 2-18, Dec. I8.

I697, Feb. I, July 6-9, Sept. 6-7.

I698, Oct. 3I-Dec. 2.

ı699, Feb. 27-Mar. 3, Apr. ıо, May I 5, Sept. I8.

I7 7, Oct. 7-9.*

I7I8, Mar. 3, Apr. 7-9.*

I722, Nov. 22.*

I723, Apr. I I.*

I724, Mar. 4.*

I725, Oct. 12-1 3 .*

I726, June $27-30 . *$

I727, Jan. 2-3, Feb. 6-7, Mar. 6, Apr. I I, June I2-15, Sept. 21-26.*

I732, Nov. $21-23$.

1735, May 6-8.

I739, Mar. 6-8.*

I741, May 5-9, Nov. 3-6.

I742, Oct. 5-6.

I744, Jan. 25-27, May 7-8, July 2-7.

1745, Jan. 7-1o, Mar. 4-7, Aug. 5-6, Sept. 30-Oct. I, I4-I7.

I746, May 5-8, Nov. 3-7.

1747, May 4-5, Sept. I 5-26, Nov. 9-Dec. 5.

I749, Feb. 6-7, June 19-23, Nov. 6-i6.*

I750, May 7-I2, June 4-23, Nov. 5.*

1751, Apr. 15-16.*

I752, Feb. Io-13, Oct. 16-17.*

I754, Oct. I4-I7.

I755, Feb. 3-4, Mar. 3-7, Apr. 8-9, May 5-10, 26-31, June I6-2 r, July $2 \mathrm{I}-26$.

I756, July I9-24, Nov. I-3, I 5-20.

I762, May 10-12, 24, June I4-16, 29-30, July I2-I3.

I78I, Nov. I2-I7, and on through I784 and I 785.$]$ 
6. Inward :

\section{O. 4 I :6-7. Shipping Returns.}

I7I 5, Oct. I I-I720, Oct. 20. I729, Mar. 26-I737, Oct. 26.

7. I738, July 9-I74I, Dec. 25. I747, June 22-I75I, June 24.

Outward:

Same periods.

\section{BRITISH GUIANA. ${ }^{1}$}

C. O. I I : 3 -20. Secretary of State: Original Correspondence, Demerara and Essequibo. I795-I8I5.

3. $1795^{-1} 799$.

Letter from Gov. Antony Beaujon (Demerara), stating necessity for export of coffee and cotton in neutral vessels if provisions are to be imported from U. S. Aug. I8, I797.

Id. Jan. 24, I799. Encloses return of exports, I789-I799.

6. I805-I806.

Letter from Gov. Beaujon, reporting issue of proclamation for importation in American bottoms of certain articles subject to 5 per cent.

7. 1807 . duty; also export of certain articles of produce. May $4, \mathrm{I} 805$.

Letter from Lieut.-Gov. Bentinck, no. I4. Jan. I8, I807. Encloses accounts of imports from and exports to Br. N. Am. and U. S., Oct. IO, I803-Oct. IO, I806, distinguishing nationality of shipping.

$I d$., no. I5. Describes effect of order in Council restricting American trade, and limiting exports in payment to rum and molasses. Jan. I9, I807.

Letter from Lieut.-Gov. Nicholson, no. 2. Encloses return of imports of salt fish in $\mathrm{I} 807$ from N. Am. and U. S. Dec. 2I, I807.

13. $\mathrm{I} 8 \mathrm{I} 2$.

Letter from Gen. Carmichael, no. I I. Rumors that Gen. Miranda had opened his ports to Americans; necessity for guarding coasts from probable depredations; less than 400 men fit for duty; raising of corps of mounted chasseurs proposed. Sept. 8, I8II. Encloses memorial relative to American war and probability of entry into it of Spanish republics.

Id. Measures taken against an enemy brig which appeared Sept. 27. Inhabitants well affected but "there are many Americans and Republicans of different Nations who require strict attention". Oct. I3, I 812.

Id. Reports blockade by American privateers, and measures taken for defense. Nov. I, I8I2.

Id. Acknowledges receipt of circular letter of Sept. I4, accompanying act of Parliament regulating trade with U. S. Dec. I9, I8I2.

15. I8I3.

Letter from Gen. Carmichael, acknowledging receipt of letter of Nov. 6 respecting coin and bullion found on American vessels. Jan. 20, I8I3.

Id., nos. 45, 50. Apr. I5, 21, I8I3. Encloses minutes of court of policy, Feb. 25, Mar. 26, I8I3.

16. I8I3.

Letter from Gov. Codd, no. I6. Oct. 5, I8I3. Encloses letter from wood-cutters on trade in lumber : protection necessary against Ameri-

${ }^{3}$ See also Surinam. 
can competition in order to obtain trade of Windward and Leeward

17. 1813. Islands. Oct. 4, I8I 3 .

Letter from Lieut.-Gov. Codd, no. 18. Encloses letter on claims of American mortgagees. Nov. 20, I8I3.

18. 1813 .

Minutes of court of policy, July 30, I8I 3 .

20. I8I 5 .

Letter from Lieut.-Gov. Murray, no. 3I. Acknowledges receipt of circular, Dec. 27, giving information of signature of Treaty of Ghent. Mar. I I, I8I 5 .

Id., no. 35. Acknowledges receipt of copy of Treaty. May I4, I8I5.

C. O. i i i :77-8I. Secretary of State: Original Correspondence,

77. $1808-1809$. BERBICE. I8O8-I8I4.

Letter from Lieut.-Gov. Woodley, no. 6, on importation in neutral vessels, and desiring permission to export coffee or cotton in payment. July I7, I809.

78. I8IO-I8II.

Letter from Gov. Gordon, acknowledging receipt of information that order in Council of Feb. 7, I8Io, would not be continued so far as it relates to importation of fish from U. S. June 29, I8I I.

Among miscellaneous papers is letter from Board of Trade to Secretary of State to effect that application for permission to export sugar and coffee in neutral vessels could not be granted. Aug. 2, I8I I.

79. I8I2.

Among miscellaneous papers is letter from R. Gordon, giving information of news of "great depredations committed by the American

81. I8I4. privateers on our coast". Nov. 30, I812.

Letter from Gov. Bentinck. Defenseless condition of settlement; several schooners destroyed or taken and used by American privateers for attacks on coast. Aug. I, I8I4.

C. O. il2:I-4, 8, io. Secretary of State: Entry-Books. i8oi-i8i8.

1. I80I-I807. Précis of In-Letters, Berbice.

2. 180I-1807. Précis of In-Letters, Demerara and Essequibo.

3. I797-I802. Out-Letters, Demerara, Essequibo, and Berbice.

Letter to Gov. of Demerara and Essequibo, no. I, relative to exportation in neutral bottoms. Exports to be confined if possible to rum and molasses. Apr. I3, I797.

4. I80I-1816. Out-Letters, Demerara and Essequibo.

8. I8OI-I8I8. Out-Letters, Berbice.

10. I8I2-I8I6. Out-Letters, Surinam.

\section{BRITISH HONDURAS.}

C. O. i23:i-24. Secretary of State: Original Correspondence. I744-I8I 5 .

1. I744-I756. (See Andrews, I. 202.)

2. $1779-\mathrm{I} 783$.

Material on early history of Mosquito Shore. 
3. $1784-1785$. (Relates largely to settlement of Mosquito Shore after treaty of I 783 ; contains also matter of earlier date.)

Letter from Robert White (representative in London of principal inhabitants of Mosquito Shore), transmitting memorials from persons dispossessed of their property in N. Y. by British forces in I775-I778. Feb. I, I785.

Id. Distress of Loyalists from E. Fla. for want of provisions. Apr. 7, I 785 .

4. 1786 .

Letter from Robert White. Encloses memorial from a Loyalist. Mar. $25, \mathrm{I} 786$.

6. I 787-I 788 .

Letter from Superintendent Despard, referring to trade of Americans and alleged intrigues of one Finlay. Jan. I I, I788.

Id. Encloses list of small craft in Bay of Honduras on June I, distinguishing American and other vessels. June 4, I788.

7. I788-I 789 .

Letter from Superintendent Despard. American trade. Nov. I7, I788.

Id. Permission granted to some small vessels to carry local produce to U. S. to purchase provisions. Arrival of vessels from America and Jamaica has made further permits unnecessary. Nov. 20, I788.

Id. Trade with America. Dec. 7, I788.

10. I $784-1790$.

"A Narrative of the Publick Transactions in the Bay of Honduras from I784 to I790 by Edward Marcus Despard Esqr. with his complaint of Mr. White's Conduct."

11-12. I784-1790. (Same subject.)

15. I8OI-I803.

Letter from Superintendent Barrow. Encloses "A Short Sketch of the present situation ... of Honduras", including account of exports, shipping, etc., distinguishing American and others. Mar. 3I, I803.

Id. Apr. I9, July 29, Sept. 24, Nov. 16, I803. Encloses naval office returns, Jan. I-Sept. 30 , I803.

16. I804-1805.

Letters from Superintendent Barrow, Jan. 29, Mar. 27, July 28, 1804. Encloses naval office returns, Oct. I, I803-June 30, I804.

Id. Encloses letter on supply of provisions from America. July 28, I804.

$I d$. Encloses account of vessels cleared and entered between Great Britain and the Bay, $1783^{-1803}$, distinguishing British and foreign. Aug. I0, I804.

17. I $806-1807$.

Letter from Brig.-Gen. H. T. Montresor. Oct. 22, I806. Encloses account of exports of mahogany and logwood, I797 et seq., and return of American vessels entered, Jan. I-Dec. 3I, I805.

Among miscellaneous papers at end of volume is report of a committee of "the Committee of Merchants" on application of settlers at Hon-

24. I8I 5 . duras for free importation of provisions from U.S.

Letter from Lieut.-Col. Arthur, no. 2I, with enclosures on arrival of British ship Ariel from N. Y., Aug. 24. Sept. I, I815. 


\section{CURAÇAO.}

C. O. 66:I-4. Secretary of State: Entry-Books. i800-I8it.

1. $1800-1807$. Précis of In-Letters.

2. 1807-1811. Sir Charles Brisbane's Letter-Book. Minutes of "Extra Ordinary Meeting Tuesday 30 June I807" of assembly (pp. I83I87); also for June 8, I807 (pp. 194-202).

Letter from Frey, Bruner, and Co., relative to vessel sent to Curaçao. Baltimore, Oct. I0, 1807.

3. I80I-1806. Copies of Out-Letters.

4. I807-I8II. Miscellaneous Papers.

Minutes of court of policy. June 8, June 30, July I5, July 24, I807.

Naval office returns, Amsterdam. June IO, I808-Mar. 3I, I8II ; July ISept. 30, I8II.

\section{DOMINICA.}

C. O. 7 I i. Board of Trade: Original Correspondence. I770-i 778.

1. $1770-1778$.

Order in Council, approving report of committee of Council and ordering preparation of commissions and instructions in accordance with suggestions in report. Report recommends change of Dominica, which already possesses lieutenant governor and separate council, assembly, and courts, into independent government. Governor to receive $£_{3} 000$ per year, raised by annual grant, fees of office, and allowance by crown from proceeds of $4^{\mathrm{T}} / 2$ per cent. duties as soon as same shall be established in island. June 6, 1770.

Letter from Ellis, agent for Dominica, asking for appointment that he may obey instructions to solicit confirmation of twelve acts of assembly, passed I768-1771. May 7, I77I.

Petition for licenses to assign leases.

Richard Jackson's opinion on various acts.

Orders in Council for preparation of commission and instructions for first governor, approving design for settling of island, and regulating other matters relating to establishment of government.

Proceedings in court of oyer and terminer, general gaol delivery, and general sessions of peace. Oct. 7, I773.

"The State, Condition of Trade and Cultivation of H. M. Island of Dominica. In answer to several Queries". . . . Dec. 24, I773.

Petition by free mulattoes against act regulating manumission and possession of free people of color before the law.

C. O. 71 : 2-50. Secretary of State: Original Correspondence.

2. $1730-1801$.

$$
\text { I730-18I5. }
$$

Report of Board of Trade on English title to Dominica. I730.

Draft of letter to Richard Burke on settlement of Loyalists in Dominica. Dec. 2,1783 .

Draft of instructions for Orde. Pencilled date, Oct. 8, I783.

Draft of letter to governor, on changes which may be necessary in constitution of island; and directing that he secure adoption by assembly of $4 \frac{1}{2}$ per cent. duty. Oct. 8,1783 . 
Draft of letter to Gov. Adml. Hamilton, on bringing in of bill of attainder against rebellious subjects who take up arms against his Majesty. Undated.

Copy of agreement concluded by president of council and commander of forces in Dominica with French intendant, on quit-rents due to French king. 1785. Other papers.

Letter from Sydney to Lords of Treasury, on removal of seven hundred persons from E. Fla. to Dominica. Nov., I785.

Letter from Gov. Orde, thanking committee of Council for sending cotton seeds. Dec. I I, I 788 .

List of prices current. May Io, I788.

Deposition on impressment of British subjects by French man-of-war, and correspondence of governors of Dominica and Martinique on subject. I788.

Letter from Orde, on attempts of French to introduce their sugar into Dominica and other foreign plantations, on account of difficulty of getting it safely home in their own ships. June I3, I792. Other papers.

Report of committee of Council on charges against Orde, of obstruction to trade, exaction of exorbitant fees, etc. Gives names of committee. May I, I793.

Printed list of freeholders or lessees of land, showing both original and "present" holders. Unsigned, undated.

3. $1770-1772$.

Letter from Young, on success in securing permanent grant of governor's salary in spite of assembly's jealousy of power of crown and desire to keep financial control in its own hands. The $4 \frac{\mathrm{T}}{2}$ per cent. duty is paid, thanks to royal proclamation; but assembly refuses to vote it, and claims that collection by proclamation is illegal. Oct. 3I, I77 I. Enclosures.

$I d$., on suppression of black Caribs in St. Vincent. July $28, \mathrm{I} 772$.

Various letters, addresses, etc., on defenseless condition of island.

4. I773-I774.

Address of commander-in-chief, council, and assembly, showing that free port act is about to expire, and suggesting improvements. Mar. 6, I773.

Letter from Lieut.-Gov. Stuart, showing compliance of island in insertion of suspending clause. Aug. 24, I773.

Letters from Young to Lords of Treasury, showing that he has been compelled to draw on Treasury for money to construct fortifications. Aug. 27, Oct. 3I, I77I.

List of various officials, chaplain, engineer, surgeons, officers of customs, judges, etc., with rates of pay. I77I.

"Some Account of the most important Transactions in H. M. Island of Dominica during the administration of Sir Wm. Young, captain general and Governor In Chief." Jan. 6, I774.

Copies of correspondence between Young and Treasury. Jan. 6, I774.

Letter from Lieut.-Gov. Stuart, on settlement of island, and its increasing importation of shoes and other manufactured articles from North American colonies. Dec. 24, I773. Encloses detailed answers to customary queries, including what appear to be abstracts of naval office lists, I 772-1773, and figures for totals of various imports and exports, I $767-1773$. 
Letter from A. Henderson, deputy collector at Roseau, on renewal of free port act, and reduction of duties on imports of slaves. Gives quarterly rates of collections on negroes and other imports for preceding year. Nov. 27, I773.

"Account of Lands sold and disposed of by His Majesty's Commissioners in the Island of Dominica." I765-1773.

Returns of militia and military stores. I773.

Letter from Stuart, on relief of garrison. Jan. 30, I774.

Dartmouth to Stuart, stating that importation of manufactures from N. Am. "is highly prejudicial to the Interest of Great Britain and repugnant to every purpose of the Government in planting those Colonies". Apr. 6, I774.

Petition from Ellis, agent for Dominica, on encouragement of coffeeplanting. Apr. I6, I774.

5. I $774-\mathrm{I} 775$.

Stuart to Dartmouth, on courts in Dominica. Oct. 30, 1771.

Letters from Shirley, on financial and economic difficulties of colony, and his disputes with council and assembly. Council "will not admit that I have power either to adjourn, prorogate, or dissolve them when considered as part of the Legislature", but insist that they may always meet on summons of their president, according to custom of island. Assembly has not granted the $4^{\mathrm{T}} / 2$ per cent., but has voted to consider it. Nov. 25, I774; Mar. 3, June 6, 9, I2, I3, I 775 .

Dartmouth to Stuart, pointing out that meetings of council, as council of state, are dependent solely on governor, but meetings it holds as legislative body must be coincident with meetings of assembly. Aug. 2, I775.

6. I $775^{-1} 777$.

Letter from Gov. Shirley, no. I8. Lack of provisions, and partial supply through interception of cargoes destined for French and other foreign islands. Feb. 17,1776 .

Id. Encloses copy of correspondence with M. d'Argent on exercise by English privateers of right of search, and assistance given to Americans by French ports. Apr. 30, I777.

Draft to Gov. Shirley, no. 8, informing him of decision to empower governors to grant letters of marque. July 2, 1777.

Letter from Gov. Shirley. Encloses copy of letter to Marquis de Bouillé, May 30, I777, relative to assistance to Americans. June II, I 777 .

7. I777-I779.

Letter from Gov. Shirley, reporting sight of fleet of eleven sail, under French convoy, undoubtedly Americans bound for St. Eustatius; also engagement of Grenville Packet with rebel privateer. Mar. I2, I 778 .

Id., no. I3. Avowal by French court of treaty made with Americans. Aug. 5, I778.

Letter from Lieut.-Gov. Stuart. Declaration of war at Martinique and Guadeloupe. Aug. 24, I778.

Id. Describes capture of Dominica by French on Sept. 7, Sept. 9, I778. Encloses articles of capitulation.

Id. Encloses report on fortifications, etc. Sept: 29, I778. 
Letter from W. Hewitt, reporting pursuit for nearly twelve hours by American privateer. Tobago, June I, I779.

Letter from Lieut.-Gov. Stuart. Information of progress of war. Barbados, Aug. 28, I779.

8. $\mathrm{I} 783-\mathrm{I} 784$.

Letter from Gov. Orde, giving account of island. Feb. 3, I784. Encloses documents on cession of island, also naval office returns, Roseau, Jan. IO-Feb. 2, I784.

Naval office returns, Roseau, Jan. IO-Mar. I2, I784.

Letter from Gov. Orde. Aug. I3, I784. Encloses:

Minutes of council. Apr. I4-Aug. Io, I784.

Journal of assembly. Apr. 2-Aug. 6, I784.

Minutes of privy council. Jan. Io-Mar. I3, I784.

9. $1784-1785$.

Letter from Gov. Orde. Oct. 26, I784. Encloses journal of assembly, Aug. 26-Oct. I, I784.

Id. Jan. 21, I785. Encloses account of imports, Jan. IO, I784-Jan. Io, I785, and account of vessels entered, etc., Jan. Io, I784-Jan. Io, I785.

Letters from Gov. Orde. Mar. 6, June 7, Nov. Io, I785. Encloses:

Minutes of privy council. Oct. I 5-Dec. I7, I784.

Journal of assembly. Oct. I4, I784-Mar. 30, I785.

Minutes of legislative council. Jan. I I-Mar. 3I, I785.

" " " Apr. I4-Nov. 25, I785.

" " privy council. July Io-Oct. IO, I785.

Journal of assembly. Apr. I3-Nov. 22, I785.

Naval office returns. July io-Oct. 10, I785.

10. 1786.

Letter from Gov. Orde. May I, I786. Encloses:

Minutes of privy council. Feb. 2I-Apr. 7, I786.

" " council in assembly. Feb. 23-Apr. II, 1786.

Journal of assembly. Jan. 23-Apr. 7, I786.

Id. Encloses copies of correspondence with Baron de Clugny, governor of Guadeloupe, on commercial regulations. June I3, I786.

Id. July 20, I786. Encloses minutes of privy council, July 4-13, I786.

11. 1786.

Letter from Gov. Orde, relating to an American-built vessel captured by English in 1778 , condemned and registered as a prize, retaken by Americans and bought by a merchant of Dominica. Aug. 4, I786. Encloses minutes of privy council, Apr. 22-July 26, I786.

Id. Sept. 29, I786. Encloses:

Minutes of legislative council. Aug. 2-19, I786.

Journal of assembly. July I5-Aug. I9, I786.

12. $1786-1787$.

Letter from Gov. Orde. Encloses papers on seizure of French vessel. Mar. $7,1787$.

Id. Apr. 25, I787. Encloses:

Minutes of legislative council. Oct. 25, I786-Mar. 16, 1787.

Journal of assembly. Oct. 25, I786-Mar. I4, I787.

Id. Enquires "how far the acknowledgment of the Independence of the United States of America render the Americans foreign". Apr. 26, I787. 
13. 1787.

Letter from Gov. Orde. July 26, 1787. Encloses:

Minutes of legislative council. June 6-July II, I787.

Journal of assembly. Mar. I5-July 3, I 787 .

Id. Encloses account of vessels out of port of Roseau driven ashore in Aug., 1787; also copy of proclamation issued Aug. 24, admitting American lumber and certain provisions to Oct. I. Sept. 2, 1787.

15. $1788-1789$.

Letter from Gov. Orde. Oct. 4, I788. Encloses:

Minutes of privy council. Dec. 19, I787-Sept. 3, I788.

" "legislative council. Jan. IO-Feb. 25, 1788.

Journal of assembly. Dec. 7 , 1787-Sept. 18, I788.

Id. Dec. 12, 1788. Encloses minutes of privy council, Dec. 6, I788.

$I d$., giving information received from Dutch governor of St. Eustatius of opening of port for importation of negroes in foreign bottoms. Spaniards have opened ports for same purpose in Cuba, Hispaniola, and Porto Rico. May 3I, I789.

16. I789-179o.

Letter from Gov. Orde. July I6, I789. Encloses:

Minutes of legislative council. Sept. 30, 1788-July I4, 1789. I 789 .

" privy council. Sept. 24, I788-June 9, I789, July 4-14,

Journal of assembly. Sept. 19, 1788-May 7, 1789.

17. 1790 .

Letters from Lieut.-Gov. Bruce. May I7, July Io, Oct. Io, I790.

Encloses:

Minutes of privy council. Oct. 30, 1789; Mar. 27, 1790.

" legislative council. Jan. 4-July 8, I790.

Journal of assembly. Jan. 7-July 7 , r79o.

18. r790-r791.

Letter from Gov. Orde, no. 9. Jan. 8, r791. Encloses:

Minutes of privy council. May I2-Dec. 18, I790.

19. I79I.
“ " legislative council. Sept. 2-Dec. 18, I790.

Letter from Gov. Orde, no. 12. Feb. 3, I791. Encloses:

Minutes of privy council. Jan. I7-29, I I 9 I.

20. 1791 .

" legislative council. Jan. 2I-Feb. 4, I79I.

Letters from Gov. Orde, on conditions at Prince Rupert's Head, where

land was granted to Loyalists. Sept.-Dec., I791.

23. I792.

Letters from Gov. Orde. Sept. 13, Oct. 3, 14, 1792. Encloses:

Minutes of privy council. Aug. I7-Sept. 3, I792.

“" “" “ Sept. 19-Oct. 12, I792.

24. I792-I793.

“ legislative council. Sept. 3-28, I792.

Letters from Lieut.-Gov. Bruce, nos. 2, 7, on the Free Port Act. Nov.

I5, Dec. 21, 1792.

Id., no. 9 and unnumbered. Jan. I4, Apr. 28, I793. Encloses:

Minutes of privy council. Nov. 21, I792-Apr. 9, I793.

"legislative council. Feb. I2-Apr. 8, I793.

Journal of assembly. Feb. I2-Mar. 5, I793. 
25. 1793 .

Letter from Lieut.-Gov. Bruce, no. 3I. June I4, I793. Encloses:

Minutes of legislative council. Feb. I2-Apr. 9, I793.

" privy council. Nov. 21, I792-Apr. 9, I793.

$I d$., on arrival of $5000-6000$ emigrants from Martinique, in addition to those received from La Trinité after defeat of royalists at "Morne Ver-pré". Cargoes received from two American vessels provided supplies : proclamation issued admitting flour, biscuit, etc., in American bottoms. July I3, I793.

Draft to Lieut.-Gov. Bruce, no. I2, authorizing extension of proclamation to cover lumber, should there be pressing want of it. Whitehall, Oct. 26, I793.

Letters from Lieut.-Gov. Bruce, nos. 45, 47. Oct. 5, Nov. 8, I793. Encloses:

Minutes of privy council. Aug. 29-Sept. 3, I793.

Journal of assembly. Mar. 6-Oct. I I, I793.

$I d$., no. 46 , reporting continuation of opening of port for three months from Nov. 3. Nov. 8, I 793 .

26. I793-I794.

Letter from Lieut.-Gov. Bruce, no. 5I. Dec. 27, 1793. Encloses:

Minutes of privy council. Oct. $3 \mathrm{I}$, Nov. 7, I793.

“ legislative council. Apr. 9-Oct. Io, I793.

Journal of assembly. Oct. 29-Dec. 4, I793.

$I d$., no. 59, reporting capture of prizes. Great mortality among American seamen has led to appointment of surgeon to attend them as is done with prisoners of war. Mar. 9, 1794. Encloses minutes of privy council, Dec. 6, I793-Feb. 8, I794.

Id., no. 60. "No American vessels have arrived for some time past". Apr. 29, I794.

Id., no. 4. Oct. I8, I794. Encloses minutes of privy council, Mar. 27June 20, July 24, I794.

27. I794-I795.

Letters from Lieut.-Gov. Bruce, no. 7, and Gov. Hamilton, nos. II, 36, 37: Jan. 16, Feb. 8, Aug. II, Sept. 12, I795. Enclose:

Minutes of privy council. Oct. 9-Oct. I7, I794.

“ " legislative council. Oct. I I-Dec. I9, I794.

“ " privy council. Dec. I, I794-Jan. 25, I795.

“ " " " Mar. I7-May 6, I795.

“ “. “ “ “ June 8-July 27, I795.

Journal of assembly. Dec. 2, I794-Mar. I9, I 795.

Letters from Gov. Hamilton, unnumbered and nos. 5I, 62, 64, and Pres.

Matson, no. 3. Dec. I4, I795; Feb. 2I, May 3, Junę 7, Sept. II, I796. Enclose:

Minutes of legislative council. Aug. 25-Dec. 3, I795.

" " privy council. Dec. 9, I795.

Journal of assembly. Oct. 7-Dec. 3, I795.

Aug. 25-Sept. 18, 1795 .

Minutes of privy council. Apr. I6, 21, 1796.

Journal of assembly. Dec. 4, I795; Apr. 5, 6, I796.

Minutes of legislative council. July I-4, I796.

“ " privy council. June I3, Aug. 6, 1796. 
29. $1796-1797$.

Letters from Pres. Matson, nos. I0, I3, I9, 27, 28, and Gov. Johnstone, no. 2. Nov., I796; Jan. 23, Mar. I9, May 26, June 22, Nov. I3, I797. Enclose:

Minutes of legislative council. Oct. I8-Nov. I, I796.

Journal of assembly. Apr. 8-Oct. I6, I796.

Minutes of privy council. Nov. 9-Dec. 20, 1796.

" "legislative council. Nov. 24, I796-Feb. I7, I797.

Journal of assembly. Nov. I7, I796-Jan. I I, I797.

Jan. 20-Feb. 24, I797.

Minutes of legislative council. Mar. 9-Apr. I2, I797.

Journal of assembly. Mar. 8-Apr. I2, I797.

Minutes of privy council. Apr. I2-June I7, I797.

" " "legislative council. Apr. 26-Sept. 28, I797.

Journal of assembly. Apr. 20-Nov. 3, i797.

30. I797-I798.

Draft to Gov. Cochrane Johnstone, no. 6, enclosing extract of letter making reference to presence of Quakers among regiment of blacks who fought on English side in America. Mar., I798.

Letter from Gov. Johnstone, no. 12. June 7, 1798. Encloses:

Minutes of legislative council. Nov. I I, I797-Jan. 26, I798.

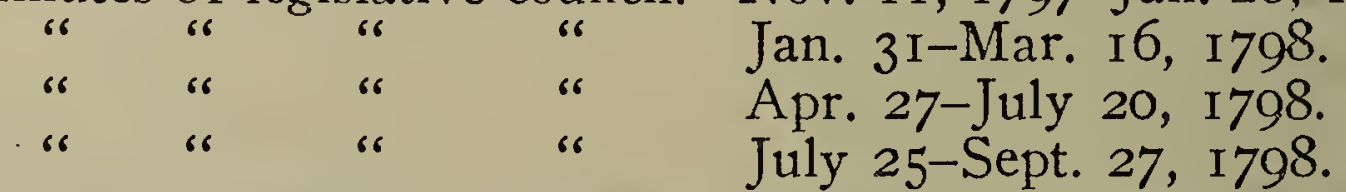

Journal of assembly. Nov. 3, I797-Mar. 16, 1798.

July i7-Sept. 27 , I798.

31. I798-1799.

Letter from Gov. Johnstone, no. I8. Necessity for importation from America. Feb. I2, I799.

$I d$., no. 20. " Of all the States of America, the Currency of New York approaches the nearest to that of these Islands." Mar. IO, I799.

Letter from Pres. Matson, no. II. Aug. 20, I799. Encloses:

Minutes of council. Oct. 2, I798-July I9, I799.

Journal of assembly. June I I-July I7, I799.

32. $1799-1800$.

Letter from Pres. Matson, no. 17. Nov. 14, I799. Encloses naval office returns, July 6-Oct. 5, I799.

Id., nos. I9, 26, and Gov. Johnstone, no. 4. Dec. 3, I799; Apr. 25, Oct. 7, 180o. Enclose:

Minutes of legislative council. Sept. Io-Oct. Io, I799.

" " privy council. Sept. 4, I799-Apr. 23, 1800.

" " legislative council. June 3-Sept. 3, I800.

Journal of assembly. Sept. 6-Oct. 8, i799.

“" "“ " May I4-June 4, I80o.

33. 1801.

July 8-Aug. 29, I800.

Journal of assembly. Nov. 5-20, I800.

Dec. I6, I7, I800.

Minutes of legislative council. Sept. 3-Dec. 16, I80o.

Letters from Gov. Johnstone, no. 5 and unnumbered. Jan. 7, Feb. I9, Apr. 20, July I7, Aug. 3, Oct. 12, Nov. 6, 1801. Enclose: 
Minutes of privy council. Oct. IO, 23, I80o.

" " legislative council. Apr. I4-May 25, I80I.

Journal of assembly. Dec. I8, I800-May 5, I801.

Minutes of legislative council. June I I-Oct. 27, I80I.

Journal of assembly. June 2-Oct. 23, I801.

Naval office returns. Oct. 6 , I8oo-Oct. 5 , i8o I.

$I d$., no. 5, relating to supply of flour from America for troops. Nov. 30 , I8OI.

34. 1802 .

Letters from Gov. Johnstone, unnumbered, and Gov. George Prevost, nos. 2, 3. Mar. 24, May 3, Dec. 26, I802. Enclose:

Naval office returns. Oct. 6, I8oI-Apr. 5, I802.

Minutes of council. Dec. 22-25, I802.

35. $\mathrm{I} 8 \mathrm{O} 3$.

Letters from Gov. Prevost, nos. 4, 8-II, I7-I9. Jan. 5, 26, Feb. 28, Apr. 27, May 3I, June 3, I802. Encloses:

Minutes of privy council. Jan. 4, I803.

“ "legislative council. Dec. 25, I802-Jan. I8, I803.

Journal of assembly. Jan. 5-2I, I803.

Minutes of privy council. Jan. $2 \mathrm{I}-\mathrm{Feb}, 22$, I803.

Journal of assembly. Feb. 2I-Mar. I8, I803.

Minutes of legislative council. Feb. 3-May 5, 1803.

Naval office returns. Oct. 5, I802-Apr. 5, I803.

36. 1803 .

Letters from Gov. Prevost, nos. 20, 22, 24, 27, 32. June 4, July 25,

Sept. 2, 3, Nov. I8, 1803 . Encloses:

Journal of assembly. Apr. I9-May 5, I803.

Minutes of legislative council. July I2-Aug. 25, I803.

Journal of assembly. July I2-Aug. 24, I803.

Minutes of privy council. Apr. 28-July I3, I803.

Naval office returns. Apr. 5-Oct. 5, I803.

Draft to Gov. Prevost, no. 5, on proclamation permitting importations in foreign vessels, stated "to have been renewed every four Months for several years past". Such permission should be granted only in case of absolute necessity. Downing Street, Sept. 23, I803.

37. 1804 .

Letters from Gov. Prevost, nos. 39, 40, 46, 48, 51, 58, 60. Jan. I4, Feb. 18, May 14, June 16, Aug. 27, Dec. 10, 31, I804. Encloses:

Minutes of legislative council. Nov. 2-Dec. I5, I803.

Journal of assembly. Nov. I, I803-Dec. 5, I804.

Minutes of legislative council. Feb. I4-Oct. I I, I804.

Naval office returns. Oct. 5, I803-Oct. 5, I804.

$I d$., no. 57 , on importation in neutral vessels of bread, rice, etc., admitted by proclamation of Nov. 12, I804. Nov. I5, I804.

38. 1805 .

Letter from Gov. Prevost, no. 65. Feb. 12, I805. Encloses:

Naval office returns. Oct. 5, I804-Jan. 5, I805.

Minutes of assembly. Dec, 20, I804-Jan. I7, I805.

$I d$., nos. 67,73 . Admission of provisions, etc., in neutral vessels. Mar. 6, Apr. 12, I805. Encloses minutes of privy council, Mar. 2-Apr. 9, I805. 
$I d$., nos. 76, 77, and from Pres. Metcalfe, nos. 2, 4, I2. July 3, 5, 27, Aug. 19, Dec. 12, 1805. Enclose:

Naval office returns. Jan. 5-Oct. 5, I805.

Minutes of legislative council. Dec. II, I804-July 4, I805.

Journal of assembly. Apr. 9-May 16, 1805.

$$
\text { " " June 18-27, I805. }
$$

Letters from Pres. Metcalfe, nos. 9, I I. Sept. 3, Oct. 8, I805. Encloses papers on importation in foreign vessels.

39. 1805 .

Letters from Pres. Metcalfe, nos. I4, I 5. Dec. I4, I805. Encloses:

Minutes of legislative council. Sept. 25-Nov. 2I, I805.

Journal of assembly. July 4-Sept. 26, 1805.

Minutes of privy council. July 8-Dec. 3, I805.

Among miscellaneous papers at end of volume is correspondence between Treasury, Board of Trade, and Secretary of State's office, on admis-

40. 1806. sion of provisions, etc., in foreign vessels.

Letters from Pres. Metcalfe, nos. 18, 21, 26, 34, 37, 38, 40. Mar. 8, Apr. 6, May i6, Oct. I, 8, Nov. 8, i8o6. Encloses :

Minutes of legislative council. Feb. I I-25, 1806.

Journal of assembly. Feb. II-25, I806.

Minutes of privy council. May 22-Sept. 19, 1806.

" "legislative council. May I9-Sept. 19, I806.

Journal of assembly. May I3-Oct. 22, I806.

Naval office returns. Oct. 5, I805-Oct. 5, 1806.

No. 37 encloses also copy of proclamation admitting flour, rice, etc.,

41. 1807 . in foreign vessels.

Letter from Pres. Metcalfe, no. 43. Forwards account of imports and exports in American and British vessels in trade with U. S., Br. N. Am., and Great Britain. Jan. I, 1807.

Id., no. 44. Jan. I3, 1807. Encloses copy of proclamation, Nov. I9, I806, admitting American beef and pork to Jan. I, I807.

Id., nos. 47, 3, 7. Mar. 7, June I6, Aug. 27, I807. Encloses naval office returns, Oct. 5, I806-July 4, I807.

Id., no. 4. Encloses proclamation on admission of American beef, etc. June $16,1807$.

Id., no. IO. Encloses account of imports, Oct. I, I806-Oct. I, I807,

42. 1807. distinguishing place of origin. Oct. $\mathrm{I} 7, \mathrm{I} 807$.

Letters from Pres. Metcalfe, nos. II, I2. Oct. I7, 20, I807. Encloses:

Naval office returns. July 5-Oct. 5, I807.

Minutes of legislative council. Sept. 25, I806-July 23, I807.

Journal of assembly. Nov. I2, 1806-July 22 , 1807 .

Id., no. 13. Encloses proclamation on admission of American beef, etc. Nov. $27,1807$.

Id., no. I4. Encloses account of imports of fish, Nov. 20, I806-Nov. 20, 43. 1808 . I807, distinguishing place of origin. Nov, $27,1807$.

Letters from Pres. Metcalfe, no. 23, and Lieut.-Gov. Barnes, nos. 3, 5 , with enclosures relative to import of provisions. June 2, Sept. II, I2, I808. 
Among miscellaneous papers at end of volume is correspondence between Board of Trade and Secretary of State's office on imports and

44. I809. exports, especially to and from America.

Letter from Lieut.-Gov. Barnes, no. 6, on passage of act imposing duty of not less than five shillings sterling per ton on all neutral vessels bringing fish, and also a duty on fish imported. July 29, 1809.

45. I8Io.

Letter from Lieut.-Gov. Barnes. Duties on American trade enumerated in order in Council of Feb. 7, I810. June 29, I8Io.

46. I8I I.

Letter from Lieut.-Gov. Barnes. Encloses account of fish imported, Nov. I, I8Io-May I, I8I I, showing place of origin. June 23, I8I I.

50. I8I 5 .

Letter from Pres. Lucas, no. I6. Acknowledges receipt of information of Treaty of Ghent. Mar. 7, I815.

Id., nos. 19, 44. Mar. 9, Oct. 23, 1815. Encloses minutes of privy council, Dec. I2, I8I4; Mar. 2, Sept. 20, I8I 5.

C. O. $72: 2-8$. Secretary of State: Entry-Books. I770-I807.

2. 1783 . Instruction to Gov. Orde.

3. I770-I779. Letters to Secretary of State.

4-7. 1789-1807. Précis of Correspondence.

8. I770-I80I. Out-Letters.

Order in Council, for placing Dominica under separate government. June 6 , I770.

Letters patent, for appointment of Gov. Young, with marginal notations showing how changed from those issued in case of Shirley. July 31, I770.

Hillsborough to Admiralty, stating that, Dominica having become separate government, it is his Majesty's pleasure that Admiralty should give to Young powers customarily given to "Captains General in Plantations". July 31, I770.

Hillsborough to Young, expressing satisfaction that island has carried out "those engagements upon which His Majesty consented to erect it into a separate Government", by supplying salary of $£ 2000$ currency to governor. Apr. I8, I772.

Dartmouth to Stuart, sending commission for trial of pirates. Feb. 2, I774.

Warrant to attorney general and solicitor general, to prepare bill to pass great seal, for appointment of Shirley. Same form as letters patent for Young, except for minor corrections, and for additional article giving governor power to provide for custody of idiots and lunatics and their estates. Feb. 22, I774.

Germain to Shirley, expressing satisfaction that "the operation of Act for prohibiting Commerce with the Rebellious Colonies has had the good effect with respect to them of procuring a supply of Provisions and other necessaries from North America which it was the intention of those Colonies to have withheld from them". May I7, I776.

C. O. $73: 1-8$. Acts.

1. $\mathrm{I} 768-1787$.

6. $177 \mathrm{I}-1773$.

2. $1768-1803$.

7. $1774-1775$.

5. $\mathrm{I} 768-\mathrm{I} 77 \mathrm{I}$.

8. $1776-1785$. 


\section{O. 74:I-5. Sessional Papers.}

1. I767, Nov. I8-I768, Mar. 8. Minutes of council (a number of small detached pieces), pp. 67 .

I768, June 17-1770, July 29. Minutes of council (numbered and certified as pp. 49-246), pp. 198.

2. I768, Jan. 6-Feb. 19. Journal of assembly (with proclamation proroguing to Mar. 8), pp. I34.

I768, May 30-Sept. 28. Journal of assembly, pp. I27. I768, Mar. I 5-22.

pp. I2.

3. I769, July Io-I770, July I7. Journal of assembly, pp. I45. I771, Apr. 12-May 22. I77I, July 29-Oct. 7 . I771, Dec. 2-I772, May 8. I772, May 9-30.

I773, June 7-Oct. 20. :773, Oct. 25-1774, Feb. I6. I774, Feb. I7-Oct. I3. I774, Nov. 21-I775, June 15. I775, Sept. 4-Dec. 23. I776, Mar. 23-July 9.

4. I770, Sept. I-Dec. I 5 . I77I, Apr. 22-Oct. 7. I77I, Dec. I7-I772, May 30. I773, Aug. I2-I8. I773, Dec. I3-I774, Feb. I7. I774, Mar. I8-Oct. I3. I774, Mar. I8-Oct. I3.
I774, Nov. I2-1775, June 19. “ “ “ “ “
I775, Sept. 4-Dec. 23.

5. I776, Sept. 25 -Nov. 29. Minutes of council, no. 3, pp. I8. I776, Sept. 25-Nov. 29. “" " (duplicates no. 3), no. 4, pp. I8.

I777, Apr. 2-May 30. I777, July $28-$ Sept. I 2 . I777, July 28-Sept. I2.

Minutes of council, pp. 35 .

pp. 15.

pp. 57.

pp. 57.

pp. 12.

pp. 47.

pp. 44.

pp. I I4.

pp. 6I.

pp. 82.

pp. 45 .

\section{pp. 28}

I776, Sept. 25-Nov. 29. Journal of assembly, no. Io, pp. 25 .

I777, Apr. 2-May 31 .

I777, July 28-Sept. I2.

I777, July 28-Sept. I2.

pp. 40.

$$
\begin{aligned}
& \text { " } \quad \text { " } \quad \text { " } \quad \text { no. } 5, \mathrm{pp} .2 \mathrm{I} \text {. } \\
& \text { " " } " \text { no. } 6, \text { pp. } 28 .
\end{aligned}
$$

\section{O. 76:4. Shipping Returns.}

4. Inward:

I763, Aug. 5-1764, Jan. $5 \cdot^{2}$

Outward:

I763, Aug. 5-Dec. 26. ${ }^{2}$ I764, Jan. 5-1765, Jan. 5.

\section{MISCELLANEOUS.}

4. Statement of account of one per cent duty on provisions and dry-goods. Jan. 5-June 9, I764.

\footnotetext{
${ }^{1}$ A duplicate is in the correspondence (C. O. 7I:5), ending at June 15 .

${ }^{2}$ Vessels having on board goods subject to one per cent. duty. This vol. also contains returns for the years $1784-1789$.
} 
Amounts received and paid annually, in connection with duties on imported slaves, under the Free Port Act. I766-1788. (Gives number of slaves.)

Detailed summaries of goods imported and exported in foreign vessels pursuant to the Free Port Act. Nov. I, I766-Apr. 5, I778.

\section{GRENADA.}

C. O. ioi :i-6. Board of Trade: Original Correspondence. i i63-i 777.

1. $1763-1766$.

Letter from Col. George Scott, lieutenant governor of Grenada, on conditions under French rule, possible productivity, taxation, population, etc. May 15, I763. Enclosures:

I. Replies to heads of inquiry on numbers of English and French inhabitants, settlement and land tenure, cultivation, sugar plantations, and taxation by French.

2. List of officials at Grenada under French rule, with salaries.

3. "Déclaration du Roi Sur Les Réunions des Terres du 3me aoust I722."

4. Extract from capitation rolls of various "quarters" for $\mathrm{I} 763$, showing individual tax-payers, with numbers of slaves and live stock belonging to each, amounts of taxes paid, etc., seemingly a complete list.

5. Naval officer's lists for Fort Royal, Grenada, Mar., I762-Mar., I 763 .

6. Letter from Brig.-Gen. Rufane, acting lieutenant governor of St. Vincent, on conditions in island; and enclosing description covering population, cultivation, live stock, etc. May 2, 1763 .

Letter from Halifax, sending list of forfeitures, sales, and escheats of land by French inhabitants. Sept. 27, I763.

Many papers on transfer of property, confirmation of titles, settlement, and various questions of tenure in ceded islands, but mainly in Grenada.

"Letter from Campbell Dalrymple, Esq., Commander-in-Chief of Dominico, to the Board, dated August, I763, containing account of the measures he has pursued for fortifying and settling that Island, St. Vincent's and Tobago, and remarks on the State of Dominico, and the Proceedings of the French at Guardelupe and Sta. Lucia, and transmitting Answers to Heads of Inquiry on the State of Dominique."

Letter from Scott, on good behavior of French, their gratitude for good treatment by English, and arrival of vessels from New Spain to trade at island. Aug. 30, 1763 .

Letter from Sedgwick to Pownall, on complaint of French ambassador that Dominicans are not allowed to sell their sugar plantations. Dec. I9, I763. Memorial of Dominicans as delivered by French ambassador.

Letter from Robert Melville, governor of Grenada, the Grenadines, St. Vincent, Dominica, and Tobago, urging sending to Tobago of two war vessels, of which one to provide shelter for lieutenant governor and other officials, and the other a refuge for sick persons during early days of settlement. Jan. 23, I764. 
Opinion of his Majesty's advocate and attorney general on list of cases relative to seizure of effects of French inhabitants, and to forfeiture, sale, or escheat of lands in Grenada. Jan. 25, I764.

"Order in Council, dated Febry. Io, I764, requiring the Board to prepare and lay before His Majesty the Draught of a plan for the settlement of the Islands of Grenada, etc., and the disposal of His Lands there, agreeable to what is proposed in the annexed Report of the Lords of the Treasury. And likewise the Draught of a Proclamation for Promulging such parts of the said Plan as they shall judge necessary." Refers to Grenada, the Grenadines, Dominica, St. Vincent, and Tobago.

Memorial from Melville, "containing his sentiments on the establishing of a General Council for the islands under his Government".

Order in Council, approving plan of Board for settlement of the islands, and requiring Lords of Treasury and members of Board to give orders for carrying same into immediate execution. Mar. 26, I764.

$I d$., for constituting a council for the islands. Members to include: Francis Gore, to be appointed lieutenant general of Grenada and islands dependent thereon, and lieutenant governor of Grenada; George Scott, to be appointed lieutenant governor of Dominica; George Maddison, lieutenant governor of St. Vincent; and Alexander Brown, lieutenant governor of Tobago.

Letter from Melville, stating terms on which private vessels can be secured as shelter for officials and sick persons. May 4, 1764.

Letter from Joseph Partridge, commander-in-chief of Dominica, on seizure of French sugars alleged to have been consigned to British merchants in payment of debts, and compensation due them from inhabitants of French islands in which they had resided. Feb. Io, I 764 .

"State" of St. Vincent, sent and signed by Capt. Paul, and covering slaves, live stock, cultivation, etc. Feb. 28, 1764 .

Letter from Scott. Payment of subsistence for regular troops from local revenues, and maintenance of forts and batteries. Grenada, Feb. 6, 1764 .

Id. Prevention of illicit trade. Mar. 15, I764.

Naval officer's lists for Grenada, inwards and outwards. Jan. 20, $1763-$ Jan. 20, 1764 .

Letter from Melville. Measures taken for promoting settlement of Grenada and Tobago. Jan. 3, 1765 .

$I d$., on calling of general assembly. Apr. 20,1765 .

Address of inhabitants of Grenada to Melville begging establishment of complete legislature. Apr. 19, I765.

Memorial of merchants of London and proprietors of lands in Grenada for establishment of legislature in Grenada. I765.

Letter from Scott, on conditions and prospects in Grenada and Dominica. Mar. 26, 1765.

Orders in Council on organization of separate legislature for Grenada. Feb. 15, Mar. 1, I766.

Papers on land grants and tenures. I765, I766.

Papers on calling of assembly for all islands of group, and for Grenada only. I765-1766. In particular: "An Ordinance for regulating the elections for the General Assembly of Grenada, the Grenadines, Dominica, St. Vincent, and Tobago, and for limiting the powers of 
that part of the said General Assembly properly to be called for Grenada and the Grenadines." Feb. Io, I766.

Letter from Melville, on organization of court of common pleas and court of error. Mar. I, I 766.

"A List of Names of Sundry Persons to whom Governor Scott granted Town Lots in the Town of St. George on the Island of Grenada", with amount of each grant. I766. Many other papers on land grants, including official forms.

Papers on opening of assembly of Grenada and Grenadines, and on dispute with governor over privileges. I766.

Many papers on settlement, and treatment of French religious orders.

2. $1767-1768$.

Many papers on land grants and settlement.

Letters from Melville. Importation of slaves (with incomplete statistics); organization of governments in various islands; illicit trade. Jan. I4, I 5, I6, I767.

The Freeport Gazette or the Dominica Advertiser, for Jan. Io, I767. Printed. Partly French.

Letter from Shelburne, referring memorial of merchants, traders, and other inhabitants of Dominica for establishment of independent government. July I 5,1767 .

Memorial of merchants of London for same. I 767 .

Memorial of merchants of Liverpool for establishment of courts in Dominica. 1767.

Account of population, produce, exports, etc., of Dominica. Unsigned, undated.

Order of committee of Council, referring petition of Society of Merchants Venturers of Bristol for independent government in Dominica. Aug. 28, I767.

Id., referring memorial from proprietors of lands in Grenada, complaining that establishment of legislature there is defeated by certain clauses in governor's commission which tend "to deprive the Assembly of the said Island of several privileges constitutionally inherent in the Representatives of the People". Oct. 9, I767. Thirty-one signatures, many French.

Order of committee of Council, referring: (I) memorial of his Majesty's new subjects in Grenada, begging that they receive some share in administration of island; and (2) paper entitled, "Objets de consideration mis sous les yeux du Ministre Concernant les Isles Grenade, St. Vincent, la Dominique, et Tabago".

Papers on alleged illegal, partial, and oppressive acts of Thomas Atwood, senior assistant judge in Dominica, affording much information on social conditions, trade, and legal procedure.

Letter from Hillsborough, sending printed copy of all laws passed in Grenada since establishment of legislature. Feb. 2, I768.

Copy of instructions from Melville to Scott, on establishment of separate (not independent) government for Dominica. I768. Other papers.

Papers on establishment of quit-rents in islands. I 767.

Melville to Shelburne. Resentment of French at being excluded from all share in government. But French papists cannot enjoy more rights than British papists in colonies. Nov. 16, I767; Feb. I, I768.

Melville to Treasury, on contingent charges of his government. Jan. 3I, I768. 
Melville to Walter Pringle, president at Dominica, on Melville's "Troubles and Vexations" over affairs there. Jan. 28, I768.

Letter from Hillsborough, on establishment of council at Tobago. Apr. 16, 1768. Other papers.

Melville to Hillsborough, on troubles at Dominica. Apr. 24, I768.

$I d$., showing that, assembly of Grenada having refused to provide for troops, he has had to do so as contingent charges on Treasury. May r, I768.

Papers on establishment of separate legislature for St. Vincent, and on action against collector there, for taking the $4 \frac{T}{2}$ per cent. duty.

3. I768-1771.

Order in Council, for disallowance of several acts and ordinances, passed in Grenada, $1767-1768$, and directing the Board to prepare and lay before his Majesty draft of additional instructions to governor for carrying into execution certain parts of proposal therein mentioned. This document outlines constitution for government of all four islands, providing, and regulating selection of, councils for all four, and assemblies for Grenada, Dominica, and St. Vincent. Also defines rights of French Roman Catholics; provides for support of Church of England; and regulates establishment of courts. Also grants permission for passage of laws assimilating methods used in appropriation and collection of $4 \frac{\mathrm{T}}{2} \mathrm{z}$ per cent. duty to those employed at St. Christopher. Sept. 7, I768.

Lieut.-Gov. Fitzmaurice to Hillsborough. Sends account of act for raising money and establishing treasury in Grenada. Comments upon "an Opinion which Generally Reigns throughout the Whole Colonies, that Multiplied Inconveniences of Expense and Delay might proceed from a Power in the Lord Commissioners of the Treasury to Approve or Reject the Acts of the Colonies"; and gives reasons for existence of this opinion. Papers on disallowance of this act, on ground that it provided for no accounting to or auditing by home government. Oct. 6, i768.

Papers dealing with land grants.

Fitzmaurice to Hillsborough, on packet service. Sept. 22, 1768.

Proclamation, signed by Fitzmaurice, that Caribs of St. Vincent are to have perfect freedom and proper assignment of lands, but shall not assemble in arms. June Io, I769. Printed.

John Graham, president of council of Grenada, to Hillsborough, on Carib rebellion, and on acts of Grenada for regulating fees and establishing court of chancery. July 5, I769.

Order of committee of Council, referring memorial of certain proprietors of Dominica for separate government. Nov. 20, 1769. Other papers.

$I d$., that Board suggest names of persons fit to carry into execution commissions for trial of pirates to be issued in Grenada and Dominica. Dec. 15 , I770.

Richard Jackson's opinion on act of St. Vincent for regulating towns, which operates to limit prices of provisions. Dec. 5, 1770.

4. I77r.

Melville to Hillsborough. Refusal of British proprietors to pay taxes, on ground of same being illegal, being levied under bill passed since admission of Roman Catholics to assembly. Nov. 25, 1770. 
Papers on defense; land purchases from Caribs; relations of French 5. $177 \mathrm{I}-\mathrm{x} 773$. with Caribs in St. Vincent; and on threatened rupture with Spain.

Memorial of Gov. Leyborne against contention of Sir William Young, governor of Dominica, that all patents for lands sold or let on lease in Dominica should be passed by him under seal of Dominica, and not by commissioners appointed for sale of lands in ceded islands. I772.

Opinion of Richard Jackson on act of St. Vincent, voiding purchases from Caribs. Objects to confirmation because "Notice was not publickly given of the bringing in the Bill in the Parish Church wherein the Lands affected by it lye three Sundays successively before the Bill proposed"; and also because no suspending clause included. May 28, 1772.

Order in Council, approving new establishment of ordnance officers for ceded islands, giving old and new establishments, with salaries in both cases. Jan. 5 , I770.

$I d$., for restoration of six members of council suspended by Fitzmaurice. Apr. 5, 1770.

Id., for admission of Roman Catholics to council. Feb. II, I77x.

$I d$., for disallowance of act of St. Vincent for regulating towns, said act operating to fix prices. June 7, I77I.

$I d$., that all future grants or leases of land in Dominica shall be passed under seal of Dominica, and not under that of Grenada. Jan. I5, I773.

6. I773-1777. (Notable absence of documents for latter part of 1773 , and for I $774-1775$.)

Papers on sale of public lands, including: letters from John Greg, secretary to commissioners for sale of public lands, I773; and report of commissioners to Board of Trade, July I9, I773.

Opinions of Richard Jackson on various acts. In particular, on act of Grenada for "Re-Establishing Courts of Common Pleas, Error, King's Bench, and Grand Sessions", Oct. 18, 1774; and on act of Grenada to establish regular markets and fix prices. Mar. 23, I776.

Letters from Leyborne, on defenses of islands. Sept. Io-14, I773.

Extract of letter from Lieut.-Gov. Young to Dartmouth, on suspension of George Leonard Stanton, Andrew Irwin, and other members of council. "I had other private reasons for wishing Mr. Stanton out of the Council, one is that he was an active Person in carrying on the Address in favour of American Rebels sent home by his friend, Mr. Winiet, an American, for which I dissolved the late assembly, a respectable but deluded body of gentlemen, as now appears by their return to their duty." Mar. I, I776. Memorial of five suspended members of council to Sir George Macartney, stating that "when the House of Assembly had addressed the Crown in favour of His Majesty's Rebellious Subjects in America, the same Commander-in-Chief wrote a letter to the Speaker of the House requiring such address to be rescinded, and not until he had received a positive refusal did he dissolve them". I776. Macartney to Germain, stating opinion that "it would be highly improper to restore Mr. Irwin to the Seat in the Council, as his opinions upon the authority of Great Britain over America are as pernicious as his language has been indecent". It would be better to let matter rest 
"till we see how the prospect clears in North America; between which and this Island there was formerly a constant and intimate Intercourse". May 25, I777.

\section{O. ioi :8. Board of Trade and Secretary of State: Original Correspondence. I743-1812.}

8. $1743-1812$.

"Letters and Inclosures from M. Stone and Weston to Lord Carteret, I743." Admiralty papers with no special reference to West Indian affairs.

"La Grenade. Etat Général Année I747." Inhabitants, live stock, etc. Correspondence on refusal of governor of Margarita to deliver fugitive slaves. I770.

Copy of bond given by purchaser of land in ceded islands to Sir William Young, receiver of monies arising from sales and leases of lands in ceded islands. I77I. Shows terms of sales and leases.

Extract from minutes of court of king's bench and grand sessions, "shewing that a Freeman had been found Guilty and executed for murdering a slave". Grenada, Sept., I775.

Letter to Lord North from Timothy Brecknock, who desires to be chief justice of Grenada, and who is supported by an unnamed patron. "Mr. B's patron hath, in the course of this last week, rendered Lord North a most essential Service: he hath not only pacified Mr. Washington's resentment against his Lordship, but he hath also gained over Dr. Franklyn from fomenting any sanguinary prosecution against Lord North. His Lordship may possibly have heard of the combination entered into by Dr. Lee and twenty-one other Americans who have each of them signed a Compact with their own Blood and who have made a point of it to demand, as they term it 'Blood for Blood'. But this Compact, so far as it included Lord North, hath been over-ruled by the private intermediation of Mr. B's powerful friend and Patron." Apr. I5, I783.

Id. "He is a person of too great a Rank to ask any favor for himself, and he is pleased to say that he confers a favor when he recommends to your Lordship's notice a Man of my Years, knowledge in the Laws, and acknowledged Services". North appears to have ignored two letters from Brecknock. Brecknock's patron did not think that "his Recommendation could be treated by Lord North with such apparent Inattention and Disrespect. He therefore commends me to tell your Lordship that before the next Month is over, you will critically stand in Need of his Assistance and Support". Apr. 18, I 783 .

Draft of instructions for Gov. Mathew. 1783 .

Papers on restoration of government after 1783 , and establishment of titles after French occupation.

"Monthly Return of His Majesty's Forces in the Leeward and Caribbee Islands under the Command of Lieut.-Gen. Edward Mathew." July, 1784 .

"Copy of Proceedings in a Suit instituted in the Court of Vice Admiralty against the Brig Fanny, belonging to Mr. Charles Morris, for not being owned, built, and navigated as directed." 1786.

Letter from George Chalmers, on trade between N. Am. and Br. W. I. Aug. I3, I788. 
Correspondence of Gov. Mathew with Stephen Cottrell and Lord Sydney. Slave trade; suppression of smuggling of tea and tobacco from U. S. into West Indian colonies; importation of provisions from Spanish colonies. I788.

Treasurer's return of produce. Grenada, I788-I790.

Despatches on military matters. I 790-I79I. (Some secret.)

Accounts of landing of French at Dominica. I 793.

Correspondence of Gov. Green with Lieut.-Gen. Trigge, commander-inchief, and with Duke of Portland. I797-180o.

Gov. Green to John King, asking that George Chalmers, who has acted as Green's secretary for last three months, may be made postmaster general of Grenada. Jan. 9, I80I.

Humble memorial and petition of John McNeill, Loyalist of N. C., who served with British troops throughout the Revolution and later obtained commission in corps of free blacks stationed in West Indies, asking promotion. I812 (?).

Various papers on trade, unsigned and undated.

\section{O. ioi :9-55. Secretary of State: Original Correspondence.} I $762-1815$.

9. $\mathrm{I} 762-\mathrm{I} 764$.

Letters from Lieut.-Gov. Scott, on his appointment by Gen. Monckton, and giving important information on conditions. July 17,1762 ; Jan. 19, 1763 .

Naval office lists, inwards only. Mar., I762-Jan., I763.

Monthly returns of garrison of Fort Royal, Grenada. I762-1763.

Letter from Scott, on raising of regular troops in American colonies generally. Grenada, Mar. 2, 1763.

Colored map of Fort Royal harbor and other defenses at Grenada.

Letter from Egremont, on granting of lands. Aug., I763.

Campbell Dalrymple to Egremont, on evacuation of Guadeloupe, and occupation of ceded islands. Encloses statement of produce exported from Guadeloupe, Dec., I762-July, 1763, and account of British merchants in Guadeloupe. July 19, I763. Other papers.

Account of 63rd Regt. of foot, stationed at Grenada, showing organization, effective strength, etc. July 23,1763 .

Many papers on taking over of private property in ceded islands. Disputes as to whether property could be sold by departing French; and whether it had become forfeited to the crown by failure of occupiers to comply with terms of grants.

Several returns of garrison at Grenada, showing reductions being made in establishment. I763.

Papers on rights of Dominican friars and other religious orders to lands. 1763-1764. In particular: Halifax to Scott, directing that Dominican friars be permitted to sell lands. Jan. 30, I764.

Halifax to commanders-in-chief at St. Vincent, Dominica, and Tobago, on relief of regiment stationed in those islands. Halifax to Scott, on relief of 68th Regt. by 63 rd Regt. in accordance with plan of rotation. Halifax to commanders-in-chief of St. Vincent, and Tobago, on sending of 7 oth Regt. Other papers. I764.

Memorial to Capt. Partridge, commandant at Dominica, from British merchants of Dominica, lately resident in Martinique and Guadeloupe, protesting against examination of their vessels coming to 
Dominica on charges of illegal importation of French sugars. Other papers. $1763-1764$.

Halifax to Melville, reminding him that French of Grenada, like those of Canada, are guaranteed right to withdraw within a certain time, taking property. June 30 , I 764 .

Letter from Melville. His visit to Barbados in order to remove the "Universal Dread and Dislike" of Tobago, "occasioned by the sudden death of almost every White Person who had lately gone thither". Nov. I3, I764.

10. $1764-1766$.

Numerous papers, on departure of French, arrival of British, transfer of property, organization of government, and settlement of islands.

Copy of order in Council, granting permission for organization of separate assembly for Grenada, in case Melville thinks it best, and has not already created general assembly for all islands. Mar. I, I764.

Copy of letter from attorney general of Grenada to Melville, on preparation of list of documents required for enforcement of Stamp Act. Throws some light on legal procedure. Feb. 6, 1765.

Numerous papers, on charges of injustice, violence, and corruption brought against Scott by French inhabitants and French religious orders. French.

Letters from Melville, on pretensions of assembly of Grenada. Apr. 7, June 15, I 766.

11. $1765-1768$.

Representation from Board of Trade, on two memorials from inhabitants of Grenada praying establishment of separate legislature. Dec. ro, I 765 .

Order of committee of Council, for preparation of draft of instruction to governor of Grenada on calling of assembly. Feb. I 5, I766. Other papers on instructions to Melville for establishing government at Grenada.

Numerous papers on land grants and settlement.

Estimate of required outlay for military buildings, totalling more than $£_{36,000 .}$ i 767 .

Account of sums of money drawn by Melville for service of islands under his command, Feb., I765-Nov., I766. Shows that governor's salary was obtained in part from $4 \frac{1}{2}$ per cent. duty, and in part from "the Revenues of the Islands". Shows also sums drawn by Col. Johnstone, 7oth Regt., at Grenada, Sept.-Nov., I765, as provision for troops.

Papers on efforts to sustain struggling colony at Tobago. I766.

Representation of Board of Trade, and other papers, on actions of governor of Grenada in setting up, Apr. 15, 1766, and dissolving, May 21, I766, assembly for Grenada and Grenadines only. Assembly proceeded at once to claim privileges, on analogy of West Indian and North American colonies where largest concessions in this regard had been made by the crown. Governor's instructions produced no effect, dispatch of business became impossible, and house adjourned itself.

Extracts from letters, unsigned, sent by John Stewart, Dec. 5, I766, to Shelburne from Dominica, on plans for defense and trade. Urge that North Americans be allowed to trade at Dominica with French; and Dominica should supply neighboring islands with slaves and 
meat. Islands would thus secure French cotton and cash which French get from New Spain. Other papers, urging establishment of free port at Dominica, and describing trade and produce of island. Others in commendation or condemnation of free port act.

Numerous papers, as before, on transfer of property, and alleged oppression and injustice by officials.

Docket registers of land grants in all four islands, showing prices for cleared and uncleared land, initial payments, etc. I765-1 766.

Journal of assembly of Grenada and Grenadines. Apr. I5-May 20, I766.

Extracts from minutes of general council of Grenada, the Grenadines, Dominica, St. Vincent, and Tobago.

Melville to Shelburne, on illicit trade and measures against same. Jan. I6, I767.

Memorials for establishment of separate government and separate courts of justice at Dominica. I767.

Letters from Melville, on establishment of separate legislature for St. Vincent. May 23, 24, I767.

"List of Inhabitants [names given], Number of Slaves and Quantity of Land in the Island of Carriacou, and of the taxes collected by virtue of an act of the Leg're."

Votes of the Assembly of Grenada and the Grenadines, Oct. I5-Dec. I2, I766, printed at St. George's by William Wayland, I767. French and English.

Papers on establishment of separate government for Dominica.

Papers on disposal of lands in ceded islands, with draft of instructions for commissioner charged with sale of such lands.

12. $1767-1768$.

Letter from Melville, explaining that, in order to secure adequate revenue, he has been compelled to consent to payment of public money to a treasurer instead of to receiver general. Treasurer to be appointed by governor, but "the Security taken from him, the Comptrolling of the Accounts and the Applications of Publick Monies to be made by the directions of the Joint Legislature". Such arrangement said to be in force at Antigua. Nov. I4, I767.

"Account of the Appropriations of the Money raised by the Act of Legislature of Grenada, I767."

List of inhabitants, with number of slaves and amount of land owned by each, in island of Carriacou. Undated.

Several papers on sale or lease of lands in ceded islands, and on collection of quit-rents.

Letter from Melville, on establishment of separate legislatures in Dominica and St. Vincent. Nov. I4, I767.

$I d$., pointing out unfortunate effects seen, or apprehended, from absence of lieutenant governor and so many other civil and military officers from islands. Nov. I6, I767.

Hillsborough to Melville. Privy Council is now considering representation of Board of Trade in favor of separate government for Dominica, Hillsborough having found said representation among Shelburne's papers. Discusses project of separate council and assembly for St. Vincent. Feb. II, I768.

Letter from Melville. Disputes with assembly, arising from attempt of latter to punish returning officer for refusing to consent to candidature of French Roman Catholic. Use of Habeas Corpus Act 
involved, and much bad feeling created. Also complains that assembly claims privileges on analogy of House of Commons. Dec. 27 , I 767 .

$I d$., on same as foregoing, and including suggestions for treatment of Roman Catholics. Feb. I, I768.

"State of the Poll for the Members returned for the Parrish of St. John on a Scrutiny had before the Honorable the House of Assembly of Dominica, I Ith January, I768." Shows seven voters and four candidates, two voters appearing also as candidates. Voters all freeholders. Other papers, with particulars of qualifications, etc.

Papers on suggested establishment of separate government for Tobago. 1768.

Letter from Melville. Trouble with assembly over privileges. Prorogation necessitated by refusal of council to have further dealings with assembly. Blames "new Subjects" for much of trouble. May I, I768. Other papers, including addresses of council and assembly, and extracts from minutes of council, Nov., I767-Mar., I 768 .

"A list of the Polls taken for the Assembly to be Convened for the Island of Grenada and the Grenadines the I 5 th day of December, I 767 ", showing, for each parish, names of candidates and number of votes cast for each candidate by "natural born" and "new adopted" subjects.

Letter from Melville, on distress of troops in islands. May r, 1768 .

An Ordinance for the establishing of an Assembly in the Island of St. Vincent; and Regulating the Elections thereof. Feb. 25, 1767. Printed.

Copy of proclamation issued by Melville at Grenada, May ıo, I768. Points out that by proclamation of Oct. 17,1763 , which divided British acquisitions in America into four governments, and established legislatures and courts, laws of England were declared to be in force. But previously established courts in Grenada having continued to administer justice by methods not consistent with British law, proclamation was issued Dec. I9, I764, declaring that all jurisdictions and officers must be founded on laws of England. Moreover, although Parliament has legislated that no person not a subject or free denizen of Great Britain shall engage in trade, or command a ship, foreigners flock to Grenada, take oath of allegiance, engage in trade, command vessels, and carry on illicit trade. It is therefore now proclaimed: (I) that all persons frequenting the islands must render strict obedience to laws in force there; (2) that no stranger will be allowed to exercise privileges of citizenship by merely taking oath of allegiance without taking up residence; (3) that no foreigner shall remain in islands without permission; and (4) that all free persons of color who are foreigners shall depart at once.

Letters from Melville. Internal conditions; difficulties raised by "new subjects"; objections to establishment of separate government for Dominica. May 25, June i8, July i 5, i 768 .

Memorials of council and assembly of Dominica for separate government. July 4-19, I768.

Letter to Lieut.-Gov. Fitzmaurice, acting governor of the islands, sending instructions on proper methods of government. In particular: provision in election of assemblymen for election of some French 
representatives who refuse declaration against transubstantiation; establishment of courts of chancery; organization of militia; alteration in method of appropriating and collecting the $4 \frac{1}{2}$ per cent. duty; support of Church of England; and grant of religious privileges to new subjects. Oct. I2, I768.

13. $1768-1769$.

Proclamation by Fitzmaurice, regulating elections for assembly of Grenada, and providing for choice of members who refuse to take declaration against transubstantiation. Dec. 31, I768. Printed.

Letter to Fitzmaurice, referring to appointment of "new subjects" to council and bench. May I3, i 769 .

Report of Captain Gordon, engineer for ceded islands, on requirements for their defense. Jan. 5, I769.

Letters from Fitzmaurice. Disturbances at St. Vincent by Caribs, who fear being deprived of lands. May II, 22, June Io, I769. Important enclosures. Other papers.

Papers on suspension by Fitzmaurice of five members of council for refusal to consent to admission of Roman Catholic.

Address of thanks to the king from his new subjects in Grenada. I 1769.

Letter from Fitzmaurice, on suit in court of exchequer for non-payment of capitation tax. May 23, I769.

Report of principal officers of ordnance to Marquis of Granby, mastergeneral of ordnance, on fortification of ceded islands. Aug. 3, 1769.

Letter from J. Graham, president of Grenada, on Carib rebellion, and weakness of islands. July 5, I769.

Various papers on petitions against return to Grenada of Gov. Melville, who is charged with screening offenders from justice, torturing negroes to secure convictions, calling council in legislative capacity during prorogation of assembly, and stirring up trouble between French and British inhabitants.

Letter from Fitzmaurice, on conditions in Trinidad, Martinique, Guadeloupe, St. Lucia, and other foreign islands. July 28 , I769.

Hillsborough to Fitzmaurice, on $4 \frac{1}{2}$ per cent. duty; and stating that the crown did not intend appointment of "new subjects" to council until royal pleasure made known. Nov. 4, I769.

Minutes of council of Tobago. July I2-15, I769.

Various papers on defense of St. Vincent, and especially on operations of sloop Ranger, sent out to cruise between St. Vincent and St. Lucia for prevention of intercourse with Caribs.

Weymouth to Hillsborough, sending papers presented to him by Spanish ambassador, to prove that in I767 Melville granted passes to at least two British sloops to trade in negroes and dry-goods on Spanish Main, in clear violation of treaty. Dec. 7, I769.

14. 1770.

Memorial of proprietors of St. Vincent now in London, asking for assistance against Caribs, who still hold nearly two-thirds of best lands. Jan. 22, I770.

Correspondence with lieutenant-general and other officers of ordnance, on fortification of islands. Feb.-Nov., I 770.

Papers on Melville's answer to complaint of Spanish ambassador, describing custom of granting "let passes", as in other Br. W. I. islands. 
Hillsborough to Melville, on measures taken to establish separate government for Dominica, and to reduce black Caribs of St. Vincent. Feb. 15, 1770 .

Weymouth to Hillsborough, asking for some explanation to be given to Spanish ambassador as to why Melville is being allowed to return to his government under accusation of having broken treaty with Spain. Mar. 15, I770.

Hillsborough to Weymouth, stating that Melville's explanations are considered satisfactory. Passes were addressed only to his Majesty's ports and ships, and certified only that vessels had complied with customary requirements. Believes that by this explanation he can give satisfaction and avoid discussion of "a Commerce of the greatest Importance to this Kingdom which has been, ever since the date of this Treaty ( 1670 ), carried on from Jamaica to the Spanish ports in America by Vessels clearing out of the Ports of these Islands with Certificates of a like Nature to those now complained of". Mar. 16, 1770.

Representation of Board of Trade, on impossibility of completing settlement of St. Vincent without such military force as will compel Caribs to acknowledge the king's title. Mar. 29, 1770. Enclosures.

Various papers on refusal of military officers at Tobago to take orders issued by president of council acting as commander-in-chief.

Papers on land tenure and land transfers; and in particular on purchases from French landowners and from Caribs.

Letter from Melville, announcing returin to Grenada as governor. Apr. 6,1770 .

Letter from office of Secretary at War on inadequacy of accommodations afforded troops at Grenada. July 12, 1770.

Letter from Melville, on black Caribs at St. Vincent, and measures needed for defense. July 5, i770.

"Present State of the Plantations now settling in Tobago", giving names of owners, acreage cleared and uncleared, and numbers of men and women, white and black. 1770.

15. $1770-1771$.

Hillsborough to Melville, on regulating sale through commissioners of land held in St. Vincent by Caribs; and declaring all previous sales invalid. Jan. 25, 177 I.

Letter from Melville. Relations between "old" and "new" subjects of the crown in the islands. Nov. $15,1770$.

Id. Slave insurrection in Tobago. Measures taken for defense of islands in accordance with despatches from home. Nov. 14, Dec. 3, 1770. Other papers on same subject.

Id. Disposition of troops stationed in islands. Dec. 6, I770.

Id. Danger from maroons in Grenada, and dispersal of same. Dec. 1o, 16, I770; Jan. I, I77.

Account of French troops in Martinique and its dependencies. Mar. I, 1771 .

Numerous letters from Melville on political and other local conditions. Report on conditions in Tobago, showing classified statistics on population, live stock, arms and ammunition, acreage and produce. June, I771.

Reports on conditions in the Grenadines. 
16. I $770-1772$.

Letter from Gov. Leyborne. Intrigues of French with Caribs of St. Vincent. Nov. 30, I770.

Letter to Hillsborough from five members of council of Grenada, removed by Fitzmaurice for refusal to consent to admission of Roman Catholics to council; with statement of their reasons. Dec. 5, I77 I.

Letter from Leyborne, on preparations by council for resistance to royal mandamus for admission of Roman Catholics. Nov. 24, I77I.

$I d$. Suspension of five members of council for resisting mandamus. Difficulties with maroons. Dec. 6, I77I.

Hillsborough to Leyborne, approving his conduct in treatment of council. Mar. 4, I772.

Letter from Leyborne. Difficulties with Caribs at St. Vincent. Packet service. Dec. 19, I77 I. Enclosed are estimates of necessary outlay for barracks and batteries at Tobago, and customary statistics of population, acreage, produce, etc., for same island.

Estimates of required outlay, and other papers on defenses of various islands.

Letter from Leyborne, on fire which destroyed St. George's, Grenada. Encloses lists of sufferers and of property destroyed, with values in island currency. Jan. 6, 1772.

Memorial of some gentlemen interested in St. Vincent, replying to Hillsborough's inquiry as to need for removing black Caribs from St. Vincent. Apr. 4, I772.

Hillsborough to Leyborne. Representations of commissioners for sale of lands in ceded islands on refusal of Caribs at St. Vincent to transfer allegiance to Great Britain have induced the crown to resolve upon "effectual measures for the reduction of them". Measures to be executed by local troops, with some from Dominica and two battalions from North America. Reinforcements to be drawn from Leeward Islands if necessary, and Leeward Island squadron also to assist. Command given to Leyborne. Caribs to be retained in islands on terms of agreement similar to those made with maroons in Jamaica. Apr. I8, I772.

$I d$., on same subject. No interference with yellow Caribs to be allowed. May 6, I772.

Id., on packet service. May 6, I 772.

Letter from Leyborne, on admission of Roman Catholics to council, assembly, and bench. Apr. 25, I772.

"Mr. Midleton's Account with the Post Office", showing rates of postage. I772.

Letter from Leyborne. Trouble in assembly with "Irish party", which is headed by Mr. Connor, clerk to collector and receiver general, and is largely composed of officials. "New subjects" suggest dissolution of assembly. May 5, I772.

Leyborne to Commissioners of Customs, complaining that vessel seized with cargo at Tobago, for introduction of wines and other prohibited articles, was sold at one-tenth cost to former owners, inhabitants of Tobago agreeing not to bid. Full particulars. Mar. II, I772.

Detailed account of Tobago, with usual statistics. I 772 .

Letter from Leyborne. Preparation for expedition against black Caribs. June $18,1772$. 
Dartmouth to William Pulteney. Promises attention to memorial on threatened slave insurrection at Tobago, as soon as Caribs at St. Vincent are subdued. Aug. 20, 1772. Other papers on troubles with maroons and Caribs.

Dartmouth to Leyborne, on relief of $32 \mathrm{~d}$ Regt. by 6th Regt. Sept. 27, 1772.

Papers on expedition against black Caribs. I772.

Detailed account of island of Grenada. I772.

Letter from Leyborne. Arrival from Boston of 14th Regt. sent by Gage. Proceedings against Caribs at St. Vincent. Sept. I2, I772. Encloses Leyborne's proclamation demanding submission of Caribs. Other papers.

17. I772-1 774 .

Papers on black Caribs and difficulties encountered with respect to them in sales of public land. In particular: "Extract from the Records of the Superior Council of the Island of Martinico . . . Registered . . . this 6th day of April, I660", as laid before House of Commons, Jan. 26, I773, on negotiations of French with Caribs in St. Vincent and Dominica. Report of Board of Trade on papers requested by House of Commons respecting Caribs. Jan. 22, I773.

Dartmouth to Dalrymple, on change in arrangement for 3Ist Regt., which is to proceed to England instead of returning to N. Am. Jan. 6,1773 .

Dalrymple to Dartmouth. Operations against Caribs. Encloses copy of treaty concluded with Carib chiefs, and return of casualties in various regiments. Dec. 26, I772; Feb. 22, 1773.

Dartmouth to Leyborne, on writs of intrusion against those who still claim land bought from Caribs. Mar. 3, I773.

Letters from Leyborne, on assistance alleged to have been given by French to Caribs. Nov. 30, I772; Jan. I5, I8, I773. Correspondence of Leyborne with governor of Guadeloupe enclosed.

Letters from Leyborne. Insistence of assembly on appointing treasurer to receive public funds.

Papers on maintenance at St. Vincent, at public expense, of botanical garden, with "a chemical Laboratory, negroe huts, etc.".

Various papers on defeat of Caribs, conclusion of peace, enforcement of peace as against Carib infringements, obstruction offered by Caribs to survey of land and construction of roads, objections of British settlers to treaty, and insistence of Dartmouth on conciliatory attitude towards Caribs. Memorial signed by two lieutenant-colonels and six majors of the 6th, 32d, 14th, 68th, 50th, and 6oth Regts., on behalf of all officers of said regiments, stating that they have undergone "uncommon Fatigue, Sickness, and Expense" at a time when "Your Majesty's other Troops are in profound peace", and asking that they may be enabled "to defray their extraordinary expenses" by obtaining grants of conquered lands. Also papers defining relations of governor with commanders of troops.

Papers sent by Leyborne to Dartmouth, on refusal of governor of Margarita to give satisfaction concerning slaves escaped from Carriacou. Forwarded to Rochford in order that representation thereon might be made to court of Spain.

Letter from Leyborne, reporting that "this Island is in the most perfect State of Tranquility". Mar. 24, I773. 
Dartmouth to Leyborne, on relief of 7oth Regt. by 48 th Regt. Sept. I, 1773 .

Leyborne to Dartmouth, complaining that "we suffer great inconvenience in this Island for want of a Commission for the Tryal of Pyrates; the trouble and expense of sending them to Antigua is very great, and Notorious Offenders frequently escape punishment". July 20, I773.

Id. Distress in Tobago and other islands occasioned by "the failures that have lately happened in Europe", and "the damage that Island [Tobago] is likely to sustain from the Ant, an Insect very destructive to Sugar Cane, and which has lately made its appearance here". July I7, I773.

"State" of Tobago, I77I-I773. (Very detailed.)

Reports from Maj. Gordon on defenses in Grenada and its dependencies.

Letter from Leyborne, on sending to England two prisoners accused of murder on shipboard, on coast of Africa. Having no commission for trial of pirates, he sent them to Antigua, but Payne did not consider that his commission extended to murder committed on high seas. Oct. 7, I773. Encloses differing opinions of attorney general of Antigua and attorney general of Grenada. Dartmouth to Leyborne, stating that "the authority of Commissioners for the trial of pirates does not extend to the Case of Murder". Did his best long ago to send separate commission for trial of pirates to governor of Grenada; but it has not passed through all the offices "and perhaps will meet with further delay unless the Agent for the Island thinks fit to interest himself in the despatch of it". Jan. 8, I774.

Dartmouth to Leyborne, stating that all matters not relating to regimental control of troops in any of the islands shall be at disposal of lieutenant governor or president of council, except that governor may interfere with disposition of troops. Apr. 6, I774.

Petition from council and assembly of Tobago for better fortifications and more troops. Inhabitants too deeply distressed even to provide for public worship. Apr. 7, I774.

Report on St. Vincent by Valentine Morris. July I I, I774.

18. I774-1775. (This volume contains so much important material that only a few documents, typifying the nature of the whole, may be listed. Letters about equally from Leyborne of Grenada and Morris of St. Vincent.)

Letter from Morris, on a "spirit of something more than independancy which seems to have gone forth of late years among the King's Colonys, and of which many individuals of even this, and also of the neighbouring Islands partake, to the frequent obstruction of His Majesty's measures". This is illustrated by rejection at St. Vincent by large majority, of bill for $4 \frac{1}{2}$ per cent. duty. Discusses various remedies, including taking advantage of every opportunity to claim escheat. Dec. 25, I774.

Id. Complains of party in assembly of St. Vincent, often commanding majority, and composed of "men of very confined, and some of them of no education at all, and led away with the delusive sound of liberty and independence, etc., etc., the true, just sense of which words they do not know, but catch the sounds from their ideas of these [sic] from North American gazettes and North American Capts., both of which swarm in all these Islands". . . . Best 
remedy probably in changing of majority by creation of new constituencies, since attempt to exclude undesirable members "would be to transfer to St. Vincents the late Middlesex disputes". Apr. 28, I775. Other important letters from Morris, showing disaffection in St. Vincent.

Letter from Lieut.-Gov. William Young, stating that "disaffected Subjects ... . are but few in this Island [Grenada] and none in the rest"; but complaining of address to his Majesty, passed by assembly and sent home by Mr. Winiet, "a Native of New England ... and late Speaker of the Assembly". Assembly dissolved on refusal to rescind address, as not forwarded through proper channels. States also that "Provisions and Lumber are as Cheap, if not Cheaper, upon the Average, than they have been these Nine Years bygone". Encloses address of assembly, on "the Contests which now subsist between your Parliament and your provinces of North America". Members of assembly "are attached to both by every tie that binds the human heart, and cannot, therefore, but deplore the horrors of a Civil War". Other papers.

Letter from Morris, stating that example set by N. Am. colonies causes assembly of St. Vincent to claim absolute control of finances, and power of self-adjournment. July 2 I, I 775 .

Letter from Leyborne, supporting coffee and cocoa planters in request for lower excise on their products in Great Britain, and pointing out great destruction wrought by cane ants. Nov. 23, I774.

Papers on land grants, settlements, and relations with Caribs in St. Vincent.

Letter from Morris. Disappointment of French that British free ports prevent French trade and shipping from keeping pace with increase of production in French islands. Complains that Gen. Monckton has received in St. Vincent a grant of 4000 acres, which extends along the shore and includes "almost all the practicable or at least good shipping places". Mar. 2, I775.

"A Plain Narrative of sundry Facts and Consequences which have happened in the Island of Grenada since its Submission to the British Arms in 1762 , in order to show what were the real Causes which first produced and since then have fostered public Disorders in that Island, and also to point out how they might be speedily and effectually removed." Blame laid chiefly upon French inhabitants and the over-indulgence shown to them in constitution and laws. Signed, Thomas Townshend. I775.

Suffolk (in absence of Dartmouth) to Lieut.-Gov. Young, directing sending of three companies of 6oth Regt. from St. Vincent to St. Augustine, "in order to give the necessary assistance for forming, regulating, and disciplining the Recruits for the augmentation of the Royal Americans, and for the Composition of the two additional Battallions of that Reg., which Recruits, as they arrive from Germany, will be sent from hence to that place". Oct. I4, I775.

Detailed "monthly return of the Brigade Quartered in the Charibbee Islands". June, I775.

Papers on conditions in Grenada, including : reply to query sent to governor, I766; detailed "states" of various parishes, giving names of proprietors, acreage for various kinds of cultivation, slaves, mills, etc., I772; papers showing values of certain lay and ecclesiastical 
offices, I773; abstract of "state" of Grenada, I772; "regulations established for the Practice in the Court of Vice Admiralty, by Alexander Symon, Esquire, Sole Judge of the said Court", I773 (?); "Docket of the Judge's fees in the Admiralty; also a list of the fees taken and received by the Collector, Comptroller, Searcher, and Weigher of His Majesty's Customs at the Port of Grenadoes"; lists of imports and exports, I772.

Answers to queries on Tobago. (Very comprehensive and detailed.)

19. $1775^{-1776 . ~}$

Letter from Lieut.-Gov. Young, no. II. Dec. 7, I775. Encloses monthly return of brigade quartered in South Caribbee Islands. Sept., I775.

Id., no. I2. Treatment of American pirates. Dec. I6, I775.

$I d$., on suspension of members of council. Mr. Stanton was "an active person in carrying on the address in favour of the American rebels". Jan. Io, 1776 .

Minutes of council. July 22, I775-Jan. 30, 1776.

Letter from Lieut.-Gov. Young. May 7, 1776. Encloses monthly return of brigade quartered in South Caribbee Islands. Feb., I776.

Letter from Gov. Macartney, no. I7. Sept. 4, I776. Encloses monthly state of troops. Aug., I776.

Id., no. 2. Arrival of merchant fleet except one vessel "which seems to have parted convoy on purpose and was taken by a Rebel Privateer". Feb. 6, I777.

$I d .$, no. I2. Captures made by rebel privateers. The French give all possible assistance but are not likely actually to declare war at present. "Whatever Trade the Rebels carry on is with the French (for that with the Dutch is comparatively inconsiderable); whatever captures are made in those seas, it is the French who receive the benefit of them. The Privateers are nominally Americans, but since our late successes in North America, they are become really French, being fitted out from French ports with french money and by French Adventurers, tho' under the name of William Bingham and Richard Harrison residing at St. Pierre's as profest agents for the Rebels. I believe there are now I4 or I 5 of those privateers chiefly manned with French, Spaniards and other foreigners, but the Majority is French. . . They are furnished with two sets of papers, one is a Commission from the Congress, under which authority they take all our vessels which they can master, the other is a Clearance from the French Custom houses for the Spanish Main, which they shew to such of our ships as are too strong for them." Mar. 6, I 777.

Id., no. I6. Apr. 27, I777. Encloses letter to Vice-Adm. Young, Apr. 2, - 1777 , describing answers of governor of Martinique and commandant of St. Lucia to letters written to them as to treatment of the "Rebel" privateers. Encloses also "List of Rebel and French Privateers at Martinique, and Vessels taken by them. April 9th, I777".

Id., no. 24, reporting capture of "rebel" privateer Oliver Cromaell. June 8, 1777 .

$I d$., no. 26, reporting professions of $M$. de Bouillé, new governor of Martinique, on relations with "rebels". July I I, I777.

21. I777-1778. (Volume contains also "Monthly State of the Troops", May, 1776-Aug., I777.) 
Letter from Gov. Macartney, no. 28. Encloses "List of the Antigua Squadron". July 23, I777.

$I d$., no. 34. Capture of two small prizes by two trading vessels of the island. Oct. I, I777. Encloses sales of two American prizes taken June 17 and 25,1777 .

$I d$., nos. 35, 36. Encloses "State of the Ordnance" in Grenada and Tobago. Oct. 2, 12, I777.

$I d$., no. 39. Reports information as to the "countenance and protection which the Rebels received from the French, Dutch and Danes in the neighbouring Islands (not to mention their wellwishers in our own)". Martinique ever since the beginning of the rebellion "has been considered by the Americans as their chief Magazine and Asylum in these seas". The Marquis de Bouillé professes neutrality, but Americans continue to receive assistance. About forty or fifty Americans are now in Martinique, the principal one Bingham of Pennsylvania, who is regarded as "a kind of agent, or Consul for his Countrymen. . . . He corresponds with the Congress, fits out their ships, sells their prizes, and is in general charged with the whole of their affairs there. He prepares all the American Articles for the Martinique Gazette, has constant access to Monsieur Joubert, the Commandant at St. Pierre, . . . The Americans boast that he is well received at Fort Royal by Monsieur de Bouillé, but all the french officers and Gentlemen absolutely deny it. . . . The number . . . of American privateers in the West Indies, has of late been very much diminished. . . . The Rebels find it very difficult to man their ships, ever since we have sent the prisoners to England. . . A Among the prizes which have fallen into our hands, not a third of the people are natives of America. The french smugglers and other small Craft have almost all Congress Commissions (perhaps without Monsieur de Bouille's knowledge) and don't fail to make use of them when a fair opportunity offers. There is generally one American on board, a man of Straw, whom they then pass as the Commander, to justify their captures.

The Americans on the Continent are chiefly supplied in the articles of Cloathing and hardware, with British Manufactures, which are sent thither thro' the Medium of St. Eustatia and Santa Cruz. Gun powder, Artillery, and all kind of Naval and Military Stores, are furnished them by the french. A Merchant at St. Pierre's, told the Gentleman whom I sent there, that if he wanted Io,00o stands of Arms he could supply him, and wou'd ship them in ten days, on board a french bottom to any part of America. It appears that the French, Dutch and Danes, are prodigious gainers by this trade, whilst America itself is almost exhausted to the last farthing, having no foreign credit."

$I d$., no. 50. Encloses "A List of Rebel Privateers now cruising in these Seas and fitted out from Martinico", also "A List of Rebel Privateers now fitting out at Martinico". Dec. 25, I777.

Id., no. 7. Capture of rebel armed ship Alfred. Asks for definite instructions regarding prisoners. Those taken in arms sent to England, others given choice of leaving the island or taking oath of allegiance. Americans have instruction not to release any prisoner without particular directions from Congress. All other West Indian 
governments release all prisoners, some of whom have been taken "above twenty times over". Apr. IO, I778.

22. 1778 .

"Monthly State of the Troops", Sept., Oct., Dec., I777.

Letter from Gov. Macartney, no. 20. Encloses copy of military report on islands of government of Grenada, received from Capt. Morse, engineer. July 22,1778 .

$I d$., no. 36, communicating information from America from one "who had good opportunities of knowing the truth". Oct. I8, I778.

23. I778-1779.

Letter from Gov. Macartney, no. 45, reporting expectation of Gen. Grant and Commodore Hotham, who sailed from N. Y. at beginning of Nov. Dec. I, I 778 .

$I d$., no. 4. Describes plundering descent by large American privateers at Man-of-War Bay, Tobago. Jan. 28, I779. Enclosure on same subject.

$I d$., no. I3. Refers to fleet sailing under convoy for Great Britain, etc., including N. Y. and Savannah. May 23, I 779.

"Monthly State of Troops". Nov., Dec., I778; Jan., Feb., Apr., May, Aug., I779.

26. $1784-1786$.

Letter from Gov. Mathew. Encloses tables on trade, including that with U. S. Jan. I, I785.

Letter from Pres. Lucas. Apr. 9, 1786. Encloses Votes of Assembly, Feb. 6-23, I786, printed.

30. 1790.

Letter from Gov. Mathew. Apr. I8, I790. Encloses list of grants of land, Jan. I, I784-Apr. 22, I790.

Id. July 30, I790. Encloses journal of assembly, Feb. 2-Nov. I7, I789.

32. I79I-I792.

Letter from Gov. Mathew. Feb. 9, I792. Encloses journals of assembly, Feb. I 5-Aug. 20, I79I.

33. I792-I794.

Letter from Lieut.-Gov. Home, reporting admission of American vessels to Jan. I next. Aug. 31, I793.

$I d$., reporting extension of time to Mar. I. Dec. 3I, I793.

$I d$., reporting extension of time to May I. Mar. I3, I 794 .

$I d$., reporting extension of time to July I. May 2, I794.

$I d$., stating that no supplies have been received from America "for some time past" owing to embargo. June 23, I794.

$I d$., reporting arrival of American vessels, and extension of time for two months. Aug. I, I794.

34. $1794-1796$.

Letter from Lieut.-Gov. Howe, reporting extension of time for admitting American vessels to end of year. Nov. 21, I794.

Letter from Pres. Mackenzie, reporting admission of American vessels to end of Sept. Aug. I I, I795.

35. $1796-1798$.

Letter from Lieut.-Gov. Houstoun, reporting admission of American vessels for six months from Dec. 20, I796. Feb. 21, I797.

Letter from Gov. Green, reporting extension of time. July I4, I797. 
36. I798-I799.

Letter from Gov. Green, acknowledging receipt of circular of July I "upon the subject of sugar illegally exported in American Bottoms,

38. I8OI. from some of the West India Islands". Aug. 26, I799.

Letters from Gov. Green and Pres. Dent. Apr. 23, July 22, I80I. Enclose naval office returns, St. George's and Grenville, Jan. IJune 30 , I80I.

39. 1802 .

Letters from Pres. Dent. Feb. 4, May Io, July 3I, Dec. I4, I802. Encloses naval office returns, St. George's and Grenville, Oct. I, I80I-Sept. 30, 1802.

40. 1803 .

Letters from Pres. Dent. Mar. 5, Nov. 23, I803. Encloses naval office

41. 1804 . returns, St. George's and Grenville, Oct. I, I802-Sept. 30, 1803.

Letters from Pres. Dent and Pres. Adye, Mar. I6, June, July 24, Nov. 8, I804. Enclose naval office returns, St. George's and Grenville,

42. 1805 . Oct. I, I803-Sept. 30, 1804 .

Letters from Pres. Adye and Gov. Maitland, nos. II, 5. Feb. I4, Aug. I2, Oct. 22, 1805. Enclose naval office returns, St. George's and Grenville, Oct. I-Dec. 30, I804; Apr. I-Sept. 30, I805.

Letter from Gov. Maitland, no. 9, on petition of William Davis Robinson, a subject of U.S. resident at Caracas, asking for license to export from S. Am. into free port of St. George's. July 26, I805.

43. 1806.

$I d$., no. I3, reporting issue of proclamation extending period for importation in American vessels. Aug. I3, I805.

Letter from Gov. Maitland, no. I7, relative to W. D. Robinson. Jan. 8, I 806.

Id., nos. 20, 28. Jan. 21, Apr. 23, July I5, I806. Encloses naval office returns, St. George's and Grenville, Oct. I, I805-June 30, I806.

$I d$., no. 25 , on proposal to grant bounties on $\mathrm{Br}$. N. Am. salt fish, and to 44. 1806: levy a duty on U. S. salt fish. July I, I8o6.

Letters from Gov. Maitland, nos. 33, 42, 6o. Aug. 7, Sept. I I, Nov. I4, I806. Encloses:

Minutes of council. June 2-27, I 806 .

Journal of assembly. June 2-Oct. 24, I806.

Minutes of council. Aug. 12-Oct. 24, I806.

$I d$., nos. 39,53 , relative to Br. N. Am. and U. S. salt fish. May 5, Oct. $27,1806$.

$I d$., no. 67 , on importation in foreign vessels. Dec. $7,1806$.

Among miscellaneous papers at end of volume one, from Board of Trade, relates to opening of ports of Grenada for American lumber and provisions. Oct. 22, 1806.

Letters from Gov. Maitland, nos. 78, 89, 90. Feb. 4, May I, II, I807. Encloses:

Naval office returns, St. George's and Grenville, July I, I806-Mar. $31,1807$.

Minutes of council. Oct. 25, I806-Apr. 2, I807.

Journal of assembly. Oct. 25, I806-May 7, 1807. 
Id., no. 79. Encloses returns of exports and imports, I794-I805, in British and American vessels. Feb. I0, 1807.

47. 1808 .

Letters from Gov. Maitland, nos. 7, I2, relative to bounty on Br. N. Am. fish and admission of U. S. provisions in U. S. vessels. June 20, Aug. 25, I807.

Id., no. I5. Sept. 5, I807. Encloses naval office returns, St. George's and Grenville, Apr. I-June 30, 1807.

Letters from Pres. Harvey, nos. I, 2. Nov. 2, 10, I807. Enclose: Minutes of council. May 8-Sept. II, I807.

Journal of assembly. May 8-Sept. I I, I807.

Naval office returns, St. George's and Grenville, July I-Sept. 30, 1807.

Among miscellaneous papers at end of volume is correspondence on seizure of American vessels returning from Demerara to U. S. in

48. 1809. Feb., I806: barque Jane seized by revenue officers of Grenada.

Letter from Pres. Adye. May 3, I809. Encloses table of imports from Br. N. Am., I807-I808.

Naval office return, St. Vincent. Oct. I I, I808-Jan. 5, I809. (Inwards only.)

50. I8I I.

Letter from Gov. Maitland, no. 23. All American vessels entered since Dec. I, I8Io, have paid duties enumerated in order in Council of Feb. 7, I8Io. Feb. 7, i8I I.

Letter from Pres. Adye, Sept. 5, I8I I. Encloses account of British and American fish imported, Jan. I, I805-Dec. 3I, I8Io.

51. 1812 .

Letter from Gov. Ainslie. Acknowledges receipt of circular of Sept. I2, relative to specie found on U.S. vessels. Nov. 7, I8I2.

55. 1815.

Letter from Gov. Shipley, no. I07, relative to importation from U. S. Oct. I5, I8I5.

20. $1776-1777$.

Letter from Gov. Macartney, no. 29, reporting action of rebel privateers. "Their head quarters are at Martinico, but they extend their cruises as far to Windward as Barbados". Dec. I4, I776.

C. O. IO2: I-3. Board of Trade: Entry-Books. I763-I783.

1. I 763-I77 I.

Letter to Gov. Scott, announcing appointment of new members to Board of Trade, and sending order in Council of Mar. II, I762, on correspondence of governors with Board and Secretary of State. Mar. 5,1763 .

$I d$., directing Scott to stop sales or conveyances of land by French. Aug. I 5,1763 .

Commission for Robert Melville as governor. Oct. 4, I763.

Instructions for Melville. Nov. 3, I763.

Many entries on disposal of lands in ceded islands, including representations on method of disposing of lands in the four islands. Nov. 3, I763; Mar. I, I764.

Representation, with draft of additional instruction to governor of 
Grenada, agreeable to order in Council of Apr. I8, I764, on establishment of general council for all the islands. Apr. 30, I764.

Letter to Melville, directing that Spanish vessels entering in distress are to receive assistance as formerly. Feb. I 5, I765.

Representation, recommending establishment of separate legislature for Grenada. Dec. Io, 1765.

Draft of additional instruction for Melville, on calling of separate assembly for Grenada. Feb. 27, I766.

Letter to Melville, sending instructions on separate assembly for Grenada. Mar. 25, I766.

Representation on establishment of general council for all four islands and separate legislature for Grenada. Aug. I, I 766.

Letters for securing testimony on petitions and memorials for separate government for Dominica. Representation on establishment of separate government for Dominica. Dec. 21, 1767. Letter on memorial of Merchant Venturers of Bristol on separate government for Dominica. Dec. 21, I767. Representation on ordinance of governor and council of the four islands for establishing separate assembly for Dominica. Feb. 25, I768.

Representation on conditions under which new French subjects might receive appointments to judicial positions or to membership in councils in the islands. Nov. $20,1767$.

Id. On various acts recently passed in the four islands relating to government of same. Mar. 4, I768.

Id. On ordinance passed by Melville for establishing council in Tobago. June ro, 1768.

Id. On establishment of separate councils and assemblies in various islands, and admission of new subjects of Grenada to council under certain limitations. Oct. 6, I768.

Id. For disallowance of bill for raising money and establishing treasury in Grenada. May I I, I767.

Id. On memorial of proprietors of Dominica for independent government. Mar. I, I770.

Id. For appointment of commissioners to try pirates in the four islands, suggesting names. Dec. I9, I770.

Id. On appointment of Roman Catholics to councils. Feb. 6, I77I.

Draft of commission for William Leyborne as governor. Mar. 6, I77I.

2. $\mathrm{I} 77 \mathrm{I}-\mathrm{I} 78 \mathrm{I}$.

Draft of instructions for Leyborne. Mar. 6, I77I.

Representation on act of St. Vincent, I768, for regulating towns and fixing prices of provisions. Mar. I5, I77I.

Id. On several acts of St. Vincent relating to division of authority between executive and legislature in raising, appropriating, and issuing public money; and on authority of ecclesiastical laws and jurisdictions in colony. Mar. 27, I77I.

Draft of additional instruction, permitting governor to receive additional salary. May I5, I77 I.

Letters to Secretary of Treasury, and representation, on acquisitions of land from Caribs in St. Vincent. Dec. IO, I77I; June 24, I772.

Representation on two acts of Grenada, I772, on establishment of courts of common pleas, error, king's bench, and grand sessions. Nov. 5 , I774. 
Draft of commission for Sir George Macartney (omitting mention of St. Vincent). Dec. I2, I775.

Instructions for Macartney, governor of Grenada, the Grenadines, and Tobago, showing changes forbidding assent by governor to acts by which: (I) property of persons who have never lived in islands may be attached for recovery of debt in any manner inconsistent with usages and practice in Great Britain; (2) aliens may be naturalized; (3) persons may be divorced; (4) title is established in any real estate granted to or purchased by aliens antecedent to naturalization. Feb. 6, I776.

Representation for restoration of Stanton and two other suspended councillors to council. May 5, I778.

3. 1783. Instructions for Gov. Mathew.

C. O. i02:4-I8. Secretary of State: Entry-Books. i766-I825.

4-8. I766-178I. In-Letters.

9-13. I789-I8I4. Précis of Correspondence.

14-18: I766-1825. Out-Letters.

14. I766-I768. Correspondence on matters of routine, or of secondary importance.

15. I768-178I. For Grenada, Tobago, Dominica, and St. Vincent to I770; Grenada, Tobago, and St. Vincent to I776; Grenada and Tobago to 1780 ; and Grenada to I78I. Letters to Treasury, Admiralty, Board of Trade, attorney general, governors and lieutenant governors. Also numerous orders in Council, some not quoted elsewhere. (See also Andrews, I. 20I.)

$$
\text { C. O. Iо3:I-6. Acts. }
$$

1. This volume comprises:

Two manuscript acts of February, I766: The Lawes of the Legislature of the Islands of Grenada and the Grenadines (Grenada, St. George's Town. Printed, by Order of the Council and Assembly, by $\mathrm{Wm}$. Wayland, I767, pp. I I8). Then follows a printed act of Sept. 7, I 768 , with headline and pagination continuous II9 to I 30 ,

2. $1766-1767$. ending with part of another act and catchword.

3. $1767-1774$.

4. $1773-1776$.

5. $1776-1778$.

6. A printed compilation, pp. 288 , but without title-page or imprint. On the last page is: "End of the third volume". The first page is headed: "The Laws of the Legislature of the Islands of Grenada and the Grenadines". Most of the acts are passed in 1784 , but there are two of 1778 , viz., pp. $42-56$, act for a hospital, assented to Apr. 22, and pp. 57-7I, act for a dock and dockyard, assented to Aug. 4. The last act is one assented to May, 1785 .

C. O. I04: I-5. Sessionai Papers.

1. I766, Sept. I2-I767, Apr. 28. Minutes of general council "for the Southern Charibbee Islands", pp. 54.

I767, Mar. 30-July 21. Minutes of council for Grenada and the Grenadines, pp. $3 \mathrm{I}$. 
1768, Apr. 23. Endorsement only, for minutes of council of this date: "In Gov. Melville's No. 5."

I767, July 22-I768, Mar. 25. Minutes of council, Grenada, pp. 42.

I768, July 26-Aug. 26. Minutes,-both headed, "At a Meeting of the General Council", p. I.

I768, Aug. 26. Minutes of council (seems to be referred to by the governor as "the particular Council of Grenada and the Grenadines"), pp. 2.

I768, July 27. Minutes of council (certified as "a copy of the Separate Council"), p. 3.

I769, Feb. 17-Aug. 24. Minutes of council (contains an address from the assembly dated Aug. 27), pp. 34 .

I769, Oct. 23-I770, Jan. 23. Minutes of council, pp. 9.

I770, Feb. 15-16.

I770, Feb. 26-Mar. 3.

I771, Jan. 5-16.

$$
\text { “ “ “ “ } \quad \text { “ } 12.7 .
$$

Copy of petition of inhabitants to Gov. Melville to convene council and assembly. Undated.

Copy of petition from parish of St. Andrew about a port and custom-house. Undated.

Letter from Richard Burke to A. Symson. Custom-house, Grenada, Jan. 7, I 771 .

Id. Jan. 8.

Deputation to Richard Burke, collector, from the Commissioners of Customs. London, May 19, 1763 .

Id. To William Hall, collector of the $4 \frac{1}{2}$ per cent. duty. Mar. 24, I 770 .

Letter from Joseph Robley to the governor. Oct. 23, I770.

Copy of patent to Edward Sedgwick for the naval office of Grenada, Dominica, St. Vincent, and Tobago. Apr. 6, 1765.

2. 1766, Oct. 15-Dec. 12. Votes of the General Assembly of Grenada and the Grenadines (St. George's Town, William Wayland, 1767 , pp. 144). In French and English on opposite pages, ending with the English version on p. I44.

1775, May 29-June 26. Votes of general assembly, pp. 42.

1776, July 25-Oct. 28. “ “ “ “ pp. 106.

1777, Feb. 18-1778, Jan: 24. Journal of general assembly, pp. 136.

I768, Jan. II, I5. Minutes of council (same as in vol. I for these two days), pp. 7 .

I776, July 27-Oct. 26 . Minutes of council, pp. 50 .

I777, Aug. I2-1778, May 30. Minutes of council in assembly, pp. 70 .

3. 1767 , Dec. 15-24. Votes of general assembly, pp. 48.

I768, Mar. 12-25. "Minutes" of general assembly, pp. 35.

I768, Aug. 26 and 27. Votes of general assembly, pp. 8.

1769, Feb. I6-June 24. “ “" “ " " pp. 38.

I769, June 24-Dec. 4. “ “ “ “. (June 24 a repetition), pp. 34 .

I769, Dec. 5-8.

I770, Jan. I5-Mar. ro. "Minutes" of general assembly, pp. 24.

4. I772, Mar. 9-May 14. Votes of general assembly, pp. 49.

I775, May 29-June 26. " " " " (cf. vol. 2), pp. 22.

I775, Oct. 30-1776, Feb. I. “ “ “ “ pp. 202. 
I776, Feb. I5-July 24. Proceedings of general assembly, pp. 220.

5. I772, Jan. I6-July 23. Minutes of council, pp. 35.

I772, Oct. 29-I773, Oct. $2 . \quad$ " " " "

I773, Nov. 26-I775, June I3. " " " " " " " " "

I776, Jan. 3I-July 24 . " " "

\section{O. io6:I. Shipping Returns.}

I764, Nov. 13-1767, July I.

Outward:

Same period.

MISCELLANEOUS.

List of vessels entered with slaves, giving the number of slaves, and details as in shipping returns. Nov. I3, I764-Oct. Io, I766.

List of all registers granted at Grenada, giving details of ships, etc. Nov. I3, 1764-Oct. IO, I766.

\section{GUADELOUPE.}

C. O. i io:I-3. Serretary of State: Original Correspondence. i758-

1. $1758-\mathrm{I} 76 \mathrm{I}$.

I794.

Letters to the Secretary of State, dealing principally with articles of capitulation, conditions of occupation, and plans for further conquest. Some papers on commerce, condition of troops, and supplies of provisions and ordnance. In particular: letters from Maj.-Gen. Hopson, I750-1759; from Maj.-Gen. Barrington, who succeeded Hopson in 1759; and from Commodore Moore.

2. $1761-1763$.

Letters from Campbell Dalrymple; brief statistics of exports; returns of troops under Dalrymple's command, I762; and papers on restoration of Guadeloupe to French, 1763.

3. I759-I794.

Letters from Board of Trade to Pitt, recommending appointment and reappointment of Hugh Grame as naval officer. Aug. 2I, I759; Mar. i I, I76I.

Seven printed copies of addresses to inhabitants of Guadeloupe, urging them to join the British in freeing island from destructive tyranny of French. Undated.

Letters on appointments to offices.

\section{HAVANA.}

C. O. im 7 : . Secretary of State: Original Correspondence. iz621763 .

1. I762-1763. (See Andrews, I. 202.)

\section{JAMAICA.}

C. O. i37:9-43. Board of Trade: Original Correspondence. i7io-i782.

9. I7IO-I7I3.

Letter from Gov. Handasyd, on quarrel between council and assembly over latter's action in placing a rider on a money-bill, and assembly's 
unwarrantable claims in matter of adjourning itself. June 2, July I6, I7II.

Address of governor, council, and assembly to House of Commons, asking that African trade be opened to private traders. June 2, I III.

Account of her Majesty's revenue, I7IO-I 7 II.

Letter from Gov. Hamilton, on assembly's claim to right of self-adjournment. Aug. 29, I7II.

Project of Mr. Dummer for resumption, on new lines, of monthly packet service to West Indies. I7I2. Enclosed is schedule, printed in I705, showing proposals for operation at that time, with list of ports and ships.

Various papers on payments due from factors of the Asiento.

Letter from Dartmouth, directing issue to colonial governors of instructions forbidding sending to Great Britain of persons charged with crimes or misdemeanors, unless full proofs of guilt are forwarded at same time. Aug. 2I, I7I2.

Letter from Hamilton. Operations of flags of truce. Dec. I8, I7I2.

Address of board of merchants settled in Jamaica, complaining that war vessels engross trade on Spanish coast. Jan. 3, I7I2/3.

Numerous papers on quarrels between governor and admiral on the Jamaica station, over powers of naval officer and of officers of war vessels in making seizures, and right of governor to issue orders to officers of war vessels.

10. I7I3-I7I5.

Papers on the land system, relating to escheats and to new act for "quieting possessions", passed in I 7 I 2 and confirmed in I7I5.

"Account of Goods Exported from Jamaica From 25th March I709 to the 29th Sepr. I7I I." Distinguishes exports to Great Britain from those to plantations.

"Goods Imported to Jamaica from 25th of March I709, to 29th September I7 II."

"Account of all Goods Imported and Exported to and from Jamaica from 29th Sepr. I7 I I to March 25th I7 I2." Number of vessels also given.

Receipts and expenditures for fortifications. I7I I-I 7 I2.

Four statements of "Her Majesty's Account Current", Sept., I 7IIJuly, I7I3; with separate accounts of quit-rents, imports, wine licenses, fines and forfeitures, escheats and outstanding debts. A fifth statement covering Michaelmas, I 7 I3, to Michaelmas, I7 I4.

Lists of escheated lands and slaves, with valuations showing current prices. I7I2-I7I3.

List of militia regiments in Jamaica, Oct. II, I7I2, with strength of each and name of commander.

List of militia troops of horse in Jamaica, with names of captains. I7I2.

Lists of stores. I7I2.

List of 39 vessels lost or damaged at Port Royal, being the "most part" of the shipping there, and nine lost or damaged at Kingston during earthquake and hurricane of Aug. 28, I7 I2. Tonnage, rigging, number of guns, etc., given.

List of patent officers, with names of persons by whom the various duties are actually executed.

Proceedings of council of war held Sept. I, I 7 I2. 
Memorial of council and assembly against re-establishment of monopoly in African trade; alleging that, trade with Spanish settlements having been ruined by provisions in treaty concerning the Asiento, and by unwarrantable seizures made by vessels under Admiral Walker's command, the island needs free trade in negroes. Dec. 24, I7I3.

Papers relating to quarrels between Gov. Hamilton and Adm. Walker, involving mutual accusations of connivance at piracy and illegal trade, and on use of flags of truce, and seizure by naval officers of Spanish vessels and British privateers. I7I3-17I4.

Receipts and expenditures for fortifications. I $7 \mathrm{II}-17 \mathrm{I} 2$.

Many papers on series of disputes between governor and assembly on: objections of assembly to "the maintenance of a standing army in time of peace"; assembly's claim to right of adjournment; refusal of assembly to allow council to amend money-bills; act passed by assembly to prevent any person from holding two or more places of profit; voting of money for soliciting in England public affairs of island in interests of assembly alone; withdrawal of the "opposition" in order to make a quorum impossible; repassage of disallowed acts; refusal of supplies. Governor's views are seen especially in an "Abstract of Occurrences in Jamaica", submitted to Privy Council, and in letter to Earl of Orkney, Nov. I5, I7I4.

Letter from Bolingbroke. "Disorders and confusions" in West Indies have reached such a height that it is proposed to send someone there on mission similar to that of Nicholson in northern colonies. Mar. I8, I7I $3 / 4$.

Letter from Admiralty to Stanhope, on authority of colonial governors over officers of the navy. Mar. 26, I715\%6.

11. I7I 5-17I6.

Memorial of South Sea Company, complaining of duties laid by assembly on exportation of slaves to Spanish coast. Dec. I, I715. Other papers, with arguments for and against the duties. I7I 5-1716.

Papers on enforcement of acts of trade, and in particular on disputes between Gov. Hamilton and Surveyor General Keith. Keith complains that vessels are entered and cleared without reference to officers of customs; and Hamilton, that Keith refuses to recognize governor's authority. Question of fees taken by collector is also involved. Commencement of disputes is described in letter from Hamilton, July 2, I7 I 5 .

Letter from Hamilton, on the land system. "The greatest part of the valuable land unsettled has been long since patented and is now in hands who neither cultivate nor care to dispose of it." Aug. 30, I 7 I 5 .

Id. Complains of "spliting of freeholds" and other improper devices resorted to in election of assemblymen. Nov. I4, I7I 5 (I).

Id. Refusal of assembly to supply funds for subsistence of troops, danger of negro insurrection, and decline of Spanish trade. Nov. I4, I7I 5 (2).

Account of money received and disbursed for subsistence of Handasyd's regiment, I 7 I4-I 7 5 .

Account of militia. Nov., I7I5.

Papers on disputes between governor and assembly. Besides old questions, the most prominent issue raised is the refusal of assembly to 
reimburse governor for his expense in subsisting troops. In particular: letter from Hamilton, Nov. 28, I715, and a "Memorial in Vindication of the Island of Jamaica and the Assembly thereof". I7 I 5 .

Report of engineer on defenses of Jamaica. Feb. 21, I7 I $5 / 6$.

Letter from Stanhope, announcing that governor has been ordered to place reimbursement of his expenditure on troops as first charge upon revenues of Jamaica, and to see that future subsistence is provided in same manner, unless assembly shall make other provision. Apr. 24, I7I6. (Attempts by the crown to secure reimbursement for Hamilton continued through a number of years, as may be seen in succeeding volumes of correspondence; but it does not appear that complete repayment was ever secured.)

Numerous papers on piratical depredations committed by vessels from Jamaica on Spanish vessels, wrecks, and settlements, subsequent to conclusion of peace. Repeated charges that governor is involved. I7I5-I7I6. In particular: draft of letter to Heywood, president of council, ordering him to secure persons and effects of those engaged in recent depredations against Spaniards. I7 6.

List of ten vessels commissioned by Hamilton, ostensibly for suppression of piracy, Nov.-Dec:, I7 I5.

Letters from Hamilton. Act passed to compel all office-holders to take communion within three months in Church of England or in any Protestant church tolerated in English law; refusal of chief justice to issue.writs of habeas corpus; action of assembly in subscribing funds to solicit business in England after refusal of council to pass bill appropriating money for this purpose. Mar. 5, I7 $5 / 6$; June I2, I7 I6.

Papers on Hamilton's recall, arrest, and despatch, as a prisoner, to England. Besides complicity in piracy and illegal trade with French settlements, he is accused of bribery and intimidation in connection with elections and with assembly and court of chancery. In particular: representation of assembly, Dec. 3I, I7I5; memorial of council (defending Hamilton), Mar. I3, I7 I5/6; and an "Extract of the Maladministration in Jamaica during the government of Lord

12. I7I6-I7 8 .

Archibald Hamilton", r7 6 .

Many papers on piracy, including :

Letter from Hamilton, on piratical acts committed by British vessels on Spanish coast. June 12, I7 6.

Forms of commissions issued to, and bonds given by, persons commissioned for suppression of piracy. I7 6 .

"Extract of a Letter to Mr. Onslow from Jamaica", stating that pirates are leaving the island "in swarms" as result of measures now being taken for their suppression. (This letter also deals with lack of currency, decline of trade, and rise in price of slaves occasioned by Asiento agreement in peace treaty.) Aug., I7 16.

Letter from Secy. Methuen on establishment of pirates in the Bahamas, and enclosing interesting letters, depositions, etc., from Va., S. C., and elsewhere. Nov. 30, I7 6 .

Letters from Heywood, on prevalence of piracy at Jamaica and its effect on the population, frequent capture of vessels from 
northern colonies, Hamilton's complicity, and Heywood's apologies to Spanish governors. Aug. I I, I6, I716.

Minutes of council, Sept. 3, 4, I7I6.

Copies of proceedings in court of admiralty at Port Royal in condemnation of vessel seized by Hamilton's (piratical?) sloops.

Numerous papers on seizure, condemnation, and letters of appeal against condemnation, in I7I5, of Nostra Signora de Bethleem. The papers include copy of the ship's manifest (I $30 \mathrm{pp}$.) and other documents, throwing much light on trade, prices, etc., and upon operations of Spanish Asiento company. I7I5-I7I6.

A list of 37 vessels, constituting "some of the many ships . . . taken from the Subjects of the King of Great Britain in America by the Subjects of the King of Spain since the Conclusion of the last Peace". Sept., i7i6.

Letter from Heywood, complaining that assembly places riders on money-bills. Nov. 14, I716.

"Copy of Mr. Congreve's Commission for the place of Secretary of Jamaica." I7 7 .

Copy of receiver general's patent. I7I 7 .

Copy of subscription paper signed by members of assembly to raise money for soliciting affairs in England. Received, Feb. I6, I7 I6/7.

Petition of South Sea Company, against act laying export duty on negroes, which will "greatly Affect and Prejudice the said Company in carrying on the Asiento". Counter-memorial of assembly. Letters from Daniel Wescomb, secretary of South Sea Company, and from agents of company at Jamaica. "Account of Negroes Sent to the Spanish West Indies on Account of the Asiento." Other papers. I7I 7 .

Letter from Sir Nicholas Lawes, on illegal trade between Jamaica and French settlements. Nov. 4, I7I7.

Papers relating to seizure, by Spanish man-of-war, of Capt. Harry Beverley of Va. with his vessel and crew. I7I7. (Beverley was proceeding, under orders from Spotswood, to inquire into state of Bahama Islands, location of Spanish wrecks, and activities of pirates.)

Papers on dispute over division of profits between secretary of the island and his deputy, Mr. Cockburn. I7I7.

13. I7I8-I72I.

Papers showing continued prevalence of piracy, especially in Windward Passage, and continued participation by convicts shipped out to Jamaica, and by other residents. Included are copies of two commissions sent to Gov. Lawes for trying and pardoning pirates, and of commissions issued by him for their pursuit. Conditions are described in letter from Lawes: "There is hardly any Ship or Vessell coming in or going out of this Island that is not plundered. And this in good measure I impute to the neglect of the Commanders of his Majesty's Ships of Warr." The war vessels, he explains, prefer to devote their energies to trading with the Spaniards. June 2I, I7I8. Burchett, in letter to William Popple, states that orders have been given to stop this abuse. Aug. 5, I7I8.

Accounts of his Majesty's revenue. I7I6-I720.

Letter from Lawes. Complains that most of revenue derived from enforcement of acts of trade is eaten up "in extravagant and 
unnecessary charges and salaries to the officers". Until recently the king's share was paid over to governor, who accounted for it to Treasury; but during Heywood's administration Beckford, the controller, succeeded in having payments transferred to collector. Sept. I, I7 8 .

Account of collector of customs, Mar. 25-June 24, I7I8.

Letter from Commissioners of Customs, objecting to act for "ascertaining" the number of ports of entry in Jamaica, on ground that it promotes growth of towns and increase of manufactures. Apr. 3, I7I9.

Letters from Lawes. Describes ill effects of sending of convicts to Jamaica, and complains of assembly. Assembly makes unwarrantable claims to right of self-adjournment; has refused to pass an act "to extend real estate to the payment of debts"; is quarrelling with council over appointment of an agent; has lodged large sum of money raised by taxation in hands of commissaries, who have given bond to pay it only for specified purposes; and has passed act for peopling of island, which places special tax on absentees, and provides that money raised shall be paid to receiver general, not as receiver general, but as assembly's commissioner under special bond. Sept. I (two letters), Oct. Io, I7I8; Jan. 3I, Mar. 24, I718/9. In the last of these letters Lawes asks for renewal of instructions issued during last war to permit trade with Spanish settlements. Further arraignment of assembly is found in letter of Thomas Barnard, councillor, to John Chetwynd, Feb. 4, I7 I9/20.

Papers relating to protest of certain merchants against seizure at Jamaica of cargo of indigo, on ground that it was of French growth; and showing regulations covering importation and exportation of foreign indigo. 1718 .

The whole Proceedings of Captain Dennis's Expedition to the Governor of the Havamna. An interesting description of trade, piracy, and general conditions in Cuba. I7 8 .

Two copies of The Weekly Jamaica Courant. 1719.

Letter from Kelly, collector at Jamaica, to Commissioners of Customs, describing injury done to Spanish trade by pirates and South Sea Company; and urging desirability of acquiring the Bay of Campeachy for purpose of reducing piracy and reviving trade. Apr. 30, I7I9.

Letters from Lawes, pointing out damage done to Spanish trade by South Sea Company, and by French competition; and describing trade with continental colonies. Dec. 6, I7 I9; Feb. 2, I719/20.

Letter from Lawes, replying to customary queries of Board. Dec. 6, I7I9.

Copy of agreement made with Mosquito Indians for assistance against maroons. I720.

Papers on complaints that governor sends officials to search vessels and make seizures upon them after they have been cleared by collector and naval officer. Various questions concerning enforcement of acts of trade and conflicting powers of governor and commander of vessels on the Jamaica station are involved. I72I.

A number of important papers on negotiations which culminate, in 1728 , in grant of permanent revenue to the crown for support of government in Jamaica; the crown in return permitting permanent adoption 
by island of such laws and statutes of England as had been "at any time esteemed, introduced, accepted or received as laws in Jamaica". The settlement of 1728 represents the close of a contest which arose at intervals from early days of British rule, and which constitutes one of the most important episodes in the constitutional history of Jamaica. A number of subsidiary questions, such as applicability of Habeas Corpus Act to colonial conditions, financial independence of governor, and provision of subsistence for a garrison are involved. It is impossible to enumerate even the more important of the orders in Council, representations, memorials, and letters on all the various aspects and stages of the negotiations which are to be found here and in vols. 14,16 , and 17 . These papers, besides representing the views of the various organs of colonial government in England and in the colony, give a mass of important facts and statistics. The main issue is presented in letters from Lawes, Dec. 6, I719, Aug. 24, I 720 , and in a letter from Thomas Barnard of the council to 14. I72I-I724. John Chetwynd, Feb. 4, I7 19/20.

Important papers concerning the perpetual revenue (see C. O. I37:13). Reports and representations from attorney general, solicitor general, committee of Council, Treasury, Board of Trade, and Richard West.

Order in Council for new provisions to be incorporated in instructions of Duke of Portland as governor of Jamaica, on insertion of suspending clauses in acts providing for issue of bills of credit, or for payments of money to governors or other individuals. Jan. 20, $\mathrm{I} 72 \mathrm{I} / 2$.

List of 73 vessels lost or damaged at Port Royal and Kingston in hurricane of Aug. 28, I722, with particulars of tonnage, etc.

Papers on piracy, including printed accounts of trials of pirates by commissioners appointed under act of II and I2 Will. III. I72I.

Order in Council for restoration of indigo seized under local act. Aug. 24, I72I.

Letter from Commissioners of Customs, giving opinion of solicitor of the customs that, while officers of the customs and governor and naval officer enjoy concurrent powers in making seizures for violations of acts of trade, a clearance granted by one officer cannot prevent seizure by another. Aug. 7, I72I.

Letter from secretary of South Sea Company, complaining of duties on negroes. Mar. 2, I721/2.

Account current and account of fortifications, Mar. 25-Sept. 29, I72I. Additional instruction to governor forbidding council and assembly to lay any tax on exportation of negroes brought to island for "refreshment". Other papers relating to slave-trade.

Papers on capture and condemnation of French schooner Espérance for breach of acts of trade.

15. 1724 .

This volume consists of papers on the seizure, trial, and condemnation of the ship Chandos and the schooner Espérance for breaches of the acts of trade. Both vessels were seized in Kingston roads by the naval officer, and were condemned in the court of vice-admiralty in Mar., I724. The governor states that the court sat under his protection "for the prevention of tumults". The Royal African 
Company and the Royal British Asiento Company were interested in the vessels, and considerable light is thrown on the trade of the companies by the reports of the proceedings in the admiralty court and the accompanying papers.

16. I $724-\mathrm{I} 727$.

This volume is largely composed of papers relating to the struggle over the perpetual revenue bill (see C. O. I37:I3) which was at its height during these years. The refusal of the assembly to accept a bill framed in England by the joint efforts of the various departments of government, which provided for the permanent subsistence of regular troops, and the refusal of the crown to confirm successive bills framed by the assembly, produced a temporary deadlock and a virtual paralysis of government. In the numerous orders in Council, representations, and letters, the opinions and policies of the various organs of the central government with regard to colonial finances are clearly exposed.

A number of papers on the contest between the South Sea Company and the legislature of Jamaica, over export duties on slaves, and flour used for subsisting slaves, in transit from Jamaica to Spanish coast. South Sea Company admits that no duties are now levied on negroes taken into Jamaica for refreshment, but asks that all export duties be forbidden, since "they have found it expedient to buy negroes at Jamaica and to satisfy themselves with others on that island by contracting with the Royal African Company". Besides two memorials of South Sea Company, Aug. 3, I724, and Oct. 6, I726, letters from Wescomb, secretary of South Sea Company, memorials from Jamaica merchants for and against the duties, copies of acts and orders in Council, and other papers are found.

Interesting letter from Portland, complaining of independence of patent officers, and his lack of success in securing the nomination of the deputy provost marshal (who is an officer of the court of viceadmiralty); and describing dispute between council and assembly over appointment of coroners. Dec. 30, I724.

Papers on seizure by naval officer of French indigo illegally imported in I718. Unusually detailed. Valuable in showing procedure, values, and fees.

Information on Adml. Hosier's movements. I 726.

List of queries from Brig.-Gen. Hunter, appointed governor of Jamaica, on his instruçtons. I726.

Answers by Ayscough, president of council, to inquiries on trade of Jamaica. Oct., I726.

Accounts current to Apr., I725; also accounts of imposts and of fortifications.

List of fifty vessels lost or damaged in hurricane of Oct. 22, I726, giving tonnage, from what ports and to what ports, bound, number of men carried, etc.

17. I727-I 729.

Papers on final passage of perpetual revenue act. I727-1728.

Further letters, memorials, orders in Council, etc., on duties on negroes, and on instructions sent to governor forbidding him to assent to any act placing duties on negroes brought in for refreshment only. Show part played by private traders in slave-trade, and resentment 
felt in Jamaica against South Sea Company on account of its interference with private trading. I727-1728.

Letter from Ayscough. Sufferings of regular troops in consequence of assembly's refusal to provide subsistence, pending settlement of revenue dispute. Dec. 19, I727.

Accounts current, Lady Day, I725, to Lady Day, I728.

Accounts of imposts and of fortifications, Apr., I725, to Lady Day, I728.

18. I729-1730.

Two orders in Council, confirming the perpetual revenue act and act to compel employers to provide themselves with a certain proportion of white servants. May 22, I729.

Letters from Gov. Hunter. Describe beginnings of negro insurrection, and "the Spanish design" against the island. Mar. I2, I729/30; July 4 , I730.

$I d$. Unreliability of white servants, who make up most of the militia, and who are mainly "native" Irish. Obstruction offered in assembly by Irish lawyers, and reasons for passage of "Act for preventing Dangers from disguised Papists”. July I7, Sept. 6, I729.

Account of ordnance and stores. I728.

A calculation of the quantity and value of produce and manufactures of Jamaica shipped annually to Great Britain.

Minutes of councils of war. Jan. 7, I728/9; Apr. 7, 8, 29, June 30, I729.

19. $1730-1732$.

Numerous papers on negro insurrection and arrival of reinforcements.

Papers on protests against act for "the better Regulating. Slaves and rendring Free Negroes and Mullattoes more useful". I73I.

Address of governor and council on weak condition of island, decrease in white population, and danger from enemies and slaves. Nov. 21, I730.

Letter from Hunter, enclosing unusually full replies to queries of Board, which include reports on: soil, produce and manufactures shipped annually to Great Britain; value of such produce and manufactures in pounds sterling and Jamaica currency; cost of freights to Great Britain and amounts of duties and excise paid there; numbers and values of slaves, stock, and sugar-works; numbers of men and vessels engaged in different branches of trade; measures taken to prevent illicit trading; statistics on population by parishes, distinguishing different classes, ages, and sexes; statement on the extent of, and reasons for, decrease in whites; amounts received and spent for militia, and for the garrison; and lists of military and civil (including patent) officers, with salaries paid. Dec. 24, I730.

Letter from Hunter, on trade of South Sea Company at Porto Bello. Apr. 2I, I73I.

Three petitions from merchants trading to Jamaica, Society of Merchants Venturers of Bristol, and "Merchants and Owners of ships of and in the Port of Liverpool", against laying of duties on negroes. I73I.

Petition of planters, merchants, and traders of Jamaica, asking for encouragement in planting of coffee, which is proposed there and in other sugar islands. I730.

Papers on quarrel between council and assembly over nomination and control of an agent. 
Letter from Hunter, explaining that imposition on convicts is necessary to prevent their coming in from the North. None come direct. More complaints of lazy and useless "native" Irish, who come cheap and serve for deficiencies. Nov. I3, I73I.

"Address and Representation of the Council of Jamaica to His Majesty relating to the unhappy situation of the affairs of that Island, by the Increase and Success of their Rebellious Negroes, the Decrease of White People, the Decay of Trade and Planting, and the pernicious Trade from thence and our Northern Colonies to the French and Dutch Sugar Plantations." Nov. 27, 3I.

"Address and Representation of the Assembly of Jamaica relating to the languishing Circumstances of that Island . . . and the pernicious Practice of the Northern Colonies Supplying the French and Dutch Sugar Colonies with Necessaries for Carrying on their Works." Undated. Read Mar. 23, I73I/2.

20. $173^{2-1733 . ~}$

Accounts of the negro insurrection.

Petitions and memorials from South Sea Company, council and assembly, merchants of London, and merchants of Liverpool, concerning duties on slaves. An interesting unsigned paper, endorsed "Observations on the Assiento Contract", designed to meet charge that Asiento agreement is injurious to Jamaica. I $73^{1}-173^{2}$. Order in Council, for instructions forbidding governor to assent to any act placing duties on negroes and convicts. Dec. 9, I73I. Id., for instructions forbidding assent to any act laying duties on negroes exported within twelve months of arrival. Oct. I3, 1732 .

Papers on act for regulating slaves and rendering free negroes and mulattoes more useful.

Letters from Hunter, on quarrels between council and assembly over right of council to amend money-bills.

Id. Threatening acts of Spaniards in Cuba. Mar. 27, I733.

21. I733-1735.

Letters, petitions, and other papers on levy of duties on negroes. In particular, memorial of South Sea Company, reviewing history of affair from I7I7 to date. Nov. 22, I734.

Letter from Newcastle, directing that governor furnish to Board information to be used in compiling "state" of British islands requested by House of Lords. Apr. 5, I734.

"Letter from Mr. Oxenford, Assistant Inspector General, with Accounts of Imports and Exports to and from England, Jamaica, etc." Totals given for all $\mathrm{Br}$. W. I. Nov. 2, I734.

Order of Committee of Council that Board, together with attorney general and solicitor general, prepare draft of act to vacate exorbitant grants of land in Jamaica, for passage by council and assembly there. Governor to be instructed that his Majesty expects council and assembly to "comply with such measures as His Majesty judges necessary for their own Happiness and Security". In case of noncompliance the matter to be laid before Parliament. July 2, I735.

Two memorials from Gov. Cunningham. Decline of Spanish trade "since the Assiento contract and the Annual Ship sent to those parts by the South Sea Company"; resulting decrease in revenue; lack of currency; need for ordnance stores. Oct. I8, Nov. I, I734. 
Various papers on measures for suppression of negro insurrection, arrival of reinforcements, and offers of pardon to rebels.

Representation of council and assembly, declaring that population and prosperity of island are diminishing, on account of "the Establishing a Factory of the South Sea Company" and "the Farming the (logwood) Trade to Campeachy". These measures have deprived Jamaica of support of 2500 seamen. To restoration of prosperity of declining sugar colonies nothing would be so conducive as "the Carrying our Sugars directly to Forreign Marketts and the lowering of the Duty upon Rum . . . as proposed by Your Lordships". May 2, I735.

22. $1735^{-17} 3^{8}$.

Order in Council, for additional instruction, that governor secure passage of law vacating exorbitant grants of land. July 30, I735.

$I d$., for empowering governor to assent to act laying reasonable duty on negroes purchased in island, provided such duty payable by purchaser. July 9, I735.

Papers on act for "the more effectual directing the Provost Marshall's proceedings".

Order of committee of Council, referring "Memorial and Proposal of the Merchants of London, Bristol and Liverpool relating to the State of and better settling the Island of Jamaica". Oct. 27, I735.

Papers on discrimination against Jews.

Letter from Gregory, president of council, forwarding, with useful comments, following important accounts. Apr. 10, 1736.

Accounts, by separate years, of money raised, I $725-1735$, by imposts on wines and spirits, quit-rents, gunpowder tax, wine licenses, fines, forfeitures, and escheats.

Corresponding accounts of money raised on importation and exportation of negroes, $1725-1732$, showing numbers imported and exported, and rates charged.

Corresponding accounts of money raised, I725-I 735, by the following taxes: deficiency tax; tax on Jews; poll-tax on slaves and cattle; tax on house rents in Spanish Town and Kingston; tax on public offices; duty on negroes purchased in the islands (for $\mathrm{r} 733$ and I734 only); tax on hiring-out of slaves as "tradesmen", etc.; tax on "Trading Inhabitants of St. Catherine's and Kingston"; tax on retailing of rum (the last three for I734 only); tax on shipping, for repair of wall at Port Royal (for I730, I73I, and I732); and import duty on Madeira wine (Sept., I 734-Mar., I735, only).

Accounts of totals raised in each year from all above sources.

"Account of what Laws were in force on the I2th of May I735 in the Island of Jamaica by which any Duties, or Impositions etc. were payable on the Importation or Exportation of Negros, Wines or other kinds of liquors, or any goods wares or merchandise, and on Shipping."

Letter from William Wood, who wishes to print laws of Jamaica, and asks to be allowed to take copies, as he was permitted to do when he printed laws in 1716 . June 30,1736 .

Letters from Gregory, with enclosures, on alleged improper seizures of British vessels by French and Spaniards, and of French vessels by British in the Windward Islands. Dec. 28, I736; Nov. 25, 1737. 
Papers on granting of any gold or silver mines which may be discovered in Jamaica.

23. $\mathrm{I} 738-\mathrm{I} 743$.

Letter from Trelawney, stating that unpatented land in Jamaica is "enough and upon all accounts as good as that already planted"; and asking for grant to be used in assisting settlers, "even though it were only a third or fourth part of what has been granted to Georgia". Mar. 30, I739.

Copy of treaty made with rebellious (maroon) negroes. Mar. I, I738/9. Further papers on special taxation of Jews.

"Account of all Receipts and Payments of all Publick Money from the 29th Septbr. I735, to the 29th Septbr. I738."

Letter from Sharpe, agent for Jamaica, requesting confirmation of a number of acts, of which one (for "quieting possessions") was passed in I73I, and two in I733. July I6, I740. Petition to Board from Sharpe on same subject, claiming that failure of Board to report on acts relating to land tenure is retarding settlement. Undated. Read Dec., I74I. Instructive letter on same subject from Trelawney. Nov. 2I, I74I.

Letter from Trelawney, referring to recent printing of laws of Jamaica. Dec. I4, I740.

Order of committee of Council for additional instruction to governors of all states where acts imposing gunpowder duty exist, demanding strict enforcement, and sending of statements on methods of enforcement, with amounts collected. Colonies concerned are Jamaica, Barbados, the Bermudas, N. H., and Va. Apr. 9, I74I.

Three lists of persons naturalized under "An Act for Naturalizing such Foreign Protestants and others therein mentioned as are Settled, or shall Settle in any part of His Majesty's Colonys in America". Persons concerned are nearly all Jews, mainly with Portuguese or Spanish names.

Order in Council for sending to governor of Jamaica (as to other colonial governors) of additional instruction on colors to be carried by vessels having "private commissions or letters of marque issued by him". Sept. 8, I741.

Accounts of finances similar to those sent by Gregory (vide vol. 22), with answers to special queries as to settlement, cultivation, quitrents, and population. Forwarded by Trelawney, Nov. 2I, I74r.

Representation for confirmation of nine acts, passed I73I to date. Feb. $20,174 \mathrm{I} / 2$.

24. I $743-\mathrm{I} 748$.

Letters from Trelawney, with enclosures, on British and Spanish plans and operations in island of Ruatán, and in Bay of Honduras generally. Dec. 19, I743; Nov. 24, I745; Aug. 9, I747.

$I d$., on impressment of merchant seamen in Jamaica. Dec. 24, I743; Mar. 2I, I 745/6.

Lists of persons naturalized.

Orders in Council for sending of infantry and ordnance stores to Jamaica, which "is now become the grand Repository of Goods to be vended in that Part of the World". Extent of Jamaica's contribution to her own defense at this time partially shown. Sept. 6, I744; Mar. 27, I746; June 3 , I747.

Papers on grants of gold or silver mines. 
Letters from Trelawney, endorsing enclosed address from council and assembly, asking that chancery jurisdiction be vested in commissioners appointed by the king for that purpose. June I8, I746; Oct. I4, I747.

Id., containing interesting account of internal politics. July I4, I747.

Petition of number of planters against special taxes on absentees. Referred to Board Feb. I7, I746/7. Other papers.

Letter from Trelawney, asking to be instructed not to permit use of money collected as quit-rents for any purpose other than completion of fortifications. Nov. 14, 1747 .

25. $1748-1753$.

Letter from Trelawney, with enclosures, on Spanish raids on coast, and weakness of colony through absenteeism. Jan. I9, I747/8.

Id. Taking of Port Louis in Hispaniola; attack on Santiago de Cuba; and desirability of employing black troops. Mar. 12, I747/8; Apr. I 5,1748 .

$I d$. Retention at Cuba of fugitive slaves. July 4, I75I. Correspondence with governor of Cuba enclosed.

Id. Proposes negotiations with Darien Indians, describes conditions on Mosquito Coast, and urges establishment of civil government there. May 7, Oct. 7, I748; Apr. I4, I750; July I7, I75I.

$I d$. Suggests disallowance of triennial act recently passed. May Io, I748.

Order in Council, approving additional instruction to forbid governor to assent to any bill imposing extra tax on absentees, without suspending clause. June 30 , 1748 .

Letter from Trelawney. Foregoing order, condition of militia, lack of currency, and fall in price of sugar. June 8, I749.

Letter from Bedford, enclosing address from governor, council, and assembly, asking that instruction regarding taxes on absentees be revoked. Mar. I9, I749/50.

Two letters from Trelawney. Financial conditions produced by fall in price of sugar on signing of preliminaries of peace, and lack of currency have made people prefer possible capture to certain ruin entailed in providing for defense; and have rendered it advisable that import duties on negroes be permitted. June 8, I749.

$I d$., enclosing account of negroes imported and exported, and numbers sold to planters, I739-1749. July I, I749.

$I d$., enclosing address of governor, council, and assembly on trade of northern colonies with French sugar islands, and, in particular, "a most Pernicious Intercourse and Commerce between the French of Hispaniola and your Majesty's Colony of Rhode Island". Other enclosures, relating mainly to capture of the Enterprize, examination of her master, Richard Mumford, before assembly, and correspondence between "M. L'Cholet" of Santo Domingo and Mr. Nicols of R. I. Dec. 4, I749.

Lists of persons naturalized, distinguishing Jews.

Letters from Trelawney, explaining that need of money has forced him to assent to bill placing money raised in hands of commissioner instead of those of receiver general. Apr. IO, I750.

Opinions of Matthew Lamb. On act placing tax on negroes, with special tax for absentees. Nov. 2, I748. On jurisdiction of Bishop of London in Jamaica. Jan. 28, I749/50. On acts, regarding tenure 
of judges ; placing tonnage duty for fortifications ; for quieting possessions; and "for Choosing the Members of the Assembly of this Island by Ballot, and for the more effectual Preventing Abuses and Indirect practices in Elections". Nov. 20, 1752. On acts appointing commissioners to receive public money. (Stated that one act was designed in part to prevent frauds by persons trading to northern colonies.) Feb. 6, I750/I ; June 6, I753.

Letter from Trelawney, on dealing with exorbitant grants of land. These now causing some discontent. He sees for first time possibility of obeying instructions on this point. Also, threat to place matter before Parliament has had some effect. Suggests tax on uncultivated land, though many in island fear precedent of any land tax. Sept. I6, $175 \mathrm{I}$.

Letter from Holdernesse, sending copy of address of House of Commons to the crown, desiring that directions be given to Board to lay before Parliament account of settlement, land laws, trade, fortifications, etc., of Jamaica. Mar. 28, I752.

Order in Council, approving representation of Board for repeal of act limiting duration of assemblies. June 30 , I 752 .

Letter from Trelawney, on acts recently passed. Act for restoring credit of island very important in that real estate applied for first time to payment of debts. Tried to obey instructions in having suspending clause inserted, but "that is a point they never can be brought to". Succeeded only in having operation deferred. Regarding act giving judges tenure during good behavior, "a standing body of planters made judges for life would have a much greater influence and authority in this Island than the Governor and council appointed by His Majesty". Planters dislike idea of judicial appointments from England. Mar. 25, I753.

$I d$., sending account of island, which includes statement of laws made since I734 on land grants, cultivation, and encouragement of newcomers, and on operation of these laws; also brief statement of trade with northern colonies. Aug. I 5, I752.

Id. Suggests repeal of clause of act of 25 Car. II. which compels merchants from northern colonies to pay duties on clearing out from Jamaica. Considers this one reason for extensive trade of northern colonies with Hispaniola. Aug. 15,1752 .

Letters from Gov. Knowles. These give clear and detailed description of enforcement of acts of trade in Jamaica in entrance and clearance of vessels, and point out changes made or projected. Habitual understatement of tonnage in registers, for avoidance of duties. Descriptions of, and statistics on: trade of North Americans, as well with French islands as with Jamaica; illicit trade at Jamaica; loss of currency through decline of trade with Spaniards; unsatisfactory condition of fortifications; success of assembly in making itself preponderant element in government of Jamaica. Suggests remedies for many of these conditions. Nov. I8, I752; Jan. IO, I753. Enclosed: copy of "Declaration concerning a Clandestine Trade carried on between Philadelphia and the French Sugar Colonies"; and list of ordnance stores required at Jamaica.

"An Humble Address of the Council and Assembly of Jamaica relative to the present State of that Island": military weakness; large sums raised by inhabitants for defense; loss of Spanish trade; lack of 
currency; pernicious effects of trade of northern colonies with Hispaniola and other foreign settlements (statistics given); need for better protection and for outside assistance in planting and settlement, etc. Ask for total exclusion of French produce from northern colonies, and other changes. Nov. 22, 1752. Enclosures. (Important.)

Order of committee of Council, referring foregoing to Board, and ordering such parts of it to be incorporated with "state" of Jamaica, now being prepared for House of Commons, as Board may think necessary. Feb. 20, I753.

Copies of letters, Knowles to Holdernesse, on events on Mosquito Coast. Jan. I, Mar. 26, I753.

Opinions of attorney general and solicitor general on acts concerning tenure of judges, election of members of assembly by ballot, quieting possessions, regulating fees of provost marshal, etc. June 22, I753.

Petition of receiver general of Jamaica against recent acts providing for payment of public monies to commissioners. I753.

"An Account of Gun Powder Received on the Duty of Tonnage on all ships and Vessels that arrive at Jamaica of One Pound of Gun Powder per Ton, as appears by their Registers. In Pursuance of the Revenue Law passed April 1728." Sept. 29, I745-Mar. 25, I753. Yearly totals.

"An Account of the State of His Majesty's Revenue in Jamaica as it stood on the 25th of March I753."

26. $1753-1754$.

Letter from Knowles. Complains of improper procedure in entering and clearing of ships, and of preponderant influence of assembly in government. Despairs of any success as regards use of suspending clause. Assembly's recent bill to exclude all officers of the crown from council and assembly passed because some of said officers are properly servants of the two houses, and inclusion of one more patent officer in council would have given crown officials control there, removing necessary supervision of their activities. Sept. I3, I753.

Various papers on disallowance of ten acts: giving judges of supreme court tenure during good behavior; quieting possessions; establishing use of ballot in elections for assembly; appointing commissioners of nisi prius and enlarging jurisdiction of justices of the peace; regulating proceedings of provost marshal; excluding certain officials from council and assembly; providing subsistence for troops through temporary deficiency act and temporary duties on wines and spirits, etc.

Papers of varied interest on suit brought in court of chancery against Edmund Hyde, member of council, for non-payment of legacy from estate for which he was executor. Hyde suspended from council for circulation of paper reflecting upon court of chancery. Appeal in case carried to Privy Council. Papers give rare and valuable information on laws of property, current system of long extended credit, interest rates, etc. Of particular interest are: (I) inventory of negroes and plantation utensils on estate in question, with values; and (2) inventory and appraisement of all goods and chattels, rights and credits of testator, including negroes, Spanish currency, etc., 
and long list of debts due, with particulars as to how each was incurred, what interest paid, etc.

Petition of merchants, factors, and agents of Jamaica, praying for removal of seat of government to Kingston. Forwarded by Knowles, Feb. 5, I754. Long list of signatures.

Letter from Knowles, complaining that in Jamaica royal prerogative is "scarcely acknowledged". Feb. I3, I754.

27. I754.

Letter from Knowles. Disputes with assembly over latter's refusal to frame bills in compliance with governor's instructions as to custody of public money, period for which subsistence money should be granted to troops, and use of suspending clause. Jan. I2, I754.

Account of contingent charges of government, met from proceeds of deficiency bill, and duties on rum and negroes.

"Account of the value of the Produce of the Island of Jamaica in the Year I753, as taken from the Collector and Naval Officer's Books, and the justest Computation that could be got." Incidentally gives rate of currency and "The Contingent Charges of Estates which is $1 / 4$ of the value of their produce and $12 \mathrm{p}$. Ct. likewise for getting home their Commoditys to Market".

Account of yearly collection under revenue act, with calculations on average per capita income and taxes, and estimates of amounts spent in encouraging settlement of white population.

Detailed "statement of His Majesty's Revenue in the Island of Jamaica on the 27 th of October I753".

Detailed list of appropriations under annual money-bills passed since Apr. 27, I745.

List of bonds in receiver general's office, with amounts of principal and interest involved in each case.

Extracts from minutes of council, Sept. I8-Nov. 25, I753; and of assembly, Jan. 6-Nov. 25, 1753 .

Letter from James Gerrard, on illicit trade between Scotland and Jamaica, whereby continental manufactures are introduced into the colony. Jamaica, Feb., I754.

Letters from Knowles. Invasion of royal prerogatives by justices of supreme court in holding courts without authorization. Apr. IO, I8, I754.

$I d$, on new maroon insurrection. Mar. I2, I754.

Papers on removal of seat of government to Kingston.

28. I754-I755.

Letter from Knowles. Severe punishment inflicted on a stranger for "inveigling" a negro. June 20, I754.

Accounts of revenue balanced to Mar. 25, I754.

Letter from Knowles. Courts of nisi prius held in spite of disallowance of act for appointment of commissioners of misi prius, on alleged belief that act remains in force until royal disallowance received in form. June 24, I754.

Id., sending report of proceedings on two Spanish vessels seized for illegal trade. June 25,1754 .

Jamaica Courant. June 22-29, I754.

Papers on dismissal of attorney general for declining, "on frivolous excuses", to attend the governor when ordered. 
Papers on removal of seat of government to Kingston, giving information on internal politics, and extensive lists of names. Change in location alleged to be for purpose of transferring control of island from landed interest to "factors of Bristol, Liverpool and the noble kingdom of Scotland". Bitter feeling and insults to governor. Order kept by troops.

Papers on quarrels of governor with justices of supreme court, who claim position of justices of king's bench in England.

Letter from Knowles, sending "state" of island. Brief, but accompanied by valuable tables, showing:

(I) For each plantation in St. Andrew's parish name of plantation and of owner, total acreage, acreage devoted to each principal product, to provisions, to pasture, and to woodland, number of white servants, negroes, and cattle.

(2) Account of white families and artificers introduced under acts of Dec. 2, I749, and Nov. 27, I752, showing name and extent of each family, etc.

(3) Account of white persons who came to island under acts of May 15, I732, May 21, I743, July 2, I747, and Oct. 27, I750, showing for each family the number, names, dates of patents, expenses involved, number of acres received, etc.

(4) Report of committee of assembly on encouragement of white settlers. Oct. 2I, I752.

(5) Receipts and expenditures connected with works at Bath.

(6) Accounts of forts.

(7) Bonds (escheat and quit-rents) in receiver general's office, with account of what is due on them. Aug. 20, I754.

(8) "Dockets of the Patents of Land vested in His Majesty for the use of the New Comers by virtue of the Laws made for Encouragement of new Settlers since I734."

(9) "A List of Ships that have entered at Jamaica from Africa between the 22nd September 1752 and 25 September I754 with the Number of Negroes imported and exported." Gives names of vessels and masters, dates, persons to whom negroes consigned, etc.

Answers to queries of Board of Trade, with particulars of legal and illegal trade in various branches, consumption of British manufactures, natural produce, manufactures, revenues, land system, defense, population, etc.

29. I $755^{-1} 757$.

Papers on disputes of Knowles with assembly over use of suspending clause, raising, custody, and expenditure of public money, and denial by assembly of right of the crown to issue writs for election without message from assembly.

Opinion of attorney and solicitor general respecting four acts on removal of seat of government. Governor has exceeded instructions in assenting. Dec. $27,1754$.

Letter from Henry Fox, with list of papers for which House of Commons had addressed the crown. Papers cover disputes of Knowles with assemblies. Jan. 26, I756.

Addresses and representations of council and assembly on latter's disputes with governor and council. In particular, on propriety of 
recent dissolutions of assembly and alleged official influence in elections. Sept.-Nov., 1756 .

Letter from Lieut.-Gov. Moore, sending depositions on treatment of French prisoners. Oct. I, 1756 .

Address of lieutenant governor, council, and assembly on defense of island. Oct. I 5,1756 .

Order of committee of Council, referring to Board papers on disputes over seat of government. Jan. 25, I757.

Letters from Pitt and Holdernesse, on submission to Parliament of papers on disputes. Feb.-May, I757.

30. $1757-7^{-1759 .}{ }^{1}$

Opinions of attorney and solicitor general on acts concerning entrance and clearance of shipping, location of courts, registration of deeds and patents, and appointment of commissioners of nisi prius. May, I757.

Letters from Moore. Recent proclamation of martial law, use of militia, etc. Apr. 26, 27, 1757.

Papers on opening of ports of entry.

Letter from Samuel Dicker, property owner and former resident of Jamaica, on change in seat of government, this involving some discussion of the two towns and of system of courts. Nov. 16, I757.

Letter from Rose Fuller, on ports of entry and circuit courts. Nov. 20, I752.

Papers on dispute of Moore with council, over latter's refusal to sit after proclamation of martial law, claiming that "the High Court of Parliament" can no more sit under such conditions than other courts.

Letter from Moore. Sends statistics of troops fit and unfit for duty, by months, July, I756-May, I758, and list of barracks with capacity of each. Feb. 7, I758. (Data taken from minutes of assembly.)

Papers on draft of act to divide Jamaica into three counties, and to appoint justices of assize and of oyer and terminer in two of them. June 15,1768 .

Letter from Stanhope, agent of island, asking that more troops be sent out. Feb. 24, I758. Other papers.

Letter from Moore, on repeal of acts for establishing ports of entry and circuit courts, and on reinstatement in council of chief justice and three others. Oct. 3, 1758 .

$I d$, , on repeal of act to encourage settlers, which has cost $f 6000$ without yielding returns; on act to ascertain value of milled Spanish money; on scarcity of currency, especially since the Spaniards called theirs in, in order to mill the edges; and on rates of currency, as fixed by law and as actually prevailing. Feb. 25, 1759.

Papers on appeal to postmaster general of Great Britain by deputy postmaster general of Jamaica, against removal from office by lieutenant governor and assembly. Contain much information on appointment and control of officials in colonial postal service, methods of carriage, rates, and quality of service rendered. 1759.

Letter from Moore, complaining that trade carried on at Monte Cristi by vessels from northern colonies and elsewhere enables French to maintain privateers which injure W. I. commerce. Mar. 28, I759. Encloses "A List of Ships and Vessels spoke with by His Majesty's

\footnotetext{
${ }^{1}$ Neither this nor the preceding volume contains more than the most incidental references to the war.
} 
Sloop Viper in Monte Christi Harbour the 5th February I759"; giving very full particulars on nature, activities, control, etc., of each vessel listed.

Letter from Gov. Haldane. Announces his arrival, and discusses differences between trading and plantation interests in island. Apr. 3; I759.

Id. Affairs at Mosquito Coast. May I I, July 20, I759.

Id. Capture and bringing into Jamaica of several vessels from N. Am. colonies laden with French produce from Monte Cristi and other places. June 2, I759. Enclosures give reports of examinations of Benjamin Tucker of the Dolly, John Northam of the Defiance, Harper of the Penguin from R. I., Nathanial Davis of the Speedwell, Constant Freeman of the Betty of Boston, Thomas Mansfield Cooper of the Fair Lady of Salem, and Nicholas Tracy of the Dolly of Massachusetts Bay.

Letter from Moore. Affairs at Mosquito Coast. Aug. 28, I759.

31. $1758-1760$.

Letter from Moore. Affairs at Mosquito Coast. Nov. IO, I759.

Matthew Lamb's recommendation that act for ascertaining value of Spanish milled money be disallowed. Nov., I758.

Order in Council, forbidding council of Jamaica to name its own clerk, and directing that that office shall, as in past, be appendage to office of secretary of island. May 8, I758.

Id., creating ports of entry at Kingston, Savannah la Mar, Montego Bay, and Port Antonio; and directing that receiver general, naval officer, collector of customs, secretary of island, and all other officials connected with trade of Jamaica shall attend at, or keep representatives at, said ports. June 29, I $75^{8}$.

$I d$., for disallowance of act "for the settling of mutual Debts one against another". Aug. IO, I759.

32. $\mathrm{I} 760-1762$.

Letters from Moore. Negro insurrection. Suspension of Thomas Bullock from court of vice-admiralty on charges of injustice and partiality. Apr. I9, Aug. 20, I760.

Id. Condition of militia. Nov. 7 , I760.

$I d$. Explains his action in signing acts which placed extra taxes on absentees, or which should have contained suspending clauses. Jan. 2, I 760 .

Memorials and other papers on inadequacy of garrison. I760.

Letter from Commissioners of Customs on act of Jamaica, I759, for prohibiting importation of produce of foreign colonies and preventing frauds by persons trading to northern colonies. Provisions are contrary to 7 and 8 Will. III., c. 22 , sec. II, and to I3 and I4 Car II., c. II, sec. I5, which provide that seizures may be made only by Commissioners of Customs. Act is objectionable also in assigning entire proceeds to persons making seizures. June 20, I76I.

Letter from Moore, forwarding address of council and assembly complaining of trade at Monte Cristi. Jan. 26, I762.

Numerous papers on military events, danger to island, and measures for defense.

Copy of manifesto published at Madrid, Dec. I5, I76r. 
Sir James Douglas to Lyttelton, on latter's complaints that Douglas refuses to report operations of squadron and to give the governor proper salutes. Apr. I5, I762.

Accounts current of revenue. July, I759-Dec., I76I.

Letter from Lyttelton, on flags of truce. July 3, I 762 .

Id. Proceedings in assembly on his recommendation that it repass certain acts after elimination of provisions objected to by Board of Trade. Assembly resolved that "they are by no means disposed to submit their sentiments to the determination of Their Lordships, nor ever will at any time suffer them in any respect to direct their procedure by any proposal or decision whatever". Assembly further proceeded to appoint committee of inquiry into number of acts "which appear not to have been reported upon by the Board of Trade", since I 25 , "intending, as I am well informed, to ground thereupon a charge against Your Lordships' board of having neglected to have laid many of their laws before the King". Has prevented further measures by prorogation; "but I must observe that I have not even the Council with me upon this occasion". In spite of assurances of loyalty, "there is nevertheless, so far as I am able to judge, such an eager desire to be free from those restraints which the wisdom of His Majesty's Councils have put them under, in common with the rest of His Majesty's colonies . . . and such an aspiring endeavor to acquire in their assemblies ... the same powers and privileges as are enjoyed by the British House of Commons, as I humbly conceive may well deserve the consideration of His Majesty's Ministers". This attitude especially shown in persistent refusal to insert suspending clauses, and attempts of assembly to get its way through refusal of supplies. Other constitutional questions also reviewed at length. Oct. I3, I762.

$I d$. Sends resolution of assembly accusing Board of "misrepresentation of the constitution of this colony", and defines at length opinion of assembly as to its proper relations with the crown. Oct. 24, I762.

33. $1762-1765$.

Letter from Lyttelton, on continuance of constitutional disputes with assembly. Jan. I2, I762.

Letter from Stanhope, on inquiry to be held by Board on act respecting grants and devises to negroes. May 9, I763. Other papers, showing that act represented attempt to correct increasing ratio of blacks to whites, and throwing much light on conditions arising therefrom.

Letter from Lyttelton, on dispute with assembly over fees demanded by crown officials. Jan. I2, I763.

Account of powder collected at outports. I756-I762.

Letter from Lyttelton. Refusal of clerk of assembly to allow governor to see minutes without permission of assembly, and oath of secrecy delivered to clerk. July 9, I763.

Answers to customary queries. I763.

Letter from Lyttelton, with historical account of remuneration of lieutenant governors and presidents. Aug. 30, I763.

Order in Council, referring act placing additional taxes on absentees. June 29, I76r. Other papers.

Letter from Halifax, forbidding seizure at Jamaica of Spanish vessels coming in for refreshment. May 12, I764. 
Letter from Lyttelton, on dispute between council and assembly over control of agent. Jan. I, I764.

Id. His activities in obeying recent orders relative to suppression of trade with Spaniards and other illegal trade. Apr. 2, I764.

Papers on conditions at Mosquito Coast.

Order in Council, referring petition of certain merchants of London that a member of council be removed in order that they may sue him for debt. June 6, i 764 .

Proceedings in committee of Council on request of council and assembly of Jamaica that import duties on their produce be lowered, and that further troops be stationed there. Apr. I6, I764.

Letter from Lyttelton. In obedience to orders, he is no longer seizing Spanish vessels which enter for refreshment. July I6, I764. Enclosures.

Many papers on dispute as to privileges.

Petition from secretary, legislative officers, and collector of customs, for relief against lawsuits commenced against them for taking of fees. Feb. 20, I765. Other papers.

34. $1765-1768$.

Letter from Joseph Maud to Lyttelton. Conditions at Honduras. Oct. 7, I765. Ottway to Board of Trade on same subject. Jan. 20, I766. Other papers.

Account of proceedings in Council on proposal to lay before Parliament papers on the "extraordinary proceedings and resolutions of the late assemblies" of Jamaica. "Mr. Conway . . . acquainted Their Lordships that the great attention necessarily given to the American affairs before Parliament has prevented anything being done on this subject". May 28, I766.

Letters from Lyttelton, on developments of the dispute over privileges.

Id. Duty imposed on importation of negroes intended for exportation. Gives much information, with statistics, on financial and economic conditions. Oct. 8, I765. Enclosures, showing collection of revenue and expense of maintaining troops.

$I d$. "The good order of the Government has been preserved . . . and particularly the act of Parliament for laying a stamp duty has been duly carried into execution." Dec. 24, I765.

Letter from Lieut.-Gov. Elletson. Sends, with comments, resolutions of assembly on power of governor to appoint and dismiss judges and other officials. Developments of dispute over privileges. Sept. 29, I 766.

Id. Suspension of Douglas, late collector, for failure to make account of receipts at outports; involves question whether governor and council had power to compel collector to appear with books, and on refusal to commit him for contempt. Jan. 4, I767.

Id. Dispute with council, involving question of its privileges. Mar. I8, I 768.

35. I768-1770.

Papers on act limiting transfers of property to negroes and descendants of negroes. I768.

Opinions of Richard Jackson on various acts.

Stephen Fuller to Rose Fuller. Sends lists of expired acts, taxing masters of vessels and supercargoes, and for raising and appropriating money for fortifications. July 6, I770. 
$A$ Letter to the Public concerning the Policy of this Country on a Difference in Opinion relating to the Appropriation of the Surplusage of Monies, etc. (I769 ?).

Text of act "for Applying the Surplusage of Money already arisen or that shall arise by Virtue of an Act Intitled 'An Act for granting a Revenue to His Majesty' . . . to certain Uses”. I769.

Papers on Mosquito Coast.

36. I770-I772.

Order in Council, forbidding governor to assent to any bill with riders or clauses for applying surplus arising from operation of the revenue law. Dec. 9, I770.

Reports of Richard Jackson on acts for raising money.

Account of condition of forts. I770.

Numerous papers on currency question.

Lamb's opinion on act to prevent counterfeiting of coins. Mar. 3I, I776.

Letters from Trelawney, on currency. Apr. I2, Oct. 4, I77I ; Jan. 27, I772. Other papers, relating to counterfeit coins manufactured in N. Am.

Papers on Mosquito Coast.

37. I77I-I777.

Opinions of Richard Jackson on various acts.

Letter from Trelawney, on coinage bills. July I3, I772.

Proceedings and orders in Council on payment of treasury requisition, appropriation of surplus revenue, change in electoral constituencies in Jamaica, and import duties on slaves. June, I770-Feb., I 775.

Letter from Gov. Dalling. Decline of trade with Spaniards. Apr. II, I773.

Opinions of Richard Jackson on financial bills. Apr. 23, I773; Oct. I, I774.

Memorial of Stephen Fuller on additional duty bill placing duties on slaves. June 6, I775. Other papers.

Report of Richard Jackson on act forbidding vessels carrying produce of foreign colonies to enter any port or harbor which is not a port of entry. Mar. I7, I775.

38. $\mathrm{I} 778-\mathrm{I} 78 \mathrm{I}$.

Deals chiefly with acts of assembly and reports thereon.

Memorial of Stephen Fuller. Jan. 30, I778. Appended is an account of the number of negroes imported and exported at Jamaica each year from 1702 to I775, which is printed in F. W. Pitman, The Development of the British West Indies, I700-I76 3 (New Haven, I9I7), Pp. 39I-392.

39. I 780-I78I.

Mainly judicial and constitutional matters.

41. I702-I7I9. Abstracts of governors' letters, from Board of Trade, Original Correspondence.

42. I720-I737. Id. (Incomplete and sometimes misleading.)

43. I737-I753. Id. (Classed as abstracts, but more properly brief and unsatisfactory descriptions of general conditions.)

C. O. i 37:46-i4i. Secretary of State: Original Correspondence.

46. I I I I-I 728 . I7II-I8I5.

Letter from Board of Trade, "showing by what Power and Authorities the Admiralty Jurisdiction is Exercised in the Plantations". Oct. 26, I7II. 
Id., on manner in which troops have been subsisted in Jamaica. Mar. 9, I 7 I $3 / 4$.

Papers on Hamilton's dispute with assembly. I7 6.

Report of Board of Trade on memorial of South Sea Co. I7i6.

"Extracts of Minutes of Council and Journal of the Assembly of Jamaica, Letters and other Papers in the Office of Trade and Plantations in relation to the memorandum delivered in by Mr. Pitt." Pitt asks to be informed: whether assembly has power to adjourn itself; whether council has right to amend money-bills; whether assembly may appoint persons other than receiver general to collect public monies; and what shall be done to subsist troops if assembly refuses to provide for them. He asks to be instructed to recommend to assembly repayment of money advanced for subsistence to soldiers; and inquires what ought to be done regarding other debts of government of Jamaica not provided for, and towards securing more settlers and increasing the permanent revenue. He also asks about privilege of members of council and assembly in suits at law, application of real estate to payment of debts, and proper attitude of governor towards raising subscriptions to solicit affairs of island in Great Britain. He requests that ships of war may be sent to Jamaica and placed under orders of governor; and that governor have power to appoint clerk and other officials of assembly. The "Extracts" supply hundreds of precedents on these points, dating back to 1662, and otherwise furnish in part answers to questions raised. I7ı. 58 pp. (Valuable.)

Papers on piracy, some not noted elsewhere. I7I6-I7I7.

Extract of letter from Heywood to Board of Trade, on distressing condition of troops in Jamaica. Dec. 3, I7 I7.

"Representation from the Board of Trade to His Majesty relating to the cutting of Logwood in the Bay of Campeachy." I7 I7.

Copy of memorial from Lord Archibald Hamilton on his difficulties with members of council and others. I7I7.

Surveys of ordnance. I7I8.

"Petition of merchants of London to the Lords Justices that commanders of war vessels threaten to seize British vessels trading on the coast of New Spain." Read June i6, i7ig.

Report of proceedings of Lords Justices in Council in consideration of report of committee of Council on acts passed in Jamaica for making perpetual his Majesty's revenue, and for declaring what laws are in force in the island. Aug. 6, I723. Many 'other papers on question of perpetual revenue.

Ayscough to Newcastle, stating that Adm. Hosier and his officers are demanding men in the W. I. although they have already impressed about I000 seamen from the trade of the islands. Feb. Io, I726/7.

47. I729-1734.

Correspondence with Maj.-Gen. Hunter on militia, defense, and plans of Spaniards.

Out-letters on military matters, including drafts with interesting corrections in Newcastle's own hand. I729.

Petition of Jamaica merchants, asking that Hamilton be ordered to remove embargo. June $17,1729$.

Papers on disorders in Jamaica and need for increased protection. In particular: draft of letter to Hamilton on sending of regiments from 
Gibraltar and supply of military stores. The king has referred request for ordnance to Board of Ordnance with directions to apply to Parliament at its next meeting for sums necessary to defray expense. When these are granted by Parliament ordnance will be sent. Oct. 12, I730.

"Establishment" of two independent companies in Jamaica, showing pay of all ranks from captain down. Undated.

Many papers on negro insurrection.

Letter to Bernaert, merchant at Ostend, stating that regiments sent to Jamaica ostensibly against negroes are in reality to protect it against Spanish attacks. London, Oct. I2, I730. Unsigned. (French.)

Draft of letter to Board of Trade, on use to which regiments now in Jamaica may be put in promoting settlement. I73I.

Complaint from Royal British Asiento Company, and other papers, on illegal seizures of vessels by British and Spaniards. I731, I732.

48. $1735-1777$.

"A short view or abstract of the Principal matters in the Board's Representation to His Majesty concerning the Island of Jamaica." Gives brief historical outline of developments in government. I735.

Papers on Spanish depredations, with some information on trade of South Sea Company. I737.

Papers on British activities in Bay of Honduras, I737-I777, including: Bladen to Newcastle, Mar. I8, I737/8; and Sir William Godolphin to Earl of Arlington, Madrid, May 10/20, I672, on cutting of logwood in Bay of Campeachy.

Letter from John Sharpe, on trade of Jamaica with Hispaniola. Nov. I3, I738.

Petition of merchants, on improper seizure of vessels by guarda costas. June I, I739. Other papers, including copy of commission to guarda costa issued by president of Santo Domingo.

Papers on complaints of governor of French Leeward Islands on seizure of French vessels by Vernon. I740.

Vernon to Newcastle, on naval operations. Dec. 12, I740. Papers on reasons for attacking Santiago.

Memorial of William Bradley, on seizures by Spaniards, and giving information on methods of trade with Spaniards. I752 (?).

Papers on trade with French by means of flags of truce. I745.

49. I779-I786.

Letter from Stephen Fuller, dealing with enemy forces at Santo Domingo. Aug. 20, I782.

Memorandum, undated and unsigned, showing tonnage of vessels employed in trade between America and Jamaica. Sept. 29, 1783Sept. 29, I784.

50. I $787-1821$.

Contains some papers relating to the Mosquito Shore.

51. I704-I72I. Letter from Handasyd, no. 20. Practically identical with letter to the Board of the same date. Apr. 9, I7Io.

$I d$., no. 22. Quite different in parts from letter to the Board of the same date. Deals largely with condition of British war-vessels and their probable success. Other parts of the letter quite similar. In general, difference pronounced. Few subjects discussed and those mostly have to do with war, numbers and plans of naval forces on both sides, capture of enemy merchantmen, etc. June 4, I7Io. 
Occasional letters of the Board to the Secretary of State show that both, as well as the island authorities, were interested in the Spanish trade. English vessels engaged in the Spanish trade disturbed by French privateers, etc.

Attorney general of Jamaica dies. The governor appoints his successor by patent under the great seal of the island during her Majesty's pleasure. On this Handasyd writes not only to Dartmouth as Secretary of State but to Rochester as "my lord President".

Copy of an act for quieting possessions.

Careful watching of Spanish galleons, especially at Cartagena (and sometimes Porto Bello), and plans for capture.

Correspondence with the Secretary of State shows more apparent humility and desire to be conciliatory than that with the Board. Much request for future patronage, etc.

Letter of the governor of Cartagena to the viceroy of New Spain. No. 29. Movements of Ducasse, trade at Porto Bello, superior strength of the French in the W. I., etc. May 3, I7II.

Papers on dispute of governor and assembly on the right of adjournment.

The Board transmits a memorial from planters and merchants, on defenseless state of the island, etc.

Hamilton wishes to have sole right to nominate for the council.

Copy of memorial of council and assembly to the crown concerning duties on prize goods.

Information on governors of the various Spanish possessions in the W. I., their relations with the French, with one another, etc. Claim that Spanish governor of Hispaniola tried to entice Irish papists from the British islands.

The Spanish governor of Hispaniola is being sent to England in one of her Majesty's ships, with his papers.

Letters on appointments to the council and to patent offices, etc.

A certain man accused of high treason for trading with the enemy; but the attorney general of Jamaica holds that he cannot be tried for that offense anywhere but in G. B. He is therefore sent to England.

At times the governor states specifically his avoidance, in writing the Secretary of State, of many matters covered in his letters to the Board, since the former will be informed when necessary, etc.

The matters on which the Secretary is especially to be informed are those of a "national" character. "National" matters include accounts of Spanish trade, and denunciations of the British privateers, whose violence endangers the continuance of this trade.

Negotiations of the governors with the governors of foreign colonies reviewed. Copies of the correspondence, $e . g$., on exchange of prisoners, sometimes added.

Particulars of Hamilton's quarrel with the admiral concerning the taking and disposal of French prisoners (given also in the original correspondence of the Board). Quarrel seems to have hinged in reality on jealousy concerning the trade with the French which the governor of Jamaica was attempting to open up, even before the signature of peace, and which war-vessels had already commenced.

Complaint that the squadron has gone to Bluefields, which is too far from Jamaica to make possible the protection either of the island or of its trade. 
Complaints that vessels of the squadron have acted improperly to Spanish vessels in seizing them in spite of the truce, etc., while on the other hand the island gets no protection against Spanish privateers.

The scattered papers of dates after Mar., I7I3, are of little significance.

52. $1723-\mathrm{I} 727$.

Letters from Portland. Neglect of island by naval vessels, which prefer to engage in Spanish trade. July 25, I723; Mar. 4, I723/4.

Id. Taxation of produce of northern colonies. Mar. 4, I723/4.

Id. Violations of acts of trade; operations of South Sea Company; and position of patent officers in colonial governments. July I3, I724.

Id. Perpetual revenue and use of suspending clause. Aug., r723. Captain Lawes to Portland. His dealings with pirates. Apr. 24, I723.

Report of Committee of Council on currency of Jamaica, and restoration of its credit and finances. Mar., I723/4.

Additional papers on condemnation of Chandos and Espérance. I724I726. (See C. O. I37: I4, I 5.)

Correspondence of Portland with Newcastle, on political conditions in island; and in particular, on perpetual revenue, position of patent officers, use of Habeas Corpus Act, and "Jacobitism" of some members of council. Oct., I724-June, I726.

53. I728-I73I.

Letter from Gov. Hunter. Depredations by Spanish privateers. Aug. 3, I728. Other papers.

Townshend to Hunter, announcing that naval vessels have orders to seize piratical Spanish vessels. Sept. I 5, I728.

Papers on preparations for hostilities with Spain, including martial law, embargo, and seizure of Spanish vessels. Feb., I728/9-July, I729. In particular, "The Affair of the Jamaica Embargo Stated". Mar., I729/30.

Draft of letter to Hunter, announcing that British naval vessels will receive permissions to proceed to Spanish ports whence piratical vessels have issued, and, failing to obtain satisfaction for authenticated depredations, to make reprisals. Sept. 25, I730.

Weekly Jamaica Courant, containing list of duties payable on goods imported into Jamaica, as issued from receiver general's office. Apr. 24, I728.

Letters to Hunter. "Most secret." Procedure to be followed in case of Spanish treasure ship wrecked off coast of Jamaica. Nov. 9, I I, I730.

Papers on troops in Jamaica, including extracts from letters written by officers, and lists of deaths and promotions among officers.

Papers on the Mosquito Shore, import duties on slaves, perpetual revenue, importation of provisions for squadron without payment of duties, bill making produce of island legal tender, condition of militia, and use of suspending clause.

54. I732-I733.

Numerous and important papers, many not found elsewhere, on the negro insurrection, including journals of officers engaged in its suppression.

Letter to Hunter, ordering restitution of Spanish vessel seized in reprisal for taking of British-owned vessel. Oct. I2, I732. Also, papers on piratical seizure of French vessel at Hispaniola by Jamaica mer- 
chant, including account of proceedings in admiralty court, and other papers on seizure of Jamaica vessel by governor of Santiago de Cuba with object of obtaining information on British fleet, including correspondence between governors of Jamaica and Santiago, which throws light upon commercial matters.

Letters from Hunter. Plundering of Spanish wreck at Jamaica, and acquittal of guilty persons by Jamaican juries. May 8, June 29, I733.

Papers on disputes of governor and assembly, and determination of latter to establish duties on negroes.

Address of council and assembly, approving of the Molasses Act. Oct., 1733.

55. I734-I735.

Many papers on the negro insurrection and measures for its suppression, reinforcement of troops, their condition, and provisions made for them, and manner and effect of imposition of martial law. In particular: "Queries concerning the Troops at Jamaica", drawn up by Gov. Cunningham, and giving considerable information as to conditions among troops; answers to queries, unsigned; and lists of effectives.

Draft of letter to governor of Jamaica and lieutenant governor of Virginia, on complaint of Spanish ambassador that many Spanish Indians are taken to Jamaica and sold there as slaves. Jan., $1734 / 5$.

56. $1736-1740$.

Papers on rebellious negroes, mortality and general condition of troops, etc. 1736.

Petition to the king from "Mahomet, Chief Sachem of the Moheagan Indians" for relief from wrongs inflicted by "Your Majesty's Subjects of the Colony of Connecticut in New England". I736.

Many papers on quarrels with French and Spaniards on seizures of vessels and reprisals for same at Windward Islands, Hispaniola, and elsewhere. In particular, correspondence on seizure, by Spaniards from Cuba, of three vessels homeward bound from Jamaica, as being too near Havana and as carrying logwood, bars of gold, and Spanish coins. Redress refused. I737.

Letter from commander of H. M. S. Antelope, explaining refusal to inform president and council of Jamaica of seizures at Hispaniola. His orders require him to send information to Secretary of State through his superior officers. Dec. 27, I736.

Copy of letter from Kingston, reporting preparations for war and provocative answers to demands for redress for seizures by Spaniards at Cuba. Calls attention to reports that agent of South Sea Company at Jamaica is importing flour from N. Y. for Spaniards, and procuring vessels to be used as Spanish privateers. Unsigned. Feb. $20,1737 / 8$. Other papers on alleged preparation for war by Spaniards.

Extract from letter from Havana, on projected Spanish expedition against Georgia. Sept. 7, 1737 .

Letter from Trelawney. Unsatisfactory condition of militia. July 2, I738.

Papers on discrimination against Jews.

Lists of Spanish war vessels in W. I., mainly at Cartagena, Vera Cruz, and Havana. I738, 1739. 
Draft of confidential letter to Hunter, announcing break with Spain, and urging that he do his best to revenge injuries of his countrymen. June I5, I739.

Letter from Trelawney. Prospects of military success at Jamaica and elsewhere in W. I. Discusses feasibility of attack on Havana. Aug. 8, I739.

$I d$., on disposal of prisoners brought by British war vessels, island being unwilling to subsist them. Sept. 22, I739.

$I d$., on reinforcements given to Vernon for attack on Porto Bello; and on despatch to England of Spanish prisoners, who will assist depleted crews of homeward-bound vessels. Oct. 30, I739.

Id. Plans for attacking Spaniards ; in particular, for attack on Mosquito Coast. Jan. 20, I739/40.

Id., on Jamaica privateers. Feb. I, I739/40.

Papers on projected conspiracy against Spaniards in Peru. I740.

Papers on Cathcart's expedition against Havana. Particulars of troops raised in N. Am., and of negro levies in Jamaica. I740.

Letter from Trelawney, on Vernon's bombardment of Cartagena. May II, I740.

Correspondence of Trelawney with governor of Vera Cruz, on detention by latter of agents of Asiento Company. I74.O.

Papers on condition of troops. In particular, report on eight independent companies in Jamaica. Oct., I740.

57. I74I-I753.

Several important letters from Trelawney. Military and naval operations projected or executed at Mosquito Coast, Havana, Cartagena, Panama, and other places; complaints by Dutch at Curaçao of British privateers; negotiations with French governor at Hispaniola; levy of negro troops; on difficulty of providing for defense of Jamaica. Jan., I740/I-May, I74I. Enclosures include captured correspondence of French and Spanish authorities, in particular, letter from Maurepas to Marquis d'Antin, dated Fontainebleau, Oct. 7, I740.

Letter from Trelawney. Relations between governor of Jamaica and commander of troops in island, and condition of, and service rendered by, troops. Oct. 20, I74I.

$I d$. Declares that no military success is possible on account of disagreements of Adm. Vernon and Gen. Wentworth. Jan. 3I, I74I/2.

Letters and other papers on operations of $\mathrm{I} 742$ at Panama, Porto Bello, Mosquito Shore, Ruatán, and elsewhere; and on disputes of governor with naval commander. Enclosures include plan of Port Royal harbor at Ruatán.

Newcastle to Trelawney, announcing immediate recall of all land and naval forces not necessary either for defense or for interfering with Spanish commerce. Aug. 5, I742.

Papers on fresh complaints of seizures by French at Hispaniola. I 742 .

Copies of correspondence between Trelawney, Lieut.-Gov. Bull, and Gov. Tinker on French and Spanish plans for attack.

Numerous papers on military operations and on settlement at Ruatán and Mosquito Coast.

Trelawney to Admiralty, on impressment in America. Dec. 2I, I743.

58. I746-I749.

Letter from Trelawney, sending "A List of Rebell Prisoners brought to this Island by the St. George Capt. George Snow, and the Carteret 
Captain Charles Friend as appears by a List sworn to by the said Captain Friend". One hundred and twenty-six names, nearly all distinctively Scottish. Dec. 29, I 747.

Account of disbursements at Mosquito Coast by governor of Jamaica. I 747 .

Accounts of taking of Fort St. Louis, and attack on Santiago. Articles of capitulation at Fort St. Louis. I747.

59. I749-1752.

Plan of Fort St. Louis in Hispaniola at time of capture by Adm. Knowles. Mar. 8, I747/8.

Many important papers on Mosquito Coast, including: statements of British and Spanish territorial rights; accounts of attempts of British and Spanish settlers to oust one another and extend settlements, through Indian insurrections and other means; and accounts of establishment of civil government for British settlements. I749I750.

Letter from Trelawney, on planning and financing of fortifications at Jamaica. Apr. 4, I750.

$I d$., on judicial system of Jamaica and difficulties connected with its operation. June I, I750.

Numerous papers on disputes with Spaniards relating to: seizures of British vessels and their ill-treatment when driven by bad weather into Havana; retention and emancipation at Cuba of fugitive slaves from British and Dutch islands who "arrive to embrace the Holy Catholic Religion"; "piratical" acts of Spanish guarda costas, alleged to be private vessels, acting under commissions and receiving full proceeds of lesser seizures. Letters, proclamations, copies of commissions and instructions, etc. I750, I75I.

Copies of proceedings in admiralty court at Spanish Town in trial of pirates, under commission issued under great seal of Admiralty pursuant to act of II and I2 William III., since made perpetual and entitled "An Act for the more effectual suppression of Piracy". Nov., I752.

60. I753-176I.

Numerous papers on Mosquito Coast, including: statistics of population; lists of settlers; lists of vessels arriving at Jamaica from Mosquito Coast; accounts of attempts to counteract Spanish influence with Indians; correspondence of governor of Jamaica with president of Guatemala; instructions for British agents at Mosquito Coast; accounts of attempts to promote cutting of logwood, etc.

Papers on relations with Spaniards, including: accounts of trials of Spaniards for piratical acts; instructions to Knowles that better relations must be established; complaints that guarda costas are allowed to seize all vessels within ten leagues of the coast near Cartagena; and correspondence on grant by Spanish government of licenses for importation of slaves from Jamaica into Cuba if carried in Spanish vessels.

Letter from Knowles, on removal of seat of government from Spanish Town to Kingston. Throws much light on political and social conditions. Feb. 5, I754.

Id. Misbehavior of Thomas Delap, lately provost marshal, who has been arrested and put in irons, pending removal to England for trial, for refusing to deliver writs of election to governor and for other 
alleged misuse of official documents. Dec. I, I754. Other papers show development from this of bitter disputes between three branches of legislature, which involve dismissal of Chief Justice Pinnock and suspension of members of council, and bringing of charges of bribery and cruelty in administration of justice, refusal of writ of habeas corpus, meeting of council without summons, and attempt of council to force dissolution of assembly.

Lists of British and French war vessels at Jamaica and Santo Domingo. 1756.

Letters from Lieut.-Gov. Moore, on the war. In particular, on attempts to avoid friction with Spaniards, and numbers and state of troops. I758.

Id., on minor negro insurrections in two parishes. Apr. 19, I760.

Very important papers on trade carried on with French by continental and W. I. colonists and by Irish merchants, mainly at Monte Cristi or under flags of truce. Lieut.-Gov. Moore conducts investigation, pursuant to orders. Correspondence of Moore with Lieut.-Gov. Delancey. Detailed descriptions of the Monte Cristi trade by Edward Long and Rear-Adm. Holmes. Letters, memorials, lists of vessels seen at Monte Cristi, etc.

61. $176 \mathrm{I}-1764$.

Letter from Moore, with petition of merchants of Kingston, complaining that Rear-Adm. Holmes, in prosecution of far-off schemes and in pursuit of prize-money, gives no efficient protection against enemy privateers. Oct. 29, I76I. Other papers, showing lively dispute arising out of this charge, Holmes maintaining that his real crime has been interference with trade carried on with French. Information of exchange of prisoners and on convoys.

Egremont to Lyttleton, on raising of 500 free negroes and 2000 slaves for expedition against Spanish colonies. Jan., I762.

Letters from Lyttleton, and other papers. Rumored attack on Jamaica; forces available for defense; and employment of free negroes and slaves for expedition against Spanish colonies. Slaves furnished at $5 d$. sterling each per day, with promised compensation up to $£_{50}$ sterling for loss. Jan.-May, I762.

$I d$., on comparative poverty of Jamaica, and lack of currency. June I5, I762.

Papers on disputes of Lyttleton with Adms. Douglas and Keppel, commanding successively on the Jamaica station.

Papers on siege of Havana and other military operations against Spaniards. I762.

Correspondence of Egremont with Lyttleton, on demolition of fortifications at Bay of Honduras and bringing away of troops. 1763 .

Correspondence of Board of Trade, Halifax, and Lyttleton with Otway and Hodgson on affairs at Mosquito Coast. In particular, on Spanish aggression against logwood cutters. 1763, I764.

Halifax to Lyttleton, on relief of troops at Jamaica. Mar. 5, I764.

Papers on enforcement of new regulations of trade. In particular, on use of soldiers to assist in enforcement of acts of trade, and on total exclusion of Spanish vessels from trade of Jamaica. I764.

Correspondence on French raid on Turks Islands. I764.

Return of ordnance brought from Mosquito Shore to Jamaica. June, I764. 
W. Shirley to Lyttleton, on Spanish complaints of piracies. June I7, I 764 .

Letter from Lyttleton, sending list of "public instruments" (to be taxed under Stamp Act). Dec. I I, I764.

62. $1764-1767$.

Important group of papers on complicated series of disputes between governor and assembly, arising, at time of Stamp Act troubles, on question of privilege, and extending to many other matters. Among points raised, investigated, and argued are: origin of parliamentary privileges claimed by assembly; whether privilege extends under any circumstances to personal property of members; whether person committed to custody by order of assembly may be released during session through writ of habeas corpus or in any manner other than by its own warrant; whether it may be contended that no question of authority of assembly may be raised in chancery, assembly being a higher court; and whether Habeas Corpus Act actually constitutes part of laws of Jamaica. Refusal of assembly to proceed with business until acknowledgment of its right to certain privileges is made, and reparation for alleged breaches of privilege given brings new questions: whether assembly is bound to repay advances made by Treasury for additional subsistence of troops (to extent of additional subsistence customarily furnished by assembly) during time when assembly is prevented by dissolutions from passing supplybills. Papers show attempts of government to settle, by replacement of governor, vacating of proceedings in chancery, and consent to future acknowledgment of privilege in personal property. They show also cost and methods of subsisting troops, etc. I764-I 767 .

Letter from Lyttleton, on seizure by collector at Kingston of French wines and brandies, and other prohibited goods. Feb. 21, I765.

$I d$. State of Spanish forces and ships in W. I. Dec. I2, I 5, I765.

Correspondence of Conway and Lyttleton on removal of impediments to importation of bullion through trade with Spaniards. I765, I766.

Conway to governors of Barbados, Jamaica, Grenada, and the Bahamas, on acts of Parliament for securing the just dependency of the colonies on the mother country, and for repealing the Stamp Act. Apr. Io, I766.

Letter from John Howell, complaining of losses sustained, as distributor of stamps, by repeal of Stamp Act. His losses the harder to bear by reason of "the success I had in the execution of my duty in opposition to repeated threats of violence, torrents of personal abuse and many other very disagreeable circumstances which I had to contend with". Gives some particulars. May 3I, I766.

Lieut.-Gov. Elletson to Shelburne. Case of J. C. S. Douglas, late collector of customs, who was committed to custody for contempt in refusing to appear and give evidence before governor and council, but was released by chief justice on ground that lieutenant governor and council had no power to compel his presence or commit him to custody. Jan. 4, I767. Letter from Board of Trade, and opinion of attorney general and solicitor general sustaining opinion of chief justice of Jamaica. July I, I 767 .

Elletson to Richmond. Refusal of assembly to permit council to amend appropriation bill. Sept. 20, I766. 
Elletson to Shelburne, on fining of persons unable to comply with summons to appear as jurors in grand court. Jan. 23, 1767.

Papers on retention by Spaniards of fugitive slaves.

63. $1767-1768$.

Papers on attempts to make assembly pay requisition of Treasury for sums advanced for subsistence of troops during I 765 , when assembly was prevented by dissolution from passing supply-bills for this purpose.

Letter from Elletson. Refusal of council to agree to supply-bill with rider attached. Suspension of seven members for insult to lieutenant governor. Mar. I8, I768. Other papers, showing measures for reinstatement, by royal order, of members suspended.

Memorial of Allan Auld of London, trading to Honduras, on behalf of himself and his correspondents there, complaining of conduct of Spaniards in trying to entice settlers from their allegiance and slaves from their masters. July II, I768.

Opinion of Matthew Lamb on competence of Jamaica court to have tried person court-martialled for murder of sailor in Port Royal harbor. Mar.-Nov., I768. Other papers.

64. I768-I769.

Papers on continued efforts to secure payment of Treasury requisition.

Letter from Elletson, on insurrection of Mosquito Indians and on other conditions at Mosquito Coast. Sept. 3, i768. Encloses accounts of events and finances at Mosquito Coast, and copies of acts of Jamaica, $\mathrm{I} 68 \mathrm{I}-\mathrm{I} 767$.

Papers on retention of fugitive slaves at Cuba. I769.

Letter from Trelawney, sending, in obedience to secret circular letter, information on such of French and Spanish colonies "as may by their situation and vicinity to my government anyways affect its interest or security" (i.e., Hispaniola, Cuba, and Spanish Main). Jan. 3I, I769.

Correspondence of Trelawney with Hillsborough, on methods followed in selection of members of council. Trelawney reprimanded for objection to appointments based so largely upon personal friendships or recommendations of former governors. May-Nov., 1769 .

Papers on conditions at Mosquito Coast.

Letters from Trelawney. Suggested appointment of president of council from England. Attempt of members of council to secure alteration in governor's power of suspension. Apr. I4, June IO, I769.

$I d$. Naturalization under act of Jamaica. "It is my intention to receive with open arms and to naturalize without any scruples or questions all aliens or foreigners who are already settled or who shall come to settle or plant in this island . . . and I shall not consider myself at liberty (till properly authorized to the contrary), to give up a subject of His Britannic Majesty by whatever means he became so." Aug. I2, I769.

Commodore Forrest to Admiralty. Conditions in French and Spanish islands; fortifications of Jamaica; and new French free port at Cape Nicholas, which "inveigles the whole North American trade to them which supplies them with lumber and provisions at a low rate and drains us of cash and at the same time supplies North America with sugar, molasses and rum, to the great distress of our West India Islands". Oct. 8, I769. 
65. $1769-1770$.

Papers on further unsuccessful attempts to secure payment of Treasury requisition for advances to troops in 1765 .

Commodore Forrest to Hillsborough. Relations with Spaniards at Mosquito Shore. Nov. 29, I769. "Report of the Proceedings of Mr. Jones, His Majesty's Chief Civil Magistrate at Bluefields Bluff on the Mosquito Shore." Apr. 4, I770. Copy, Bedford to Hodgson, on Hodgson's appointment as superintendent at Mosquito Coast. Oct. 5, I749. Copy of Trelawney's instructions to Hodgson. Dec. I I, I74I. Detailed lists of gifts made to Mosquito Indians, I769, I770. Memorials from inhabitants, letters from governor of Cartagena, and other papers.

Correspondence with Trelawney, Admiralty, Forrest, and others. Preparations for war at Havana and Santo Domingo; fortifications, militia, and martial law at Jamaica; garrisoning of New Orleans; seizures of vessels by Spaniards; and otherwise on relations with Spaniards.

Letter from Trelawney. Disputes of council and assembly over appropriations of surpluses in supply-bills. Attempts of assembly to force dissolution in hope of larger majority for "Kingston" party. Nov. 20, I769.

$I d$., on same matters, and on threatened slave insurrection. Dec. 3I, I769. Other papers on financial disputes, giving much information on finances and relations of branches of legislature thereto.

Memorial of Stephen Fuller. Retention at Cuba of 95 fugitive slaves valued at $£ 9500$ currency or $£ 6785 \mathrm{I} 4 s$. $3 d$. sterling. Also, correspondence of Trelawney with French governor at Santo Domingo on fugitives, slaves and free, escaped to Jamaica.

Letters from Trelawney. Failure of legislature to provide for troops, as results of disputes between council and assembly on financial management. Mar. 3, May 2, I770. Memorials from officers and other papers showing distress of troops.

Id. Treasury requisition; disputes of council and assembly; Mosquito Coast; local support of fortifications; militia and martial law; and threatened slave insurrection. May 28, I770. Important enclosures including: letter from Wollere Meng and John Miller of Germantown, May 29, I768, on trade between Philadelphia and Mosquito Coast and settlement of Philadelphians at Mosquito Coast; and Rules and Articles of War, issued by His Excellency Sir William Trelawney . . . and a Council of War, Dec. 19, I769.

Letter from Admiralty, with numerous enclosures on naval movements, and trade of continental colonies at St. Nicholas Mole and Turks Islands. July I I, I770.

Letter from Trelawney. Loyal attitude of Jamaicans regarding troubles in N. Am. June I2, I770.

Papers on expedition by H. M. S. Druid to Vera Cruz, at request of lieutenant governor of W. Fla. to obtain satisfaction in case of schooner Britain of Md., John Steele master, bound from Potomac to New Orleans. Vessel, entering in distress, was seized and plundered, and passengers imprisoned. I770. Papers include letters of Lieut.-Gov. Durnford to goverror of Vera Cruz and viceroy of Mexico.

66. I770-I77I.

Letter from Trelawney, on threat of Hillsborough to lay matter of Treasury requisition before Parliament. Has not informed assembly 
of threat, because not ordered to do so; and because "it was moreover thought by those who best know the temper of Assemblies here that anything which could by the least possibility be construed into a threat had better be suppressed". Although some influential persons were confidentially informed of the threat, assembly persists in refusing to pay. Expresses satisfaction that the crown will avoid pronouncement in dispute on appropriation of surplus revenue. Light doubloons (worth only three pistoles) "are supposed to be coined for the most part at Rhode Island" and are brought into island by N. Am. traders. Nov. 24, I770. Enclosures. Hillsborough to Trelawney, warmly approving latter's policy. Feb. II, I77I.

Admiralty to Hillsborough, on strengthening of defenses of Port Antonio, in pursuance of address of assembly. Feb. 27, I77I. Encloses plan of Port Antonio.

Letter from Trelawney. Suggests three names for one vacancy in council, this being in accordance with instructions, although not with precedent. Dec. 22, I770. Id., on selections. Aug. 4, I77I.

Reports on fortifications in French and Spanish islands and on movements of French and Spanish naval and commercial shipping.

Numerous papers on conditions at Mosquito Coast, including: Hodgson's diary of tour among Mosquito Indians, Mar.-May, I770; Hodgson's correspondence with governor of Cartagena; list of vessels entered at Black River; accounts of Hodgson's disputes with settlers; plans of Hodgson for conquest of Vera Cruz, Buenos Ayres, and other Spanish possessions; and descriptive reports by Hodgson on Spanish possessions.

Letters from Trelawney. Proceedings in assembly on improvement of currency, and, in particular, on measures against introduction of inferior currency from N. Am. Apr. I2, Oct. 4, I77I. Hillsborough's reply. July 3 , I77I.

Robinson (of Treasury) to Pownall. Sends memorial of Commissioners of Customs for instructions to prevent, as far as possible, delays in prosecution against Douglas, late collector at Jamaica, for account of monies received by him. July 3I, I 77I.

Letter from Trelawney. Explains assent to acts which should have contained suspending clauses. June I9, I77I. Hillsborough's reply. Dec. 4, I77I.

67. I77I-I772.

Hillsborough to Trelawney, on currency at Jamaica. Jan. II, I772.

Letter from Trelawney. Currency; appointments to council; and, in particular, the qualifications of Bryan Edwards. Dec. I5, I77I. Encloses loyal addresses from council and assembly. Hillsborough's reply. Mar. 4, I772.

Id. Currency. Aversion in island to suspending clause. Jan. 27, I772. Copy of petition to Gov. Tryon from merchants of N. Y. trading to Bay of Honduras, asking Tryon to point out to Trelawney that anarchy and confusion in Bay of Honduras may ruin trade. Signed by Thomas Buchanan and Co., Thomas Franklin, jr., Samuel and Walter Franklin, John and J. W. H. Cruger, John Murray, and W. McAdam. Oct. 29, I77I.

Further correspondence of Trelawney with Hillsborough and Dartmouth, on currency. 
Papers on conditions at Mosquito Coast, including: copy of letter to Hodgson on restraint of enmity of natives towards Spaniards; copy of orders to agent sent by Rodney to attend to this and other matters; and diary of Hodgson's tour on Mosquito Coast, I772.

Rochford to Trelawney, on relief of 36 th and 66th Regts. in Jamaica by 5oth Regt. from Ireland and 6oth Regt. from America. Oct. I, 1772 .

68. $1772-1773$.

Dartmouth to Trelawney, on packet service. Jan. 6, I773.

Papers on conditions at Mosquito Shore.

Letter from Dalling, on death and popularity of Trelawney. Dec. 19, 1772 .

Dartmouth to Dalling. All possible assistance to be given to Mr. Knill, "appointed by the Commissioners of Customs to examine into the state of the several ports, and likewise into the condition and behaviour of all the officers of Revenue under their management, in the Island of Jamaica". Feb. 26, I773.

$I d$. Disallowance of act of 1770 on account of omission of suspending clause. Apr. I0, I773.

Id. Dartmouth's desire for appointment to council of William Barnett, in whom several of his friends are interested. "It would be a satisfaction to me to find that you had no objection to his nomination." Apr. I0, I773.

Dalling to Dartmouth. Describes in detail injurious effects of free port act on trade of island with French and Spaniards, and praises regulations adopted by French for trade with foreign colonies. Nov. II, I773. Encloses his account of Spanish trade, which is extensive and valuable.

$I d$. Prevalence of smuggling. May 2, I773.

Papers on distress of coffee planters from operation of free port act. In particular, Dartmouth to Dalling, Aug. 4, I773.

69. $1773^{-1774}$.

Letter from Dalling. Tranquillity of island and the voting of a residence to commander of vessels on Jamaica station; circulation of adulterated and clipped coins from N. Am. and Spanish colonies, and measures taken against same; rapid and dangerous increase of ratio of blacks to whites; vulnerability of island to attack; numbers of French and Spanish troops in Santo Domingo, Cuba, and other colonies; and suggested remedies for some of these conditions. Jan. 3, I774.

Letter from Gov. Keith. Fresh dispute between council and assembly over appropriation of surplus revenue. Feb. 18, I774. Dartmouth's reply. June 4, I774.

$I d$. Danger of attack from maroons. Defenseless condition of island. Apr. 22, 1774 .

$I d$. Complains that ordnance stores recently supplied have been almost useless, although agent is ready to buy stores from Board of Ordnance. June II, I 774 .

Id. Announces publication of circular of Apr. 6, "for the information of those who may be concerned in carrying on commerce with the Province of Massachusetts Bay". June 23, I774. 
Id. Sends and endorses petition of coffee planters, who complain that $\mathrm{N}$. Am. colonies are supplied with coffee from Hispaniola, and that British import duties on coffee are too high. Oct. 4, I774.

Dartmouth to Keith. Promises to confer with Commissioners of Customs on coffee duties. Sends copies of memorials from merchants of London, Bristol, and Liverpool, complaining of import duties on negroes. Dec. Io, I774.

70. I774-I775.

Keith to Dartmouth, on tranquillity of colony, and settlement of dispute on appropriation of surplus. Nov. 19, I774.

Id. Forwards petition to his Majesty adopted by assembly Dec. 24, I774, on behalf of $\mathrm{N}$. Am. colonies. Text of petition is given in full in Bryan Edwards, History of the West Indies. Requests that the king "will be pleased, as a common parent of your subjects, to become a mediator of your American and European subjects, and to consider the latter ... as equally entitled to your protection and the benefits of the English Constitution, the deprivation of which must dissolve that dependence on the parent state which is our glory to acknowledge". Encloses text of petition and describes circumstances of passage. Jan. 4, I775.

Dartmouth to Keith. The "indecent, not to say criminal conduct of the Assembly", in passing the petition of Dec. 24, I774, "may probably lead to measures of a very serious consequence". Forbids Keith, upon pain of removal, to assent to greater duties on negroes than those in force at commencement of r774. Board of Trade is now to consider what measures may be necessary to quiet alarms occasioned by restrictions placed at Jamaica on slave-trade. Mar. 3, 1775 .

Id. Sends disallowance of act imposing extra duties on importation of negroes, and complains that assembly, "in justice and humanity", should make better provision for garrison. July 5, I775.

Letters from Keith. Reports firm loyalty of Jamaicans as a whole, and argues that dangerous increase in ratio of blacks to whites and necessity of larger appropriations for increased garrison explain imposition of heavier duties on negroes. May 16, June 12 , 1775 .

Stephen Fuller to committee of correspondence. Opposition in England is due to increased import duties on slaves. Describes investigation held before Board of Trade on memorials and petitions from African Company, and merchants of London, Liverpool, and Bristol. Dec. 24, I774.

Answers to customary queries of Board. Unusually detailed and valuable. Jan., I774.

Germain to Keith. "The intelligence has been received from Carolina of the rebels in North America having been supplied with large quantities of gunpowder from Jamaica." Dec. 23, I775.

72. I776-I777. (Deal mainly with the Mosquito Shore.)

Letter from Gov. Keith, referring to despatch of 5 oth Regt. to N. Am. Dec. 24, 1776.

73. I777-I 778 .

Letter from Gov. Dalling to Lord George Germain, no. II. Encloses letter from collector of customs at Montego Bay, Dec. 5, I777, on French forces assembled at Hispaniola. He cannot discover whether 
they have hostile intentions; they admit American trading vessels, but none that are armed. Dec. II, I777.

Letter from Peter Ingram. Describes course of war. Dec. 4, I777.

Letter from Dalling, no. I3. Encloses correspondence with Lord Howe and Sir William Howe on circular of Oct. 3; also list of vessels commissioned under letters of marque. Jan. I3, I778.

$I d$., no. I8. Depredations by Americans on north side of island; some committed "by persons in the French Islands using Commissions of the North American Congress". Apr. 25, I778.

Id., no. I9. Despatch to Pensacola of company of 3 rd Battalion of Royal Americans with detachment of Ist Battalion. Apr. I9, I778.

$I d$., no. 25. Capture of frigate Minerva by French. Sept. 22, I778.

74. 1778-1779.

Letter from Capt. Lawrie to Stephen Fuller. Capture of vessels by two armed sloops from Cartagena. Black River, Mosquito Shore, May 29, 1777.

Letter from Alexander Cumine. Describes situation in the Carolinas and Georgia. Oct. I8, I778.

Letter from Dalling, no. 3I. Reports removal of embargo on Nov. I9. "Seven transports with troops from New York arrived on ... the 3oth of November." Regrets their destination-Pensacola. Dec. 20, 1778 .

Id., no. 33. Encloses papers on Mosquito Shore. Jan. I2, I779.

$I d$., no. 37. Same subject. Apr. I, I779.

Draft from Germain to Gov. Dalling. Secret and confidential. Outlines proposed attack on New Orleans, in which ships on Jamaica station are to co-operate. June 17, , 1779 .

75. I779.

Letter from Dalling, detailing plan of operations relating to Hispaniola. May 25, I779.

Draft from Germain, on relief to sufferers from American war. Oct. 8, I779.

Letter from Dalling, no. 44. Gives intelligence secured by sending an advice boat to the Cape (Cap Français), an expedient sometimes cloaked by professions of commercial business. Aug. I, I779.

$I d$., nos. 45, 46. Defense of Jamaica. Aug. 6, 28, I 779. No. 46 encloses plan of fortifications.

Memorial of Stephen Fuller on defense of Jamaica. Dec. 8, I779.

76. $1779-1780$.

Draft from William Knox to Dalling. Encloses papers on troops, etc., of Spain in S. Am., captured from Spanish packet-boat by N. Y. privateer in Oct., I779. Jan. 5, I780.

Letters from Dalling, nos. 48, 50, 54. Account of activities in Bay of Honduras. Oct. 29, Nov. I5, Dec. 28, I779.

Id., no. 47. Reports removal of embargo on Sept. 20. Nov. I3, I779.

Id., no. 59. Encloses account of Mosquito Shore. Feb. 4, I780.

77. $\mathrm{I} 780$.

Letter from Dalling, no. 61. Mississippi settlements. Feb. 6, I780.

Id. Mosquito Shore. Feb. 9, I780.

Letter from Brig.-Gen. A. Campbell. Plan of operations from Jamaica. Apr. 6, I780. Encloses private instructions to Col. Kemble with reference to Nicaragua. 
Letter from Dalling. Encloses instructions for Maj. Jenkins with reference to Nicaragua. Apr. 26-May I0, I780.

$I d$., nos. $7 \mathrm{O}, 7 \mathrm{I}$, on expedition to Nicaragua. May $2 \mathrm{I}$, June $2, \mathrm{I} 780$.

78. 1780.

Letter from Brig.-Gen. Campbell. Capture of Fort St. John's, Nicaragua, on Apr. 29. June 3, I780.

Letters from Dalling, nos. 67, 75. Encloses instructions for Col. Kemble. Apr. I4, June 25, I 780 .

$I d$., no. 76. Encloses "Copy of Instructions to Captain Bain, whilst on the recruiting service in America", destined for July 2, I780.

Id., no. 77. Arrival of French and Spanish fleets, and progress of war. Aug. I2, I780.

Id., no. 78, and two unnumbered. Expedition of Gen. Kemble to Mosquito Shore. Aug. 29, Sept. I9, 22, I780.

Draft from Germain to Dalling, no. 32. Regrets failure on Mosquito Shore. Hopes it will yet be possible to secure the Nicaragua country, which would be filled with adventurers from the revolted provinces. Dec. 7 , I780.

79. $\mathrm{I} 780-\mathrm{I} 78 \mathrm{I}$.

Letters from Dalling, no. $8 \mathrm{I}$, and one unnumbered and private, relating to Mosquito Shore. Oct. 25, Nov. 2, I780.

$I d$., no. 83. Describes attempt to raise a corps in S. C. for defense of Jamaica or for "outward service". Nov. 5, I780. Encloses despatch to Gen. Kemble for abandonment of Mosquito Shore expedition: impossible to give assistance for defense of W. Fla.

80. I78I.

Id., no. 85. Dec. 28, I780. Encloses letter from Capt. Bain on recruiting.

Letter from Germain, no. 35. Expresses hope for success of recruiting among prisoners of war, etc. "I see no other resources for keeping up your force." Mar. 7, I78I.

Letter from Dalling. Impossibility of giving effectual support for protection of Pensacola. Arrival of part of Loyal American Rangers, Odell's company, from N. Y.: sent off immediately to W. Fla. Feb. I 5, I78I.

Id., no. 94. Feb. 24, I78I. Encloses "List of Spanish Fleet and Land Force at the Havanna, sent down from New York by a Mr. Buchanan who quitted Cuba the Ist of Jany last".

Id., no. 95, on the Mosquito Shore. Mar. 6, I78I.

Id., no. 96. Encloses papers on defense of Pensacola and settlement of Ruatán. Apr. 25, I78I.

Id., no. 97. Encloses letter from Lord Charles Montagu, Charleston, S. C., Mar. I8, I78I, on "the uncommon Success I had found in recruiting". Apr. 27, I78I.

Id., no. 98. Delay in departure of Odell's company for W. Fla. May 6, I78I.

Id., no. 99. Encloses two letters from Col. Odell and Capt. Amherst regarding forces; also journal, Feb. 8-June 2, of Maj. Alexander Campbell of the Loyal American Rangers. May 24, I78I.

Id., no. IOo. June 22, I78I. Encloses journal of Capt. McEvoy of same corps, Mar. 8-Apr. 8, I78I.

Id., no. IOI. Encloses letter relating to Havana from "a person, arrived a few days ago" thence. June $25,178 \mathrm{I}$. 
Notes on the expedition towards Lake Nicaragua in I780. Narrative of Mr. Hodgson.

81. I78r.

Letter from Dalling, no. Io9. Arrival on Aug. Io of Lord Charles Montagu's corps, consisting of five companies of roo men each. Aug.-Sept., I78I.

Letter from Lieut.-Gov. Campbell. Encloses copy of proclamation of Jan. 25, 1779, providing that "in regard to the Crews of any trading Vessels belonging to the Rebels, such of them as the Commanders of His Majesty's ships do not think fit to Press into the King's Service are directed to be set at liberty". Owing to precedents set by officers of the navy American seamen now regard their liberation as a right. They are liberated even if taken on board privateers: not less than 1000 merchant seamen have been freed in this way. Sept. 27, I78I.

Letters from Dalling, nos. II3, I I4. Encloses papers relative to attacks on Curaçao and San Pedro (from Mosquito Shore). Sept. 28, 30, $\mathrm{I} 78 \mathrm{I}$.

82. $\mathrm{I} 78 \mathrm{I}-\mathrm{I} 782$.

Letter from Dalling, no. II 5. Encloses narrative of proceedings of Lord Charles Montagu. Oct. Io, I781.

Letters from Gov. Campbell, nos. 7, I4, I8. Reports position in islands and on the Mosquito Shore. Feb. 2, June 15, Oct. Io, I782.

$I d .$, no. I6. He suspects certain merchants of supplying the enemy with naval and military stores. July I I, I782.

Id., no. I7. Arrival of rooo men from Charleston for Antigua. Now possesses proof confirming previous letter.

Memorandum giving tonnage employed in America, etc., for transports. Mar., 1782.

83. $1782-1783$.

Letters from Campbell, nos. 32, 33, 36. Loyalists arrived from S. C. and Ga. Transmits list of French, Spanish, Dutch, and American vessels brought into Jamaica during the war. (List not present.) July I4, Aug. I, Sept. 6, I783.

84. $1783-1784$.

Letters from Campbell, nos. 35, 46, and unnumbered. Difference of opinion in assembly as to interpretation of order in Council of July 2, I783, regulating American intercourse. Acknowledges receipt of letters of Sept. II, Dec. 4, 5, I783, with copy of definitive treaty of peace with U. S. Encloses letter from Gov. Tonyn, May 27, I784, on 243 Loyalists wishing to settle on the Mosquito Shore. Nov. 26, 1783; Feb. 22, July 3 , I784.

Letter from J. Gambier, referring to contraband trade between Jamaica and N. Am. Apr. 12, 1784.

85. $\mathrm{I} 784-\mathrm{I} 785$.

Letter from Gov. Clarke, no. 19. Suspicion that "several Owners and Masters of Ships belonging to the Citizens of the United States . . . have . . . been furnished with British Registers". Mar. 8, I785. Encloses answers to heads of inquiry from Secretary of State (Nov. II, I784) : 4th query, amount of fraudulent importation from U. S.; 6th query, difference in price of articles imported from U. S. and G. B., etc. 
86. $1785-1787$.

Letter from Clarke, no. 45. Proposes appointment of a Loyalist, James Johnson, as collector of customs at Kingston. July 3, I786.

Id., no. 52. Encloses letter from J. Lawrie, Oct. I6, I786, covering: (I) memorial of Loyalists residing at Black River; (2) return of American Loyalists on the Mosquito Shore. Nov. 5, I786.

Id., no. 65. Encloses letter from Col. Despard, Dec. I, I786, describing conditions at Honduras: "they have lately made an Act . . . wherein no distinction whatever is made between the Shipping and Manufactures of Great Britain and those of the United States." American vessels are as common as those of $\mathrm{G}$. B. He would be glad of instructions on this point and also as to admitting citizens of the U. S. to settle in the district. Apr. 30, I787.

90. I79I-I792.

Letter from Gov. Williamson. Shortage of specie. Both Spaniards and Americans refuse to take anything but gold "as they get what they want much cheaper at Curaçao". May 20, I792.

91. I792-I793.

Letter from Williamson, no. 4. Encloses printed copy of Proceedings of the . . . Assembly . . . on the Sugar and Slave Trade, containing price of lumber, etc., from America in I772-I775 and I788-I791, also tables of exports of sugar, etc., to England, Scotland, and America during same years. Dec. 5, I792.

Drafts from Secretary Dundas. Deprecates opening the ports except under stress of necessity. Oct., Nov. 8, I793.

Letter from Williamson, no. I. Reports opening of ports for five months from Aug. 7. Aug. I0, I793.

Id., unnumbered. Encloses extract of letter from G. Boyle, stating that American vessels were found at Jeremie on their arrival and were permitted to unload. Oct. I7, I793.

92. I793-I794.

Letter from Williamson, no. I. Reporting opening of ports for staves and heading for four months. Nov. 18, r 793 .

Id., no. 2. Reports extension of opening of ports for provisions to five months. Jan. I8, I794.

93. 1794 .

Letter from Williamson, no. 6. Aug. 9, I794. Encloses account of imports and exports, dependency of Grand Anse, (I) British and (2) foreign ports, Sept. 30-Dec. 3I, I793, Apr. I-June 30, I794. (Includes name, tonnage, nationality, etc., of vessels.)

94. I794-I795.

Journal of assembly. Nov. 4-Dec. 20, I794; Feb. 24-28, I795.

95. 1795 .

Letter from the Earl of Balcarres. Prevalence of practice when the ports were open of running in from America "contraband and prohibited Articles upon the plea of Ignorance". These goods were generally permitted by the lieutenant governor to land. This practice now prevented. May I I, I795.

Minutes of council. Jan. 20, I794-Feb. 28, I795.

96. I795-I796.

Mainly concerned with the maroons. 
97. $1795^{-1796 . ~}$

Largely concerned with the maroons. Journal of council. Sept. 22, I795-May I, I796.

98. I796-I797.

Letter from Balcarres, dealing with "improper behaviour of the American Consul at Lisbon". June 29, I797. Encloses letter from H. Parker describing measures taken by U. S. agent to secure release of seamen from British ships on plea that they are U. S. citizens when they are in many cases English subjects. June I9, I797. Encloses also copy of certificate issued by the American consul, and other papers relating to the same subject.

101. I798-i799.

Votes of assembly. Oct. 30-Dec. 21, I798.

Draft from Duke of Portland to Balcarres, with reference to purchase by U. S. of ordnance stores from Santo Domingo. June 7, r799.

Id. Empowers Balcarres to admit provisions in Am. vessels of one deck into Honduras for a limited time. June 26, I799.

102. I799.

Letter from Balcarres. Negotiations with Toussaint: "much will depend upon the good understanding and mutual arrangement which it is to be hoped will take place between General Maitland and the Executive Government of the United States." Apr. 28, I799.

Id. Same subject. May I6, I799. Encloses letter from Lieut.-Col. Harcourt, describing negotiations with Toussaint and Am. consul, Dr. Stevens. May 2, I799.

Id., no. I. Same subject. July I4, I799. Encloses letter from Gen. Maitland to Sir Hyde Parker: "On reaching Saint Domingo, I soon found, that in consequence of the arrival of $\mathrm{Mr}$. Stevens, Toussaint had closed with the American propositions, and had withheld coming to any positive agreement with Colonel Harcourt." Convention was signed with Toussaint. Character of the trade particularly suited to Americans. May 3I, I799.

Id., no. 6. Same subject. Appointment, as English agent, of Charles Douglas. Until his arrival English affairs were in the hands of Dr. Stevens. If latter should be recalled Douglas is not to take over Am. affairs. July I4, I799.

Id. Same subject. Oct. 8, I799. Encloses letters from Charles Douglas : American vessels authorized to enter at Port de Paix and the Cape after Aug. I, "instead of allowing them to sail from America on that Day"; thirty of them were now at the former and nearly sixty at the latter; several American vessels said to be waiting at the Cape for passports to go to the outports. Aug. I5, I799.

American merchantmen arrived with passport from Dr. Stevens only, contrary to terms of convention. Aug. 22, I799.

Granting of passports by Dr. Stevens said to be because he was acting for both nations pending arrival of British agent; a hundred Am. vessels now at the Cape and nearly fifty at Port de Paix. Aug. 27, I799.

Letter from Hugh Cathcart (vice-agent), enclosing "list of the names of the American Vessels that have brought here contraband Articles". Port Républicain, Sept. I6, I799. 
103. $\mathrm{r} 799-1800$.

Letter from Balcarres, enclosing information from Mr. Douglas on projects in Santo Domingo for attack on Jamaica. List of articles given which "this Agent of the Directory has requested the Commandant at the Cape to endeavour to obtain through the means of the Consul General of the United States". Oct. 28, r799.

104. I800.

Draft to Balcarres, objecting to permission granted by him for exportation of Jamaica produce in U. S. vessels. May 29, I800.

Report from the Committee of the . . House of Assembly .. . as to Trade, Navigation and Culture (Santiago de la Vega, I80o). Contains account of imports from America, Sept. I, r798-Sept. I, r799.

Letter from Balcarres. Encloses extract of letter from E. Robinson, subagent at Santo Domingo, June 23, r8oo, covering copy of U. S. proclamation, May 9, granting permission to American citizens to trade to "Jacquemie" [Jacmel] and southern ports of Santo Domingo to the west thereof. July 24, I800.

105. I8oo-r8or.

Letter from Balcarres. Encloses letter from magistrates of Honduras, Aug. 19, r800, submitting memorial on cessation of intercourse between Honduras and America. Nov. 24, r8oo.

Id. Dec. 6, r8oo. Encloses letter from E. Robinson, Nov. I, r8oo, covering copy of U. S. proclamation permitting commercial intercourse with all the ports, and denying any share in grant of passport to an American brig proceeding from Cap Français to Jacmel.

Id. May r6, r8or. Encloses letter from Edward Corbet, agent for British affairs in Santo Domingo, giving his opinion that "the Americans . . . have acquired a greater degree of ascendency than perhaps it was originally intended". Mar. 3I, I80I.

Id. Refers to unsuccessful attempt made to get horses for 20 th Regt. of light dragoons lately arrived from Va. May 28, r8or.

Id. July I8, I80 I. Encloses letter from Edward Thornton, lately succeeded to Liston in charge of British affairs in U. S., dealing with question of extension of American trade to southern parts of Santo Domingo. Deprecates any opposition to this extension. Apr. I7, r8or. Also reply from Balcarres. June 28, r8or.

Id. Aug. 2, r8or. Encloses letter to Maj.-Gen. Nugent, urging agreement to extension of district over which benefits of the convention apply: "the good faith of the British are through me absolutely committed both to the United States . . . and to the Chieftain Toussaint". Aug. r, r8or.

106. I $80 \mathrm{I}$.

Letter from Lieut.-Gov. Nugent, with reference to Santo Domingo. Aug. r 5, r8or.

Id. Same subject. Encloses undated extract of letter from Edward Corbet, reporting arrival of American vessel at Jacmel from France bearing a cargo admitted to be French property. Sept. 5, I80 I.

Id. Delay in extending commerce to remaining ports owing to death of Adm. Lord Hugh Seymour; "the American Vessels having for a considerable time had free access to the Ports in question". Constant correspondence maintained between the British envoy in 
America and Mr. Corbet, and between Mr. Corbet and Mr. Lear, the American consul general in Santo Domingo. Sept. 27, I80I.

Id. Oct. I I, I80 I. Encloses letter from Edward Corbet, Sept. 9, I80 I, covering "Copy of the only Correspondence I have had with $\mathrm{Mr}$. Lear", viz.: letter from Edward Stevens to Edward Corbet, July 5, I80I; Edward Corbet to Tobias Lear, Aug. Io, I80 I, sending twenty blank passports; Edward Corbet to Tobias Lear, Aug. 27, I8or, with reference to schooner Poisson Volant, which has passport to Jeremie, to which port he is not yet authorized to grant passports.

Encloses also letter from Edward Thornton to Edward Corbet, May I9, I80I, asking that causes of capture of vessels may be sent to him to avoid misrepresentations. Also letter from same to same, expressing regret at failure hitherto to grant passports to American and British vessels proceeding to the southern ports. He has to explain the difficulty to the new administration of the United States "(which at the best cannot be regarded as partial to Great Britain)". He assumes that "many of the recent captures made by His Majesty's Ships of American Merchantmen on the South side ... . must be imputed to the want of regular Passports". The new President professes "impartial neutrality", hence recall of Mr. Stevens, who was considered "too much in the Interests of Great Britain", and appointment of Mr. Lear. May I8, I80i.

Encloses also letter from Edward Corbet to Maj.-Gen. Nugent, reporting commencement of practice "of American Vessels proceeding to and from Jamaica to this Island". He has represented the matter to the American consul. Sept. 26, I80I.

Id. Reports assent of Adm. Montagu to opening of remaining ports of late French part of Santo Domingo. Transmits "Account of the Commerce of St. Domingo" (not enclosed), whence it appears that "the Americans no longer consider themselves bound by our joint Treaty with Toussaint". Nov. I, I80I.

$I d$. Agreement made with M. Bunel for opening of remaining ports, including "that the Americans shall be confined ... . to the Terms of the Treaty made jointly between the British Government and America, and General Toussaint". Nov. 7, I80 I.

Draft to Maj--Gen. Nugent. Secret. Information of French designs to retake Santo Domingo. Requires recall of Mr. Corbet. Downing Street, Nov. I8, I80 I.

$I d$. Private and confidential. French designs to retake Santo Domingo. No obstacle to be placed in their way; no supplies to be given either to French or to Toussaint. Downing Street, Nov. I8, I80 I.

Letter from Lieut.-Gov. Nugent. Cessation of negotiations relating to Santo Domingo; Toussaint informed that strict neutrality will be observed; licenses to trade no longer granted; Toussaint furnished by Americans "with every Article he wanted". Nov. 29, I80I.

Id. Encloses letter from Edward Corbet to W. L. Whitfield, Nov. 29, I8o I, announcing former's recall. Dec. 2I, I8OI.

"Mr. Corbet's Correspondence I80 I." Includes:

Letter from Robert Liston, on extension of trade to "such parts of the island as might be reduced by Toussaint". Idea of England 
and United States as to intercourse with Santo Domingo changed; originally perhaps they wished to restrict it as much as possible, the coast trade being left to the inhabitants; later they extended their aim because they realized "that a principal danger to be apprehended from the liberty of the negroes in St. Domingo and the possible independence of the island was the increase of their navigation". Nov. 4, I800.

"Copy of the Proces verbal of the Installation of the Colonial Assembly of Saint Domingo at Port Republicain." Apr. 7, I80I.

Letter from Edward Corbet, urging that agreement with regard to Santo Domingo should either be carried out more liberally or abandoned; few prizes are to be obtained in "a Saint Domingo cruize", except American vessels whose condemnation will probably be reversed in England. June I7, I80I.

Letter from Edward Stevens, announcing his retirement owing to "the impaired state of my health". July 5, I80I.

"Note upon the necessity of enlarging the intercourse between Jamaica and the United States of America." Jan. IO, I80I.

Letter from G. Hibbert to Sir S. H. Clarke, setting forth views of planters and merchants on American trade; the merchants insist that "the Americans should in no instance become carriers to other Markets than their own of our Colony Produce". Dec.

107. 1802 . I4, I8OI.

Letter from Nugent. Private. Mr. Whitfield will remain at Santo Domingo until second week in January. Jan. $3, \mathrm{I} 802$.

Id., no. 8. Withdrawal of Mr. Whitfield and all British subjects. Jan. I9, I802.

Id., no. 9. Jan. 20, I802. Encloses letter from Edward Corbet stating that American trader has advantage over British: he brings manufactures of all countries, especially linens of Germany. Aug. 3I, I80 I. Encloses:

Account of vessels entered and cleared at Santo Domingo for Jamaica.

"A General Account of the number of Vessels to which Droging Passports have been granted from the 22nd Day of February to 3I August i80I." . . .

"An Account of Produce exported from Port Republicain . . . to America", May 2I-Aug. I8, I80I.

Letter from Edward Corbet to Tobias Lear, objecting to arrival of American vessel from Hamburg; has received from Mr. Lubin the explanation that trade is now being conducted "under the late Treaty with France" and not under the convention. Oct. 6, I80I.

Letter from Edward Thornton, setting forth principles of U. S. administration with reference to trade with Santo Domingo. June I8, I8OI.

108. 1802 .

Minutes of council. Oct. 5, I799-Jan. I8, I802.

Minutes of council. Oct. 20-Dec. I2, I80I.

Letter from Edward Corbet to Nugent. Encloses "Journal of Occurrences at Port au Prince from the 3 d to I4th February 1802 by a Gentleman of the Place". Apr. IO, I80I. 
Letter from Nugent. Encloses "Notes upon the present state of St. 109. $\mathrm{I} 802$.

Domingo". Aug. 12, 1802 .

Letter from Nugent. Private. Mentions fact that British agents "were scarcely permitted to have any Intercourse" with Cap Français, "which was the Resort of the Americans principally". Sept. 5, I802.

Id. Private. Dec. 5, I802. Encloses:

"List of Papers relative to the Settlement of Honduras. . . . 5 Dec. I802."

Letter from Edward Corbet, Oct. 20, I802, covering "Answers to the Queries put to the Magistrates by Edward Corbet".

Exports, Jan. I, I797-June 30, I802, distinguishing commodity and destination; also "A General Account of Mahogany and Dye Wood exported from . . . the Bay of Honduras", with note on the cessation of export to America except in British vessels. Letter from William Ross, Nov. I4, I802, endorsed "Opinion of the Attorney General of Jamaica relative to the Commercial Intercourse between America and Honduras in British Vessels".

Letter from Beeston Long, suggesting that intercourse between Jamaica and U. S. if allowed in American vessels should be confined to those of not more than Ioo tons burthen. Jan. 29, I802.

110. I8o3.

"Communications from Mr. Corbet relative to St. Domingo, received from Lt.-Genl. Nugent the 24th January I803." Sept. 27, Nov. I9, 1802 .

Letter from Nugent. Jan. 30, I803. Encloses letters on Santo Domingo, dated Jan. 5-29, 1803 .

Id., no. I7. Many families of Santo Domingo "are flocking to New Orleans as an Asylum". Apr. 30, I803.

Draft to Nugent, no. I4. Importance of re-establishing commercial relations with Santo Domingo, on equal terms with Americans, on expulsion of French. Oct. 7,1803 .

Letters from Nugent, nos. 22, 23. Aug. 9, Oct. 8, 1803. Encloses papers on Santo Domingo.

$I d$., no. I8. Refers to laws passed by U. S. government against admitting the "Blacks and People of Colour who had been apprehended and confined in Jamaica". Dec. I9, I803.

111. I804.

Letter from Nugent, no. 26. Expects that British subjects will have at least equal privileges with Americans in Santo Domingo. Jan. I4, I804. Encloses "Secret Convention proposed to be agreed upon between the Governor of Jamaica, and the General in Chief of St. Domingo".

Id. Private. Mar. 8, I804. Encloses memorandum on Guatemala.

Id., no. 28. Encloses, with comments, papers relating to Santo Domingo. Mar. IO, I804.

Id. Information from Fitzgerald, formerly of Port au Prince and now attempting to settle his family in New Orleans, that French emigrants are removing rapidly from Cuba to the U. S., and particularly New Orleans. Mar. 23, I804.

Id. Private. Frequent captures by French privateers of American vessels trading to Santo Domingo. Apr. 4, I804.

Id. Continued emigration from Cuba to New Orleans. Apr. I4, I804. 
Id., no. 30. French troops escaped from Santo Domingo have proceeded to Charleston. American vessels continue to supply Dessalines, despite numerous captures by French. May 20, I804.

112. 1804 .

Id. Private. Encloses letters, etc., on Santo Domingo. May 20, June IO, I804.

Minutes of council. Jan. I9-Dec. 9, I803.

Journal “" in assembly. Oct. 25-Dec. 22, 1803.

Letter from Nugent. Little danger exists from Santo Domingo "provided that we permit the Americans to supply them . . . and our Cruizers prevent them from navigating beyond a certain Distance

113. $\mathrm{I} 8 \mathrm{O} 4$. from their Coast". Aug. 29, 1804.

Letter from Nugent. Encloses resolution of council of Nov. 21, I804, on importation from U. S. Nov. 25, I804.

Id. Reports a meeting of merchants of Kingston on Dec. I3. They "came to no Resolution respecting the American Intercourse, the Merchants having no capital to carry it on from hence in British Vessels; but the Planters will probably employ some of their own Ships for the Importation of Lumber and Provisions". Dec. I5, I804.

Draft to Nugent, no. 9. Alarm had been caused in America through omission by lieutenant governor of that part of letter of Dec. 5 permitting in case of necessity importation from America in neutral bottoms. Mar. 7, I805.

Letter from W. Fawkener, Committee of Privy Council for Trade, expressing doubt whether trade to Santo Domingo could be profitable, owing to superior opportunities of Americans. July 3, I804.

114. 1805 .

Letter from Nugent. Jan. 27, I805. Encloses letter from David Gordon, N. Y. merchant, on trade of Santo Domingo. Nov. I7, I804.

Id. Encloses address and petition from assembly on American intercourse. Feb. I0, I805.

Draft to Nugent, no. Io. Refers to trade between Honduras and U. S. Mar. 7, 1805 .

Minutes of privy council. Dec. I5, I803-Nov. 2I, I804.

Journal of council in assembly. Oct. 23-Dec. I8, I804.

Letter from Nugent. May 19, 1805. Encloses proclamation for admission of American lumber and provisions, and letter from Anthony Merry, Feb. 23, I805, on American intercourse.

Id. June 6, July 5, Aug. 3I, Oct. 3I, I805. Encloses lists of prices current in Kingston, May I-Nov. 7, 1805.

Id. American intercourse. Nov. I6, I7, 1805 .

Id. Santo Domingo fully supplied by Americans. Dec. 27, 1805 .

115. 1805 .

Id. Intercourse between U. S. and Honduras. Dec. 27, I805.

Letter from George Hammond. Feb. 27, 1805. Encloses extract of letter from Mr. Merry, British minister to U. S., stating that announcement by governor of Jamaica of alteration to basis of commercial intercourse with U. S. has caused a "very disagreeable sensation". Jan. 25, I805.

Id. July II, I805. Encloses extract of despatch from Mr. Bond, British consul general at Philadelphia, expressing satisfaction at 
news that discretionary power in connection with American intercourse had not been removed from governors. June 3,1805 .

Series of tables giving imports in American bottoms, British bottoms, and from British colonies. Exports to U. S. in British bottoms, and in American bottoms, Sept. 30, 180 I-Sept. 30, 1804; imports of provisions from U. S. in American bottoms, and in British bottoms, Sept. 30, I80I-Sept. 30, I804; similar table for imports of lumber.

116. 1806 .

Letter from Sir Eyre Coote, no. 9. Importation from U. S. Mar. 6, 1806.

Id., nos. I2, I9, 3I, 39, 47, 53, 57. Mar. 23, Apr. 22, June 3, July 4, Aug. I, Sept. I, Oct. I, I806. Encloses lists of prices current in Kingston, Mar.-Oct., I806.

$I d$., no. 50. Encloses letter and memorial from settlers at Honduras on American intercourse. Aug. 25, 1806.

Id., no. 52. Importation from U. S. Aug. 28, 1806.

$I d$., no. 58 , relating to imposition of duty on fish imported from the U. S. Oct. 2, 1806. Encloses on same subject extract of letter from Anthony Merry, July 25, 1806 .

117. I806.

Letters from Coote, nos. 64, 71. Nov. I, Dec. I, I806. Encloses lists of prices current in Kingston, Nov.-Dec., 1806.

Id., no. 72. Importation from U. S. Dec. 2, 1806.

Draft to Coote, no. Io, enclosing authorization for William Tudor to import three cargoes of ice and snow in American vessels to Jamaica, etc. Dec. 4, 1806.

Letter from Coote, no. 76. Dec. 13, 1806. Encloses account of imports of provisions into port of Savanna la Mar from United Kingdom, British colonies, and U. S. in British and in American vessels, I794-1805; also similar account of exports, and similar returns for

118. 1807 . other ports, lumber being generally included in the return of imports.

Letters from Coote, nos. 77, 89, 95, 99, ro4. Jan. I, Feb. Io, Mar. I, Apr. I, May I, I807. Encloses lists of prices current, Jan.-May, 1807.

$I d$., no. 88. Encloses letter from James Wilkinson, New Orleans, Dec. 17, 1806, covering letter of Dec. 7 to "Admiral Commanding on the Jamaica Station" describing "illegal" project of certain U. S. citizens "hostile to our peaceful relations with the Spanish Governments", and warning against any assistance being rendered by British. Feb. $7,1807$.

$I d$., no. 96, dealing with custody of Santo Domingo records: already "decayed" and apparently useless. Mar. 2, 1807.

Minutes of council. Oct. 30, 1805-Oct. 22, I806.

Journal “ " Oct. 2I-Dec. 19, I806.

Letter from Coote, no. I05. Encloses letter from Lieut.-Col. Hamilton (Honduras), Mar. I3, I807, relating to importation from U. S. May 6, 1807 .

119. 1807 .

Letter from Coote, no. ro6. Encloses letters on state of Santo Domingo. May 8, 1807.

Id., nos. III, I30, and unnumbered. June I, Sept. I, Oct. I4, I807. Encloses lists of prices current, June-Oct., 1807 . 
Id., no. I I9. Importation from U. S. into Honduras. June 30, I807.

$I d$., no. I23. Encloses accounts of imports and exports at the various ports of Jamaica for I806, showing country of origin or destination, nationality of vessels, etc. July 5,1807 .

Id., no. I3I. Sept. 2, I807. Encloses letter from Lieut.-Col. Hamilton (Honduras) relating dealings with Indian chiefs: "The message alluded to in my letter to them was, that they were by no means to permit any settlement to be formed on the Musquito Shore, by the Citizens of the United States of America." July I 5, I807.

Id., no. I34, on custody of Santo Domingo records. Sept. 5, I807.

Id., no. I37. Encloses letter dated New Providence, Sept. 3, I807, acknowledging receipt of letter conveying information from British consul general at N. Y. of probability of rupture between G. B. and the U. S. Sept. 29, I807.

120. 1807 .

Letter from Coote, no. I47. Dec. I, I807. Encloses list of prices current in Kingston. Dec. I, 1807.

$I d$., no. I56. Importation from the U. S. Dec. 29, I807.

121. $\mathrm{I} 8 \mathrm{o} 8$.

Letters from Coote, nos. I58, I62, I67. Jan. 12, Feb. 6, Mar. I, I807. Encloses list of prices current in Kingston, Jan.-Mar., I807.

Id. Feb. 19, I808. Encloses letter (marked "Private") from Thomas Barclay, British consul general at N. Y., on supply of provisions from the U. S. Dec. 29, I807. Also reply of Sir Eyre Coote approving plan so far as it relates to flour, corn, bread, and lumber. Feb. 7, 1808.

Memorandum by Sir Eyre Coote "respecting the Defence etc. of Jamaica". Outlines conditions at Honduras with reference to importation from America.

Letters from Duke of Manchester, nos. 2, 4, II. Apr. 23, May I5, July IO, I808. Encloses lists of prices current in Kingston, Apr., May, July, 1808 .

$I d$., no. I7. Encloses paper relating to Dissenting preachers, some of whom have come from U. S. as missionaries to the slaves. July $3 \mathrm{I}$, I 808 .

122. $\mathrm{I} 808$.

Letters from Manchester, nos. I8, 20, 23, 25. Sept. I I, Oct. I6, Nov. 20, Dec. II, I808. Encloses lists of prices current in Kingston, Sept.Dec., I 808.

Note from the Treasury. Dec. 27, I808. Encloses "Extract from State of Account of Rob: Liston Esq. late Envoy to the United States of America".

124. I809.

Letters from Manchester, Jan.-Aug., I809, enclosing lists of prices current for those months.

125. 1809 .

Letters from Manchester, Sept.-Dec., I809, enclosing lists of prices current for those months.

127. 1809 .

Letter from Maj.-Gen. Carmichael. July i7, I809. Encloses plan of Santo Domingo, I809. 
128. I8IO.

Letters from Manchester, Jan.-Nov., i8ro, enclosing lists of prices current in Kingston, Jan.-May, July-Nov., i8ıo.

129. I8Io.

Letter from Manchester, no. II I. Dec. 30, I8Io. Encloses list of prices current in Kingston, Dec., I8Io.

131. I8II.

Letters from Manchester, Jan.-May, I8I I, enclosing lists of prices current in Kingston for those months.

Id., no. I3I. May 25, I8II. Encloses list of queries submitted to attorney general by governor and his replies: includes questions a.s to American intercourse.

Id., no. I32. Acknowledges receipt of letter of Mar. 2I on importation of American fish. June 22, I8II.

Letters from Lieut.-Gov. Edward Morrison, July-Nov., I8I I, enclosing lists of prices current in Kingston, July-Sept., Nov., I8II.

Id., no. 25. Acknowledges receipt of despatch of Sept. 9, enclosing order in Council of Sept. 6. Nov. I4, I8II.

132. I8II.

Petition of inhabitants of two parishes on imports in neutral vessels in Annotto Bay: in $1803-1804,76$ Americans landed there.

134. I8I2.

Letters from Lieut.-Gov. Morrison, Jan.-Oct., 1812, enclosing lists of prices current in Kingston, Dec., I8II-Oct., I8I2.

Id., no. 63. Describes precautions taken relating to admission of foreigners, especially from the U. S. June 12 , I8I2.

$I d$., no. I (to Bathurst), reporting need for security in view of declaration of war by the U. S. Sept. 3, I8I2.

Id., no. 8. Acknowledges receipt of despatch of Aug. I, enclosing order in Council of July I7, I8I2, directing detention of U. S. vessels. Oct. 20, 1812 .

Id., no. I5. Acknowledges receipt of despatch of Sept. I I, dealing with coin or bullion found on U. S. vessels detained or captured. Nov. 28,1812 .

Id., no. I6. Acknowledges receipt of despatch of Sept. I4, enclosing copy of act on exportation from Bermuda of British plantation sugar and coffee to the U. S. Nov. 28, I812.

$I d$., no. 20. Encloses address of assembly with copy of report from a committee on effect of war with U. S. on commerce and agriculture of the island. Dec. I2, I8I2.

135. $\mathrm{I} 8 \mathrm{I} 2$.

Letter from Edward Morrison. Sept. 5, I8I2. Encloses "Return of European Serjeants Drummers, rank and file of the several Regiments stationed on this island". Total $34 \mathrm{I} 8$ men.

136. I8I3.

Letter from Edward Morrison, no. 22. Promises support to Messrs. Bogle and Co., appointed to take charge of American property detained. Jan. 29, I8I3.

Id., no. 23. Acknowledges receipt of despatch of Oct. $\mathrm{I} 3$, with order in Council of same date ordering general reprisals against the U. S. Jan. 29, I813. 
$I d$., no. 25, relating to issue of licenses for importation of enumerated articles from the U. S. Jan. 29, 1813. Encloses printed form of license.

Id., nos. 27, 37. Jan. 30, Apr. 22, I813. Encloses lists of prices current in Kingston, Nov., I8I2-Apr., I8I3.

Id., no. 30. Acknowledges receipt of despatch of Nov. I8, dealing with coin or bullion found on U.S. vessels. Feb. 3, I8I 3 .

Letters from Manchester, nos. 4, I I, I6. July I7, Oct. I6, Dec. I0, I8I3. Encloses lists of prices current in Kingston, June-July, Sept.-Dec., I8I3.

137. 1813. "Inclosures in General Morrison's Despatch to Earl Bathurst dated 28 Jan. I8I3."

140. 1814 .

Letters from Manchester, nos. I9, 26, 38, 44. Jan. 29, Apr. 23, Oct. I6, Nov. I2, I8I4. Encloses lists of prices current in Kingston, Jan.Apr., Aug.-Nov., I8I4.

$I d$., no. 32 , referring to American vessels laden with government flour detained and sold in Jamaica. June 3, I8I4.

Letter from George Hibbert. Encloses despatch from committee of correspondence relating to American intercourse. May 25, I8I4.

141. I8I5.

Letters from Manchester. Feb. 28, Apr. 23, I8r5. Encloses lists of prices current in Kingston, Jan.-Apr., I81 5.

Letter from George Hibbert, asking whether any change is contemplated in conditions of intercourse with the U. S. in treaty then depending. July 20 , I8I 5 .

C. O. I38: I3-25. Board of Trade: Entry-Books. I706-I782.

C. O. 326:39-4I. Board of Trade: Indexes. I704-I759.

13. I709-17г3.

Letters to Admiralty on convoys. Feb., I7Io/I.

Letter to Hamilton, on passage of new act "for Encouragement of Trade to America", with new provisions for duties on prize goods; and pointing out that assembly has no right to adjourn itself otherwise than de die in diem, since it sits only by virtue of governor's commission. Nov. 22, I7II.

"Certificate" in favor of Dummer's proposal for packet service, showing that monthly service had been maintained I702-17II under Dummer's management. Feb. I7, I7II/2.

Letter from Dartmouth, on issue of letters to colonial governors forbidding sending to England of persons accused of crime unless with full proof of guilt. Aug. 25, I7 I2.

Representation, on petition of Jamaica merchants respecting sale of slaves to factor of Asiento, and relating briefly history of agreement. Nov. 7, I7I2.

Letters, memorials, report of attorney general, and other papers on act for quieting possessions, passed Oct., I ZII. I I I2-I 7 I 3 .

Copy of order of committee of House of Commons, for production of extracts from minutes of assembly on levy of duties on prize goods. May 27, I7I3. 
Report of lords of committee for hearing appeals from plantations, on petition of Mr. Saunders concerning privilege of immunity from trial claimed by member of assembly of Jamaica. May 28, i7i 3.

Various papers on charges against Hamilton.

14. I7I3-I7I6.

Letter to Hamilton. Latter's disputes with Walker; levy of duties on prize goods; prejudice to trade involved in carrying of negroes and merchandise by naval vessels; and action of Board on act of Jamaica for quieting possessions. On advice of crown counsel act held without recommendation for confirmation or disallowance; and assembly informed that disallowance would be recommended, unless new act omitting objectionable features passed within reasonable time. July 20 , I7I3.

Report of attorney general, on "Account of Escheats in Jamaica", showing that, by local revenue act of 1703 , all fines, forfeitures, and escheats are to go to support of government of island; informers having only prior right of purchase at valuation fixed by jury. Aug. 6, I 713 .

$I d$., on act to prevent one person from holding two or more places of profit. Aug. 6, I7I3. Representation and order in Council for disallowance. Aug. 6, 8, I7 I3.

Letter from Bolingbroke, directing inquiry and report on keeping of Handasyd's regiment at Jamaica. Feb. I6, I713/4. Other papers, showing proceedings of Board in inquiry. Letter to Bolingbroke, advising retention of regiment at Jamaica, giving statistics of white and black population, estimating amount needed for subsistence of troops, and pointing out dangers of slave revolts, attack from maroons, and attacks from outside. Mar. 9, I7I3/4.

Letter from Bolingbroke, directing preparation of instructions to qualify some person to quiet disorders and confusions in Jamaica, Barbados, the Leeward Islands, and other "British Southern Colonies". Mission to be similar to that of Nicholson in N. Am. Aug. I8, I7I4.

Letter from Bromley, ordering that copies of papers on retention of regiment at Jamaica be laid before House of Commons. Apr. Io, I7I4. Other papers, showing decision to break up regiment and leave only independent companies at Jamaica.

Letter to Hamilton, stating that assembly, which sits only by virtue of governor's commission, "must not assume to themselves the rights and privileges of the House of Commons", in matter of adjournment and in denying to council right to amend money-bills. June 2I, I7I 4 .

Representation, on act for relief of freeholders of Kingston, giving much information on founding of that town. July I6, I7I4.

Letter from John Thurston, enclosing letter to him from Hamilton, on factious elements in assembly which refuse to give subsistence to soldiers; which claim for assembly same powers and privileges as House of Commons; and which demand a lieutenant governor instead of a captain-general. Mar. 3, I7i4/5.

Letter from R. S. Harris, enclosing representation of merchants interested in Jamaica on settlements in Hispaniola and N. Am. Mar. II, I7I4/5. Memorial from several planters and others concerned in Jamaica on better peopling and planting of island. Read Mar. 25, I7I 5 . 
Letter to Stanhope. Relations of governors with commanders on naval stations; and especially on alterations made in governors' commissions "upon His late Royal Highness Prince George's being made High Admiral". Mar. I5, I7 14/5. Other correspondence.

Draft of instructions for Hamilton, showing alterations on: passage of money-bills; suspension of councillors; handling of escheated property; and procuring passage of laws to encourage planting and increase settlement of whites, apply real estate to payment of debts, and provide subsistence money for troops. Apr. 25, I7 I5.

Letter to Hamilton, on increase of white population. Apr. 25, I7 15.

Opinions and representations on recent acts for quieting possessions and regulating fees. I7I5.

Letter from T. Parker, sending extracts from two letters from Hamilton to Earl of Orkney on political conditions in Jamaica. Mar. 24, I 7 I $4 / 5$.

Letter to Stanhope, noting that "not only the Assemblys of Jamaica, but of several other Colonies in America as has been represented by various governors, have of late pretended to assume new Privileges and Powers". Assembly of Jamaica claims right to address the crown separately and to forward address by its own channels, on precedents from Va., I70I, and Barbados, I704/5. Also directs that money advanced by Hamilton for subsistence of troops be repaid "out of the first and readiest of His [Majesty's] Revenues in that Island". Feb. I7, I7 $5 / 6$.

Letters and memorials on objections of South Sea Company to duties on negroes.

Letter to Commissioners of Customs, sending list of colonial acts found in office of Board for regulating or establishing fees in any plantations. Mar. I4, I7 5 / 6.

Letter to Hamilton, on conditions under which his instructions allow appeals from court of chancery. Apr. I9, I7I6.

Numerous papers on subsistence of troops, and on charges against Hamilton.

15. I716-1717.

Memorandum from Thomas Pitt, on causes of disorders in Jamaica. Read Oct. I6, г7ı6.

Papers on piracy, and on charges against Hamilton.

Letter from Methuen, with translation of letter from Spanish ambassador on attempts of British to settle and to cut logwood at Campeachy. Nov. I5, i7 16.

Opinion of attorney general, on act of assembly fixing qualifications for its own membership. Sept. 26, 1717.

Draft of instructions for Sir Nicholas Lawes, with fresh instructions on: power of governor to suspend councillors; use of suspending clause; granting of land; powers of governor as vice-admiral; conditions under which appeal to Privy Council to be allowed; value of certificates granted by bishops other than Bishop of London in preferment to benefices; power of adjournment possessed by assembly; right of council to amend money-bills; deposit of public money with receiver general; extent of privilege to be allowed to members of council and assembly; and conditions (as to amount and control) under which money may be raised for soliciting affairs of island in England. Oct. I I, I7 I7. 
Reference from Addison of petition of several merchants of Jamaica on open capture of 37 vessels and raiding of coasts by Spaniards since cessation of hostilities. Oct., I7I7.

Letter to Ury, secretary to South Sea Company, on duties on negroes imposed by Jamaica legislature. Nov. 6, I7I7.

Representations, I7I7, for disallowance of acts fixing qualifications for membership in assembly, and forbidding member of council or assembly to act as commissioner for receipt of public money. Also for disallowance of deficiency bill, which provides for bringing of white people to island; parts of said bill being joined by "tack" (rider), and its provisions granting subsistence to troops only for one year, forbidding military officers to accept civil offices, prohibiting holding of more than one office by individual, interfering with freedom of elections, and conflicting with confirmed acts of 1703 and I7I2.

16. I7I7-I724.

Representation, on petition of South Sea Company against export duties on negroes in Jamaica. Dec. 21, I717. Other papers.

Representations, for disallowance of act "for the Effectual Discovery of all Persons that are Disaffected" (a local test act); "for ascertaining the Number of Ports of Entry in this Island"; and an act "to prevent all fraudulent Trade to Hispaniola". I7I8, I72I.

Order in Council, for preparation of additional instruction to Lawes, to investigate and give satisfaction for piracies complained of by Spaniards. Feb. I7, I717/8. Other papers on piracy and pardon of pirates.

Letter to Lawes, on payment for ordnance stores supplied. Dec. 27, I720.

Draft of instructions for Duke of Portland, with changes concerning: use of suspending clause in currency and certain other bills; acceptance by governor of additional salary; and authority of Bishop of London in granting certificates to clergymen and teachers. Dec. I3, I72I.

Letters to Portland, on raising of permanent revenue. Board hopes "that His Majesty will not be under necessity of applying to the Legislature of Great Britain". June I3, I723; July 30, Aug. I I, I6, I724. Representations and other papers.

Letter to Newcastle. Board divides all acts submitted into three classes, in order that immediate consideration may be given to those requiring it. "We take leave to observe to your Grace, that the fewer Acts there are confirmed, the greater will be the dependance of the Colonies upon the Crown; Of which the present state of the Island of Jamaica is an instance." July I, I724.

17. I725-I734.

Important representation, on perpetual revenue act and other acts recently passed in Jamaica, with recommendations for confirmation or disallowance of fifteen acts passed in 1699, 1702, 1703, and more recently. Feb. 19, 1724/5.

Representation, showing that draft of revenue act has been sent to colony for passage. Text of act and suggestions for possible amendment enclosed. Draft makes provision for subsistence of regular troops stationed in Jamaica. May 4, I726. 
Representation, advising confirmation of permanent revenue act passed in 1728 , although it makes no permanent provision for garrison. May I4, I729.

Additional instruction to Portland, for suspending execution of judgments against which appeal is being made to Privy Council, until latter's decision is received. July $28,1726$.

Draft of Gov. Hunter's commission. Mar. 14, I726/7.

Draft of Gov. Hunter's instructions, showing no changes not covered by additional instructions already sent. June 8, 1727. (Owing to the death of George I., neither these instructions nor commission above referred to were ever issued.)

Letter to Newcastle. Duties on negroes, and objections made by South Sea Company. Mar. 12, I724/5. Important representation on same subject, reviewing question from I7I7 to date. May 3I, I727. Representation on same subject, and also concerning duties imposed on convicts. Latter duties are contrary to act of 4 George I., "For the further preventing Robbery, Burglary and other Felonies and for the more effectual Transportation of Felons". Aug. 25, I73I. Representations on same subject. Aug. 3, Sept. 6, 1732. Other papers.

Letter to Portland. Tenure and powers of provost marshal and other patentees. June 30, 1725.

Draft of Gov. Hunter's commission. July 19, I727.

Draft of Gov. Hunter's instructions, showing no essential changes from previous draft. July 25, I 727.

Letter to Hunter. Instructions as to limitations under which governor's assent could be given to any bill for making produce of Jamaica legal tender in payment of debts. Nov. 20, I728.

Representation, on five acts passed to encourage settlement. Dec. 9, I729.

Representation, for confirmation of act imposing penalties on importation or purchase of Irish Roman Catholic servants. Nov. IO, I730. Letter to Hunter on this subject. July 7 , I730.

Representation, for disallowance of act "for the better regulating Slaves and rendring Free Negroes and Mullattoes more useful". July I3, I73I.

Representations, on 'despatch of two regiments to Jamaica, suggesting uses to which they should be put for defense against slaves and outside attacks, and in providing settlers. July I5, Aug. I I, I73I. Letter to Hunter on same subject. Oct. 22, I730.

Representation, on petition of planters and merchants that encouragement be given to coffee planting. Jan. 28 , $173 \mathrm{I} / 2$.

Draft of instructions for Gov. Cunningham, showing no important changes. July I0, I734.

18. I734-I 743.

Important representations, on laying of duties on negroes; reviewing history of question, and discussing management of slaves, peopling, and defense of island. Dec. I2, I734; June 29, I736.

Letter to Cunningham, directing him to prepare, in compliance with demand of House of Commons, account of all money raised in Jamaica during preceding ten years. Dec. I7, I735.

Draft of bill for better peopling and settlement of island, limiting size of grants, and providing for forfeiture of uncultivated land. Sent to Cunningham, who is to secure passage if possible. July 9, I735. 
Letter to Ayscough, president of council, acknowledging receipt of twelve letters since Board's last communication to him, which was sent May 23, I734. July I7, I735.

$I d$., on farming of logwood-cutting at Campeachy. Contract made between South Sea Company and certain private persons in this matter will soon be cancelled, since King of Spain disputes power of company to license anyone to trade in its name. Sept. 4, I735.

Representation, and draft of additional instruction, on act withdrawing subsistence from officers enlisting men in the colony, or from men who consent to be enlisted. Oct. 3I, I735.

Report to Committee of Council, and draft of additional instruction, on use of suspending clause in acts imposing special taxation on Jews. Mar. I8, I735/6.

Id., on the state of Jamaica. Apr. I, I737.

Draft of Gov. Trelawney's commission. June 30, I737.

Draft of Gov. Trelawney's instructions, showing changes on: enlistment; measures for peopling island; duties on negroes; subsistence for garrison; and governor's additional salary. Addition of special article for securing enforcement of the Molasses Act (no. I3 of instructions for enforcement of Acts of Trade). Sept. I4, I737.

Draft of additional instructions, giving governor power to grant, under certain restrictions, "royal" mines of gold and silver. Feb. I6, $1737 / 8$.

Letter to Trelawney, complaining of small output of Jamaica, and reviewing unfavorably acts passed since $\mathrm{I} 720$ to increase population and cultivation. Nov. 8, I739.

19. I743-I753.

Report on petition for grant of royal mines. Aug. 15, I745. Additional instruction on same. Jan. IO, I745/6.

Representation, recommending adoption of suggestion of governor, council, and assembly, that chancery jurisdiction be vested in commissioners appointed by his Majesty for that purpose. Jan. I5, $1746 / 7$.

$I d$., and draft of additional instruction, on laying of extra taxes on absentees. May I, I747; June 29, I748.

Letter to Trelawney, on impressment of seamen. June I6, I747.

Representation, recommending disallowance of act imposing further qualifications for members of assembly. Aug. I3, I747. Letter to Trelawney on same subject. July 2I, I748.

Letters, reprimanding Trelawney for assenting to act laying import duties on negroes, payable by importers; act repealing former act and containing no suspending clause; act imposing duties to be in force less than one year; and acts providing for lodging of public money with commissioner instead of with receiver general. "We every day experience the fatal effects of the encroachments of American assemblys upon the Prerogative of the Crown more especially in Money Bills." Jan. 3I, I748/9; Aug. 3, I749; Aug. 6, I75I.

Representation, recommending disallowance of triennial act, passed May, I748. July 3I, I749.

Letter to Treasury, sending address of governor, council, and assembly on trade of northern colonies with French sugar islands. May 4, I750.

Draft of Gov. Knowles's commission. Mar. 28, I752. 
Draft of Gov. Knowles's instructions, including orders that, pursuant to order in Council of Mar. II, I75I/2, he shall in future correspond only with Board, except on matters requiring immediate attention of one of the secretaries of State, or on which he has received orders from one of the secretaries. May I4, I752.

Letter to Trelawney, ordering him to transmit a "state" of Jamaica prepared with especial reference to an (enclosed) address of House of Commons. Apr. 24, I752.

Letter to Knowles, recommending him to take all possible means to prevent people from leaving for foreign colonies, as has lately been done from America; and to check importation of foreign sugar. June $3, \mathrm{I} 75^{2}$.

Letter to Commissioners of Customs, transmitting account of value of imports and exports, I748-1752. Dec. 7, I752.

Extensive report on state of Jamaica, as submitted to House of Commons, with list of papers appended thereto. Feb. 22, I752/3. (Apparently compiled from the reports of Trelawney and Knowles. Covers population, trade, settlement, land system, etc.)

Letter to Knowles, denying that he lacks sufficient authority over naval officer (whom the crown now sees fit to appoint) ; and reprimanding him sharply for assenting to act which excludes patent officers from council and assembly: "probably the first of its kind which has ever been transmitted from any of His Majesty's Colonies". May I6, I753.

Representation, recommending disallowance of twelve acts passed in I75I and I752. One provides for election of members of assembly by ballot, a practice obtaining only in S. C., where it was adopted under proprietary government. Other acts relate to tenure of judges, administration of justice, and powers of provost marshal. Four lack suspending clause. July I9, I753. Letter to Knowles on several of these acts. Feb. 13, I753.

20. I754-1759.

Several representations and letters, on failure of assembly to insert suspending clauses, and of governor to insist upon such insertion.

Numerous letters and representations, on quarrels of governor with assembly and courts, and especially in connection with removal of seat of government to Kingston. In connection with removal are discussions on opening of new ports of entry and establishment of circuit courts. Power of assembly in financial matters also brought under review.

Letter to Knowles, complaining that Board possesses no account of perpetual revenue for years $1735^{-1752}$, and none of temporary annual revenues for any years. Oct. I 5, I754.

Warrant for his Majesty's signature, appointing John Pownall naval officer of Jamaica. Transmitted Nov. I3, I755.

Draft of instructions for Henry Moore as lieutenant governor of Jamaica. Mar. 9, I756.

Letter to attorney general and solicitor general asking for their opinion on refusal of council to act in legislative capacity after proclamation of martial law. Jan. 22, I757.

$I d$., asking for opinions on certain points connected with change in seat of government, and incidentally affording information on enforcement of acts of trade, and on judicial system in Jamaica. Feb. 23, I757. 
Draft of Gov. Haldane's commission. Jan. 31, I758.

Draft of Gov. Haldane's instructions, showing no important alterations. Mar. 22, I758.

Several papers on dismissal of the postmaster of Jamaica.

Representation, on vessels from northern colonies captured and taken into Jamaica, for trade with French islands, especially at Monte Cristi. Severe strictures, particularly as regards R. I. and Conn., which "assume to themselves an absolute government, independent not only of the Crown, but of the Legislature of the Mother Country". An opinion on this trade should be secured from attorney

21. 1760 . general and solicitor general. Aug. 31, I759.

Representation for disallowance of act "for ascertaining the value of Spanish milled money, and for rendering the payment of debts more certain". May 16, i760. (Valuable.)

Letter to Moore, expressing disapproval of act on appointment of agent. June 13,1760 .

Representation on petition of Peter Furnell, who is prevented from recovering money owed him by Norwood Witter, member of council, by Witter's privilege. July 3r, 1760 .

22. $\mathrm{I} 760-1767$.

Draft of commission for Lyttelton. Mar. 4, I76r.

Representation, with warrant to governor of Jamaica, to issue letters patent constituting Gilbert Ford attorney general of Jamaica. Mar. 4,1761 .

Draft of instructions for Lyttelton, showing no important alterations. Apr. 28, I76I.

Correspondence with Commissioners of Customs on act prohibiting importation of produce of foreign colonies into Jamaica and "for punishing several frauds, committed by Several Persons trading to and from the Northern Colonies". June-July, r76r. Representation on act. Jan. 27,1762 .

Letter to Eyres, on act concerning exportation from Jamaica of prize goods. Dec. 4, I76r. Representation on act. Jan. 27, 1762. Other papers.

Representation on act of 1760 , regulating judicial procedure, and complained of by provost marshal as being injurious to his rates of office.

$I d$., on address of council and assembly complaining of trade carried on at Monte Cristi by British subjects. Mar. 27, 1769.

$I d$., on petition of Adm. Knowles, complaining that Philip Pinnock protects himself against prosecution for debt by his privilege as member of council. Jan. 3I, 1763 .

$I d$., on resolutions passed by assembly with reference to Board of Trade's advice that certain acts should be disallowed. Feb. I7, 1763.

Letter to William Beckford, lord mayor of London, offering him opportunity to express his views on act of $176 \mathrm{r}$ concerning exorbitant grants and devises made to negroes or descendants of negroes. May $7,1763$.

Representation on Lyttelton's complaint of oath of secrecy administered by assembly to its clerk. Oct. 26,1763 .

Entries relating to consideration of bill placing double tax on absentees. Feb.-Mar., I764. 
Letters to Lyttelton, on admission of Spanish vessels. May I4, Dec. 24, I764.

Reports of proceedings on privilege dispute. Mar., 1765 .

Letter to Lyttelton, on duties on slaves. Mar. I5, I 765.

Report to committee of Council, on petition of secretary, naval officer, and collector to be protected from suits brought for fees collected. May 21, 1765 .

$I d$., on bills to regulate constitution of committee of correspondence and the appointment of an agent. Dec. 12, I765.

$I d$., on additional instruction to be sent to governor on privileges of members of council and assembly. June 3, i 766.

Draft of commission for Trelawney. July 8, I 767 .

Draft of instructions for Trelawney, showing alterations on privileges of members of council and assembly. July 29, 1767.

23. $\mathrm{r} 768-\mathrm{I} 780$.

Draft of instructions for Trelawney, on enforcement of acts of trade. July 29 , I767.

Representation, on acts regulating legal procedure. Dec. 24, I767.

$I d$., on jurisdiction in cases of murder committed by seamen on board H. M. ships in the harbor of Kingston. Nov. I I, r 768 .

$I d$., on dispute between council and assembly over appropriation of surplus revenue. June 15 , I770.

Draft of Keith's commission. Apr. I, I773.

Draft of instructions for Keith, showing insertion of articles forbidding assent to bills: (I) establishing lotteries; (2) altering constitution of assembly; (3) providing that property of persons who have never resided in island may be attached for recovery of debt in manner inconsistent with usages in G. B. ; or appropriating surplus of revenue arising under revenue act of $\cdot$ I 728 . July $\mathrm{I}, \mathrm{I} 773$.

Representations, and draft of additional instructions, on acts imposing additional duties on negroes. Dec. 19, I774; Feb. 23, June 26, I775. Other papers.

$I d$., on act for quieting possessions. May 24, I776.

Draft of Dalling's commission. Aug. 20, 1777.

Draft of instructions for Dalling, showing alterations on privileges of members of council and assembly; grants of land; powder-duty laid on trading vessels; and assent to bills on naturalization, divorce, and acquisition of lands by aliens before naturalization. Apr. I4, I778.

Draft of instructions for Dalling, on enforcement of acts of trade, showing some omissions. July I, I773.

Representation on act "ascertaining who shall compose future councillors of war and regulate their proceedings". May 4, I779.

$I d$., on act "to limit the duration of assemblies". May 25, I780.

24. I78I. Reports and Instructions.

25. I782. Instructions to Gov. Archibald Campbell.

C. O. 326:39. I704-I733. Index to Board of Trade Original Correspondence and Entry-Books. (Complete and accurate for earlier years.)

40. I734-I754.

Id. (In general accurate.)

41. I754-I759.

Id. (Unsatisfactory.) 
C. O. I38:26-46. Secretary of State: Entry-Books. i766-i8i8.

26-29. I766-1782. In-Letters. (Partly correspondence, partly précis.)

30-38. I789-I8I3. Précis of Correspondence.

39-46. I782-1818. Out-Letters.

42. I782-I8OI.

Letter to lieutenant governor of Jamaica, relative to furnishing of registers to Americans. June 2, I785.

Letter to lieutenant governor of Jamaica, referring to grant of royal bounty to Loyalists from N. Am. colonies and E. Fla. Immigrants from Nova Scotia not to receive it. July 8, I785.

Letter to Balcarres, enclosing letter from Mr. King, the American minister, on purchase of stores transferred from Santo Domingo to Jamaica. A "proper Person" to be appointed to treat with the American agent in this matter. June 7, I799.

43. $\mathrm{I} 8 \mathrm{O} \mathrm{I}-\mathrm{I} 808$.

Letter to Lieut.-Gen. Nugent, no. I4, relating to intercourse with Santo Domingo: essential that British subjects should have privileges equivalent to those of Americans. Oct. 7, I803. Encloses copy of convention between Gen. Maitland and Toussaint L'Ouverture.

$I d$., no. 9, on cancellation of import permits by Gen. Nugent. Alarm excited thereby in America. Gen. Nugent omitted to state power conferred upon him of permitting importation in case of urgent necessity. Mar. 7, 1805.

$I d$., no. Io, communicating decision of Board of Trade on commerce in mahogany between Honduras and U. S. Exportation to be allowed in logs not exceeding twenty inches in diameter in return for provisions and lumber. Mar. 7, 1805.

44. $1809-18 \mathrm{I} 6$.

Letter to Duke of Manchester, notifying permission granted to Thomas Whitcomb, an American, to go to Jamaica. Mar. 30, 1810.

Letters to Manchester, nos. I3, I5, 3, I5, and Lieut.-Gen. Morrison, no. 5 Civil, notifying approval of acts imposing duties on American goods and vessels. Nov. I, I8Io; Apr. II, I8II ; Jan. 3I, I8I2; Oct. I6, I8I $3 ;$ Dec. 28, I8I 4 .

Letter to Morrison, no. I Civil, on treatment of American property under order in Council of June 23. Nov. 9, I812.

Letter to Manchester, no. 9, on grant of passports for Cuba: not to be given to Americans. May 7, I8I4.

45. $\mathrm{I} 8 \mathrm{IO}-\mathrm{I} 8 \mathrm{I} 3$.

Letter to Admiralty, on issue of letters of marque against U. S. vessels. Oct. 20, I8r2.

$I d$, on port of entry at Hamilton, Bermuda. Dec. I7, I8I2.

$I d$., on means taken by U. S. to seduce British seamen from their allegiance. Mar. 25, I8I3.

$I d$., reporting inaction of Gov. Cameron in issue of letters of marque: authorization not reached him. Apr. I2, I8I3.

46. $18 \mathrm{I} 3-18 \mathrm{I} 8$.

Letter to Admiralty, referring to course adopted in allowing American prisoners of war to enter British service. Jan. IO, I8I4.

Letters to George Hibbert. Trade, and attitude of commanders-in-chief towards American slaves desirous of giving assistance. June 6, July 2 , I8I 4 . 
Letter to Treasury, enclosing papers on three American vessels detained and sold in Jamaica. July I3, I8I4.

Letter to Board of Trade, on American trade in salt with Turks Islands. July IO, I8I5.

Letter to W. Hamilton, referring to alleged injuries inflicted on Creek Indians by U. S. since the peace. Apr. 2, I8I7.

$$
\text { C. O. I39: } 1-38 \text {. Acts. }
$$

C. O. I $39: 1.1662-1673$.

2. 1672.

3. 1674 .

4. 1675 .

5. 1677 .

6. 1678 .

7. I68I-I683.

8. Acts of Assembly passed in the Island of Jamaica; from I68I, to I737, inclusive (London, Printed by John Baskett, Printer to the King's Most Excellent Majesty, I738, pp. xxii, 387). An Abridgment occupies pp. 329-387; title-page to the Abridgment is dated I739.

9. $1695-1707$.

10. $1716-1723$.

11. $1723-1727$.

12. $1728-1730$.

13. I $73 \mathrm{I}-\mathrm{I} 733$.

14. I734-I 737 .

15. $1738-174 \mathrm{I}$.

16. $1742-1745$.

17. I75 I-I753.

18. I754-I756.
19. I757-I 758 .

20. I759-I760.

21. 1760.

22. I 762-I 766 .

23. $1767-1768$.

24. 1768-1770.

25. I770.

26. I77I.

27. 1772 .

28. I773.
29. I773-I774.

30. I774.

31. I 774-I775.

32. 1776 .

33. 1776.

34. $1776-1777$.

35. I777-1 778 .

36. I778-1 779 .

37. I779-1 780 .

38. I783.

\section{O. I39: I, I40: I-67. Sessional Papers.}

By an order of the Jamaica assembly in December, I792, the journals of that house, from its earliest institution, were to be collected and printed, after the style of the journals of the House of Commons. While missing materials for the first volume were being sought for and supplied from records in England, vol. II. was prepared and published in I795, followed by later volumes, vol. I. not appearing until I8II. The first seven volumes extend to I 783, and a set of them is included in C. O. I 4O. It has therefore been possible when listing these volumes to make a brief comparison with those in print, the result of which is given in the foot-notes to the following pages.

C. O. I 39:1. I66ı, June 18-1662, July 16. "Journal and Laws I66I-1679" (minutes and orders in council of various dates, with royal proclamation for encouraging planters, Dec., I66I), ff. I-I2. 1662, Aug. 30-1664, Apr. 7. Minutes of council, ff. I7-23. 1662, Oct. Io. Declaration for liberty of conscience, ff. 24 . 1662, Oct. I0-1662/3, Feb. I. Orders and acts, ff. $24 \mathrm{~b}-28$. . . Acts not dated, ff. 33-50.

I664, Oct. 20, Nov. 2, I0; A Acts of these dates, with others not dated, I664/5, Mar. I6. $\}$ ff. 5I-8I.

1673/4, Feb. I8-1674, May I3. Journal of assembly, ff. 88-99. ${ }^{2}$ I67I/2, Jan. 8 and I672/3, Jan. 8. Acts and an order (only two dated), ff. $100-138$. 
I675, Apr. 26-May I5. Journal of assembly, ff. I43-I53. ${ }^{2}$

I677, Apr. 9-July 26. " " “ ff. I 54-I82.

1677, Sept. 6-28. “ “ “

I678, Sept. 2-Oct. II. " " “ “

I679, Aug. I9-Nov. 29. " “ "

C. O. I 40: 1. I66I, June I8-1672, July 2. "The Council Book of Jamaica" (minutes of council), ff. I-308.

2. I664-I709. Vol. I. of the printed set of Journals of Assembly (Jamaica, Alexander Aikman, I8II, pp. 470).

3. I672, Aug. 4-1678, Sept. 3. "Continuation of the Council Book of Jamaica." (A note pinned to the end of the book states: "Minutes wanting from 3 Sept. I678 to I4 May 1682. Another from I4 Feb. I682/3 to 5 Sept. I683.") Ff. 309-668.

4. I682, May I4-I682/3, Jan. I9. Minutes of council, ff. I-I 3 . I683, Sept. 5-I685, Sept. I9. “" “"ff. I4-88.

I685, Aug. I-29. Abstract of minutes of a council of war; with articles and rules of war established by Lieut.-Gov. Molesworth, ff. 89-99.

I685, Aug. 24-I688/9, Feb. I8. Minutes of council, ff. IoO-267.

I688/9, Jan. I5-1689, May 28. Minutes of a council of war, ff. 268-274. I689, June 3-Sept. 30. Minutes of council, ff. 275-292.

I688/9, Jan. I5, Mar. 20, Apr. II. Minutes of a council of war (partly the same as no. 268, partly different days), pp. 293-299.

I69o, Apr. 22-July 5. Minutes of council, pp. 300-3II.

5. I689, Oct. I4-I695, Nov. 29. Minutes of council, ff. 332. I682, Sept. 2I-Oct. 7.

I683, Sept. 5-Oct. I9.

I686, June I-Sept. 24.

I687/8, Feb. I6-25.

I687/8, Feb. 25-Mar. I5.

Journal of assembly, pp. 5 .

$$
\text { tition), pp. I } 3 \text {. }
$$

1687/8, Mar. I6-I688, Apr. II. “ “ “ “ $“ \quad$ pp. I7.

I688, July 20-Aug. 4. A " “ " pp. $25 .{ }^{4}$

1694/5, Mar. 4-1695, Aug. I. Minutes of council in assembly (endorsed: "with Assembly"), pp. 24.

6. I695, Dec. 4-1696, Aug. I9. Minutes of council, ff. I-I6.

I697, Aug. I 3-Dec. I.

I696, Sept. I4-1697, June 30.

I697/8, Jan. I8-I698, July 8.

I702, Dec. 7-I702/3, Jan. 29.

I $702 / 3$, Feb. 5-Mar. 25.

I703, June 5-July 2.

I703, July 8-Aug. 2I.

I703, Sept. 2I-Nov. 25.

I703, Sept. 2I-I703/4, Jan. I I. partly a repetition), ff. I67-I 84 .

ff. I $7-28$.

ff. $29-73$.

ff. 74-103.

pp. II.
ff. IO5-I I9.

ff. I 2 I-I 30 .

ff. I $3 I-I 52$.

ff. I $53-\mathrm{I} 66$.

(Sept. 2I-Nov. 25

I703, Dec. 7-I703/4, Mar. I. Minutes of council (Dec. 7 and I7 are repeated, but Jan. II has an extra paragraph), ff. I85-200.

${ }^{2}$ From 1674 to 1677 the printed volume quotes from minutes of the council in assembly, not having traced these assembly journals.

${ }^{3}$ The printed volume has four items for I684: in Jan., Apr., May, and Sept.; also on Apr. 8, I686, but these are supplied from records of the council in assembly.

${ }^{4}$ An item for June II, I688, is also taken from council in assembly. 
I703/4, Feb. 8-I704, June 3I. Minutes of council (Feb. 8-Mar. I same as above), ff. $201-218$.

I704, July 4 and 27 . Minutes of council, ff. 219-222.

r704, July 4-Aug. 3I. “ “" “" (July 4 and 27 same as above), ff. 223-230.

I704, Sept. 2I-Oct. 2I. Minutes of council, ff. 230-252.

I704/5, Jan. 22-Feb. 22. “" " " "

I705, Apr. 2.

I705, Apr. 2, May 8, 30.

I705, Apr. 2-Nov. I7.

supplement one another), ff. $275^{-294}$.

I705/6, Jan. 2I-I706, Mar. 27. Minutes of council, ff. 295-312. I706, Nov. $5,7,12,13$.

I706, May Io, July I 3 .

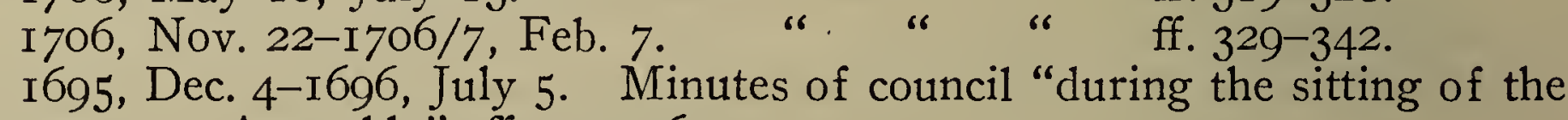
Assembly", ff. 343-362.

I7OI, June 24-July 28 . Minutes of council in assembly, ff. $363-392$. I702, Aug. 6-22.

I702/3, Jan. I3-Mar. 25.

ff. $393-414$.

ff. $263-274$.

(the repeated dates

I703, Apr. I2-May 15.

I703, June $3-$ July 3 .

I703, July 6-Aug. 25.

I703, Aug. 25-Sept. 29.

repetition), ff. $52 \mathrm{I}-53 \mathrm{O}$.

I703, Oct. I, 2.

I703, Oct. 5-Nov. II.

I703, Oct. 5-Nov. Ir.
ff. $557-574$.

Minutes of council in assembly, ff. $53^{\mathrm{I}-538}$.

I704, Apr. I I-June I3.

I704, Sept. 22-Nov. 29.

I705, July Io-Aug. IO.

I705, July ro-Oct. 30 .

Io a repetition), ff. 643-694.

I706, Oct. 8-15.

I706, Oct. 23-Nov. I3.

I706, Nov. I9-Dec. 24.

I706/7, Jan. I-25.

I706/7, Jan. 29-Feb. 8.

7. I703, Mar. I-25.

I703, May 31-I707, Feb. 5 .

Minutes of council in assembly, ff. 695-702.

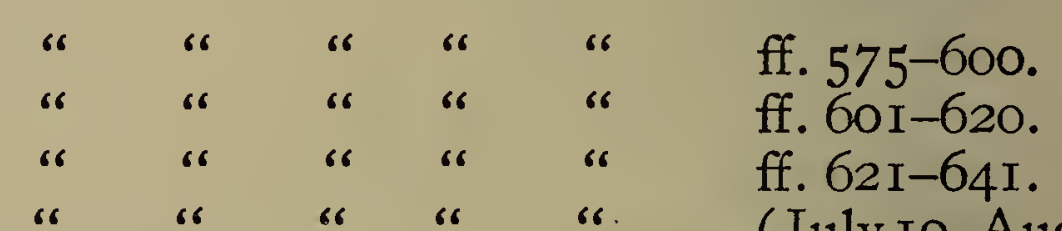

ff. $539-556$.

(duplicate),

ff. $46 \mathrm{I}-478$.

ff. $479-498$.

ff. 499-520.

(Aug. 25 a

(July Io-Aug.

8. 1707, May 28-1707/8, Feb. 28. Minutes of council, ff. I-25.

I708, Apr. 19-1709, Apr. I9.

I709, June I6-I7Io, Apr. 5 .

I707, Dec. 29-1707/8, Feb. 28.

ff. $72-95$.

I708/9, Jan. 4-I709, Apr. 20. ff. $97-129$.

I709/IO, Mar. I-I7IO, Apr. 5. ff. I $32-143$.

${ }^{5}$ The printed volume supplies from 1688 to this date, but from Aug. I6, I688, to Oct. 30 , I695, it quotes from minutes of council in assembly. Apr.-May 29, 1703, is also from the same source. 
I708/9, Jan. 4-I709, Apr. 20. Journal of assembly, ff. I45-I99.

I707, Dec. 29-1707/8, Feb. 27. “ “ “ “

I709/10, Mar. I-3I. “" “ “ ff. 295-3I8.

9. I7IO, Mar.-I73I, Feb. Vol. II. of the printed set of Journals of Assembly (Jamaica, Alexander Aikman, I795, pp. 766, index, pp. 47).

10. Separate issue of the index to the above printed volume (Alexander Aikman and Son, 1805 ).

11. I7II, Apr. I7-June 8. Minutes of council in assembly, ff. I-64.

I7I I, July 23-Nov. 3. "Journal of two Sessions of the Governor, Council and Assembly", ff. 65-1 I8.

I7Io, Nov. 7-I7II/2, Jan. 8. Minutes of council, ff. I I9-I74.

I7II/2, Jan. 8-I7I2, Sept. 29. " “" “" Jan. 8 is fuller than the foregoing), ff. I $75-258$.

I7I2, Oct. I4-Nov. I4. Minutes of council in assembly, ff. 259-326.

I712, Oct. 6-Dec. I8. Minutes of council, ff. $327-352$.

I7I2/3, Jan. 20-I7I3, July 28 . “ “ “ “

I7I3, Aug. I8-Oct. 20. “ " “ ff. 4OI-440.

I7I3, Oct. I-15. Minutes of council in assembly, ff. 44I-454.

I7I3, Nov. 26-17I3/4, Feb. 20. "“" "“" " “" ff. 455-534.

I7I4, Dec. 2-4. “ “ “ “ “ ff. $535-546$.

12. I7I I, Apr. I7-I II4, Dec. 4. Journal of assembly, ff. I-390. ${ }^{7}$

13. I7I3, Oct. 23-I7I4/5, Mar. 22. Minutes of council, ff. I-92.

I7I5, Oct. 3I-I7I5/6, Feb. II. Minutes of council in assembly, ff. 95-229.

I7I4, Oct. 2-I7I6, May 16. Minutes of council (in part a repetition of first item), ff. $230-464$.

I7I6, July 25-Sept. I9. Minutes of council, ff. 465-897.

Printed let-pass by Gov. Hamilton to Henry Jennings, master of sloop Bathsheba. Feb. 28, I715/6. Also deposition by Samuel Page, Oct. I2, I7ı6.

I716, Sept. I7-Nov. 9. Minutes of council in assembly, ff. 899-Ior6.

14. I7I 5, Oct. 3I-I7I 5/6, Feb. II. Journal of assembly, ff. I-I76.

I7I6, Sept. I7-Nov. I7.

I7I7, Aug. 7-3I.

I7I8, Aug. I-Nov. 21.

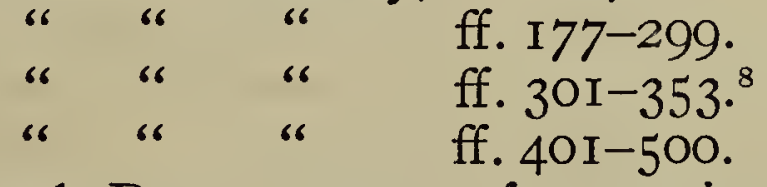

Petition of Dr. Samuel Page, report of committee on grievances, and other papers referred to in the foregoing journals. I7 pp.

I7I9, Oct. 20-I7I9/20, Jan. 29. Journal of assembly, ff. 50I-582.

15. I7I6, Nov. IO-I7I8, Nov. 21. Minutes of council, ff. I-367.

I7I7, Aug. 7-31. Minutes of council in assembly, ff. 369-394.

I7I8, Aug. I-Nov. 2I. " “" “" " ff. 4 OI- 565.

16. I718, Dec. I6-r719, Aug. 26. Minutes of council, A, pp. 32 .

I719, Oct. 2I-I7I9/20, Jan. 29. “" “ “ B, Pp. 30.

I719, Oct. 20-1719/20, Jan. 29. Minutes of council in assembly, C, pp. 45 .

I720, Apr. I2-July 27. Minutes of council, D, pp. 27.

I720, June I 5-July 9. Minutes of council in assembly, E, pp. II.

- The print adds Feb. 28, 1708, but from council in assembly.

"At Aug. 6, I7I I, the manuscript quotes a list of outstanding debts not given in full in the printed vol. II., p. 5 I.

${ }^{8}$ The manuscript journal under Aug. 29, I7I7, has in full the report of the committee of public accounts, not given in the print. 
I720, Aug. I6-Nov. 29. Minutes of council, F, pp. I5.

I720, June I5-July 9. Journal of assembly, G, pp. 3I.

1720, Oct. 5-Nov. 5. Minutes of council in assembly, H, pp. I2.

17. 1720/1, Jan. 26-1721, Mar. 31. Minutes of council, A, pp. 29.

I720, Oct. 4-I72I, Mar. 30. Journal of assembly ${ }^{9}$ (erroneously endorsed: "Minutes of Council in Assembly"), B, pp. 36 .

I72I, Oct. I9-I72I/2, Feb. 8. Minutes of council, C, pp. IO. I72I $/ 2$, Feb. 8-1722/3, Feb. 9. " " " D, " " 23. I720/I, Jan. I9-1721, Mar. 30. Minutes of council in assembly, E, pp. I6. I 721 , Oct. I7-I I I I $/ 2$, Feb. 8 . "
I 722 , June I4-I722/3, Feb. 9. I72I, Oct. I7-Nov. 28. Journal of assembly, H, pp. 79.

I $722 / 3$, Jan. 23-Feb. 9. " " " I, pp. 35.

18. I722/3, Feb. 9-I723/4, Jan. 3I. Minutes of council, A, pp. I29. I723/4, Mar. 3-I724, Nov. 27. " " " B, pp. 53.

I 723 , Oct. I-I723/4, Jan. 30. Minutes of council in assembly, C, pp. 88.

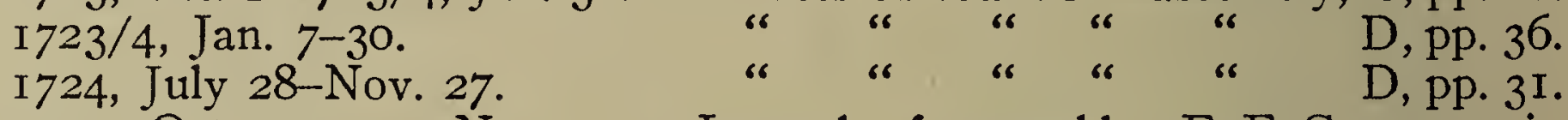
1723, Oct. I-I724, Nov. 27. Journal of assembly, E, F, G, I34 pp. in all. ${ }^{10}$

19. I724/5, Jan. 20-1725, Nov. 23. Minutes of council, A, pp. 54 . I $725 / 6$, Jan. 26-Mar. 9.

I726, Apr. 5-1726/7, Jan. I7.

I $726 / 7$, Feb. I I-Mar. I8.

I724/5, Jan. I9-I725, Nov. 23. $\mathrm{D} 2$, pp. 56.

I725/6, Jan. I I-Mar. 9.

E, pp. 37 .

I726, Oct. I8-i726/7, Jan. I7. F, pp. 37 .

I726/7, Mar. I-I8.

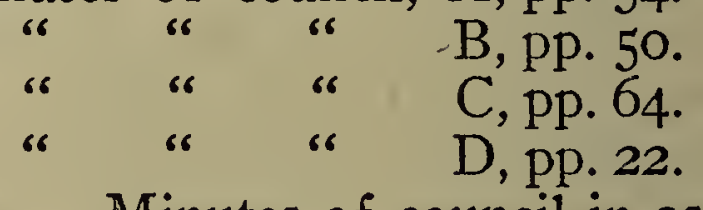

Minutes of council in assembly,

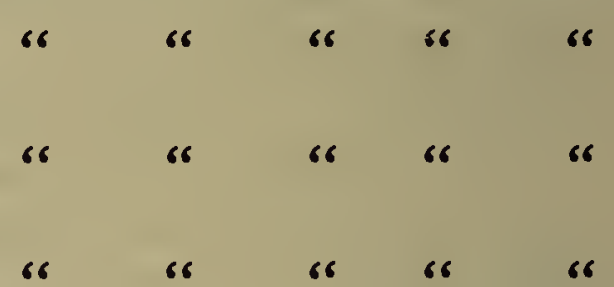

\section{G, pp. I3.}

I724, Nov. 2I-I726/7, Mar. I8. Journal of assembly ${ }^{11}$ (Nov. 2I-27, I724 same as in vol. I8), G2, H, I, K, L, 200 pp. in all.

20. I727, Apr. I3-July 4 .

Minutes of council, A, pp. ro.

I727, Aug. I5-1728, Apr. 20. " " " "

I728, May 7-Aug. 2. " " "

r728, Sept. 3-1728/9, Feb. I 5. " “" “ D, pp. 26.

I727, May 23-June 3. Minutes of council in assembly, E, pp. 9.

I728, Mar. 28-Apr. I8. " “" “" “ " " " "

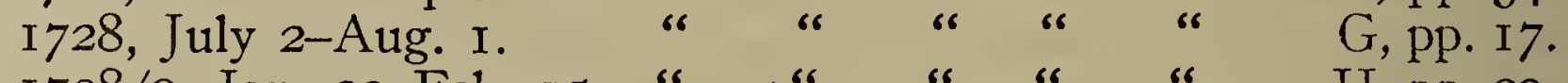

I728/9, Jan. 22-Feb. I 5. " " " " " "

I727, May 25-1729, Feb. I 5. Journal of assembly, ${ }^{12}$ I, K, L, M, I40 pp. in all.

21. I728/9, Mar. 4-I729, Apr. 26. Minutes of council, A, pp. I7. 1729, Apr. 29-Aug. I6. B, pp. 20.

${ }^{\circ}$ The manuscript contains for Feb. I7, I721, a full list of supernumeraries paid, referred to in the printed volume II., p. 358 .

${ }^{10}$ On Oct. 25, I723, Jan. I8, 23, and Nov. 20, 1724, the manuscript contains detailed states of the deficiency tax, lists of outstanding debts, and other papers abstracted from or merely referred to in the printed volume II., pp. $475,495,497,5 \mathrm{II}$.

${ }_{11}$ On Oct. 22, 1725, and Jan. I7, I727, the manuscript has detailed accounts of debts and deficiencies, etc., referred to in the print on pp. 545 and 599 of vol. II.

${ }^{12}$ Similar details on Apr. 18, I728, and Feb. 14, I729, referred to on pp. 636 and 675 . 
I729, Sept. 29-I729/30, Mar. I8. Minutes of council, C, pp. 23. I730, Mar. 28-Dec. Io.

I730, Dec. I5-I730/I, Mar. 9.

I73I, Apr. 6-Sept. 7.

I73I, Oct. 5-Dec. I6.

I73I $/ 2$, Jan. II-Feb. II.

“" “ " $"$ D, pp. 77.

“ “ “ $“ \quad$ E, pp. 35.

“" “ " $"$ F, pp. 42.

" " $"$ " $\quad$ " G, Pp. 45 .

H, pp. I3.

I729, July 24-Aug. I6. Minutes of council in assembly, Ii, pp. I6.

I729/30, Mar. 5-28.

r730, June I6-Nov. 20.

I730/I, Jan. 2I-Feb. 19.

I73I, May 4-July 8.

I73I, Nov. 4-27.

I73I $/ 2$, Jan. 3-Feb. II.

“

Kk, pp. I9.

L1, pp. 8I.

$\mathrm{Mm}, \mathrm{pp} .2 \mathrm{I}$.

$\mathrm{Nn}$, pp. 50.

Oo, pp. 25 .

Pp, pp. 54 .

22. I729, July 24-I733/4, Mar. 9. A volume of journals of assembly, in numerous portions. ${ }^{13}$ (About 650 small pages.)

23. I73I, May-I745, July. Vol. III. of the printed set of Assembly Journals (Jamaica, Alexander Aikman, I797, pp. 707; index, pp. 45).

24. Separate issue of the index to the above (I805, pp. 45).

25. I73I/2, Feb. 29-May 6. Minutes of council, pp. II.

I732, June 8-Nov. I7.

I732/3, Jan. 2-I734, Sept. I8.

r732, Apr. 4-Nov. I7.

I732/3, Mar. I3-I734, Sept. 3 .

26. I734, Sept. 30-I735, Dec. I9. Minutes of council, A, pp. 79.

I735, Dec. 20-I736, June 4 .

I736, Aug. 3I-Nov. 27.

I736/7, Jan. 4-I737, May 3.

I734, Oct. I-I735, Dec. I. Minutes of council in assembly, a, pp. 80.

I735/6, Mar. 9-I736, June 5. " " “ " “ " $"$ " b, pp.93.

I736, July IO-Nov. 27. “ “ “ “ “ “ “

I736/7, Feb. I-I737, May 3. “ “ “ “ “ d, " " “. II.

I734, May 7-Oct. 7. Journal of assembly, I, pp. I04. ${ }^{14}$

I735/6, Mar. 9-I736/7, Feb. I9. “ “ “ nos. 2, 3, 4, 265 pp. in all..$^{15}$

27. I736, July Io-Nov. 27. Minutes of council in (or and) assembly (duplicate; same as in vol. 26 supra), a, pp. I8.

I739, July 3-I742, June 4. Minutes of council in assembly (in five portions; duplicates of those listed below in vol. 30 ), b to $f$.

I739/40, Mar. I8-I740, May 27. Journal of assembly (duplicate; see vol. 28 for Dec., I740), no. I, pp. 82.

I740/I, Mar. 7-r74I, May 29. Journal of assembly (duplicate), no. 2, pp. 83.

I742, Apr. 6-June $4 . \quad$ “ “ “ no. 3, pp. $75{ }^{16}$

${ }^{13}$ The manuscript gives detailed accounts of debts, deficiencies, etc., at various dates for the years I730, I73I, I732, and I733, and also other papers. See references in the printed vol. II., at pp. 687-689, 717, 7 I9; and vol. III., pp. I7, 18, 94, 102, 126, 137, I93.

${ }_{14}$ The manuscript contains in full accounts and papers only mentioned in the print, in Aug. and Oct., on pp. $263,269,27$ I, 277, 278 of vol. III. The print supplies here from Oct. 8, I734, to June, I735:

${ }_{15}$ The manuscript contains accounts in full, at May II, I3, 21, 22, I736, summarized or referred to in the printed vol. III., pp. $36 \mathrm{I}, 363$ et seq.

${ }_{10}$ The print supplies here Oct. I3-I7, I74I. On May 29, I742, the manuscript has a list of debts as referred to on p. 6 ro of the printed volume. 
28. I739/40, Mar. I8-I740, May 27. Journal of assembly (same as in vol. 27), no. I, pp. 76 .

I740, Dec. 2-20.

I740/I, Mar. I7-I74I, May 29.

$$
\text { “ “ “ “ } \quad \text { " } \quad \text { (same as in vol. }
$$
27), no. 3 , pp. 64 .

I752, Sept. 26-Nov. 27. Printed votes of assembly. (No imprint. William Daniell authorized to print. On p. 68 is a manuscript marginal note.) Pp. I07.

I753, Sept. I8-Nov. 25. Printed votes of assembly. (No imprint.) Pp. 96.

I736, Aug. 3. Attested copy of minutes of council of this date, with the accounts of James Barclay, receiver general from $I 728$ to I $735, \mathrm{pp} .89$.

I760, July I4-I76I, Jan. Io. Minutes of council, pp. 33.

I761, Mar. I3-1762, May 29. “" “" " pp. 49.

I76I, Oct. I2-Dec. I9. Minutes of council in assembly, pp. 58.

I762, Feb. 4-Apr. I8.

I766, Sept. 23-Dec. 22.

I77I, Apr. 4-Dec. II.

Minutes of council, pp. 35 .

pp. 24.

29. I737, June $2 \mathrm{I}-\mathrm{July} 9$.

Minutes of council, A, pp. 9 .

I737, Sept. I-I737/8, Mar. 4. “" “" B, pp. I6.

I738, Apr. 30-July I 5. “" “" “ C, " " " 24.

I738, Sept. 27-I739, May I9. “ “ “ (contains long accounts for fortifications, revenue, etc.), D, pp. 75 .

I737, June 2 I-July 9.

I737, Sept. I-I737/8, Mar. 23.

I738, May 5-July I9.

I738, Sept. I I-I739, May I9.

I737, June 21-I739, May I9. Journal of assembly, nos. I-4, 230 pp. in

Minutes of council in assembly, a, pp. 8. all. ${ }^{17}$

30. I739, Aug. 7-I740, May 27. Minutes of council, A, pp.9I.

I740, July I-Dec. 20.

I740/I, Feb. 3-I74I, May 29.

I74I, Sept. IO-Oct. 22.

I74I, Dec. 22-I 742, June 4.

I739, July 3-I740, May 27.

I740, June I6-Dec. 23 .

I740/I, Jan. I6-I74I, May 29.

I74I, June 20-Oct. I7.

I74I, Nov. 23-I742, June 4.

(For duplicates see vol. 27.)

b, pp. 25 .

c, pp. 38 .

d, pp. $6 \mathrm{r}$.

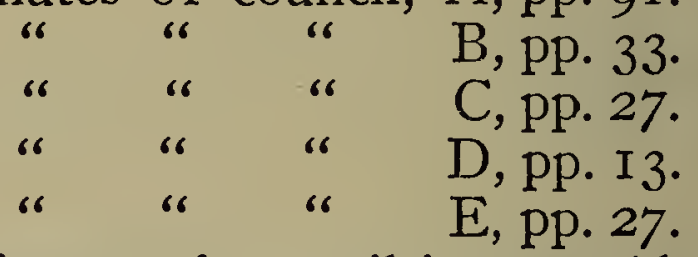

\begin{tabular}{|c|c|c|c|c|c|}
\hline & 6 & 66 & “ & "6 & \\
\hline & “ & 6 & “ & “ & $\mathrm{H}, \mathrm{pp} .47$. \\
\hline 66 & 6 & 66 & “ & "6 & I, pp. 6. \\
\hline d6 & or & 6 & "6 & "6 & $\mathrm{K}$, pp. 47. \\
\hline
\end{tabular}

Minutes of council in assembly, F, pp. 80 .

31. I742, Aug. I7-I743, May 27. Minutes of council, A, pp. 74.

I743/4, Feb. 23-I744, June 8. “ “" “ B, pp. 60.

I744, Nov. I2-Dec. 21 .

I $744 / 5$, Feb. 2-I 745 , June I8.

I745, July I $3-1746$, May I 5 .

I 742, July 24-I743, May 28.

I743, July I9-I744, June $2 \mathrm{I}$.

I744, July 2I-Dec. 2 I.

$$
\begin{aligned}
& \text { " } \text { " } \quad \text { " } \quad \text { C, }, \text { Pp. II. } \\
& \text { " " " } " \text { " } \\
& \text { " " " E, " }
\end{aligned}
$$

Minutes of council in assembly, a, pp. 46 .

b, pp. 58 .

c, pp. 9 .

${ }^{17}$ The manuscript has, on July I5, I738, and Mar. 29, 1739, detailed lists of deficiencies, etc., referred to in the print, pp. 453 and 467 ; and accounts in full. See references on pp. 486-488, Apr. 28. 
I744/5, Feb. I4 (prorogued to
Mar. I9), I745, July I 3 . Minute of council in assembly, d, pp. 30 . I745/6, Mar. I8-I746, May I5. “ “ “ “ “ I743, Apr. 7-May 28. Journal of assembly, no. I, pp. 88..$^{18}$ I744, Mar. 28-June $20 . \quad$ " “ “ “ no. 2, pp. 7I. ${ }^{18}$ I745/6, Mar. I8-1746, May I5. “ “ “ no. 3, pp. II $4 .{ }^{19}$

32. I746, May I6-I747, July 2. Minutes of council, pp. 69 .

I747, July 20-1748, Aug. I3. “" “" “" pp. 48.

I748, Nov. 28-I749, June I. “ “ “ “

I749, Oct. 23-Dec. 20.0 “" “"

I749/50, Feb. 27-I750, Nov. I7. “ “ “ “ “ (duplicate), pp. 23.

I75I, Mar. 29-Dec. I4. “ “ “ " pp. 20.

I746, June I4-I747, July 2. Minutes of council in assembly, pp. 83 .

I747, Aug. I I-I748, Sept. I2. Minutes of council "during the sitting of the Assembly", pp. 42.

I748, Sept. I2-I749, June I. Minutes of council in assembly, pp. 36.

r749, Oct. 3-Dec. 3. “ “ “ “ “ “ “

I749/50, Jan. 20-Nov. I7. “ “ “ “ “ (duplicate), pp. 4I.

I750/I, Jan. I2-Dec. I6. “ “ “ “ “

33. I746-1756. Vol. IV. of the printed set of Assembly Journals. (Alexander Aikman, I797, pp. 722.)

34. I746/7, Mar. I7-I749, June I. Journal of assembly, pp. 235.

I749, Oct. 24-I75I, Dec. I4. Journal of assembly, pp. 43I. ${ }^{20}$

35. I752, Sept. 26-I 753, Nov. 25. Journal of assembly. (See vol. 28. The printed compilation of $\mathrm{I} 797$ agrees with the latter rather than with the manuscript.)

36. I752, Feb. 24-Dec. I2. Minutes of council, no. I, pp. 52.

I753, Jan. 6-Nov. 25. " “" “" (title-page reads, "An Extract of the Minutes of the Council"), no. 2, pp. 45 .

1754, Jan. 8-Nov. II. Minutes of council, no. 3 , Pp. 56.

1755, Jan. 16-Apr. 24. “ “ “ “ “ no. 4, pp. 43.

I755, June 30-1756, Feb. $7 . \quad$ " " " no. 5, pp. I8.

I752, Sept. 26-Nov. 27. Minutes of council in assembly, A, pp. 67.

I754, Oct. 8-Nov. 8. “" “" “"

I755, Jan. 20-May I9. “ “ “ “ “ “ “ C,

I755, Sept. 23-1756, Feb. $7 . \quad$ “ “ “ “ “

I754, Oct. 2I-Nov. 8 . Journal of assembly, a, pp. 90.

I755, Apr. 8-1756, Feb. 7. " “" " b to e, 253 pp. in all. ${ }^{21}$

37. I756, Aug. I7-Nov. 6. Printed votes of assembly. (These occupy sometimes one leaf only or a sheet of four pages, each with imprint, "St Jago de la Vega, Curtis Brett and Co.", but the pagination is continuous.) Ff. I-299.

${ }^{18}$ On Apr. 15, 1743, and Apr. 5, 1744, the manuscript gives in full lists of debts, etc., referred to in the printed volume III., pp. 618 and 643 .

${ }_{18}^{18}$ The print supplies here from Dec. 18, 1744, to July, 1745. On Apr. 17, 1746, the manuscript quotes in full a list and letter in Spanish, referred to in printed volume IV., p. 2I, and on Apr. 26, four Spanish letters, p. 36; some accounts shown on p. 49 are also fuller in the manuscript.

${ }_{20}$ The printed vol. IV. supplies here Oct. 3-23, 1749, 3d session. Ort Nov. 9, 1749, the manuscript gives in full a letter in French referred to on p. 205 of the printed book.

${ }_{21}$ The print supplies Jan. 20-24, 1755 . On Jan. 28, 1756, some accounts are given in more detail in the manuscript than on p. 560 of the printed volume IV. 
I756, Nov. 8-Dec. 22. Journal of assembly, ff. $230-265 .{ }^{22}$

38. I756, July 5-Dec. 22. Minutes of council, pp. 39.

I756, Dec. 22-I757, Nov. 26. “ “ “ $"$ " pp. 30.

I758, Feb. I3-Aug. 26. “ “ “ “

I758, Oct. 2-Nov. 23. “ " “ " "

I758, Dec. 20-1759, Mar. I7. “ “ “ “

I759, Apr. II, I8, May 3. “ “ “ “

I759, Oct. 2-Nov. I7. " “ " "

I756, Aug. I7-Dec. 22. Minutes of council in assembly, pp. I65.

I757, Sept. 27-Nov. 26. " “" “" " " $" 36$.

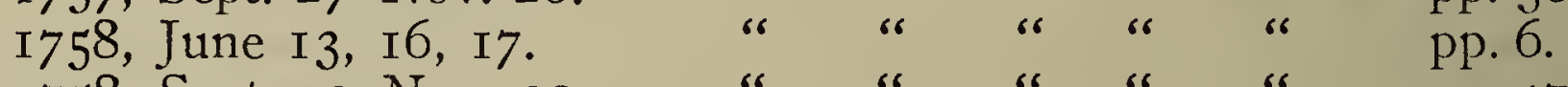

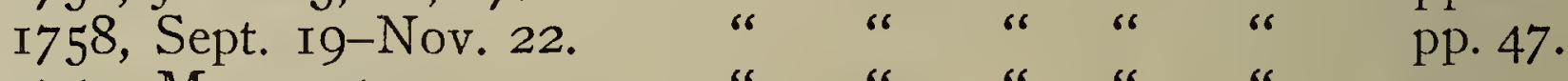

I759, May I-5. “ “ “ “ “ “ " “

I759, Sept. 25-Nov. I4. " " " " " "

39. I757, Sept. 27-Nov. 26. Journal of assembly, pp. I62.

I758, Sept. I9-I759, Nov. I4. " " " pp. 256 in all. ${ }^{23}$

40. I757-I766. Vol. V. of the printed set of Journals of Assembly (Alexander Aikman, I798, pp. I63).

41. I760, Sept. I8-1763, Dec. 30. Journal of assembly. About 750 pp. in all. ${ }^{24}$

42. I760, Feb. 25-May 25. Minutes of council (contain besides accounts current, etc., examination of Thomas Bullock, judge of viceadmiralty, on a complaint of Adm. Cotes), pp. 62 .

I76o, July I4-I76I, Jan. Io. Minutes of council, pp. 34 . I76I, Mar. I3-I762, May 29.

I762, June I4-Nov. 27.

I763, Jan. I I-Dec. 3 I.

I764, Feb. I-Dec. 22.

I765, Sept. I7-I766, Dec. 22.

I 767 , July 20-Dec. 23.

43. I760, Sept. I8-Dec. I9.

I76I, Mar. 3I-Apr. 9.

I761, Oct. I2-I762, Apr. I8.

I762, Sept. 28-Nov. 24.

I 763 , Oct. I I-Dec. 30 .

I764, Oct. I7-I765, Mar. 22.

I766, June 24-Dec. I4.

I767, Oct. 20-Dec. 3I.

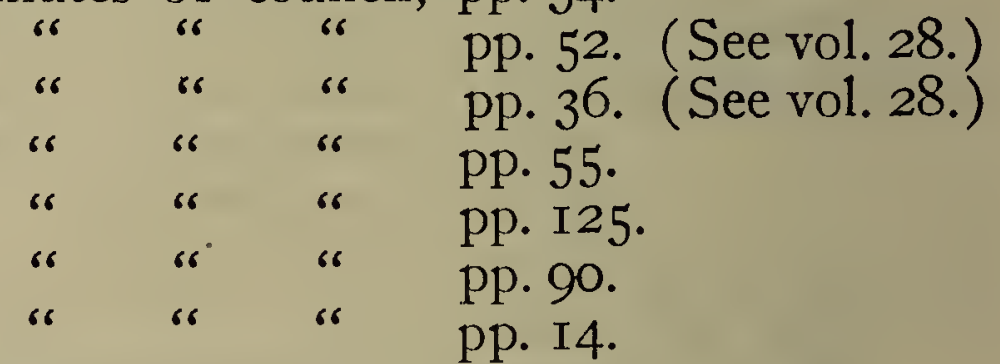

Minutes of council in assembly, pp. $8 \mathrm{I}$.

\begin{tabular}{|c|c|c|c|c|c|}
\hline & & & & & D \\
\hline & & 66 & “ & “ & pp. 9I. \\
\hline & 6 & “ & “ & “ & pp. 3I. \\
\hline & 6 & “" & “" & “ & pp. 76 . \\
\hline & 6 & “ & " & $"$ & pp. $5^{\circ}$. \\
\hline & “ & “ & 6 & 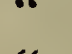 & pp. I 30. \\
\hline & 6 & " & " & " & pp. І І 20 \\
\hline
\end{tabular}

44. I764, Oct. I7-Dec. 2I. Journal of assembly, pp. I68. ${ }^{25}$

I765, Mar. I9-22. "Copy of Votes of the Assembly", pp. 22.

I767, Oct. 20-Dec. 3I. Journal of assembly, pp. I7I..$^{26}$

45. I766, June 24-Dec. 24. Journal of assembly, pp. 370 and $85 .{ }^{27}$

${ }^{22}$ The print of Nov. Io seems fuller, quoting an examination.

${ }^{23}$ The print supplies June $13-17,1758$. On Oct. 21,1758 , and Oct. 23, I759, the print quotes reports in full which the manuscript omits.

${ }^{24}$ On Nov. 9, I760, and Nov. 28, I76I, the print quotes accounts and reports not in the manuscript, but on Nov. I6, I762, and Dec. 29, I763, where, on pp. 378, 379, and 457 (vol. V.), reports and accounts are merely referred to, they are found in the manuscript.

${ }^{25}$ List of negroes and accounts are given in full in the manuscript under Nov. 20 and Dec. II, I764. They are merely referred to (pp. 494, 496, 5I4) in the printed vol. V.

${ }^{26}$ Accounts on various dates in Nov. and Dec. are in full in the manuscript, but only referred to on pp. $46,54,55,66$, and 73 of the printed vol. VI.

${ }^{27}$ The print supplies Aug. I3-I6, I765. Accounts, etc., on July 24 and Aug. 8, I766, are in full in the manuscript, but only referred to in print $(V .567,598)$; and in Nov. and Dec. likewise, referred to in vol. VI., pp. 9, I0, I I, I5, I7. 
46. I766, Nov.-1776, Dec. Vol. VI. of the printed set of the Assembly Journals (Alexander Aikman, I800, pp. 704).

47. I768, Sept. I3-I770, Apr. I9. Journal of assembly, pp. $625{ }^{28}$

48. I768, Sept. I3-Dec. 31. Minutes of council in assembly, pp. Io6.

I769, Oct. 24-Dec. 23. Minutes of council in assembly: Anno 1769. Journal of the Honorable the Council of Jamaica (St. Jago de la Vega, Printed by Sherlock and Lowry, I770). The headings are always "Council and Assembly". Pp. I57.

I770, Feb. I3-23. Minutes of council in assembly (attested and endorsed, "Council"), pp. I I6.

I770, Apr. I0-19. Minutes of council in assembly, pp. 20.

49. I768, Mar. I6-I769, Jan. 2. Minutes of council, pp. 35.

I769, June 13-1770, Dec. 24. “ “ “ “ "

I771, Apr. 4-I772, Dec. 4. “ “ “ “

I772, Dec. II-I774, Feb. I3. “ “ “ " pp. I09.

50. I770, Oct. 23-I771, Dec. 2I. Journal of assembly, $523 \mathrm{pp}^{29}$

51. I770, Oct. 23-Dec. 23. Minutes of council in assembly, pp. II2.

I77I, Oct. 29-Dec. 2I. " " " " " "

I772, Nov. 3-Dec. 23. “ “ “ “ “ “ “ “

I773, Oct. I9-I774, Feb. I3. “ “ “ “ “

52. I772, Nov. 3-1774, Feb. I3. Journal of assembly, pp. 470. ${ }^{30}$

53. I774, Oct. 25-I775, Dec. 22. Journal of assembly, pp. I35, I26. ${ }^{31}$

54. I774, Oct. 25-Dec. 24. Minutes of council in assembly, pp. 85 .

I775, Oct. 3I-Dec. 22. “ “ “ “ “ “

I776, Oct. 22-Dec. 2I. " " " "

55. I774, Feb. II-Dec. 24. Minutes of council, pp. 43.

I775, Aug. 30-Dec. 23. " " " "

I776, Feb. I3-Dec. 21. " “ “ " pp. 92.

I777, Feb. 24-Dec. 22. Minutes, headed: "of the Privy Council"; endorsed: "of Council", pp. 42.

I778, Feb. 3-Dec. 22. Minutes similarly headed and endorsed, pp. 4I.

56. I776, Oct. 22-Dec. 21. Journal of assembly, pp. 256.32

57. I777, Oct. 2I-Dec. 22. Journal of assembly, pp. I9o.

58. I777, Oct. 2I-Dec. 22. Minutes of council in assembly, pp. 94.

I778, Oct. 20-Dec. 23. " " " " " "

I779, June 29-July $3 . \quad$ "

I779, Aug. I7-Dec. 23. “ “ “ “ “ “ “ " “

I780, Apr. II-2I. “ " " " "

(Each piece is attested as "Journal of Council".)

${ }^{28}$ In Nov. and Dec., I768, and Dec., I769, various accounts, given in full in the manuscript, are merely referred to in the printed vol. VI., pp. 124, I29, I5I, 21 I, 219, 225.

${ }^{2 a}$ List of negroes on Oct. 25, 1770 , and accounts and report in Nov. and Dec. are in full in the manuscript, but only referred to on pp. 28I, 302, 3I2, 318. On Dec. 8, however, the print contains more than the manuscript. In Nov. and Dec., I77I, accounts are again given in the manuscript; see pp. $357,362,364,373,375$ of the print.

${ }^{30}$ List, accounts, and returns in Nov. and Dec., I772, and Nov. and Dec., I773, are in full in the manuscript but only referred to on pp. 405, 407, 408, 4II, 43I, 453, 458, 479, 488,499 of vol. VI. of the printed set.

${ }^{31}$ Accounts in Nov., I 774 , are in the manuscript, but only referred to on pp. 522, 523, 525, 532 of print. Later, from Dec., I774, the print quotes accounts in full and in many cases both print and manuscript merely refer to such accounts as being with the papers of the session.

${ }_{32}$ Accounts in Nov., 1776 , are in the manuscript, but only referred to on pp. 643,654 , 656 of the printed vol. Elsewhere both refer to them as among the papers of the session. 
59. I777, Oct.-I783, Dec. Vol. VII. of the printed set of Assembly Journals (Alexander Aikman, I802, pp. 663).

60. I778, June I I-Dec. 23. Journal of assembly, pp. $202 .^{33}$

61. I779, June 29-I 780 , Apr. 21. Journal of assembly, pp. $422 . .^{33}$

62. I779, Jan. I8-I780, Apr. I9. Minutes of council, pp. 36. I780, June I2-I78I, May 24. “" “" (attested and endorsed: "Privy Council"), pp. 46.

I780, Nov. 7-I78I, Jan. I3. Minutes of council in assembly, pp. I57. I780, Nov. 7-I78I, Jan. I2. Journal of assembly, pp. 41 $3 .^{34}$

63. I78I, May 23-I782, Mar. 4. Minutes of council (attested as "Privy Council"), pp. $7 \mathrm{I}$.

I781, Oct. I6-I782, Dec. 22. Minutes of council in assembly, pp. 50, 40. I782, Oct. 29-I783, Mar. I. “" “" “ "

64. I78I, Oct. I6-Dec. 22. Journal of assembly, pp. 220.35 I782, Oct. 29-I783, Mar. I. ““" “ pp. 242.

65. I782, Oct. 29-1783, Dec. 23. Minutes of council in assembly, pp. 277. (The volume continues with papers of I784 and I785.)

66. I783, Oct. 2I-Dec. 2I. ${ }^{36}$ Printed votes of assembly, 7 th session (Alexander Aikman, I804, pp. I58).

I783, Dec. 22, 23. Id. 8th session. Pp. 3-I2.

67. I783, Oct. 21-Dec. 23. Journal of assembly (manuscript of above, but the print is more detailed), pp. IOI.

\section{O. I42: I3-21, 31, Treas. 64:72. Shipping Returns.} INWARD.

13. I683, Sept. 29-1684, Mar. 25. 1685, Sept. 29-1692, Mar. 25.

OUTWARD.

(To Great Britain.)

13. I68o, Mar. 25-I68I, Mar. 25. I68I, Sept. 29-1684, Mar. 25. 1685, Sept. 29-1690, Sept. 29. I69o, Dec. 25-I692, Mar. 25.
(To British Plantations.) 1682, Apr. 5-1684, Mar. 25. I684, Sept. 29-I685, Mar. 25. I685, Sept. 29-1687, Sept. 29. I687, Dec. 25-1689, Dec. 25 . I690, Mar. 25-I692, Mar. 25.

13. I692, June-1693, July.

(General.)

I697, Dec. 25-I700, Sept. 29.

I704, June 25-Dec. I 5.

\section{INWARD AND OUTWARD.}

14. I709, Mar. 25-I712, Mar. 25.*

I7I2, Mar. 25-I7I3, Sept. 29.

IZI3, Sept. 29-I7I 5, Mar. 25.*

${ }^{38}$ In both cases the printed volume is fuller in accounts and papers.

${ }^{34}$ Accounts in Nov. and Dec. are mostly in full in the manuscript, and referred to only in the printed vol. VII., pp. 255, 260-262, 266, 267, 269, 274, 277, 282, 313,335, 34I; but some parts of the print give more than the manuscript.

${ }^{25}$ On Dec. 20, I78I, the manuscript has in full some short accounts, referred to in the print on p. 542, but otherwise the print is more detailed. The print supplies items in $\mathrm{I} 782$, to July $2 \mathrm{I}$.

${ }^{30}$ In some cases, particularly Dec., this contemporaneous print gives accounts in full not found in the manuscript.

* See last foot-note on opposite page. 
INW ARD.

14. I7I8, Mar. 25-June 24. I7I 8, June 24-I720, June 25.* I721, Sept. 29-I722, Mar. 25.*

15. I727/8, Feb. I-I730, Mar. 25.* I742, Sept. 29-Dec. 25.* I743, Mar. 25-1749, June 20. ${ }^{37}$ I75I, Dec. 25-I752, Sept. 29. I752, Sept. 29-1753, Sept. 29.*

16. I753, Sept. 29-I756, Mar. 25.*
I756, Sept. 29-1757, June 25.*

I755, July 20-I757, Mar. 7. (Port Antonio.) I76I, Dec. 25-1762, Dec. $25^{38}$

18. I762, Dec. $25-1765$, Dec. 25 .

17. I765, Dec. 25-I766, June 25. I766, Sept. 25-I 767, Dec. 29. I768, Mar. 29-Sept. 29. I769, Mar. 29-June 29. I769; Sept. 29-Dec. 29.

Treas. 64: 72. I780, Jan. 5-178I, Jan. 5. (Port Antonio only.) I78I, Jan. 5-1785, Jan. (Port Antonio and Savanna la Mar only.)

C. O. I42:20. I78I, Dec. 29-I782, Mar. 29.

19. I782, Mar. 29-Dec. 29.

21. I783, Sept. 29-Dec. $29{ }^{39}$

19. I783, Dec. $29-1784$, Dec. 29.

\section{(Foreign Vessels.)}

19. I783, Sept. 29-1784, Dec. 31. (Kingston and Montego Bay.) OUTWARD.

14. I7 I8, Mar. 25-June 24. I7 I8, June 25-I720, June 25* I721, Sept. 29-I722, Mar. 25.*

15. I742, Sept. 29-Dec. 25.* I743, Oct. I-I747, June 20. I745, Sept. 29-I747, June 24.* I747, June 25-1749, June 25. I75I, Dec. 25-I752, Sept. 29. I752, Sept. 29-1753, Sept. 29.*

16. I753, Sept. 29-1756, Mar. 25.* I756, Sept. 29-1757, June 25.* I761, Dec. 25-1762, Dec. $25^{40}$
18. I762, Dec. $25-1765$, Dec. 25.

17. I765, Dec. 25-1766, June 25. I766, Sept. 29-1767, Dec. 29. I768, Mar. 29-Sept. 29. I769, Mar. 29-June 29. I769, Sept. 29-Dec. 29.

20. I78I, Dec. 29-I782, Mar. 29.

19. I782, Mar. 29-Dec. 29.

21. I783, Sept. 29-Dec. 29.

19. I783, Dec. 29-I784, Dec. 29.

\section{(Foreign Vessels.)}

Same dates and references as inward returns for this class.

\section{MISCELLANEOUS.}

13. Copies of ships' bonds. I692-1693.

List, with details, of vessels registered in Jamaica. Apr. 2, I703-May I4, 1705 .

${ }^{37}$ There are duplicate returns for Sept. 29-Dec. 25, 1745, and Dec. 25, 1745-Mar. 25, 1746.

${ }_{38}$ These and subsequent returns include the outports of Port Antonio, Montego Bay, and Savanna la Mar. There are not, however, returns for all ports each quarter. Lucea first appears in a return in Mar., I782.

${ }^{20} \mathrm{C}$. O. I42: 20-2I also contain lists for broken periods from I786 to I804.

${ }^{40}$ These and subsequent returns include the outports of Port Antonio, Montego Bay, and Savanna la Mar. There are not, however, returns for all ports each quarter. Lucea first appears in a return in Mar., I782.

* Returns marked with an asterisk are for Kingston and Port Royal. The return for Mar., I709-Sept., I7II (in C. O. I42:14), has headings for number of negroes imported by the Royal African Co. and by individual traders. 
14. Summaries of goods imported and exported, with number of negroes imported by the Royal African Co., the South Sea Co., and individual traders. June 24-Dec. 25 , I7I9.

List, with details, of ships belonging to Jamaica.

16. Ships arrived from the Guinea coast, with number of slaves imported. Sept. 22, I752-Dec. 22, I753.

19. Imports and exports, annual totals for each port. I767-1784. Kingston shipping and cargoes, inwards and outwards.

Dec. 25, I766-Dec. 25, I767. (Similar lists for American and for British shipping, Kingston and Savanna la Mar.)

20. Imports into Jamaica, Barbados, Grenada, Dominica, St. Vincent, Antigua, St. Christopher, Nevis, and Montserrat, from different provinces in America. I77I-I774. (Year, island, whence exported, number and tonnage of ships, and cargo.)

Account of rum and sugar exported from islands named in the previous item to different provinces in America. I77I-I774. (Corresponding details.)

Treas. 64:72. Quarterly summaries for Kingston, Port Antonio, and Savanna la Mar, of vessels owned in G. B., Br. N. Am., or the $\mathrm{Br}$. W. I., which have entered with produce of the U. S. since the king's proclamation relating thereto. July, I783-Jan., I785.

Imports, Kingston and Port Antonio, from Canada and Nova Scotia. July, I783-Jan., i785.

Rum exported from Kingston and Port Antonio in 1784 , compared with former years.

Imports (a) in British bottoms, (b) in British and foreign bottoms, for the last ten years. Mar., r785.

Annual imports into Kingston, with foot-note on prospects for trade. (Undated.)

C. O. 142: 31. List of landholders. I754. (See Andrews, I. 206.)

\section{LEEWARD ISLANDS.}

C. O. i 52:9-36. Board of Trade: Original Correspondence. i7io-i782.

9. I7I0-1713.

List of inhabitants of St. Christopher who suffered by invasion of 1706. Papers showing relief granted by Parliament to sufferers here and at Nevis. I7II. (See Andrews, I. 217.)

Accounts for Antigua, of fees taken, I7II; powder, I7ro-I7II; and stores of war received and given out, I7ro. Also for St. Christopher, stores, I707-1710; and inhabitants, I7II.

Letter from Hamilton, on denial by lieutenant governor of Antigua of Hamilton's right to sit in any council but that of Nevis. July 28, I7rI. Order in Council for Hamilton's admission to all councils of the Leeward Islands in absence of the captain-general. Dec. I9, I7II.

Order in Council and other papers, on Mr. Walton's petition for grant of the Virgin Islands. I7 I I/2.

Petition to Lord High Treasurer from Society for Propagating the Gospel in Foreign Parts and from William Codrington, for reversion of Barbuda; with copy of grant of Barbuda to Col. Codrington, 35 Car. II. I7I2. 
Letters from lieutenant governor of St. Christopher and other papers on attack on Montserrat. I7I2.

Correspondence with commanders of naval vessels at Barbados on assistance for Leeward Islands.

Letters from Cunningham, member of assembly of St. Christopher, complaining of sale of provisions and four field pieces to Martinique. I7I2-17I3.

Papers on land settlement in St. Christopher.

10. $1713-1716$.

Letter from Sir John St. Leger on capture of the Bristol Gally, with acts and sessional papers of various islands. Aug. 23, 1712. Enclosures include: accounts of negroes imported, I7II-I7I2; account of powder-duty collected with particulars of vessels paying same, I7 IoI7I2; account of stores at Antigua, I7IO, I7I2; accounts of proceedings in courts of chancery, queen's bench, and common pleas at Antigua, I7I2. Also, "answer to several articles of Major Douglas's instructions", with schedule of fees collected in Antigua, classified return of inhabitants by parishes, and return of christenings and burials in that island, Mar. I7Io/I-Mar., I7II/2.

Abstract of imports and exports to and from Antigua, May-Aug., I7I2.

Letter from Douglas, and from lieutenant governor, council, and speaker of assembly of Antigua, complaining that island is unprotected, and vessels captured daily by privateers in sight of shore. Oct. IO, I7I2.

Letter from Douglas, on establishment of court of exchequer. Mar. 30, I7I 3 .

Memorial of S. Duport, agent for St. Christopher, on resettlement of that island. I7r3.

Letter from Lowndes, on petition of persons who obtained debentures from Board of Trade for losses sustained in French invasions of Nevis and St. Christopher, that debentures "may be admitted to be subscribed into the South Sea Stock according to the direction of the Act of Parliament in that behalf". Oct. 28, r713.

Papers on grants of land in St. Christopher, and especially on grants in French portion which are now to be restored to French settlers. (Very numerous.)

Papers on damage done by French at St. Christopher, Nevis, and Montserrat; estimates of damage made pursuant to treaty of peace; bounties for resettlement; distribution of relief.

Papers on capitulation of Nevis, and refusal of French to return hostages given as security for 1400 negroes promised the French as ransom for island. In particular, petition of two hostages, alleging that they have been imprisoned for eight and a half years at Martinique, that no money on credit has been allowed them, and that they have been abandoned to reproaches of French. Dec. 20, I7I4.

Papers on the Virgin Islands.

Order in Council, referring petition from owner of Three Sisters, small ship taken as prize, employed in service of the crown, sold to petitioner, and, driven by weather into Antigua, seized as foreign

11. I716-1717. built. Sept. 9, I715. Also, Northey's opinion and other papers.

Papers on hostages at Martinique.

Account of stores in the Leeward Islands. Oct., I7I 5.

Roll of militia in St. Christopher and Antigua. I7I3. 
Letters from Gov. Hamilton. The Virgin Islands; grants in French portion of St. Christopher; and risk in travelling between islands on account of activities of pirates. Mar. I, 6, I7 15/6. Enclosures include lists of grants in French portion of St. Christopher, with names of grantees, areas, dates, etc., and petition of governor of Anguilla for permission to settle St. Croix.

Order in Council referring report from Board of Ordnance, with accounts of ordnance stores sent to Leeward Islands since I702. June I2, I7I6. Order in Council referring report of Board of Ordnance on supply of military stores for Leeward Islands. Contains estimates of former outlays for Leeward Islands and application of the $4^{\mathrm{T}} / 2$ per cent. duty towards them. July I9, I7I6.

Letter from Lowndes, with representation from Board of Ordnance on above. Feb. 19, 1716/7.

Many papers on settlement of French portion of St. Christopher.

Papers on the Virgin Islands.

Letters from Carkesse, with controller general's account of annual proceeds of $4 \frac{\mathrm{r}}{2}$ per cent. duty in Barbados and the Leeward Islands since I702. Sept. 20, Nov. 22, I7I6.

Letters from Gov. Hamilton on the Virgin Islands, Tortola, and St. Christopher. Disapproves of large grants to planters. "What has weakened these Islands most has been occasioned chiefly by rich men buying out the Poor out of their Little Settlements, by this means they have been in time drove off the Islands." Apr. I4, 30, I7 6 .

Id., on settlement of small islands and on piracy. Oct. 3, Dec. I4, I7 I6. Encloses depositions on piracy.

$I d$., on currency. "There being no such thing as money in any of these Islands, the want whereof lays Trade as well as everything else under very great difficulties." Apr. I4, I7 I6.

Id. Pirates. The Virgin Islands and other small islands. Enclosures include depositions on pirates, and list of inhabitants in Anguilla. Oct. 3, I7 I6; Mar. 3, I7I6/7.

List of families in the Virgin Islands. I7 6.

List of 24 ships and sloops surrendered to Spanish squadron in Bay of Campeachy, Nov. 30, I7I6. Ships and cargoes retained. Ships entering later also seized. More than one-third were from northern colonies, others mainly from G. B. and Br. W. I. Also copies of correspondence between prisoners and Spanish authorities.

Papers on Danish claim to St. Thomas.

12. I7I7-I7I9.

Letter from Hamilton. Success of pirates. New governor (Varenne) and intendant (Ricouart) in French islands. These are so strict on trade that "they have Condemned a New England Vessel only for Anchoring at Martinico to take in Water". British vessels also seized at Martinique. Encloses copies of correspondence with Ricouart. May I5, I7I7.

Report of attorney general on two acts of Antigua for establishment of courts of common pleas, error, and chancery. Dec. 12, I716. Order in Council for disallowance of act establishing court of king's bench in Antigua. Jan. 30, I7 $17 / 8$.

Report on Virgin Islands by Capt. Candler of H. M. S. Winchelsea, who was detailed to make report. 
Letter from Addison, giving decisions of committee of Council on measures against pirates, French and Spanish claims for redress for seizure, and other matters. Sept. 3, I7I7.

Numerous papers on grants, purchase and planting of lands in French part of St. Christopher, with information on methods pursued in other islands.

Papers on capitulation of Nevis.

Memorial of agents of Leeward Islands on need for war stores and employment of the $4 \frac{1}{2} 2$ per cent. duty. Sept. I 3, I7 I 7 .

Letter from Carkesse, on act passed at Antigua, June, I7I6, on importation of foreign sugar, rum, etc.; and on collection of the $4 \frac{\mathrm{T}}{2} \mathrm{per}$ cent. duty. Dec. 24, I7 7 .

Id. Illegal trade with French. Oct. 7, I717.

Northey's report on an act of St. Christopher, I712, "for settling the Estates and Titles of the Inhabitants of this Island to their Possessions within the same". Undated. Read Feb., I717/8.

Letter from Hamilton. Pirates, and recent visit to Virgin Islands. Undated. Read Mar., I717/8. Encloses lists of inhabitants of Anguilla, Tortola, and other islands, and petitions for permission to settle Crab Island.

Northey's report on act "to prevent the Increase of Papists". Jan. 4, I7I7/8. "Petition of several Popish Inhabitants of Antigua" against act. Read Mar., I7I7/8. Order in Council for disallowance. July I, I 7 I8. Other papers.

Letters from Hamilton and other papers, on settlements and attempted settlements at St. Croix, St. John, Tortola, Anguilla, St. Thomas, and Crab Island; on Danish settlements; and on Spanish attacks and threats against British and Danish settlements.

Richard West's report on Montserrat act of 4 Anne, for quieting possessions and confirming titles to land. May 27, I718.

Letter from Hamilton, on rents from lands formerly granted. "The Rents Generally reserved upon such Grants are one Ear of Indian Corn." Also, on importation of Negroes purchased from Dutch at St. Eustatius, and paid for in sugar. Also, on seizure of British vessels by Spaniards. Sept. I0, I7I8. Depositions on seizures enclosed.

"Account of the Qualifications of the present Grantees of the french part of St. Xtopher's", with list showing claims of 97 grantees. I7 18.

"Present State of the french part of St. Xtopher's", showing amount held by each holder, original grant, and improvements made. I7I8.

Letter from Hamilton on two acts, apparently of Antigua, for laying additional duty on liquors and gunpowder-duty on trading vessels; both with suspending clauses. Oct. I4, I7I8.

Paper on bounties for resettlement given to sufferers in St. Christopher and Nevis.

Letter from Hamilton, on pirates. Dec. I9, I7 I8. Depositions enclosed.

$I d$., enclosing observations on acts of Antigua: for declaring qualifications of those who vote for assemblymen or vestrymen, or serve as such, and for ascertaining the rules, rights, and privileges of assemblies; for establishing court of king's bench, common pleas, and error; and for quieting possessions. Also, on revenue bill where 
the governor was compelled to give way to assembly on method of issuing public monies. Mar. 21, I7 $18 / 9$.

Papers on losses of inhabitants of Montserrat through French invasion, including list of individual losses. I7rg.

Letter from Hamilton, with answers to customary queries of the Board, especially on trade with northern colonies. July 20 , I 7 I9.

13. I719-I721.

Letter from Richard Harris. Trade of Leeward Islands with Dutch in negroes. Compares Guinea trade of Dutch with that of English. Sept. I, I7I9.

Letter from Hamilton, on pirates, and especially on destruction of vessels at St. Christopher. Oct. 3, I720. Deposition enclosed.

Order in Council, referring petition of South Sea Company for grant of former French part of St. Christopher, Nova Scotia, and other parts of America. Jan. 3, I720/I. Petition enclosed.

Letter from Craggs, enclosing copy of petition of council and assembly of Nevis against demands in memorial presented by D'Iberville in I7I7 on capitulation of Nevis. Nov. 21, I720. Other papers.

Letter from Hamilton, on seizure of vessel entering at custom-house and delivering manifest of goods including tallow laden in Ireland. Question what constitutes importation where goods not landed. July 20, I7I9.

Id. Difficulty of making returns for all islands. Pirates. Oct. I4, I719; Feb. 14, I719/20.

$I d$. Pirates. Division of proceeds from sale of prizes; whether governor as high admiral receives share of proceeds. Mar. 28, I720.

Papers on Virgin Islands and Dutch islands.

Letter from Hamilton. Aug. 22, I720. Enclosures include: copy of all acts in force at Montserrat; lists of individual assessments and house taxes in Montserrat; "Schedule of the Titles of the several Laws that are in Force which relate to all the Leeward Islands"; list of the laws in force at Antigua in Aug., I720; treasurer's accounts for Montserrat to Nov., I719; public accounts for Nevis, May, I7I3-Dec., I716; account of vessels from Madeira arriving in Leeward Islands with cargoes, Mar., I715-Mar., I7I8; list of all officers in Leeward Islands, July, I720; list of fees taken in public offices, I720; classified lists of inhabitants of Leeward Islands (in which are included Tortola, Spanish Town, and Anguilla), I720; christenings and burials, Feb., I7I5/6-July, I720; state of fortifications and military stores, I720; and "Copies of all Petitions that have been Preferred and entred on the Councill Book of this Island, for Patents for Lands" since commencement of Hamilton's government, I720. ${ }^{1}$

List of vessels belonging to Antigua, Aug., I718-May, I720, and number of sailors in the island.

Account of produce of Leeward Islands, Midsummer, I719, to Dec., I720.

Letter from Hamilton. Sept. I3, I720. Encloses large and detailed chart of Antigua prepared for Board of Trade and now returned to it, and list of present possessors of French land in Basseterre quarter of St. Christopher.

${ }^{1}$ Three enclosures, comprising treasurer's accounts of Antigua and St. Christopher, are apparently missing. 
Richard West's opinions on acts of Antigua, dealing with qualifications and privileges of assemblymen, qualifications of voters for assemblymen and vestrymen, quieting of possessions, revenue, and the constituting of courts.

14. I $72 \mathrm{I}-\mathrm{I} 724$.

Letter from Hamilton. Illegal trade at Antigua, and act imposing duties on importation of foreign sugar, molasses, rum, cotton, and ginger. June 30, I72I. Encloses memorial of Surveyor General Dunbar against act. Letters from Carkesse stating objections of Commissioners of Customs to act. Aug. 23, 30, I721.

Order in Council referring back draft of instructions for Hart for alterations. Sept. 5, I 72 I.

Letters from Hamilton. Piracy, and lack of naval protection. May I9, I72I; Jan. I6, I721/2. Enclosures.

Memorial from William Nivine, agent for Antigua, requesting action on several acts of various islands. Read Apr., I722.

Order in Council for disallowance of acts of Antigua on qualifications of assemblymen and for establishment of courts of king's bench and common pleas. Aug. 24, I72I.

Letter from Gov. Hart. His success in bringing assembly of Antigua to compliance with instruction that all grants by assembly to governor must be made by first assembly; duties on liquor, and other taxes; courts; and valuation of sugar, formerly accepted as currency at fixed rate irrespective of quality. Apr. 24, I72I.

Two memorials on petition of South Sea Company for grant of French part of St. Christopher. Read July, I72I.

Letter from Hart, on governor's additional salary, and on duties on sugars. May 2, I722.

$I d$., on revenue acts and act concerning white servants. June $2 \mathrm{I}, \mathrm{I} 722$.

Id. General conditions in colony, and especially the militia. July I I, I722.

Id. Landing at St. Lucia of Mr. Uring, appointed governor by commission from Duke of Montagu; success of French in dislodging expedition; cruelty of French to Englishmen at Guadeloupe. Jan. 26, 1722/3. Enclosures include copies of Uring's capitulation and of Hart's correspondence with the governor of Martinique.

Order in Council, for repeal of act of Antigua to raise the governor's additional salary by duties on imports. Nov. 29, I722.

Letter from Hart. French seizure of ships approaching St. Lucia, and resulting danger to trade. Absenteeism and disaffection in Leeward Islands. In Nevis best people are absentees, while many of the rest are "most Obstinate and Perverse in their Nature and Manners: Inveterately disaffected to His Maj'ties Government". In Montserrat reverse true. Antigua loyal but economically weak. Piracy very prevalent in islands. Apr. 9, I723.

Papers on complaints of ill treatment of English in French islands. In particular, "Letter from Mr. Delafaye, Secretary to the Lords Justices, of 22d. Inst: inclosing the Copy of a letter from Mr. Crawford in relation to Remonstrances made by him at the Court of France, upon the ill Treatmt. some English Subjects met with at Martinico".

Order in Council, for disallowance of act of Montserrat granting salary to Hart by impost on dry-goods and liquors. Aug. 27, 1723. 
Letter from Hart. Piracy. Resentment of assembly of Antigua over disallowance of act granting salary to Hart. Are informed that disallowance came because act imposed duty on trade. "Some Gentlemen of the Assembly ... . have often asked me in particular whether the Assemblies here have not as much right and priviledge as the Parliamt. of Great Britain, for imposing a duty on their Trade." June 8, I723.

Id. Conditions in Nevis and Antigua. At Nevis ill feeling ever since I688; assembly now swayed by Jacobite, quarrels with governor; and both council and assembly refuse to meet when ordered. Dec. 3, I723.

Id. Expectation of war prevailing both in British and French islands when news arrived of regent's death. Mar. II, I723/4. Undated letter from governor of Martinique enclosed.

Id. All records of Montserrat to I7I2 have been burned. Mar. I6, I723/4.

Id. Piracy. Encloses depositions, and accounts of trials of pirates. Mar. 25, I724.

Id. Courts and judicial procedure at St. Christopher. July Io, I724.

Id. Describes Virgin Islands, Danish settlements there, and attack of Spaniards on English at Crab Island. Substance of recent correspondence with governor of St. Thomas. Proposes the "repossessing" by English of St. John. July I2, I724.

Copy of letter, Hart to Carteret, on Hart's instructions to claim Virgin Islands; to allow no settlements except at St. Thomas; and to inform Danes at St. Thomas, should they misbehave, that they have no good title. Hart's notification to governor of St. John that Danes have no rights there; his suggestion for forcible seizure of St. John. May 24, I722. Other correspondence.

Letter from Hart, with answers to customary queries of Board. July I2, I724.

Papers on grant of lands in French part of St. Christopher.

15. I725-I727.

Numerous letters from Hart, and other papers, on minor constitutional questions in various islands. Complaints of Smith, secretary of Leeward Islands, that Hart deprives him of fees.

Order in Council, referring petition of several merchants and others on avarice and tyranny of Hart. June 22, I725.

"Precedents of complts against Governors of Plantations, Shewing by whom Such Complaints have been brought and the method of proceeding thereon." Instances mainly from Barbados, but include Va. I704.

Letter from Hart. Asks for instructions in case of one White, condemned under 33 Hen. VIII. c. 23 at St. Christopher for murder committed in Virgin Islands. Attorney general and solicitor general of colony doubtful whether statute applies to islands since these unsettled at time of passage. July 26 , I725. Other papers, including Fane's report that statute is applicable, and report of attorney general and solicitor general of G. B. that statute is not applicable to colonies. I725.

Id. Dispute with secretary over fees. July 20, I725. Other papers.

$I d$. Threatened negro insurrection at Nevis. Jan. $6,1725 / 6$. 
Letter from Newcastle, forwarding address of House of Commons, Mar. 29, 1726, for reports from Board of Trade on sale or value of lands in French part of St. Christopher. Apr. 2, I726.

Numerous papers on land grants and land tenures, especially in French part of St. Christopher. Include copy of commission to Lieut.-Gen. Mathew and two others to dispose of "late french Lands" in St. Christopher. June 4, I726. Also, letter from Newcastle, showing "Pensez-y-bien" not granted to Popple. May 4, I727.

Letter from Hart. Slave-trade. Importations into St. Christopher, especially of rooo brought in from St. Eustatius free of duty, I72II723. In last three years British have undersold Dutch. Slaves brought by Dutch West India Company to St. Eustatius go to Martinique and Guadeloupe; but British slave traders rival Dutch in French islands. Feb. I5, I726/7.

Accounts of negroes imported into Antigua and St. Christopher, Dec. 20, I72I-Dec. 25, I726.

Letter from Hart. Seizure of British vessels cutting wood at St. Croix, and other relations with Spaniards. Mar. 5, 1726/7. Depositions enclosed.

Fane's report on act of St. Christopher to establish court of king's bench. June $30,1727$.

Letter from Hart. Refusal of Spaniards to give redress for injuries, and their preparations for war. Apr. 10, 1727. Other papers.

Accounts of negroes imported into Nevis and Montserrat, Dec., I72IDec., I726.

16. I727-I729.

Letter from Lieut.-Gen. Mathew. Conditions in colony. Encloses accounts for Nevis of yearly ascertained expenses, negroes imported, forts, christenings and burials (in only parish possessing incumbent), and treasurer's accounts. Nov. I, I727.

Account of duties collected at St. Christopher on exportation of sugar, rum, molasses, and other produce, under local act, June I-Sept. 20, I727. Separate cargoes and rates shown.

Account of negroes imported into St. Christopher, Mar. 25-Sept. 25, I727.

Numerous papers on disputes of Mathew with assembly and with various officials at St. Christopher.

Account of losses of inhabitants of Montserrat by French attack of I7I2. Individual names and amounts sworn to.

Letter from Mathew. Powers of governor, lieutenant general, and lieutenant governors in Leeward Islands. Dec. I, 1727. Encloses accounts of military stores in various islands, and of current standing revenue, yearly salaries, and other ascertained expenses, in Antigua.

Account of christenings and burials at Antigua, Michaelmas, 1726, to Michaelmas, 1727.

Account of slaves imported into Antigua, Mar. 25-Nov. 20, I727.

Papers on dispute of Hart with secretary of Leeward Islands on fees and other matters.

Letter from Mathew, enclosing: lists of councillors in various islands; accounts of salaries and other expenses in Montserrat, and of revenue raised to meet same; of ordnance and naval stores at Mont- 
serrat, I727; and of importation of negroes into Montserrat, Mar. 25-Nov. 9, I727. Dec. I, I727.

Id. Constitutional and political issues in colony, decline of Nevis and rise of Antigua, the Virgin Islands and need for courts there. Jan. 20, I727/8. Encloses account of christenings and burials at St. Christopher, Michaelmas, I726, to Michaelmas, I727.

Papers on establishment at Antigua of court merchant to promote at all seasons rapid collection of debts; and on act of assembly placing special tax on transient merchants in consideration of special advantages secured them by this court.

17. I729-1730.

Papers on constitutional and political questions, and especially on acts of St. Christopher: providing representation in assembly for part formerly French, and thus assuming power to fix number of members; excluding from assembly patent and other officials; and permitting denizens and non-freeholders to qualify as voters and assemblymen. Include letters from Londonderry, Sept. 30, Dec. 26, I728, and from Smith, secretary of colony, Apr. 28, I728.

Letter from Londonderry. Precedence in council. Jan. I6, I728/9.

Id. Slave conspiracy at Antigua. Jan. 30, I728/9.

$I d$., on act constituting court of chancery at Antigua. Jan. 7, I728/9.

Order of committee of Council, referring back representation on acts of Antigua, Nevis, and St. Christopher granting additional salary to the governor. Apr. 30, I729. Petitions enclosed against acts from merchants trading to colony.

Letter from Londonderry. Slave conspiracy at Antigua, and burning of three slaves. Jan. 30, I728/9. Papers on court merchant and tax on transient merchants enclosed. Use of suspending clause involved. Papers on taking of Pink Pheasant, 250 tons, Barbados to S. C., by Spanish privateers, and on cruelty of Spaniards to crew, also enclosed.

Id., on establishment of courts at Montserrat. Apr. 25, I729.

Letters from Newcastle and former governor Hart, on St. Croix. Apr. I 5, July Io, I729.

Papers on the governor's additional salary and proper division of its burden among islands. Order of committee of Council that Board of Trade consider same. Dec. I8, I729.

Letter from Newcastle, with depositions of master and sailor of British vessel plundered and carried away from St. Croix by French. Feb. I2, I729/30. Id., sending reply of French court to complaint on this matter. Apr. 3, I730.

Account, from inspector general's office at custom-house, of sugar imported into England from Leeward Islands, Christmas, I72I, to Christmas, I728. Returns by years and islands. Signed, Oxenford. Apr. I6, I730.

Memorial of Yeamans, agent for Antigua, for confirmation of act for

18. I730. holding court of chancery. Read Aug., I730.

Letter from Mathew, enclosing: marshal's docket of fees at St. Christopher; classified returns of population of St. Christopher, Nevis, and Antigua by parishes; account of christenings and burials at St. Christopher, I72I-I730 ; and accounts of fees collected by secre- 
taries, in various branches of their offices at St. Christopher and Montserrat. May 28, I730.

"Political Anatomy" of Montserrat, giving list of male adults, and, for each, particulars of family, slaves, live stock, real estate, amount of land devoted to various crops, etc.

Accounts for Montserrat: fortifications, I729/30; christenings and burials, I72I-I729; treasurer's accounts, I722-I729; and importation of slaves, Lady Day, I721, to Michaelmas, I729.

Id., for Nevis: population, I729; treasurer's accounts, I724-I730; and military stores. Also, christenings and burials (excluding Jews) in St. Paul's parish, Nevis, May, I72I-Dec., r729, distinguishing number of "Soldiers and Transient Persons" buried, and adding statement of fees due "minister", parish clerk, and sexton for various services in christenings, marriages, and burials.

Accounts for Antigua: Madeira wines and "other strong liquors" imported, I727-I730; imports and exports, Christmas, I720, to Christmas, I729; imports of slaves, Christmas, I720, to Christmas, I729; treasurer's accounts, I727-1730; christenings and burials, I72II730; fortifications, I730; and fees taken in various offices.

19. I730-I733.

Papers on act establishing court of chancery at Ántigua.

$I d$., on act "for regulating Vestries and Erecting into a parish part of Basseterre quarter (in St. Christopher) by the Name of St. George Basseterre". Copy of "Genl. Hart's Institution of Mr. Anderson to be Rector of St. George's", Apr. 23, I723. Other papers.

Memorial from Yeamans, agent for Antigua, that lieutenant governor of Antigua be in future lieutenant general of the Leeward Islands. Read May, I73I. Other papers.

Id., from Beak, agent for St. Christopher, asking removal from council of St. Christopher of Smith, secretary of Leeward Islands.

Three representations from lieutenant governor, council, and assembly of Antigua, president, council, and assembly of St. Christopher, and commander-in-chief of Leeward Islands, and council and assembly of Nevis, on trade of northern colonies with French and Dutch islands, and resultant injury. to British islands. Read, respectively, Nov. and Dec., I73I, and Feb., I73I/2.

Report of Fane on two acts of St. Christopher, I7I2 and I7I8/9, for quieting titles. Dec. 23, I73I.

Letter from Yeamans, with reply on behalf of Leeward Islands and Jamaica to observations on, and answers to, representations of assemblies of Barbados, Antigua, and St. Christopher, on trade of northern colonies with French and Dutch islands. Jan. I9, I73I/2. Papers on despatch of military stores to Leeward Islands.

Copies of numerous acts "enabling" persons to make sales of, or acquire good title to, land in colony.

Letter from Lord Harrington. French ambassador has contracted to sell St. Croix to Danish West India Company. Directs Board to lay before the king state of British title to island. May I4, I733.

Order in Council, that grants of additional salary to governors of Leeward Islands must be made in first assemblies of various islands and before said assemblies proceed to other business. June 2I, I733.

Letter from Mathew, forwarding "The Present State of the British Sugar Colonys in South America and of the Trade of the Northern 
Colonys On the Continent To and From the French Sugar Islands and Surinam Considered", by Dunbar, surveyor general of customs. Oct. 3, I730.

Accounts for St. Christopher of negroes imported, Dec. 25, I726-Sept. 25, I730, and treasurer's accounts, Christmas, I722, to Midsummer, I730.

20. I734-1735.

Numerous representations on weakness of islands, with appeals for military stores and recruits.

Letter from Mathew. French, British, and Danish claims to, and activities in, St. Croix. Mar. I9, I733/4.

$I d$., enclosing: account of persons employed and fees collected in treasurer's office at Antigua; lists of fees collected by secretaries in St. Christopher and Montserrat; and list of fees taken by clerk of assembly at Montserrat. Apr. I8, I734.

Letter from Harrington, on Danes at St. Croix. Sept. II, I734.

Letters from Mathew, enclosing detailed answers to customary queries, with maps of Antigua, St. Christopher, and Montserrat. Aug. 3I, Sept. I4, I734.

Letter from Newcastle, with copy of treaty of neutrality and defense between French and Dutch governors of Martinique and St. Martin. July I 4, I734. Letter from Cooper, agent for St. Christopher, on same treaty. Jan. 6, I734/5.

21. I734-I735.

Memorial from Yeamans, showing encouragement needed to promote trade of British sugar colonies; and, in particular, permission to export produce directly to Europe. Undated.

Papers on levy of gunpowder-tax in various islands.

Letter from Mathew, on Virgin Islands. Nov. 6, I734.

Extensive and valuable papers on sale of St. Croix by French to Danes.

Letter from Harrington, enclosing letter from $\mathrm{H}$. Walpole, written at the Hague, May 20, I735 (N. S.), on treaty of neutrality at St. Martin between governors of Martinique and St. Eustatius. June 6, I735.

Letter from Mathew, on Virgin Islands. June I7, I734.

$I d$., enclosing abstracts of treasurer's accounts for Nevis, I73I-I734. Feb. I 5, I 734/5.

Id., enclosing : account of collection of gunpowder-tax at St. Christopher, I734-I 735; attested account of licenses for taverns, public houses, etc., at St. Christopher, Apr., I735; liquor office account (apparently of imports) at St. Christopher, Apr., 1735, giving rates; treasurer's accounts for Antigua, Mar.-Nov. I 734; accounts of christenings and burials at Antigua, I733-I734. Apr. I4, I735.

$I d$., on titles to St. Croix; and enclosing treasurer's accounts for Nevis, I734-I735. May 5, I735.

Id., giving, as postscript, numbers of civilians and soldiers able to bear arms in various French islands; and enclosing treasurer's accounts for Montserrat, 1735, and account of christenings and burials at Nevis, I733-I734. June I8, I735.

22. I735-I737.

Opinions of Richard West, Francis Fane, attorney general and solicitor general, on acts of four Leeward Islands on constitution of courts and appointment of agents. I 733-I 735. 
Papers on gunpowder-duties.

Letter from Mathew, enclosing powder-office accounts, and account of duties on liquor imported, both of St. Christopher, and to July, I735. July 3I, I735.

Id. Organization of government in Virgin Islands. Sept. I4, I735.

$I d$., enclosing: accounts, by totals, of proceeds of all impositions and taxes levied in each of the four islands, including gunpowder-tax, I725-1734; account of laws under which taxes raised in Antigua, I725-I734; and list of laws in force in Antigua, St. Christopher, and Montserrat, Mar. 25, I73I, with account of laws imposing duties or impositions on shipping or trade, passed since that date.

Memorial from Yeamans, complaining of French settlements at St. Lucia, St. Vincent, and Dominica. May 12, 1736.

Papers on complaints of the secretary against acts abridging his fees.

Letter from Mathew enclosing treasurers' accounts of St. Christopher and Montserrat, 1735-1736, and of christenings and burials in two parishes of St. Christopher, Oct., I734-Oct., I735.

Id. Currency situation in Leeward Islands; act of Antigua to settle value of coins; weakness of Virgin Islands and danger there from Spaniards. May 3I, I736.

Mathew to Popple. Illegal trade with French by W. I. and northern colonies; legislative and other measures taken by islands to check trade of northern colonies with French; complaints by French of cruel and domineering treatment of French by British in neutral islands; French settlement at Dominica. July I7, I736. Memorial from agent of St. Christopher on similar matters. Read Oct., I736.

Letter from Newcastle, with enclosures on seizure of two French vessels at Montserrat by Mathew's sloop Pall Mall. Nov. 3, 1736.

Fane's opinion on recent act of Montserrat for preventing trade in those ports between British subjects and French: that said act attempts to explain and amend certain articles of treaty of 1686. Opinion also refers to French edict, I727; and to complaint on same made in memorial presented, by direction of governor of Leeward Islands, to one of secretaries of state, Feb., I735. Oct. 30, 1736. Letter from Coope, agent for St. Christopher, on same. Feb. I3, I734/5. Memorial presented by agents for Antigua and St. Christopher on same subjects, and on general "depredations" of French in W. I. French edict, 1727, made all vessels approaching within one league of French island, whether or not inhabitable, liable to seizure without warning by French subjects under general letter of marque. Enforced at deserted islands. Presented to Newcastle, Apr. 22, I736. Memorial from merchants trading to W. I. on French "depredations", reviewing developments since treaty of I686; complaining that treaty is violated by French edict of 1727 ; and claiming that French exercise dominion over non-territorial waters. Memorial also states that Montserrat passed act making French vessels seizable within one league, and enforced act by seizure of vessels Fleuron and Fortune as only means of securing relief from French edict. Printed copy of French edict, 1727: Lettres Patentes $d u$ Roy en Forme d'Edit, concernant le Commerce Estranger aux Isles et Colonies de l'Amerique. . Données à Fontainebleau au mois d'Octobre I727. Memorial from society of merchants at Bristol, complaining of edict. Numerous related papers, including reports 
and memorials, copies of correspondence between Mathew and the governor of Martinique, and extracts from treaties, agreements, and letters. The whole unusually valuable for study of W. I. trade in various branches.

Letter from Newcastle, referring complaint of Dutch envoy against seizures of vessels from St. Eustatius by vessels commissioned by Mathew. Feb. I9, I736/7. Reply from Mathew's agent, Sharpe; and other papers.

Letter from Mathew. Negro conspiracies in various islands, and burning of some conspirators. Jan. I7, I736/7. Valuable report of justices appointed to examine into recent slave conspiracy at Antigua, with lists of slaves executed, and those to be banished or otherwise punished. Dec. 30, I736. Other papers.

$I d$., enclosing papers on Spanish piracies, affidavits on slave conspiracies in Virgin Islands, and accounts of christenings and burials in St. Philip's parish, Antigua, I733-1736, and in two parishes of St. Christopher, I735-1736.

Id. French at St. Lucia, St. Vincent, and Dominica; land tenure and other conditions in Virgin Islands; emigration from Leeward Islands to Dutch and Danish islands. Feb. 5, I736/7.

"State" of councils in Leeward Islands. I737.

Memorial from agents of various W. I. islands in response to proposals made by court of France on British and French trade in America. Apr., I737.

Order in Council, approving report of Committee of Council on representation of Board of Trade on French edict of 1727 and retaliatory law of Montserrat: report being that British ambassador to France should "make the proper Instances and Representations". Apr. 2I, I737.

Order in Council, on petition of Sir Charles Paine of St. Christopher on Danish usurpations in St. John. Mar. 22, I736/7.

23. $x 737-1740$.

Letter from Mathew. Recent legislation concerning slaves. May I I, I737. List of negroes executed for recent conspiracy at Antigua, with names of owners, nature of occupations, etc. Six "Jibitted alive", five broken on the wheel, 77 burned, and others banished.

Id. French and Dutch trade in W. I. and trade of French with northern colonies. Also, in refutation of charges of Dutch against him. May 26, I737. (Valuable.)

Id. Burning of Panama. Capture of two large British ships by Spaniards. June I4, I737.

Id. Encloses affidavit on "depredations" of Spanish privateer. July I8, I737.

Letter from Newcastle, Oct. 27, I737, and other papers on adjustment of relations of French and British in W. I. Include letter from Waldegrave at Fontainebleau, and memorials and representations of agents of W. I. colonies and British merchants, complaining of new regulations proposed by French, and asking return to conditions existent before 1727 under treaty of I686. I737.

Letters from Mathew, enclosing treasurer's accounts for St. Christopher, I736-I737. Very detailed, giving lists of taxpayers, and tonnage of each vessel paying gunpowder-tax. Oct. 20, Nov. I2, I737. 
Id. Capture of English sloop by French vessel near St. Christopher. Mar. I, I737/8.

Id. Encloses account of births, marriages, and burials for two parishes of St. Christopher, I736-I737. Feb. 23, I737/8.

Id. Capture of English sloop by French vessel near St. Christopher. Dispute with George Thomas, who, having accepted position of proprietary governor of Penn., stopped at Antigua on his way to Penn. and demanded admission to council of Antigua. Mar. 31, I738.

Printed letter from "a considerable Person" at St. Christopher on history of governor's sloop Pall Mall, and captures, including unlawful seizures of French vessels, made by it.

Papers on negro conspiracies.

Letter from Mathew, complaining of seizure of London ship by Spaniards; and relating that vessel from St. Christopher having taken Spanish ship, all people of latter, including six friars, were fastened below hatches and vessel sunk. Guilty person acquitted. May 26, I738. Encloses affidavit on seizure of London ship.

Letter from Yeamans, on currency situation in Leeward Islands, giving rates. Dec. 20, 1738 .

Papers on demands for military stores.

Letter from Mathew. Encloses account of burials and christenings in two parishes of St. Christopher, I737-1738. Dec. 5, I738.

Letter from Newcastle. Sends copies of three addresses of House of Commons for copies of papers on sugar colonies. Mar. 2I, I738/9.

Copy of petition of merchants, planters, and others trading to, and interested in, British sugar colonies to House of Commons ; complaining of depression of sugar industry through heavy duties on sugars in England; calling attention to advantages enjoyed by French colonies in getting stores from Ireland and northern colonies; and asking that direct exportation to foreign markets be allowed.

Order of Committee of Council, referring petition of merchants and inhabitants of Antigua against act recently passed there to reduce and settle rate of interest. June I4, I739.

Accounts of currency situation in four islands, prepared by councils of same and forwarded by Mathew. I739-I740.

"Accompt of the Virgin Islands." Endorsed, "Rec. from Lieu. Genl. Fleming". Read May I8, I740.

24. I739-1744.

Order in Council for postponement of consideration of act of Antigua reducing rate of interest. Nov. 22, 1739.

Several orders in Council and orders of committee of Council for additional instructions to governor on subsistence for troops, collection of powder-duty, sending of military stores to colony, and preservation of stores. Dec., I739-Apr., I74I.

Letter from Col. Fleming, lieutenant general of Leeward Islands and lieutenant governor of St. Christopher, on history of dispute between council and assembly of St. Christopher concerning raising of government supplies and payment of public debts. Undated. Read Mar. 3, I74I/2.

Petitions in behalf of and against Charles Dunbar, surveyor general, accused of extortion in creating fees for himself and in other ways. Referred May, I742. 
States of councils in Leeward Islands.

Order of committee of Council, referring petition of planters interested in Antigua and now resident in G. B. against acts of Antigua of last three years placing double taxes on absentees. Nov. 24, I742.

"A State of the Leeward Islands for their Defence", showing conditions of militia, forts, military supplies, etc. Oct. 16, I742.

Fane's opinion on act of Antigua, June, I744, laying additional tax on absentees on ground that, in escaping fatigue and danger of defense, they should make special contribution to expenses of militia. "If Dependant Colonys are permitted to lay such heavy and unequal burthens upon the Estates of Persons who are returned to their Mother Country or employed elsewhere in the Service of the Crown, The Duty, the Obedience and the Dependancy, which ought to subsist between the Mother Country and the Colony will be soon destroyed." Nov. 26, I744.

25. I744-I747.

Memorial of George Douglas, agent for St. Christopher, against repeal of two acts, passed July and Sept., 1744, for additional taxes on absentees. Read Mar. 20, I744/5.

Collection of 53 reports by Fane and West on 145 acts passed in islands, I722-I744. Most opinions rendered within reasonable period, but not filed until this time.

Two orders in Council, for military supplies to islands. Apr. 9, I745.

Order in Council, that governor shall not approve any act of Antigua whereby special taxes are placed on absentees, unless act contains suspending clause. Mar. 7, 1744/5.

Letter from Mathew, forwarding brief answers to customary queries and state of councils in islands. July 6, 1745 .

Lists (as distinguished from customary statistics or accounts) of marriages and burials in Antigua, Apr.-Sept. 1745; and of christenings and burials in various parishes of four islands.

Letter from Mathew, giving reasons for assenting to law of St. Christopher: said law was rendered necessary by recent refusal of northern colonies to supply provisions to such of $\mathrm{Br}$. W. I. as had passed acts referring to action of northern colonies in supplying enemy through neutral ports. Also, on disputes in Montserrat between Roman Catholics and Protestants, who comprise respectively 75 per cent. and 25 per cent. of population. Apr. 15, I746.

Order in Council, forbidding governor to consent to extra taxes on absentees. July 23, I746.

Letters from Mathew. Religious difficulties in islands. Refers to law passed in I70I, for all islands to curb Roman Catholics, and now eluded; and argues for recent law of Antigua against papists. Nov. 6, I746; Oct. I3, I747.

Id. Unlawful trade with French islands through St. Eustatius and other neutral islands. Oct. 16,1747 .

26. I $747-175^{\circ}$.

Depositions on suspension from council of St. Christopher of Col. Jessup, as being a Roman Catholic. I744.

Many papers, comprising most of volume, on misdemeanors of Benjamin King, member of council and judge of admiralty in Antigua. Accused of extortion in capacity of judge of admiralty; of piracy in attacking, 1747, French island of St. Bartholomew, which was 
under British protection; of neglect of his duties as member of council; and of being author of memorial in which the governor was treated with "great Indignity and Contempt". King suspended from council and found guilty on some counts in court of king's bench and grand sessions.

Letter from Mathew, on "the violent proceedings in St. Bartholomew's". British protection extended to inhabitants there for sixty years but now withdrawn on account of cruelties practised. Oct. I5, I748. Encloses account of indigo imported and exported at Nevis, I748, and of indigo grown at Montserrat and exported, Mar., I745/6Sept., I748.

Id. Production of indigo in Leeward Islands. Nov. I7, I748. Account of indigo works of planters of Montserrat. Dec., I748.

Order in Council, approving representation of Board for repeal of act of Antigua to prevent increase of papists. I746.

Several papers on act of Nevis for establishment of registry office. Secretary appeals against act as infringement of his patent; but governor supports assembly. Letter from Mathew, showing that other islands have registry offices; while "Our Secretary's offices are kept in such plight that few if any would register a Deed in them". Act deprives secretary of very little-perhaps $\mathfrak{t}_{\text {Io }}$ per year. Sept. 28, I749.

Letter from Lieut.-Gen. Fleming. Power of preferment to ecclesiastical benefices as practised in Leeward Islands. July 26, I750.

27. I750-I754.

Order of committee of Council for preparation of draft of additional instructions on office of ordinary. Dec. II, I750. Order in council approving additional instructions. Apr. 30, I75 I.

Order of committee of Council, referring petition of council and assembly of Antigua, that, in absence of governor, lieutenant general, and lieutenant governor, commander-in-chief should have power to hear cases in chancery. Nov. I5, I750.

$I d$., approving representation of Board favoring said petition; and ordering preparation of additional instruction. Feb. 7, I75I. Order in Council approving additional instruction. Apr. 30, I75I.

Memorial of lieutenant general, council, and assembly of Antigua, on clandestine trade carried on by British continental colonies with French, Dutch, and Danes; and on attendant evil consequences. Read Jan. 23, I75I. Address of council and assembly of St. Christopher to Fleming, on same matters. Dec. 20, I750.

$I d$., on slave-trade, complaining that negroes fit for hard labor, who come from "Whidaw" and Gold Coast, are not being brought to the island. Read Jan. 23, I75I. Memorial from lieutenant general, council, and assembly on same. Dec. 20, I750.

Letter from Fleming. Recovery of part of treasure from Nuestra Señora buried at Norman Island, comprising 450,000 dollars, plate, cochineal, indigo, tobacco, etc. Much dug up and appropriated by inhabitants of Tortola. Trouble caused by Spaniards infesting seas around Virgin Islands. Dec. 22, I750. Fleming's account of money recovered-more than 20,000 dollars.

Lamb's opinion that act of Montserrat to regulate assembly and election of members should be disallowed. Order in Council, approving representation of Board for disallowance of act. Dec. 20, I752. 
Letter from Fleming. Financial powers claimed by assemblies of various islands. Act of Nevis to prevent settlement of papists there. Apr. IO, I75I.

Many papers on legislation against papists at Nevis.

Letters from Purcell, governor of the Virgin Islands. July II, I75I ; Jan. 3I, I753.

Letters from Fleming. Claims of assemblies to financial powers, in particular, examination of accounts. Apr. 4, Dec. I3, I75 I.

Order of Lords of Committee, referring petition from president, council, and assembly of Antigua, for confirmation to assembly of privilege of examining accounts of public money before payment thereof under governor's order. May 26, I752.

Letter from Fleming, forwarding and explaining two acts of St. Christopher "to make more effectual an Act of Parliament of Great Britain, Intitled an Act for the better securing and encouraging the Trade of His Majesty's Sugar Colonys in America, so farr as regards this Island". States that Nevis has passed similar act, that Montserrat is doing so, and that Antigua will probably accept his recommendation to take similar action. June 18 , $175^{2}$.

Id. "Disorders" at Nevis. The "Rebel Club" formed "in defiance of the Supreme and all temporal powers". Assembly imagines its privileges to be "unlimited and uncontroul'd by Law, reason, or the Rules of any civiliz'd Government". Oct. 4, Dec. 23, I752; Apr. 4, I753. Enclosures.

Letter from Horace Walpole, complaining of Dunbar, receiver general of casual revenue, who has sent no real accounts since his appointment in 1736 . Apr. 14, I753.

Letter from Gov. Thomas, announcing his arrival and enclosing general report on all fortifications, batteries, etc., of Antigua, I753, and list of families in Antigua, with number of adults and children of either sex in each. Aug. I3, I753.

Letter from Holdernesse, on British title to Crab Island. July 2, I75I. Encloses memorial from Rosencrantz. Other papers.

28. I75I-I757.

Lamb's opinion on act of Nevis to make more effectual an act of Parliament "for the better securing and encouraging the Trade of His Majesty's Sugar Colonys in America". Formal and light objections only. Nov. 30,1752 .

Translation of letter from governor of Porto Rico to Purcell, lieutenant governor of Virgin Islands, explaining that negroes who escape to Porto Rico cannot be returned, since they resort thither, according to their own statements, to embrace the Roman Catholic religion. They are under instruction for one year after arrival, and after that free.

Letters from Thomas. Conditions in the islands; weakness from migration of many inhabitants to Jamaica and St. Croix; evil effects of drought; high range of prices; and distress of soldiers of garrison for lack of proper food. Jan. 21, May 22, I754.

Treasurers' accounts: Nevis, I750-1753; Montserrat, I752; St. Christopher, I747-I753; Antigua, I753.

Letters from Thomas. Condition of defenses. Aug. I2, 1755; Feb. 20, I756. 
$I d$., on same, and complaining that naval squadron fails to give proper protection. Feb. 25, I757.

Id. French are taking possession of St. Lucia. Sept. 25, I755.

Classified accounts of population, by divisions; and accounts of forts, militia, and military stores in four islands. I755-1756.

Account of population and military stores in Virgin Islands. I756.

Letter from Thomas, showing actual and anticipated naval force of French in W. I. Apr. 21, I756.

Memorial of Sir William Codrington, on grant made to him of island of Barbuda. July 14, I756. Other papers, including letter from Thomas in reply to Codrington's memorial. Oct. $16,1756$.

Order in Council on petition of John Sharpe, agent for Antigua, for granting of the "navy allowance" to troops in Antigua, on account of dearness of subsistence there; also for grant of sum for construction of barracks at Antigua.

Letters from Thomas. Naval forces and naval encounters. I756.

Id. Success of privateers fitted out from Leeward Islands. Oct. I2, I756.

Id. Capture of St. Bartholomew by seven English privateers, which defeated three small French privateers and fifty to sixty white men, women, and children. Advantages of possessing this island. Exchange of prisoners. Feb. 25, I757.

29. $1757-1760$.

Letters from Thomas. Action on complaints from governors of Santo Domingo and Porto Rico that two privateers from St. Christopher had taken and plundered the King of Spain's "advice" boat. Trial, condemnation, and execution of offenders. Mar. 27, Aug. I2, Nov. 7, I757. Other papers, including copy of proceedings in trial.

Letter from Admiralty, replying to complaints of Gov. Thomas and of Henry Wilmot, agent for Antigua, St. Christopher, and Nevis, that Leeward Islands do not receive proper naval protection. Sept. 2I, I757. Other papers, including answer to same complaints from Adm. Frankland, commander of squadron at Leeward Islands. (Valuable for naval conditions, privateers, etc., in W. I.)

Letter from Thomas. Complaints of governor of St. Eustatius concerning seizure of Dutch vessels carrying provisions to French islands. Supply of French islands from Ireland, through Dutch islands. May 18, I758. Intercepted letters from Dominick Farrell of Waterford to Francis Peisby at St. Eustatius, showing how trade was carried on. Jan. $26,28, \mathrm{I} 758$.

Papers on improvement in methods followed by privateers from St. Christopher, who had previously "been used to plunder all Wrecks and sometimes to murder or maltreat the unhappy Sufferers, especially Spaniards". I 758.

Letter from Thomas. Assistance given to French by Dutch, who now carry on practically all of French colonial trade, sometimes under convoy of French men-of-war. Nov. 30, I758.

Letters and other papers containing some information on naval forces and encounters.

Letter from Thomas. Assistance given by Leeward Islands to expedition against Guadeloupe. July I3, I759.

Letter from Robert Wood, under secretary for southern department, enclosing, by Pitt's direction, "Memoire Des Articles sur Lesquels 
Le Sieur Robert Deshayes, chargé des affaires de La Guadeloupe et Dependances, doit traiter, Lors de son arrivée a Londre". June I4, I 760.

Order in Council, on appointment of William Burke as secretary and register of Guadeloupe. Sept. 12, I759.

30. $\mathrm{r} 760-\mathrm{r} 769$.

Memorial of Edward E. Cooke, commissioned as privateer from admiralty court of N. Y., asking for recognition of services, especially as commodore of eight privateersmen which captured St. Bartholomew and St. Martin. Referred Feb. r6, r76r.

Letters from James Verchild, president of council of St. Christopher, acknowledging receipt of order in Council of Aug. 8, I766, revoking order in Council of Mar. II, I752, and directing that governors shall send correspondence to Secretary of State, with duplicate to Board, except in cases of secret matters. Feb. 7, I767.

Letter from Gov. Woodley. Threatened negro insurrection at Montserrat. June $21, \mathrm{r} 768$.

Order in Council for disallowance of act of St. Christopher, Aug., I766, for constituting court of chancery in that island. Feb. 26, 1768.

Letters from governors on various local matters. No mention of Stamp Act. No returns enclosed.

31. I769-1772.

Duplicates of letters from Woodley to Hillsborough.

Lieut.-Gen. Losack to Hillsborough, on dispute as to whether members of council should vote in elections of members of assembly. July 25, 1770 .

Letter from Rochford. Capture of vessel of Antigua by Spaniards at Crab Island. Desires opinion of Board on British and Spanish titles to Crab Island. Apr. 4, I772. Other papers.

Powder accounts: Montserrat, I764-1770; St. Christopher, I769-1771 ; and Antigua, 1769-177r. Names of ships and masters, and dates given.

32. $1772-1773$.

Gov. Payne to Hillsborough. Announces his arrival, and states that, while he found some "turbulent" persons in assembly of Antigua, he saw "no immediate Cause of Apprehension". Complains that Spanish guarda costas seize and carry off vessels at Crab Island and near St. Vincent. Feb. I, Mar. I2, I772. Other papers on seizures by Spaniards.

$I d$., on great hurricane of Aug. 3I, I772, which has devastated the island and destroyed the governor's papers. Sept. 5, 18, I772. Other papers.

Copies of orders in Council for disallowance of act passed at Montserrat, I767, "for Attaching Monies, Goods, Chattels and Effects in this Island of Montserrat belonging to persons absent therefrom", and act passed at St. Christopher, I768, for determining number of representatives in assembly to be elected by each parish, fixing qualifications of electors and candidates, providing for freedom of elections, etc. Jan. I5, r775.

$I d$., approving draft of additional instruction to Payne to prevent assembly of St. Christopher "from usurping authorities inconsistent with the peace and good Government of the said Island". June I9, I772.

Payne to Dartmouth. Tranquillity of the islands. Dec. I9, I772. 
Petition of lieutenant governor, council, and inhabitants of Virgin Islands to Payne, asking for his influence for establishment of assembly. I773.

Payne to Dartmouth. Conditions in Virgin Islands. Assembly of St. Christopher has relinquished attempt to deprive councillors of franchise. June Io, I773.

Returns for Antigua, St. Christopher, Nevis, and Montserrat of births and deaths, negroes imported, military stores in forts and batteries, and powder-duties collected. I772-I773.

33. I773-I777.

Mainly Richard Jackson's opinions on acts of the several islands.

Letter from Payne, sending petition from council and assembly of Antigua that St. John's and Parham be made free ports. Aug. 20, I773.

Accounts of christenings, funerals, negroes imported, and powder-duties,

36. I704-I752.

for Antigua, St. Christopher, Nevis, and Montserrat. I773-I775.

Abstracts of in-letters from governors. (Incomplete. In latter part descriptions and endorsements replace abstracts.)

C. O. I52:39. Board of Trade and Secretary of State: Original CORRESPONDENCE. I693-I720.

39. $1693^{-1720 .}$

Mainly duplicates of papers in C. O. I52:8-I2. Letters from Board of Trade, enclosing copies of letters from governors; drafts of letters to governors; licenses for absence, etc. Relate especially to seizures of vessels by French and Spaniards; disputes on claims to St. Lucia and Tobago; operations of pirates; and Parke's treatment of troops stationed at Antigua.

C. O. I52:40-I05. Secretary of State: Original Correspondence. I704-I8I5.

40. I72I-I749.

Letter from Board of Trade, on increasingly violent and unreasonable depredations committed on British subjects by French at Martinique. "It will be absolutely necessary His Majesty should have the Goodness to interpose His authority without Loss of time." June 2I, I723.

Copies of letters from Hart to Board, and of other correspondence (partly French), on Montagu's settlement at St. Lucia, Uring's capitulation and evacuation. Include good narrative of expedition, and copy of French orders. I722-1723.

Papers on Hart's additional salary; relating also to taxation and currency.

Representations, letters, and related papers, on claims of Denmark to St. John and St. Thomas. Include correspondence of Hart with the governor of St. Thomas. I725.

Papers on disputes of Hart with Wavel Smith and Savile Cust, secretary and clerk of crown for Leeward Islands.

Numerous papers on seizures of vessels from British continental and W. I. colonies by Spaniards at St. Croix; and relating also to retention at Antigua of contents of Spanish ship stranded at Barbuda. Largely original. Include depositions and letters giving full details: 
e. g., detailed inventories of cargoes seized, with values in pieces of eight. Among continental ships were Alida of N. Y., Philip Cockran, master, and Eagle of Amboy, George Fraser, master. I726I727.

Important and extensive group of papers on settlement of neutral islands, British titles to same, and contests for ownership. Relate especially to St. Lucia. "Reasons humbly offered the Earl of Sunderland for settling the Island of Tobago", by W. Gordon. Apr. 23, I72I. Two drafts of orders for evacuation of St. Lucia, St. Vincent, and Dominica, prepared for Worsley of Barbados. Sept., Nov., I73O. "A State of the Right of the Crown of Great Britain to the Island of Snt. Lucie, Snt. Vincents and Dominica." Elaborate and careful treatment on historical lines, with many marginal references to various Board of Trade papers. Unsigned. Endorsed in pencil, "I730". Letter from Worsley of Barbados, on number of French at St. Lucia. June 27, I73I.

Hart to Townshend, on Porto Rico and possibilities of expedition against it. May 8, I729.

Letter to Harrington, discussing British title to St. Croix; with representation to the crown on same. June 27, I733.

Letter from R. Coope, describing arrival at St. Thomas of Danish commission under Motte sent out for settlement of St. Croix. Aug. 28, 1734. Letter from Board of Trade on settlement of St. Croix. Sept. I2, I734. Other papers.

Papers on weakness of British islands, and measures to be taken for strengthening them.

Letter from Hart, with copy of treaty of neutrality between Dutch and French for St. Martin and St. Bartholomew. Sept. I4, I734.

Memorial to Newcastle, from secretary and inhabitants of Leeward Islands, stating: that Mathew's sloop has seized French vessels; that said vessels have been condemned in admiralty court; that one vessel was confiscated without trial; and that reprisals are feared. I736. Complaint on same matter from Jamaica, where also reprisals were feared. I737.

Accounts of depredations of Spanish privateers. I737.

Proceedings in Privy Council on reports of unlawful acts by British,

41. $1750-1806$. French, and Spanish vessels in W. I.

Letter from Board of Trade to Bedford, on preparation, in accordance with orders received, of commission and instructions for William Shirley and William Mildmay, nominated as "Commissarys by His Majesty for settling all the Points in dispute in America between the Crowns of Great Britain and France as well in relation to the Limits in North America, as to the four disputed Islands in the West Indies". Board desires time for study before complying with orders. Points "most agitated between the Crowns" are limits of Nova Scotia and British right to four disputed islands. Apr. 6, I750.

$I d$., stating that Board, in obedience to orders, has prepared separate memorial, answering that part of French commissary's memorial which relates to French claims to Canceaux [Canso]. Dec. Io, I750.

Lieut.-Col. Sharington Talbot to Secretary at War, on reluctance of people of Antigua to provide for defense. Oct. 24, I750. Enclosures 
include address of council and assembly to governor of Leeward Islands.

Id. Subsistence and condition of troops. I75I.

Germain to Admiralty. Secret. Commander of squadron at Leeward Islands is to give all possible assistance to land forces in expeditions against French, as referred to in letter of this date to Gen. Grant. July 29,1778 .

"Establishment of the Rank and File" of forces in Leeward Islands, I763-I779, I785-I788; Leeward Islands here include Grenada, St. Vincent, Dominica, and Tobago, while no reference made to St. Christopher, Nevis, or Montserrat; 8000 in I779.

State of garrisons left at St. Christopher and Antigua, Mar. 8, I780.

"State and Disposition of the Army under the Command of His Excellency the Hon. John Vaughan, General and Commander-in-Chief", in Barbados, St. Lucia, St. Christopher, Antigua, St. Eustatius, and St. Martin, and on board ships-of-war; 5800 , of whom 4200 fit for duty. Barbados, June 30, I78I.

Papers on government of Virgin Islands. I782-I783.

Papers on internal affairs of St. Christopher. I789.

"The Memorial, Principles, Propositions and Plan of John Drummond Esq. for the speedy Recovery and Reduction of the French Windward Islands." I793. Detailed statement on military strength of said islands, prepared by Drummond and forwarded to Dundas, Sept. 3, I 793 .

"Memorial of Isabella, Countess Dowager of Glencairn, formerly wife of the late Hon. William Leslie Hamilton, Attorney General of the Leeward Islands, . . . Sheweth that upon the defection of the American Colonies the Revolters were supplied with Military Stores by the disaffected Subjects in the Leeward Islands." The proximity of St. Christopher to St. Eustatius, "whither the disaffected resorted to carry on their Treasonable Practices with Security", made detection difficult. Petitioner, who incurred losses and asks reimbursement, has lost powerful advocates through deaths of Nelson and Pitt. I809. Other papers include clipping from The Statesman, announcing that Lady Glencairn will publish appeal to nation, with all correspondence involved. Correspondence "completely implicates $\mathrm{Mr}$. Perceval in the charge of having wantonly and invidiously aspersed the character of the ever-to-be-lamented Lord Nelson".

42. I704-I725.

Papers on French plans for operations in W. I. culminating in attack on Montserrat, I7I2. Intelligence of these plans secured in British islands. Mainly I7I I and I7I2. List of individual losses sustained through French attack on Montserrat.

Papers on cartels with French. I7II.

Hart to Carteret, with enclosures on pirates. Mar. 24, I723/4. Other papers.

$I d$., on Danish islands, enclosing correspondence of Hart with the governor of St. Thomas. July IO, I724.

"Memorandum about St. Lucia." Unsigned. Undated.

43. I $727-\mathrm{I} 733$.

Letter and memorial from Londonderry, on governor's additional salary. Dec. 8, I727. Other papers. 
$I d$., on cutting of logwood by British at St. Croix and St. Eustatius. Apr. I 5, May I, I729. Other papers.

Collection of extracts from letters and other papers on St. Lucia. I719I730. Unsigned.

Papers on activities of French, and their attacks on British vessels, at St. Croix. I729-1730.

Copy of additional instructions to the governor, on taking up residence at Antigua as "windermost" and most important of islands. Each island to contribute to house rent in proportion to fraction of year the governor spends there.

Papers on "neutral" islands, St. Lucia, Dominica, and St. Vincent. Yeamans to Newcastle on French settlements at Dominica and St. Lucia. July I I, I730. Copy of letter, apparently from Duke of Montagu, on "the State and Trade of the French Islands". Received Aug., I730.

Sir Philip Yorke's opinion that, since "the laying Siege to Gibralter was an avow'd making Warr by Spain upon the Crown of Great Britain", seizure of Spanish vessel Sancta Reta stranded near Antigua, Feb., I726, became legal. Other opinions.

Letters to Newcastle, from president of council at Nevis, on minor local hostilities with Spaniards at Virgin Islands. Also, on plundering by British inhabitants of Spanish vessel wrecked there, and murder of some of Spanish crew. I73I-I732.

Papers on seizure and condemnation of sloop Catherine of Boston. Probably I729.

Sessional papers: assembly of Nevis, Jan. I, I730/I-Dec. 2, I73I ; council of Nevis, Apr. 28-Dec. 2, I73I ; council of St. Christopher, Oct. I, I730-Oct. 30, I73I ; council of Antigua, Jan. 26, I729/30June II, I730; July 20, I730-July I9, I73I.

44. I734-I746.

Letter from Mathew. Measures of defense, strength of Leeward Island squadron, and military stores on hand. Jan. I7, I733/4.

Id. Piracies of Spaniards from Porto Rico. Mar. 22, I734/5. Depositions enclosed.

Memorial from agents for Antigua and St. Christopher, on depredations by French, and violations of treaty of I 686 involved in French edict of 1727. I735. Appended are many papers, comprising depositions, copies of correspondence between Mathew and French governors, and extracts from treaty of 1686 and governor's instructions.

Papers on charges of improper seizures of French and Dutch vessels by Mathew's sloop, and on action of council respecting same. I736I737.

Papers on threatened negro insurrection at Antigua. I736-r737.

"An Account of the several Applications made to His Majesty for stores for the Leeward Islands, Barbados, and Jamaica, since His Majesty's Accession to the Throne."

Copies of letters, Newcastle to Mathew, on declaration of war, and on large naval and military expedition under Adm. Vernon and Lord Cathcart to attack Spanish W. I. possessions. Directs raising of volunteers in W. I. and continental colonies. Hopes to secure 500 from Leeward and Virgin Islands. A "just share" of plunder and booty, and priority in grants of lands captured and retained, offered 
to recruits. Regular troops in Leeward Islands to remain there for defense. Apr. 30, July 4, Oct. 9, I740.

Numerous papers on preparations for Cathcart's expedition, purchase of supplies partly at St. Eustatius, movements of French, and strength of defenses in the islands.

Letter from Fleming, on operations. "Our Northward forces Mett with bad weather soon after their departure", but eleven vessels passed on Nov. I4, and others have touched before or since. Nov. 24, I740.

Extracts from Mathew to Yeamans, on building at Bermuda of privateers for enemy, Jan. 6, I740/I.

$I d$., complaining of trade of continental colonists at St. Eustatius. "Benjamin Smith of Rhode Island Laden with Beef came a few days ago to this Island, Anchored in the Road to try the Markett, then went to St. Christophers for the same pretended purpose, thence to St. Eustatia and sold his Beef publicly there to a French Trader." May 29, I74I.

Affidavit of Mathew, on illegal trade between British and Danish islands; refusal of Dunbar, surveyor general, to check it by insisting on proper clearances. May 26, I74I.

Lieut.-Col. George Lucas's account of attack on Puerto Cabello by British and Dutch soldiers, sailors, and marines. Apr. 30, I743.

Letter from Mathew. Capture of St. Bartholomew and French half of St. Martin, by forces including nineteen privateers firom St. Christopher alone. Between war-vessels and privateers "the French in their Islands will Starve". July 20, I744.

Copies of intercepted letters, sent during the war from Martinique to Richard Bradshaw, merchant at Cork. I744.

Letter from Mathew. Movements of Caylus. Wretched condition of British troops in the W. I. Mar. 23, I744/5.

Report of the "General Officers" to Lords Justices on condition of Lieut.-Col. Dalzell's regiment: strength, establishment, deficiencies in clothing and equipment, disbursements, recruiting, etc. Sent from Horse Guards, June I2, I 745. Signed by Cornewall, Phillip, Guise, Reade, Frampton, Blakeney, and Oglethorpe.

45. I748-I752.

Mathew to Bedford, on "prohibition of Commerce between His Majesty's Subjects and those of the French King. . . . That evil chiefly concerns Bermuda, New York, Pensilvania and other Northern Colonys". The inhabitants of Providence supply Cap Français with provisions under cover of flags of truce. Hopes that St. Martin and St. Bartholomew can be retained after peace, to prevent French from gaining a footing "in the middle of this government". If this proves impossible, hopes they will go to France and not to Holland. Dutch islands have not only supplied enemy in war, but have done much injury in time of peace "by forwarding from their Port the illicit Trade carryd on between the worst of His Majesty's Subjects of the Northern Colonys and of these with the French". May 5, I748.

Papers on settlement of the "neutral" islands. (Numerous and valuable.)

Mathew to Bedford. Depredations of French at Martinique, and still greater misdoings of Spanish at Porto Rico, where guarda costas seize vessels, not only in, but far outside, one league limit. Suggests that British naval vessels treat as pirates guarda costas encountered 
outside one-league limit. "Puerto Rico is the Chief Nest of Pirates and Searchers." Mar. 31, I749. Deposition on French seizure enclosed.

Letter and memorial from Wavel Smith, secretary of Leeward Islands, on currency situation there. May, I750.

Fleming to Bedford. Threatened negro insurrection at St. Christopher in imitation of that at Curaçao. Measures of security taken. Aug. I3, I750.

Id. French frigate Galathea fired on at Nevis, Feb. 25, I749/50, for refusing to give account of herself. Governor of Porto Rico refuses to give satisfaction for seizure of several British ships by Spanish privateers after conclusion of hostilities. Refuses also redress for escape of slaves to Porto Rico, which threatens seriously to discourage settlement of Leeward Islands. Spaniards make excuse of religion, christening runaway slaves immediately on landing. Assembly of Antigua insists on having part in ordering payment of public money. Nov. 10, I750. Copies of Fleming's correspondence with governor of Porto Rico enclosed. Fleming to his Excellency Don Agustin Pareja, governor of Porto Rico, on retention of runaway slaves, whether for good of their souls, or perhaps because "it is imagined that a Leeward situation gives the advantage of laying hold of more of our slaves than we can of your's". May 2r, I75I.

Many papers on plundering of ship Nuestra Señora of Guadeloupe, which went ashore on coast of N. C. with president of Santo Domingo and treasure worth $\mathfrak{f}_{200,000}$ on board, I750. President of Santo Domingo procured sloop and loaded treasure; but sloop and treasure stolen. Treasure buried at Norman Island, dependency of Tortola.

Papers on various disputes with Spaniards: cutting of wood at Crab Island; seizures for illegal trade; harboring by Spaniards of fugitive British slaves, etc.

Fleming to Bedford, on evacuation of French part of St. Martin, as ordered. June 26 , I75I.

Petitions of councils and assemblies of four islands against French encroachments in four "neutral" islands, reviewing progress of French in each. I751.

Petition of council and assembly of Antigua, that members of council should not sit in chancery as judges in cases to which they are parties. I75I.

Petition of council and assembly of St. Christopher for better protection by regular troops. I750.

"A New and Correct Map of the Caribbee Islands." Colored. Shows 46. $1754-1760 .^{2}$ country to which each belongs. I $75 \mathrm{I}$.

Papers on question whether jurisdiction of admiralty court extends to case of captain of slave vessel Bristol, accused of murdering member of crew in African port, and now arrived at St. Christopher. I754.

Letter from governor of Martinique and French Windward Islands to governor of Leeward Islands, complaining of seizure of two French vessels by British squadron on N. American coast, and of the "parti violent que les habitants de la nouvelle angleterre ont pris sur toutes nos côtes de la nouvelle france". Also Thomas's reply.

${ }^{2}$ Consists in considerable part of papers relating to Barbados and Bahamas, q. v. 
Papers on appeals for arms and better fortifications.

Thomas to Fox. Capture of H. M. S. Warwick by French; naval strength of France and G. B. in the W. I. Mar. 25, I756.

Thomas to Pitt. Arrival of eleven French ships-of-war at Martinique, French naval superiority in W. I., and danger to Leeward Islands. May 28, I757. Lists of British and French ships-of-war enclosed.

Thomas to Holdernesse. Acknowledges orders to apprehend Hadden and Snooke, commanders of privateers belonging to N. Y. and Halifax. Hanging of Capt. White and three "accomplices" for seizure of King of Spain's "advice” boat. Nov. 7, I757.

Thomas to Pitt. Engagement of H. M. S. Buckingham with three French men-of-war convoying sixteen vessels, chiefly Dutch, from St. Eustatius to Martinique; great assistance afforded by Dutch to French; report that Dutch are arming their ships. Nov. 20, $175^{8}$.

Representation to governor of Leeward Islands from president of court of vice-admiralty at Antigua, "and other his Majesty's Commissioners appointed for examining and adjudging High Treason, Piracy, Felonies and Robberies". Ask that William Pickles, under death sentence, be reprieved until royal pleasure be known. Pickles British subject, born in Philadelphia, lately resident at St. Eustatius, and captured while apparently conveying provisions to Martinique. His conviction necessary as warning to North Americans and Irish, who, if not warned, would soon carry provisions directly and openly to French islands. Privateers from N. Am. have convoyed American vessels carrying provisions to St. Eustatius and Spanish part of Hispaniola. But this the court's first conviction, and extenuating circumstances exist. I758.

Thomas to Pitt. Preparations for attack on Guadeloupe. Encloses papers found on homeward-bound French vessel which show conditions in French islands. Apr. 27, I759.

Id. Enemy privateers have declared that "they will give no Quarter to the Captains of such Merchantmen as shall make any resistance". Mar. 20, I760. Encloses depositions on cruelty of privateer from Martinique, giving vivid details.

Id. "Illegal and iniquitous Trade" carried on by British subjects with enemy. Attempts of the governor to stop it in Leeward Islands "have been attended with such Success that many Vessells and Cargoes have been seized and condemned and some Persons have been sentenced to Death for Trading with the Enemy". But continental colonies and Ireland continue traffic. Certificates made out only for lumber and other articles landing of which in neutral islands not forbidden, while provisions taken in later at outports and carried to St. Eustatius, St. Croix, St. Thomas, and Curaçao. In other cases evasion of laws successful through connivance of officials who do not demand certificates on return. No law exists against exportation of beef, pork, etc., from Ireland to Dutch and Danish islands. Guadeloupe now channel for supplying Martinique and for sending French sugar to England as produce of Guadeloupe. Dec. 8, I760.

Id. Illegal trade between St. Christopher and St. Eustatius in Dutch vessels which profess to enter St. Christopher for water. May 20, I760. 
47. $1761-1767 .^{3}$

Thomas to Egremont. Complains that French are again putting into operation rule against foreign vessels approaching within one league of their coasts; and objects to renewal of permission to continental colonies to trade with French islands. Sept. 9, I763. Encloses copy of decree of governor and intendant of Guadeloupe for preventing illegal trade.

Copy of letter from Capt. Knowles to Adm. Tyrrell, describing capture of ship Chance, Philadelphia to Cayenne, although cleared for Barbados. Papers show that "the French Agent when at Philadelphia had made an agreement with one Mr. Richie a Merchant there to supply the Colony of Cayenne with Provisions". Carlisle Bay, Apr. I, I765. Letter from Tyrrell to Halifax, on capture by Knowles of brigantine from Philadelphia, carrying letter from John Remsen of Philadelphia to governor and intendant of Cayenne. Letter refers to contract concluded June I, I764, for supply of provisions. But brigantine carried only tar, pitch, and turpentine and was condemned at Barbados for having these without bond. May 6, 1765 .

Thomas to Halifax. He cannot transmit in time list of papers wanted in connection with Stamp Act. Jan. 16, I765. Id., sending list. Apr. II, I765.

Id. Trade of continental colonies with French, and importation of French goods. "The Business of Forged Clearances, as from Anguilla, was happily detected by Mr. Gumbs, the Collector of that Port, and notice given to the Officers of the Customs in North America, though not so timely as to prevent all those Cargoes being admitted and sold as the Produce of Anguilla." Mar. 26, I765.

Letters from Egremont and Halifax to Thomas on military matters: reduction of 38 th Regt. at Leeward Islands to peace strength; relief of 38 th Regt.; and system of rotation employed in relief of troops serving in America. $1763-1764$.

Letters and depositions on arrival of French settlers and warships at Cayenne, and on other activities of French there.

Thomas to Conway. Distribution of stamped paper at Nevis and St. Christopher. "Mobs in both places had in the most riotous and tumultuous manner seized and burnt the Stamp Papers." At Antigua protection of distribution and paper by sentries prevented disturbance, although "it is easy to observe a general uneasiness and discontent in the People of all Ranks". Has offered reward for apprehension of leaders at Nevis and St. Christopher, but discontent so general that he has little hope of discovery. Dec. 2I, 1765. Enclosed is letter from William Tuckett, distributor for Nevis and St. Christopher. Was knocked down, otherwise assaulted, and compelled to promise resignation. Does not dare to receive more paper.

Letter from Verchild, on stamp riots. No one injured in person or property. Leaders could not be discovered. June I4, I766.

Id. Encloses address of council and assembly of St. Christopher, expressing thanks for repeal of Stamp Act. Sept. 9, I766.

${ }^{3}$ Unlike preceding volumes, contains some out-letters. 
48. 1768 .

Letter to Gov. Woodley, ${ }^{4}$ announcing disallowance of act of St. Christopher establishing court of chancery. Mar. 5, I768.

Letters from Woodley. Consternation in Montserrat over threat of negro insurrection planned to take place during St. Patrick's Day

49. 1769 . celebrations. Many particulars. Apr. 22, June Io, I768.

Letter from Woodley. Desires decision on question whether members of council may vote in elections of members of assembly. Members of council claim right to votes as freeholders, while members of assembly deny right on analogy of House of Lords. Feb. 7, I769.

Id. Complains of weakness of forts and poor distribution of military stores in colony; proposes to send unserviceable cannon to the "Foundery" in England. Feb. 23, I769. "State and Condition of Ordnance" enclosed.

$I d$. Sends, in compliance with orders, military and other information on Martinique and Guadeloupe; and complains of lack of co-operation by crown officials and local assemblies in provisions for security of Leeward Islands. May Io, I769.

Hillsborough to Master General of Ordnance, enclosing Woodley's letters and signifying his Majesty's pleasure that cannon and stores now lying useless in Leeward Islands be turned over to the governor for use in forts and batteries, unless Master General of Ordnance thinks that this would interfere with his Majesty's service in any other respect. July $29, \mathrm{I} 769$.

Correspondence between Hillsborough, Gov. Woodley, the Postmaster General (of Great Britain), and the captain of a W. I. packet. Postal service and operations of packet-boats in W. I. June-Sept., I 769 .

Woodley to Hillsborough. "His Majesty's Most Gracious Speech, from the Throne, hath diffus'd universal Joy through all Ranks of People here." July I7, I769.

Id. Disastrous fire at St. John's, Antigua, Aug. I7, I769. Sept. 20, I769.

Id. Sends petition of council and assembly of Antigua for relief on account of fire. Oct. 26, I769.

50. $1769-1770.5$

Woodley to Hillsborough. Reports receipt of order from Board of Ordnance giving him disposal of cannon now in custody of storekeeper at English Harbor. Nov. 7, I769.

Hillsborough to Woodley. Reproves him for making no mention of "a most extraordinary Proceeding in the Assembly of St. Christopher's in October last, respecting some of their members". Apr. 21, I770.

Classified returns of population in St. Christopher, Nevis, and Montserrat. I 770 .

Letter from Woodley. Choice of governor, council, and assembly by negroes had proved to be merely part of negro entertainment; and

"The governor was at this time styled: "Captain General and Governor in Chief in and over the Islands of St. Kitts, Nevis, Montserrat, Antigua, Barbuda, Anguilla, and the rest of the Carribbee Islands in America lying to the Leeward from Guadeloupe to Porto Rico."

${ }^{5}$ Identical letters found in Board of Trade series, C. O. 152:30-31. These are marked "Duplicate"; but both series bear original signatures and carry enclosures. Enclosures sometimes differ. 
that, since no indication of affair being serious had appeared, he had refused to allow use of torture in examination. Apr. 20, I770.

Id. "Public dissension . . . rages at present with great violence in this little Island" (St. Christopher). Gives no particulars. Apr. 25, I 770.

Copies of letters from Capt. Garnier of H. M. S. Scarborough to Commodore Mann, giving military and other information on French islands and Porto Rico. Apr. 8, May 20, I770.

Lieut.-Gen. Losack to Hillsborough. States that "the unhappy divisions" in St. Christopher originated in dispute as to whether councillors had franchise in elections of assemblymen. July 25, I770. Other papers.

Id. Sends papers on dispute with captain of guineaman, who, though carrying slaves reported to have smallpox, refused to place his ship as directed by quarantine regulations, and, landing with some of his men, walked through town. Vessel was finally fired upon, some slaves being killed and one white seriously wounded. Captain claimed that "he had not a negro on Board but who had been inoculated a full month". Sept. 7, I770.

Letter from Woodley. Sends petitions from councils and assemblies of St. Christopher, Montserrat, and Nevis, requesting that troops be sent, and offering to supply barracks and provision as Antigua does. London, Nov. I6, I770.

Account of trial, in court of king's bench and grand sessions, of corporal and two other soldiers for murder of two sailors during riot of drunken sailors. Corporal convicted of giving word of command, and hanged. Others convicted of obeying, and sentenced to death, but reprieved till his Majesty's pleasure be known. Mar., I769.

51. I770-I77I.

Lieut:-Gen. Losack to Hillsborough. Fears that acts of violence at St. Christopher can be prevented only by intervention of home government. Dec. I I, I770.

Hillsborough to Losack. Conditions at St. Christopher are under consideration by Privy Council. Feb. I I, I77 I.

Losack to Hillsborough. Leeward Islands hope for preservation of public tranquillity, being rendered so weak by decrease of white population and "disorder" of fortifications. It is difficult to recruit regiment stationed in islands "equal to the established Plan of Augmentation". Jan. 25, Feb. 28, I77 I.

Copy of letter from Rear-Adm. Mann to Admiralty, sending information on strength of French and Spaniards in W. I. Mar. 29, I77x. Losack to Hillsborough. Apr. 27, I77I. Two important enclosures:

(I) Michael White, deputy lieutenant governor of Montserrat, to Losack, on impeachment, by members of assembly, of two justices of courts of king's bench and common pleas in council. Aug. and Sept., I770. Articles of impeachment, extracts from minutes of council and assembly, etc., enclosed. Sept. I4, I770.

(2) Losack to White, "strongly" dissenting from propriety of impeachment, which "has given a wound to the Authority and Prerogative of the Crown. . . . To impeach is a species of power, which I cannot admit to be vested at any rate in an House of Assembly". Also assembly had no right to ask, nor White to grant, power to adjourn itself; and proceedings of 
time when they were not regularly sitting must be expunged from records. Also note to be made in council-book that permission given assembly to adjourn itself was null and void. Oct. 7, I770.

Numerous enclosures include extracts from minutes of council and assembly, showing council's compliance with Losack's directions, and assembly's resistance and final compliance.

Hillsborough to Losack. Strongly endorses his action on impeachment of judges at Montserrat, but reminds him that governor's instructions allow him to delegate power of adjournment to assemblies pro hac vice when he considers it reasonable. June 8, I77I.

Representation of Lords of Trade on disputes at St. Christopher. It appears from act of $\mathrm{r} 727$, on constitution of assembly, that members of council "have a clear right to vote in the Election of Members of the Assembly". June 6, I77 I.

52. $177 \mathrm{I}-\mathrm{I} 772$.

Maj. Dundas, 68th Regt., to Hillsborough, pointing out that royal pleasure not yet signified regarding two soldiers sentenced for murder and reprieved in 1769. Nov. 5, I77I. Hillsborough to Gov. Payne, sending pardon for soldiers. Jan. II, I772.

Payne to Hillsborough, complaining of packet service. Feb. 23, I772.

$I d$. No cause for anxiety in any of the islands. Even in St. Christopher only "personal piques". No satisfaction to be had from Spaniards on seizure of Adventure of Antigua. July 3I, I772. Other papers on seizures by Spaniards.

53. I772-I773.

Payne to Dartmouth. Methods of Spaniards in driving British settlers from Crab Island; further settlement of Virgin Islands; oppression, extortion, and incompetence in government of them. Hopes that they will receive same form of government as other islands, provided they consent to grant the $4 \frac{\mathrm{T}}{2}$ per cent. duty. Has reason to believe they will do so. Jan. 20, I 773 .

Dartmouth to Payne, sending orders for convening of assembly and appointment of council in Virgin Islands. July 5, I773.

54. I773-I774.

Payne to Dartmouth. Absenteeism and other social conditions; courts of chancery and judicial procedure generally; conditions in Virgin Islands. Oct. 6, I773.

Proclamation, signed by Payne, announcing establishment of assembly and council for Virgin Islands and regulating elections for assembly. Nov. 30, I773. (Printed.)

Correspondence between Vice-Adm. Parry and the governor of Porto Rico on British claim to Crab Island. I774.

Payne to Dartmouth, on passage of act establishing the $4 \frac{\mathrm{T}}{2}$ per cent. duty in the Virgin Islands. Payne finds a "too apparent Reluctancy .. among all Ranks of People .. . to discharge their Covenant". Attempt made to establish custom of paying duty on hogsheads of sugar in custom-house at $600 \mathrm{lbs}$. weight, as is said to be done at Dominica. But, although hogsheads at Virgin Islands are considerably smaller than those in the Windward Islands, they average I 200 to I $400 \mathrm{lbs}$. Crown would thus be deprived of more than half the tax. Also gives much information on beginnings of government, and other affairs in Virgin Islands. Mar. 2, I774. 
Id. Reviews conditions at Crab Island, where English and Spaniards both refrain from settling in order to avoid inevitable conflict. June $3, \mathrm{I} 774$.

Id. Sends unusually full replies to customary queries. June 26,1774 .

Id. Courts of chancery in islands, and "concern" of people over troubles in N. Am. "They applaud the wisdom of Parliament for the Steps which it has taken to express its own Resentment and reclaim the intoxicated Disposition of the Inhabitants of Boston." Generally considered that closing of port of Boston will bring inhabitants to proper sense of dependence. Hears of associations "for restraining every Branch of their Commerce with these islands". This would be fatal to islands. July 3, I774.

Id. "General harmony and tranquillity" in all parts of his government. Oct. IO, I774.

55. $1775^{-1} 776$.

Payne to Dartmouth. Packet service; escape of slaves to Porto Rico; perfect tranquillity in islands. Jan. I2, 1775 .

Letters from Lieut.-Gov. Nugent on conditions in Virgin Islands.

Germain to Pres. Greathead, at St. Christopher, sharply reproving him for declining, on account of "doubts upon speculative points of law", to forbid exportation of powder, arms, and ammunition, and thus prevent N. Am. from being supplied. Dec. 23, r775.

Greathead to Dartmouth. Sends copy of proclamation forbidding exportation from St. Christopher of corn, rice, flour, and all other provisions, except those from G. B. Dec. 29, I775.

Several papers on arrest at Antigua of Charles Hobby Hubbard, passenger on brigantine Manners, which was forced by weather into Antigua while bound from London to Boston with provisions for navy. Hubbard accused of making seditious statements. Nineteen letters found in his bed, addressed to: "Doctor Jeffries in the Provincial Army at Cambridge near Boston"; "John Wendell Esq., Portsmouth near Boston"; Henry Brownfield, Thomas Lee, Byfield Lyde, Thomas Cushing, and William Mackay of Boston; Capt. William Brown, of Lincoln, New England; Thomas Martin of Portsmouth, N. H.; Dr. John Califf of Ipswich; Tobias Lear of Piscataqua; Thomas Russell, near Boston; Mrs. Storer, Dr. Edward Watts, and Simeon Mays of Falmouth, Casco Bay; and the Rev. Mr. Gordon, late of Jamaica Plain. One letter is addressed to John Hancock, Samuel and John Adams, and Generals Washington, Ward, Lee, and Putnam, and contains a cipher to be used for dispatches which may be sent to them. A second cipher also found. All letters sent by favor of Capt. Charles Hubbard. Hubbard will be sent to England in man-of-war, with witnesses. Enclosed are copies of seized letters. That to Hancock et al. promises that all information arriving in enclosed cipher (a clumsy and obvious substitution of numbers for letters) may be relied upon. Inner addresses on some letters show other addressees. William Lee writes from London to Thomas Cushing, Aug. 21, I775, that Hubbard "seems to have taken some pains to learn the ministerial disposition with respect to America", and seems to be well informed. Letters in general deal with public opinion in England on colonies; with business; and with military preparations. "C. Do." writes Jeffries: "It is not the opinion of a few but the real fear of by far the greater 
part of the people in Engld. that the preparations now making by the $\mathrm{K}$ - and his Ministers the War is ment to be carried on with the greatest vigour next Spring and that 30 ooo or at least 25 Thousand men wh. Sr. Jeffry Amherst at their head will be ready to go out." Dec., I775.

St. Christopher Gazette. Mar. 2, I776.

Addresses of council and assembly of Virgin Islands containing strong protestations of loyalty. Apr. 6 and 9, I 776.

Letter from Greathead. Sends papers to show that Hubbard is violently insane, and has, by desire of attorney general for Leeward Islands, and with Greathead's consent, been sent to his wife and family in N. Am. June 5,1776 .

Naval officer's lists, St. Christopher and Nevis. Apr. I-Sept. 27, I775.

56. I776-I777.

Letter from Greathead, enclosing correspondence with governor of St. Eustatius on insults to the British colors and assistance to " $\mathrm{H}$. M. Rebel subjects". St. Christopher, Dec. 3I, I776. Enclosures:

Letter from Greathead to Johannes de Graaff, governor of St. Eustatius, making charges against the Dutch of supplying "all sorts of Provisions and warlike Stores . . . almost daily and publickly . . . to His Majesty's said rebellious subjects", and of permitting vessels to be "equipped and set forth in a Warlike Manner, from that Island, for the express and avowed purpose of cruizing against, and making prize of the Ships and properties of his peaceable and faithfull subjects"-in particular a sloop called the Baltimore Hero. Dec. 17, i 776.

Letter from Johannes de Graaff, denying knowledge of abuses alleged. St. Eustatius, Dec. 23, I776.

Reply of Greathead. Dec. 26, I776.

(The three letters listed above, and Greathead's of Dec. $3 \mathrm{I}$ in which they are enclosed, are printed in Missive van Repraesentant en Berindhebberen der Westindische Compagnie, etc., I779; see American Historical Review, VIII. 692, note I, in art. "St. Eustatius in the American Revolution", by J. F. Jameson.)

Letter from Carter Braxton of Va. to a correspondent in Curaçao suggesting opening of trade: states trade to be opened between Willing and Morris, merchants of Philadelphia, and the writer and Mr. John Philip Meikle, merchant of Amsterdam. Sept. 28, I776. Further correspondence on this subject.

Id. Encloses copies of previous letter and its enclosures, including those relating to correspondence between the governor of Guadeloupe and the deputy lieutenant governor of Montserrat on restitution of an American sloop. Jan. 3I, 1777 .

Petition to the king from owners of the sloop Reprizal on trade between rebellious colonies and W. I. Endorsed: "Antigua. Rec'd 25 Apr. I7 I7."

Letter from Greathead. Encloses correspondence with Danish commandant of St. Thomas and with Mr. Fahie commanding officer at Tortola, on action of one W. Stephens in pursuing a French sloop. May 6, I 777 .

Letter from Gov. Burt. Information collected as to relations between rebels and governors of Martinique, Guadeloupe, St. Eustatius, and St. Croix. He understands that "the Governor of Martinique not 
only permits the American rebellious Privateers to bring all their Prizes into the Ports within his Government, . . . but that an Agent from the Congress, Mr. Bingham, Publicly resides at Martinique from whence Privateers are daily fitted and manned by French Seamen". The governor of St. Eustatius has returned the salute of American rebel armed vessels, and fired on the Ballahoe, a British armed tender. He reports further a difficulty between the admiral and the "Commercial Interest" of the island owing to the condemnation as droits of the Admiralty of vessels fitted out by the inhabitants to make reprisals on "the Provincials": the vessels sailed without commissions with the double purpose "of distressing the Rebels and of bringing supplies to the Government". Antigua, May 4, I777. Encloses information on American privateers in harbor of St. Pierre, French privateers, and English merchantmen taken as prizes by American privateers and now at St. Pierre.

Id. He has granted several licenses to vessels for carrying rum, sugar, etc., to N. Y. or Halifax. St. Christopher, June I3, I777.

Id. Intercourse between Dutch in Virgin Islands and Americans. Encloses correspondence relating thereto. St. Christopher, July 30, I777.

Id. There is no reason at present to complain of governors of St. Eustatius and St. Croix. "The Gentleman who formerly was security for the North American Privateers by the Measures taken against the Pirates, who cut out the Brig Marquis of Rockingham, has positively refus'd being further security, and the hunting Mr. Vanbibber from thence to Sta. Croix, and driving him from thence, has absolutely for the present rooted up that Nest of Pirates." The fort at west end of St. Croix was ordered to fire on an American armed vessel. Conduct of the French governors of Guadeloupe and Martinique not so satisfactory. Antigua, Sept. I7, I777.

57. $1777-1778$.

Letter from Gov. Burt. Intercourse between French and Americans. Antigua, Nov. I, I777. Encloses papers on attitude of De Graaff; also copy of prohibition of trade with Americans issued by the governor of Guadeloupe.

Id. Further information as to French attitude: every assistance given to American privateers; remonstrances of no avail. Antigua, Nov. 30 , I777.

Id. Encloses assurance of Count d'Arbaud that no American privateers should be admitted to Guadeloupe. Martinique now "the only and general receptacle of Pirates", and no change is likely under the present governor. "I have just receiv'd Intelligence of a rebellious American Privateer's being fitted out at the Danish Island of Saint Thomas's. . . . I have already acquainted your Lordship of Houses and Agents for the Americans in each of those Governments. Byngham resides publickly at Martinique: Tenant and Ross I have sent your Lordship a Proof at Sta. Croix, Messrs. Jennings, Stevenson, and Donaldson I am told at St Eustatius, of this I have not yet but hope to have soon Proof positive." Questions legal position of Dutch, French, and Danish vessels loaded with American property bound to America. Antigua, Jan. 6, I778.

Id. Encloses proofs of hostile action by inhabitants of Martinique and the Dutch islands. Antigua, Jan. 3, I778. 
Id. Action of French frigates convoying American vessels. There is no proof of countenance given by the Spanish governor to American armed vessels, but he suspects the commandant at St. Thomas. St. Christopher, Mar. 10, I778. Encloses copy of commission from United Colonies, giving command of a certain vessel.

Id. St. Christopher, Mar. 21, I777. Encloses memorandum from Gov. Morris of St. Vincent on presence of French and American vessels

58. 1778 . in St. Pierre roadstead. Feb. 24, I778.

Draft from Germain to Burt, no. I6. Is gratified that correspondence between Dutch and rebels is checked, and that Gov. De Graaff has been recalled: France is "no longer to be considered a neutral Power". Commends insistence that importation of necessaries shall be in British vessels, but "no human Law can be supposed of too sacred a nature to be dispensed with when a Famine must be the inevitable Consequence of inforcing the Observance of it". Aug. 5, I 778 .

Letter from Burt, no. I. Describes state of "consternation" at Martinique and Guadeloupe at news of approaching war: many Americans have sold their cargoes for ready cash at 50 per cent. discount and have left the islands; "some have entered on Board of our Privateers thirsting for Revenge for the Oppression and Injury they have received in the French Islands". St. Christopher, June 9, I778.

$I d$., no. 2. "We had long .. . suspected . . . that Agents for the Rebellious Americans Resided at Sta. Croix and Publicly received Consignments which they either sold at Sta. Croix or Covered as their Property and Remitted to Europe: Mr. Tennent Refusing to Claim the American Produce but immediately Relinquishing it, is a Proof that it does not belong to His Danish Majesty's Subjects." Questions propriety of capture of vessels stated to be Danish, coming immediately from America loaded with tobacco, rice, flour, and staves. St. Christopher, June I4, I778. Encloses copy of proceedings in court of admiralty, St. Christopher.

$I d$., no. 5. Since news was received of the recognition of the independence of America by France, the Dutch admiral at St. Eustatius, Count de Bylandt, has permitted American colors to fly publicly in the roadstead of St. Eustatius. The admiral has been told that no water can be taken by his squadron from the river at Old Road so long as this continues. "They have . . . at St. Eustatius . . . a kind of Congress as it is so called: it consists of Monsieur Tenier, where Count Byland constantly Resides, Mr. Stevenson, Donaldson, Smith, Jennings, Gordon and James." St. Christopher, June I7, I778.

Id. The Dutch "have already began the Trade of convoying, and in each convoy are more Americans than Dutch". They are making large profits which "must be plundered from deluded America". St. Christopher, June I7, I778.

Id., no. 7. Encloses correspondence with Dutch officials. St. Christopher, July 6,1778 .

$I d$., no. 9. Provides further proof of position of Messrs. Tennent and Ross at St. Croix as agents for the American produce shipped by them. St. Christopher, July 29, I778. 
59. $1778-1779$.

Letter from Burt, no. 21. Daily complaints from Dutch of capture of vessels. "If . . . our Cruizers were not to touch anything with a Dutch clearance or Papers there would not be found a French or American Vessel at Sea. . . . The Dutch claim a Right to insist that a Friends Bottom Protects and covers an Enemy's Goods : this your Lordship knows was denied His Majesty of Prussia after the Peace of r748." Encloses a deposition proving that "one of Count Byland's Squadron" convoyed North American traders. Nov. 2, 1778.

Id. Nov. 25, 1778. (See Andrews, I. 208.)

$I d$., no. $3^{6}$. Refers to "Constant . . intercourse held between the American and Gallo-American factions" in St. Eustatius and St. Christopher. May 3, r779.

60. $1779-1780$.

Letter from Burt, no. 59. Action taken in appointing "a proper Person" to attend sick "Rebellious Americans ... taken in Armed Vessels" and confined according to his Majesty's commands. Captains of British ships loath to take American prisoners on board, only very few masters of merchantmen will carry them home; they have therefore to be confined. He has refused all proposals from Mr. Bingham, Congress agent at Martinique, for a "Cartel"; and has disregarded Mr. Bingham's citation of exchanges of persons with Adm. Byron and Gen. Grant. Nov. 8, I779.

Id., no. 73. Mar. 18, I780. Encloses deposition of J. J. Reynolds, asserting formation of a committee at Belfast "determined in case Belfast should be attacked they would declare on the side of America in case a Charter was granted to make Belfast a free Port. That in the latter end of April or the middle of May they purposed to send out a number of Vessels to America to supply the rebels with every Article they could. . . . That Letters were sent from Virginia by the Council to M. Burch of Antigua to go by the way of St. Christopher inclosed to Doctor Clifton who holds a private correspondence with the Rebels in America. That Doctor Buncauf [Bancroft] formerly Secretary to Mr. Dean is now placed as a private spy in London to communicate all matters to the French ministry and American Congress. . . . That the Bermudians had sent an Address to Congress setting forth that if Congress would send them One Thousand Men they would declare for America". Names of signers follow.

$I d$., no. 75. American prisoners in his government will be immediately exchanged as directed. Nearly forty had been taken on board British ships by Adm. Parker; American prisoners taken not in arms have been already set at liberty. Antigua, Mar. 28, r780.

Id. Mar. 30, I780. (See Andrews, I. 208.)

Id., no. 95. Acknowledgment of American vessels by Dutch. Oct. 25, I780. (See ibid.)

$I d$., no. 96. Discord between French and Spanish prisoners. Spanish more favourable to British. Nov. I, I780.

Id., no. IOI. "Private." News through a Dutch frigate at St. Eustatius of conclusion of treaty of commerce between Holland, Denmark, Sweden, and "North America". Jan. r6, r78r.

Letter from Pres. Johnston, May I3, r78r. (See Andrews, ubi supra.) 
61. $1780-178 \mathrm{r}$.

Letter from Gov. Shirley, no. 3. Reports alleged traffic in salt between America and British islands. Antigua, Aug. 30, I78r.

62. I78I-I782.

Letter from Shirley. Capture of St. Christopher and Nevis by French. St. Christopher, Feb. I5, I782.

63. I782-I784.

Letter from Shirley, no. 47. Trade with the U. S. Antigua, Nov. I7, 1783. Encloses table of imports from America, Oct. 6, Nov. I2, I783.

Id., no. 59. May, I784. Encloses naval office returns: Antigua, Oct. I, I783-Mar. 3I, I784; Montserrat, Jan. 5-Mar. 31, I784; Nevis, Jan. 5-Mar. 3I, I784.

$I d$., no. 8I. Commercial intercourse with U. S. "Notwithstanding every precaution . . . a great deal of American produce is introduced into these Islands, by methods which are contrived to evade the restrictions of the late order in Council." July 30, 1784 .

$I d .$, no. 86. Asks for directions as to treatment of men coming from the U. S. and offering to take oaths of allegiance. "I shall also be glad if your Lordship will inform me in what light the 13 united States are held, whether altogether as foreigners." Sept. 2 I, I784.

64. I784-1786.

Letter from Shirley, no. 95. Information that American commodities are imported through St. Eustatius but at an advanced price. Asks approval of action taken with respect to an American vessel which requested leave to enter the harbor to repair damages. Antigua, Jan., i785.

Id. No. I47. Encloses copy of proceedings of vice-admiralty court on three American vessels cut out of Basseterre Road in May, I782. Sept. 10, 1786.

Draft to Capt. Horatio Nelson relating to prosecution commenced against him by some masters of American vessels. Whitehall, Aug. 4, I785.

Letter from William Hutchinson to Nepean. Case of brigantine Haward, involving question of American alienage. Portman Square, Feb. 7 , I786.

Letter from Horatio Nelson to Lord Sydney, regarding trials: "nearly the whole Trade between the British Colonies and the United States of America, was carried on in American Bottoms." Nevis, Nov. I7, I 785 .

Id. Stratagem by which an American obtained a register, and carried on trade with the islands. Nevis, Feb. 4, I786.

65. I786-I 788 .

Naval office returns, Antigua, July I-Sept. 30, I 786.

Letter from Shirley. Encloses remarks of solicitor general on annual law passed for enabling his Majesty to make regulations for carrying on trade with the U. S. Antigua, Dec. 5, i786.

Id., no. I64. Encloses tariff established by Sweden in St. Bartholomew: provides for payment of three per cent. import duty on all European goods coming from American or any of the W. I. islands; all American or W. I. produce coming from the continent or the islands free from duty; all European goods exported to America in Swedish or American vessels free from export duty. Nevis, Apr. 20, I787. 
Id., no. I69. Acknowledges receipt of act and order in Council on American intercourse. The effects of the act will be to "draw to us a considerable portion of the carrying trade". The U. S. are not likely to retaliate; "it is impossible for the bulk of the people to exist without Commerce. It is also notorious that there are more different opinions upon almost every subject, amongst the United States, than there are States". Indulgence of thirty days granted before act is enforced in order to obtain supplies. Nevis, June 7,1787 .

$I d$., no. I72. Reports extension of indulgence until Oct. I. Antigua, July 24, I 787 .

66. $1786-1789$.

Minutes of council, Antigua. June 5, I786-Dec. 21, I787.

“" " Montserrat. Jan. 27-Dec. 24, I787.

“" “ $"$ St. Christopher. Jan. 12-June 30, I787.

" " " Nevis. Jan. I2-June 24, I786.

Letters from Lieut.-Gov. Nugent, nos. 3I, 43. Encloses sentences of court of admiralty on vessels captured by Lord Rodney. St. Christopher, June 29, I789; Antigua, June 3, I789.

Id., no. 46. Opening of ports of Nevis and St. Christopher. Merchants of Antigua carry on direct trade with N. Am., to their great benefit. Antigua, July I 3, I789.

68. 1789 .

Minutes of council, Antigua. June 4, I788-Mar. 26, I 789.
"“ St. Christopher. July I-Dec. 31, I788.

Letter from Shirley, no. 8. Discretionary power vested in governor and council under act for encouragement of shipping and navigation. It will scarcely ever be necessary to take advantage of this power by opening the ports; Antigua and St. Christopher have sufficient number of small vessels to trade to America, and they can supply the smaller islands. Antigua, Dec. 8, I789.

69. I790.

Journal of assembly, Antigua. Mar. 23-Sept. Io, 1789.

Letter from Shirley, no. 26. Apr. I4, I790. Encloses letter from J. Burke, solicitor general to the Leeward Islands, on case of vessel belonging to John Leak of Newhaven but purporting to belong to John Bristow of Jamaica. Antigua, Apr. I4, I790.

Id., no. 33. Acknowledges receipt of act on trade with America. Antigua, June 8, I790.

Minutes of council, St. Christopher. Dec. 4, I789-May 24, I790.

70. 1790 . Antigua. Apr. 22, I789-Apr. 22, I790.

Minutes of council, Antigua. Apr. 29-Aug. 23, I790.

Journal of assembly, Antigua. Apr. 8-Aug. 23, I790.

71. I790-I79I:

Minutes of council, Montserrat. Feb. 20-June 29, I790.

St. Christopher. June 30-Dec. 3I, I790.

Journal of assembly, Antigua. Sept. 28, I790-Mar. Io, I791.

Minutes of council, Antigua. Sept. 23, I790-Mar. 3I, I79I.

Journal of assembly, Antigua. Feb. 24-July 21, I79I.

72. I792.

Journal of assembly, Nevis. Oct. 22, I79I-Apr. I4, I792.

Minutes of council, Antigua. Sept. I, I79I-Aug. I6, I792.

Montserrat. July I, I79I-June 29, I792. 
Journal of assembly, Antigua. Sept. I, I79I-Sept. I 3, I792.

74. I793.

Minutes of council, St. Christopher. Nov. I4, I79I-Nov. I4, I792.

Letter from Pres. Stanley, no. 2. Report received that National Convention of France had declared the French islands open to American commerce, the same duties only as those imposed on French traders being charged. St. Christopher, June 27, I793.

$I d$., no. 3 , confirming previous letter and enclosing actual text of decree issued in Guadeloupe on American trade. July 27, I793.

Minutes of council, Antigua. Mar. 2I-Aug. I, I 793 .

“ " " Montserrat. Oct. 26, I792-Oct. I, I793.

Journal of assembly, Montserrat. Jan. I-Oct. I, I793.

75. I793-I794.

Letter from Stanley, no. I8. Admission of neutral vessels, carrying lumber and provisions, until further orders. Antigua, Jan. II, I794. Journal of assembly, Montserrat. Oct. I-Dec. 3I, I793.

Letter from Stanley, no. 3I. Continuance of admission of American bottoms. St. Christopher, June 23, I794.

Minutes of council, Antigua. Oct. 4-Nov. 8, I794.

76. I794-I795.

Minutes of council, Antigua. Mar. 20-Sept. 25, I794.

77. I795.

Journal of assembly, Antigua. Oct. 3, I793-Mar. 20, I794.

Minutes of council, Antigua. Mar. 16-28, I795.

78. I $796-1798$.

Journal of the General Council of the Leeward Islands, Mar. I-Apr. 23, I798.

Journal of the General Assembly of the Leeward Islands, Mar. I-Apr. 23 , 1798 .

79. $\mathrm{I} 798-1800$.

Letter from Pres. Thompson, no. 34. Owing to scarcity in the islands he has permitted Americans "to Barter for Muscovado sugar, in the proportion of one Third Part of the Value of their Inward Cargoes of Provisions and Lumber, for the space of Six Months". St. Christopher, Apr. I0, I799.

$I d$., no. 44. Urges permanent settlement of commercial relations with U. S. Permission reported in despatch no. 34 revoked in accordance with despatch no. I9 of July I, I799. Sept. 5, I799.

$I d$., no. 66. Capture of mulatto chief Rigaud by American cruiser and with him a trunk of papers; Mr. Liston asked to obtain copies of

81. I801. the papers. Oct. 29, I800.

Minutes of council, Antigua. Feb. I4-Sept. I, I80I.

"“" " Montserrat. Feb. I4-Sept. I, I801.

82. 1802. Nevis. Feb. I4-18, I80I.

Minutes of council, Nevis. Feb. I9, I80I-Feb. I8, I802. St. Christopher. Feb. I4-Sept. I, I80I.

Journal of assembly, Antigua. Feb. I4-Sept. I, I80 I.

" " " " Montserrat. Feb. I4-Sept. I, I8or.

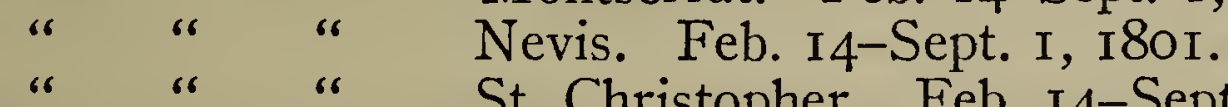

" " " St. Christopher. Feb. I4-Sept. I, I80I.

Minutes of council, Antigua. Sept. IO, I80I-Feb. 25, I802.

“" " Montserrat. Sept. I, I80I-Mar. I, I802. 
84. $\mathrm{I} 8 \mathrm{O} 2$.

Minutes of council, St. Christopher. Sept. I, I80I-Mar. I, I802. " " "Virgin Islands. Mar. I I, I80 I-Feb. 26, I802.

Journal of assembly, Antigua. Sept. I, I80I-Mar. I, I802.

" " " Montserrat. Sept. I, I80I-Mar. I, I802.

" " " $\quad$ St. Christopher. Sept. I, I80 I-Mar. I, I802.

" " "Virgin Islands. Sept. I, I80I-Mar. I, I802.

Letter from P. Colquhoun. Free ports in Tortola: the indulgence of granting free port to Tortola far less than that laid down in treaty of commerce rejected by America. Proposes that American vessels trading to Tortola should be required not to have more than one deck nor to exceed in burden 70 tons. James St., Westminster, Apr. 9, 1802.

Letter from Stephen Cottrell to John Sullivan, transmitting order in Council (for transmission to governor of Virgin Islands) of Aug. I6, opening trade to and from Road Harbor in Tortola. Council Office, Whitehall, Aug. I7, I802.

85. $\mathrm{I} 8 \mathrm{O} 3$.

Letter from P. Colquhoun to John Sullivan, enclosing memorial on renewal of Free Port Act, proposing that Tortola should be put on same footing as St. Thomas. James St., Westminster, June I7, I803.

86. 1804 .

Letter from Gov. Lavington, no. 5. Encloses proclamation relative to prohibition of trade, required in Camden's circular letter of Sept. 5 . Antigua, Dec. I4, I804.

Letter from Stephen Cottrell to William Sturges Brown, on illicit commerce in W.I. Reference to commercial laws shows that "no ships belonging to the United States" can trade with British islands, except for the purpose of carrying salt from Turks Islands under 28 Geo. III., c. 6, and from Exuma, Caicos, and Crooked Island by 44 Geo. III., c. IOI, or unless licensed so to do by the governors from time to time for special and limited purposes. Whitehall, Dec. $18, \mathrm{I} 802$.

88. $\mathrm{I} 806$.

Letter from Lavington, no. 6. Admission of beef and pork for three months just before Christmas: from Nov. 29, I805, ports were closed for nearly I3 months. Antigua, Mar. I0, I806.

Id., no. 7. Mar. I2, I806. Encloses letter from James Robertson, referring to 400 barrels of flour landed from an American vessel and condemned to the crown. Tortola, Aug. 3, 1805.

Id., no. Io. Aug. 16, เ806. Encloses minute of council and assembly of St. Christopher on grant of bounties on Newfoundland and other British American salt fish and the imposition of duty on U. S. fish. July 9, I806. Also resolution of assembly of Montserrat, deprecating duty on U. S. fish; "as this Island is almost destitute of the Advantages of General Commerce, supplies from America of salted Provisions are an Object of the greatest Importance".

$I d$., no. I4. Encloses resolution of assembly of Nevis, deprecating duty on U. S. fish "until some other Means of Supply are established". Antigua, Oct. 2I, I806.

Id., no. I5. Immediate publication will be made of orders in Council of Sept. I7 and Oct. I permitting for a limited time importation of 
provisions (except beef, pork, and butter) in neutral vessels, and export of rum, molasses, etc. Antigua, Nov. 17, 1806.

Draft to Lavington, no. I I. Encloses order in Council of Nov. 26, I806, granting permission to William Tudor to import from the U.S. to Jamaica, Barbados, and Antigua, in U. S. vessels, three cargoes of 89. 1807 . ice and snow "as a matter of Experiment". Dec. 4, 1806.

Letter from Lavington, no. I8. Encloses tables giving for ports of St. John's (Antigua), Parham (Antigua), Montserrat, Nevis, and Sandy Point (St. Christopher) accounts of imports of provisions and lumber, I794-1805, from G. B. and Ireland in British vessels, from $\mathrm{Br}$. N. Am. in British vessels, from the U. S. in British vessels, and from the U. S. in American vessels; also similar accounts for exports. Antigua, Feb. 20, 1807.

Id., no. 22. Encloses tables as before for the port of Basseterre (St. Christopher). Antigua, Mar. 23, 1807.

Id., no. I. Encloses tables as before for port of Tortola (Virgin Islands). Antigua, June 19, I807.

90. 1807.

Letter from Pres. Woodley, no. II. St. Christopher, Dec. Io, I807. Encloses letter on privateers, stating that no American vessels had been captured en route for Dominique. Antigua, Dec. 8, 1807.

Minutes of council, Antigua. Aug. I I-Oct. 15, I807.

Journal of assembly, Antigua. Aug. 18-Oct. 15, 1807.

Minutes of council, St. Christopher. Mar. 6-Aug. 27, 1807.

An Almanack for the year 1807 . . . Antigua, giving at p. 29 under head "General List for I807", "Commercial Agent to the United

94. 1809 . States of America, Joseph Warner Rose".

Letter from Pres. Julius, no. 9, referring to revival in U. S. of non98. I8II. intercourse act. St. Christopher, Oct. 23, I809.

Letter from Gov. Elliot, no. 47. Tortola, July I, I8I I. Encloses letter from Antigua containing statement from custom-house at St. John's of returns of imports of dry and pickled fish from U. S. and from Br. N. A., July I7, I806-Jan. 5, I809.

$I d$., no. 64. Asks for discretionary power to be granted to governors to permit export of sugar in foreign bottoms. This the only practical medium of payment to Americans for provisions under present circumstances : they will not take bills. St. Christopher, Sept. I6, I8I I.

$I d$., no. 65. Reports "considerable duty" placed on U. S. fish imported in American bottoms by all Leeward Islands legislatures. Oct. I7, I8I I.

99. 1812.

Letter from Gov. Elliot, no. II4. Refers to U. S. embargo. Antigua, 100. 1812 . July $2 \mathrm{I}, \mathrm{I} 8 \mathrm{I} 2$.

Letter from Gov. Elliot, no. 2. Receipt of unofficial news of declaration of war by the U. S. Antigua, Aug. 5, I8I2.

$I d$., no. I4. Acknowledges receipt of order in Council of July $3 \mathrm{I}, \mathrm{I} 8 \mathrm{I} 2$, directing detention of U. S. vessels. St. Christopher, Nov. 19, I8I2.

Id., no. 21. Acknowledges receipt of order in Council of Oct. I3 directing grant of general reprisals against ships, goods, and citizens of 
the U. S. President of vice-admiralty court of Antigua is waiting for special directions addressed to him. St. Christopher, Dec. 30, I 812 .

101. 1813 .

Letter from Gov. Elliot, no. 32. Parole given to a number of American prisoners at St. Christopher; is still in ignorance as to how they ought to be disposed of. Antigua, Feb. 8, I813.

Id., no. 33. "Every facility is afforded to American Vessels to obtain Swedish Papers, for the purpose of navigating between the United States of America, and St. Bartholomew." Feb. Io, I8I3.

Id., no. 37. Mar. 3I, I8I3. Encloses letter on condemnation of American vessel Hiram. Mar. I4, I8I3.

Id., no. 44. Grant of licenses for importation of certain enumerated articles. "I at first granted some of them to persons belonging to the United States." Later granted only to British merchants resident in Leeward Islands. Apr. 28, I8I3.

$I d$., no. 45. Lays complaints against action of privateers and prize court; no vessel considered as Swedish if bought from Americans after

102. I8I3. commencement of war with the U. S. Apr. 30, I8I3.

Letter from Gov. Elliot, no. 52. Principle laid down by some lawyers of prize courts "that every British subject in time of War whether bearing a Commission or not, has a right to make Captures whenever he can". Antigua, June 9, I813.

$I d$., no. 63. Dissolution of assembly of Montserrat which had sat for thirty years. Difficulty in new election over a member born in the U. S. Aug. IO, I8I3.

103. $\mathrm{I} 8 \mathrm{I} 3$.

Letter from Gov. Elliot, no. 67. Acknowledges receipt of despatches of June $2 \mathrm{I}$ and July I 3 with instruction for release of American brig Jane and renunciation of British rights in American brig Hiram. Antigua, Sept. 24, I8I3.

104. I8I4.

Letter from Pres. Julius, no. I3, relative to American brig Hiram. St. Christopher, June 23, I8I4.

105. I8I5.

Letter from Gov. Rawlins. Encloses minutes of council of Antigua and of council and assembly of Nevis regarding threatened protraction of restriction of commerce with the U. S. after conclusion of peace. St. Christopher, Aug. 6, I8I5.

C. O. I53: II-21. Board of Trade: Entry-Books. i7io-I78I.

C. O. 326:42-44. Index to Board of Trade Original Correspondence and Entry-Books. I703-1759.

11. I7IO-I7I2.

Numerous letters and papers on Gov. Parke's death and difficulties in securing punishment of guilty persons. Orders in Council for punishment of persons concerned in death of Hamilton. Dec. 19, I7I I; Jan. IO, I7II $/ 2$.

Draft of instructions for Douglas. Apr. 6, I 7 I r.

Letter to Douglas on matters not covered in instructions: to see that assemblies be not allowed to affix signatures to acts after signatures 
of lieutenant governor or lieutenant general, as assembly of Antigua has tried to do; to inquire whether laws passed by governor, council, and assembly are invalid without signatures of governor and speaker; will "do well" to have agent appointed "to solicit the Dispatch of Business in the Respective Offices" for his government and get assembly to provide reasonable salary. Apr. ro, i7rr.

Papers on land grants and settlement.

Papers on sufferers at Nevis and St. Christopher.

Memorials and other papers on the Virgin Islands.

12. I7I2-I7I7.

Papers on losses of inhabitants of Nevis and St. Christopher, resettlement, and bounties offered for resettlement. Include forms of oaths and debentures, etc. In particular: three representations on settlement of French part of St. Christopher, May 5, I7I4; May 3, 4, I7I 5. Also papers on settlement by French Protestant refugees.

Papers on despatch of accused persons to England.

Draft of commission and instructions for Walter Hamilton as governor of Leeward Islands. Aug. 21, 17r3. "N.B. The Commission and Instructions never passed, and therefore are not entered."

Letter from Stanhope, requiring preparation of commission and instructions for Col. Codrington. Jan. 5, 17 14/5.

$I d$., requiring preparation of commission and instructions for Walter Hamilton, orders concerning Codrington having been withdrawn. Jan. $31,1714 / 5$.

Draft of commission for Walter Hamilton. Feb. 4, I7I4/5.

Correspondence on capitulation of Nevis. In particular, opinion of Sir Nathaniel Lloyd on right of French to retain hostages. Aug. 2, I7I 5 .

Draft of instructions for Hamilton, showing no important changes. Aug. $3 \mathrm{I}, \mathrm{I} 7 \mathrm{I} 5$.

Papers on the Virgin Islands.

Representation on Three Sisters, declaring her liable to seizure if visiting Antigua for trade, but not if driven in by weather. Sept. Io, I7r 5.

Letter from Stanhope, referring petition from William Popple for grant of plantation of "Pensez-y-bien", comprising 400 to 500 acres in French part of St. Christopher. Popple claims he could have made considerable fortune by acceptance of gratuities. But, in spite of size of his family, "he did so far prefer the Publick to his private Interest (at a time when he could not have the least Prospect of Reward) that he run the greatest risque of being turn'd out of his Place-which would have happen'd had the late Queen lived a few Days longer, for his place was actually offer'd to another". Lord Halifax "was so sensible of the Service he had done" that he bade petitioner ask something for his family and promised to use his interest. June $28, \mathrm{r} 7 \mathrm{r} 6$.

Papers on supply of military stores and application thereto of the $4 \frac{T}{2}$ per cent. duty.

Numerous papers on piracy.

13. I7I7-I721.

Memorial from Rowland Tryon and William Nivine on permission to governor to accept grants for house rent. Apr., i7I7. Letter to Addison on same. Apr. 16, I717. 
Letter from Addison, referring letter from Danish envoy on Danish claims to St. Thomas and adjacent islands. May II, I7I7. Representation on same. Aug. 9, I7I7.

Northey's opinion on acts of Antigua constituting courts of common pleas, error, and chancery. Dec. 12, I7 66.

Correspondence on disposal of lands in French part of St. Christopher.

Letter from Addison. Governor's house rent, measures against pirates, and seizure of vessel by Spaniards. Sept. 3, I717.

Representation on several acts of Antigua and St. Christopher, relating especially to courts. Oct. I6, I717.

Letter to Hamilton, objecting to special tax on land of absentees in St. Christopher. Oct. 24, I7I7.

Correspondence on capitulation of Nevis.

$I d$., on supplies of military stores and application of $4 \frac{T}{2}$ per cent. duty. Letter from Carkesse, with observations of Commissioners of Customs on act of Antigua concerning importation of foreign W. I. produce; also, on collection of $4 \frac{1}{2} 2$ per cent. duty. Dec. $24,1717$.

Northey's report on act of St. Christopher "for Settling the Estates and Titles of the Inhabitants of this Island to their possessions within the same". Feb. 24, I717/8.

Order in Council, for disallowance of act of Antigua for establishing court of king's bench. Jan. 30, I7I7/8.

Correspondence on pirates.

Northey's opinions on acts of Antigua to prevent increase of papists, to provide for building of new church, and to "quiet" titles. Jan. 3, I $717 / 8$.

Letter to Hamilton, showing Board's policy on settlement of St. Christopher, St. Croix, and other small islands, and policy involved in act of Antigua to prohibit importation of foreign sugars. Apr. 4, I7I8.

Representation on anti-papist act of Antigua. May 2, I7I8.

Letter to Hamilton, showing disposal made of acts of four Leeward Islands. June 24, I 718 .

West's opinion on act of Antigua, I716, to prohibit importation of foreign W. I. produce. May 7, I718. Representation on said act. July Io, I7 18.

$I d$., on act of Montserrat, 4 Anne, for "quieting possessions". July II, I 718 .

Letter to Hamilton, directing that he inquire what claims in early settlement Danes have to St. Thomas; "upon what account they were suffered to make such Settlement"; and whether foreign settlements in general, and Martinique and Guadeloupe in particular, are more favorable to sugar raising than British islands. Aug. 8, i7 8 .

Representation for disallowance of revenue act of Antigua, placing additional duty on wines. Held that, since payment to be made only on order of governor, member of council, and speaker of assembly, prerogative is infringed. Dec. 24, I 718.

Letter to Craggs, on memorial of Danish envoy for assistance to Danes in St. Thomas against Spaniards. Feb. 3, $1718 / 9$.

Letter to Hamilton, reproving him for failure to execute certain instructions; and ordering that communications to Board be sent directly and not through private hands. Apr. 24, I7 19.

$I d$., ordering him to send all possible information on capitulation of Nevis and detention of hostages at Martinique, for use of "commissaries" 
going to Paris to arrange outstanding questions arising from Treaty of Utrecht. Sept. 29, I7I9.

Draft of commission for John Hart as governor. Nov. 5, I72I.

14. I $72 \mathrm{I}-\mathrm{I} 729$.

Representation for repeal of two acts of Antigua, on qualifications of voters and assemblymen, and establishment of court of king's bench. Aug. IO, I72I.

Draft of instructions for Gov. Hart, so drawn as to conform with instructions to Belhaven. Aug. 25, I72I.

Representation, showing reasons for alterations in Hart's instructions, which are drawn to conform with Lawes's and Belhaven's instructions on suspension of councillors, use of suspending clause, relations of governor to commander of war vessels, preferment to ecclesiastical benefices, and judicial appeals to Privy Council. Sept. 8, I $72 \mathrm{i}$.

$I d$., for repeal of act of Antigua raising additional salary for governor by import duties; same affecting British trade and containing no suspending clause. Sept. 25, I722.

$I d$., for repeal of act of Montserrat granting salary to governor by impost on dry-goods and liquors. July Io, I 723 .

Papers on the Virgin Islands, and on disposal of lands in French part of St. Christopher.

Representation on number of acts passed in St. Christopher and Montserrat, I7I4-I723. Apr. 24, I724.

$I d$., on letter from Smith, secretary of Leeward Islands, on supplementary offices, such as clerk of courts, register in chancery, etc., which secretary should properly hold. May I9, I726.

Draft of additional instruction for Gov. Hart, defining conditions under which judicial appeals to Privy Council are to be allowed. July 28, I 726.

Draft of commission for Londonderry, addressed to Lords Justices. June 7,1727 .

$I d$., addressed to Newcastle. Jan. I, I727/8.

Draft of Londonderry's instructions, showing no important alterations. Apr. I2, I728.

15. I $729-\mathrm{I} 735$.

Letter to Londonderry, showing that many papers, including sessional papers as far back as 1722 , which should have been sent, have not been received. May I6, I729.

Id., on act of St. Christopher to enable inhabitants of former French part to send representatives to assembly. Objection to eligibility of denizens for election, to exclusion of royal officials, and to absence of suspending clause. May I7, I729.

Report on three acts passed in islands granting additional salary to the governor. Held that acts laying duties on produce of islands should not provide for collection at time of shipping, since this places taxes on masters of ships and makes them charges on merchants. Objection also to lack of suspending clause and other matters of form. Acts to be laid aside until Londonderry can secure more proper ones. June 20 , I 729 .

Several letters written to discover what title French had to St. Croix. I730. 
Letter to Mathew. Place which assembly should occupy in colonial legislature. In particular: right of assembly to address the governor for removal of member of council; procedure of assembly in securing attendance before it of member of council; and extent to which assembly may, on analogy of House of Commons, acquire powers by precedent and usage. Much emphasis laid on importance of maintaining, as closely as possible, analogy between three branches of legislature in colony and corresponding branches in England. Oct. 22, I730.

Draft of commission for Col. Cosby as governor of Leeward Islands. May I I, I73I.

Representation on act of Antigua, Oct., 1728, for constitution of court of chancery. May 27, I73I.

$I d$., on alteration in governor's commission to prescribe devolution of power in case of absence of governor and of lieutenant general from colony. June Io, I73I.

Representation, with draft of additional instructions to governor, on court of chancery in Antigua. Dec. I5, I73 I.

Report to committee of Council, on settling of estates and quieting of possessions. Jan. $2 \mathrm{I}, \mathrm{I} 732$.

Draft of commission for William Mathew as governor. Apr. 3, I733. Text not given, since identical with that prepared for Cosby.

Draft of instructions for Mathew, showing no important alterations. Apr. 25, I733.

"Letter to Lord Harrington with a Represtatn. upon the French Ambassador's Selling of the Island of Sta. Cruz to the Danes." June 27, I733.

Report to Committee of Council, with draft of additional instruction for Mathew on additional salary. July 3, I 733 .

Several representations on military supplies in colony.

Letter to Harrington, in answer to his letter of Sept. II, I734, on new settlement by Danes at St. Croix ; and on value of the island. Sept. I 2,1734 .

Letter to Mathew, on British titles to St. John and St. Croix, giving early history of latter, and directing that he secure additional information on British title. Sept. 26, I734.

Letter to Newcastle, with representation on "the Treaty of Neutrality lately concluded between the French Govr. of Martinique and the Dutch Govr. of St. Martins". Feb. 4, 1734/5.

Letters and representations on levying of gunpowder-duties in islands. Report of Committee of Council, reviewing history of St. Croix and setting forth British title. Apr. 22, I735.

16. I735-I747.

Papers on powder-duties and military stores.

Letter to Mathew. Instructions set by Admiralty to commander of ships on Leeward Islands station, that sloop should, when required, be placed at disposal of governor, for preventing clandestine trade and conveying him between islands. Question whether Anguilla, Tortola, and Spanish Town should constitute one government under governor of Leeward Islands, or three. Illegality of setting up any legislature without the king's permission. Aug. I3, I735.

Letter to Newcastle. Commercial relations of British and French in W. I. as affected by treaty of 1686 and French edict of 1727. 
Retaliatory law of Montserrat, and seizure of Fleuron and Fortune. Forwards representation on act of Montserrat to prevent illegal trade by French vessels. Dec. I7, I736.

$I d$., forwarding representation on complaints by Dutch envoy of seizures of Dutch vessels in W. I., showing unwarrantable nature of some seizures, and reviewing commercial conditions in the islands. Mar. $8, \mathrm{I} 736 / 7$.

$I d$., with representations on French proposals for preventing illicit trade in the W. I. Apr. 21, June 6, Dec. 3, 1747.

Representation, on petition against act of Antigua for lowering rate of interest. Aug. 3, I739.

Representation to Lords Justices on need for civil government in the Virgin Islands. June 25, I740.

Letter to Col. Fleming, lieutenant general of Leeward Islands and lieutenant governor of St. Christopher. Dispute between council and assembly of St. Christopher on raising supplies. "It appears evidently to us that they ought to conform themselves to the Methods and Forms of their Mother Country." Proceeds to explain powers of House of Commons in financial matters. Apr. 2, I742.

Representation to Committee of Council on petition of several planters of Antigua against acts imposing double taxes on absentees, and proposing additional instruction. June $27, \mathrm{I} 744$.

$I d$., on act of Antigua, June, I744; recommending that governor be forbidden to assent to acts laying special taxes on absentees which contain no suspending clauses. Dec. I4, I744.

$I d$, on two acts of St. Christopher, imposing double taxes on absentees and containing no suspending clause. Mar. 27, I745.

Letter to William Wood, in answer to his inquiry whether any court of exchequer was established in his Majesty's islands in America. Nov. I4, I744.

Representation for disallowance of act of St. Christopher, Sept., I745, permitting export of provisions with alleged object of encouraging importation of same. Mar. 26, I746. Id., for disallowance of similar act of Antigua, Apr., 1745. Dec. 3, I746. (For relation of these acts to disputes between islands and northern colonies see Mathew to Board of Trade, Apr. 15, 1746, in C. O. $152: 25$.)

17. I748-1754.

Representation to Lords Justices, on memorial and petition of Edward Jessup, suspended from council of St. Christopher by Gov. Mathew, as being Roman Catholic. July I2, I748.

$I d$., recommending disallowance of act of Antigua, Sept., I746, relating to papists. Aug. 25, 1748.

Letter to Mathew. Suspension of Benjamin King. Act of Nevis, I748, for establishing registry office: said act constitutes infringement on secretary's patent and is therefore improper. July 28, I749.

Letter to Fleming. Methods of appointment of judges and justices of the peace in the Leeward Islands; exercise by lieutenant governor in each island of powers of ordinary preferment to ecclesiastical benefices; act establishing registry office at Nevis. Said act to be re-passed with addition of suspending clause.

Representation, on "the powers of collating to benefices, granting licenses for marriages and probate of wills-commonly called the Office of Ordinary": in particular, as to whether said powers may be exercised 
under deputation from governor by other persons in islands where governor does not reside. Oct. 28, I750. Draft of additional instruction for Mathew on performance by deputies of his powers as ordinary. Jan. I4, I750/I.

Representation, on petition of council and assembly of Antigua on holding of court of chancery by commander-in-chief in absence of governor, lieutenant general, and lieutenant governor, Feb. I, I750/I. Draft of additional instruction on same. Feb. 27, I750/I.

Letter to Bedford, on theft of treasure from Nuestra Señora, driven ashore on coast of N. C. in great storm of Aug. I8, I750. Mar. I5, I $750 /$ I.

Letter to attorney general, transmitting act passed at Nevis, to repeal act to prevent papists and reputed papists from settling in island; and setting forth arguments for and against. June 25, I75I. Letter to Fleming, permitting him to assent to act. Jan. I 5, I752. Representation on act recommending its approval by the crown. July I8, I753.

Letter to Fleming. As regards "the Pretensions of the Assembly of Antigua to join with the Govr. and Council in the Disposal of Publick Money", it is not proper "in any degree to acquiesce therein". It has never been allowed in any colony under direct government of the crown. Aug. 6, I75I.

Letter to Purcell. Establishment of civil government in the Virgin Islands. Apr. 29, I752.

Draft of commission for George Thomas as governor of Leeward Islands. Jan. 3I, I753.

Draft of Thomas's instructions. Apr. I8, I753.

Representation on act of Montserrat, I748/9, to regulate assembly and election of members. Mar. I2, I753.

18. $1754-1760$.

Representation, on expediency of establishing civil government in the Virgin Islands, and containing much information on them. Mar. 20, I755.

Report to Committee of Council, on letters from Gov. Thomas, and from John Sharpe, agent for Antigua, on augmentation of regiment in Leeward Islands, with much information and comment on defensive system. May 30, I755. Representation on same, discussing proportional contributions of colony and home government to defense. Nov. I8, I756. Other papers.

Representation, on Codrington's grant of Barbuda. July 29, 1756.

Letter to Holdernesse, on sending of copy of commission for trying pirates to governor, for use in punishing those who attacked King of Spain's “Advice Boat". June 23, I757.

Representation, on question whether Guadeloupe should be subject to regulations laid down in navigation acts; and showing views of Board on enforcement of acts of trade, and judicial organization in colonies. Aug. 3I, I759.

19. I76I-I770.

Draft of commission for George Thomas as governor. Apr. I, I76I.

Draft of Thomas's instructions, showing no important changes. May 19, I76I.

Letter to Thomas, directing that Spanish vessels "coming into any of the Ports within your Government through distress or for refresh- 
ment may receive the assistance they have usually been allowed in Jamaica". Feb. 15, 1765.

Draft of commission for William Woodley as governor. Nov. 28, I766.

Draft of Woodley's instructions, showing no important changes. July 29, I767.

Representation, for approval of act of St. Christopher, for establishing court of chancery, and containing suspending clause. Oct. I4, I767.

20. $\mathrm{I} 77 \mathrm{I}-\mathrm{I} 78 \mathrm{r}$.

Draft of commission for Ralph L. Payne as governor. May ro, I77I.

Representations for disallowance of act of St. Christopher for regulating elections to assembly, and act of Montserrat "for attaching Monies, Goods, Chattels and Effects . . . belonging to persons absent therefrom". May 29, I771.

$I d$., on petition of Samuel Crooke, member of council of St. Christopher, for establishment of proper court of errors. May 31, I 77 I.

$I d$., on resolution of assembly of St. Christopher on right of members of council to vote in elections of assemblymen. June 6, I77 I.

Draft of instructions for Gov. Payne. Changes: specific prohibition of governor's assent to bills establishing regulations relating to assemblies, or to bills establishing lotteries, where permission has not previously been given. June 6,177 r.

Representation, embodying draft of additional instructions, on contention of assembly of St. Christopher that members of council may not vote in elections of assemblymen. Since assembly has "unwarrantably assumed a Power analogous and coequal to that of the House of Commons", the governor to keep it "more within the legal Bounds of a Provincial Council”. May 21, I772.

$I d$., for disallowance of act of Montserrat to regulate assize and price of bread and other provisions. Dec. 5, I775.

Draft of commission for William Mathew Burt as governor. Sept. I3, 1776 :

Draft of instructions for Burt. Dec. Io, 1776.

Draft of commission for Thomas Shirley as governor. Mar. 23, I78I.

21. I781. Instructions for Gov. Shirley.

C. O. 326: 42-44. I703-I729, I729-1743, I744-I759. Index to Board of Trade Original Correspondence, and to letters and representations issued by Board which are contained in Entry-Books.

C. O. I53:22-34. Secretary of State: Entry-Books. i766-i8i6.

22. $1766-1774$.

Entry-book of letters from Verchild, Woodley, Payne, and Losack. Also one from Vice-Adm. Parry. Earlier letters from Verchild given in abstract, with abstracts of replies sent. June-July, 1767. In rare instances enclosures of especial importance included. Collection complete or nearly so.

23-25. I774-1782.

Continuation of vol. 22.

26. 1789-1791. Précis of Correspondence.

Letter to Gov. Shirley, transmitting act to regulate trade with America, etc. Apr. 9, I790.

27-30. I79I-I796. Précis of Correspondence.

31. I795-I805. Out-Letters. Military. 
32-34. I768-1816.

Entry-books of despatches from Secretaries of State to governors. Orders in Council sent to governors also included. Commissions of Govs. Payne and Burt and of other persons.

1. $1644-1673$.

$$
\text { C. O. I 54: I-5. AcTs. }
$$

2. $1668-1682$.

3. Acts of Assembly Passed in the Charibbee Leeward Islands, from I69o, to 1730 (London, Printed by Order of the Lords Commissioners of Trade and Plantations, by John Baskett, Printer to the King's most Excellent Majesty, I734, Pp. Xv, 23I). Between pp. 24 and 25 is a "Table [really alphabetical index] of the General Acts of the Leeward Islands", four pages not numbered; after p. 23I is another

4. $1680-1692$. "Table" (or index), $7^{1 / 2}$ sheets.

5. $1680-1703$.

\section{O. I $54: 5,155:$ I-8. Sessional Papers. ${ }^{6}$}

C. O. I 54:5. Nevis. Several manuscript acts with table marked: "The Laws of Nevis transmitted with Col. Johnson's letter of the 26th May I705", ff. I-I04. I704, Dec. 7. I704/5, Jan. 25.

Nevis. Minutes of council, ff. I05-106. bly, f. 107.

I704/5, Feb. I9-Mar. I7.

I704/5, Mar. IO, I7. bly, ff. II 2 -I I 3 .

I704, Mar. 25-I704/5, Mar. 17. “ Minutes of council and assembly. ("Taken out of the Assembly Booke"; also state of forces, table of forts and stores.) Ff. II 5-I43.

(The above is a continuous record. $C f$. corresponding items in $155: 3$.) C. O. I 55:1. I680, July I2. Nevis. Proceedings of a court of admiralty, ff. I-22.

I683, Oct. 8-I683/4, Feb. I4. Nevis. Proceedings of assembly, ff. 25-33. Nevis. Letter from the clerk of the assembly to Lords of Trade. Feb. 20, 1684, f. 38 .

1685, Apr. I7-1686, Nov. 16. St. Christopher. Proceedings of council and assembly (the first day's minutes are those of a council of war), ff. 39-63.

1685, Mar. 30-1686, Apr. Io. Nevis. "Orders of Council made by Sir Wm. Stapleton and the gentlemen of the Council I685-I686." (The meetings are in Mar. and Apr., I685, and Jan., Mar., and Apr., I686. With minutes of Apr. Io are a petition of merchants, Apr. 5, an answer from the Commissioners of Customs, Apr. 6, and a petition of Joseph Crisp, Apr. Io.) Ff. $59[$ sic $]-78$.

1685, Sept. 15-1687, Apr. 26. Antigua. Proceedings of council and assembly, ff. 79-120.

1686, Sept. Io-I687, June II. Nevis. Proceedings of assembly, ff. I2II 30 .

- See also sessional papers of Antigua, Montserrat, Nevis, St. Kitts, and St. Vincent; also C. O. $152: 43$. 
I686/7, Jan. 6-1687, May 7. Nevis. Minutes, endorsed: “Orders of Council", ff. I 3 I-I 46 .

I687, May 17-1688, Nov. 28. Nevis. Minutes endorsed: "Orders of Council", ff. I47-2I2.

I687, Aug. 6-1688, Nov. 20. Nevis. Proceedings of assembly (with letter from clerk of assembly to Lords of Trade, Dec. 3, I688), ff. 2 I $3-234$.

I693, July 28-Sept. 8. Antigua. Proceedings of council and assembly, ff. $235^{-268}$.

I692/3, Mar. I7-1695, Nov. 15. Nevis. Minutes of council, ff. 27I-307. I692/3, Mar. 2-I695, Nov. 5. Montserrat. Minutes of council, ff. 3 I I334.

2. "Council in Assembly."

I692, Nov. I-1695, Dec. 19. Antigua. Minutes of council and assembly, ff. I-I6o.

I695/6, Feb. I I-1696, Oct. I. Antigua. Minutes of council and assembly, ff. I6I-186.

I697, June 29-Dec. 28. Antigua. Minutes of council and assembly, ff. $187-234$.

I697/8, Jan. 20-1699, Dec. I5. Antigua. Minutes of council and assembly (endorsed: "General Assembly of Antigua"), ff. 235-342.

I695/6, Feb. I2-I696, July II. Nevis. Proceedings of council and assembly, ff. $343-360$.

I696, July II-I697/8, Jan. I5. Nevis. Proceedings of council and assembly (the first page is headed: "Minutes of Assembly"), ff. $36 \mathrm{r}-449$.

I697, Dec. 29-1699, Dec. I2. Nevis. Minutes of council, ff. 453-5I4.

1695, Dec. 24-1696, Aug. 28. Montserrat. Minutes of council and assembly, ff. 51 5-522.

1697, Apr. 26-1697/8, Feb. I. Montserrat. Minutes of council (endorsed: "in Assembly"), ff. 523-530.

1698, Apr. 5-1699, Dec. 20. Montserrat. Minutes of council (endorsed: "in Assembly"), ff. 533-546.

3. I705, May 23-June 25. Leeward Islands. Minutes of the general council in assembly of all the Leeward Islands, met at Nevis, pp. 54 .

1704, Dec. 7-1705, Aug. I8. Nevis. Minutes of council in assembly (sometimes the headings are: "At a Council"), pp. 22.

I704/5, Jan. 25-1705, Aug. 18. Nevis. Minutes of council in (or and) assembly, pp. I7.

I705, May 23-June 25. Leeward Islands. Minutes of the general assembly of the islands of Nevis, Antigua, Montserrat (those of St. Christopher not being come), pp. 55 .

I709/10, Mar. 23-1710, Apr. I4. Leeward Islands. Minutes of the general council of all the Leeward Islands, held at St. Christopher, pp. 54.

I707, Dec. I I-I708, June 2I. Nevis. Minutes of council (endorsed: "in Assembly"), pp. 67.

I706, Aug. 9-1707, June II. Nevis. Minutes of council in assembly, "No. I", pp. 93.

r707, June II-Dec. 3. Nevis. Minutes of council (endorsed: "in Assembly"), "No. 2", pp. 8 o. 
I704, Aug. 23-Oct. 24. Nevis. Minutes of council. (This is the governor's council.)

4. I7 Io, Dec. I5-I7 I I, Aug. I. St. Christopher. Minutes of council, pp. 49. I7 I I, Aug. 3I-I7I2, Sept. 8. St. Christopher. Minutes, endorsed: "of Council and of Council in Assembly", pp. 56 .

I712, Aug. I-I712/3, Feb. 5. St. Christopher. Minutes of council (endorsed: "in Assembly"), pp. I6.

I7I2/3, Feb. I9-I7I3, Apr. 22. St. Christopher. Minutes of council (endorsed: "in Assembly"), pp. 24.

I 7 I , Mar. 27-Dec. 29. Montserrat. Minutes of council, pp. 39.

I7I2, July 29-I7I2/3, Jan. 22. Montserrat. Minutes of council (endorsed: "in Assembly"), pp. 8.

I7I2/3, Feb. I7-I7I3, Oct. 22. Montserrat. Minutes of council (certified to Oct. 23), pp. 40.

I7 I0/I, Mar. I-I7 I I, Nov. 30. Nevis. Minutes of council, pp. 88.

I7 12, June 26-I7I3, Oct. 26. Nevis. " " "

I7I3, Dec. IO-I7I5, Apr. 20. Nevis. Minutes of council and assembly (endorsed: "Minutes of the Assembly"), pp. 52 .

I7I3, Dec. IO-I7I5, Apr. 20. Nevis. Minutes of council, pp. 67.

5. I7I5, June 30-Sept. I9. Nevis. Minutes, endorsed: "of Council and Council in Assembly", A, pp. 9.

I7 I5, Sept. I9-I7 18, Dec. I8. Nevis. Minutes of council, B, pp. 88.

I7 15, Sept. I9-17I7/8, Mar. I2. Nevis. Minutes of council and assembly (endorsed: "in Assembly"), C, pp. 70.

I7I8, May 27-Dec. I8. Nevis. Minutes of council and assembly (endorsed: "in Assembly"), D, pp. 24.

I7 18, Dec. 30-I7 I9, June I . Nevis. Minutes of council, E, pp. I3.

I718, Dec. 30-1718/9, Mar. 23. Nevis. Minutes of council and assembly (endorsed: "in Assembly"), F, pp. I3.

I7I5, Sept. I-I9. Nevis. Minutes, each day headed, "Council and Assembly", the whole endorsed: "Minutes of Assembly", $\mathrm{G}, \mathrm{pp}$. Io.

I7 19, Apr. 23-Aug. 27. Nevis. Minutes, headed, "Council and Assembly" (apparently of assembly), H,pp. 5 .

I7I9, Aug. 27-Nov. 27. Nevis. Minutes, headed "Council and Assembly" (seems to be assembly; Aug. 27 is a repetition), I, pp. 6.

I7 I8/9, Jan. 6-Mar. 24.

A, pp. 26.

I7I9, Apr. 7-June I8.

B, pp. I2.

I7I9, July 23-Sept. Io.

C, pp. Io.

I7I9, Oct. 6-Nov. I2.

D, Pp. II.

I7 I3, Mar. 26-I7 I 5, Aug. 5.

a, pp. 92.

I7 5, Aug. I6-I7I6, Nov. 27.

b, pp. 77 .

I7I6, Nov. 28-I7I8, Dec. 23.

c, pp. 100 .

I7I2/3, Mar. 23-I7I8/9, Jan. I3. Montserrat. Minutes of council, pP. II8.

St. Christopher. Minutes of council,

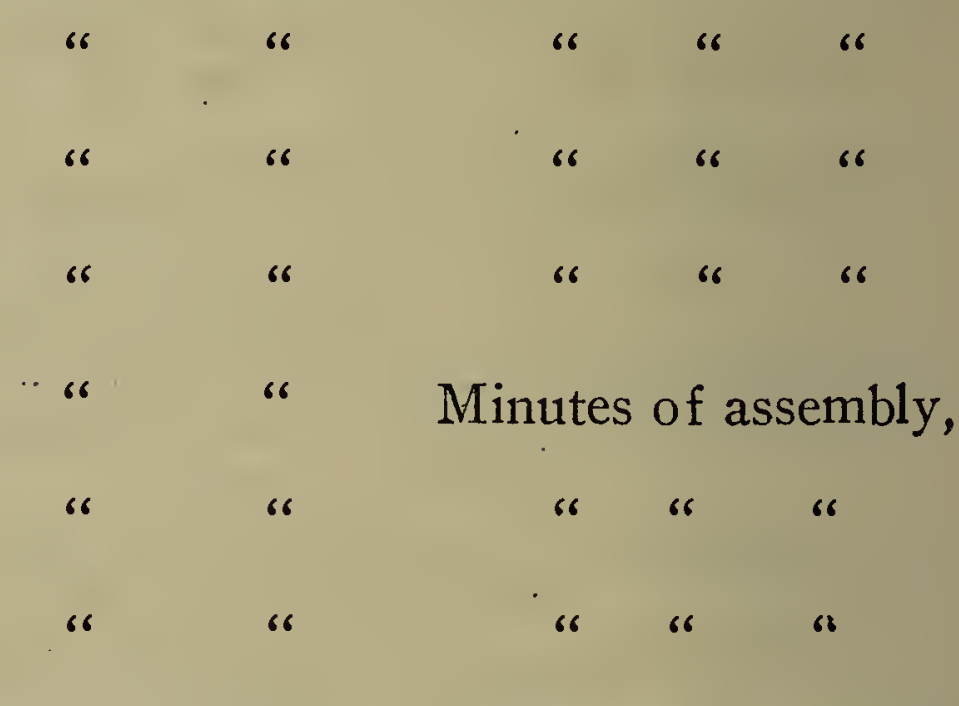


I7 18/9, Jan. I3-Sept. 23. Montserrat. Minutes of council (Jan. I3 a repetition), C 26 , pp. I 3 .

I719, Sept. 26-1719/20, Mar. I9. Montserrat. Minutes of council, D, pp. I 5 .

I7I3, Apr. 27-I719, Apr. I I. Montserrat. Minutes of assembly, E 24, pp. I04.

I7I9, Aug. 4-I720, June 2. Montserrat. “ “ “ F 25, pp. I4.

6. I724/5, Feb. I8-I725, Oct. 2. Antigua. Minutes of council and assembly (endorsed: "Council in Assembly"), A, pp. I28.

I724/5, Feb. I8-I725, Oct. 2. Antigua. Minutes of assembly (no title), B, pp. $2-74$.

I726, Apr. 27-Oct. 4.

Antigua. $\approx$ “ “ C, pp. 5I.

I721/2, Mar. 8-I723, Sept. 27. Nevis. Minutes of council (endorsed: "in Assembly"), D, pp. 70.

I723, Aug. 13-Nov. 7. Nevis. Minutes of council (endorsed: "in Assembly". Aug. I3-Sept. 27 a repetition), E, pp. 2 I.

I721/2, Mar. 22-I722, June I6. St. Christopher. Minutes of council, F, pp. 69.

I722, June 22-1722/3, Jan. I6. pp. 68.

I722/3, Feb. I2-I723/4, Jan. 21 . pp. $69-148$.

I723/4, Jan. 28-1724, Aug. I9. pp. 87.

I724, Sept. IO-Dec. I9.

G, pp. 2 I.

I 724/5, Feb. 23-I725, Oct. I4.

$\mathrm{H}, \mathrm{pp} .26$.

I725, Oct. I4-I725/6, Mar. 5 .

I, pp. 34 .

I721/2, Mar. 2-I723/4, Mar. 4. Montserrat. Minutes of council (endorsed: "Council in Assembly"), K, pp. 98.

I723/4, Feb.[26]-Mar. 4. Montserrat (duplicate of pp. 84-98 of the foregoing), L, pp. I5.

I724, Apr. IO-Sept. 7. Montserrat. Minutes of council, M, pp. I3.

7. I728, Mar. 25-Dec. 3I. St. Christopher. Minutes of council, A, pp. 25 .

I728/9, Jan. I-I 729 , June 23 .

B, pp. 45 .

I729, July 7-Sept. 4 .

C, pp. 23 .

I727, Dec. I3, I9.

$D, 23-28$.

I727/8, Feb. I3-1728, Dec. I6.

E, pp. 26.

I724, Nov. IO-I726/7, Feb. I8. Montserrat. Minutes of council (the title-page says, "ending 3 March"), pp. 45.

r727, Sept. 26-I727/8, Jan. 2. Montserrat. Minutes of council, pp. 9. I727/8, Jan. I6-Feb. 26. I728, Aug. 29-Dec. 23.

title-page says, "I9 Aug. to. 3I Dec."), pp. r2.

pp. 6 . 
I728/9, Feb. 5-I729, June 28. Montserrat. Minutes of council (the title-page says, "I Jan. to 30 June"), pp. 37.

I729, Aug. 26-Dec. 22. Montserrat. Minutes of council (the title-page says, "I July to 3 I Dec."), pp. I9.

I729/3O, Jan. 24-I73O, June 2. Montserrat. Minutes of council, pp. 4. I727, Sept. 27-1728, Dec. 23. Montserrat. Minutes (headed, "Council and Assembly", sometimes "Assembly" alone; title-page and endorsement, "Minutes of Assembly"), pp. I6.

1728/9, Feb. 5-1729, June 28. Montserrat. Minutes (headed, "Council and Assembly", endorsed, "Minutes of Assembly"; title-page reads, "I Jan. to 30 June"), pp. 24.

8. 1749, Oct. I7-I750, May 8. Nevis. Minutes of council, pp. 23.

I750, Dec. 20-1750/I, Mar. 21. Nevis. “" “" "

I757, Aug. 26-I758, July 19. St. Christopher. "Extracts from the Minutes of Council" (seems very like council in assembly), pp. 3I.

I77I, Dec. [part of 9]-I772, May Ir. St. Vincent. Journal of assembly. "No. 3." (Apparently a continuation. Marked in pencil: "Dup. of this in B. T. St. Vincent", now C. O. 26I:2). Pp. 53.

I775, Feb. 6-Dec. 22. St. Vincent. Minutes of council. (Endorsed: "in Assembly." Marked in pencil: "Dup. in B. T. St. Vincent 6", now C. O. $26 \mathrm{I}: \mathrm{I}$ ). Pp. 54 .

\section{MARTINIQUE.}

C. O. i66: I-2. Secretary of State: Original Correspondence.

1. $1693-1814$.

$$
\text { I693-1814. }
$$

In addition to papers listed by Andrews, I. 209:

Collection of despatches sent mainly by French Minister of Marine and Colonies and found in possession of aide-de-camp to captain-general of Martinique. I807.

Group of unsigned letters describing conditions in Martinique. I790.

Papers on purchase of provisions from American merchants and on attack on Martinique. I793.

"Translated copy of Proposal of the Deputies of the Islands of St. Lucia and St. Vincent to the Right Honble, the Earl of Cardigan." May 6 , i762.

Certificates and passports of various French persons in Martinique. I794-I795.

Legal papers on property rights. I80o.

Printed extract from registers of council of Martinique on manumission of slaves. I80o. Papers on condition of slaves and free blacks.

Extract of letter from Adm. Duckworth on negro uprising. I8or.

2. I7OI-I763.

See Andrews, I. 2 Io.

Despatches to Monckton, on attacks on Havana and other Spanish possessions. Feb., I762. Monckton's answers.

Copy of letter from Adm. Rodney on operations. Jan., I762.

Papers on operations against Martinique, including articles of capitulation of Fort Royal, Martinique, Feb. 4, I762. 
"An Exact Account of the Gross Sums paid out of the Treasury in Barbados from Taxes raised from the Inhabitants in compliance with an act of the Island for Assisting His Majesty's Forces." Dec. I4, I762.

Papers on taking over of Martinique, appointment of several officials, and settling of conflicts of law. Elaborate census table. Return of forces in Martinique.

C. O. i66: 3. Précis of Correspondence: Secretary of State.

3. I794-I798.

$$
\text { I794-1798. }
$$

Letter from Sir John Vaughan, referring to infesting of St. Kitts and Antigua by American privateers. Nov. 24, I794.

Letter from the governor, reporting extension of time for opening of ports. July 20, Dec. Io, I795; May 4, Nov. 7, I797; May 9, I798.

Id. Despatch of agent from the U. S. to claim American seamen pressed into the British service. Mar. 22, I797.

\section{MONTSERRAT. ${ }^{1}$}

C. O. I75: I. Secretary of State: Original Correspondence. I $726-1787$.

1. I726-1787. (See Andrews, I. 210.)

C. O. I76: I-8. Acts.

1. Acts of Assembly Passed in the Island of Montserrat, from 1668, to I740, inclusive (London, Printed, by Order of the Lords Commissioners of Trade and Plantations, by John Baskett, Printer to the King's most Excellent Majesty, I740, pp. I-146, an Abridgment occupying pp. I2I-I46). Bound up with this at end of book is: Acts of Assembly Passed in the Charibbee Leeward Islands, from 1690, to 1705 (London; same imprint as above, I740, pp. v, 24; table, or alphabetical index, $4 \mathrm{pp}$.). This text, pp. $\mathrm{I}-24$, and table are the same as indicated in C. O. $154: 3$, with exception of the headline of p. I, which here (Montserrat book) reads "The Laws of

2. I68I-I 735 . the Leeward Islands in general".

3. I694-I734.

4. $1735^{-1} 749$.

5. $1750-1760$.

6. $1761-1769$.

7. $1769-1775$.

8. $1777-1778$.

\section{O. I77: I-i6. Sessional Papers. ${ }^{2}$}

1. I704, Aug. I7-Oct. 6. Minutes of council (endorsed: "from I4 July to 26 October"), pp. 3.

I704, Nov. 14-1705, Aug. 27. Minutes of council, pp. 9.

I706, Aug. 5-1707, Dec. I3. “" " " (endorsed: "Council in Assembly"), pp. 16.

${ }^{1}$ See also Leeward Islands.

${ }^{2}$ For 1693-1699 and 1711-1724 see Leeward Islands. 
I706, Nov. 25-1707, Dec. I3. Minutes. (Headings read: "Council and Assembly." Endorsed: "Journal of the Assembly.") Pp. I3. I726/7, Mar. 4-I727, Aug. 28. Minutes of council (this and the next three are loose papers "from B. T. Antigua 6", C. O. I77: I), pp. 4.

I727, Sept. 27. Minutes of council and assembly, p. I.

I727, Sept. 27. Duplicate, p. I.

r727, Sept. 26-r727/8, Jan. 2. Minutes of council (C. O. I55:7), pp. IO.

$2 .^{3}$ I730, June 2-I73I/2, Jan. 22. Minutes of council, pp. 24.

I $73 \mathrm{I} / 2$, Feb. 5-I732/3, Jan. 3. " " " " " " "

r732/3, Jan. IO-I733, Dec. II. " “ “ “ "
I734, Mar. 28-I738, Sept. I3. tive quarterly portions), $300 \mathrm{pp}$. in all.

I729, June 28-I733, Oct. I3. Minutes of "Council and Assembly", pp. 4I. I733, Nov. 6-r734, Mar. 25. Minutes of council and assembly, pp. I8.

I734, Mar. 25, 28, Apr. 25. Minutes of council and assembly (Mar. 25 is a repetition; Apr. 25 is assembly without the council), pp. 6.

I734, Sept. 7-r738, Sept. I3. Minutes of assembly (in small consecutive portions); pp. 2 I 4 .

3. I738, Oct. I6-I742, Sept. Ir. Minutes of council (in consecutive quarterly portions, to Sept. 29, I742), pp. I78.

I738/9, Feb. 28-r740, Sept. I5. Minutes of assembly (likewise in consecutive portions, to Sept. 29, I740), pp. 136 .

I74I, Aug. 3-I742, Sept. I I. Minutes of assembly (in similar portions, to Sept. 29, I742), pp. 69.

4. I740, Oct. 6-I741, May 2. Minutes of assembly, pp. 26.

r742, Dec. 9-r743, Sept. 27. " " " (in quarterly portions, as from Sept. 29, I742, to Sept. 29, I743), pp. 94.

r743, Oct. I3-I745/6, Feb. I3. Minutes of assembly (endorsed: "in ten distinct quarters from Michaelmas 1743 to Lady day I746"), pp. 3 Io.

5. I742, Mar. 27-I745/6, Mar. 20. Minutes of council (endorsed, "Council and Assembly", the volume being lettered, "Council in Assembly"; quarterly consecutive portions to Mar. 25, I746), pp. 280.

6. I746, Oct. I6-I750, Oct. 6. Minutes of council, pp. I73.

I753, Mar. 30-r754, June 22. " " " pp. I92.

7. I746, Apr. Io-June 5. Minutes of assembly (endorsed: "25 March to 25 June"), pp. I3.

I747, Mar. 30-Dec. I2. Minutes of assembly (three quarterly portions, to Dec. 25), pp. 37 .

I747/8, Jan. 2-r749/50, Jan. 8. Minutes of assembly ("In 8 parts to the 8th January I749/50"), pp. I87.

I749/50, Feb. Io-r750, Dec. 8. Minutes of assembly (four quarterly portions, to Dec. 25 ), pp. 93.

I753, Mar. 30-r754, June 20. Minutes of assembly, pp. 343.

8. I754, June 29-1756, Dec. I8. Minutes of assembly, pp. $3^{8} 3$.

9. I754, June 29-1756, Dec. I8. Minutes of council (quarterly or halfyearly sections ending Dec. 25), pp. I62.

${ }^{3}$ For $1724-1730$ see C. O. $155: 7$. 
I757, Jan. 26-I759, Dec. 6. Minutes of assembly (quarterly sections, Dec. 25, I756-Dec. 25, I759), pp. 422.

10. I760, Jan. 3I-I762, Dec. I I. Minutes of assembly, pp. 438. I767, Jan. Io-Dec. 19.

11. I767, Jan. I0-Dec. I9. I768, Jan. 6-Dec. 28. I769, May 4-I770, Feb. I.

I77I, Jan. I2-May 8. I77I, July 4-Nov. 28. I77I, Nov. 30-Dec. II. I772, Jan. I5-May 30. I772, May 30-Oct. 3 . tion), no. II, pp. 39 .

I772, Oct. 3-I773, Mar. 3I. tion), no. I2, pp. 50.

I773, Apr. 3-Sept. I8.

I773, Oct. 2-I774, Mar. 30.

(The above nos. I-I4 are marked "Duplicate". For nos. I $5-26$ see vol. I 5.)

12. I767, Jan. Io-Dec. I9. Minutes of assembly. Duplicate. (See vol. Io.) Nos. 27-30, pp. 200.

I768, Jan. 6-May I4. Minutes of assembly. Duplicate, no. 3I, pp. 46. I768, Oct. 6-Dec. 7. “ “ " “ I769, Apr. 8-Dec. 23. " " “ “ “ “ I77 I, Jan. I2-Dec. 4. " “ “ “ “ “ I772, May I6-Sept. 24. “ “ “ “ “ “ no. 35 , pp. I4. I772, Oct. 2-I773, Mar. 3I. " “ “ " “ no. 36 , pp. I6. I773, Apr. I7-Sept. 18. “ “ “ “ “ $\quad$ no. $37, \mathrm{pp} .9$. I773, Oct. 2-I774, Mar. 30. " “" “ “ $"$ no. 38, pp. I7. I774, Apr. 26-Sept. 28. " “ “ “ “ no. 39, pp. 22. I775, Nov. I0-I776,Mar.23. " “ " " no. 40, pp. 36. I776, Oct.12-I777, Mar.29. " “" “ $"$ Duplicate, no. 4I, pp. 36. I777, Apr. 22-Sept. 25. " " " " " no. 42, pp. 25. I777, Oct. 2-I778, Mar. 24. “ “" “" no. 43, pp. 3I. I778, Apr. I8-Sept. 30. " " " " no. 44, pp. 29. I779, Apr. I7-Sept. I7. " " " " no. 45, pp. I2. I779, Oct. 30-1780, Mar. 29. " " “ " no. 46, pp. Io. I780, Oct. I I-I78I, Mar. 3I. Minutes of council (endorsed: "Council in Assembly"), no. 48, pp. 28.

13. I768, Jan. 6-I774, Sept. 28. Minutes of assembly (in nine sections; the same as in vol. I2, nos. 3I-39), pp. I83.

I774, Oct. I2-I775, Mar. 23. Minutes of assembly, pp. 46. I775, Apr. 8-Sept. 28. " “" " pp. 3I.

14. I772, May 30-1774, Mar. 3o. Minutes of council (in portions; same as in vol. II, nos. II-I4), Pp. I95.

I774, Apr. 26-Sept. 28. Minutes of council, pp. 29.

I774, Oct. I2-1775, Mar. 23. “" “" “" pp.62. I775, Apr. 8-Sept. 28. “ “ “ “ “ I775, Oct. 7-I776, Mar. 23. “ “ “ pp. 59 .

${ }^{3}$ Pencilled memoranda state that nos. $3 \mathrm{I}-34,36,38$, and 39 are duplicated in B. T. I5 (C. O. 177: 13), and 35 and 37 in B. T. 14 (C. O. 177:12). 
15. I774, Apr. 26-Sept. 28. Minutes of council. Duplicate. Nos. I5-I7, I775, Apr. 8-Sept. 28. " " " " " " $" C f$. vol. I4.

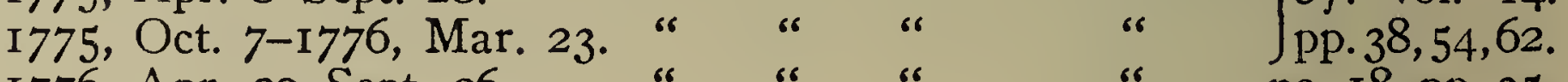

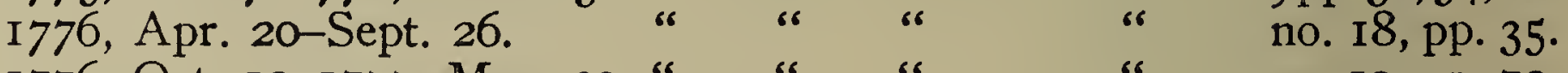
I776, Oct. I2-I777, Mar. 29. "
I777, Apr. I4-Sept. 25. I777, Apr. I4-Sept. 25. Same as preceding item, no. 21, Pp. I24. I778, Apr. I I-Sept. 30. Minutes of council. Duplicate, no. 22, pp. 57. I778, Oct. 8-i 779, Mar. 26. I779, Apr. I7-Sept. I7. I779, Oct. 9-I780, Mar. 29. I779, Oct. 9-1780, Mar. 29.

16. 1776, Apr. 20-Sept. 26.

pp. 37.

I776, Oct. I2-I777, Mar. 29. pp. 75 .

I777, Oct. 2-I778, Mar. 24.

I778, Apr. I I-Sept. 30.

"6 6406

no. 23 , pp. 50. no. 24, pp. 27. no. $25, \mathrm{pp} .28$. Minutes of council (see vol. I 5, no. 18 ) pp. $5 \mathrm{I}$

$\begin{array}{llll} & \text { * } & & (\text { see vol. I5, no. I9), } \\ \text { " } & \text { " } & \text { " } & \text { (sp. } 7 \text { I. } \\ & & & \text { (see vol. I5, no. 22), }\end{array}$

C. O. I57: i. Shipping Returns.

1. Inward:

I704, July I2-I705, May. I2. I7 I2, July I9-I7I2/3, Feb. 7. I784, Mar. 3I-Sept. 30.

Great Britain or American plantations :

I7 I5, June 25-Dec. 25.

Outward:

Same periods as inward returns.

With shipping returns are weekly accounts of prices current. Oct., I785-June, I786; Mar.-June, I787.

\section{NEVIS. ${ }^{1}$}

C. O. I84: I. Secretary of State: Original Correspondence. I703-I787.

1. I703-1787. (See Andrews, I. 210-2II.)

\section{O. I85: I-7. Acts.}

1. I664-I735.

2. Acts of Assembly Passed in the Island of Nevis, from I664, to I739 inclusive (London, Printed, by Order of the Lords Commissioners of Trade and Plantations, by John Baskett, Printer to the King's Most Excellent Majesty, I740, pp. viii, I68). Pp. I43-I68 are occupied with the Abridgment. Bound up with this at the end is: Acts of Assembly Passed in the Charibbee Leeward Islands, from I690, to I730 (London, same imprint as above, I740, Pp. v, 24, and Table of 4 pages). This is the same as in C. O. I76: I, but the head line of page I reads like that in C. O. I 54:3: "The Laws of the Leeward Islands".

\footnotetext{
${ }^{1}$ See also Leeward Islands.
} 
3. $1699-1713$.
4. I735-I 749.
5. I750-I 757.
6. I789-1802.
7. I761-I779.

C. O. I86: I-8. Sessional Papers. ${ }^{2}$

1. I723, Dec. I2-I729, Nov. 5. Minutes of council, "within these dates except what have been delivered to the $E$. of Londonderry. Referred to in Lt. Gen. Mathew's letter to the Secretary Io July I730". (There is a break from May, I727, to May, I729.) Pp. 75.

I729/30, Jan. 5-I730, Aug. 25. Minutes of council (five days only), pp. 3 .

I72I, Dec. 2I-I727, Oct. 2. Minutes, headed sometimes, "Council and Assembly", sometimes "Assembly" only; endorsed: "Minutes of Assembly", pp. Izo.

I728, Dec. 2I-I729/30, Jan. 5. Journal of assembly, pp. Io.

I727, June I-Sept. 26. Minutes of council, pp. 7.

I727, Nov. 20-1728, Sept. I6. “ “ “ pp. 8.

I 727, June I-Oct. $2 . \quad$ Journal of assembly, pp. 6.

I727, Nov. 20-I728, Oct. 28. " " " (sometimes headed, "Council and Assembly"), pp. I9.

2. I73I, Oct. 22-I732/3, Feb. 26. Minutes of council, pp. 35 .

I732/3, Mar. 8-1733/4, Mar. 6. “" “" " " "

I734, Apr. 2-June 25. “" “" " " pp. 15.

I734, June 25-I735, Sept. II. " “ " (June 25 a repetition), pp. 66.

I735, Nov. I7-Dec. 22. Minutes of council (endorsed: "from 29 Sept. to 29 December"), pp. I8.

I735/6, Jan. 29-Mar. 23. Minutes of council (certified as council and assembly, Dec. 29, I735-Mar. 29, I736), pp. I2.

I736, Mar. 30-June 21. Minutes of council (endorsed: "Council and Assembly 29 March to 29 June"), pp. I4.

I740, Oct. I3-Dec. I3. Minutes of council and assembly (Dec. I3 headed, "At an Assembly", writs being returned that day; endorsed, "Minutes of Assembly"), no. 9, pp. 7.

I740, Dec. I $3-1740 /$ I, Feb. I7. Minutes of council (certified as council and assembly), no. Io, pp. 4.

I740/I, Jan. I2-Mar. 26. Minutes of council and assembly (endorsed: "Minutes of Assembly"), no. I I, pp. 28.

I740/I, Mar. 3-174I, Apr. I6. Minutes of council (certified as council and assembly to May 23), no. I2, pp. 7.

I74I, Mar. 3I-May 27. Minutes of assembly and of council and assembly (endorsed: "Minutes of Assembly"), no. I3, pp. 6.

I74I, May 28. Minutes of council (certified as council and assembly), no. I4, pp. 2.

I74I, Sept. 7. Minutes of council and assembly (so headed), pp. 4.

I742, Mar. 25-June 8. Minutes of council and assembly (sometimes headed, "Assembly" only; endorsed: "Minutes of Assembly"), no. I5, pp. I 5.

${ }^{2}$ For earlier dates see Leeward Islands. 
I742/3, Mar. 24-I 743, May 24. Minutes, headed, "At an Assembly" on Mar. 24, when writs were returned; other days, "Council and Assembly", no. I6, pp. I4.

I744, Apr. 23-Aug. 9. Minutes similarly headed, writs being returned Apr. 23, no. I7, pp. I8.

I745, May 20-Sept. I7. Minutes similarly headed, writs being returned May 20, no. 18 , pp. Io.

I745, Oct. I I-Nov. I3. Minutes of council and assembly, no. I9, pp. 4.

I745/6, Jan. 27-I746, Apr. 23. Minutes of council and assembly (endorsed: "Minutes of Assembly"), no. 20, pp. 9.

I746, Oct. I. Minutes of council and assembly, no. 2I, Pp. 3 .

I746/7, Mar. I8-I747, June 7. Minutes of council and assembly (endorsed: "Minutes of Assembly"), no. 22, pp. Ir.

I747, July 23-Nov. Io. Minutes of assembly (writs returned July 23; and of council and assembly), no. 23, pp. 8.

I747, Dec. 3I-I748, Apr. II. Minutes of council and assembly, and endorsed as such, no. 24, pp. I5.

I736, Nov. I2-I738, Apr. I3. Minutes, headed, "At a Council", in six consecutive sections certified as "Council and Assembly". A subsequent endorsement is, "Minutes of Council". Pp. 32.

1730, Aug. 24-1732/3, Feb. 26. Journal of assembly, pp. 26.

I732/3, Mar. 8-I733/4, Jan. 28. ““" “ " pp. 36.

I734, Apr. 4-June 25.

I734, July IO-I 735, Mar. 25.

I735, Apr. 29-June 2I.

I735, July I 5-1737, June I 3 .

I737, July $7-1738$, June 27 .

I753, June 2I-I754, Mar. 2 I.

I755, Nov. 6-1756, Dec. 22.

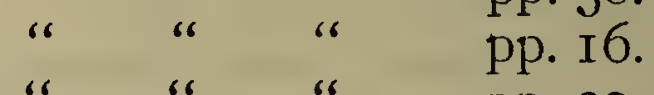

" " " $"$ pp. 20.

" " " " $\quad$ pp. 7 .

" " " $"$ pp. 58 .

" " " $"$ "

"

3. I738, Oct. 6-1739, Sept. 3. Journal of assembly (endorsed: "Council in Assembly"), no. I, pp. 2I.

I738, Dec. I5-I739, Mar. 27. Minutes of council (certified as council and assembly, Nov., I738-May 12, I739; endorsed: "Council in Assembly", ), no. 2, pp. II.

I739, June 2I-Dec. I5. Minutes of council (certified as council and assembly and endorsed: "Council in Assembly"), no. 3, pp. Io.

I739, Nov. I9-I740, Mar. 25. Journal of assembly (writs returned Nov. I9; also council and assembly), no. 4, pp. 20.

I739/40, Jan. IO-I740, Mar. 25. Minutes of council (certified and endorsed: "Council and Assembly"), no. 5, pp. I4.

I740, Apr. 17. Minutes of council (certified as council and assembly), no. 6 , pp. 4.

I740, Apr. I4, I7. Minutes of assembly and of council and assembly (Apr. I7 is not a duplicate of the above, but is written from the standpoint of the two houses), no. 7, pp. 5 .

I740, Aug. I9-Nov. I7. Minutes of council (certified as council and assembly), no. 8, pp. 22.

I748, Apr. 29-July I5. Minutes of council and assembly (the last date headed, "At a meeting of the Assembly"; endorsed: "Minutes of Assembly"), no. 25, pp. 9.

I748, Aug. I8-Nov. II. Minutes of assembly (on the first date when writs were returned; other days council and assembly), no. 26 , pp. 6 . 
I748, Nov. 23-1748/9, Jan. 3I. no. 27, pp. 6 .

I748/9, Feb. 21-1749, June I5. no. $28, \mathrm{pp} .7$.

I749, June 27, Nov. I.

(writs returned Nov. I), no. 29, pp. 5

I749/50, Jan. 3-Feb. I. Minutes of council and assembly, no. 30, pp. 6. (Most of the above are endorsed: "Minutes of Assembly".)

1749/50, Mar. 19-1750, Aug. 9. Minutes of council and assembly (endorsed: "Council and Council in Assembly"; see C. O. I $55: 8$ ), no. 3I, pp. 22.

I752, Jan. 3-Dec. 20. Minutes of council and assembly (endorsed: "Minutes of Assembly"), no. 32, pp. 63 .

1752, Sept. 26-Dec. 20. Minutes of council and assembly (from the council's standpoint and not same as above; endorsed: "Council in Assembly"), no. 33, pp. 38 .

1753, Jan. 16-1754, Mar. 21. Minutes of council, pp. 49.

I754, Apr. I8-I755, Jan. 22. “ “ “ “ pp. Io.

I756, Jan. 9-Dec. $22 . \quad$ " “ “ (endorsed: "Council and Council in Assembly"), pp. 9.

4. I762, Apr. 24-1763, Feb. 9. Minutes of council, pp. I6.

I763, Mar. 29-1764, July 20. “" " “

I766, June 4-I768, July 9. “ “ “ "

I765, Feb. I4-July I3.

I766, June 4-I768, July 9.

item), pp. 86.

I 768 , Oct. I3-I769, June I4.

I5), pp. I6.

5. I762, Feb. I I-1765, Mar. 19. Journal of assembly, pp. 36 .

I765, Aug. I5-1766, July 24.

I766, Sept. I 5-1767, July 2.

1767, Oct. I 5-1768, Oct. I3.

1768, Oct. 27-1769, Feb. I6.

I 769 , June 9-Sept. I2.

I769, Nov. I6-1770, Apr. 3 .

I770, May I7-Nov. I6.

I770, Dec. 4-I771, May 28.

I77I, Aug. 20, Dec. 3 .

I77 I, Dec. 7-I772, June 4.

I772, June 20-Sept. I7.

I772, Dec. 9-1773, Jan. 28.

I773, May 8-Sept. 7.

I773, Dec. 2 ; I774, Mar. 24.

I773 to I April 1774"), pp. 4.

I774, June 23-Sept. 21 .

I774, Oct. I-I775, Mar. 3 .

I775, Apr. IO-Sept. 20.

Journal of assembly, pp. II.

I775, Oct. II-1776, Apr. 12. Virgin Islands. Journal of assembly, pp. 105 .
Pp. I5.

pp. II.

pp. 33 .

pp. I I.

pp. 8.

pp. 8.

pp. 22.

pp. I 5 .

pp. 3 .

pp. 42.

PP. I 3 .

pp. 37 .

pp. I6.

(endorsed: "I Oct.
" " " $"$ pp. I4.

" " " $"$ pp. 22. 
6. (Vohume erroneously marked: "Council and Assembly".) I765, Aug. I 5-1766, July 24. Journal of assembly. Duplicate. ) I766, Sept. I 5-1767, July 2. I767, Oct. $15-1768$, Oct. I3. I768, Oct. 27-1769, Feb. I6. I769, June 9-Sept. I2. r769, Nov. I6-1770, Apr. 30. x770, May 17-Nov. 16. 1770, Dec. 4-1771, May 28. I77I, Dec. 7-1772, June 4. I772, June 1o-Sept. I7.

I772, Dec. 9-1773, Jan. 28.

I773, May 8-Sept. 7.

I773, Dec. 2 ; I774, Mar. 24.

I774, June 23-Sept. 21 .

I775, Oct. I I-I776, Feb. 28. Journal of assembly, no. 38, pp. II.

1776, Apr. 4-Aug. I3. Oct. I), no. 39 , pp. I7.

I78I, Feb. I5. Journal of assembly of this day. Duplicate. "In Pres. Johnson's of I4 March." No. 4I, pp. IO.

7. Volume marked, "Council and Assembly". (The items seem to be council in assembly, though the headings throughout are: "At a meeting of the Council".)

I768, Oct. I3-I769, June 4. Minutes of council. Duplicate. (Certified as to July I5.) No. 3, pp. I8.

I769, July I8-1770, Feb. 27. Minutes of council. Duplicate, no. 4, pp. II. ${ }^{3}$

I770, Mar. 27-I771, Mar. 6. pp. 67.

I772, July 2-Sept. 17.

pp. I7.

1772, Dec. 9-1773, Apr. I.

I773, May 8-Sept. 7. pp. I7.

I773, Oct. 19; I774, Mar. 24. pp. 5 .

I774, June 23-Sept. 2I. pp. I7.

I775, Apr. IO-Sept. 20. pp. 22.

1775, Oct. II-1 776 , Mar. 7.

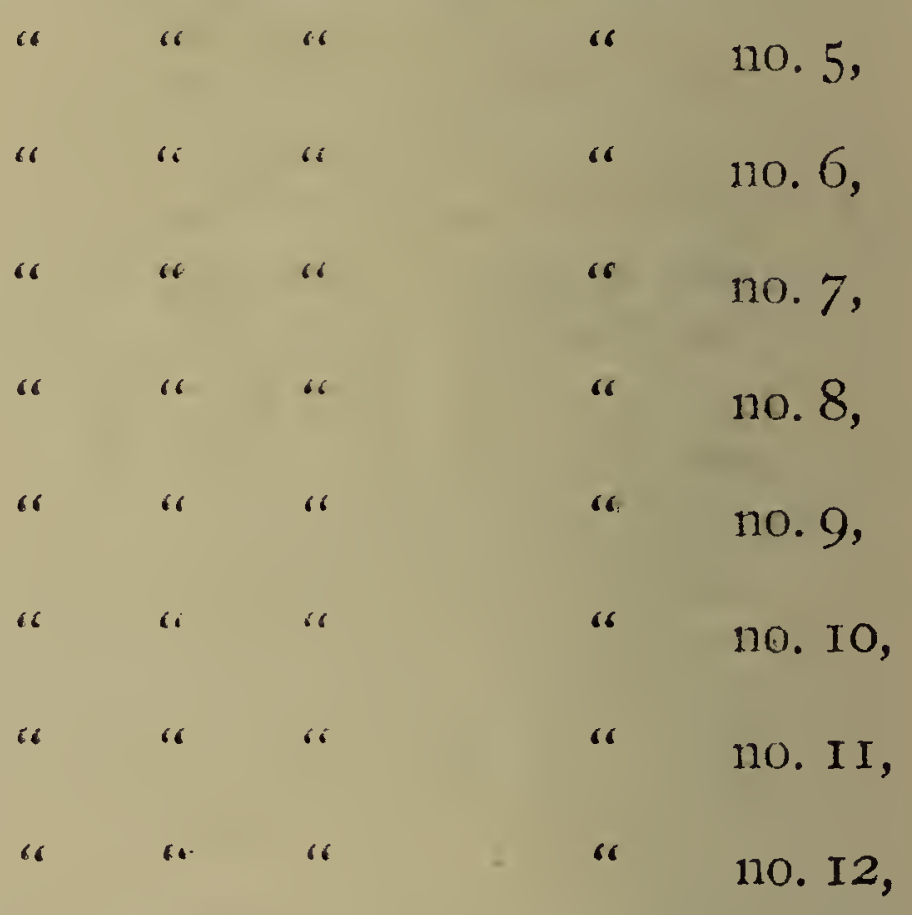
pp: 20.

I775, Oct. II-I776, March 7. Same as preceding item, no. I3, pp. 20. I776, Apr. 4-Aug. I3. I777, Apr. 8-Sept. 26. I778, Oct. 6-I779, Mar. 26. I779, Apr. 5-Sept. 4. I779, Oct. 5-1780, Mar. 28. Minutes of council, no. I4, pp. I7. no: $16, \mathrm{pp} .39$. no. $18, \mathrm{pp} .40$. no: 20, pp. 29. no. 22 , pp. 5 .

With reference to the duplicate minutes for July 18 ; $1769-$ Sept. $20,1775, c f$. vol. 8, with missing portion. 
8. (The following seem to be council in assembly. See vol. 7.) I769, July I8-1770, Feb. 27. Minutes of council, pp. I2. I770, Mar. 27-I77I, Mar. 6. “" "“" pp. 5 I. I772, Feb. I-June Io. " " " " pp. 53. I772, July 2-Sept. I7. “" " " I772, Dec. 9-I773, Apr. I. “" " " " I773, May 8-Sept. 7. " " " " pp. I9. 1773, Oct. 19; I774, Mar. 24. " " " " pp. 5. I774, June 23-Sept. 21. " " " " I774, Oct. I-I775, Mar. 30. “ “ “ “ " pp. I5. I775, Apr. IO-Sept. 20. " “" " pp. 29.

I775, Oct. I I-I776, Mar. 7. Journal of assembly (a duplicate of no. 38 in vol. 6), pp. II.

C. O. I57: I, I87: I. Shipping Returns.

INWARD.

C. O. $157: 1$. I684, Aug. 25-1685, Mar. 25. I685, Nov. 4-I687, Aug. 6.

C. O. I87: 1. I704, July I2-Oct. 12.4

C. O. I $57: 1$. I704, July I2-Oct. I2. I704/5, Jan. I2-I705, Dec. 25. I706, May I8-I708, Oct. 25.

C. O. $x 87: 1$. I720, June 25 -I729, June $25{ }^{5}$

OUTWARD.

C. O. 157 :1. I683, Aug. 29-1684, Aug. 25. I685, Nov. 4-I687, Aug. 6.

C. O. I87:1. 1704, July I2-Oct. I2. ${ }^{4}$

C. O. $157: 1$. I704, July I2-Oct. I2. ${ }^{4}$ I704/5, Jan. I2-I705, Apr. I2. I705, July I $2-$ Dec. 25. I 706, May I8-1 708, Oct. 25.

C. O. $187: 1$. I720, June $25-1729$, June $25 .^{5}$

ST. CROIX.

C. O. 244: I. Secretary of State: Précis of In-Letters. I808-1813.

1. $1808-1813$.

Letter from Lieut. Gov. Harcourt, no. 4. Probable imposition of duty on American lumber. Jan. I5, I809.

Id., no. Ir. Hardship on Americans of paying tonnage-duty when it had already been paid at another island. Aug. 22, I8Io.

$I d$., no. 33, giving figure of $t$ Io, 000 as produce of duties arising from American trade at one port only. Oct. 30 , ISII.

- Imports from and exports to the American plantations are separated.

- Entries of vessels which have produced certificates to bonds given in Great Britain; and of clearances of vessels bound for Great Britain or British plantations in America. C. O. I $87: 2$ is a duplicate set of these returns. 


\section{ST. EUSTATIUS.}

C. O. 246: I. Secretary of State: Original. Correspondence. I779-I 783 .

1. $1779-1783$.

Letter from Hasell and Tasker to Curzon and Gouverneur, indicating existence of trade in Maryland tobacco, etc., through "Statia"; also direct trade in tobacco between America and France. Sept. I I, I 780.

\section{ST. KITTS. ${ }^{1}$}

C. O. 239: I. Secretary of State: Original Correspondence. I702-I8I2.

1. I702-I8I2. (See Andrews, I. 2I6; and $i d$. I. 2I7, for C. O. 243:8.)

1. I7OI-I722.

$$
\text { C. O. 240:I-I3. Acts. }
$$

2. I7II-I I I .

3. Acts of Assembly Passed in the Island of St. Christopher; from I 7 I, to I735, inclusive (London, Printed by John Baskett, Printer to the King's Most Excellent Majesty, I739, pp. x, I63). P. I65 is headed: "These following Acts were not come to hand when the foregoing were printed off", and the pagination continues to 182 ; then follows title-page to An Abridgment (1740), with two pages of alphabetical table, and the text of the Abridgment, pp. I69 to I 98. Bound up with this is a similar set of the Leeward Island Laws; see C. O. $185: 2$, p. 286 , supra.

4. (Laws from I7I I to I83I.) The Laws of the Island of Saint Christopher, from ITII to 1831 , inclusive, Printed by order of the Council and Assembly Under the Superintendence of the Colonial Secretary (Saint Christopher, printed by Samuel Cable, Advertiser Office, I832, pp. xv, 399). At end is: List of Acts of the Leeward Islands, 2 pp.; Laws of the Leeward Islands, pp. I-48; List of Acts not printed in this rolume, such as expired, obsolete, etc., I I pages.
5. $172 \mathrm{I}-1735$.
6. $1723-1737$.
7. $1739-1743$.
8. $1744-1750$.
9. $1752-1760$.

10. $1762-1766$.

11. $1768-1771$.

12. $1772-1776$.

13. $1777-178 \mathrm{I}$.

C. O. 24I : I-I6. Sessional Papers.

1. I704, Sept. 5-Oct. 20. Minutes of council (a loose paper), pp. 9.

I704, Sept. 5-Oct. 20. The same (both endorsed as to Oct. 26), pp. I3. I704, Sept. IS-I705, Apr. Io. Journal of assembly, pp. 30.

I706, Aug. 2I-I708, June 29. Minutes of council (endorsed: "Council in Assembly"), pp. 64.

(For intermediate dates see Leeward Islands.)

I727, May 29-Oct. 25. Minutes of council (endorsed: "Council in Assembly"), pp. 46.

1727, Oct. 24-1728, May I8. Minutes of council (Oct. 24-25 the same as above; endorsed, "Council and Council in Assembly" to Sept. 5 . I728), pp. 54 .

\footnotetext{
${ }^{1}$ See also Leeward Islands.
} 
I 727 , June 5 , IO, I4. Journal of assembly, pP. 4.

1727 , Oct. 24-Dec. I2. “" “ " 2 " 5 .

I725/6, Mar. I9-I727, May I3. Minutes of council (similar to those marked, "in Assembly"), pp. 50.

2. I7 3, Mar. 26-i I 8, Dec. 23. Minutes of council, pp. 288.

3. I729, Sept. I8-1729/30, Mar. I8. Minutes of council, pp. Io7.

I730, Mar. 28-Sept. I 7 .

I73 I, Nov. 26-I732, June 7 .

pp. $108-160$.

that "the minutes from 17 Sept. to 30 to these had never been transmitted". These are in C. O. I 52:43.) Pp. 28.

I732, June 2-Sept. I8. Minutes of council. (June 2-7 a repetition), Pp. 25.

I732, Oct. 4-I733, June 28. Minutes of council, pp. I4.

I733, Oct. 8-i $733 / 4$, Feb. 20. Minutes of council. (Memorandum: "No Minutes from 28 June 1733 to the beginning of these have yet been transmitted.") Pp.6o.

I733/4, Feb. 26-Sept. 26. Minutes of council, pp. 80.

I729, Oct. 3I-I730, Nov. 26. Journal of assembly, pp. 55 .

I 734/5, Mar. I-I735, Nov. 29. “" “ “ “

I736, Apr. 5-1736/7, Mar. 5. “ “ “ " pp. 18.

4. I737/8, Feb. 9-1738, July 20. Minutes of council, pp. I5.

I 738 , Sept. I2-I738/9, Mar. I. " " " "

I738/9, Mar. I6-I739/40, Jan. 9. “ “ “ " "

I739/40, Feb. 28-i740, Sept. 30. " " " " "

I740, Oct. 3-1740/1, Feb. 25. " “ “ “ " "

I740/I, Mar. I6-I74I, Aug. 24. " “ " "

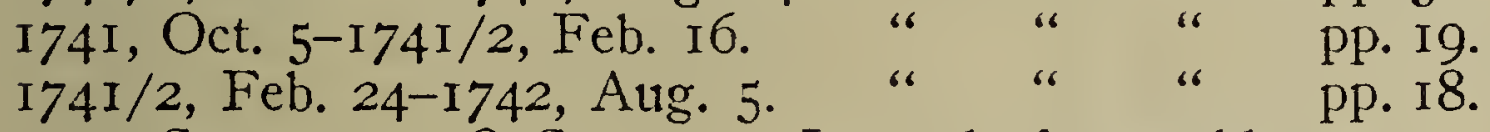

I737, Sept. 22-1738, Sept. I2. Journal of assembly, pp. 25.

I739, Apr. I7, May 4, I 5. “ “ “" " " 2.

I739, July 24-Sept. 8. “ “ “ “ “

I739, Nov. I-I739/40, Jan. 9. “ “ “ “

I739/40, Jan. 29-I740, July 4. “ “ “ " "

I740, Sept. 5-174I, Aug. 24. “ “ “ “

I74I, Oct. 5-I74I/2, Mar. 3. " " " pp. I5.

5. I742, Sept. Io-I $742 / 3$, Jan. 28. Minutes of council, pp I I.

I742/3, Feb. I0-1743, Aug. I 5. " “" “" " "

I744/5, Mar. I3-I745, Dec. 23. " “ “ “ " “

I745/6, Feb. II-I 747 , June I8. “ “ “ “

I 74I / 2, Mar. 3-1743, Nov. 3. Journal of assembly, pp. 39.

I743/4, Jan. I9-1745, Dec. 23. " " " (certified as to Mar. 3, I745/6), pp. I34.

6. I743/4, Jan. I9-1745, Dec. 23. Journal of assembly (certified as to Mar. 3 , I745/6), no. I, pp. 126.

I745/6, Mar. 3-I746/7, Feb. I3. Journal of assembly, no. 2, Pp. 33 .

I747, Apr. I6-1748, June 25. July I7), no. $3, \mathrm{pp} .64$.

I748, July 27-Nov. I6. Journal of assembly, no. 4, pp. I2.

I748/9, Feb. 8-Mar. I7. “ “ “ "

I749, Apr. 27-May I5. " “ " “ no.6, "

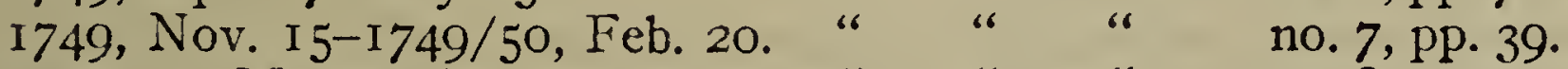

1749/50, Mar. 5-Apr. 2I. " " " $"$ no.8, pp. I3.

I749, Apr. 27-May I5. Same as no. 6, no. 9, pp. 7. 
I750, May I5-June 28.

I750, July I 3 -Oct. 20.

I750, Nov. IO-I750/I, Feb. 25.

I750/I, Mar. 4-I75I, June 25.

I752, Aug. 24-Dec. I8.

I753, Jan. 29-Mar. 5.

I753, June 5-Aug. Io.

I753, Nov. I2-1754, Mar. 26.

I754, Apr. 29-Oct. I8.

$$
\text { "to } 29 \text { October"), pp. } 48 .
$$

Journal of assembly, no. IO, pp. I 5 .

7. I750, Apr. 30-Sept. 20.

Minutes of council, pp. 42.

I753, Nov. IO-I754, Apr. 6.

I754, Apr. 29-Sept. 24.

I754, Dec. 23-1755, June 13.

I755, July 3-1756, May I8.

I756, July 2-I757, Feb. 23 .

I757, Feb. 28-I758, Feb. 23.

I758, Mar. 2I-Sept. 5 .

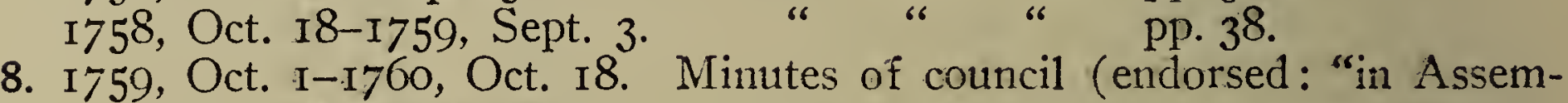

\begin{tabular}{|c|c|c|c|}
\hline 66 & 6 & 66 & no. I I, pp. 38 . \\
\hline 66 & 66 & 66 & no. 12, pp. 23 \\
\hline 68 & 6 & 68 & no. $\mathrm{I} 3$, pp. 20 \\
\hline 66 & 66 & os & no. $\mathrm{I} 4, \mathrm{PP} .4 \mathrm{I}$ \\
\hline 6 & 66 & 66 & no. $15, \mathrm{pp} .15$. \\
\hline 66 & 66 & 66 & no. I6, pp. I I. \\
\hline$\because 8$ & 66 & 68 & no. I7, pp. I I 2. \\
\hline 6 & 6 & 66 & (title-page reads, \\
\hline
\end{tabular}
bly"), pp. 25.

I755, June 26-1756, May i8. Journal of assembly, pp. 76.

I756, July $2-1757$, June $30 . \quad$ “ “" “ pp. 62.

I757, July $22-1758$, Jan. I8. “ “ “ “ “

I757, Dec. I4-I758, July 19. “ “ “ (Dec. I4, I757-Jan.

I8, I758, a repetition), pp. 39 .

1758, Sept. 5-1759, Sept. 3. Journal of assembly, pp. 58.

I759, Oct. I-I760, Sept. 24.

9. I760, Nov. 3-7761, Nov. 4. Minutes of council, pp. 22. I761, Nov. $23-1762$, Nov. I5. “ “ “ “ “ I762, Nov. 20-1764, Jan. 20 . “ “ “ “ “ I764, Mar. 5-Sept. 5 . I764, Sept. 19-1765, Apr. 4. I765, Apr. 25-Oct. 23. 1765, Nov. 5-1766, Apr. I5. 1766, May 14-Oct. 15. “ “ “ “ pp. 19. I766, June I8-1767, Jan. I4. Journal of assembly, pp. I6. I767, Jan. 4-Aug. I7. I767, Aug. 28-i768, Mar. 3.

10. 1760 , Nov. $3-1761$, Sept. 9 . I761, Nov. 23-1762, Nov. 20. I 763, Feb. Io-Aug. 8. 1763, Aug. I5-Dec. 23.

Minutes of council, pp. ro. “ “ 10 Feb. 1764"), pp. 10. I764, Mar. 5-Sept. 5 . I764, Sept. I9-I765, Feb. 20. I765, Apr. 5-Nov. 5. I765, Nov. 21-1766, Apr. 15. I767, Jan. 27-Aug. 28.

11. Volume lettered erroneously, "Council and Assembly".

Journal of assembly, pp. 28. Duplicate, pp. 15. I767, Sept. 4-1768, Apr. 8. Journal of assembly. Duplicate. (Same as last item in vol. I0.) No.23, pp. 26. 
I768, Apr. I I-Aug. I 5. Journal of assembly. Duplicate. (See also vol. I4 for this and the next three items.) No. 24, pp. $3^{8}$.

I768, Sept. 27-1769, Apr. 7. Journal of assembly. Duplicate, no. 25, pp. 36. I769, May I2-Sept. 7 .

I770, June 7-I77I, Apr. I2. " " " "

I772, Apr. 20-Oct. 27.

I772, Nov. 4-1773, Mar. 26.

I773, Apr. 7-Aug. 25.

I773, Oct. 8-1774, Mar. I6.

I775, May 4-Oct. II.

I775, Nov. 23-I776, Mar. 22." " " " " " "

I776, Apr. 4-Sept. 30.

I776, Oct. Io-1777, Mar. 26. no. 26, pp. 27.

I776, Apr. 4-Sept. 30. Duplicate of no. 35. No. 37, pp. 44.

I776, Oct. Io-I777, Mar. 26. Duplicate of no. 36. No. 38, pp. 39.

I777, Apr. 16-Sept. 26.

I777, Oct. 3-I778, Mar. I9. “
I778, Oct. I-I779, Mar. 25.

Journal of assembly, no. 39 , pp. 53 .

43 pp. 75 .

I779, Apr. I 3 -Sept. 9.

I779, Oct. 6-1780, Mar. 7.

I780, Jan. I $3-J$ une I6.

no. 46), no. 47, pp. 62 .

" " " $\quad$ no. $45, \mathrm{pp} .88$.

" " " $"$ no. $46, \mathrm{pp} .67$.

no. 33 , pp. 46 .

no. 35 , pp. 44 .

no. $36, \mathrm{pp} .40$.

(partly the same as

12. 1767 , Aug. 28-1768, Mar. 3. Minutes of council. Duplicate. (See also last item in vol. 9.) No. 2, pp. I5.

r768, Mar. 29-Sept. 7. Minutes of council. Duplicate, no. 3, pp. 29.2

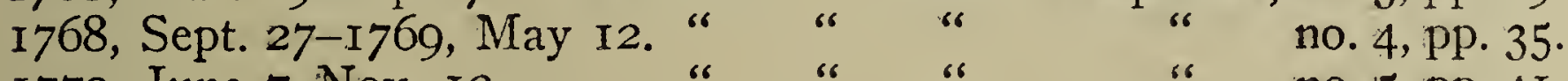

I770, June 7 -Nov. I2.

I770, Dec. IO-I77 I, June I4.

I77I, June 26-1772, Apr. 21.

I772, May 6-Nov. 4.

I772, Dec. I I-1773, Mar. 8, 26. “

1773, Apr. 7-Sept. 28.

I773, Oct. I5-I774, Mar. I6.

I774, Apr. 6-Sept. 30.

I775, May 4-Sept. I 3 .

I775, Oct. 5-1776, Mar. 22.

I776, Apr. 4-Sept. 30.

I776, Oct. I-I 777, Mar. 26.

I777, Apr. I6-Sept. I2.

I777, Oct. 3-I778, Mar. I2.

I778, Oct. I-I 779, Mar. 25.

I780, July 7-Dec. 28.

no. 5 , pp. $4 \mathrm{I}$.

$\therefore \quad$ no. $6, \mathrm{pp} .25$

" 64

" " "

“

no. 7, pp. 53 .

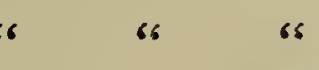

"

no. 8 , pp. 32 .

“

no. Iо, pp. 9.

" $"$ " $\quad$ " $\quad$ " $\quad$ no. $\quad$ no. $12, \mathrm{pp} .25$.

pp. 30.

" $"$ " $"$ " $\quad$ " $\quad$ no. I3, pp. 7.

" no. I5, pp. 22.

" no. I6, pp. 3 .

" no. $17, \mathrm{pp} .9$.

" no. I9, pp. 26.

" no. $20, \mathrm{pp} .36$.

no. $2 \mathrm{I}, \mathrm{pp} .26$.

I781, Mar. 9. Minutes, headed, "At a Meeting of a Privy Council", and consisting of letters and papers laid before them, no. 22, pp. 8.

13. I768, Mar. 29-Sept. 7.

I768, Sept. 27-1769, May I2.

Minutes of council, pp. 3 I.

I769, June I-Nov. 22.

I770, Jan. 29-May Io.

I770, June 7-Nov. I2.

$\begin{array}{llll}\text { " } & \text { “ } & \text { “ } & \text { pp. } 35 . \\ \text { “ } & \text { “ } & \text { “ } 46 . \\ & \text { “ } & \text { pp. } 20 . \\ & & & \text { pp. } 45 .\end{array}$

- See the originals of the rest of this vol. in vols. 13 and 16 , with the missing portions. 
I770, Dec. I0-1771, June I4. Minutes of council, pp. 25.

I77I, June 26-I772, Apr. 2I. “" “" " pp. 37 .

Most of these are marked: "Recd from the Secretary of States Office."

14. I768, Apr. II-Aug. I5.

Journal of assembly (duplicate in vol. I I), pp. 39.

I768, Sept. 27-1769, Apr. 7. “ “ “ (duplicate in vol. II), pp. 39.

I 769 , May 12-Sept. 7. pp. 27.

I769, Oct. 24-I770, Apr. 26. I770, June 7-I771, Apr. I2. pp. 65.

I771, Apr. I6-1772, Mar. 9.

15. I771, Apr. 16-1772, Mar. 9.

I772, Apr. 20-Oct. 27.

I772, Nov. 4-I773, Mar. 26.

I773, Apr. 7-Aug. 5 .

I773, Oct. 8-I774, Mar. I6.

I 774 , Oct. 25-1775, Mar. 22.

I775, May 4-Oct. II.

II ), Pp. 22.

16. I772, Dec. II-I773, Mar. 26. Minutes of council, pp. 9.

1773, Apr. 7-Sept. 28.

I773, Oct. I5-1774, Mar. I6.

1774, Apr. 6-Sept. 30.

I 774 , Oct. I4-I775, Feb. 9.

I775, May 4-Sept. I3.

I 775, Oct. 5-1776, Mar. 22.

1776, Apr. 4-Sept. 30.

1777, Apr. 16-Sept. I2.

I777, Oct. 3-1778, Mar. I2.

"October $x 777$ to April I 778 "), pp. 32.

(For duplicates of most of these see vol. I2.)

Journal of assembly (see vol. I4), pp. 77. (duplicate in vol. II),

pp. 93.

(duplicate in vol. II),

pp. 72.

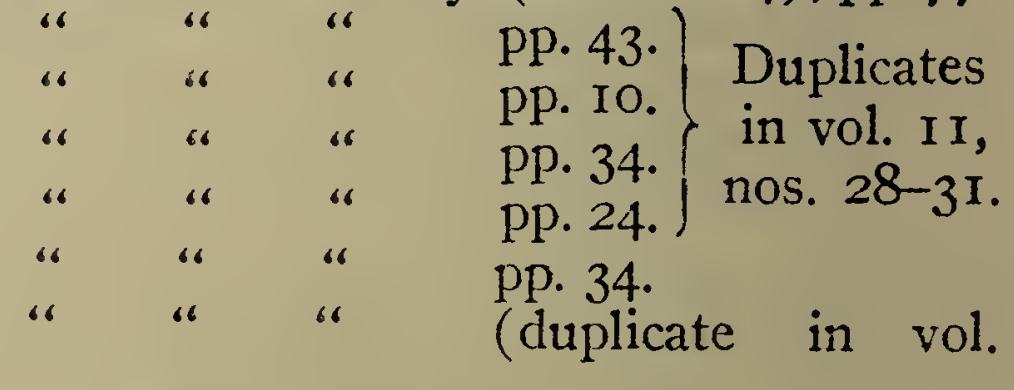

C. O. I57: I. Shipping Returns. ${ }^{3}$

INWARD.

C. O. $157: 1$. I683/4, Feb. 8-1684/5, Mar. Io.

I 704, July 28-Oct. 3 .

I705, May 8-July I2.

I706, May 24-Oct. 7 .

1707, Dec. 25-1708, June 25.

(Inward from Great Britain.)

C. O. $157: 1$. I715, June 25-Dec. 25.

\section{OUTWARD.}

C. O. I57: 1. I704, July 12-Oct. 26.4

I705, May 9-Sept. I5.

I705/6. Mar. 12-1706, Oct. 8.

1707, Dec. 25-1708, June 25.

'For treasurer's accounts, I $716-1718$, in C. O. 10: 4, see Andrews, I. 186.

A duplicate is in C. O. $243: 1$. 
ST. LUCIA.

\section{O. 253: i-7. Secretary of State: Original Correspondence. I709-1812.}

1. 1709-1798. (See Andrews, I. 219.)

2. $1798-1802$.

Letter from Lieut.-Gov. Prevost, no. 28, referring to "small tax on American Vessels trading to the Island". Oct. 9, I80I.

3. $1803-1807$.

Letter from Gov. Brereton. Transmits letter referring to large numbers of American vessels visiting the island. Nov. I4, 1803 .

Id. Mar. 30, I804. Encloses return of exports in foreign vessels. Aug. 23-Nov. $20,1803$.

Id. Admission of certain articles of provisions and lumber in American bottons. Oct. 26, I804.

Id. Opening of port of Castries for three months for certain articles. Apr. I0, I805.

Id. Same subject. Oct. 24, I805.

$I d$., on bounty on fish from Br. N. Am. and duty on U. S. fish. May I8, 1806.

Id. Nov. I6, I806. Encloses account of exports to Br. N. Am. and the U. S.; also of imports from the United Kingdom, Br. N. Am., and the U. S., June 22, I803-July 5, I806.

Id. Opening of port of Castries for two months for certain articles. Mar. I4, I807.

Id. Extension of time for opening of port: few Americans entered. Apr. 27, I807.

Letter from Gov. Wood. Refers to continuation of bounty on fish from Br. N. Am. and payment of duty of Is. per quintal on U. S. fish.

6. I8IO-I8II. Oct. 24, I807.

Letter from Gov. Wood, on importation of U. S. fish. Sept. I, I8I I.

7. I8I I-I8I2.

Letter from Gov. Wood. Acknowledges receipt of letter enclosing order in Council of Oct. I3, I8I2, directing general reprisals against ships, goods, and citizens of the U. S. Dec. 23, I8I2.

C. O. $258: 3-4$. Miscellaneous. J722-1724, 1755.

3. 1722-1724. (See Andrews, I. 219.)

4. 1755 .

Papers on negotiations between British and French commissioners appointed to discuss title to St. Lucia in accordance with terms of Treaty of Aix-la-Chapelle. Memorials signed by La Galissonière and Silhouette for France, and W. Shirley and W. Mildmay for Great Britain. French and English. (Printed.) London, I755, pp. 520. 
ST. VINCENT.

\section{O. 260:3-32. Secretary of State: Original Correspondence. I668-I8I5.}

3. I668-1812. (Described in part by Andrews, I. 219, 220.)

Representation, on conflict between British and French claims to various islands. I7I9.

Id. Aug., I739. "Copy sent to Earl Waldegrave, Nov. 30, I73o."

Memorial from Valentine Morris, asking to be reappointed governor of St. Vincent, relating events before and after capture by French. Feb. 15, I783. Similar letters and memorials from Morris and others.

Compilation of current prices of imports and exports, I785-I787.

Abstract of act for establishment of court of chancery. I787.

Draft of letter to Gov. Lincoln, with comments on his instructions. Oct. $8,1783$.

Draft of additional instructions on land grants. I 783 (?).

Draft of commission for James Seton. Feb. 12, 1787.

4. I776-I777. (For vols. 4 and 5, see also Andrews, I. 220-221.)

Letter to Morris, sending instructions for establishment of separate government. At first meeting of assembly he is to "require of them in His Majesty's Name" to grant the $4 \frac{1}{2}$ per cent. duty "in the manner it has been made in the Leeward Islands. . . . It is the more incumbent on you to use your best endeavours . . . as you will see" that "their Lordships assigned no other Fund... . for the Payment of your Salary". But he is not to make demand in such manner as to arouse controversy or impede public business. Apr. 3, 1776.

Letters from Morris. Land grants; complains of provisions made for his salary. June 27, July 22, I776. Germain to Morris, on same. Sept. 5, 1776.

Id. Engagement just off St. Pierre, Martinique, of the Shark with one of "Hopkins's little Squadron, now, as we learn, hovering among the Windward Islands. . . . The Americans fought, as I learn, under Colours with thirteen stripes meant to imply the Colours of the thirteen United Colonies". Aug. I, 1776.

Germain to Morris, on recommendation of persons for council. Nov. 18, 1776 .

Letter from Morris, on issue of writs. "The public Papers teemed with Letters and Hints strongly recommending the Free-holders not to chuse Men known to be inclined to load the Colony . . . with the $4 \frac{I}{2}$ P. Cent." Morris judges that assembly as now constituted will not grant the $4 \mathrm{I} / 2$ per cent. duty ; and suggests creation of new electoral constituencies where elections could be influenced, and the appointment to the council of leaders opposed to the $4 \frac{\mathrm{T}}{2}$ per cent. duty. If he could be instructed to enforce the oath of qualification for members of assembly or not, as he chose, he could crush all opposition. Sept. 6, I776.

$I d$. Resistance offered to attempt of receiver general to fix rate of exchange in receipt of fines and quit-rents. "The turbulent example of North America seems so much to pervade every part of the Colonies, that nothing but strengthening the hands of His Majesty's 
Governors . . can effectually enable them to carry smoothly into execution the measures of Government." Crown officials must receive every possible power to conciliate or chastise; but "all this will be found scarcely sufficient. . . Our attorney general [brother of the speaker, Charles Sharpe] and whole Family are American Rebels at heart. He broke Jail in America some years ago, to avoid punishment that waited Forgery and thus escaped, a Fact so notorious as to be the common publick table Talk in this Island, to which he is appointed Attorney General". Sept. I9, I776.

$I d$., on $4 \frac{T}{2}$ per cent. duty, defense, surveys, and land grants. Oct. 23 , 1776.

Id. Departure of 6th Regt. for America. Oct. I3, г776.

Opinion of attorney general of St. Vincent on right of receiver general to fix rate of exchange, "to demand a Discharge of the Quit Rents . . . at the rate of $\pm 3-18-3$ per oz. Gold (which is equal to an exchange of $\left.82^{\mathrm{I}} / 2\right)$ ". Aug. 30,1776 .

Letter from Germain. Secret. May 7, r777. Sends three letters signed "R. S." (Resolve Smith), lately intercepted. Letters are addressed to Smith's wife in England, Mar. I9, I777; to Henry Keene, Mar. 25, 1777; and to one Mills at Salem, Mar. 25, 1777, Mills being apparently owner of vessel in which Smith was captured. Letters show that Smith, having been appointed agent for exchange of prisoners for Mass., and being about to receive appointment as secretary of St. Vincent, is carrying on trade in flag of truce. If he can secure manufactures most in demand he will, through "a certain Resolve of Congress", make I75 per cent. on the cash, and 500 per cent. on most of the articles, without any risk. Will use influence with governor of St. Vincent to get pass for his vessel as cartel to the admiral at the Leeward Islands. Property would be British until he reached S. C., and then it would belong to him (Smith) as a free-born subject. This, by resolve of Congress, would make the property American.

Letter from Morris. Desperate need of military stores; and consequent impunity with which American privateers touch at the island. Feb. 9, 1777 .

Id. Regrets he has no warship for capture of American privateers, "since by different expressions sent me privately from the French Islands, I know of their fitting out, and within forty-eight hours and sometimes much less of their actual sailing". But capture difficult "since the American Cruisers in these Seas generally are Spanish launches or some small sloops and schooners that sail with a degree of swiftness which evades, nay mocks all the chasing of His Majesty's Ships, and still more so by keeping too close in shore to be reached by anything but similar Vessels". Complains that "the recruits which have been sent out these last twelve months are, in general, the very scum of the Earth. The streets of London must have been swept of their refuse, the jails emptied . . . and many nearly superannuated and too disabled to even carry their arms". Feb. II, 1777.

Morris to William Knox (?) ${ }^{1}$. The success of British arms might have extended to these seas had it not been for French assistance to

-The only letter in this volume not addressed specifically to Germain. May have been sent to Knox or D'Oyly. Initials "W. K." appear on endorsement. 
American vessels. These are very successful: "I must own that this is now got to such excess that people will not let their craft out even to go along coastwise as drougers to carry the Planters stores from the Town to their Plantations. . . They being mostly or all Bermudian built, they sail like the wind. . . . At present and for three weeks past a perfect fleet of them has been very considerably to the Windward of Barbadoes trying to intercept the expected merchant fleet." Mar. 23, I777.

Id. Same matters. Intercourse of North Americans with Caribs and slaves. "Many of the Privateers now begin to have avowed French captains and the Crews of the far greater part consist of French." Mar. 25, 3I, I777.

Id. Land tenure and settlement. Mar. I4, I777.

Id. Describes conversion of prizes into privateers at French islands. Capturer, after unloading cargo, sails vessel to Martinique, where, although well known to inhabitants, he is permitted to impersonate former captain and sell vessel as his property to the French, who convert her into privateer. Commissions for privateers issued by Bingham, American agent at Martinique; but "sometimes, to save Expenses, they copy a Congressional Commission and forge the Name of Hancock, Adams, etc. with as little ceremony as they would their own". Particulars of prizes brought in. Mar. 3I, I777.

Other letters of similar character and equal interest supply particulars of operations, and show increasingly open participation of French, trade of N. Am. with Ireland, and superiority of German over British troops. In particular, papers on operations of American privateer Rattlesnake.

$I d$., on mobbing of collector in connection with dispute over rate of exchange. June 13, I 777 .

Id., on Resolve Smith, whom governor was about to appoint secretary of island, describing his past career and present methods of carrying on trade. June 2I, July 8, I 777.

Letters from Morris. Difficulties with assembly over quit-rents, and the impossibility of securing grant of $4^{\mathrm{T} / 2}$ per cent. duty. Advises that tax be levied by act of Parliament. His attempts to prevent creation of court of exchequer, which he regards as a device for escaping payment of quit-rents.

Letters and numerous other papers on land grants, showing names, locations, terms, etc.

Letter from Morris. "The second of this month arrived at Martinique Monsr. Delaplaine, a Captain lately in the French Service, but now serving on leave in the first Regiment of the Carolina Rebel Troops and had an audience from the Ms. de Bouillé, and is now proceeding to France, as he says, to Dr. Franklyn, as a deputy to him from the Congress." Aug. 18, 1777.

Papers on military weakness of the island, and danger from slaves and Caribs.

5. $1777-1778$.

Letter from Gov. Morris. Refers to acquittal of Resolve Smith. All letters written in Mass. "inspired by . . . the Committee of Safety on behalf of the Congress". Jan. I 5, I778. Encloses correspondence with Marquis de Bouillé, and other papers relative to attitude of French. 
Id. Jan. 22, 1778. Encloses minutes of council, July 19, 1776-Nor. 5 . 1777 .

Id. Feb. 18, 1778. Encloses "Memorandum of American privateers in Martinique and the conduct of the French towards the Americans".

Id. Aug. 24, I778. Encloses copy of letter from the King of France to the Marquis de Bouillé, June 28, I778.

6. $1778-1782$.

Journal of assembly. June 29-Dec. 24, 1778 .

Minutes of council. Aug. 7, 1778-Feb. 2, I779.

7. $1783-1786$.

Letter from Gov. Lincoln, no. 4. 2 May i784. Encloses naval office returns, Jan. 8-Apr. 5, 1784.

Id., no. 8. Refers to application from Loyalists in the Bahamas. Aug. I8, 1784 .

Id., no. I6. Grant of registers to Americans: none improperly obtained in St. Vincent. Feb. 28, I785.

$I d$., no. 26. Describes trade at Martinique, Guadeloupe, and St. Eustatius with Americans; profitable whale-fishery carried on by Americans in Caribbee Islands. Dec. I, 1785 .

Among miscellaneous papers at end of volume is "Sketch of a Plan proposed for the future settlement of the Loyalists now in East Florida".

8. $1786-1788$.

Letter from Lieut.-Gov. Seton, no. 28. Mar. 23, I788. Encloses "List of seizures made by John Fisher commanding the schooner Szift of the Island of St. Vincent”. Sept., I785-Feb., I788.

9. $\mathrm{r} 788-\mathrm{r} 789$.

Letters from Seton, enclosing:

Minutes of privy council. Mar. 4-July 24, I788.

" "legislative council. Mar. 4-July 23, I788.

Journal “ assembly. Mar. 4-July 23, I788.

Minutes " privy council. Aug. I4-Dec. 19, I788.

" " legislative council. Aug. I4-Nov. I3, I788.

Journal " assembly. Aug. I4-Nov. I3, I788.

Feb. 5-June 3, 1789

Minutes “privy council. Feb. 5-July 30, I789.

10. 1790.

" "legislative council. Feb. 5-June 4, 1789 .

Letters from Seton, enclosing:

Minutes of legislative council. July 30, I789-Apr. I3, 1790.

“ " privy council. Aug. 6, I789-Mar. 12, I790.

Journal “ assembly. June 4-Nov. 24, 1789.

11. I790-I792. Dec. 4, I789-Apr. I3, I790.

Letters from Seton, enclosing:

Journal of assembly. May 25-June 24, I790.

Minutes " legislative council. May 25-June 24, 1790.

“ " " " " " "

“ " " " Sept. 23-Dec. 8, I790.

" " legislative council. Sept. 23, I790-May 3, I79I.

Journal “ assembly. Nov. 19, I790-Oct. 25, I791.

Minutes " legislative council. May 7-Oct. 25, 179I.

“ " privy council. May Io-Aug. I2, I791.

“ " legislative council. Nov. 8, I79I-Apr. II, I792. 
Minutes of privy council. Oct. 25-Dec. 22, I79I.

12. I792-I794.

Letters from Seton, enclosing:

Minutes of privy council. Apr. 10, 1792-Apr. 30, I793.

" " legislative council. May 17, r792-Apr. 9, 1793.

Journal “ assembly. May I-Sept. 8, I792.

Minutes “ privy council. 2, I792-Apr. 9, I793.

ncil. July I-Sept. 7 , I793.

" legislative council. May 6-Sept. 12, 1793.

Journal “ assembly. May 6-Sept. 12, I793.

Minutes “ privy council. Oct. I, 1793-May 22, 1794.

" legislative council. Dec. 3, I793-June 24, I794.

Journal “ assembly. Dec. 3, I793-July I, 1794.

Id., no. 2. Acknowledges receipt of letter of Aug. 8 transmitting order

in Council relative to appeals from vice-admiralty courts in cases

14. $1796-1797$.

concerning U. S. ships and goods. Sept. 6, I794.

Letters from Seton, enclosing:

Minutes of legislative council. July $1,1794-$ Mar. $3,1795$.

“" “ " July I3-Aug. 15, 1796.

“ " " privy council. July 1, r794-June 16, , 796.

“ " legislative council. Aug. 26-Dec. 30, 1796.

Journal “ "assembly. July 13 -Sept. 30, 1796.

Oct. 3 I, I796-Jan. I I, I797.

Id., no. 6I. Describes trade permitted with U. S. from beginning of the

war. Feb. I6, I797.

15. $1797-1798$.

Letters from Gov. Bentinck, enclosing:

Minutes of legislative council. Jan. IO-Dec. 7, I797.

Jan. II-Feb. 20 , I798.

16. $1798-1800$.

" " privy council. June $25, \mathrm{I} 796-\mathrm{Jan} .3 \mathrm{r}, \mathrm{x} 798$.

Letter from Bentinck, no. 16. Jan. 17, 1799. Encloses:

Minutes of legislative council. Mar. 2-Sept. 25, I798.

17. $\mathrm{I} 8 \mathrm{O} \mathrm{I}-\mathrm{I} 8 \mathrm{O} 2$.

Oct. 9, 1798-Mar. 8, I799.

Letters from Bentinck, enclosing:

Minutes of privy council. July I7-Dec. I8, I800:

" "legislative council. July I7-Dec. I8, I800.

Journal " assembly. June I I-July 8, I802.

Minutes " legislative council. Jan. I7-June 26, 1802 .

18. $\mathrm{I} 803-1804$.

“ privy council. Jan. $12-J u n e$ II, I802.

Letters from Bentinck, enclosing:

Minutes of privy council. Aug. 6-Nov. 5, 1802.

“" legislative council. July 7-Dec. $14, \mathrm{I} 802$.

" " legislative council. Jan. I8-June 20, 1803 .

" "legislative council. Jan. I8-June 20, 1803 .

Journal " assembly. Aug. 6, I802-June 20, I803.

Minutes “ privy council. Sept. $3-26,1803$ 
Minutes of legislative council. July 4-Oct. $26, \mathrm{ISO}_{3}$.

" " privy council. Apr. 3 -June 7,1804 .

19. ISO5.

Journal " assembly. Mar. 6-June 7, I804.
Minutes " legislative council. Mar. 6-June $7,1804$.

Letter from Bentinck, no. I2. Mar. 30, I805. Encloses:

Minutes of legislative council. Öct. $23-\mathrm{Dec} .4$, I804.

" " privy council. Oct. $23-$ Nov. 20, I 804.

" "legislative council. Jan. 8-Mar. 22, ISO5.

" " privy council. Jan. 8-Mar. 22, I805.

Journal “ assembly. Oct. 22, I804-Mar. 23, 1805.

$I d$., no. I9, giving information that such intercourse as took place with other colonies was under Danish and Swedish colors, the American

20. I806. vessels being hampered by embargo at Barbados. July I4, I805.

Letters from Gov. Beckwith, enclosing:

Minutes of legislative council. Apr. I8-Dec. 4. 1805.

Journal " assembly. Aug. 7, I805-Mar. 4, I806.

Minutes " privy council. May 2-Dec. 3, I805.

“ " " "legislative council. May I-Sept. 30, I806.

21. 1806 .

Journal " assembly. May 5-Sept. 30, I806.

Letter from Beckwith, no. 29. Nov. II, I806. Encloses accounts of shingles and provisions imported, Jan. I, I794-Dec. 3I, I805, distinguishing place of origin; also of sugar, rum, and molasses exported, distinguishing destination.

$I d$., no. 35. "The great object of the American intercourse is the Market for Rum and Molasses." Dec. 20, I806.

22.

Letter from Beckwith, no. 5o. Describes lack of salt provisions: American vessels "have ceased to resort as formerly to this colony". Port of Kingstown opened for two months for all provisions. May I5, 1807 .

Id., no. 2. June 9, I807. Encloses:

Minutes of privy council. Oct. 23, r8o6-June 6, ISo7.

" "legislative council. Oct. I, I806-May 12, I807.

Id., no. II. Aug. 19, 1807. Encloses account of provisions imported, May I5-July I5, I807, under proclamations issued May I5 and July 3 .

24. 1808 .

Letter from Beckwith, no. 3o. Seizure of American vessel, the Alligator.

The governor's one-third share and that of the king relinquished owing to "the critical situation of affairs between His Majesty's Government, and the American States". Mar. 5, I808.

$I d$., no. 36. Sends letter from collector and comptroller of customs, describing system of trade "recently established" by act of American

29. 1812. Congress. May I6, 1808.

Letter from Pres. Paul, no. 34. Refers to steps taken to guard against dangers from foreigners. June Io, I8I2.

Letter from Brisbane, no. 4. Acknowledges receipt of letter of Sept. I4 transmitting copy of act regulating trade with the U. S. Nov. 6, I 812. 
30. $\mathrm{I} 8 \mathrm{I} 3$.

Letter from Brisbane. Acknowledges receipt of letter of Nov. 16 relative to coin or bullion found on board American vessels. Jan. I6,

32. $18 \mathrm{I} 5$. I8I3.

Letter from Brisbane, no. II2. Acknowledges receipt of circular of Dec. 27, giving information of signature of Treaty of Ghent: hostilities not to cease before ratification. Mar. 8, I8I5.

Id., no. I29. Permission granted for landing of "a few Cargoes of American Lumber". July I8, I8I 5 .

C. O. 261 : 2. Board of Trade: Entry-Book. i 783.

2. 1783 . Instructions for Gov. Lincoln.

C. O. 26i : 3-8. Secretary of State: Entry-Books. i776-i8io.

3-4. $1776-1780$. In-Letters.

5-8. I789-1810. Précis of Correspondence.

1. $1768-1769$.

C. O. $262:$ I-3. Acts.

2. $1769-1772$.

3. $1774-1777$.

C. O. $263:$ i, 2. Sessional Papers.

1. I769, Apr. I3-June 7 .

I77 I, Nov. 29-1772, June 26.

I772, July IO-I 774, Dec. 22.

I775, Feb. 6-Dec. 22.

Minutes of council, pp. I2.

(These seem to be council in assembly though there is no statement to that effect.)

2. I769, Mar. 22-June $7 . \quad$ Journal of assembly, pp. 4I.

I770, Dec. I7-I77I, Dec. 9. " "
but see the following), pp. 86.

I77 I, Nov. 28-I772, May II. Journal of assembly (Nov. 28 to part of

Dec. 9 is a repetition of above), pp. 54 .

I774, Apr. 27-I775, Apr. I7. Journal of assembly, pp. 66.

i775, May i8-i776, Mar. I. " " "

1. Inward:

$$
\text { C. O. } 26_{5} \text { : i. Shipping Returns. }
$$

I 763 , July $30-1765$, June $25^{2}$

Outward:

Same periods as inward returns.

With shipping returns is an account of the number of ships, and cargo totals, cleared annually, Apr. 6, I788-Apr. 6, I792.

\section{SANTO DOMINGO.}

C. O. $245:$ i-2. Secretary of State: Original Correspondence.

1. $1693-1805$. I693-I805.

Exports of produce for I788.

2Partly custom-house and partly naval office returns. There is duplication for the period Jan. I, I $764-J$ an. I, 1765 . 
Memorandum of plantations and works in French part of island. I788.

Papers on regulations for permitting coasting-trade to continue without interference. I803-1805. In particular, case of schooner Dart, W. Z. Nicoll master, sailing from Baltimore to Cap Français and seized at Nassau, I805. Question whether Haytians to be regarded as enemies of French.

Letters and other papers on negotiations with Toussaint. Relate to dangers to Jamaica from insurrections in Santo Domingo, and use of troops from Jamaica for suppression. In particular, corrected drafts of secret despatches to Balcarres on relations with Santo Domingo, Mar., I80o; statement of finances of Santo Domingo, 1799; and letter from Edward Stevens, U. S. consul at Cap Français, to commanders of armed American ships, recommending that they should not molest commerce of Santo Domingo as its government is attempting to prevent assaults by French privateers on American commerce.

Draft of letter to Col. Picton, on export of negroes from Trinidad, in pursuance of royal instructions to commanders of war-vessels and privateers, issued June 24, I797. Mar., I798.

Letters from Gen. Simcoe, captain-general and commander-in-chief of British forces at Santo Domingo. 1797.

"Abstract of the Army who were actually upon the Island of San Domingo the fourth day of June 1764 when the Town of Port au Prince was reduced by the British Forces, and who consider themselves Intitled to a Share of the Prize Money arising from the Sales of Property captured at that Place." I795.

Papers on British occupation of Santo Domingo, showing relations of Santo Domingo with the Convention, and emigration to Jamaica.

"Ordres et Memoire pour Monsieur P. L. Doger Commandant le Navire Le Veillon destiné pour St. Dominigue." I 779.

Letter from Lanarge to Count Maurepas on need for military precautions against the English. Partly in cipher, which has been deciphered. Aug. 22, I744.

2. $1737-1799$.

"Arrêt du Conseil Supérieur du petit Goâve", for securing more regular baptism of infants. I737.

Forty-two letters and decrees addressed by the "Agent Particulier du Directoire Exécutif à Saint-Dominigue" to Toussaint L'Ouverture, and others, "le $7^{\mathrm{e}}$ de la Rẻpublique française, une et indivisible".

\section{SURINAM. ${ }^{1}$}

C. O. 278: 1. Secretary of State: Orteinal Correspondence. $1728-1800$.

C. O. 278:io-II. Misceldaneous. 1752.

1. $1728-1800$.

"Memorial of Jeronimy Clifford complaining of the hardships sustained by him from the Dutch Governor of Surinam in the disposal of his Estates in that Colony." I685-1695. July 9, 1705. Related papers.

"Memorandum respecting Surinam", briefly sketching history. I800.

10-11. 1752. (See Andrews, I. 221.)

${ }^{1}$ See also British Guiana. 
C. O. $278: 4-6$. Précis of Correspondence. I I $799-1813$.

4. $1799-1805$.

Letter from Gov. Friderici, giving account of trade with America before the war. Oct. I7, I80I.

Letter from Sir Charles Green, transmitting copy of proclamation allowing importation in neutral bottoms for four months. Dec. 29, I804.

TOBAGO.

C. O. 285 : i. Board of Trade: Original Correspondence. I778-1781.

1. $1778-178$ I. (See Andrews, I. 222.)

C. O. $285: 2-20$. Secretary of State: Original Correspondence. I $700-18$ I 5 .

2. $1700-1808$.

Extract from representation on British title to Tobago. June 2, I709.

Letter from Board of Trade to Lord Townshend, asking that island may be included within Lord Irwin's commission as governor of Barbados. Feb. I 5, I720/I.

Copy of Montagu's petition for grant of Tobago. 1722.

Letter from Board of Trade on French claim to Tobago. Apr. I4, I725.

"A State of the Right of the Crown of Great Britain to the Island of Tobago", 1732. "Paper of Facts relative to the Island of Tobago delivered Dec. 2I, I748 from the Earl of Halifax."

Representation on the British title, enclosed in a letter to Bedford of Jan. $26,1748 / 9$.

Letter from Board of Trade to Bedford, with extracts from letters of Gov. Grenville of Barbados, on measures adopted for asserting his Majesty's sole right to sovereignty over Tobago. Jan., I748/9.

Id., on French settlements. June 22, I748. Enclosures.

Letter from Board of Trade to Pitt, enclosing extract of letter from Pinfold to Board, on publication of his conmission in Tobago and on conditions there. Apr. I2, I758.

Memorial of proprietors of Tobago against relinquishment of island to France or Spain. I783. Other papers.

Proclamation of G. P. Ricketts, captain general and governor in chief of Tobago, "Hereby permitting and allowing of the importation from America in American bottoms of provisions of all kinds, of lamp oil, and of all such articles as are admissable by law from America in British bottoms, and of the exportation of rum and molasses in American bottoms in return, for the term of four months of the date hereof". Apr. 23, 1794 .

Letters from Ricketts to Committee for Trade and Plantations, showing conditions in island. I794.

Petition from John Balfour, president and commander-in-chief in Tobago, on observance of proclamations issued Sept. I7 and Oct. I. I806, on importation from the U. S. Jan. I7, I807.

"Garrison Monthly Return." May I, Aug. I, I807.

List of public officers. June, I 807 .

Despatches from Gov. Young. I807.

Copies of Tobago Gazette. October I6, Nov. I3, I807; Oct. I4, I808. 
3. I794-I795.

Letters from Pres. Robley and Gov. Lindsay, enclosing:

Minutes of council. Jan. 6-June I6, I794.

Oct. 9, I794-June 19, I795.

4. $1795^{-1} 797$.

Letters from Gov. Lindsay, Pres. Campiell, and Gov. Delancey, enclosing:

Minutes of council. June 29-Aug. I5, I795.

Journal " assembly. Apr. 6-Aug. I5, I795.

Minutes "council. Feb. 3-June I, I796.

" " " " $"$ June I5-Sept. 8, 1796.

Journal " assembly. July 21-Aug. 23, 1796.

Minutes " council. Jan. 3-Aug. 30, r797.

" "privy council. Jan. 3-Aug. 30, I 797.

Letter from Gov. Lindsay, no. 23. Has extended time limit for opening of ports. Feb. I, I796.

Letter from Pres. Campbell, no. 5. Acknowledges receipt of circular of Dec. 9 relative to exportation of sugar to America: no sugar has been exported, rum and molasses having been found sufficient to pay for American provisions. Feb. 19, 1797.

5. $1798-1799$.

Letters from Gov. Delancey and Pres. Robley, enclosing:

Journal of assembly. Sept. 4, I797-June 25, 1798.

Minutes " privy council. Sept. 5-Dec. 23, 1797.

“ “ council. Sept. 4-Nov. 2, 1797.

" "council. Jan. I7-June I2, I798.

" " privy council. Jan. 24-Sept. I 7, I 798.

" " council. June 25-Sept. I2, 1798.

Journal “ assembly. Oct. I-Dec. I2, I798.

" " " Apr. II, I799.

Minutes “ privy council. Sept. 25, I798-May 4, I799.

“ " council. Sept. 25, I798-Jan. 21, I799. Journal “ assembly. Jan. I4-Feb. I I, I799.
"May 16-I7, I799.

6. I799-1800.

Letters from Gov. Master, enclosing:

Minutes of privy council. Dec. 3, 1799-Jan. 28, 1800.

" "council. Oct. 3, I799-Aug. 8, I800.

Journal “ assembly. June Io-Oct. 3, r799.

" " " " Dec. 3, I799-Jan. 9, I800.

7. $1800-1801$.

Feb. 5-May 16, I800.

Letter from Pres. Robley, no. 5. Dec. 22, I80o. Encloses proclamation on admission of provisions. Dec. Io, 1800 .

10. 1805 .

Letter from Pres. Campbell, no. 25. American vessels permitted to enter, but "few make their appearance on account of the alarm which has spread among them". Sept. I, I805.

Among miscellaneous papers at end of volume is departmental correspondence with Board of Trade on importation from America. 
11. ISO6.

Letter from Pres. Balfour, no. I5. Dec. 16, 1806 . Encloses accounts of

12. 1807 . imports from America, Jan., I794-Jan., I806.

Letter from Gov. Young. July 20, I807. Encloses returns, etc., of

13. 1808 . provisions imported in nine months ending July 1,1807 , distinguishing place of origin.

Letter from Young, reporting intelligence that "the American Congress is leaning to Hostility with Great Britain". Jan. 29, I808.

Id. Encloses statistical report of Tobago, Apr., I808: including imports 14. I809. from the U. S., I805-I807, and return of shipping. Apr. 27, I808.

Letter from Young. American brig in Scarborough Bay. Another American vessel last week proceeded elsewhere when it was found it could not land the whole cargo. Advantage taken of confusion between La Guaira in S. Am. and La Guira, an old Indian village in Tobago, under instructions of Apr. I, I808, to pass over irregularity in papers of neutrals. May 25, 1809 .

Id. Duties on neutral fish and vessels. Americans warned, and did not bring fish; eleven Americans arrived last week with corn, lumber, etc. June 29, I809.

15. I8Io.

Id. Arrival of 26 American vessels since July I. July 27,1809 .

Letters from Young, on American trade: vessels evade embargo and non-intercourse acts by clearing for Spanish Main and then procuring a forged clearance in a Spanish name at a W. I. island. Feb. I3, Apr. I4, May 4, I8Io.

Id. Arrival of three American vessels with regular clearances for Tobago. Embargo and non-intercourse act must be no longer in force. June 30,1810 .

Id. Nov. 2, I8Io. Encloses printed Mimutes of Assembly, Sept. 4-Oct. I3, I8ro.

Id., relating to passage of bill imposing duties on imports in neutral vessels. Dec. 4 , I8Io.

16. I8II.

Letter from Young, giving particulars of imports of fish from Br. N. Am.

17. I8I2. and the U.S. June I2, I8II.

Letter from Young. Acknowledges receipt of circular on admission of

20. $18 \mathrm{I} 5$. foreigners. May $17, \mathrm{I} 8 \mathrm{I} 2$.

Letter from Pres. Balfour, no. 9. Acknowledges advice of ratification of treaty with the U.S. Gives cletails of trade of colony. May 3, 1815 .

Id., nos. I1, I9. June 3, Aug. 24, 1815. Encloses:

Minutes of privy council. May 8,1815 .

Mimutes of Asscmbly. July I I-I5, I8I5.

C. O. 286: I-5. Secretary of State: Entry-Boors. I703-18i7.

1. ISOI-1807. Précis of Correspondence.

2. $1793-1803$. Out-Letters.

3-4. I703, I794. Précis of Correspondence. 
5. ${ }^{1}$ I80I-1817. Out-Letters.

1. $\mathrm{r} 768-\mathrm{r} 78 \mathrm{r}$.

C. O. $287:$ I. Acrs.

C. O. 288: I-3. Sessional Papers.

1. I768, July I I-I6. Journal of assembly, pp. 20. I769, July 12-1771, Mar. 12." “" " I771, July 16-1772, Mar. 17. “ “ “ " pp.53. I772, June 15-1773, June 12. “ “ “ "Great seal taken off”), pp. 56.

I773, Nov. 2-I774, Apr. 9. pp. 63 .

I774, Apr. I I-I775, Mar. 7. “

pp. 59.
I775, July 4-Aug. I2. pp. 49.

I775, Oct. 5-1776, Apr. 2. pp. 69.

I776, Apr. 4-13. pp. 27.

2. I 768 , June $29-$ July I8. 1768, Sept. 7-1770, July 18. I770, Sept. 24-1771, Mar. 12. I771, July 29-1772, Feb. I8. 1772, Mar. 24-1773, Jan. 21. off"), pp. 48 .

I773, Apr. 6-Nov. II.

1774, Jan. 25-1775, Mar. 6. “ “ “ (Title-page: "Legislative Minutes commencing from the IIth day of Nov. I773 to the 6th day of March 1775": Is certified as from Jan. 25, I774.) Pp. 62.

I774, Jan. 25-Nov. 4. Minutes of council. (Title-page: "Privy Council Minutes commencing from the IIth day of Nov. I773 to the 6th day of March I775". Certified as Jan. 25, I774-Mar. 6, 1775.) Pp. I3.

I775, June 24-Aug. II. Minutes of [privy] council (certified as June I-Aug. 12 ; to this and each of the following there is a sealed attest), pp. ro.

I775, July 6-Aug. I2. Minutes of council (certified as "Legislative business", June I-Aug. I2), pp. 32 .

1775, Oct. 5-13. Minutes of council (certified as "Legislative business", from Aug. I2), pp. I8.

1775, Oct. 6, 9. Minutes of privy council (certified as from Aug. 12), pp. 4.

I776, Feb. 20-Apr. 13. Minutes of privy council (certified as to June 30 ) , pp. 7 :

1776 , Feb. 20-May 16. Minutes of council (certified as "Legislative", to June 30 ; the title-page for this calls it "Council in Assembly"; "Great seal taken off"), pp. 53 .

${ }^{1}$ Numbering of volumes in Lists and Inderes, no. XXXVI. does not correspond to above, which is actual numbering on volumes. 


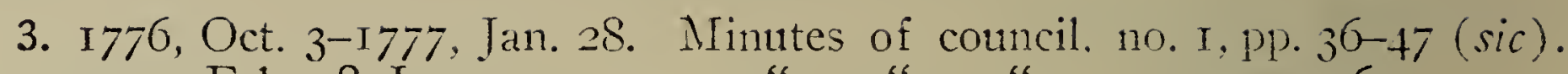

I777, Feb. I8-June 23.

I777, June 27.

I777, Aug. 2I-I778, Nar. 24.

I780, Feb. 23-July I I.

I 776 , July I-I 777 , Jan. 22. pp. I 78-193 (sic).?

I777, Feb. I8-June 27.

no. 4 , pp. 22.

I777, June 28-I778, Apr. 9.

pp. 33 .

I780, Apr. IO-July 7.

no. $5, \mathrm{pp} .24$.

I780, Nov. 2. Minutes of council (a loose paper "enclosed in a letter of I8 Jan. I785"), pp. 4.

I777, Feb. I8-June 28. Journal of assembly. Duplicate, no. 7, pp. 79. I778, Jan. 6-Apr. Io.

I780, Apr. Io-May 6.

I780, May I5-June 17.

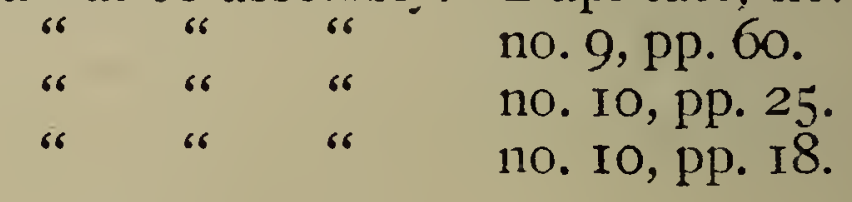

C. O. 290: i. Shipping Returns.

1. Inward:

I766, Oct. I-I767, July I.

Outward:

Same periods as inward returns.

\section{TRINIDAD.}

C. O. $295: 3$-37. Secretary of State: Original Correspondence.

3. 1802 .

$$
\text { I802-1815. }
$$

Draft to "Commissioners for administering the Government of . . . Trinidad". No. 3. Sends letter referring to information from British chargé d'affaires in America as to probable emigration of British subjects in America to Trinidad. Dec. I5, I802.

"Account of Duties received in Cargoes of Vessels Inwards and Out4. 1803 . wards at Trinidad." Jan.-Dec., I802.

Letter from Gen. Picton, no. 3. Apr. 2, 1803. Encloses minutes of council, Jan. 4-Apr. 2, 1803 .

Returns of shipping, British and foreign, and of imports and exports.

6. I8o3. Jan. 6-Apr. 6, I803.

Among miscellaneous papers at end of volume is a detailed plan for encouraging Scottish emigration to Trinidad instead of to America. Apr., I803.

7. 1803 .

Letter from Lieut.-Gov. Hislop, no. 9. Nov. 24, I803. Encloses memorial from John Rutherford, a Loyalist, asking for grant of land.

\footnotetext{
${ }^{2}$ Minutes for July $1,1776-J u l y ~ 7,1780$, are grouped and endorsed, "Council in Assembly".
} 
9. 1804 .

Letter from Lieut.-Gov. Hislop. Encloses extract from minutes of council, Nov. 22, I804, deprecating prohibition of intercourse with America: sole source of revenue is duty of $3^{\mathrm{T} / 2}$ per cent., of which

11. 1805 . half is raised on American trade. Dec. 18, I805.

Letter from Lieut.-Gov. Hislop, no. 2, relative to prohibition of trade

14. 1806. with America except in provisions and lumber. Apr. 5, 1805.

Letter from Lieut.-Gov. Hislop, no. 30. Nov. 9, I806. Encloses accounts of imports from the U.S. and Br. N. Am. and exports to the U.S.,

15. 1806 . 1802-1805, distinguishing nationality of shipping.

Among miscellaneous papers is a memorial from Archibald Gloster, agent .

17. 1807. for Trinidad, relative to American intercourse.

Letter from Board of Trade to office of Secretary of State, relative to American intercourse. Feb. I0, 1807.

Letter from chairman and deputy of East India Company to Castlereagh, with enclosures (dated 1803) relative to American trade with Indian and Chinese ports. Apr. I, I807.

Letter from Joseph Marryat, agent for Trinidad, referring to memorial being sent from Trinidad on trade with America. Apr. 29, 1807.

18. I807. Proceedings against the Fortitude from the East Indies, laden with goods adjudged contrary to Navigation Acts.

21.

Letter from Gov. Hislop, no. 5. Refers to losses consequent on American embargo. Feb. 22, I809. Encloses account of vessels inwards and outwards, $1804-1807$.

26. I8I I.

Among miscellaneous papers are letters from Doctors Commons to office of Secretary of State, relative to condemnation of American ship Adams. Feb. I5, 22, I8I I.

28. I8I2.

Letter from Maj.-Gen. Monro, no. II, dealing with admission of foreigners via America or otherwise. May 17, I812.

Id., no. 12. June 29, I812. Encloses memorial relative to the Adams.

Id. Acknowledges receipt of order in Council of July 31, I8I2, directing detention of vessels of the U. S. Sept. 28, I8I2.

Id., no. Io. Acknowledges receipt of act of Parliament relative to trade with America. Nov. 3, I8I2.

Id., no. II. Acknowledges receipt of circular of Sept. I2, relative to coin or bullion found on American vessels. Nov. 3, I8I2.

$I d$., no. I4. Acknowledges receipt of order in Council of Oct. I3, authorizing general reprisals against ships, goods, and citizens of the U. S. Dec. I2, I8I2.

29. 1813.

Letter from Maj.-Gen. Monro, no. 5. Acknowledges receipt of circular of Nov. 16, relative to coin or bullion found on American ressels. Jan. II, I8I3.

Id. Acknowledges receipt of circular enclosing declaration issued by the Prince Regent on causes of the war. Mar. 5, I8I3. 
36. $18 I_{5}$.

37. 1815 .

Letter from Gov. Ralph Woodford, no. 85 B. Receipt, Apr. I, of news of ratification of peace with the U.S. Apr. I8, I8I5.

Letter from Woodford, no. I03. Arrival of refugee American negroes, desirous of receiving grants of land: mostly creoles, intelligent and well-developed, particularly those from New Orleans. June 6, I8 I 5 .

Id., no. I 3 . Arrival of 58 refugee American negroes, "principally from the Indian country". Aug. 5, 18 I $5_{5}$.

Id., no. I32. Refusal to permit an American to practise surgery in the island without examination. Nov. $30, \mathrm{I}^{8} \mathrm{I} 5$.

Id., no. I34. Arrival of 66 American refugees, including three whites. Nov. 30,18 I 5 .

C. O. $296:$ I-5. Secretary of State: Entry-Books. I797-I823.

1-2. 1797-1807. Précis of Correspondence.

3. I799-1823. Id. (A compilation dated July I, 1825.)

4-5. I $80 \mathrm{I}-\mathrm{I} 82 \mathrm{I}$. Out-Letters.

\section{VIRGIN ISLANDS. ${ }^{1}$}

C. O. 314: I. Secretaky of State: Original Correspondence.

$$
\text { r7II-r79r. }
$$

1. I7II-1791. (See Andrews, I. 223.)

1. $1774-1788$.

$$
\text { C. O. 3I5: I. Acrs. }
$$

\section{O. $316:$ I. Sessional Papers.}

1. 1773, Apr. 23-1776, Jan. 22. Minutes of the council for the Virgin Islands, held at Tortola, no. I, pp. I25.

I776, Jan. 30-Mar. 20. Minutes of council (a loose paper), pp. 24.

1776, Apr. 6-Aug. 29. “ “ “ “ " "

I777, July 5-Sept. 30. " " " " no. 5, pp. 28.

1775, Feb. 24-Aug. 7. Journal of assembly, no. 6, pp. 29.

I775, Feb. 24-Aug. 7. " " " (similar to previous item but not precisely the same), no. 7, pp. 28.

1775, June 6-1776, June 17 . Journal of assembly, no. 8, pp. 30 .

I776, June 12-1777, Sept. 20. "Minutes of the House of Representatives of the Virgin Is. from the rath April I776 to which date they were with duplicates sent to the Hon. Craister Greatheed Esq. then Commander in chief of his Majesty's Leeward Charibbee and Virgin Is. in America", no. 9, pp. 156.

1777. July 14-Aug. 2. Minutes of the "House of Representatives" (so styled in the headings; endorsed as minutes of assembly), no. I I, pp. 26.

I777, Oct. 21, 29, Nov. 5, 12, 19, 26. Meetings only of the "House of Representatives"-no business (two copies), pp. 5 .

1778, Apr. 8-Aug. 6. Journal of assembly (headed as Apr. I-Oct. I), no. I2, pp. 49.

1778, Apr. 8-Aug. 6. Duplicate of above, no. 13, pp. 40.

I778, Oct. 2I-I780, Sept. 26. Journal of assembly, no. I4, pp. 83 .

${ }^{2}$ See also Leeward Islands. 


\section{WEST INDIES.}

C. O. 318: i-2. Board of Trade: Original Correspondence. i624-i8o8.

1. 1624-1808. (See Andrews, I. 223-224.)

Much information on history of trade in sugar and other plantation products, contrasting British with French methods and results, and throwing light also on readjustment of commercial relations after the American Revolution. Some at least of the papers were prepared under direction of George Chalmers and William Collow. Some tables identical with those in Whitworth. The following documents are listed as representative:

Signed and sealed statement of prices of Santo Domingo sugar at Hamburg, with notation of exchange there on London and Paris, I750-1790.

Prices of sugar at Bordeaux, I750-1790.

Tables of imports from British and foreign W. I.

Accounts of duties collected in England on W. I. produce.

Copies of orders issued to W. I. officials for limiting commerce in W. I.

Minutes of committee of Council, showing proceedings on effects of treaty of 1786 with France, and on opening of free ports. Nov. I4, I786. Many papers on trade at free ports.

"Sketch Committee Report respecting the Trade between the West Indian Islands and the United States of America." May 3r, I784.

Statistics on trade of W. I. with other islands, showing shipping employed. I783-I787.

Accounts of trade between France and French W. I.

Detailed tables showing trade between Br. W. I. and N. Am. I785I 787.

Detailed table of all vessels clearing from Br. W. I. for all parts of the world; accounts of quantities of all principal articles imported and exported; and accounts of revenues collected on same. Jan. 5, I787-Jan. 5, I 788.

Estimate of value of property in $\mathrm{Br}$. W. I., totalling $\epsilon_{37,257,73 \mathrm{I}}$ I3s. $4 d$. Undated.

Account of produce of Martinique and Guadeloupe. I79r.

"An account of the Number of Ships with their Tonnage which Entered and Cleared in the several British West India Islands, distinct as from and to all Ports during the years I790, I79I, and 1792, distinguishing the Inwards and Outwards Shipping, . . Pursuant to an Order of the Right Honorable the Lords Committee of Council for Trade." Aug. I9, I793.

Minutes of "West-India Merchants", including report of committee to facilitate discharge of ships. Dec. 20, I793.

Copy of memorial of W. I. planters and merchants to Dundas, on intercourse with the U. S. I793 (?). Also correspondence between Sheffield and Chalmers on same. I794.

Memorials on depressed state of sugar trade. I799.

Copy of order in Council for granting licenses for British vessels carrying specified articles to go to places in the W. I. not under immediate dominion of his Majesty's enemies. July 21, 1806 . 
Copy of minutes of assembly of Jamaica, relating to sugar duties and depression of trade. Nov. 13, I807.

"Remarks on Causes of the Distress of the West Indian Plantations, and on the Plans Proposed for their Relief." 1808.

2. 1627-1807. The following documents have been noted, in addition to those described in Andrews:

Extensive statistics on slave-trade, for all islands and for separate islands; giving figures for particular years, or averages for several years.

Answers to customary queries for various islands. I773-1774.

Copy of letter of Charles Long, Treasury Chambers, May 8, I792, to clerk of Council, on quit-rents in the colonies, and especially in Dominica. Governor of Dominica believes that "there is no other Island where Quit Rents is payable on Leasehold Land except St. Vincents, the Inhabitants of which conceive themselves exonerated of that Charge under an agreement made with the French Government". Other papers on quit-rents.

Abstracts of reports on population of Jamaica, I698-I787; with account of negroes imported and exported, I739-1749.

Trade statistics for various islands.

Papers on slave-trade, showing percentage of deaths in transit.

Statistics of population in Barbados, I748-1 786.

Account of militia in Barbados. I783.

Many papers on the Bahamas and Turks Islands.

Lists of references to accounts of population and other matters in Board of Trade Original Correspondence, for Bermuda, Grenada, St. Vincent, Dominica, and Carriacou, 1773-1775.

Petition of committee appointed in Dominica, for leave to apply to Parliament for legislation to restore and amend acts establishing free ports there. I784. Other papers on free ports.

Memorial of W. I. planters and merchants, expressing fears of slave insurrections arising from "the new Language and Proceedings held in this country respecting the Slave-Trade". I79I.

Accounts of principal exports from Santo Domingo. I783-1789.

C. O. $3^{18}: 3^{-47}$. Secretary of State: Original Correspondence.

3. $1699-\mathrm{r} 78 \mathrm{I}$. I699-1812.

Papers on packet-service, including: representation of Committee of Trade to Nottingham on Dummer's proposal for "a Course of Correspondence with Her Majesty's Islands, Plantations in the West Indies"; report from Dummer on first year's operation of four packet-boats giving monthly.service and carrying mail, Sept., I703; copy of order to commanders of packets on carrying of freight and passengers.

Papers on naval matters, including: line of battle of seven British ships going into action on "the Maine Continent of America", Aug., I702, under Adm. Benbow, showing plans and tactics; correspondence of Benbow with Admiralty and with governors of foreign plantations, showing division of prize money; list of twenty-three vessels with number of men on board, and numbers who have died or deserted since reaching the W. I., Jan., I702/3; and letters to Admiralty from other naval officers.

${ }^{1}$ Chiefly military and naval despatches. 
Letters descriptive of various islands and of trade with Spanish W. I. in time of war. I702-1703.

Military papers, including: instructions for Maj.-Gen. Spotswood, Apr., I740; schedule of money, clothes, and arms furnished to Col. Blakeney, I740; copy of instructions on military operations sent to colonial governors in N. Am., I740; commission issued to Spotswood as colonel of regiment to be raised in N. Am.; draft of instructions to Spotswood, Blakeney, and governors of continental colonies for levying troops, Janl., I739/40; Spotswood's commission as major-general and quartermaster-general, Dec. 26, I739; draft of Cathcart's instructions, and of letters to governors of Jamaica and Leeward Islands, May, I740; quotas of troops to be raised in various continental colonies, I740; draft of Cathcart's instructions for distribution of plunder; copy of Gen. Wentworth's instructions for recruiting officers in N. Am., Aug. I2, I74I ; and statement of forces in the W.I., and of proposed reductions, $1764-1774$.

"Representation of the Lords Commissioners for Trade upon a Paper delivered by Mon. Maurepas to Ld. Waldegrave for preventing disputes in the West Indies." Apr. 21, 1737.

Papers on disputes with Spaniards over seizures, I728-I729; pardon of pirates, I718; and Franco-Spanish trade.

Form of letter sent to governors of W. I. islands authorizing them to grant letters of marque. June I5, I739.

Heads of agreement between Royal A frican Company and sundry IV. I. merchants.

Petition of Hutchinson Mure of London, merchant, for permission to carry slaves in British ships to the W. I.

"Libro de Servicios de los Oficiales y Sargentos de las tres compañias de Infanteria Ligera de la Havana, Reglado Hasta Fin de Diciembre de $1778 . "$

4. $1782-1783$.

Circular, July 7,1783 , to governors of Jamaica, Barbados, Leeward Islands, and Bermuda, relative to order in Council of July 2 regulating trade with the U.S.

Small bundle marked "Calculations etc. relative to the Trade between the West Indies and America".

5. I $778-1779$.

Letters from Maj.-Gen. Grant, unnumbered and nos. 7, 8, I I. Details military position at St. Lucia, and encloses returns of state of troops. Jan. 6, Apr. 4, May I 3, I779.

Id., no. I3. Describes naval action in attempt to retake St. Vincent and save Grenada. July 8, I779.

$I d$., no. I4. Describes military and naval situation in the W. I. July $I 7$, I779.

"List of Papers delivered in by Major General Grant Sept. I779", dated Nov. 20, I778-May 31, 1779, describing the military situation in the W. I.

6. $1779-1780$.

Draft to Maj.-Gen. Vaughan, describing project of attack on Porto Rico. Dec. 7, I779.

Letters from Vaughan, describing the military situation in the various islands. Feb. I4, Mar. 9, 28, Apr. 25, May 31, June 19, I780. 
7. $1779-178 \mathrm{I}$.

Letters from Robert Prescott (St. Christopher) and Henry Calder (St. Lucia), enclosing state of troops, St. Christopher and St. Lucia, at nine successive dates.

Letter from Prescott. "The Island of Eustatia is a Magazine for the French and Rebels and greatly supplied by Ourselves." Nov. 20, I779.

Letter from Adm. Rodney (St. Eustatius), enclosing papers proving correspondence of Dutch with the rebels. Supplies furnished to latter; British subjects settled in the island assist in intercourse. Mar. I8, I78I.

Letter from Brig.-Gen. Christie, no. I. Encloses letters from Sir Henry Clinton at N. Y. and Adm. Rodney. He has sent the 4oth Regt. to N. Y. to be returned by Nov. Aug. 20, I78I.

Id., no. 3. The 40th Regt. not likely to be returned. Nov. I8, I78I.

8. $\mathrm{r} 780-\mathrm{r} 78 \mathrm{r}$.

Letter from Maj.-Gen. Vaughan. Offensive operations impossible in spite of arrival of $I$ st, I $3^{\text {th }}$, and 6gth Regts. Barbados, Jan. 25, 1781 .

Letter from Adm. Rodney. Encloses copies of intercepted letters giving evidence of correspondence between certain inhabitants of Grenada and the French. Barbados, June 29, I78I.

Letter from St. Leger to Vaughan, describing French attack on St. Lucia, May 12. May 14,178 I.

9. I78I-I 782 .

Letter from Maj.-Gen. Christie. Capture of St. Eustatius and St. Martin by Marquis cle Bouillé. Barbados, Dec. I5, I781.

Id., no. 9. Describes the military situation. Feb. 17,1782 .

Id. Mar. 10, I782. Encloses papers relative to attack on St. Christopher Feb. I3; also state of troops, St. Christopher.

Letters from Maj.-Gen. Mathew. Apr. 16, 22, I782. Encloses state of troops, St. Lucia.

10-45. $1783-1812 .^{2}$

46. I8I2.

Letter from Gov. Beckwith. Military I68. Reports receipt of infor-

47. 1812. mation of declaration of war by the U.S. July $22, \mathrm{I} 8 \mathrm{r} 2$.

Letter from Beckwith. Military no. 2I. Encloses copy of advocate general's opinion on treatment of vessel arriving from the U. S. under Swedish colors. Nov. 7, 18I2.

Id., no. 23. Encloses report of engagement with American privateer schooner near northern extremity of island on Dec. 7. Dec. $21,1812$.

C. O. 3I9: I-20. Secretary of State: Entry-Books. I699-I8i6.

1. I699-I710. (General description in Andrews, I. 224.)

Additional instructions, dealing with disposal of prizes and division of prize money, cartels for exchange of prisoners, punishment of offenders in matters of state, and land titles. Acts dealing with establishment and regulation of courts, sales under distraint for rent, attempts to supply currency for island, etc.

2. I7 I8. (See Andrews, I. 224.)

${ }^{2}$ Volumes not examined in detail. 
3. $1783-1794$. Instructions to Governors, St. Vincent, Grenada, Dominica, and the Baliamas.

4. I789-1796. Instructions to Governors, Jamaica, Tobago, Bermuda, Barbados, Santo Domingo, and Martinique.

5-9. 1793-1807. Précis of Military Correspondence.

10. I80I-I8I4. Précis of Despatches, Bahamas, Dominica, Perbice, Demerara, and Essequibo.

11. I80I-18I4. Précis of Despatches, Grenada, Honduras, Leeward Islands, and St. Lucia.

12-20. $1792-1816$. Out-Letters. 


\section{WEST INDIA COMMITTEE.}

At the offices of the Committee, I4 Trinity Square, London, are preserved certain volumes of minutes of the old committees. Any application with regard to this naterial should be made to Mr. Algernon Aspinall, C. M. G.

"West India Committee, Minutes, West India Merchants."

This is the main series of minutes. Many petitions, reports, and letters are entered. The amount of material relating directly to North America is scanty, as can be seen from the subjoined list. There is, however, a much larger quantity dealing with trade, navigation, the particular products and economic history of the West Indies, that is of value to any study of colonial development along broad lines. Thus, in addition to the items listed below, nearly every volume has material on such topics as freights, drawbacks, stealing from ships, lending of money by aliens in the British sugar colonies, etc. Information on the supply of lumber and provisions from America is also a fairly constant component. During the American Revolution many minutes deal with the convoying of ships, and some with other effects of the war on West Indian trade, privateers, etc.

Apr., 1769-Apr., 1779. (350 pp.)

Action taken on a letter from merchants of $\mathrm{Md}$. and Va. respecting appointment of a river-master. July $4,1769$.

Action with regard to effect on the sugar colonies of proposed regulations relating to Boston. Mar. 16,1774 .

Action as a result of measures taken by the Congress at Philadelphia tending to harm W. I. trade. Jan.-Feb., I775.

June, I779-Aug., I783. (224 pp.)

This volume has some material on the supply of lumber and provisions from N. Am. during the war, and also deals with naval defense of St. Lucia and the Leeward Islands.

Mar., x794-Dec., I802. Indexed. (393 pp.)

This book seems to contain little relating directly to America. The main topics are trade, and the establishment in 1798 of a Marine Police Institution to protect shipping in the Thames. The single exception is a long report of Sept. 24, 1799, on the present stagnation of foreign demand for sugar and coffee, which relates in part to trade with America.

Apr., I803-July, I804. Indexed. (81 pp.)

Sept., I804-July, I827. (428 pp.)

For the War of 1812 nothing was found beyond material on convoys.

May, 1785-Dec., 1792. Indexed. (223 pp.) Minutes of Standing and Certificate committees of West India planters and merchants.

These minutes are not complete for either committee. There are also a few minutes of general meetings. Trade with Br. N. Am. and its regulation are taken up by minutes for Apr. 5, 1787, Mar. 15, 1791, and Feb. 28, 1792 .

Feb., I793-Apr., I801. Indexed. (342 pp.)

This volume is a continuation of the preceding one, and relates mainly to commerce, and opposition to the movement to abolish the slave-trade. There are a few references to trade with America. 
Jan., I792-June, I804. Minutes of a subcommittee appointed by the Standing Committee.

They deal with opposition to the movement for abolition of the slavetrade.

Oct., 1799-July, i800. Minutes of a subcommittee of West India merchants. They relate to assistance given by the Bank of England to planters during trade stagnation. 


\section{ARCHIVES IN THE ISLANDS.}

The preface of this book has mentioned the Report on Records in the West Indies which Professor Charles H. Hull, of Cornell University, wrote after visiting many of the islands in the winter of 1905-1906. A copy of his manuscript, of which only a part was printed in the Second Report of the Royal Commission on Public Records ${ }^{1}$ was, with great kindness, placed by him at the service of the Department of Historical Research in the Carnegie Institution of Washington, for the purposes of the present survey. Use has been made of it, without much textual quotation, in the pages which follow. We here quote from it the following paragraphs of general statement, which are as applicable to the conditions of 1925 as to those of $1905^{-1906 .}$

"In general the archives of the British West Indies contain two classes of papers: the political records, generally in the custody of the Colonial Secretary, and the non-political records, generally in the custody of the Registrar.

"The political records include the journals of the council, sometimes in one series, sometimes in two (legislative and privy), the minutes of the assembly, the manuscript laws, and in some cases the letter-books of governors and of committees to correspond with the colonial agent. But there are few letterbooks preserved in the colonies dating before $178 \mathrm{I}$.

"The non-political records are of two chief classes. One comprises such papers, relating chiefly to the ownership and transfer of property, both real and personal, as the law required to be filed or recorded-these are always in the custody of the Registrar. The other comprises the proceedings, papers, and judgments of the courts-these are sometimes in the custody of the Registrar, sometimes at the court-house.

"In many cases the files are incomplete, because of damage by fire or hurricane, and not a few of the volumes that are preserved bear traces of neglect in the past. There are few lists and no calendars available.

"The law usually requires the payment of fees for the search of the records, or at least for the search of those in the keeping of the Registrar, but in general the insular governments show a willingness to waive that requirement in favor of a properly accredited student engaged in bona fide historical investigations, not of a genealogical nature. Such a student will meet everywhere with a courteous reception ; but he must not expect of overburdened officials, absorbed in current problems, that detailed knowledge of the older records which he has found in European archives."

It is also worthy of note that the Second Rcport of the Royal Commission on Public Records contains a "Memorandum on Official Records in the West Indies", communicated by the Secretary of State for the Colonies in I9I I, and a "Note on the West Indian Records", communicated in the same year by the late N. Darnell Davis, C.M.G., formerly auditor general of British Guiana. ${ }^{3}$

Students desiring to make personal investigations in the archives of any of the islands should apply frrst to the governor (in the case of Antigua, the Bahamas, Barbados, Bermuda, Grenada, Jamaica, or Trinidad) or to the

${ }^{1}$ Vol. II., part II., pp. II6-II9.

'Ibid., pp. II5-116.

${ }^{8}$ Ibid., pp. II9-I20. 
administrator (in the case of the lesser or dependent islands). Persons desiring to obtain copies of documents or information from them should either apply to the officials indicated in the relevant passages of the text which follows, or, when no special indication of this sort is given, to the colonial secretary.

\section{ANTIGUA.}

The minutes of both assembly and council show that in the early days of their history these bodies from time to time took note of the state of the colony's archives when hurricane caused sad damage, or continued neglect threatened irreparable loss. A sequence of reports with praiseworthy recommendations finds place in the minutes, but action continually halted short of accomplishment. In $\mathrm{I} 809$, for instance, a committee was appointed to see that certain recommendations as to the safety and arrangement of the records were carried out. Then as now the military buildings were used. Some papers were above the arsenal, and it was proposed to use the armory as a record-room. The success of this effort can be judged from the report of a similar committee only two years later, which urged that the recommendations be carried out as soon as possible, "as the Deficiency of fastenings and of several Window Shutters renders it [the depository] a Receptacle for drunken and diseased Persons, from which circumstance a shocking nuisance is created, and the dreadful Effects of Fire are seriously to be apprehended". Instead of following later endeavors that were more or less futile one may simply note that among the traditions strongly maintained in this part of the world neglect of historical records not in daily use has ever stood prominent. Danger from fire still exists, and although the manuscripts that remain are no longer used as pallets by the indigent, on the other hand official committees have long ceased to be troubled as to their condition or indeed as to their very existence. During the course of the present examination the custodian of some of the most valuable records acknowledged that he looked upon them for the first time. They are infested with vermin, and covered by dust and filth. Some papers still remain in the arsenal, but they are only a small part of what once existed, and it was said that but for the interest taken in them by one official nothing would have survived.

Any application to work among the archives at St. John's should be made to the governor of the Leeward Islands, who resides there. If copies are wanted the register can furnish them, as he is custodian of records in the arsenal and of the old legislative papers at the court-house.

\section{The Arsenal, Sr. John's.}

Some years ago a quantity of papers in the ordnance vaults were examined and roughly classified. They are now in the old arsenal. Sturdy of aspect, and barred by a series of doors, this depository seemed to promise a fireproof interior. Once within, however, a glance showed an open window guarded sparsely by iron bars, through which passed a refreshing breeze. As the building is in a corner of an enclosed quadrangle of police offices one may venture to hope that the danger of a lighted match being tossed upon loose papers and wooden furniture by the window may be somewhat minimized.

Most of the manuscripts lie in a deep wooden cupboard spanning one end of the room. Volumes mingle with bundles of papers assorted roughly by classes but not by dates. This material comes from two sources, one judicial the other executive. Of the first, chancery and common pleas form the 
major strains, while courts of ordinary and vice-admiralty are comparatively small adjuncts. The amount of local and intercolonial correspondence of the governor's office is not small, but nearly all of it is too recent for our purpose. Judicial papers on the contrary reach back to the seventeenth century.

With one exception, which shall be noted in due course, the contents of this vault for us are limited to three bundles of papers of the court of viceadmiralty. They may be briefly characterized as an armful of historical scraps without any arrangement, but valuable fragments for all that. No registers were seen, and the loose papers can be no more than a tiny remnant of the archives of that important court. The earliest document noted is a bond of I687; as the seventeenth century opens we find material in irregular waves; and at the close of the eighteenth we are left stranded. For the War of I8I2 there is nothing. We have to do then with remnants of an historical mosaic covering roughly two centuries, of which the substance has been so rent that the most we can do is to point to bits of color and to isolated pieces of design. In spite of the routine of judicial procedure several of these samples afford relief from monotony, and in more than one direction the range is wide. There are French certificates made out in Martinique and Guadeloupe, papers in Dutch with small clear seals, from St. Eustatius, Spanish documents from sundry parts, English depositions by Danes at St. Croix, and even an occasional Quaker affirmation. On the other hand cases of murder and piracy on the coast of Africa lie side by side with seizures of petty articles that would not crowd a merchant's pocket.

The agencies of destruction have been capricious, and the material, as noted above, is in irregular waves. Some of the periods of comparative plenty are I745-I747, I756-I758, I777, I796-I799. The earliest paper relating directly to the northern colonies is an affirmation of Joseph French, Quaker, in the cause of Capt. Isaac Royall against Samuel Lillie of Boston, and bears the date of Dec. 2I, I720.

In the course of a voyage to Pennsylvania the brigantine Vernon came into the hands of the admiralty authorities at Antigua. She had coal on board, and a deposition of Peter Tufts, Jan. I8, I745, states that it was commonly carried as ballast in voyages from Ireland to Philadelphia. According to him, it was not only necessary for firing, but his Majesty's officials at the Quaker port were lenient when any surplus was left. What the authorities at Antigua thought of Mr. Tufts's premises does not appear, but they differed strongly from his conclusions.

During the same year four American privateers were cruising together in W. I. waters. They were the brigantine Greyhound, Richard Jeffrey commander, the sloop William, Nathaniel Richards commander, both of N. Y., the Queen of Hungary, of Boston, James Grushy commander, and the Prince Charles of Lorraine, of R. I., Simeon Potter commander. The Postillion of Cadiz was sighted, and after a long chase, during which some members of the quartette sailed much better than others, she was captured and brought to Antigua. Then the confederates fell out over the spoils, and various depositions attest to their wrangling.

A case of another type came before the court two years later. From stocks on the Piscataqua had come a vessel christened the Ann, which was soon captured by a French privateer. Two New Englanders, Luke Mills and William Walden, apparently were examining British captures at Antigua late in I747, and claimed to recognize the Amm even though alterations included the name Le Diable. Their joint deposition of Dec. 9, I747, abounds in details of naval construction which they alleged distinguished this ship from those 
built elsewhere. It may be noted here that in these papers are many claims for salvage arising from recaptures.

Apparently most of the material relating to seizures during the American Revolution has been destroyed, for there are comparatively few cases in that period. An account of Judge Edward Byam of the court of vice-admiralty with the register, Feb. I, I779-Sept. 30, I785, furnishes us with a long list of ships. There is nothing beyond the names to denote their nationality. A handful of insurance policies is interesting. Most of them are dated I779, and deal with short voyages only. A typical policy of that year on $f$ Iooo from Antigua to St. Lucia totalled $\AA_{84-8-3}$, insurance alone being at 8 per cent. commission and the policy accounting for the rest. Some were much higher.

Two years after the close of the Revolution a Canadian captain from St. John, N. B., made bold to break his voyage at a New England port, to fill his water casks and do a bit of trading. Clearance was at first granted without trouble, but this visit of an individual from a settlement of United Empire Loyalists was not to end in such an insipid fashion. The captain received a call from a person who declared himself the successor of the complaisant collector, and intimated that he was not in accord with the latter's attitude. One official visit followed another, and finally the captain was told that his ship was seized. At this point the New Brunswicker acknowledges that he leaned over the bulwarks and threatened to blow out the collector's brains if he dared to come aboard. The collector beat a hasty retreat, and marshalled his reinforcements. In the meantime a compatriot warned the captain of certain plots forming in that locality against him. As a result he cut his cables and worked the ship out of the harbor, just distancing a light craft sent in pursuit. At Antigua he made a formal deposition of his losses, detailing the number of hogsheads and so many feet of cable left on the New England shore, but there is nothing in the document to suggest that he had any intention of returning for them.

Another aspect of certain admiralty cases is shown by a letter to Campbell Brown at Antigua from Willing and Francis, dated Philadelphia, Oct. 27, I797. This contains instructions to buy a number of sugar boilers or cauldrons, the cargo of a captured American vessel, and now for sale in Antigua. Authority is given to draw on them for $\$ 22,800$, but a subsequent letter shows that such a sum could not be raised in the island by bills of exchange.

The above examples by no means form a complete list. They are noted simply as illustrating various sides of cases that came before the court of vice-admiralty at St. John's. Many of course in which American interests are concerned do not present any new features, and a still larger proportion give no hint as to nationality.

In the same vault was found a governor's letter-book. Beginning and end are missing, the actual dates being Sept. 6, I822-Nov. 3, I823. In it is copied a memorandum sent to the governor by the acting collector, dated Sept. 6 , I822, a part of which is as follows: "During the intercourse between the American and British Governments under orders of His Majesty in Council, permitting the Vessels of the United States to bring certain Articles to the British West. India Islands, it appears by Records in this Office in the years I8IO and I8I I that Articles prohibited by the said Orders in Council to be imported, were brought from America and allowed to be entered at this Port for exportation, on the principal Officers of the Customs taking sufficient security that none of the said prohibited Articles so brought were landed here." The case of the schooner Millenium is instanced, and the acting col- 
lector argues that the practice should be continued even under later regulations ; otherwise American vessels will go to the "neutral islands".

The Court-House, St. Join N's.

Such of the old legislative records as still exist are to be found in a series of wooden cupboards in an upstairs corner room. The files have disappeared. Books of minutes have been and are still being eaten by insects and rodents, and the shelves are in a very filthy state. Many of the assembly minutes can no longer be examined. The volume covering the Seven Year's' War, for example, is so fragile that any attempt to turn its leaves would result in their disintegration. It naturally follows that in several instances portions of books, especially at the beginning and end, are only useless masses of fragments. Every time such a volume is even opened the situation is made worse, so the dates in the list of assembly minutes must be regarded as approximate rather than absolute.

The volumes of assembly minutes average about 300 pages, some of the earliest volumes being rather smaller. Even when they are paged most of the corners are often missing, so no attempt is made to give the individual pagination.

Apart from the listed items these records have some importance for a comparative study of colonial development, though in this respect they are far less valuable than those of Barbados. Strong local tendencies are seen along certain lines. A good example is found in the first volume of assembly minutes, where we note that eight years after the battle of Sedgmoor the planters of Antigua were determined that they should not be oppressed by free quartering. It was laid down that every person billeting a common soldier was to be paid at the rate of four pounds of sugar per day, and that in this respect a captain should count as six privates, a lieutenant four, and an ensign three. This subject comes up frequently in the following century.

Another example is furnished by a dispute between governor and assembly at the close of the seventeenth century. The assembly wished to constitute the courts as in Jamaica, and proposed to copy exactly the laws of that colony, changing only the necessary names. Governor Codrington considered that it would be advantageous to make certain changes, but the assembly clung stubbornly to its idea of a legal transplantation without pruning or grafting. Along constitutional lines many further examples could be given. These records also have much interesting material on trade, legal or otherwise, colonial currency, and the economic life of the planter. For many years official financial reckoning was in terms of pounds of sugar or sometimes of tobacco.

A considerable proportion of these minutes consists of documents entered therein. At first there are messages passing between council and assembly, which form the bulk of the earliest journals. Next come messages and addresses of the governor, committee reports, sundry despatches and orders in Council from England, a varying amount of intercolonial correspondence, letters from naval officers, and others from the colonial agent. Sucl elements naturally vary in proportion from time to time, but they always constitute a factor of considerable value.

MINUTES OF ASSEMBLY.

Feb., I693-Dec. 3, I698. This book is incomplete at each end, but the paper is in good condition, showing clearly the results of protection from damp, even though such protection has been accidental. For sereral 
years the minutes were littie more than a record of messages interchanged with the council. This makes them a source for the lost council minutes.

In 1695 a tax of $3 d$. a ton was levied on incoming shipping, to be used in the protection of trade against the French.

A letter from Bastian Bayer, Joseph Martyn, and Richard Cary to the assembly, dated London, May 2, I696, shows that they had tried to have orders issued for the two men-of-war bound for New England to shift to the Leeward Islands during the winter months, but were unsuccessful.

An interesting point is raised by an incomplete letter from the assembly to the Lords - [perhaps Lords Justices] at the close of 1698 , which expresses distrust of the correctness of minutes sent home, and accuses the governor of forwarding a garbled copy.

Jan. 2, 1698/9-Dec. 30, I701. This is in bad condition, and could not be fully examined.

Jan. 7, I701/2-Aug. 3, I704.

July 28 , I 707 -June 9 , I7II. Too brittle to be fully examined.

June $21, I 7 I I-J u l y ~ 27, I / I 3$. There is some material on defensive preparations.

Dec. 13, I713-Dec. 7, I 716.

June 6, I 7 I 7 -Jan. 7, I $721 / 2$.

Jan. 9, 1 $721 / 2-$ Feb. $27,1724 / 5$.

Mar. 4, I724/5-Sept. 2I, I728.

Oct. 2, I728-July 12, I 734 .

July 23, I734-Jan. $3,1736 / 7$.

Sept. I3, I739-Dec. 3, I747. Contains some material on colonial defense, and hindrances to trade.

Dec. Io, I747-Sept. 29, I755.

Jan. 29, $1756-J u n e ~ 30,1763$. This volume could not be examined. It is almost beyond repair.

July 21, I 763 -May II, I 770.

A message from the assembly to the governor in council, relating to the prospect of a renewal of the trade between the French islands and $N$. Am., has the following passage: "But of all the reports that have reached us none seem to be matters of so serious consideration as the following that St. Lucia is to be made a free port and that they publickly at Martinique and Guadeloupe avow the design of admitting the Inhabitants of North America to import directly such commodities into their Islands as are necessary for the support and improvement of their Colonies and to carry away their Rum and Molasses to the manifest detriment of our English Islands. These reports have been transmitted hither by several persons whose characters will not admit of a supposition that they have been deceived themselves or are willing to deceive others." Aug. 4, I763.

Nothing was found on the Stamp Act. There is a long report in 1767 on custom-house fees and their effect on trade.

May 24, I770-May 12, 1775.

June 29, 1775-Nov. 26, 1778.

On Feb. 3, 1776 , a committee was appointed to draw up a loyal address to the king, expressing their "abhorrence of the rebellious proceedings of His Majesty's Colonists on the Continent of America". Measures to obtain provisions and lumber from other sources are 
shown. Some papers relate to captures of American vessels by the local armed sloop Reprisal and by other armed vessels. In I778 there is material on hasty measures for defense.

Dec. 10, 1778-Dec. 23, I780.

- Sundry material on American and French prisoners in the island; defense; correspondence on French naval and military forces and their movements; difficulty of obtaining sufficient provisions; the 2nd battalion of the 6oth (Royal American) Regiment.

Jan. 3, I78I-June 4, I783.

Account of expenses incurred in Antigua for defense, Mar. I, I776Dec. 31, I782.

Sept. 24, I783-Mar. 23, I789. (Beginning missing.)

May 8, I793-June II, I795.

Both council and assembly requested the governor in 1793 to admit temporarily provisions and lumber in American vessels. He finally gave way at the close of the year.

July 9, I795-Aug. 24, I797. (Beginning missing.)

Nov. 28, I797-July I7, I80o. (Beginning and end-missing.)

Aug. 7, I800-Feb. 16, I804.

May 23, I805-Mar. 9, I809.

Some papers deal with the importation of American provisions, and others with the question of placing a bounty on salt fish from Br. N. Am.

With the opening of the nineteenth century the amount of European and other correspondence spread on the minutes grows larger.

Apr. 6, I809-Feb. 27, I812.

Message of the council to the assembly, transmitting, with comments, copy of a British order in Council, Apr. I2, I809, on the regulation of certain trade matters. June 29, I809. (Pp. 4I-44. Enclosure copied.)

British order in Council, Aug. I6, I809. (Pp. 99-102.)

Account of powder-duty, Jan. I, I808-Dec. 30, I809, giving names of vessels, and of captains, tonnage, and distinguishing between British and American ships. (Pp. I 58-I70. Usually these accounts do not give the nationality of the vessels, and in such cases they are not noted.)

Report on bounties and duties on fish, Mar. 29, I8ro. Followed by (I) a detailed account, giving port, vessel, etc., of bounties paid on fish imported in British vessels from Br. N. Am. during I808; (2) an account of money received by the collector from tonnage-dues and duty on fish imported in American vessels, July 24-Sept. 22, I809; and (3) tonnage duty alone, Jan. 8-Mar. I9, I8Io. (Pp. I95-200.)

British order in Council on trade. Feb. 7, I8Io. (Pp. 207-2II.)

Account of money received for tonnage-dues and duty on fish, Apr. 2Aug. 8, I8ro, giving names of vessels and captains, and their

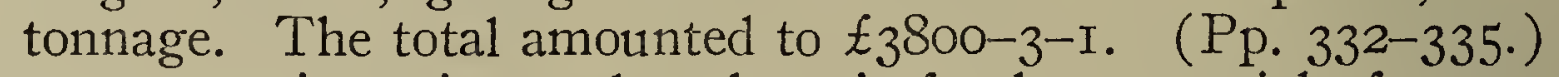

These are prominent items; but there is further material of a more general nature on the regulation of trade.

Mar. I2, I8I2-Oct. I4, I8I3.

Account of powder-duty, Jan. I-Sept. I9, I8IO, distinguishes between British and American vessels.

"List of Vessels Condemned to the Captors, which have been brought to the Island of Antigua, from the Commencement of the American 
War." Names of vessels, persons to pay duties, and particulars of cargoes are given. This list was furnished by the deputy. registrar in admiralty. There is no date, but it apparently belongs to the close of I8I3. (Pp. 428-43I.)

An item at page 433 gives the amount of duties on American commodities imported voluntarily under neutral flags, July I, I8I2-Sept. 30, I8I 3 , as $£_{33}$ I 3 I $3 s .4 d$.; while $£ 3399$ I $3 s .2$ I $/ 2 d$. were due Sept. 30, I8I3, from sundry persons, on American commodities sent into the island in various vessels which had been condemned as prizes, but no part yet received by the collector or treasurer.

Nov. II, I8I3-July 4, I8I6.

British order in Council on the regulation of trade. Nov. $30,1813$.

Id. Dec. I6, I8I4.

Report and resolutions of a joint committee on "the present distressed state of the Colony, arising from the total suspension of all commercial intercourse with Vessels arriving from the United States of America". July I9, I8I5.

A. Browne, colonial agent, to the assembly. In an interview with $\mathrm{Mr}$. Goulburn he has been unable to obtain any relaxation of the Navigation Laws. Montague Place, Oct. I9 (I8I5). Followed by a letter from Goulburn, stating "that the circumstances of that Colony do not appear to His Majesty's Government to be such as to warrant them in dispensing by their own Act, with the Navigation Laws of the Empire".

\section{MINUTES OF COUNCIL.}

Legislative and executive powers were combined for many years, and in the Leeward Islands the privy councils played a less powerful rôle than to the southward.

June 9, I796-May 24, I798. Letters from the colonial agent, addresses, reports, and messages are spread on the minutes in great variety.

On a return of powder-duty, I795, it is stated that the duty on all American vessels permitted to trade here is from that date to be commuted to three shillings per pound. (The part for June-July, I797, has been torn out.)

Apr. 9, I80I-Sept. 29, I803.

A report of a joint committee on the state of the coinage traces exchange and currency problems from I756. E. g., in 1756 exchange between Antigua and G. B. was 50 per cent. ; after the close of the "American War" it rose to 185 per cent., and for some time after $I 783$ was in the neighborhood of 175 per cent. At this time "in addition to the clipped and sweated Gold already in circulation some ingenious Citizens of the Infant American Republic were good enough to coin light Joes, in imitation of those of Portugal for the use of the sugar Colonies". There are comments on the influence of the present state of the currency on American trade. This report, dated Mar. I0, 1803 , is followed by tables showing the value of gold and silver, their relative proportion in Antigua and in places connected with it by trade, and the advantage to be gained by investing a certain sum to be sent to America in gold or silver according to certain rates.

Aug. I, I805-Mar. 3, I808. Some of the material on trade with America duplicates what has already been noted in minutes of the assembly. 
A return of powder-duty received, May 2, 1805-Dec. 3I, I806, gives names of ships, their captains and tonnage, and whether British or American.

Feb. 28, I8I I-Feb. 4, I8I3. Contains some material already noted in assembly minutes.

Mar. 4, I8I3-Sept. 29, I8I4.

\section{MINUTES OF PRIVY COUNCIL.}

I809-I83I. Until I8I6 there is scattered correspondence and other material on trade with the U. S., and the effect of sundry efforts to regulate it. Nothing was then found until the circular collection of documents in 1830 , once again opening W. I. ports to U. S. shipping.

$$
\text { ACTS. }
$$

I $76 I-I 772$. No material directly bearing on U.S.

I782-I798. No direct material.

I804-I8I4. Partly duplicates the next volume.

Act imposing a duty on certain articles imported in vessels of friendly nations, according to a British order in Council of Apr. I2, ISog. June I3, I809. (Extended June I4, I810.)

Act imposing certain duties on articles imported in vessels of friendly nations, under British order in Council of Feb. 7, I8Io. Nov. I2, I8Io. (Revived, altered, and continued by act of Dec. 6, I8II.)

I8IO-I826. Act imposing duties according to British order in Council of Oct. 26, I8I2. Feb. 5, I8I3.

Act imposing duties according to British order in Council of Nov. 30 , I8I3. May 19, I8I4.

Act imposing duties according to British order in Council of Dec. I6, I8I4. Mar. 2, I8I5.

Act imposing a duty on all goods sold by non-resident traders. Apr. 26, I821. (Renewed May 23, I822, June 5, I823, June I7, I824, July I4, I825, and in a different form July 27, I826.)

\section{Colonial Secretary's Office.}

A thorough search for the old despatches, with the aid of a member of the staff, was quite fruitless in that respect. Almost nothing of the kind remains until we reach the second half of the nineteenth century.

One huge volume found on the top of a cupboard has much useful information of an economic nature. In it are entered yearly returns under certain headings. The chief divisions are: names of owners of land, arranged alphabetically ; produce shipped, paid away, or otherwise disposed of, distinguishing between sugar and rum; number of acres of land in possession, under cultivation, or waste; amount of sugar and rum produced; and tax on sugar, rum, and land. These headings vary somewhat from time to time. The period covered is Jan. I, I794-Dec. 3I, I850. 
BAHAMAS.

The archives of the Bahamas are kept in the public offices at Nassau, the capital of the colony. Their present situation and general condition point to the prevalence in the past of a state of things in which there has been neither an official to whom was committed the special care of archives, nor any common place for their safe-keeping. Documents originating with any branch of the government service, or bearing upon matters connected with its work, are generally deposited in the office rooms occupied by it. Two of the departments have adjunct storage-rooms, to which many documents have been sent in order to get them out of the way. In these various places they have been put away in very different sorts of receptacles, witnessing to widely varying degrees of appreciation of their value. In several of the repositories there is some evidence of a creditable attention being devoted in recent years to preservation of what they contain, but many of the same documents and volumes that are now in safe-keeping testify to a serious lack of it in former times. The incumbents of the various offices are the natural custodians of the records and documents deposited in their respective departments.

There seems to have been a great loss of documents in the Bahamas, and many that are extant are badly disintegrated. Three main causes may be assigned for this: (I) the laxity of those responsible for their keeping, as to preserving official sets of papers complete-in a few cases there has been deliberate destruction of things considered useless or burdensome; (2) the climate, which favors both natural deterioration and the ravages of insects; (3) the American and Spanish occupations. The Bahamas were first brought under a permanent orderly government in I7I8. From that time to this they have continued in the possession of the British with the exception of the two brief periods mentioned. The American occupation lasted only a few days (in 1776 ), but as Commodore Hopkins carried away a governor and some of the inhabitants as prisoners, he may also have carried off some of the archives. The Spanish forces held possession of the island of New Providence for a period of two years, I78 I-I783. The present search revealed no documentary evidence as to the effect of these changes of rulers upon the archives. It is not clear whether the earlier records were largely carried away by escaping colonists and never brought back, or seized and destroyed or carried away by one body of invaders or the other. In only two departments, however, namely, that of the registrar of records and the house of assembly, are there to be found any considerable number of things of an earlier date than I 780 .

Permission to examine the archives in any particular office is commonly granted by its custodian, with little formality in the case of dates prior to I8I6. The registrar of records requires a fee of one shilling, but for one fee will allow a protracted search to be made.

${ }^{1}$ The notes here presented, on the archives of the Bahamas, are drawn off from an ampler account made by Dr. James M. Wright during a visit to the islands in I903, and kindly presented to the Department of Historical Research in the Carnegie Institution of Washington. An attempt was made, before the manuscript of this volume went to the press, to secure a revision of this account by a competent hand at Nassau, bringing its statements up to date, but the effort came to failure just too late for remedy. The reader should therefore remember that conditions, and even locations, may have changed in various particulars. Dr. Wright's inventory covered the whole period of Bahaman history (on which see his History of the Bahama Islands, Baltimore, 1905), but the present notes, like the other parts of the present volume, are confined to the period ending in I8I5. 


\section{Governor's OfFice.}

Some of the most important archives of the colony were in 1903 in the offices in the basement of Government House, mostly in two large wooden boxes lined with tin. Sir William Grey-Wilson, however, coming to the islands as governor in 1904, made better provision for their preservation, and began a work of rearrangement and systematization.

The despatches of the governors to the Secretaries of State for the Colonies are here, but they begin only with the year I829. Before that time the retiring governors seem to have taken them away on departing from the islands. Miscellaneous letter-books of the governors are present from 1838 . Despatches of the Secretary of State to the governors date from I795 to the present time, but so few remain for the first twenty-five or thirty years that most of them have been tied up in one bundle of ordinary size.

\section{MINUTES OF THE PRIVY (OR EXECUTIVE) COUNCIL.}

These are contained in folio volumes bound in leather, showing effects of exposure to both insects and dampness. Those relating to the period ending in 1815 are:
2. $1802-1805$.
3. $1805-1813$.
4. $\mathrm{I} 8 \mathrm{I} 3-1825$.

\section{Colonial Secretary's Office.}

The colonial secretary has the custody of several important sets of papers, which are received into his office for deposit, and kept, in a fair state of preservation, in the rooms occupied by that official and his clerks; but the earliest of these are of I832. Much less favorably preserved were (in 1905) the papers in the annexes to his office, two vaults on the first floor of the Public Library Building. Among these last were noted, of date previous to I8I6: a roll containing signatures of the members of the council, I797-1809; a manuscript containing returns of grants of crown land, I8I3-I823; a patent of George III. granting a great seal to the Bahamas, I767; a license for a brig to make a trip to Hayti, issued by Governor Cameron in I80r; and a folio volume containing accounts of exports and imports from Feb. 2, I796, to June 25,1800 .

\section{Receiver General and Treasurer's Department.}

In I894 the then receiver general and treasurer caused nearly all of the old records to be destroyed.

\section{Office of the Registrar of Records.}

Next to the House of Assembly this office was reported as providing the best facilities for the care of its archives, though some of the earlier volumes, which had gone quite out of use, were threatened with destruction by the climate. The record office, formerly under the custody of the colonial secretary, was made a separate department in 1862 . By the same act, 22 Victoria c. I5, a new system of classification was introduced. Before that time wills and crown grants of land were usually kept in distinct sets of volumes, but documents of other kinds were likely to be set down in the order in which they were received.

There are 219 volumes of the public records proper. These include the oldest archives in the Bahamas, some of them being dated as early as 1703 , 
and they extend down to the present time. Of the period ending in $18 \mathrm{I} 5$, the following volumes were noted:

A volume containing miscellaneous deeds. I723-1762.

Record Book, containing records of bonds; appointments of military officials; instruments of pardon to slaves convicted of capital crimes; wills; and grants of land. I760-I772.

A volume containing inventories of private effects. I753-I787.

A similąr volume. I787-I796.

A small folio volume of about roo pages, containing the record of all slaves freed in the Bahamas between I740 and I834.

A volume marked $\mathrm{A}^{1}$, containing records of land grants in I789-I79I, in the period when incoming Loyalists were being settled on the crown lands of the Bahamas.

A volume marked $\mathrm{C}^{1}$, ditto. I789-I790.

A volume marked $\mathrm{C}^{2}$, containing wills. I797-1806.

There are three large folio volumes of indexes to the above series of volumes, citing the documents under the names of the persons concerned in each.

A small trunk in the office, containing the marriage registers for the period I799-I 850 , accompanied by a complete index.

A small folio volume, colonial secretary's book. I733-I75I.

A folio volume, records of the court of ordinary. I772-I823.

Two small trunks filled with papers of the court of chancery before I862, held by the governor as chancellor.

A small folio volume, minutes of the privy council. I789-I802.

A small folio volume, records of slave trials. I785-1789. This gives brief statements of the cases, the decrees of the court, and sometimes a part of the evidence.

Manuscript volumes of the laws of the colony, as follows:

2. (Vol. I. missing.) Laws passed in I780-I789.

3. I792-I793.

4. $1795^{-1} 798$.

5. $1798-1801$.

6. $1802-1805$.

7. $1805-1806$.

8. $1808-1813$.

9. $1814-1822$.

Vestry Room of Christ Church Parish.

The following volumes are mostly in fair condition. Some of them have been transcribed.

One volume, folio, register of baptisms in Christ Church parish, I733-I79I; register of marriages, ibid., I753-1803.

Five volumes, folio, minutes of the vestry of Christ Church parish. I74II 837 .

Surveyor's Department.

This office preserves no manuscript records, but is the depository of plats of grants of crown lands and of settlements. There are $2 \mathrm{I}$ large folio volumes of certified plats of original crown grants, one or two volumes for each of the larger islands. They give the boundary lines of all such grants since I785, stating, in days of slavery, whether to a white or to a free black. There are two plans of the town of Nassau, both made by order of the assembly of the 
colony, one in 1768 , the other in 1788 , and three plans of Hog Island on one sheet, dated ISO3.

\section{Library of the House of Assembly.}

The committee room of the house of assembly contains the archives that are in the custody of that body. These are in a secure building, and lodged in substantial cases, yet some of the earlier papers have suffered from neglect or the effects of time and climate. The principal archives found here are: Original manuscript volumes of the votes (journals) of the house of assembly, as follows:

Feb. 4, I760-Aug. 8, I766.

Nov. 18, 1766-Feb. I5, 1771.

Apr. 20, 1784-Mar. I3, I 788.

Oct. 6, 1795-Nov. 30, 1798.

Oct. 22, I799-May 20, I80o.

Mar. I6-Dec. 28, I802.

Nov. 15, I803-Apr. 5, I805.

Oct. 29, I805-Dec. I8, I8II.

Nov. 3, I812-Dec. 22, I814.

Index to votes of the house from $\mathrm{I} / 78 \mathrm{I}$ to $\mathrm{I} 834$.

A large folio volume containing copies of the votes of the house. It is dated Feb. 4, I76I-May II, I 784, but the records are missing for a period of about nine years, beginning in $\mathrm{I} 77 \mathrm{I}$.

A volume like the above, containing the votes for the period May I2, I784Sept. 29, I794.

There are also some transcripts of the votes for a part of the nineteenth century.

Printed Votes of the House, volumes covering periods as follows :

1794-1798 (two copies), I794-1799 (one copy).

I 799-1800.

1800 .

I80I-I804.

$1804-1808$.

I809-18I I (two copies).

I8I2-I8I4 (two copies).

I8I5-18I7 (five copies).

A folio volume of copies of letters received by the "commissioners of correspondence" of the Bahamas. I792-I803.

A folio volume of their minutes. I795-1833.

A volume of minutes of the trustees of the Public Lot.

Account-book of the trustees of the Public Lot.

Printed volumes of the laws of the Bahamas, as follows:

A volume for $1764-1798$, incomplete.

A volume for I799-I800 (two copies).

Vol. I. I729-1805. A compilation.

Vol. II. I80 5-1808.

Vol. III. I809-18i3 (two copies).

Vol. IV. I8I4-I82I.

Bahama Gazette, first newspaper published in the Bahamas. Vol. I., I784I785. Also vols. IV. ( 787 ), VI. ( 7 /99), VII., VIII., X.--XV., XVII. The volumes are now bound, but many numbers are missing.

Journals of the House of Assembly of Jamaica, printed, vols. I.-XIV. 


\section{Library of the Legislative Council.}

The records of the legislative council are kept in presses in the chamber in which that branch of the legislature meets. They are securely housed in a dry place, and appear always to have been kept dry, but suffered somewhat from neglect at one time. The Votes of the council were printed for the first time in 1856 . For the earlier dates, to 18 I $_{5}$, there are the following manuscript volumes:

June 8, I790-Sept. 6, I793.

Sept. I0, I793-Dec. 24, I801.

Mar. 16, 1802-Dec. 28, I810.

Oct. 22, I8II-Nov. 27, I823.

\section{Arcinves of the Supreme Court.}

The papers and records of the general court (now the supreme court) are deposited in the office of the registrar of that court. The walls of a large room are lined halfway round with tall cupboards and book-shelves, most of which are filled with archives, fairly well arranged. The documents are mostly tied up in bundles, which are labelled and placed in pigeon-holes in the order of time. The documents for the different classes of casescriminal, civil. admiralty, etc.-are for the most part kept in separate presses. Some of the old papers of this office have been intentionally destroyed. One large cupboard is filled with papers of the general court, dating from $x 789$ to the present time, but they state in each case little more than the minimum respecting the suit and the court's judgment on it. There is a folio volume of records of judgments of the general court, I789-1809, but it was not the custom of the court to render written opinions; also minutes of the court in the exercise of its criminal jurisdiction, I788-1896.

A chest in this office contains 1601 wills, I722-1883. Two metal trunks are filled with papers of the court of ordinary. There is a parchment roll of the counsellors and attorneys that have been admitted to practise at the bar of the general court. The admiralty papers kept here belong, with a few exceptions, to the latter half of the nineteenth century.

\section{Office of the Marshal of the Supreme Court on the Admiralty Side.}

The greater part of the admiralty papers are (or were in 1903) kept in this office, in a cramped little room in a corner of the police court building, where they were ill protected from rain, not at all from insects and other vermin, and were rapidly deteriorating, some of them disintegrating or quite illegible. Most of the material deposited here belongs to the years I792-1815, the period of greatest activity in the history of the vice-admiralty court of the Bahamas. Privateering and wrecking are the main concerns. There are papers of almost every conceivable kind connected with commercial narigation of that period-arguments and speeches of advocates, sentences and decrees of court, libels, ships' registers, clearances, manifests, bills of lading, captured correspondence in English, French, Spanish, and Portuguese, log-books, journals of voyages, etc. The documents pertaining to each individual case are collected into a separate package, with or without a wrapper, and tied up, most commonly with a label.

There are here a number of thin manuscript volumes of minutes of the vice-achiralty court, nearly all in paper covers. One of them runs from 
February, I770, to June, I778; another from December, I786, to January, I788; there is a nearly complete series of them from May, I792, to July, I805, and another from July, I8I2, to June, I8I3.

\section{BARBADOS.}

The amount of political records prior to 1816 that now exists in Bridgetown is comparatively small, especially when one considers that the island had then been a part of the British Empire for nearly two centuries. It is customary to attribute most losses to the hurricane of I83I. Many records undoubtedly disappeared at that time; but climate and insects on the one hand, and human indifference, neglect, and wilful destruction on the other, have taken heavy toll. For this period Barbados has preserved no governors' despatches or letter-books, no records of the custom-house or of the court of vice-admiralty, no files of its council or assembly. In brief we are almost wholly confined to minutes of the council and assembly and some of their acts, and none of these three series is complete.

It will be noted that comparatively little has been listed below for those periods of the eighteenth century when European warfare overflowed into colonial areas. This is largely due to the fact that English colonists in most of the West Indies viewed such events from a defensive viewpoint. Upon any declaration of war they prepared for defense, sometimes feebly, sometimes with vigor; made representations to the governor or to the king regarding the need of troops and further naval protection; and usually showed that they wished for as little disturbance of their channels of trade as possible. The Seven Years' War and the American Revolution, therefore, appear as periods of political and economic defensive measures. The disappearance of despatches and of records of the court of vice-admiralty of course sadly blurs the local picture. In minutes of council and assembly, however, we find entered some correspondence with admirals, and other papers on defense, the French naval force, and activities of privateers.

Viewed as a whole the items relating directly to American history are not numerous, and the information is confined mainly to commercial lines. It would not be proper, however, to dismiss these records without some indication of the indirect material they contain, much of which is of no small importance for students of certain lines of colonial development. One concrete example from a large number is furnished by the governor and council acting as a court of chancery. This practice was in full bloom in I64I, for an entry under October 13 of that year states, "By this and several of the Early Entries the Governor and Councill who were chosen and appointed by the Gov'r seem from the first settlement to have assumed and practiced a Judicial power to hear and determine all matters of Complaint, Errors, Grievances and other Equitable causes, and which it is presumed continued till the Establishment of the several Courts". No separate register was kept, so we find a large amount of work performed by the council acting in this capacity spread at large among the ordinary minutes. In I652 a special court of chancery was instituted, but the act was repealed in the following year, and the former practice resumed. It is plain, therefore, that any study of courts of chancery in the thirteen colonies must take into account their existence in Barbados and certain other islands of the West Indies, as well as their later history in Nova Scotia, and the subsequent transfer from Halifax to Quebec in 1765 of the same institution of governor and council as a court of chancery employed at Bridgetown in the first half of the seventeenth century. 
Other divisions of the judicial establishment are equally fruitful in material of a collateral nature. In addition there are the relations of governor, council, and assembly, where individual pretensions and rival claims resulted in contests not only interesting as segments of local history, but which also played their part in the formation of precedents. The treatment of Quakers and Jews, the large field of shipping, problems of currency, relations with the foreign islands, smuggling and piracy-these and many other topics were matters in which the English colonial world was deeply interested. Although the mainland colonies viewed such problems from a different angle and naturally at times moved to quite another solution, yet the fact that they were common factors of colonial life formed a bond, less tangible than the commerce that united them, but whose existence was no less real. Intercolonial communication was for the most part easier by water than by land, and was wont to follow the routes of trade. With these two facts before us we can easily see why dwellers along the shores of New England often had a clearer idea of some of the West Indies than of Georgia and the Carolinas, and the Halifax merchant was apt to know better the wharves of Basseterre and Bridgetown than those of Quebec and Montreal. News of the colonial world that went with vessels laden with rum and molasses and by brigs freighted with provisions and lumber reacted on colonial life, and its traces are found in contemporary legislation. Little of this mutual influence appears in plain view: only occasional bits can be listed; but for any student of colonial development it adds much to the value of the registers and bundles of old papers lying in various depositories at Bridgetown.

\section{MINUTES OF COUNCIL.}

As a matter of convenience we may take up these records in four series, as follows:

I. Original books of minutes. Most of them are very fragile, and some portions have already fallen to pieces or have been riddled by insects. To examine such volumes in detail would be to assist greatly in their destruction.

II. From I8I8 to 1828 the late Judge Lucas had the original minutes transcribed into large volumes, which average about 500 pages. He thus performed a notable service, but it must be noted that his copies are incomplete in two respects, neither of which is serious. In the first place not every item of the original minutes was included. This is not important, and the American student need not concern himself about it at all, for certainly everything of value to him is transcribed, the chief omissions being routine items and repetitions. On the other hand, the present search brought to light two originals unknown to Judge Lucas, belonging to the years I7I9 and I755. A note in his transcripts deplores the apparent loss of these minutes for most of 1755 as a serious imperfection in the records. The writing of these copies is not of the best quality, and the paper has become yellow and brittle. In fact portions of the transcripts are in no better condition than some of the originals. Each volume has a table of contents. For the average student this aid will probably be of doubtful value. These transcripts are at the Bridgetown Public Library, with the exception of volumes I, 2, 3, 5, Io, and 35, which are in the possession of Attorney General Sir Charles Clarke.

III. A few duplicate minutes of council have been received from the Colonial Office.

IV. In the last twenty years the registrar has tried to have a full transcript made of the oldest original minutes. Gaps in the latter were filled as far as 
possible from the Lucas set. This enterprise has been halted by withdrawal of the appropriation.

A comparison of lists shows that a complete set of minutes does not exist, even when those at the Public Record Office are taken into account. Probably a still more serious loss is that of all the accompanying papers for our period.

The present examination was made from the two series of transcripts, with the exception of the few items that have not been copied. The lists for I. and II. are modifications of those drawn up in 1905 by Professor C. H. Hull, to whom grateful acknowledgment is here made.

All of these minutes, with the exception of the Lucas transcripts noted above, are in the nominal custody of the colonial secretary, but are kept in the vaults of the registrar's office, on the first story of the government buildings. These vaults would likely offer only a fair resistance to fire.

\section{Original Minutes of Council.}

June 5 , I667-May I $5,1673$.

June 7 , I68I-Oct. Io, I683.*

Mar. I9, I688/9-June I2, I694.

Aug., I694-Nov. 23, I699.

Mar. 7, I699/I700-Dec. 20, I703. June 6-July 27 , I704.

June 9, I707-June 6, I7Io.*

Tune 7, I7IO-Oct. I4, I7I2.

Oct. 28, I 7 I2-Jan. 24, I 7 I $5 / 6$.

Jan. 25, I7 I5/6-May I3, I 7 I8.

Aug. I 5, I7I9-Jan. I9, I7 J9/20.

Feb. I7, I7 18/9-July 2I, I 7 I9.

Feb., I719/20.*

Mar. I 5, I 7 I9/20-Nov. 30, I720.

Dec. 5, I720-Oct. 4, I721.*

Oct. I2, I72I-Dec. 22, I72I.

Feb. I, I721/2-Dec. 29, I722.*

Feb, 19, I722/3-Sept. 28, 1725.*
Aug. I3, I728-Nov. 6, I733.*

Nov. 7, I733-Jan. 3, I739/40.

Jan. 22, I739/40-Oct. 23, I744.*

Sept. 7, I 742-May I3, I745.*

May 20, I745-Feb. I8, I745/6.

Feb. I9, I745/6-Mar. I I, I746/7.*

Mar. I3, I745*6-June 6, I749.*

Oct. 4, I 749-Dec. 30, I754.*

Jan. 22-Aug. 6, I755.

Oct. I, I755-Dec. 20, I758.

Jan. 3, I759-Aug. 8, 1764.

Nov. 27, I764-Mar. I6, I $768 . *$

Jan. 26, I769-Apr. 28, I773.*

June 8, I773-Sept. 28, I779.

Oct. 27, I779-July 16, I782.

Aug. 7, I782-May 12, I 789 .

June 2, I789-Nov. 25, I800.

Nov. I, ISo3-Dec. 22, I8I2.

Vols.

\section{Lucas Transcripts.}

1. June 5, I667-Oct. I 5, I667.

2. Oct. 22, I66 7 -May I 5,1673 .

2. June 7, I68I-Oct. 3I, I682.

3. Oct. 31, I682-May I 5, I688.

4. This volume has been missing for many years.

5. Feb. I6, I691/2-Jan. 26, I696/7.

6. Jan. $27,1696 / 7-J a n .12,1701 / 2$.

7. Jan. 23, I7OI $/ 2-N o v .21,1704$.

8. Nov. 21, I704-Jan. 8, I708/9.

9. Jan. I8, I708/9-May 29, I7 I I.

10. June 23, I 7 I I-Aug. I, I II2.

11. Aug. I, I7I2-Feb. I5, I7I4/5.

12. Feb. I5, I7I4/5-Apr. I 5, I7I9.

13. Apr. I5, I719-Feb. I6, I7 19/20.

Deposition of William Arnold (or Arnoll) of Boston, lately master of the brigantine Friendship, as to his capture by pirates in Aug., I7I8. (P. 275.)

* Actual dates present; beginning or end of the volume missing. 
Deposition of Joseph Bloodworth, captain of the American snow Sea Nymph, owned by Stephen "Delansee" of N. Y., lately taken by the pirate ship Royal Rover, Walter Kennedy commander. Jan. I, I7I9/20; followed by the deposition of Thomas Evans, mate of the Sea Nymph. (Pp. 500-506.)

14. Feb. I6, I7I9/20-Aug. 2, I720.

15. August I5, I720-Oct. 28, I72I.

16. Oct. 28, I72I-Jan. 2I, I723/4.

17. Jan. 22, I723/4-Apr. I7, I733.

for the minutes between vols. I7 and 18 see vol. 33 .

18. Oct. 28, I735-Dec. 8, I740.

The first 84 pages contain sundry papers of a committee "to Inquire and examine into the present State, Condition and Trade of this and the rest of the West India Settlements". The first two letters, dated Oct. 27 and 28, I735, give many details of W. I. commerce and that of Barbados in particular, with comments thereon. Only small portions relate directly to trade with the northern colonies, but the niaterial as a whole is interesting for the commerce of the sugar islands.

19. Dec. Io, I740-Apr. 6, I745.

20. Apr. 6 , I745-Feb. I8, I745/6.

21. Feb. 18, 1745/6-Dec. 3, I746.

22. Dec. 3, I746-Apr. 26, I748.

23. Apr. 26, I748-May I3, I752.

Address to the king by the council and assembly, on commerce between the foreign sugar plantations and the northern colonies. Oct. 29, I75I. (Pp. 5OI-504.)

24. May I3, I752-Sept. 21, I76I.

25. Oct. I, I755-Dec. 20, I758.

26. Sept. 21, I76I-Apr. 28, I 767.

27. Apr. 28, I767-May 25, I773.

There is some material on imperial legislation for putting customs in America, and the execution of the laws there relating to trade, in the hands of resident commissioners. 1767.

28. June 8, I773-Sept. 28, I779.

Long extracts from governors' instructions are entered before the American Revolution, and continue through that period. General material relates to privateers, means to prevent trade with rebels, an address to the governor by the assembly on interruption of commerce with the rebellious colonies, and defense against the French.

Answers of a committee to numerous queries on Barbados, its produce, imports, exports, trade with various regions, etc. Oct. 26 , I773.

Measures to prevent any shipment of gunpowder or other warlike stores from Barbados to N. Am. Sept., I775.

Imperial proclamation for suppressing rebellion and sedition. St. James's, Aug. 23, I775.

Correspondence of the governor with Vice-Adm. James Young on measures to remedy the scarcity of provisions, especially of corn. Apr., I 776.

29. Oct. 27, I779-May I5, I78I.

30. Tune I3, I78I-Jan. I6, I787.

Contains some material on the regulation of commerce between the Br. W. I. and the U. S. 
31. Jan. 16, I787-Dec. 22, 1796.

32. Jan. I9, I796-May 28, I8II.

Contains material on embargoes and other regulations affecting trade with the U. S.; protests against such restrictions; and importation of fish from Br. N. Am.

33. Nay 28, I8II-Dec. 22, I8I2; May 8, I733-Oct. 28, I735.

Petition of the council and assembly to the House of Commons, relating to trade, and containing some allusions to commerce with the northern colonies. Nov. I3, I733. (Pp. 326-328.)

34. Jan. 2, I82I-Apr. I5, I825. A note at the beginning of this volume states that the minutes intervening between vols. 33 and 34 have been lost.

\section{Duplicate Council Minutes.}

One bundle received from the Colonial Office contains portions from C. O. 412. These minutes, which range from 1729 to 1782 , are only fragmentary.

\section{Recent Copies of Council Mimutes.}

1. 1609-1667: There are only three pages of extracts of minutes, covering the period Oct. I3, I64I-Jan. 4, 1653/4. The remainder of the book is filled with extracts from printed English calendars of papers dealing with the early history of the West Indies, and of Barbados in particular.

2. "I652-1671." Feb. 7, I653/4-Apr. I9, I671. (554 pp.)

Oct. Io, I684-Nov. 20, I689. (578 pp.)

Nor. 20, 1689-June 9, 1696. (578 pp.)

At page 3 is the petition of James Smith, captain of the Mary, who had come from $\mathrm{Va}$. to Glasgow, and on the return voyage instead of reaching Boston had been taken by a French ship, and finally arrived at Barbados. Nov., I689.

\section{MINUTES OF ASSEMBLY.}

All assembly minutes in Barbados previous to $1737 / 8$ have disappeared, as have also accompanying papers until comparatively recent years. The earliest minutes are very incomplete. During the years 1907-1909 the originals were copied as far as 1818 , on heavy paper of the best quality and bound in volumes averaging about 200 pages of text. Many blank pages are left, especially in the earlier volumes, corresponding to gaps in the manuscript. There is no index.

The first printed minutes in the possession of the assembly begin in 1838 , but at the public library the set starts in 1823 .

The original manuscripts still exist, but are very fragile. The present examination was made from the copies.

Addresses of the governor, proclamations, petitions of the assembly, of various bodies, and of individuals are among the important elements entered. From about the beginning of the American Revolution much correspondence with the colonial agent is also found. Many speeches appear in the later volumes.

These records are in the custody of the speaker of the assembly, to whom any application with reference to them should be made.

1. Feb. I7, I737/8-May I2, I741. 
2. Dec. I 5, I74I-Apr. $28,1745$.

Address of the council and assembly to the king, on the trade of Barbados with the northeris colonies, Ireland, England, etc. Nov. 2, I74.3.

3. Apr. 29-Nov. I, I745.

4. Nov. I, I745-Oct. I3, I749.

5. Oct. 20, I749-Jan. 21, I756.

6. Feb. I8, I756-Aug. I8, I761.

Material on the Seven Years' War is plentiful, but is confined to the W. I.

7. Sept. 21, I76I-Aug. 4, I767.

Vote of thanks to the assembly of S. C. for aid granted to sufferers from recent fires in Barbados. Apr. 28, 1767.

8. Sept. I, I767-May I2, I772.

9. June 3, I772-Sept. 6, I774.

Several speeches relate to trade and to the manumission of slaves.

10. Oct. 4, I774-Feb. I7, I778.

Speeches, addresses, and correspondence with the agent relate at times to distress in the W. I. as a result of measures to suspend trade with certain northern colonies, and to operations of American privateers. There is also some correspondence with the admiral on that station.

11. Apr. I8, I78I-Apr. 23, I782.

12. July, 1782 .

13. Oct. 29, I $782-N o v .29,1785$.

Many addresses, petitions, and letters. The publication of the treaty of peace and of subsequent orders in Council regulating trade with the U. S.; petitions for freer commerce with America, and arguments showing the need for more lumber and provisions than could be imported in British vessels manned by British seamen; a petition to the governor and legislature of Barbados by Loyalists in E. Fla.

14. Jan. I7, I786-Dec. I8, I787.

Memorial from the colonial agent on landing of corn at Barbados by an Americain vessel. Oct. 29, I785. (Pp. I2-I5.)

15. May II, I796-Nov. 9, I802.

Letter from the committee of correspondence to the agent, on the export of sugar to America from Barbados. Mar. I2, I800.

Proposal of the agent to extend the free-port bill to Barbados, and resulting problem as to importation of cotton and lumber.

16. Dec. 2, I802-June 7, 1803 .

A letter from the agent, with minutes of $W$. I. planters and merchants in London, relating to duties.

17. Jan. I5, I805-Jan. 27, I807. (With this volume begin extracts copied from the Barbados Mercury and the Bridgctoren Gazette, to supplement gaps in the originals.)

18. Nov. 20, I8IO-Nov. 28 , I8I5.

There are a few references to economic results of hostilities with the U. S. (e.g., the difficulty of getting an ample supply of staves), and to privateers.

19. Jan. I7, I8I6-July 28 , I 8 I 8.

ACTS.

All of the old acts are nominally in the custody of the colonial secretary, but are kept in the vaults of the registrar. There are no original loose acts 
prior to the nineteenth century. Original entry-books before $I 783$ seen by Professor Hull are not now in evidence. The earlier books have since been copied, and originals have probably drifted to some obscure corner.

Acts. I650-1682. Recent copies. (526 pp.)

“ 1682-1698. "“" (453 pp.)

This last volume has been wrongly labelled as "Minutes of the House of Assembly". There is no direct material for American history. One act (Dec. ro, r684) relates to pirates, and there is also material on the treatment of Quakers, Jews, and negroes, the administration of justice, etc.

Duplicate acts. $1735-1795$. (C. O. 412:70.)

" " 1768. (C. O. 412:71.)

These two items are only duplicates of material already examined at the Public Record Office.

For the period $1800-1815$ there are two volumes covering the years $1805-$ I825, and original, loose acts for I8OI-I805, I808-I8I5. The items listed below are among these loose papers, kept in a large tin box.

These were checked with a volume of The Public Acts in Force... Betreen the 8th April, I80o, and the first year of the Reign of King William the Fourth, published in 1844, and known as "Taylor's Laws". A table of acts not then in force is at pp. 178 et seq. of this book, and the information found there is given in parentheses below. It will be seen that only two acts of the list were then in force.

"An Act to remit the payment of the Tonnage Duties by the Masters or Commanders of Ships or Vessels arriving at this Island laden wholly or in part with Military or Naval Stores for the use of His Majesty's Army and Navy in the West Indies, and not taking in other loading here or breaking bulk otherwise than by landing such Stores." Nov. I2, 1805 .

An act laying a duty on all brandy, gin, and other spirituous liquors imported into this island. Feb. 2, 1808. (Expired.)

"An Act laying a Duty on all Ships or Vessels belonging to the subjects of any State in amity with His Majesty importing the articles hereinafter mentioned and also laying a duty on certain of said articles." June 5, r809. (Relates to lumber, live stock, and provisions. Repealed.)

"An Act laying a duty on certain Articles of the Growth or Produce of the United States of America, imported into this Island in Ships or Vessels belonging to the Subjects of any State in Amity with His Majesty." Sept. 18, r8ro. (Expired.)

An act to continue the preceding act. Nov. 5, I8I I. (Expired.)

An act laying a duty on all brandy, gin, and other spirituous liquors imported into this island. May I2, 1812. (Expired.)

An act to continue the preceding act. Nov. I4, I8I5.

\section{THE RECORDS.}

The registrar's office contains probate records, land records, and transcripts of the registers of parishes; the original parish records have often perished in hurricanes or otherwise. These records have value for New England and other genealogy rather than for history. Some extracts from them are given in an article by G. Andrews Moriarty, jr., "Barbadian Notes", in the Ncw England Historical and Genealogical Register, LXVII. 360-37I. 


\section{BERMUDA.}

While it did not prove practicable to investigate all possible depositories, the principal materials appear to lie in the following classes:

I. Papers in custody of the colonial secretary, preserved in the Public Building.

II. Parish records.

III. Family papers.

IV. Corporation records.

\section{Materials in the Public Bullding.}

The colonial secretary has the custody of all official documents relating to the central government of the islands, except such legal records as are preserved in the registrar's office. The secretary's office, and consequently the safes in which papers entrusted to him repose, are situated in the Public Building at Hamilton, a dignified structure erected in 1840 , and containing not only the offices of the governor and secretary but also the council chamber and certain other public offices.

The materials in this building consist of several hundred bound volumes of manuscripts, ${ }^{1}$ which are accessible to searchers by permission of the colonial secretary. While supposedly covering the full period of British occupation of the islands, the collection is very incomplete. Up to the year I782, when Secretary Henry Tucker put an end to the practice of removal of records by outgoing office-holders, and commenced systematic preservation, no classes of documents exist in any completeness except those which were necessary for the administration of property. No letters or despatches from the governors exist for dates prior to I8I4, and the despatches of the home government to the governors commence in 1809 . Except as otherwise noted, the documents are in good condition. There is in the colonial secretary's office an unpublished list, recently made, entitled "Index to Record Books", which covers 422 volumes. While the numbering of the volumes is consecutive in arabic numerals, they are classified in groups according to subject, and sometimes bear group numberings in roman numerals. Both general group numberings will be adhered to in the following description. In many cases the index also supplies dates covered by a particular volume. Most groups include index volumes, and many individual volumes have their own indexes as well. Occasionally cross-indexes are found. In general, the indexes seem to have been carefully made.

A. Richard Norwood's Survey of Bermuda, $1663 .^{2}$

B. "True Copy of Norwood's Map of Bermuda, A. D. I802, by John Van Norden."

1-16. I78I-I852. Protests.

Protests of ships' masters, filed in case of capture, wreck, or other misadventure. Supply details concerning vessels, cargoes, ownership, nationality, circumstance of capture, convoy, etc. Vol. I6 is an index to vol. I-I5, and supplies some particulars concerning the 2500 entries indexed.

${ }^{1}$ There are in addition several boxes of documents which could not be examined; but the deputy colonial secretary states that these papers are merely fragments and are probably of no value.

${ }^{2}$ Apparently the original or an early copy of Norwood's second survey (the "Bermuda Domesday"), made in 1662 and 1663 . 91 pp., bound. This corresponds to Lefroy's volume VI. 'See Memorials of Bermuda (London, I879), by Maj.-Gen. Sir J. H. Lefroy, a former governor, I. $\mathrm{xx}-\mathrm{xxv}$. 
17-29. I782-1899. Miscellaneous.

Legal documents, including warrants to survey goods imported and settle salvage, commitments, licenses to teach, powers of aitorney, bonds (of revenue officers and others), certificates of naturalization, bills of sale, acquittances of executors, debentures, assignments, and, in particular, returns of imports and exports of slaves, statistics of manumissions, slave marriages, commitments of runaway slaves, slaves escheated, taken in execution and sold for taxes, and statistics of free colored population. Volumes indexed, with exception of vol. 29, which is itself a "General Index of manumissions and bills of sale of slaves".contained in vols. $17-26$.

30-34, 34 A. 1782-1901. Proclamations.

Entry-books of proclamations, issued according to royal instructions or on governor's own authority, concerning meetings of assembly, embargoes, peace and war, apprehension of criminals, regulation of trade, etc. Proclamations concerning trade especially important, sometimes supplying detailed lists of duties.

35-40, 397. I782-1901. Administration and Guardianship.

Entry-books of administration and guardianship, renunciation of executorship, deeds of conveyance, etc. Difficult to use, and more useful for genealogy than for history. There are very interesting copies of old deeds. ${ }^{3}$ Vol. 397 is an index to vols. $35^{-39}$.

41-52. I72I-I879. Commissions.

Entry-books of commissions issued by royal warrant or by governor's own authority, to various civil officials, including naval officers, treasurers, clerks of assembly, lawyers, judges of assize, justices of the peace, parish rectors, receivers general, controllers of customs, deputy agents, registrars of vice-admiralty, etc. Vol. 52 serves as index to ten earlier volumes.

53-79, 62 A, 79 A, 392-396. I648-1881. Wills.

Entry-books of wills of date prior to 1700 , including administration papers, bonds, inventories, etc. ${ }^{4}$. Vol. $53(1648-1685)$ consists of folios restored and interleaved and rearranged by Lefroy, and includes documents of great interest, for example, Roger Wood's will, I653, and inventory of his estate made by Norwood, I654. Inventories often include detailed valuations. Original index inaccurate. A later index in Lefroy's hand incomplete. Contents of succeeding volumes similar. Separate indexes of wills and of full contents. Vols. 58, 59, and 60 are listed by Lefroy as "Wills, Nos. 4, 5, and 6." Vols. $62 \mathrm{~A}, 79 \mathrm{~A}$, and 392-396 are indexes and registers.

80-84, 84 A. 1783-1903. Writs and Forms.

Entry-books of writs and various forms, including warrants for cartels to transport prisoners, ${ }^{5}$ licenses to vessels to trade at friendly ports in war time, returns of slave population, and "sea passes".

${ }^{3} E . g$. , in vol. 35, copies of a group of deeds bearing on the sale, in 1758 , by Diamond Sargent, of York County, Massachusetts Bay, to Robert Traill, of Portsmouth, N. H., for 750 pounds sterling, of a third part of the island of Miquelon, "which island was guaranteed to the said Diamond Sargent by Governor Phillips of Nova Scotia about six and thirty years ago".

"After 1700 the related papers receive separate classification.

${ }^{5}$ E. g., warrant, Dec. I4, I782, to transport eighty prisoners to R. I. ior exchange. 
85-96. I 782-I901. Inventories.

Entry-books of inventories, illustrating in considerable detail, with valuations, all properties belonging to estates, including slaves. Vol. 85 is an index to vols. 86- 96 .

97-143, 399-403. Deeds.

Entry-books of deeds, in some cases containing other material. Vol. Ior contains earliest deeds, and also protests, depositions, powers of attorney, articles of agreement, petitions, proceedings of council, and some court records. It is not chronologically arranged, and has no index. Vol. IO3 is similar in content but has "Index to Deeds, Bonds, Protests, etc., etc., in this Book taken June 2Ist, I780". Vols. 98-I00, I02, I04-I06 ( I76I-I8I4), contain nothing but deeds, and each volume has an index, agreeing with the general and crossindexes. Later volumes not examined. Vols. 97, 399-403 are general and cross-indexes.

144-162 A, 162 F. I779 to date. Mortgages.

Entry books of mortgages, with bonds, cancellations, and transfers. Earliest volumes in poor condition, though not absolutely illegible. Arrangement not strictly chronological. Nos. I62 A, I62 F are indexes and cross-indexes.

163-181. I 847 to date. Marriage Records.

182-221. I694-1904. Minutes and Journals of Council and Assembly. ${ }^{6}$

This series, from 182 to 197 inclusive, is in bad condition. Leaves are loose, and the books have to be tied to keep them intact. Only those volumes have been listed that are prior to I8I6, and these had to be listed from a memorandum in the office of the colonial secretary, not from the originals in the room below.

182. Minutes of privy council. ${ }^{\top}$ I700-I708.

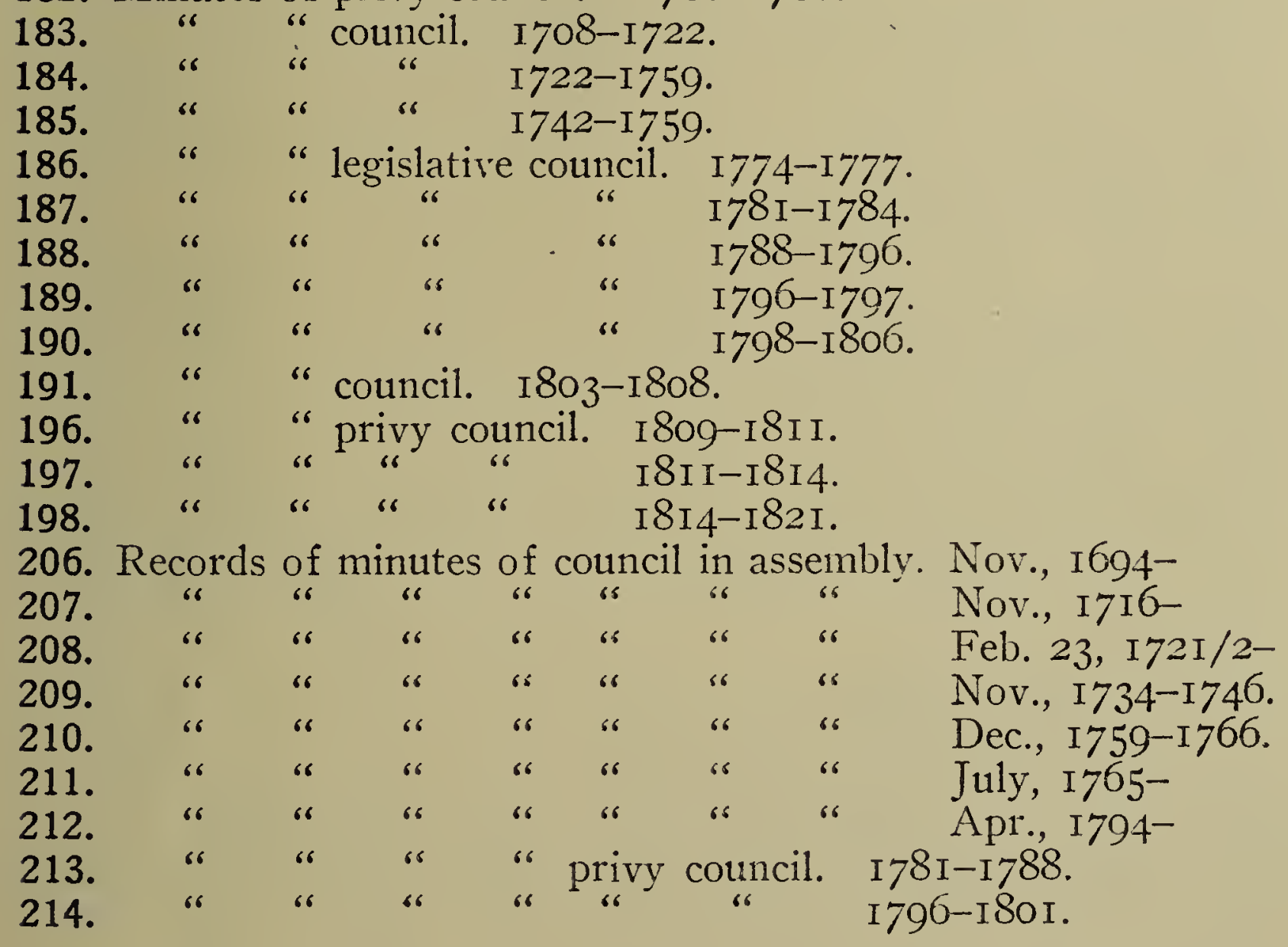

- The journals of the assembly are kept in the assembly chamber. No list is given here; they are in print from the beginning to the end of 1785 (see p. 120), and they are understood to be complete in manuscript after that date.

${ }^{\top}$ Legislative and privy councils were identical in persomel until 1888. 
215. Records of minutes of

216. “ " " " " “ I808-I8Io.

222-224, 398. I758-19I7. Grants.

Entry-books of grants, often with relevant papers, such as correspondence or instructions. Vol. 222 contains papers on sale of crown lands and revenue arising therefrom. Vol. 398 forms a general index to the other volumes.

225-236. I693-1905. Affidavits and Bonds.

Entry-books of affidavits and bonds, concerning mainly maritime commerce and intestate estates, but including bills of lading and exchange, protests regarding piracy and privateering, accounts of stores of war, discharges of bonds, powers of attorney, letters of administration, proclamations, bills of sale, warrants, commissions, and court proceedings. Frequently refer to trade with continental colonies. Vols. 232, 234 (I743-1760) are made up almost entirely of protests. Vol. 235 (I766-I779), more miscellaneous, contains many deeds and gifts. Vol. 230 contains an indenture between Edward Archer of Pembroke and Alexander Parris of Charleston, S. C., conveying 3020 acres of land near Port Royal River to Parris. Vol. 236 contains two orders for payment on account of subsistence for American prisoners, I78I. All volumes except 233 and 236 are indexed.

237-244. I700 to date. Action Books.

These volumes contain court records in civil actions only. Apparently complete in this respect, but contain no other material.

245-247. Through 1830. Slave Registrations.

Registrations of slaves, made by proprietors or agents, giving in each case name, sex, color, employment, age, and place of origin, and sometimes disposition and death. Vol. 245 bears no dates; vol. 246 is "the Second Triennial Registration of slaves in the Bermudas, under the Act entitled 'An Act for the Complete Registration of Slaves, passed the 24th day of March, I827', I830". Total numbers given. Vol. 247 continues 246.

248-250. I705-I765. Vice-Admiralty Papers. ${ }^{8}$ (Very incomplete.)

Vol. 248 ( $1705-1746$ ) contains instructions to privateers, appointments of naval officers, depositions on illegal trade, and some court records. No chronological arrangement. Contains deposition on sloop Margaret from Virginia, supposedly carrying corn but discovered to have a quantity of tobacco. Vol. 249 (I708-I725) contains papers on twelve trials, including that of David Vaughan of the brigantine Industry of Boston. Interesting details of cargoes, etc., given. Vol. 250 (I762-1765) contains record of the trial of brigantine Fairholm.

257. 1808-1821. Powder Fund.

Gives dates, names, tonnage, nationality of vessels, and amounts collected. Many American vessels listed.

258, 259, 266. I783- . Accounts of Crown Lands Quit-Rents.

Contain accounts of quit-rent returns, description of crown lands, and accounts of disposals of crown lands. Vol. 266 is a sealed volume

- According to Mr. Winslow Bell, all admiralty records were kept by justices of the peace or special registrars until 1909. At that time they were merged under a general registrar of the islands; but many are still in the hands of their former custodians, and are very difficult of access. 
which has not been examined since coming into the custody of the secretary, but is known to follow vol. 258 .

262-263. I789-I84I. Chancery Proceedings.

Records of proceedings in chancery, including an account of chancery fees for I798-I799.

264. "Copies of papers of date later than A. D. I650, collected and sorted by General Lefroy, May I874."

Miscellaneous papers (some of dates prior to I650) including council minutes, court records, and letters on shipbuilding, Quakers, tobacco, schools, whale-fishery, etc.

265. I8Io-1837. Despatches and Orders in Council.

Include commission to governor for issue of letters of marque, $\mathrm{r} 8 \mathrm{r} 2$; instructions regarding same; and order in Council authorizing importation of specified goods.

277-289. I612-17і3. Colonial Records.

These thirteen volumes form one of the most valuable parts of the collection, and correspond to the nine volumes described by Lefroy in the introduction to his Memorials of Bermuda, I. xv-xxvii. The work of restoration has been performed with great skill and success. Those manuscripts or portions of manuscripts which have been printed in the Memorials are frequently, if not always, indicated by marginal markings, a fact which to some extent lessens the inconvenience of Lefroy's failure to give exact references for his printed documents. The contents of these volumes may be judged so accurately by the selections made by Lefroy for his Memorials, and from the brief descriptions above referred to, that it remains only to establish more definite identification between Lefroy's numbering and that now in use in the colonial secretary's office, and to indicate what classes of material, if any, have been insufficiently emphasized in the Memorials.

277, corresponding to Lefroy's vol. I. I6r6-1640. Contains also much on tobacco culture and trade, parish and church difficulties, records of civil actions, correspondence between the company and governors, and various general levies.

278. I622-1633. Contains Books A, B, C, D, and E, of which the four latter correspond to Lefroy's Fragments B, C, D, and E. A contains letters, proclamations, affidavits, warrants, receipts, certificates, and proceedings of general assizes. Fragment $\mathrm{E}$ contains also proclamations, indentures, oaths of office, accounts of general levies of I6 30 and I63I, arbitrations, settlement of pews in Southampton Church.

279. I63I-1634. Corresponds to Lefroy's Fragment F (Governor Wood's Letter-Book).

280. I636-1661. Corresponds to Lefroy's volume II.

281. I647-I66r. Corresponds to Lefroy's volume III.

283. I66I-1676. Corresponds to Lefroy's End B (volume V.).

284. I647-1683. Corresponds to Lefroy's volume IV., Fragment I.

Contains list of original adventurers for plantations of the Summer Islands, I2 Jac. I., I I7 names.

285. 1676-I689. Corresponds to Lefroy's volume VII. ${ }^{9}$

286. $1677-1692$. Corresponds to Lefroy's volume IX. ${ }^{10}$

- It was from this volume that vol. 58 (Wills, No. 4) was detached.

${ }^{10}$ This volume however bears the number VIII. in the group numbering of the colonial secretary's office. 
287. I655-167I. Corresponds to Lefroy's Fragments $\mathrm{G}$ and $\mathrm{H}$. Shipping instructions referred to by Lefroy include protests, sales, ${ }^{11}$ licenses to the magazine ship, articles of agreement on portioning of prizes, inventories of plunder, etc., acts of the general assembly relating to schools, tobacco, pay of soldiers, treatment of slaves, exportation of coin, refusals to accept public office, etc.

288. I677-I.7.3. Corresponds to Lefroy's volume VIII. ${ }^{12}$

The latter part of the volume, concerning which Lefroy fails to particularize, is a "Book of Bonds, Bills, No. 5", Dec. 5, I707Apr. 24, r7I3.

289. I6r2-1623. Corresponds to Lefroy's Fragment A.

290. I720-1726. Court Records.

Records, with related papers, of proceedings in the general court sitting in the capacity of court of assizes, general gaol delivery, and common pleas.

291-315. Confidential Letters.

316-384. 1696 to date. Acts and Resolves. ${ }^{13}$

Apparently complete in manuscript, ${ }^{14}$ including laws not confirmed. Some originals, and some copies; overlapping frequent.

As noted above, no despatches from the Colonial Office were found prior to 1809 , and even after that date the series is incomplete. They do not belong to the numbered series of volumes, and are kept in the colonial secretary's room. The first volume covers the years I809-I8r6. Among the items noted are instructions (Mar. I, I8II) for strict enforcement of laws against the slave-trade; packet communications; treaty of peace with the U. S.; reduction of colonial charges, and prohibitory colonial duties. A note from Thomas Lack (Board of rrade) to Henry Goulburn (Colonial Office), July 7, I8r 5 , deals with the renewal of trade relations with the U. S., and states that their lordships are "not at present prepared to recommend any alteration in the laws by which this intercourse is regulated, as these appear to them to be fully adequate for all present purposes, and the more especially because any extension of those laws would involve a greater departure from our Colonial system than has hitherto been deemed advisable in time of peace".

\section{PARISH RECORDS.}

These are especially difficult of access, since in most cases the older records were retained by the rectors or parish clerks, and therefore suffered the fate which commonly overtakes family papers. There is at present a movement in Bermuda to collect what remains of these records, to store them in the Public Building, and to supply copies to the parishes. The existence of records was established in three cases, although it is not to be assumed that others will be discovered. What records do exist consist mainly of diaries kept by the rectors. These were personal diaries, but contain records of

${ }^{11}$ Including that of the Speedrvell of Salem, 20 tons, 470 pounds.

12 This volume however bears the number IX. in the group numbering of the colonial secretary's office. The two unpublished acts referred to in Lefroy's description are: "An Act for raising a Publick Revenue for the Support of the Government of this Her Maties. Islands", Mar., I690; and "An Act for Imposing a Tax on all Strong Liquors Imported", not dated.

${ }^{13}$ To 18 r 5 , these volumes contain acts only, but after that date resolves were included, since the assembly adopted the method of voting money by resolution.

${ }^{14}$ Vols. 316-3I9 were checked with Gray's Chronological Table, I690-1902, and were found to contain but few acts not listed by Gray; these may have been acts upon which no action was taken by the home government. Gray includes acts which were disallowed. 
baptisms, marriages, burials, and sometimes births. It was from these diaries that the periodical reports of parish populations were made up. These diaries at times contain items of some historical interest.

St. Peter's Church, St. Georges Parish.

Copy of Rev. Alexander Richardson's personal diary. I756-I772, I778I80I. During the intervening period he was at St. Eustatius. The original of this diary is in private hands.

Port Royal Parish.

Earliest records are of 1623 .

Southampton Parish.

Records commence in I626.

Pembroke Parish.

Six sheets of the rector's diary for I746.

\section{Family Papers.}

There would appear to be valuable collections of family papers extant; but they are not easy of access, and it did not prove possible to subject any to actual inspection. The papers of the Peniston and Godet families are at least among the more valuable sets. Miss Millicent Godet of Paget possesses the Godet papers.

\section{CORPORATION RECORDS.}

Minutes of proceedings of the board of corporations for Hamilton, found in Minute-Books A-K, running from the date of incorporation (I795) to present time. These books also contain copies of important correspondence of which record is desired; accessible to searchers for particular records, but notes taken are subject to examination. Records of St. George not examined, but it is understood that they commence in 1797 , and are incomplete.

\section{BRITISH GUIANA.}

No inspection of the archives of British Guiana was made for the purposes of this volume. Some information respecting them was, however, communicated to the Royal Commission on Public Records in I9II by the late N. Darnell Davis, C. M. G., formerly auditor general of British Guiana, and was printed in I9I4 in the Second Report of that commission, vol. II., part II., p. I20. It may be useful to quote here, from that page, Mr. Davis's two paragraphs upon the subject.

"The records of Essequibo and of Demerara, at first distinct Colonies, and subsequently embodied into one Colony, are kept in Georgetown, the capital of British Guiana. The records of Berbice, when a distinct Colony, were kept in New Amsterdam, in Berbice. Since these Colonies were joined into the Colony of British Guiana, the records of the Administration and of the Legislature have been kept in Georgetown, in the offices of the Government Secretary, and of the several Departments of the Government. The legal records of Berbice are, however, still deposited in the Registrar's Office at New Amsterdam, other legal records being preserved in the office of the Registrar, in the Victoria Law Courts, in Georgetown.

"A number of records were, some years ago, taken out of the Public Buildings in Georgetown, and deposited in two out-buildings specially built to hold them. Some of these papers were used for the British case in the Boundary dispute with Venezuela. The papers included a number of documents containing records of births, etc., at a time when the capital of Esse- 
quibo and Demerara was at Port Island. I do not know whether the documents in the out-buildings have yet been transferred to the several Departments to which they properly appertain."

\section{BRITISH HONDURAS.}

No inspection of the archives of British Honduras was made for the purposes of this volume. A brief statement respecting them was, however, made in the course of a Memorandum on Official Records in the West Indies communicated by the Secretary of State for the Colonies, in May, I9II, to the Royal Commission on Public Records, and was printed in I9I4 in the Second Report of that commission, vol. II., part II., p. II6. It may be useful to quote here the paragraph respecting British Honduras in that communication.

"The Governor reported (April Ig06) that the older records were in better condition than might have been expected, but that the ink was generally much faded; that a fire-proof room, opening from the office of the Registrar General (who was keeper of the Records), was approaching completion, and that provision of two fire-proof closets was contemplated. As regards current records, most official records were printed and in good order, and might be expected to last, but as regards written records the Governor feared the durability of the ink. He proposed to experiment with certain fluid carbon inks and to have the use thereof adopted in the Record Office if the result of the tests was satisfactory."

\section{DOMINICA.}

In the town of Roseau political records are found in two localities. At the administrator's office a few of the older books are located in a cupboard on the ground floor, but most of them in this cupboard are later than 1830 . In a building just across the yard another cupboard holds despatches and minutes of privy and legislative councils of varying dates.

At the court-house existing records of the assembly are in two cupboards on the ground floor, as noted below. A small room upstairs houses a collection of valuable fragments. It is the most unsuitable room in the building for the storage of records. A door and three windows leave little wall space, and rickety wooden cases were installed instead of strong shelving. The resulting congestion, and lack of appreciation of the material, led to the well-known method of obtaining more space by means of a bonfire. During the year just preceding the present inspection, many volumes and loose papers were deliberately burned, among which, according to local recollection, were some records of the court of vice-admiralty. Official opinion now views the incident with a certain amount of regret, and there is no intention to continue the practice. The question is whether the same cycle will repeat itself when the present personnel changes and memory grows dim. The fact that some of the most valuabie old records of the colony are allowed to lie in disorder on the floor of this room at the court-house, and that others shown in their mildewed condition the evidence of past neglect, is not likely to inculcate in the minds of younger officials a high regard for their value. Another discouraging feature is that none of these depositories is anywhere near fireproof.

Under the circumstances it is rather surprising that there are at least samples of so many classes of records. Early files of the councils have vanished, as have also proclamations and customs papers. Nearly every other series has at least a representative. 
As une might expect, the archives of this island frequently show that popular sympathy with illicit trade was strong and almost universal. Suspected informers were fortunate if they escaped with a minimum of tar, feathers. and a severe beating.

\section{Administrator's Office.}

DESPATCHES FROM THE COLONIAL OFFICE.

These are unbound, and are in large bundles in a wooden cupboard. The first is labelled " 1785 to $I 827$ ", but contains a variety of papers. The earliest despatch is dated July I2, I8Ir.

Certain circular despatches noted briefly here have been treated more fully under St. Lucia.

Liverpool to Lieut.-Gov. Barnes. Circular. Instructions to prevent the entrance via America of foreigners from those parts of Europe under French control. Mar. 2I, I8I2.

Bathurst to Gov. Ainslie. Circular. Sends order in Council of July $3 \mathrm{I}$, ordering the detention of any U. S. vessels together with their passengers and effects. Aug. I, I8I2. (Enclosure present.)

Goulburn to Pres. Corlet. Circular. Sends declaration of the Prince Regent on origin of the war with the U. S. Jan. II, I8I3. (Enclosure missing.)

Bathurst to Gov. Ainslie. Printed circular, enclosing an order in Council on the issue of licenses permitting importation and exportation of certain articles, and instructions regarding the same. June 23, I8I3. (Enclosure present.)

Sir Francis Laforey to same. Circular. No vessels homeward-bound to sail without convoy, under penalty. The Cressy, Carlisle Bay, Barbados, Apr. 30, I8I3.

Bathurst to same. Circular. Sends order in Council of Nov. 30 on importation and exportation of certain specified articles in neutral vessels. Dec. I7, I813. (Enclosure present.)

Same to Pres. Lucas. Circular. Instructions that henceforth any "Relaxations of the Colonial Policy" as to certain imports should take place only under exceptional circumstances. Dec. 23, I8I5.

Address of assembly to the governor, urging that the port be opened to American ships, in order to avert the famine threatened as a result of the recent hurricane. Oct. 4, 1816.

Bathurst to Gov. Whittingham, no. 5. Approves opening of the port following a hurricane, but regrets that lumber had been admitted in addition to provisions. Dec. $27,1820$.

Same to Huntingdon. Circular. In consequence of special duties on British shipping in American ports, asks if there are any "discriminating Duties, on Foreign Ships and Goods in favour of British Navigation levied in the British West India Islands under the authority of the Colonial Governments". Dec. 30, I822. (One enclosure, from Board of Trade, dated Nov. I8.)

Id. Circular. Sends order in Council of July 21, "imposing certain duties on American Vessels and Cargoes entering the British Ports in the West Indies and North America in the cases therein specified". July 3I, I823. (Enclosure present.)

$I d$. Circular. Sends letter from Board of Trade respecting heavy charges on English trade and shipping in the Br. W. I. and Br. N. Am., and requests information. June 4, I824. (Enclosure, dated Mar. I6, 
speaks of keen competition, and of trade of the U. S. and of other countries with S. A.)

Same to Maj.-Gen. Nicolay. Circular. Ports of the Br. W. I. are to be closed to ships of the U. S. from Dec. I next. Aug. I2, 1826. (Enclosure from the Treasury present, dated Aug. 2.)

Id. Circular. Details of negotiations with the U. S. on trade restrictions. Aug. I9, I826. (I5 pp.)

Id. Circular. Sends letter from Board of Trade on the interpretation of recent trade regulations. Apr. I8, IS27. (Enclosure present, dated Apr. I7.)

Huskisson to officer administering the government. Circular. Sends, with detailed comments, an order in Council of July 16 "regulating the Commercial Intercourse between His Majesty's Possessions abroad and Foreign Countries". Sept. I8, I827. (Triplicate. Enclosure missing.)

Same to Nicolay. Circular. Sends papers "respecting the Privateers, bearing Commissions from the Government of Buenos Ayres, that infest the West Indian Seas". May 3, I828. (The enclosures are from the Foreign Office and from St. Kitts. The latter says, "they are mostly manned by Americans, and frequently commanded by them". He also mentions Saba and St. Eustatius, and the employment of the Dutch flag.)

Murray to same. Circular. Sends papers on admission of vessels from the U. S. into ports of the Br. W. I., etc. Nov. Io, I830. (Enclosures missing.)

LETTER-BOOK, DESPATCHES TO THE COLONIAL OFFICE.

June 24, I822-July 28, I824. (Unpaged.)

(Huntingdon) to Bathurst. No. 33. No tonnage or light dues are levied in Dominica, and American ships are only liable to the same duties as British vessels. Mar. 12, I823.

ENTRY-BOOKS.

Three entry-books contain copies of despatches from the Colonial Office, and of replies thereto, $1824-1830$. No material for our purpose was found among the replies from Dominica.

DUPLICATE DESPATCHES.

Four volumes of duplicate despatches, Dominica to the Colonial Office, have been presented by the latter in recent years. They cover the period I8I4I840. As this material had already been treated in the portion of this book relating to the Public Record Office no examination was made.

MINUTES OF PRIVY COUNCIL.

"Vol. 3." June 9, I789-Feb. 22, I800. (243 pp.)

Minute on a petition of planters, merchants, and other inhabitants, stating: "that the Colony stands very much in need of lumber of all kinds, and of Horses and mules, with which there is very little probability of this colony being supplied by British vessels before or during the hurricane months, from the number of private and public french ships of war now cruising on the coasts of America, and between these islands and His Majesty's American colonies. That as his Honor's proclamation of the 23 rd of June last, now 
stands, the articles thereby allowed to be imported, must be purchased with ready money, or such bills of exchange as the venders may chuse to receive; which latter mode of payment seldom takes place: in either of which cases the island remains in a very distressed state: in the first, the island is drained of all its current cash; and in the latter, Bills, from the late stagnation of credit in Britain, are with diffidence and difficulty received; while the article of rum, the planters' principal resourse for the payment of contingent expences, remains an unsaleable article. The petitioners therefore humbly submitted whether their wants and distresses would not be alleviated and supplied if his honor's proclamation was extended to allow the free importation of all kinds of lumber, and of horses and mules from the united states of America; and permitted the free exportation of rum of the produce of this island in payment of such articles as are or shall be allowed to be imported in American bottoms: . . . the board were of opinion, and advised his honor, to issue a proclamation allowing the importation of scantling, shingles, staves, heading, and hoops only (these articles not being generally imported from the british american colonies) for the space of three months from the date of the proclamation." July 3I, I793.

Order for medical care to be afforded to subjects of the U. S., captured on board vessels taken as prizes of war. Feb. 8, I794.

Mr. Higginson, who has arrived from the U. S., without credentials, to obtain copies of proceedings in Admiralty upon American vessels condemned in the island, is to be allowed to have such transcripts as he desires on paying for the same. July II, I794.

Gov. Ricketts of Barbados to Lieut.-Gov. Bruce. In compliance with a wish expressed in a letter from the British consul at Philadelphia, he suggests, "whether, as the political Situation of America is still very unsettled, it might not be expedient to encourage the Merchants, and other Inhabitants, to collect and store up, if possible, at a reasonable rate, as considerable a Quantity of Provisions as can be obtained and preserved, in order to defeat the Mischiefs which might flow from the imposition of a fresh Embargo, or from the adoption of any other violent Measure, by that Country". Resolved that a proclamation issue to open the port for four months for certain articles of provisions, live stock, and lumber, and for the exportation of rum in payment. July 24, I794.

A report, on a petition from planters and others for the opening of the port to American vessels, states: "That the Board have found from Experience that neither the Trade from our own Colonies in America, nor from the American States in British Bottoms in time of War, is extensive enough to supply the Colonies: the Profits on that Trade being small, the Duties in the American Ports high, and the Danger great. That we have also found from Experience that to allow British Vessels in time of War to import American Articles from the West India Ports belonging to Powers of Europe in Amity with us, has not afforded, if any, but a very slender Assistance." It was therefore recommended that the port should be opened as requested for a limited time for the importation of certain provisions, live stock, and lumber, and the exportation of rum. Dec. I6, 1794 . 
In an address from the assembly to the governor, entered on the minutes, one paragraph is as follows: "The principle of the Law [the regulation of gold and silver currency in the colony] was further justified by the situation of the Colony with regard to the United States of America. To those States are the Inhabitants of this Island indebted for the very necessaries of Life, and the only article which can lawfully be given in Exchange for the Supplies received from them is Rum, other articles of Produce being prohibited from exportation in their Vessels. This circumstance leaves a large Balance in favor of the American States, which must be either paid in Cash or Bills of Exchange and hence it is obvious that the lowering the value of money here will induce them to prefer the former species of payment, the consequence of which must be the deprivation of the Colony of the Current Coin, the sinking of the Rate of Bills of Exchange to the mutual Injury of Government, and lowering the price of Rum to the distress of the Colony." Feb. 20, I799.

Although proclamations are rarely entered, this volume contains many recommendations and orders for keeping open the port for American vessels and goods.

"Vol. 4." Apr. I5, I80o-Nov. I8, I806. (350 pp.)

Recommendations and orders as to proclamations keeping the port open to American vessels and goods continue in this volume. An itemized list of articles to be admitted is furnished, but the actual proclamations are not entered. The period of renewal was usually for four months, the terms varying from time to time, both as to imports and exports, according to local needs. On Apr. 28, I8o I, for example, the list of imports was enlarged, and molasses was added to exports.

"Vol. 5." Jan. 16, I807-Sept. I3, I823. (303 pp.)

According to the minutes, proclamations keeping open the port to American vessels were renewed for thirty-day periods until late in I808, when a blockade of the French islands was ordered. After that date apparently the regulations were relaxed only for short periods, following the hurricanes. At times sugar and coffee were added to the list of goods exported in payment.

\section{MINUTES OF LEGISLATIVE COUNCIL.}

Feb. I4, I799-Nov. I I, I806. (Unpaged.)

Nothing was found relating to the U. S. This book is very mildewed and worm-eaten.

Dec. 4, I8o6-July 21, I8I2. (Unpaged.)

Message from the governor to the council and assembly, on the importation of fish, lumber, etc., in neutral vessels, and a bounty on salt fish from Br. N. Am. May 30, I809. Followed by copy of a British order in Council of Apr. I2, x809, on certain trade regulations in the W. I.

Message from the lieutenant governor to the council, forwarding British order in Council of Feb. 7, I8Io, extending those of Apr. 12, Aug. I6, I809, and Jan. I0, I8ro. Requests "an early determination as to the imposition of the duties on the United States American Trade". May 28, I8ro. Enclosure entered, dealing with the regulation of trade. 


\section{Court-House.}

\section{MINUTES OF ASSEMBLY.}

These volumes are in a cupboard in the main room on the ground floor. They are unpaged, but average about 400 pages each. The early numbers have suffered much from mildew.

A large cupboard on the opposite side of the room is filled with loose papers of the assembly, rough journals, and miscellaneous documents. Some draft mịnutes were seen as early as 1806 , but a brief search showed no loose files earlier than 1824 .

Mar. I3, I787-Mar. 15, I793. Nothing for U. S. history was found, but a thorough examination was impossible, as the book is partly illegible from mildew.

Apr. II, I793-Dec. 6, I797. Nothing found for U. S. history. Beginning and end wanting. This book has also suffered from mildew.

Mar. 14, 1798-May 7, 1802.

Address to the governor, respecting the currency. Feb. 20, I799. (Already noted as entered on minutes of privy council.)

May II, I802-Oct. 24, 1806.

Nov. 26, I806-Feb. I6, 18г3.

Importation of fish from the U.S. and from Br. N. Am., bounties on the latter, and exportation of part of it to the French islands. Sept. 9, I808.

"This volume also contains certain orders in Council already listed in minutes of council. It is incomplete at both beginning and end.

Apr. I7, I813-Nov. 28, 1815.

Dec. 5, 18 I 5-Aug. 18 , I8I8.

At the beginning of this volume, and separate from the minutes, are returns of all neutral vessels entered at Roseau, $\Lambda$ pr. 5, I 8 i $2-J a n$. 5 , I8I5, with an account of their cargoes. There are some American vessels in the list, even in 1813 .

A general report, adopted Nov. 8, 1816 , says among other things that at the time of the arrival of the pamphlet of the Bishop of London, "At this period all was plenty and comfort in Dominica our Port was crowded with American vessels our stores were filled with American produce and a pound of Coffee which is our staple commodity would barter for four pounds of salt fish". The report urges that American vessels and goods should be freely admitted. Nov. 8, I8I6.

Another report states: "the total Interdict laid . . . on all Commerce with the United States in Vessels belonging to that Nation has borne particularly hard on this Colony; since it has been fully proved by experience that the British Settlements in North America are utterly incapable of furnishing the West Indies with the essential Articles of Flour, Grain, Lumber and live Stock; while the severe Imposts laid on British Vessels in the Ports of the United States render the Prices of Supplies obtained in that Mode so exorbitant, that the almost ruined Planter is totally unable to afford to make the Purchase." Again it was urged that American vessels be freely admitted. Aug. 22, I8I7. 


\section{ENTRY-BOOKS OF ACTS.}

These volumes are also at the court-house. At the time of examination they were found in an upstairs room. The date given in each case is that on which the governor signed the bill.

I772-1778. (Pp. 127-435; the first I 26 pages of the book are missing.)

An act laying certain duties on goods and merchandize imported. Oct. 24, 1775 . (Relates to salt fish, lumber, provisions, etc. Continued by acts of Oct. 30 , 1776 and Sept. $6,1777$.

The book closes with a copy of the articles of capitulation between the Marquis de Bouillé and Gov. Stuart, Sept. 7, I778. These articles, in English and French, were ratified and signed by the nembers of the Council.

ISO3-18.7. (462 pp.; the end of this volume is missing.)

"An Act to raise and Levy certain Rates and Duties on salted and pickled Fish imported into this Island and a Tonnage Duty upon all Ships or Vessels importing the same and certain other Goods and Merchandizes therein enumerated." Dec. I9, I809.

"An Act for raising and levying certain duties and for applying the said duties upon the importation into this Island of certain Goods Wares and Merchandises herein enumerated being the growth or produce of the United States of America." Nov. 29, I8ro.

An act to impose a duty of two and one-half per cent. on certain goods imported by non-residents. Mar. 30, I8I I.

"An Act for raising and levying certain duties upon the Importation into this Island of certain Goods Wares and Merchandises herein enumerated being the Growth or Produce of the United States of America pursuant to an Order of Council made on the sixth day of Septem. ber One Thousand Eight Hundred and Eleven and for. applying the said Duties." Jan. 30, I8I2.

ISO5-I 822 . This is largely a duplicate of the previous volume, and has nothing further for the history of the U.S.

I822-I836. (67I pp.)

An act for raising and levying duties upon certain imports, Sept. 5, 1822. (Schedule B deals with imports from America and the foreign W. I. The duty on Indian corn or meal was taken off by act of Apr. 20, 1823.)

"An Act for raising and levying a further Duty upon the Importation of certain Goods Wares and Merchandize . . and for levying a Tonnage Duty on all Vessels of the United States which shall enter the Port of Roseau with Articles of the Growth, Production or Manufacture of the said States." June I I, I824.

MINUTES OF THE COURT OF VICE-ADMIRALTY.

These rolumes were also found in an upstairs room at the court-house. The leaves of the first are so brittle that they can hardly be touched. No loose papers were found.

I769-1793.

Material in this volume relating to the U. S. may be divided into certain categories. Prior to the American Revolution one finds from time to time orders for, and reports by, boards of survey, on ressels and cargoes damaged during the royage. Some of these belonged in the northern colonies, others traded to them. 
Beginning in 1775 there are entered many deputations from officers and crews of British ships to George Lawford, secretary to Vice-Adm. Young, respecting any future prize money. The names of the crew are given in each case, and these deputations are endorsed as recorded also in the "Book of Admiralty Proceedings in Antigua commencing November 5, r 772 ".

Proceedings for the period I776-I778, until the capture of the island by the French, account for about eighty pages. A large part of this yields definite information, most of the ships being libelled as belonging to the rebellious colonies. The names of several French ships also appear.

Between the close of $I 778$ and the year I783 there is of course a hiatus. From $r 784$ to 1793 the material is very indefinite. Actions were taken against ships and cargoes, their "tackle apparel and furniture", but usually the nationality is not mentioned.

Feb. 7, 1778-June 23, 1786. This is a copy of part of the previous book. The paper is stronger, but is badly worm-eaten.

Ang. I3-Dec. 12, I793. No direct material was found. The cover is labelled "I793-I8I5", so this loose fragment is only a part of the volume. The remainder was probably destroyed in the recent bonfire of the records.

Register of the Court of Ordinary. Apr. 28, I769-Dec. 30, I798. This book of course deals with the administration of estates, and does not relate to the U.S. It shows, however, the practice of such a court in colonial times. It is interesting to note that during the period of French occupation the only change was the substitution of the name of the French governor as the chief official. Business continued as usual.

\section{GRENADA.}

No political records of French rule are found at government offices in the town of St. George's. It is presumed that they were removed to Martinique. Thus we find nothing prior to I764, and hiatus between 1779 and 1784.

The main depository is a building that faces the office of the colonial secretary, and in fact may be considered as part of it. Interior and fixtures are entirely of wood. The cupboards contain files of a comparatively recent date. In case of fire the destruction of this building and its contents would be a matter of only a few minutes. At one side of the room is a row of boxes, most of which are of tin, filled with earlier papers mingled with active insects of the present day. These boxes are not numbered, and any arrangement of their contents is of the most casual nature. In them were found proclamations, and files of the council and assembly. One end of the building is spanned by a shelf filled with bound volumes, largely manuscript. Here are the minutes of council, letter-books, and entry-books hereafter described. Nearly all have suffered from insects. 'The paper of some of the registers of council minutes is dark and very brittle: their condition is so fragile that they can stand very little of the most careful handling. After examination these books were piled flat at one end of the shelf.

At a distance of a few hundred yards is the office of the registrar. In a vault on the ground floor, well lighted and ventilated, are such minutes of the assembly, acts, and loose papers of the court of vice-admiralty as were found. While this vault is not absolutely fire-proof it would likely hold out if help arrived promptly. 
At Grenada the colonial secretary is also registrar general, so any application with regard to these records should be made to him.

No custom-house records were found. For the period before 1830 despatches from the Colonial Office are limited to one small entry-book, and an occasional copy in minutes of the council and the assembly. Despatches to England are entered in early letter-books and also in two books of duplicate despatches, lately received from the Colonial Office, and which begin in I8I4. As material in these last volumes has already been dealt with at the Public Record Office they were not examined.

The material listed will show, it is believed, that the archives of Grenada have considerable direct value for the history of commercial relations with the United States. For the student of wider phases of colonial evolution they are still more important, especially for the years 1764 to 1776 . By the combination of letter-books, and minutes of council and assembly one can follow the problems of an area that extended from Tobago to Dominica, relations of the government of Grenada with its foreign neighbors, constitutional difficulties which found their counterpart in distant parts of the empire, and an economic life set with many a point of interest for other British colonies.

\section{Secretary's Office.}

PROCLAMATIONS.

Two of the tin boxes in the colonial secretary's office contain, among other papers, original loose proclamations. Although fairly numerous they by no means form a complete series. A large proportion of those before the nineteenth century are either entered or mentioned in minutes of the general (later the privy) council. These minutes were checked by notes made from the original proclamations. When material for American history began to overlap, listing from the registers was stopped, though checking continued. Thereafter only those proclamations were noted from the minutes that were not found among the loose papers. They are marked in the list by an asterisk. It must therefore be clearly understood that proclamations in the subjoined list come from two sources, and are only placed together for the sake of conrenience and greater coherence.

Incomplete as they are, these papers are valuable for any study of commercial relations with the United States. The reasons for their promulgation, set forth in detail in petitions copied into the early minutes of council, of course need no comment. It may not be so well known that their terms varied considerably from time to time, apt to overstep occasionally-at the governor's peril, of course-the stern wall of imperial enactment on the one hand, and swaying to temporary needs of the colony on the other.

The council records also show how the pathway of such action became progressively smoother. At the outset there were impressive petitions reinforced by much discussion at the council board. These only obtained the admission of American provisions and lumber for a very limited period, and confined such trade to British-built and owned ressels. As time went on, however, formal petitions tended to be replaced by verbal representations, and delates by a mere recommendation that the expiring proclamation should be renewed. Then the ports were opened to American ships, the list of specified articles was from time to time enlarged, and the export of rum and molasses allowed as an economic necessity. By I797 only two proclamations sufficed to cover the entire year. After a time they were no longer copied in council minutes. 
Finally, after Austerlitz and the death of Pitt, the proclamation of June 28, I 806 , shows that the colony had resigned itself to abnormal economic conditions.

Parallel with the opening of ports to American vessels went another series of proclamations of the same date, permitting the importation of similar articles from other colonies in the West Indies and South America. The terms of these also varied according to political and economic conditions. This type was of course earlier in its origin. A tew examples have been noted, but no list made, since for the greater part of the period under examination such proclamations simply formed a parallel series.

Proclamation of the Massachusetts Bay Act, for the information of merchants and others interested in trade with that province. May 27 , I774.

Proclamation extending the embargo on all ships and ressels in harbors of the island, but declaring that permission will be granted to any vessel to leave provided it has no lumber or provisions on board. Nov. 4, I 775 .

Proclamation of martial law, an embargo, and appointing persons to administer the oath of allegiance to all males between sixteen and sixty. May I8, I778. (There is another proclamation of martial law on June I8, I779.)

Proclamation permitting the temporary importation, in British-built and owned vessels, of American provisions from any island of the W. I. belonging to a European power. June I2, I787. (By a proclamation of July 26 lumber was added to the list, and in this form other proclamations were issued on Aug. 3 and Dec. 1, I788, Mar. 2, and Apr. 22, I789.)

"No. I." Proclamation permitting until Mar. I the importation in American ressels of such articles as are now by law allowed to be imported in British vessels. Jan. I, I794. (A list of the articles is given. Similar proclamations, varying slightly at times, were found bearing dates of Mar. 3, May 6, Aug. 5, Oct. I*, Nov. 4*, I794; Jan. 8, Feb. 28*, July I6, Sept. I7, Nov. 24, I795; Jan. 25, Apr. 2, June I5, Oct. 6*, Dec. 20*, I796; June 23*, Dec. 23*, I797; June 21, Dec. 2I, r798; July 8, I799; Feb. I2, Aug. I8, I800; Feb. I9, I801 ; Feb. I9, Aug. I9, Nov. 24, I802; May 19, Nov. I6, I803; May I6, Nov. I, I804; Feb. I8, Aug. I2, Aug. 17, 1805; Feb. I7, 1806. Modifications which were made from time to time related chiefly to the importation of salt fish and meat and the exportation of rum and molasses.)

"No. 4."* Proclamation of a general embargo for fourteen days. Jan. 9, I794. (Finally lifted by proclamation of Mar. 24, I794.)

"No. 6." Proclamation for carrying on trade with Santo Domingo. Feb. I3, I794. (Permits the importation into that island of lumber and provisions in American vessels according to existing regulations.)

"No. I3."* Proclamation giving further time for appeals to be made from sentences of condemnation against ships and goods belonging to subjects of the U. S. "in many of Our Vice Admiralty Courts in the West Indies". Sept. 19, I794.

Proclamation declaring an embargo. Mar. 27, 1802. (Taken off by proclamation of Apr. I, I802.)

Proclamation laying an embargo on all vessels bound for Europe. June I7, 1803. 
Proclamation declaring an embargo. May 9, I805.

June 27,1806 .

Proclamation opening the ports to American vessels carrying certain articles until the end of the present war or until six months' notice has been given. June 28, I806. (Another proclamation of the same date relates to the importation of American lumber and provisions in British vessels from other colonies in the W. I. or S. Am.)

Prociamation enlarging the terms of that dated June 28 , and allowing the exportation of rum and molasses in American vessels. July I4, I806. (These terms were again enlarged by proclamation of Nov. 29, I806.)

Proclamation specifying duties payable by foreign vessels importing provisions. Dec. I, I8II.

Proclamation extending permission for the importation, in British vessels, of certain specified provisions, lumber, and naval stores from other colonies in the W. I. and S. Am., until Dec. I8, I8I2. June I8, I8I2. Proclamation respecting the collection of duties on articles of American growth, enumerated in the British order in Council of Nov. 30, I8I3. Feb. I8, I8I4.

\section{MINUTES OF COUNCIL.}

At the outset these records embraced the entire "Southern Caribbee Islands" of Grenada and the Grenadines, Tobago, St. Vincent, and Dominica. The next step, which omitted lieutenant governors of the other islands from the list of members but made little other change in the minutes, was the institution of a separate council for Grenada and the Grenadines. The general council then had little excuse for further existence, and its meetings soon stopped. On Mar. 4, I793, the remaining series was split into separate minutes for privy and legislative councils.

Some of these books are in bad condition, and the paper is dark and very brittle.

For further information see also Proclamations, above.

\section{General Council.}

Dec. 13. I764-Aug. 26, г768. (109 pp.)

The governor's speech to the assembly on Apr. I5, I766, marks the beginning of that body. On Dec. I0, 1766, the minutes record legislation to prevent abuses in, and for the encouragement of, the trade in lumber from America.

\section{Council for Grenada and the Grenadines.}

Mar. 30, I $767-J u l y ~ 24,1776$. This is a large unpaged book, whose commencement and final pages have suffered badly from insects.

July $27,1776-$ Sept. I4, I778. (Unpaged.) This is the only volume for the period of the American Revolution.

There is some material on defense, particularly towards the end, including the proclamation of martial law in 1778 . As items of more direct incidence for American history the following were noted: A petition to the governor from merchants and other inhabitants of Grenada, asking that licenses might be issued to armed vessels to protect their commerce from depredations of American privateers, many of whom were said to reside in Martinique. This was read and approved at the meeting on Apr. 16, I7\%7. 
A petition to the governor from certain merchants of St. George's, Grenada, setting forth that American privateers with connivance in the French islands had caused much damage to trade; that to protect their commerce they had at considerable expense armed two of their ships, the Howe and the Revenge, "on a trading Voyage", in the course of which two American vessels, the sloop Orange and the schooner Rebecca. with their cargoes, had been seized, condemned in the court of vice-admiralty and sold; and praying that at least a part of the proceeds might be allowed them as a compensation for their heavy expenses. July I4, I777.

Speech of the governor to council and assembly, referring to many outrages committed by a "number of Rebel and Pirate Vessels", and to the able manner in which defensive measures had been organized in Tobago. Aug. I2, I777.

Jan. 6, I784-May 4, I79o. (Unpaged.)

Gov. Mathew's instructions, entered at the first of the volume, relate in part to trade. Minutes of the following dates deal in part with the scarcity of flour, etc., and the advisability of allowing temporary importation of American produce: June 2, II, July 25, I787; June Io, Aug. 22, I788; Feb. 28, Apr. 21, I789; Apr. 26, г790.

$\{$ June 15, I $790-$ Sept. 4, I792.

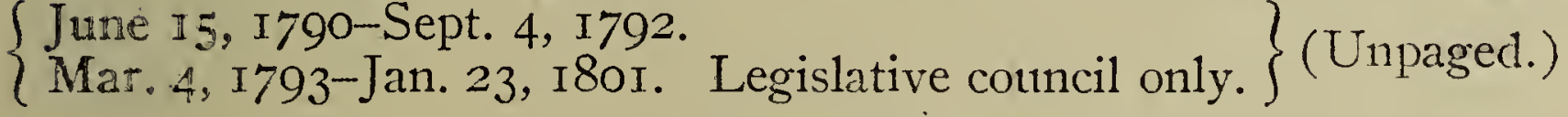

\section{Legislative Council.}

Jan. 24, 180I-Oct. 3I, I8I8. (Unpaged.)

A despatch from the Colonial Office, Mar. 2I, I8I I, relates to importation of British and foreign fish into the Br. W. I. A joint report of council and assembly deals with this subject, and gives, from customs papers now missing, statistics of all fish imported from the U.S. and from Br. N. Am. in the period Jan. I, I805-Dec. 3I, I8Io, with retail prices, and their recommendations. These papers are entered on the minutes for June $\mathrm{I} 3$ and Aug. 2O, I8II.

\section{Privy Council.}

Jan. 28, I793-Feb. 18, I805. (Unpaged.)

A petition to the governor from merchants, for the admittance of lumber and provisions in British vessels, etc., and a proclamation allowing the temporary importation of certain specified articles of American production or growth, from any island in the W. I. under any foreign European power. Feb. I2, I3, I793. A similar petition and proclamation are dated July 8, I793.

Petition to the governor by planters and others, urging that the ports be opened to admit American vessels. Aug. 22, I793.

Petition to the governor by the assembly, on the alarming scarcity of provisions, followed by a proclamation to open the ports for the importation "in American Vessels of all such Articles as are now by Law admitted to be imported from America in British bottoms", until Jan. I, I794. Aug. 23, 27, I793.

Petition to the governor by merchants, and a proclamation extending that of last August until the first of next March. Dec. 3r, 1793; Jan. I, I794. 
Similar petition and proclamation extending the term until May I. Mar. $+3,1794$.

Circular despatch from the Colonial Office on the admission of articles from the U. S. Sept. 5, 1804.

July $16,1805-$ Nov. 22,1833 .

A despatch from the Colonial Office relates to the importation of fish from the U. S. and Br. N. Am. Mar. 21, J.807.

\section{COUNCIL FILES.}

Most of these papers are tied in bundles, labelled with their dates. They are kept in tin boxes in the same room adjacent to the colonial secretary's office that also contains the books of minutes. They begin in I793, and there is something for nearly every subsequent year, though the files are very incomplete. Nearly all belong to the legislative council. Privy council material consists for the most part of petitions. Formal communications from the assembly to the legislative council form the bulk of the papers. There are also speeches of the governor or lieutenant governor, addresses in reply, petitions, etc.

On the whole these files are largely formal in character, and have little material for American history. A few items are noted below.

Signed petition to the lieutenant governor from planters, merchants, and other inhabitants, praying that the ports may remain open to American vessels bringing provisions, especially salt fish, and every kind of lumber. Mar. 3, 1793. (With it are three letters from the lieutenant governor to council, dated at different times in I794, asking the opinion of the board whether the proclamations which kept the ports open to American vessels should be renewed.)

Assembly to council, forwarding bill levying duties [on American produce] agreeably to the British order in Council of Nov. 30, I8I3. Mar. 24, I8I4.

Message from the lieutenant governor to the assembly, transmitting copies of a despatch and a report of the Board of Trade approving of his refusal to admit lumber imported in American vessels. Oct. I8, I8I5. (Enclosures present.)

\section{GOVERNORS' LETTER-BOOKS.}

The division of the early volumes is not an exact one; it means rather that the preponderance of letters is civil or military as the case may be. Civil letters are mainly to the Colonial Office, Board of Trade, Treasury, lieutenant governors and other officials of British and foreign islands in the West Indies, and to private individuals.

The later separation into "Colonial" (West Indies) and "Home" (despatches to England) is a definite one.

There is little direct material for American history here, but for those who are interested in colonial development as a whole these books are important, and should be read along with minutes of the council and the assembly.

Nov. 25, I764-Jan. 13, 1767. Military letters.

Nov. 25, 1764-Nov. 23, 1765 . Civil

Nov. 23, 1765-Apr. I6, 1768.

Apr. 2, 1770-July 25, I77I. Civil and military letters.

Apr. I0, I770-July 26 , I 77 I. Contains a larger proportion of private letters than the preceding volume. 
\{Feb. 7, I793-Dec. 3I, I794. Colonial letters. Entry-book of correspond-

Oct. 5, I792-May 7, I795. \} ence with the Colonial Office.

The last part has some material on the importation of provisions and lumber from the U.S.

Dec. 16, I795-Apr. 5, I796. Colonial letters.

May 3, I796-Mar. 22, 1797. Mainly Home correspondence.

Mar. II, I797-Feb. 20, I799. Colonial letters.

$\{$ Mar. 7, I797-June 3, I801. \} Home correspondence.

\{ Mar. 15, 1797-Apr. 29, I801. $\}$ Colonial letters.

Jan. I7, I805-July 7, I8Io. Home correspondence.

There is some material in this volume-notably a despatch to the Colonial

Office, July I, I806-on the importation of lumber and provisions

from the U. S., and on the question of placing a duty on fish from the U. S. and a bounty on that from Br. N. Am.

Aug. 21, I8Io-Oct. I5, I814. Colonial letters.

Apr. I4-Oct. I4, I8I3. Home and Colonial correspondence.

There are also two entry-books of correspondence of the governor with the assembly and council, consisting almost entirely of addresses to the assembly and replies by the latter. The dates are Mar. 15, I797June $24, \mathrm{I} 803$, and July $26, \mathrm{I} 810-\mathrm{Mar} .28, \mathrm{I} 827$.

\section{Registrar's OfFice,}

\section{MINUTES OF THE ASSEMBLY.}

These volumes bear the title "Votes of the General Assembly of the Islands of Grenada and the Grenadines". The paper of some of the early books is so brittle that the leaves will fray at the slightest touch. The amount of direct material for American history is very small.

Apr. I5, I766-Dec. 24, I767. (334 pp.)

Mar. I2, I768-Aug. I I, I770. (I73 pp.)

At the beginning there is entered a letter to the assembly from Richard Maitland, agent, stating how he and Mr. Long prevented the W. I. collectors from being placed under the North American board, as had been intended. London, Oct. 23, I 768 .

Mar. 9, I772-Jan. 26, I776.

Jan. 27, I776-June 22, 1779.

Speech of the governor on the American Rerolution. Mar. I5, I776.

Address of the assembly to the king, on the cessation of trade with America. Apr. Io, 1776.

Feb. 2, I784-July 2, I787. (554 pp.)

Sept. I7, I787-Nov. 6, I792. (462 pp.)

An interesting item for the general history of this period is furnished by two long and detailed reports in the form of queries and replies relating to slavery and the condition of slaves in the island, various factors affecting the sugar industry, comparisons with the French islands, etc. These were made by the assembly to the committee of correspondence on request of the agent. May 28,1788 .

Apr. 28, 1813-Aug. I7, 1816.

\section{ASSEMBLY FILES.}

A few papers of the assembly were found mingled with those of the council. They are not at the registrar's office, but at the depository of the colonial 
secretary, and are listed here for the sake of convenience. The only direct material noted was in 1797.

Message from the lieutenant governor on "the practice of clearing out Foreign Vessels with Sugar and other articles for foreign Countries contrary to Law" by local customs officers. Feb. 27, I797.

Signed petition to the lieutenant governor by merchants and other inhabitants of St. George's, praying that the importation of salt provisions in American vessels might be allowed. Mar. I. I797. (Copy.)

Petitions to the lieutenant governor by merchants and others, for permission to land provisions and lumber from the American brig Hannah of Falmouth. Oct. 21-27, I797. (Copies.)

I 767 . (Incomplete.)

REGISTERS OF ACTS.

$1789-1803$.

I805-I82I.

"An Act for granting to His. Majesty a Tonnage Duty . . . and also imposing Certain Duties on Dried or Salted Cod and other Fish." Nov. 17, I809.

"An Act for laying a Tax upon Transient Traders." Aug. 29, I8ro.

An act to repeal the act of Nov. I7, I809, and to substitute other duties. Feb. 6, I8II.

An act for granting to his Majesty certain duties. Apr. I2, I8I2. (Relates in part to American articles.)

An act for granting to his Majesty certain duties. Mar. 20, I8I3.

Id. Apr. I5, I8r4.

\section{COUR'T OF VICE-ADMIRALTY.}

These papers are arranged by cases and tied in bundles placed chronologically on wooden shelves in the vault. They begin in 1785 , and there seem to be few gaps, that for the years 18 IO-I8I3 being the longest. For the period before 1830 there are less than two bushels of these packages. No registers or docket-books were found.

An examination of several bundles, including the earliest dates and those for 18 I $4-1815$, revealed the names of only three American vessels. Not only is American material very scanty, but the evidence in general is vague and inconclusive. In many cases the name of neither the ship nor her captain is to be found. Papers were made out ordinarily with reference to "the Vessel, her Tackle, Apparel, and Furniture".

\section{JAMAICA.}

In recent years some transcripts from Spanish archives have been made for the Institute of Jamaica, but indigenous material does not antedate British rule. In comparison with other islands of the British West Indies the archives of this colony rank high as regards both quantity and historical value. It is true that early correspondence with the home government has disappeared, except such items as are found imbedded in legislative minutes; and that proclamations, records of the custom-house, and of the local treasury for the period covered by this book could not be found. On the other hand, as the following lists show, there are still extensive and important collections. Of these the political records include minutes and journals (but not files) of council and assembly, laws, and volumes reflecting the activities of the com- 
mittee of correspondence. Non-political records comprise papers of the courts, and various series dealing with property, vital statistics, slavery, and the parishes.

Under each repository the proper official to whom application should be made for information or copies has been indicated. It should be understood, however, that this is only a secondary step in the case of personal work, the first of course being an application to the governor, describing clearly the classes of records and the period embraced by the investigation for which permission is requested.

\section{CLASSES OF RECORDS.}

The manuscript records of a date earlier than about 18 I 5 which are to be found in the archives of Jamaica consist of the following kinds :

I. Records of births, marriages, and deaths.

2. Records relating to the ownership, transmission, and administration of land and other property. (Deeds, patents, wills, powers of attorney, etc.)

3. Records relating to the ownership of slaves: registers and records of manumissions.

4. Manuscript laws of Jamaica.

5. Court records of a civil character.

6 . Records of the court of vice-admiralty, and papers relative to prize cases.

7. Journals of the assembly.

8. Journals and minutes of the council.

9. Parochial and local records.

10. Miscellaneous records.

\section{REPOSITORIES.}

The manuscript records above referred to are to be found in general in the following repositories:

The Record Office, at Spanish Town. (Classes I-4 of the above classification.)

Headquarters House, Kingston. (Classes 8 and ro.)

Supreme Court, Kingston. (Classes 5 and 6. )

The Institute of Jamaica, Kingston. (Classes 3, 7, 8, 9, and 10.)

Parochial boards of different parishes. (Class 9.)

\section{RECORD OFFICE. ${ }^{1}$ \\ (Spanish Town.) ${ }^{2}$}

The present Record Office was established by law 6 of 1879 , as a continuation of the office of the island secretary, which had existed since the year 1659 . The nature of the archive was not affected by this change, since its functions remained the same, namely : the enrolling in proper registers of all deeds and conveyances, patents, wills which have been admitted to probate, annual produce accounts of estates and accounts current of executors, administrators, trustees, attorneys, agents, and persons acting in a fiduciary character, as well as the custody and preservation of the authenticated printed (formerly

${ }^{1}$ Papers of the court of ordinary and the court of error are at the Record Office, but for the sake of convenience they are described with other papers of civil courts.

${ }^{2}$ Spanish Town (Santiago de la Vega) was the capital of the island from 1664 to I872, excepting the years from I755 to I758. In I872 Kingston was made the capital, but the Record Office still remains at Spanish Tojvin. 
enrolled) laws of the island. Law 23 of 1886 required a register of all friendly, building, and similar societies to be kept at the Record Office. Transcripts of the rules and regulations of these societies, when certified by the attorney general, are filed in the Record Office as well as the annual general statements of the funds and operations of the societies. These statements are published in the Jamaica Gazctte, to which they are forwarded by the deputy keeper of the records.

Abstracts or notes from the registers may be taken by persons interested in searching the records, but copies of all public records must be made and certified as true copies and sealed with the seal of the office at the cost of the person desiring the same. The cost of these copies is Is. $6 d$. per legal sheet of 160 words.

The chief justice is ex-officio keeper of the records; the deputy keeper also holds the office of registrar general.

The number of volumes in this archive, exclusive of registers of births, marriages, and deaths, was in the summer of 1916,2286 . They are kept in good order and properly cared for by the staff.

Application for copies of documents may be addressed to the deputy keeper of the records or the assistant deputy keeper.

\section{RECORDS OF BIRTHS, MARRIAGES, AND DEATHS.}

In early days, civil status records of the Church of England were required by law to be kept at the island secretary's office (now called the Island Record Office) at Spanish Town; in some cases they date as far back as the second half of the seventeenth century. Public provision for the registration of births and deaths only came into force in April, I878. The following table shows, approximately in some cases, the earliest dates at which the respective records begin:

\begin{tabular}{|c|c|}
\hline Parishes & Baptism \\
\hline Kingston .. & I722 \\
\hline Port Royal & 1728 \\
\hline St. Andrew ........ & I664 \\
\hline St. Thomas the East. & I709 \\
\hline St. David ......... & I794 \\
\hline Portland ......... & I804 \\
\hline St. George & 1806 \\
\hline t. Mary. & 1752 \\
\hline letcalf $\ldots \ldots \ldots$ & I 43 \\
\hline t. Ann ........... & I768 \\
\hline relawny $\ldots \ldots \ldots$ & $177 \mathrm{I}$ \\
\hline - James ......... & 1770 \\
\hline anover ......... & 1725 \\
\hline estmorland .. & 1740 \\
\hline Elizabeth . . . . . . & I708 \\
\hline anchester $\ldots \ldots \ldots$ & 1816 \\
\hline arendon ... & I690 \\
\hline ere & I696 \\
\hline Catherine.. & 1668 \\
\hline John $\ldots . . .$. & I75I \\
\hline Dorothy ...... & \\
\hline t. Thomas the Vale. & \\
\hline
\end{tabular}

Marriages

Burials

1721

1722

1727

I668

1725

1721

I666

I794

I 708

I804

I794

I $80 \mathrm{I}$

I 808

I755

1843

I768

I77 I

I 8 I I

I 67

I 843

I768

1772

I $77 \mathrm{I}$

I7 54

I774

I 727

I 740

I $74 \mathrm{I}$

I7I9

I 827

I 722

I8IS

I695

I 769

I743

I733

I668

I67 I

I75I

I 725

I $75 \mathrm{I}$

I 816

1706

I8I 6 
2. RECORDS RELATING TO THE OWNERSHIP, TRANSMISSION, AND ADMINISTRATION OF LAND AND OTHER PROPERTY.

This class of records includes registers of all deeds and conveyances, patents, wills admitted to probate, produce accounts of estates, accounts current of executors, administrators and trustees, bonds, and similar records which by law were required to be filed in the office of the island secretary, or, after I879, in the Island Record Office. ${ }^{3}$

The antiquity of these records and their essentially economic character render them a source of information of no small value to historians. It was not feasible, however, to make any detailed study of these documents, and as their general nature is sufficiently apparent from the titles, only a mere list of them was considered to be necessary.

Title of records

Wills (proved in Supreme court)

Wills (proved in residen t magistrate's court)

Deeds

Patents (land grants)

Powers of attorney

Plat books

Inventories (of deceased persons' estates)

Letters of administration (authority to administer deceased persons' property)

Letters testamentary (authority to executors to act)

Writs of extents

Crop accounts

Accounts current (of trustees or administrators)
Date at No.
which of vols

they in the Vols. of

begin series indexes

I66I I-I37 5 Vol. I. is a transcript.

$\begin{array}{lc}I 870 & I-I 3 \\ 1664 & \left\{\begin{array}{l}I-985 \\ I-2 I 6\end{array}\right.\end{array}$

\section{I}

At first called district court.

6I Two series. Vols. I.$\mathrm{V}$. of old series are transcripts. Indexes: 3 I of grantors, 30 of grantees.

2 Vol. I. is a transcript.

$\begin{array}{lc}I 662 & I-42 \\ I 663 & \left\{\begin{array}{l}I-275 \\ I-I 7\end{array}\right. \\ I 663 & I-35\end{array}$

8

The oldest records are of the parish of St. Catherine.

$1674 \quad I-163 \quad 4$

IFIO I-4I 2

$\begin{array}{lrr}\text { I7I6 } & \text { I }-55 & 2 \\ \text { I755 } & \text { I-I3 } & \text { I3 } \\ \text { I740 } & \left\{\begin{array}{l}I-99 \\ \text { I }-2\end{array}\right.\end{array}$

I807 $\quad \mathrm{I}-54 \quad 2$

- See an article by Mr. Noel B. Livingston, in Caribbeana for July I, Ig09 (vol. I., part 3), pp. ${ }^{135-137 . ~ T h e ~ d o c u m e n t s ~ o f ~ e a c h ~ s o r t ~ b e g i n ~ w h e n ~ t h e i r ~ r e c o r d i n g ~ w a s ~ f u r s t ~}$ legally required, and the office inventory shows that all the series are substantially complete. 
Dedimus (to qualify executors)

Dedimus (to qualify administrators)

Bonds (sureties)

$\begin{array}{lcr}\text { I830 } & \text { I-IO } & \text { IO } \\ \text { I8 } 31 & \text { I-8 } & 8 \\ \text { I858 } & \left\{\begin{array}{l}I-4 \\ \text { I-I6 }\end{array}\right. & 20\end{array}$

3. RECORDS RELATING TO THE OWNERSHIP OF SLAVES: REGISTERS; RECORDS OF MANUMISSION. .

These bear a close relation to the previous class of records. The material of this kind is as follows:

Repository

Record Office

Record Office

Institute

Institute

Institute
Title of records No. of vols. Dates

Records of manumission

Slave returns

Kingston: memorandum of slaves sold

I4I I 8 I $7-1832$

I $\quad$ I738-I743

Kingston: register of slaves [manumitted]
Renartas

Vols. I.-IV. of this series are missing, Vol. V. (original, beginning I747) is in b a d condition. There are two vols. of indexes: I., I779-1819; II., I $819-1833$.

Original, with signatures of rendors, witnesses, etc.

I. I744-I795 Appears to be the index to other books, to which there are references, e.g., "Enrolled Liber i2, fol. 8". The dates of entry are $176 \mathrm{I}-$ I795, but the dates when freedom was granted run back to about I744. The upper right-hand corner of the leaves has been torn off.

Contain receipts for slaves sold. The first vol., roI sales; second vol., nos. 5-278. Is no. 234 in Cundall's Bibliograpliato Iamaicensis. 
In addition to the above volumes, data concerning the number of slaves will be found in the parochial tax-rolls, described under class 9. The slave population was such an important factor in the economic and social life of the colony that nearly all the records of the island necessarily refer more or less frequently to the condition of this class.

\section{MANUSCRIPT LAWS OF JAMAICA.}

There are two manuscript series of the laws, both preserved at the Record Office. The series of official enrolled laws is the more complete of the two; the other collection was recently transferred from the office of the attorney general. A description of these two series follows:

\section{A. Enrolled Law's of Jamaica.}

Vol. Dates

Remarks

I. I68I-I725, Jan. 28, or later. Transcript, certified Dec. 24, I846. At beginning and end there are many lines and words omitted, as well as in the body of the book, probably because the original vol. (not to be found now) was illegible in those places.

Comparing this manuscript vol. with the printed Acts of Assembly... . from I68 I to 1737 (London, I738), a copy of which is preserved in the Record Office, it will be found that the manuscript vol. begins with law no. 2 of the printed edition, p. I5, an act for regulating servants, I68r. All laws before 1703 are undated in the mannscript vol.

II. This volume is missing.

III. I735, Apr. I3-1747, May 28. Transcript, certified Nov. 28,1846 .

IV. I748, Apr. 30-1759, May 5.

V. I759, Oct. 5-1767, Dec. 21.

VI. I 767, Dec. IO-I 774 , Dec. 24.

VII. I774, Dec. 24-I781, Jan. I2.

VIII. I780, Dec. 30-1788, Jan. Io.

IX. I787, Dec. 22-I791, Dec: 9, or later.

X. I792, Mar. IO-I796, Dec. 21.

XI. I797, Aug. 4-1801, Mar. I5.

XII. I80T, Mar. I 5-1804, Dec. I8.

XIII. I804, Dec. 18-1809, May 20.

XIV. I809, Nov. 29-I8r 3, Dec. 4.

XV. I8I4, Nov. 23-18I8, Dec. I9. XVI.-XXVII. I8I9-1870.

Transcript, certified July 27, 1847, and made from a copy of the year I 761 . Original. Ff. I7O-r72 transcribed.

Original. Ff. 42 and 47 transcribed.

Original.

Original.

Original. Now has $216 \mathrm{ff}$. One or more folios lacking at end.

Original. $222 \mathrm{ff}$., of which the last 3 are transcribed.

Original.

Original. $269 \mathrm{ff}$.

Original. $264 \mathrm{ff}$.

Original. $272 \mathrm{ff}$.

Original.

These twelve volumes bring the series to a close.

This series is continued by the set of printed laws, offcially anthenticated, from I87 I to date. 


\section{B. Certified Copies of the Lawe, formerly in the Office of the Attorney General.}

This series, turned over by the attorney general to the Record Office in September, 1916, is made up of contemporary copies, certified by the island secretary as notary public. They were not originally bound, each law being on separate sheets of paper, which were later bound into volumes. The laws in these volumes are not always arranged chronologically. ${ }^{4}$ Each of the manuscripts has a note in pencil: "Duplicate B. T. Acts-Jamaica" (whence it may be inferred that they came from the series in the London Public Record Office now classed as C. O. 139), and a number and date following. All except no. 34I of this series, which is a bundle, are bound volumes.

Serial number $34 \mathrm{I}$. I705-1790.

342. I746, Nay I-I747, July 2.

343. 1748 , Apr. 30-1750, Nov. I7.

344. I752, Oct. $21-1788$, Dec. 6.

345. I761, Apr. 4-1762, Nov. 24. $346-348$.

349. I8oI, Mar. I I-I5.

350. I8or, Nov. I9-Dec. I2.

351. $\quad$ 1802, Oct. 29-Dec. 18.

352. I803, Dec. 22.

353. I804, Nov. I5-Dec. I8.

354. I805, Nov. 15 -Dec. 23.

355. I806, Oct. 2 I-Dec. 19.

356. I807, Sept. 22-Nov. 28.

35\%. 1808, Oct. 28-Dec. I.

358. I8og, May 8-20.

\section{Remarks}

A package made up principally of laws written on parchment, and a few on paper. Those on parchment, besides the large wax seal, bear the signature of the speaker of assembly, clerk of council, and governor. This package contains one law approved Aug. 15, I705 (copy on paper), and the following on parchment: I 5 approved Nov. Io, I7I6; 4 approved Aug. 3I, I7I7; 3 approved Aug. I6, I729. Several other laws, on paper, of 1771,1778 , 1789 , and 1790 , and a list of acts passed May 6, r732, are also to be found in this package.
From this volume on, all are indexed.

Also contains council minutes, Nov. 23, I807-Nov. I8, I808, bound in at end of volume. Also council minutes, Dec. I, I808-Apr. 27, I809.

\footnotetext{
"The date given in this report, referring to the laws of Jamaica, is the date of approval by the governor.
} 
Serial

numbet

359. I809, Nov. 29-Dec. I4.

360. ISIO, Nov. I4-Dec. I5.

36I. ISIt, Nor. I4-Not. 26.

362. I812, Oct. 27-Dec. II.

363. $\quad$ I8I3, Nov. 9-Dec. 4.

$364-381 . \quad 1814-1832$

\section{Remarks}

Also council minutes, Oct. $3{ }^{1-}$ Dee. I4, 1809 .

Also conncil minutes, Dec. I5. ISog-Dec. I5, I8Io.

Bound in at end are statistics of vessels entered at and cleared from Nassau, New Providence, during the quarter ending Dec., I809.

Also council minutes, Oct. 26 Dec. 4, ISI 3 .

These eighteen volumes bring the series to a close. The minutes of council are bound in at the end of the volumes.

Of the early laws of Jamaica there are several printed editions, which have been carefully listed and described by Mr. Frank Cundall, secretary and librarian of the Institute of Jamaica, in "The Press and Printers of Jamaica prior to 1820 ", a paper contributed by him to the Procecdings of the American. Antiquarian Socicty for October, I9r6." Many of these editions are rare, and it may safely be set down that they are all, to a greater or less extent, incomplete. The manuscript collection of the enrolled laws of Jamaica, therefore, contains some unpublished laws or portions of laws. A comparison with the printed Acts of Assembly. . from I68I to 1737 (London, 1738 ), revealed the fact that from this particular collection, no doubt one of the most complete of the printed editions, a number of laws were entirely omitter, and many others were given only by title. Professor C. H. Hull, in his notes on the archives of Jamaica, states that many of the laws "are not included in any of the printed editions of the statutes of Jamaica". Unfortunately; the time at the searcher's disposal did not permit him to investigate the approximate number and the general nature and importance of these laws not printed; and as the printed editions of the early statutes, with the exception of the one above mentioned, were not to be found at the Record Office, the difficulty of carrying out this comparison was increased. It is probable that the laws omitted from the different printed editions were left out simply because they had been repealed. Some light might, however, be throwin upon the question of disallowance of acts passed in Jamaica by a comparison of the printed and unprinted laws. The whole matter is one well worth investigating. and a complete edition of all the early statutes of Jamaica would be interesting and valvable, particularly if the texts were properly annotated. Such a compilation would be particularly useful to the student of the legislation of the continental colonies of Great Britain during the same period.

\section{VESTRY MINUTES.}

At the Record Office are preserved the vestry minutes of the parish of St. David, as follows :

$$
\begin{array}{ll}
\text { I785, Jan. I-1793, June 29. } & \begin{array}{l}
\text { Consists of minutes of justices } \\
\text { and vestry sitting together, } 1 \text { rol. }
\end{array} \\
& 9 \text { vols. }
\end{array}
$$

${ }^{5}$ XXVI. 296, 319-321, 379, 380, 384, 386, 389, 391, 392, 396, 400-402, 404, 406. 
MISCELLANEOUS.

In this office are also two poll-books, containing the lists of qualified voters for members of the assembly, of which vol. I. covers the years $1803-1843$.

\section{Court-House. ${ }^{6}$}

(Kingston.)

The records of the supreme court of judicature (also called the grand court) and of the court of chancery are to be found at the Court-House, Kingston, but it did not prove feasible to make any systematic examination of them.

After the earthquake of January, I907, these records, together with those of the court of vice-admiralty, consisting of several hundred large folio volumes, were transferred to the Wolmer's Free School building, and in I9Io to the first floor of the eastern block of public buildings, King Street, where the supreme court and registry, the attorney general's office, the law library, and the Kingston court are located. For the sake of brevity this is called the Court-House. On being transferred to the Wolmer Building the rolumes of old court records were completely disorganized, and on the second removal to the new Court-House they became still more confused. As many volumes were very old the covers and first and last leaves were in a great many instances torn off: Time and dampness had already done their share in destroying the volumes, when the two removals came to their aid as new factors of destruction. Yet this does not tell the whole story. The rolumes, about three thousand in number, were placed in a small room and piled up to the ceiling, one row in front and another behind, upon rude shelves erected along the walls and in the centre of the room, without the least semblance of order. In this position, it would have been well nigh impossible to have examined and listed the volumes, about one-third of which had lost their covers and first leaves, for in addition to the difficulties mentioned, there was hardly space enough for a person to walk between the shelves. The heavy volumes so arranged (or disarranged) on the rude wooden shelves proved too heavy for them, and during an earthquake shock, as the investigator was informed, the shelves broke down at the farther end of the room, so that more than one-half of the volumes fell one upon another in a huge pile, and the work of examining the records became only a secondary difficulty, the main problem being how to get at them. It must also be said that dust had accumulated very thickly on the volumes, and this fact together with the semi-darkness of the room added materially to the mechanical difficulties of the problem. With the aid of a servant books were selected here and there from the room, so as to get from such sample volumes some idea of the kind and antiquity of the records. It was discovered that the ancient records (for there were also some court records of the latter half of the nineteenth century) were those of the supreme court of judicature, of the conrt of chancery, and of the court of viceadmiralty. The last will be described in due course. At this point a brief statement is furnished of what was discovered regarding the two kinds of records first mentioned.

\section{COURT RECORDS OF A CJVIL CHARACTER.}

\section{Suprene Court of Judicature.}

Of this court volumes of judgments, beginning, "Be it remembered", etc., dating as far back as 1704 , and proceedings from 1710 , were noted. Of these

\footnotetext{
- Requests for copies of any court records or for information concerning them should
} be addressed to the registrar of the supreme court. 
two classes about twelve rolmes between s,04 and 1760 were examined. Nearly all were in a deplorable condition, partly destroyed by dampness and roish handling. Their partially mutilated condition made it difficult to determine the exact dates. The following volumes were noted:

\begin{tabular}{|c|c|c|}
\hline Judgments. & $170+1705$ & (In very bad state.) \\
\hline Proceedings. & I7IO-ITII. & \\
\hline Proceedings. & $17 I I-I 712$. & \\
\hline Judgments. & 1712 & \\
\hline Proceedings. & 1713 & \\
\hline $\begin{array}{l}\text { Judgments. } \\
\text { Tudgments. }\end{array}$ & $\begin{array}{l}1734^{-1} 737 . \\
1738-1730 .\end{array}$ & $\begin{array}{l}\text { ( I9S ff., first I } 3 \text { wanting.) } \\
\text { ( } 87 \text { ff.. first } 20 \text { wanting.) }\end{array}$ \\
\hline Judgments. & 1738 & (First and last folios wanting.) \\
\hline Proceedings. & $1743-1749$ & \\
\hline Proceedings. & $1754-1758$ & (Ff. I-6 wanting.) \\
\hline & $175 \%$ & \\
\hline
\end{tabular}

In an adjacent room were deposited about three or four hundred rolumes of rendition books, which date back to about 1784 .

\section{Court of Chancery.}

The records of this court were mingled with those of the supreme court of juclicature and the court of vice-admiralty, and the difficulty of examining them was almost insuperable. They include order-books, minute-books, fee and file-books, masters' reports, general proceedings, and enrolled decrees.

A chronological rough list of order-books, minute-books, and enrolled lecrees was found, by chance, in a volume of recorded judgments of I7391/4T. It is said to be in the handwriting of Mr. M. S. Bennett, a former resistrar of the supreme court, and is on a sheet of Whatman paper watermarked "I839". The latest order-book listed began Oct. 4, I842, and was apparently still incomplete when the list was made. Of the 76 order-books which had been made since their beginning, July 6,1682 , only nine seem to have been missing then.

Of the early order-books only the following were found:

XX. May 25, r750-Oct. 30, 1753.

XXI. Nov. 1, 17.53-Feb. 3, I757.

XXII. Feb. 14, 1757-Feb. 2, 1759.

XXVI. Aug. 2, 1,65-Mar. 31, 1767.

XXVII. Apr. I, I 767 -Dec. 31 , I768.

XXVIII. Jan. 3. r769-Aug. 31, 1771.

XXX. Apr. 2, I773-Oct. 3I, 1774.

XXXIII. Tan. 3, I780-Dec. $3 \mathrm{I}, \mathrm{I} 78 \mathrm{I}$.

But one fee and file book before I78I was found (Apr. 23, I772-Nov. I2, $1776)$; and a hasty examination of a large pile of unarranged reports of masters in chancery revealed no such reports before that date.

Mr. Bennett's list enumerates only five volumes of minute-books, covering the periods Dec. I8, I704-June 2, I7I5, and Jan. 2, I720/I-May II, I724. The following volumes were found:

1697-I704.

Aug. 26, I703-Nov. 20, I704. "No. 3."

Feb., I716/7-Dec. 8, I720. (Lettered "chancery Minute Book, 110. 10.")

Nov. 24, I724-May I7, I734.

Nov. 21, 1747-Apr. 5, 1750. 
A volume lettered "No. I, Index to General Proceedings I663-1756" (on Whatman paper, water marked " $G R$ ", undated), contains an "Alphabet of Records, from Liber I, which commences the I8th September, I663, to Liber 60 which ends the 26th June, I759". There were, in fact, 62 volumes, 9 and 22 being each in two parts. Of all these books of proceedings only the following were found: ${ }^{\top}$

$$
\begin{array}{rr}
\text { XV. Sept. 12, I707. } & \text { XLIV. Oct. II, I746. } \\
\text { XXIIh. Sept. 23, I721. } & \text { LI. Dec. I3, I750. } \\
\text { XXVIII. Sept. 25, I739. } & \text { LV. July I6, I752. } \\
\text { XXXIII. Apr. I2, I742. } & \text { LVI. Jan. 2, I753. } \\
\text { XXXV. July 21, I743. } & \text { LX. Oct. 2, I756. }
\end{array}
$$

Upon the conclusion of Liber 60 apparently a new series, of similar scope. was started under the designation of "Records". This was continued until I837, extending to 504 volumes, most of which are extant. Vol. 84 covers the period Sept. I-Nov. 3, I78I. Of the volumes antedating it, the following seem to be missing: $1,2,6$, IO, I6, I8, 30, 40, 42, 50, 53, 73, 74, and four of the six that should be numbered from 77 to 82 . Some of the extant volumes are damaged.

Of the enrolled decrees, as of the general proceedings. there appear to have been two series. Only the second, some volumes of which are lettered " $\mathrm{B}$ ", was listed in 1842 by Mr. Bennett, who appears to have found that series then complete in forty volumes, extending from May I7, I762, to Dec. I2, I8I4. The following volumes of enrolled decrees, before 1782 , are now in the Court-House:
A. May, I686-Dec., 1688.

$\begin{array}{ll}\text { I7IO- } & \text { I7I3. } \\ \text { I726- } & \text { I727. } \\ \text { I731- } & \text { I734. } \\ \text { I747- } & \text { I750. } \\ \text { I750- } & \text { I753. }\end{array}$
B.
I. May 17, I762-Nor. 29, I766.
II. Mar. 5, I 767 -Mar. I6, I77I.
V. Nov. Io, 1774-Sept. I4, 1776.
VII. Dec. 4, I779-June 2, I78I.
Court of Ordinary. ${ }^{9}$

Registers. Vols. I-IO, dating back to I796.

Citations to appear before the court of ordinary. Vols. I-8, dating back to I764.

\section{Court of Error ${ }^{9}$}

The court of error or court of appeals was composed of the governor, members of the privy council, and the chief justice and associate justices of the supreme court. The following volumes of proceedings were found:

I. 1709, Aug. 2-1740, July I.

First 3 leares damaged, partly illegible. Begins with "Extract of Her M. Instructions to His E. Capt. Genl. of the said island for constituting a court of appeal-Entered in the Patent Book, Lib. I5 fol. II9, the 8th Nor. I709".

7 This list gives initial dates only.

shese are Mr. Bennett's dates. But vol. VIII., in its present mutilated state, appears to begin July 6,1782 .

Papers of these courts are at the Record Office, Spanish Town. but have been dealt with at this point for the sake of greater convenience. 
- 1747 (or earlier)-I752, Feb. 24. First 24 leaves wanting.

IV. I784. Dec. 2-I 787 , Nov. I4.

V. I782, Nov. 25-I784, Dec. 9.

VI. 1787, Nov. I4-1798, Dec. II. This vol. is lettered IV.

VII. I799, Dec. 14-1802, Dec. 2.

VIII. ISo2, Nov. 23-Dec. I5.

II.[sic] I793, Nov. 27-1804, Dec. II.

Inside this last volume is a copy of "Rules for the Court of appeals adopted at a session of the Court on the 4th February I7 46 and divers other rules and instructions up to 1838 " ( $5 \mathrm{pp}$.).

6. RECORDS OF THE COURT OF VICE-ADMIRALTY AND PAPERS RELATTVE TO PRIZE CASES.

These records were in the same condition as those of the supreme court and court of chancery. It was therefore impracticable to list them in an adequate way. As many of the volumes were noted as time permitted, and the bundles of prize cases were examined at some length.

In one of the bundles of prize cases, an undated list and partial index of these records was found. This list is as follows:

\section{"Appendix."}

"Classification of Papers in Aclmiralty Office."

Class A. Libels and suits, numbered from I to 1565 .

Class B. Libels and suits, not numbered. I769-1855.

Class C. Ten bundles of claims, numbered from I to Io.

Class D. Thirty-nine bundles of ships' papers in connection with various suits, and which might be of use in lieu of those destroyed.

Class E. Four bundles of affidavits in various suits.

Class F. Four bundles of stipulations.

Class G. Ten bundles of briefs, numbered I-IO. I767-1859.

Class H. Indictments for piracy and murder. I700-I800.

Class I. One bundle of monitions in various suits.

Class J. Three bundles of powers of agency, etc.

Class K. Six bundles of interrogatories.

Class L. Seven bundles of examinations.

Class M. Thirteen bundles of accounts of sales.

Class N. One hundred volumes of general proceedings of prize courts, letters of marque, indexes to suits, etc.

From an examination of material at the Court-House it was apparent that all these classes of records were still in existence, although greatly damaged and in many cases almost destroyed, by dampness, duck-ants, and improper care and handling. All except class $\mathrm{N}$ are in bundles (over 200 large packages), and are in a room opposite that containing volumes of supreme court, chancery, and vice-admiralty records. The description will first deal with the bundles (classes $A-M$ ), and afterwards with the volumes.

The papers in these bundles are not put up in any order. They were wrapped up without care being taken to keep different matters separate. Labels in many cases are now illegible or missing, and the documents themselves have been partially destroyed by duck-ants and by dampness.

Corresponding to class $A$ (the distinction between $A$ and $B$ is not clear, except that $\mathrm{A}$ are numbered) are the following lists or indexes: "From 289 
to 953. List of prizes and seizures as abore-Old list, r796-99"; and "From No. 954 to no. ${ }_{5} 65$, December I799 to November I80I" (I8 pp.). These lists give name of vessel, captor, when libel was filed, and decision (date included) whether condemned or dismissed.

There is an index of 45 pages to class $B$, on the same watermarked paper as the general list noted above, giving by year the prize vessels, and the decision of the court. ${ }^{10}$

An examination showed many cases of American ships between 1776 and I782, that is to say, ships either American-built or American-owned or trading with the American colonies. There were also a number of vessels holding letters of marque from the American revolutionary government. The following is a partial list of American vessels captured, I $776-1782$, compiled by examining the ship's papers seized with each ressel.

$$
\text { I } 776 .
$$

Schooners: Betsey, Hopecuell, Lady Caroline, Nancy, Truo Brothers. Sloops: Charlotta, Flying Fish, Mary, Pacifique, Phebe.

$17 \% 7$.

Brigantines: Ame, Lucretia. Schooners: Adventure, Chowan, Dispatch, Friendship, Hannah and Eliwabeth, Harriett, Marianne, Roger, Wild Cat. Sloops: Betsey, Dolphin, Hornet, Lydia, Rover.Julian (or Juliana), La Esperance.

\section{8 .}

Brig Free American. Brigantines: Britamia, Hiram, Kettey, Recovery'. Schooners: Abigail, Betsey, Betsy Orrick, Defance, Dolphin, Experiment, Hamah, Martha and Mary, New Constellation, Rainborw, Riche. Sloops: Catherine, Dove, Fanny, Happy Couple, Hirondelle, Interruptet, James, Jaspar, Kitty, Manrice, Ushant.

\section{9.}

Brigantines: Defiance, Guadelquiver. Schooners: Acteon (privateer). Basto, Chance, Hope, Liberty, Milford, Polly. Sloops: Experiment, Dolphini, Jeany.

I780.

Brig Chester. Brigantines: Achilles, Adriana, Elisabth, Friendship. Schooner Chatham. Sloops: Fortune, Hector, Livingston.

$$
\text { I } 58 \mathrm{I} \text {. }
$$

Brigantines: Betsey, Charming Polly, Fayette, Havannah, Hope. Schooner Harriett. Sloop Argo.

\section{$\mathrm{I} 7 \mathrm{~S} 2$.}

Ships: Marquis de Bouillé, Minerva. Brigantines: Active, Hibernica. Schooners: Eagle, Neptune.

There are very few papers before I776. Among them are cases of the snow Kitty (I768) and the sloop Resolute (I773), neither of them American; depositions in the case of a vessel called the Three Friends (1762); and articles against the sloop Jupiter, of Rhode Island ( 1764 ).

\footnotetext{
${ }^{10}$ Mr. Pérez made a literal copy of this index, which is on file at the office of the Department of Historical Research of the Carnegie Institution of Washington.
} 
The ship's papers when they were seized (which was the usual thing) were attached to the libel, and they are of the greatest interest, for they constitute a first-hand source of information concerning the trade carried on by that vessel. Frequently there are small bundles of private correspondence which were seized. Many of these letters refer to matters of commerce, and would repay a careful examination. An inventory of goods carried by the vessel is frequently found.

Class $\mathrm{H}$ is a small bundle labelled, "Indictments for piracy and murder, I700-I800-Admiralty sessions". A package was found containing "bails on granting letters of marque and reprisal against the ships and vessels, goods, etc., belonging to the American colonies, King of Spain or to any of his vassals, etc., the French King or any of his vassals, etc., I779-1783".

Of class $\mathrm{N}$ a list or index was found giving the contents of each volume. As the items in this list were not arranged in any order, they are here classified as follows:

\section{"Class N. List of one hundred volumes of Bound records in Admiralty" Office."}

Admiralty Minutes and General Proceedings of the Court.

I758, May I 5 -July 25. (Rough minutes.) ${ }^{11}$

I758, Aug. 4-Sept. 8.

I759, Aug. 9-Oct. 9. (Rough minutes.) ${ }^{11}$

I 776 , Jan. I.2-I 778 , May $29 .{ }^{11}$

I778, May $27-1780$, Feb. ${ }^{12}$

I780, Feb.-I 78 I.

I781, July-I789, Sept. ${ }^{11}$ (Pp. 223-292 in a very bad state.)

I789, Sept.-I793, Nov. I $2 .^{11}$

I79I, Oct.-I794, Mar. (With adjudications on prizes.)

I793, Nov.-I794, July.

I794, July-I796, June.

I799, Apr. 8-1800, Jan. I 5.11

I803, July-18I 5 , May.

I803, Nov. 28-1804, Dec. 31. ${ }^{11}$

I803, Dec. I4-I8I8, June 29. ${ }^{11}$

I805, Jan.-I806, Apr. ${ }^{11}$

I806, May-1807, June $30 .{ }^{11}$

I807, June-I808. Sept.

I808, Nov. 26-1812, Sept. 28. ${ }^{11}$

I808, May-1809, Jan.

I809, Jan.-Aug. (Rough minutes.)

I809, July-I8I I, June. (Rough minutes.)

I809, Aug.-I8I3, Jan. (Rough minutes.)

I8II, Oct.-I8I8, Oct. (Rough minutes.)

I8I2, Oct.-I8I5, Mar.

I8I3, Feb.-I8I4, June. (Rough minutes.)

I814, June-1815, June. (Rough minutes.) "Destroyed."

1815, Mar.-1819, June. ${ }^{11}$

In addition to the above the following volumes of minutes and proceedings, not mentioned in this list, were also found:

${ }^{11}$ These volumes were found during the present search.

${ }^{12}$ Labelled May 27, 1778-Feb. 12, I780, but in its present mutilated state the volume only reaches to Nov. 9, I779. Almost entirely destroyed between pp. 281 and 441. 
I758, July 4-Aug. I. (20 leaves. In very bad condition.)

1/58, Aug. 4-Sept. 8.

1798, Feb. 16-1799, Apr. 6.

i800, Jan. 15-1801, Mar. 10.

Fee- and File-Books.

"File Book No. 5." I772-1776. (Not mentioned in the list.)

Nos. I-173. I vol. (No date given.)

1793, Jan.-1796, June. Nos. 262-320.

I796, June-1797. Nos. 321-392.

I793, May-Aug. Nos. I-74.

I793, Sept.-I795, Jan.

1795, Mar.-I797, Jan.

1796, June-1797, Nov. Nos. 397-46r.

I797, Dec.-1798, Nov. Nos. $452-588$.

1798, Jan.-I799, Aug.

1802, Jan.-June.

1803, Dec.-1812, Apr.

1804, Oct. Nos. 174-352.

Nos. 589-7 I9. (No date given.)

Nos. 720-860. (No date given.)

Nos. 861-I09I. (No date given.)

Nos. I IOI-1267. (No date given.)

1805, Oct.-I808, July.

I806, Apr.-I807, June.

1807, June-r808, Aug. Nos. 542-706.

I808, Sept.-I812, Mar. Nos. 707-8ro.

I808, July-I8I I, Dec.

I8Io, Jan.-I820, Sept.

I812, May-1822, Apr. “Destroyed."

1813, June-1816, Dec. Nos. 817-93I [sic].

I8r6, June-Dec. Nos. 8r7-93I [sic].

1824, June-183I, Aug.

Accounts of Sales.

(Book of cargoes condemned as prizes.)

I795, May-Oct. (With letters of agency of captors.)

$1799-1800$.

1799, Mar.-1801, Nov.

I800, Apr.-Nov. (28 prizes.)

$1803-1809$.

$1805^{-I} 814$.

I806, Jan.-I8II, Dec.

1806, July-1812, June.

ISo8, Jan.-1809, Mar.

$1814-18$ I8.

Letters of Marque and Agency of Prize Captors.

I762, Dec.-I802, Jan.

I803, Oct.-I807, Oct.

1807. Sept.-1823, Apr. 
Index to Libel Suits of Vessels Condemned and Otherwise.

т796, Apr.-1802, Feh.

I803-I8r4, Apr.

Index to and Account-Book of Monies paid in and out of Office in Suits.

ISo4, Jan.--r8o6, Dec.

r804, Jan.-I8ro, Mar.

1812, June-I8I6, Sept.

\section{Miscellaneous Volmmes.}

Receipts for appeal papers. Nov., isi3-Dec., I823.

Admiralty account current book. (No date given.)

Account-book of Adam Delmage, officer of court. (No date given.)

Instance court book. Nov., ISI2-June, 1839.

Log-book of ship A. Desnordescho Lore. I799.

Log-book of ship Fair Ancrican. (No date given.)

Journal of schooner Rescrve from New Orleans. (No date given.)

Log-and file-book. June, I784-Aug., I793. (Probably the log-book of some prize vessel.)

"Journal du Corsaire française La Liborté, Cap'e Étienne Rodney dit Rédonet. armée a la Guadeloupe le 2 I du mois de fremaire an r2." (13 pp.) ${ }^{13}$

From the preceding list a fair idea can be obtained of the volumes (as distinct from bundles) of vice-admiralty records which were in existence, and are still extant, although in many cases they are greatly damaged or partly destroyed. For the most part these volumes are simply thin writing- or memorandum-books of folio size with cardboard covers. In the list many dates overlap, which can partly be explained by the fact that some of the transactions were first made out in a rough form and were afterwards copied.

At the Institute of Jamaica there is a "List of prize vessels I 800 to I80I", 35 folios, giving name of vessel, nationality, captor, sentence, etc.

\section{Headquarters House.}

This builling is occupied by the office of the colonial secretary. It was purchased by the War Office in I8r4 for the use of the general officer in command of the troops, and was from that time on known as General's House or Headquarters House. Since 1872 , when the seat of government was removed from Spanish Town to Kingston, it has been the colonial secretary's office. In this building the legislative council sits and has its offices. The manuscripts in this building of a date earlier than about 18 r 5 are journals and minutes of the council, a volume labelled "Minutes of the Council of War", and proceedings of the commissioners for forts, fortifications, and barracks. These volumes are all in charge of the colonial secretary's office, not of the legislative council, and application to consult them or for transcripts should be addressed, therefore, to the colonial secretary.

It was hoped that correspondence of governors and lieutenant governors with the home government during the period covered by the investigation would be found in Headquarters House, but the colonial secretary reported that no correspondence or registers prior to I 800 existed in that office. Professor Hull in r905 did not find this correspondence. It seems clear, there-

${ }^{13}$ This is not mentioned in the list. At the other end of the volume is the "Role d"Équipage du Corsaire", I4 ff. 
fore, that no correspondence of the governors of the island before I8oo is to be found in the local archives. On the other hand there is no record of its destruction or despatch to London to be filed away there.

\section{JOURNALS AND MINUTES OF THE COUNCIL.}

The proceedings of the council of Jamaica are recorded under two titles"Journals" and "Minutes". The journal covers those periods, during the sessions of the assembly, in which the council was deemed to be acting as a branch of the island legislature; the minutes record its activities as the governor's privy council, acting independently of the assembly, and usually, though not perhaps always, during the quiescence of that body. The minutes are less formal and of more varied content than the journal, and set out at length many letters to and from the Lords of Trade in the eighteenth century.

Minutes of the Council. ${ }^{14}$

Vol. Dates

I. I66I, June I8-1672, July 2.

II. 1672, Aug. 4-1678, Sept. 3.

III. I682, May I4-I687, June I.
IV. $1686 / 7$, Feb. 10-1695, Oct. I8. 1686/7, Feb. I0-I695, Oct. I8.
Remarks

Copy on paper watermarked ISOI. $260 \mathrm{pp}$.

Copy on paper watermarked I8or. $323 \mathrm{pp}$. According to a memorandum copied from the original "Council Book Vol. 2nd" minutes of the following dates were missing: I678, Sept. 3-1682, May 14, and $1682 / 3$, Feb. I4-I683, Sept. 5 .

Copy on paper watermarked ISOI. $378 \mathrm{pp}$. On p. 30 there is a note which reads: "At the end of Book I05, marked Council Book Vol. $2 \mathrm{~d}$ is the following memorandum-viz: The Minutes of Council from the I th February I682-3 to the 5th September I683, wanting." "The minutes for Sept. 5 are, however, recorded. At the end there is another memorandum which reads : "From the Ist June to the 2Ist Sept. I687, in which time Mr. Egleton the Deputy Secretary died, the Council met 4 times but the Minutes were not entered; and the notes being taken in short hand the succeeding Secretary could not make them out." The first i 5 leaves are mutilated, being quite illegible in parts. Copy made in I889. $43^{8} \mathrm{pp}$.

${ }^{14}$ Unless the remarks denote otherwise, these are original, unpaged volumes. The early records have been transcribed for the Institute of Jamaica. 
Vol.

V. 1695, Oct. 30-I703, May 27.

VI. Missing.

VII. I7II, July I I-I7I6, July IS.

VIII. I7I6, July 25-I7I7, July 30.

IX. I7I7, Aug. 6-I72I/2, Mar. 6.

X. I722, Apr. 25-1725/6, Mar. 9.

XI. I726, Apr. 5-1732, Sept. 5.

XII. I732, Nov. I4-I736, Nov. 3 .

I732, Nov. I5-I736, Nov. 3 .

XIII. I736/7, Jan. 4-I745, Nov. II.

XIV. I745, Dec. 2-1753, Apr. I6.

XV. I753, May 28-1758, Aug. 26.

XVI. I758, Oct. 2-1764, Dec. 22.

XVII. I765, Mar. 26-1770, Dec. 24.

XVIII. I77I, Apr. 24-I784, Apr. I9.

XIX. I784, May 25-I792, Apr. 2. I799, May I6-1805, May Io.

I805, May I5-I8I5, Dec. 23.

\section{Journals of the Council. ${ }^{16}$}

Vol. Dates.

I. Missing.

II. I7II, July 23-I7I5/6, Feb. II.

III. I716, Sept. 20-I7I7, Aug. 3I.

IV. Missing.

1. See p. 380, post, under "Miscellaneous".

${ }^{16}$ Unless the remarks denote otherwise, these are original, unpaged volumes.

$545 \mathrm{pp}$. I 7 I $7-172 \mathrm{I} / 2$.

Remarks.
Remarks

In bad condition. The copy of ISta mentioned by Prof. Hull was not found. ${ }^{15}$

Paged up to p. 64. Journals for I7I6-I7I7 at the other end of the rol.

$219 \mathrm{ff}$.

First and last leaves almost completely destroyed. Paged to $18 \%$. Transcript, certified June 20, I889. "Pages $I-7$ of the original are destroyed by age." Copy omits $I 72$ pages of accounts in the original. 2I $4 \mathrm{pp}$.

At the end are 84 leaves with accounts of revenue, imposts, and fortification funds, June, I764Sept., I 772. The list gives names of tax-payers.

One or more leaves wanting at the beginning.

At the beginning are a number of documents relating to a secret convention between Col. George Harcourt, deputy adjutant general, on behalf of Brig.-Gen. Thomas Maitland, and Toussaint l'Ouverture, Aug. 3I, I798, and relative to commerce and intercourse between Jamaica and Santo Domingo.

In same vol. with minutes for 
Vol.

Dates

V. $\{$ IzIS, Aug. I-Nov. 2I. Oct. 20-I720/I, Jan. 20. $\}$ I72I, June 20-I723, Nov. I2. ifis, Aug. I-I 2 I, Nov. 23. I722, June I4-I723, Nov. I2.

VI. I723/4, Jan. 7-1728. Apr. I8.

VII. I728, July 2-I732, Nov. I7.

VIII. I $732 / 3$, Mar. I3-I737/8, Feb. 25.

I732/3, Mar. I3-I737/8, Mar. I.

IX. I738, May 5-I747, May I9.

X. I747, Nay 20-1756, Feb. 7.

XI. I756, Aug. I7-1762, Apr. I8.

XII. 1762, Sept. 28-I768, Dec. 3I. ${ }^{17}$

XIII. I769, Oct. 24-I770, Dec. 23.

XIV. I77I, Oct. 29-I774, Dec. 24.

XV. I775, Oct. 3I-I780, Dec. 30.

XVI. I78I, Jan. 2-I784, Dec. 23.

XVII. I785, Nov. I-I792, May Io.

XVIII. I792, Oct. 23-1797, Dec. 23.

XIX. I798, June I2-1803, Dec. 22.

XX. I804, Oct. 23-I809, Dec. I4.

XXI. I8ro, Oct. 30-18i6, Dec. I9.
Remarks

Leares numbered I-86, and continued at other end of book, 87 I64, for I $721-1723$.

Copy on paper watermarked I84I. 134 numbered leaves. Marked no. 5 on back.

$255 \mathrm{pp}$.

In bad condition. Pages after 362 illegible.

Certified copy, made in 1842 . $43 I$ pp.

Somewhat clamaged.

Nuch damaged in the middle.

\section{IO. MISCELLANEOUS RECORDS.}

"Minutes of the Council of War." I695-I703. One volume, which is in a deplorable condition. From what could be made out a great variety of matters are dealt with besides those relating to war. There is something about quartering soldiers on private individuals, and many statements of accounts. No internal evidence was found that these minutes were those of a body called the council of war; the proceedings open like those of the privy council, with the presence of the governor and members of the council only. In privy council minutes there are occasionally found minutes of a "Council of War". It is likely that this volume is simply the original book of council minutes for $1695-1703$ noted above, ${ }^{18}$ which happened to begin with a council of war and for this reason was so labelled, the volume of council minutes which the searcher took for the original being simply an old copy.

Proceedings of Commissioners for Forts, Fortifications, and Barracks. Sept. 15, 1769-Nov. 25, I772; Sept. 30, I773-Dec. I0, 1783. (Two vols.) This body, created by act of Dec. 3I, I768, was composed of the governor, five members of the council, and six nembers of the assembly, who were appointed "for ordering and inspecting the works in and about the forts, fortifications and barracks of this Island". The books contain principally accounts.

\footnotetext{
The John Carter Brown Library, Providence, has copies of printed Joumals of I 767 and 1768 .

${ }_{18}$ P. 379 , ante.
} 
This Institute of Jamaica.

(King Street, Kingston.)

The Institute of Jamaica was established by law 22 of 1879 , which transferred to it the libraries of the old house of assembly and of the legislative council, both of which bodies had ceased to exist in I866. Besides a library, the Institute maintains a museum and an art gallery. In the last are to be found many old portraits, autographs, prints, etc. The library consists of two departments: the general collection (downstairs) and the "West India Reference Library" (upstairs). The latter consisted in 1916 of:
I. Jamaica books.
2. Jamaica newspapers.
I.739 rols.
3. West Indies (excluding Jamaica).
4. West Africa.
504 vols.
I 375 vols.
I33 vols.
Total
$375 \mathrm{I}^{19}$

There are many rare and valuable works on Jamaica in this library, as is shown by the Bibliographia Jamaicensis (1902), and Supplement to Bibliographia Jamaicensis (I9o8), published by the Institute, and prepared by its accomplished secretary and librarian, Mr. Cundall.

In addition to printed works, there are in the Institute of Jamaica, as we have seen, a great many manuscripts. These appear to have been in the possession of the house of assembly (principally) and of the council, and were transferred, together with the printed books belonging to these bodies, in I879 when the Institute was created. The Institute is also making copies of the council minutes, the originals of which are at Headquarters House, and has already copied the first eight volumes. Transcripts of documents from Spanish archives, relating mainly to the period of Spanish occupation of Jamaica, are being made for the Institute by Miss Irene A. Wright of Seville.

The West India Library is open daily, except Sundays, from 9 to 5 .

\section{JOURNALS OF THE ASSEMBLY.}

The house of assembly, which ceased to exist in I866, had possessed a very valuable library, which was transferred to the Institute of Jamaica. Together with the printed books were transferred the original manuscript volumes of journals of the assembly, and other manuscripts, to which we shall later refer. At some time many of the manuscript volumes were, however, destroyed, so that what was found in Igi 6 was far from complete, and of the volumes now in existence a considerable number lack the first or last pages or both.

The assembly began printing its journals, Votes of the Honourable House of Assembly of Jamaica, in I749. Of these contemporary annual prints, the Institute of Jamaica possesses the volumes for the following years (printed the same year or that next following) : I784, I787, I789, r790 et seq. to the year $1866 . .^{20}$ A handsome general edition of all the journals from I664 to I828, based in the earlier portion on the manuscripts found in Jamaica and in London, ${ }^{21}$ was printed in fourteen volumes (Jamaica, 1795-1829; vols. II. and III. reprinted, London, I824, I827).

${ }^{19}$ Hasdbook of Jamaica for 1916, p. 220. The total reported in Mr. Cundall's Jamaica in 1924 is 5600 .

50 The library of Harvard College has one session of the autumn of 1763 , and fifteen (all but one) of the sessions from Oct. 3I, I775, to Mar. I, I783.

${ }^{2} C f$. sessional papers of Jamaica at the Public Record Office, see pp. 2I8-22S, ante. 
The text in the early roluncs of the Fotes corresponds exactly to the text of the 1795-1829 edition, or Journals above cited. A rough comparison of several of the early printed and manuscript volumes of the journals seemed to prove that the text was similar, and that the only omissions in the printed edition were statistical tables of secondary interest. The following is a list of the manuscript volumes discovered at the Institute of Jamaica:

Dates of manuscript vols. 1678, Sept. 2-1679, Dec. I.

1696, May 5-1702, Aug. 23. I $702 / 3$, Mar. I-I 703 , Oct. 3 o.

I704, Apr. II-r706/7, Feb. 5. 1707, Dec. 29-1710, Mar. 30.

I709/10, Mar. 23-1716, Nov. I7. I7I7. Aug. 7-1721, Nov. 28. 1722, June 18-1726/7, Mar. 9.

I730, Nov. I8-1731, July 8.

I733. Apr. I7-I734, Oct. I7.

I735, Apr.-I738, July 5 .

1739, Apr. 25-1743, May II.

I7 $\$ 3 / 4$, Mar. I9-I748, Aug. I2.

1749, Apr. 6-1750, Oct. 25.

I750, Nov. I-I753, Oct. 29.

I753, Oct. 30-1756, Sept. 7 .

1,62, Feb. 10-1 763 , Nov. 23.

I7 63, Nov. 24-1766, July 4 .

1766 , July 5-1766, July 3 I.

I766, Aug. 5-1767, Nov. I9.

I767, Nov. 25-1769, Nov. 24.
Vol. and pages of printed edition ${ }^{22}$

I. $23-56$.

I. $15 ;-258$.

I. $266-322$.

I. $324-42 \mathrm{r}$.

I. $462-470$.

II. $I-13$.

II. $6-24 \mathrm{I}$.

II. $242-408$.

II. $412-607$.

II. $754-766$. III. $\mathrm{I}-35$.

III. I $39-285$. nals of $1678-1679$.

Lacks pp. $\quad \mathrm{I}-6$ and $27-28$.

Original. First leaves wanting. Contains at other end of vol. jour-

Copy. At the other end of the vol. are journals of $1730-1731$.

264 pp. Lacks one or two leaves at end.

Copy. $378 \mathrm{pp}$.

Copy. 254 pp.

In very bad state.

missing.

Original. 567 pp. Upper part of first leaves torn off.

Original. First and last leaves wanting. Now has pp. 75-54I only. Original. 476 pp. $\mathrm{Pp}$. I-2 I missing.

IV. I50-259. Original. Begins with P. I5. Last leaves missing.

Original. Begins with p. 7.

Original.

Original.

Last leaves missing. First and last leaves missing.

First and last leaves missing.

Original.

22 The reference is omitted in the case of a number of volumes, which were found two days before leaving the island, when there was no time to compare the manuscript and printed volumes.

${ }^{23}$ In the case of many volumes it was quite difficult to be certain whether they were originals or copies. In such cases no remarks are made on that point. 
Dates of manuscript vols.

І 7 I, Dec. IO-I772, Dec. I6.

I772, Dec. 19-I773, Dec. 3 I.

I774, Dec. IO-I775, Dec. 6.

I775, Dec. 7-1776, Dec. 5 .

I776, Dec. 7-1778, Nov. I9.

I778, Nov. 20-I779, Dec. 7 .

I779, Dec. 8-1780, Dec. 2.

I780, Dec. 5-2I.

I781, Nov. I3-1782, Apr. I6. I782, Apr. I 7 -Dec. 21 .

I783, Feb. I I-Nov. 29.

I783, Dec. $2-17$.

I 787 , Oct. $24-1788$, Jan. Io.

I 788 , Sept. 30-Dec. 20.

I789, Oct. 22-I790, Dec. 3 .

I79I, Feb. 23-Dec. I2.

I791, Dec. I3-1792, Dec. I3.

I792, Dec. I7-I793, Dec. I4.

1794, Nov. 4 and part of Nov. 5 .

1794, Nov. I9-Dec. 9.

I795, Dec. I0-1796, Nov. 19.

I796, Nov. 22-1797, Nov. 23.
Vol. and pages of printed edition

Remarks

Original. First and last leaves wanting. Now has only. pp. I 53-438.

Original. Lacks pp. I20.

VI. 552-607. Original, certified by James Trower. First and last leaves missing.

VI. 6o8-673. Original. VI. 676-704. Original. First leaves VII. I-95.

VII. 95-I9I.

VII. I94-268. missing.

Original. Session of Dec. 7, I779, incomplete.

VII. $269-328$.

VII. $405-47$ O.

VII. $470-544$.

VII. 544-622.

VII. 622-646. Part of session of Dec. I7 missing.

VIII. 267-397. Begins with p. II. At end are statistical tables marked $\mathrm{A}-\mathrm{M}$ and $\mathrm{I}-4$, concerning revenue and liquors, not in the printed edition.

VIII. 398-488. 3 I2 pp. Begins with p. I7.

VIII. 492-6r3. First and last leaves wanting. Now contains p P. $7-$ I 78 .

VIII. 636-663. First leaves missing. IX. I-64. Pp. 49-385.

IX. 64-I85. Last leaves missing. Ends at p. 520.

IX. I 88-283. Pages I-6 missing.

IX. $283-285$. I2 pp. Last leaves missing.

IX. $300-4$ I6.

IX. 416-56r. Original. 579 pp. Last part of session of Nov. I9 in next vol.

IX. 559-657. Contains continuation X. I-29. of session of Nov. I9, I796. First leaf missing, and parts of sessions of Nov. 22 and 23, I797, are wanting. 
Dates of manuscript vols. 1797, Nov. 24-1798, Nov. 16.

1798, Nov. 20-r799, Mar. 7. 1799. Mar. 8-1800, Feb. I6.

ISoo, Nov. 4-ISor, Dec. I. 1801, Dec. 2-1803, Nov. 24.

1803, Nov. 25-1805, Nov. 21.

I806, Nov. I8-1807, Oct. 21.

1807, Oct. 2I-18ro, Dec. ro.
Vol. and pages of printed edition

X. $30-167$.

X. $167-279$.

X. $280-474$.

X. $475-630$.

X. $630-677$.

XI. I-I 24 .

XI. $129-350$.

XI. $470-583$.

XI. 583-647. Original.

XII. $1-322$.
Remarks

Original. 555 pp. Lacks Pp. $I-2$.

Original.

Original. $55^{8}$ pp. Lacks last leaf.

Original.

Original. Last leaves missing.

Leares missing at beginning and end.

Original. Last session continued in next vol. At the end: "End of vol. 54th."

9. PAROCHIAL AND LOCAL RECORDS.

Churchwardens' accounts, parish of Kingston :24

I722-1759. Copy. Begins Feb. 5, I722/3.

1759-1775. Copy.

I775-1786. Listed in Cundall's Bibl. Jam., no. I75, as 1771-1786.

$1778-1788$. Original.

I835-r848. This vol. is "Account current of the City and parish of Kingston with the Treasurer of the City".

Vestry accounts, Kingston. "Orders of Vestry for stipulated sums." I I792: I vol. Original. (No. $22 \mathrm{x}$ in Bibl. Jam.)

Churchwardens' accounts, Port Royal. I766-r793. I vol. Original, in bad condition. (No. 226 in Bibl. Jam.)

\section{Vestry Minutes. ${ }^{25}$}

The vestry minutes contain simply the resolutions adopted by the corporation, in the following style: "At a Vestry held. . . Ordered:" . . . They likewise contain lists of taxpayers, whose names are in all cases given. These tax-lists are principally of four kinds: (I) parish tax, giving names of tenants and landlords, rents, number of slaves, cattle, and wheels of each individual taxpayer, and amount assessed him; (2) poll tax. like the above; (3) tax on transient merchants, commanders, masters, and supercargoes, with names, places from which each individual came, and amount assessed; and (4) arrearage tax-lists. All these lists occur frequently and are extensive, the minutes proper being very short in comparison. The first list of transient merchants, etc., is of January 21, I743/4. Resolutions of the vestry deal almost entirely with taxes, church finances, church property, charity and pensions, salaries, and appointments to office. It will be noted that vestry minutes and tax-rolls were often placed in the same book.

\footnotetext{
${ }^{2} 4$ The parish of Kingston dates legally from I 713.

${ }^{25}$ For vestry minutes of the parish of St. David see close of portion dealing with the Record Office, p. 369 , ante.
} 


\section{Parish of Kingston.}

I743/4, Jan. 8-I748/9, Feb. 24. Original. 589 pp. Contains numerous taxrolls of transient merchants, supercargoes, etc. (the first dated Jan. 2I, I 743/4), and of tenants, landlords, etc. (the first occurs May 8, I 745, and occupies 35 pp.). From a list of I 745 it appears that there were then in the parish 7749 negroes and 828 cattle. This is vol. I of no. 220 in Bibl. Jam.

I750, Apr. 23-I754, May 6. Original. Incomplete, beginning with p. 92 and ending with p. 572 . Lettered, "Kingston Parish tax".

I754, May I3-27. Paged 590-605. Continues tax-roll which began in preceding vol., and contains also vestry minutes for May I3-27, I754. Lettered, "Kingston parish tax, I754 and I768-70".

I763, Mar. I2-I767, July 27. Original. Incomplete, beginning with p. I5. Following the minutes of this date is an "Arrearage parish tax for the year I763", and one for I764. There is an incomplete parish tax-list for I 767 at end of vol. Lettered on the back, "Kingston parish tax, I $763-1767$ ". According to a poll tax in this vol. for I 766 there were then in the parish 7850 slaves and 994 cattle.

I 768 , June 22-I 770 , Oct. I 5. Begins with a parish tax-list for I768, of which the beginning is wanting, the vol. lacking pp. $\mathrm{I}-8 \mathrm{o}$. This list ends on p. 88. A second list.(poll tax) covers pp. I4I-I87, and a third (poll-tax) for I770 closes the vol., which is incomplete at end (reaches p. 402).

I78I, Jan. I I-I788, Nov. I2. Lettered on back, "Kingston Vestry proceedings". Is vol. 2 of no. 220 in Bibl. Jam.

I795, Mar. I9-I805, Oct. 7. Original. Labelled, "Kingston Common Council minutes, I795-I805". Is vol. I of no. I79 in Bibl. Jam. The beginning of session of Mar. I9, I795, is missing. Vestry minutes end Jan. II, I803, and those of the court of common council begin Jan. I2, I803. The latter are not a complete record of proceedings as found in the first vol. of common council minutes listed below. The present volume contains several lists of inhabitants judged fit to serve as jurors at the assize court.

\section{Parish of Port Royal.}

I735-I74I/2, Jan. First two leaves mutilated. Consists of proceedings of justices and vestry meeting together. Contains data of number of slaves existing in the island, and many tax-rolls. There is, however, no list of transient merchants. No. 237 in Bibl. Jam.

I777-I788. Labelled, "Pt. Royal Church Tax, I777", but is a vol. of vestry minutes, beginning with a list of taxpayers.

I788, Dec. I2-I807. Contains several parish tax-rolls in addition to the minutes.

\section{Parochial Tax-Rolls, Kingston.}

I774-I780. Consists of lists of taxpayers for each of the years I774-I780. Contains no vestry minutes, and no list of transient merchants, etc. The tax-rolls give names of tenants, landlords, and rents, assessments, etc. $\left.\begin{array}{l}\text { I780-I79I. } \\ \text { I79I-I805. }\end{array}\right\}$ Two vols., similar to the above. In no. I9I of Bibl. Jam. 
There is also a volume labelled "Kingston Poll tax" (in pursuance of a local act of Mar. I5, I792), containing lists of taxpayers for the year: 1792I805. No. 192 in Bibl. Jam.

OTHER LOCAL RECORDS.

Kingston (city and parish). Minutes of the common council. I803-18 I5. I vol.

Port Royal. Register of freeholders. I756-1803. I vol. No. 229 in Bibl. Jam.

Port Royal. Receipts for slaves sold:

I783-I794. I9I sales. I vol. These two vols. are listed under no. 234

I800-1806. Nos. 5-278. I vol. Jin Bibl. Jam.

Kingston. Register of freeholders. I803-1832. I vol. No. I98 in Bibl. Jam. The volumes entitled, Kingston, Register of slaves, I76I-I795, and Kingston, toll-book, Slaves Sold, I738-I743, listed in Bibl. Jam., nos. Ig9 and 219, respectively, were not found.

Kingston quarter sessions: general court of quarter sessions of the peace of the parish of Kingston. Nov., I770-Feb., I798. I vol. Lacks four leaves at the beginning and one or more leaves at the end. Another vol. covers the years $1803-1839$. No. 193 in Bibl. Jam.

Kingston. Security bonds given to the parish (from I802, city and parish of Kingston), for the collection of taxes, for annual payments to enfranchised slaves (as required by a local act of 1774 ), for binding apprentices, eic. I786-I83I. One vol. No. I77 in Bibl. Jam.

At the Kingston city council inquiries revealed no early records. The parochial boards of the island may, however, possess some ancient minutebooks, tax-rolls, registers, etc. In the hope of discovering this material, letters were addressed to several parochial boards, but the answers obtained were vague, and there was not enough time to visit the towns throughout the island where old records might exist. The secretary of the parochial board of St. Ann's Bay replied that the "old vestry minutes are very interesting", but gave no more information. It would be worth while to investigate what there is at St. Ann's Bay, which is one of the oldest parishes.

IO. MISCELLANEOUS RECORDS. ${ }^{26}$

Letters from the Agents for Jamaica in Great Britain to the Commissioners of Correspondence, Spanish Town, Jamaica. ${ }^{27}$

I794, Nov. 4-I80I, Feb. 3. (Copy.) Deals with the abolition of slavery, cluties on sugar, the price of rum and other West Indian conmodities, and a variety of other matters.

I804, July 6-I8Io, Apr. 4.

I8I 3 , Feb. 3-i8 I5, Mar. I.

${ }^{20}$ A poll-book, $1803-1843$, is at the Record Office, q. v., p. 370.

2' The agents for Jamaica were the following, according to Cundall's Historic Iamaica, p. xxiii :
I794 Stephen Fuller
I795-1803 Robert Sewell
I803-I8I2 Edmund Pusey Lyon
I8I2-I83I George Hibbert
I 83 I-I 845 George Burge

The office was created in 1664 and abolished Dec. 8, I 845 . For agents before 17.4 see Cundall, op. cit. 
I 8 I4-I824. (Incomplete at beginning. Letters are not in chronological order.)

I 824 , Nov. 4-1832, July 4.

I 832 , July I9-1834, Nov. Io.

Communications from the commissioners of correspondence to the agents for the island of Jamaica in Great Britain. Dec. I7, I794-Dec. I3, I833. I vol. A number of letters deal with the commercial relations of Jamaica with the U.S.

Minutes of the commissioners of correspondence. Feb. 27, I795-May 22, I846. I vol. (Minutes of Feb. 27, I795, appear to lack the beginning.)

Wolmer's Free School. Proceedings of trustees appointed by an act of this island entitled, an act to explain and enforce the last will and testament of John Wolmer, goldsmith, deceased. Nov. 5, I $787-1845$. I vol. 378 pp. Begins with copy of the will. John Wolmer was born June 24, I736, and died Sept. 3, I787.

Documents copied under the direction of the historian Mr. Bryan Edwards (died I800) for the house of assembly of Jamaica, about the year I798, from originals in the Plantation Office and the British Museum. 4 folio vols. The transcripts were sent over in packages and bound into volumes in Jamaica.

Vol. [I.] On the cover is a manuscript note which reads: "This volume contains nos. 6, 7, 8 and 9 of Mr. Edwards parcels." Pasted below this note is a clipping from a printed list which reads:

"Book Ioo, marked volume 4

"Book IOI, volume 5, not paged

"Book I02, volume 6, not paged

"Book I03, volume 7 , not paged"

The contents of this vol. of $254 \mathrm{pp}$. are as follows:

(a) Documents relating to the trade in logwood, tortoise shells, and other commodities, carried on with the Indians of Darien and Juoatan [Yucatan], to the southward of Campeche, I670-1677. Contains several documents on injuries done to the English by the Spaniards in the West Indies, "upon pretence of the logwood trade". Pp. I-35. (These papers are of extraordinary interest.)

(b) Speeches and letters of governors to the assembly of Jamaica and replies of the assembly; I686-I688; I69I-I693. (At different places throughout the volume.)

(c) Letters from governors to the Lords of the Committee, 1688I69I. (At different places throughout the volume.)

(d) Letter from Lieut.-Gov. William Beeston to the home government. Pp. 96-II4.

(e) "A brief account of what happened in their Majesty's Island of Jamaica during the time the French were preparing to attack that Island and remained upon and about it in I694."

(f) Minutes of the council of Jamaica. Aug. 2-4, I694. (Begin on P. II 5.)

$(\mathrm{g})$ Address of the council and assembly of Jamaica to the king, concerning the state of the island. Sept. I5, I688. Pp. I3II4I. 
(h) Articles of high treason against Roger Elletson, Esq., late chief justice of Jamaica, and other documents relative to the case. 1689. P. I $155-167$.

(i) Protest of Col. Thomas Freeman and members of the council against Sir Francis Watson as president. 1689. Begins on p. 167.

This volume has marginal notes in the handwriting of A. Aikman (some of the notes being signed by him), printer of the Journals of the Assembly.

Vol. [II.] 342 pp. A manuscript note on the cover inside reads: "This volume contains Nos. IO and I I of Mr. Edwardis parcels." Pasted below this note is a clipping from a printed list which reads:

"Book I04, Council Book, vol. I

"Book I07, volume 4."

This volume contains the following:

(a) Minutes of the council of Jamaica (pp. $I-96)$ :

I66I, June I8-I664, Oct. II.

I668, July 28--1669/70, Jan. 26.

I672, session of Jan. 8 .

I69I, session of council of war, Feb. 4.

I69I, session of June 9.

I691, Aug. I7-27.

I693, session of May 4 (first part only).

(b) Journals of the assembly of Jamaica for the years 1682,1683 , I686, I687, and I688. These journals occupy pp. I05-342. Pp. 97-104 are blank.

There is a note at the end of the vol. which reads: "No other Minutes of the Assembly are to be found in the plantation office until the year I702. The following [sic] minutes of the Council serve greatly to fill up the chasm.'

Vol. [III.] 256 pp. Lettered at the back in an old hand, "No. 3." Contains notes in Aikman's handwriting. A number of the documents in this volume are printed either in the body of the first volume of Journals of the Asscmbly of Jamaica, or in the Appendix to that volume. The following are the documents included in the present volume:

(a) Commission and instructions to John, Lord Vaughan, governor of Jamaica, I674. (Printed in above Appendix, pp. I5-20.)

(b) Session of a court of vice-admiralty to try John Dean and others for piracy. Apr. 29, 1676.

(c) Titles of acts made at Jamaica by a general assembly, Apr. 9, I677 (pp. 50-56), followed by an abstract of the same laws.

(d) Letters from Gov. Vaughan to the Board of Trade, 1677.

(e) Address of the assembly to the governor, rejecting the laws proposed to them, and giving the reasons therefor. 1678 . (Printed in the Journals.)

(f) Account of the government of Jamaica, Gov. Vaughan. Dec., I679. (Printed in the Appendix, p. 44.)

(g) A brief account of the government of Jamaica since his Majesty's restoration, 1679 (i.e., 1661-1679), by Sir Thomas 
Lynch, governor of Jamaica, to the Committee of Plantations.

(h) Letter from Charles, Earl of Carlisle, governor of Jamaica, to the Committee of Plantations.

(i) Addresses to the governor by the assembly. I679. (Printed in the Journals.)

(j) Abstract of the Earl of Carlisle's commission and instructions, 1678.

(k) A brief account of the government of Jamaica, civil and military. Undated. Signed, Rowland Powell. Begins on p. Ior.

(1) Letters from Lieut.-Gov. Henry Morgan to the Committee of Plantations, Sept., I680, and I68I.

(m) Governor's speech to the assembly and reply of the speaker, 1682.

(n) The governor's (Thomas Lynch) explanatory rules touching the laws. No date.

(o) Speeches of the governor to the assembly and replies of the latter. $1683-1684, \mathrm{I} 686$.

(p) Letter from Lieut.-Gov. Hender Molesworth to Mr. William Blathwayt. Feb., 1685.

(q) Letter from Col. Hender Molesworth, president of the council of Jamaica, to the Committee of Trade. I683.

Vol. [IV.] 218 pp. Documents copied in 1798 for Mr. Bryan Edwards by Samuel Ayscough, from the Sloane MSS. in the British Museum. Composed entirely of council minutes, Dec. 20, 1687-Feb. 18, 1688. There is a note at the end which reads: "The foregoing are true coppyes of all the Minutes of Council since the arriveall to this Island of his late Grace the Duke of Albemarle deceased. Examined and compared this fifteenth day of March I688-By me-J. L. Hickmann."

Journal kept by Adm. John Nevell, on what proved to be his last cruise. Dec. 20 , I696-June 25, I697. This, the original journal, was acquired by the Institute of Jamaica at the recent sale in London of the Phillipps Collection of manuscripts, and has been published with notes by Mr. Frank Cundall in The West India Committee Circular, June-July, I9r4, nos. 409-4I I and 4r3.

1 stters to Messrs. John and Thomas Eyre, merchants, Jamaica Coffee House, London. I705-1708. These twenty-one unpublished letters are originals or duplicates (in the latter case there being often more than one letter copied on the same sheet). They deal with the trade in coffee, logwood, sugar, indigo, etc., giving prices and many valuable details regarding these products. The following is a list of the letters :

Messrs. Clerke and Parke. Jamaica, Apr. 15, June 9, I705; Jan. 29, Mar. 5, May I I, 1706; Feb. I4, Apr. 22, June 10, Aug. 23, 28, Nov. 10, Dec. 5, I707; May 24, June 18, July 3, Sept. 25, 1708.

William Shettlewood. Jamaica, July 22, Dec. 22, i 706.

Samuel Baker. Boston, Sept. 5, 28, Oct. 16, 1706.

I stters from J. Tyler, Kingston, to Capt. David Hamilton, Norfolk. I746I747. These original letters deal with private personal affairs, and also refer to matters of trade. Aug. 12, Oct. 18, 1746; Apr. 3I [sic], May 4, July I7, Oct. I5, Nov. I5, I747. 
"The Sate of Jamaica in the Yeare 1664 when Sr. Charles Littleton left it, and in the yeare I670 under Sr. Thomas Modyford's government." 33 large folio pages. A note states: "This is the official copy which belonged to William Blathwayt, Secretary for Trade and Plantations. This copy is signed by "Thomas Tothill, Receiver Generall'." At the head is a note which reads, "Extracted out of the Jamaica Book". (This was no. II97 of the Phillipps Collection. Cf. Journals of the Assembly of Jamaica, vol. I., App., p. 49.)

Original letter from Philafricanus (Mr. Walter Johnson) to the editor of the European Magasine, London, entitled, "Progress of a Planter and Merchant in the West Indies". Kingston, Aug. I, I793. Explains the advantages and profits to be reaped by settling in Jamaica. Written for the purpose of inducing young Englishmen to come to the colony.

\section{Manuscripts in Possession of Mr. Noel Livingston, Kingston.}

Mr. Livingston kindly permitted notes to be taken of several important manuscripts in his possession, namely:

Papers relating to the government, revenues, etc., of Jamaica. I693-I705. One folio vol., containing the following original documents: (a) case of Lord Archibald Hamilton, late governor of Jamaica; (b) accounts transmitted from Jamaica, $1696-1703$, with the auditor's notes; (c) clause in the Jamaica act of 1703 , prescribing the manner of accounting by the recorder general; and "The material differences in the Act past in Jamaica, I703, with that past there in 1682 for raising a Publick Revenue, etc."; (d) letter of the governor of Jamaica, I705; (e) original letter of L. Compere to William Blathwayt, I704; (f) long original letter of Sir William Beeston, governor of Jamaica, to Blathwayt, June I8, I698; and (g) copy of a letter from the same, July 28, I698. (This vol. was no. I00 58 of the Phillipps Collection.)

Thirty-two letters from Charles Rudlach, Jamaica, to his uncle, Charles Stewart, Edinburgh. June, I774-Mar., I795. Written from different places in the island, such as Pindars River Estate, Seven Plantations Estate, and Saint Toolie Estate, Clarendon. They deal with personal affairs and contain numerous references to the sugar: industry, the state of labor, etc. There are also eight letters addiressed to Charles Stewart by Thomas Ruddach, written from Tobago.

\section{MONTSERRAT.}

At the time of examination such political records as survive were scattered about the floor of a corner of the government office at Plymouth. Most of them were by open windows, which admitted rain as well as light and air. As a result some of the manuscripts were very damp. A severe hurricane in I899 is said to have damaged the archives, but detailed information on this point is lacking. It was officially reported about I909 that a small annual sum was available in Montserrat for the binding and care of the records. Perhaps this referred to the registrar's office. Despatches are entirely missing, and legislative journals show no signs of either binding or care. It is said that these records are shortly to be removed to another building. As their present condition could hardly be worse, it is to be hoped that the change will at any rate mean better protection. 


\section{MINUTES OF COUNCIL.}

The early council of Montserrat was of an "omnibus" type. One is of course accustomed to find such a body acting as a court of error, of chancery, or of ordinary. In the Leeward Islands it was customary in earlier years to combine executive with legislative functions. Here, however, we find a certain criminal jurisdiction as well. As a result a large part of the minutes, especially those for the earliest years, are taken up with such cases, some of which are curious reading. One negro, for example, was tried for murder, and although declared innocent he was sentenced to a goodly number of lashes. None of this material is paged.

Oct. 5, 1759-Sept. 26, 1776.

This volume is in bad condition, and could not be thoroughly examined. Commissions and instructions to governors are entered. A circular despatch from Lord George Germain, Dec. 27, I775, relating to the troubles in America, is spread on the minutes. The council made no reply, but placed a temporary bonus on the importation of provisions.

Mar. 4. I791-Mar. 21, I795.

In r793 council and assembly vainly tried to have the port opened to vessels of friendly nations.

Apr. II, 1595-July I9, I809. Nothing pertinent was found in this volume, which is incomplete at each end.

Apr. 8, I809-June I7, 1809. This damp package is a confusion of scraps, $\{$ Sept. 3, I8I6-May 8, I8I7. Which have the appearance of duplicates from July 6, I808-May 27, I8ı6. Jhe Colonial Office.

MINUTES OF ASSEMBLY.

Every volume is incomplete at both beginning and end. No direct material was found. The first book has partly fallen in pieces, and is entirely too fragile for examination.

I777-1790.

Sept. I 5-Dec. 4, I790.

Aug. 15, 1793-Sept. 3, 1793.

Dec. 4, I793-Oct. I3, I81o. (Several gaps.)

Nov. 7, 1815-May 20, 1816.

\section{NEVIS.}

Such legislative papers of Nevis as survive have been brought to Basseterre, and are stored with those of St. Kitts, $q$. $v$. There are no early despatches. A list made about twenty years ago shows two volumes of admiralty records, 1764-I805. An official note, however, to the custodian of such papers at Nevis brought the reply that a thorough search for them had been unsuccessful. As a result no personal visit was made to Nevis.

\section{MINUTES OF COUNCIL. ${ }^{1}$}

Mar. 18, 1746/7-Sept. 28, I752. (Incomplete at beginning and end.)
Apr. 10, 1761-Feb. 27, 1772. (

"A Motion was made by His Honour the President and seconded by the

Honble John Richardson Herbert Esqr. that a Committee of both Houses should be appointed to prepare an Address to His Majesty expressing their disapprobation of the irregularitys committed by a

${ }^{2}$ Both executive and legislative for some time. 
sett of Rioters in destroying the Stamps." Feb. 8, I766. (Joseph Herbert was president of the council.) The next page contains a formal message and reply.

Apr. 3, I772-Sept. 4, I780.

Some material relates to economic distress as a result of the American Revolution, 1776; proclamation by Gov. Burt at Antigua, warning all British subjects to be guarded in correspondence that might come into enemy hands, Apr. 29, I777; defense, I778; illicit trade; information of French naval movements.

I78I-I 782. (Fragments only.)

Mar. 5, I782-Jan. ro, I784.

Many papers are entered in this volume, among them the commissions of Comte Dillon and the Chevalier de Fresne as governor and lieutenant governor of Nevis. Some documents deal with trade of the island and the importation of provisions. Correspondence of President Nisbet with Lieut.-Gov. de Fresne is plentiful, much of it relating to the St. Kitts-Nevis dispute. At the end of the book is a copy of the oath taken by the principal inhabitants of the island on its capture by the French.

Jan. I4, I784-June II, I79I. (Beginning missing.)

Mar. 9, 1803-Aug. 8, I809.

Aug. I2, I809-Dec. 6, I8II.

Some proclamations, etc., deal with the regulation of trade with the U. S., and the importation of their commodities.

Dec. I4, I8I I-Feb. 22, I816.

Similar to previous volume.

\section{MINUTES OF PRIVY COUNCIL.}

Jan. 9-Aug. 29, 1782. (66 pp.)

Contains material on defense; articles of capitulation of Nevis, Jan. I4, I782 (English and French); government of the island under French auspices.

Aug. 13, I796-June 22, 1837.

Occasional material on the scarcity of provisions and lumber, the means for remedying it, and regulation of trade with the U.S.

\section{ST. KITTS.}

All political records are at the administrator's office in the town of Basseterre. No original despatches or admiralty papers survive. A few letterbooks are upstairs. All legislative journals, however, are in a storage room on the ground floor. The place is dry, but it is also a fire-trap strewn with inflammable material, and the books are too tightly packed in wooden cupboards for their own good or the convenience of anyone wishing to examine them. As in the other islands of the Lesser Antilles these volumes and remnants of volumes have as a whole suffered badly from mildew, and to a less degree from insects and rodents. As a result a few will hardly stand any examination, while several others must be handled with great care. No corresponding files remain, but, as a partial compensation, for the greater part of the period under examination the minutes are very rich in the number and variety of papers entered therein.

Any application with regard to these recurds should be made to the administrator, at Basseterre. 
MINUTES OF COUNCIL.

Nov. 7,1 I $709-$ Nov. 7, I $715 . *$

Dec. 31, 1715-Nov. 9, 1722.*

Nov. 22, I722-Nov. 9 , 1727.*

Nov. 20, I727-Aug. I6, I732.*

A message from the assembly to the council gave notice of the appointment of a committee "to Consider of the Prejudice which this Island and the rest of His Majesties Sugar Colonies in America suffer by the trade which is carryed on between his Majesties subjects in Boston and Road Island and the Subjects of the French King in Martinique Guardaloupe Highspaniola and other Places". Aug. 3I, I73I. (P. 373.)

A joint committee drew up addresses to the king and to the Lords of Trade, entered on the minutes for Sept. 24, I73I.

Aug. 28, I732-Dec. I7, 1734.*

Feb. 18, 1734/5-Apr. 2, I74I.*

Apr. I7, I74I-Sept. 26, I745.

At the beginning are entered two letters, one from Adm. Vernon to Gov. Clarke of N. Y., Port Royal, Jamaica, Nov. I3, I740, giving certain military and naval information, and a second from Gov. Clarke to Gov. William Mathew, N. Y., Jan. 21, I740/I, telling what he has done to prevent supplies reaching the enemy, and making suggestions along the same lines.

British order in Council, prohibiting exports from the sugar islands to neutral islands. Feb. 19, I740/I.

There is also sundry material on defense, convoys, and the protection of trade, etc.

Sept. 26, I 745-Mar. I7, I 749.* This volume is also badly eaten by rodents.

A long memorial by planters, etc., to the Lords Justices in Council, gives many details of military and naval forces in the English and French islands, and asks for stronger naval protection. Oct. II, I745.

Apr. 29, 1749-Nov. 18, I755.

On Dec. IO, I750, a message from the governor to the council and assembly mentions, among other subjects, "the Growing Evil of a Clandestine Trade between the adjacent Foreign Islands and North America, and with ourselves which depreciates our product, raises upon us the Value of Cash and drains us of what we have. It is notorious that in North America the Chief Consumption of the Sugar grown in the French or Danish Islands $[\mathrm{sic}]$, most of the rum they have is French or Distilled at Eustatia from french molasses, Great Quantities of Sugars from Hispaniola as well as the French Windward Islands and from Sta. Cruz are sent to the British Markets without paying the Foreign Duty, and I am well Informed that French Rum is Imported even into Ireland by way of the Northern Colonys and in such Quantities as to ruin the market there for ours". The message goes on to speak of the importance of the African trade to the sugar islands, and the extent the French had engrossed it-that of the Gold Coast was almost entirely lost to the English. As a result the Board of Trade was memorialized along these lines, and the memorials were entered on the minutes.

* Too fragile to be examined thoroughly. 
Negotiations of the French and English commissaries are referred to in letters of the colonial agent and other papers. The agent also notes the trade of the northern colonies with the French. There is also some material on the lumber-trade of New England.

Late in 1754 there came information from Antigua that large quantities of Danish sugar were imported into England "last year under colour of being from the Island St. Thomas in Africa, which by an old Book of rates was formerly admittable into England, upon less duties than Other foreign Sugar". Co-operation of the two colonial agents was suggested in order to check such a practice.

This volume is particularly rich in documents spread on its pages.

Nov. 25, I755-Aug. I8, 1762 .

This volume has material on the following topics: defense ; regulation of the export of provisions; privateers; reduction in the amount of provisions from N. Am.; maintenance of French prisoners brought to the island; co-operation with Antigua in urging the reduction and holding of Guadeloupe (I759), and later details of its capture; a description (Mar. 5, I759) of how the French obtained supplies from the English islands: "Vessels are cleared out from St. Christophers and other English Islands Laden with Flour for Barbadoes and give bond for it's delivery there. In their way up they run into St. Vincents (the Contiguity of which to the Islands in Dispute is well known). There they dispose of their Cargoes (except a few barrells) for. which they receive in return Coffee and Cocoa with which they proceed to Barbados and there by the authority of the few Barrels of Flour they have on Board, enter their Cargos according to the Bond passed at St. Christophers by which means they procure a Certificate which is returned to St. Christophers, and their bonds in Consequence Cancelled, the same is repeated from Barbados to St. Christophers." The assembly, to whom this communication was referred, made a rather brief reply, but incidentally suggested that measures be taken "to Prevent such frequent intercourses as hath been lately carried on between this Island and. St. Eustatius by Packetts going too and from these two Islands almost every day".

A detailed account by Henry Wilmot, colonial agent, Mar. 24, I759, relates how a tax was placed on sugar in spite of the planter interest in the City and the House of Commons, and describes the strong temper of the latter for the tax. This is followed by "Reasons against laying any new Tax upon Sugar", drawn up in London.

Sept. 8, I762-Jan. 20, I772. This book is too fragile for examination. It has been reported that the part relating to the Stamp Act riot is badly mutilated.

Apr. 9, I772-July 25, I778. ${ }^{1}$

A fire and a hurricane overshadow everything else in this volume, and the colony was kept busy repairing the damage. In Mar., I776, there is correspondence entered on the delivery of five iron fourpounder gums for the British army at Boston, on a requisition from Gen. Howe.

Inly 28, I778-June 23, I783. The final meeting is dated July 23 , but this is plainly a clerical error. All the papers entered are dated June 23 .

\footnotetext{
${ }^{1}$ Beginning with this volume the series has been rebound, and torn leaves have undergone amateur repair. As a result the later books are in much better condition, though some of the paper is quite brittle and must be handled with great care.
} 
There is sunciry material on defense; an account of the capture of Roseat, Dominica; a deposition of James Joshua Reynolds as to supply of rebel forces in Va. by the brigantine Jane from Belfast, and further regarding letters written from $\mathrm{Va}$. to persons in St. Kitts and Antigua alleged to be well disposed to their cause, Apr. 20 , I780; inconvenience of having upwards of 650 French and Spanish prisoners of war in and near Basseterre.

At a meeting on Feb. I7, I782, are entered the commissions of Count Dillon as governor and the Chevalier de Fresne as lieutenant governor, and the articles of capitulation of St. Kitts and Nevis, dated Feb. I2, I782, portions of which deal with freedom of trade. These documents are in both English and French.

Under May 27, I 782 , are entered a joint legislative account of the separate, prior capitulation of Nevis on Jan. I4, I782, a declaration as to the independence of Nevis as regards St. Kitts, and a protest by the former against certain financial assessments.

Many letters from De Fresne are entered, which are not only interesting for the history of French administration in that island, but also show in relief what different results were gained by a governor of that calibre from those attained elsewhere, for example at Dominica.

June $27, \mathrm{I} 783-\mathrm{July} 28, \mathrm{I} 788$. The paper is very brittle, and some leaves are broken.

There is material on the end of French occupation; complaints of restrictions on trade with America; proclamation by Gov. Thomas Shirley, permitting the temporary importation of American commodities from foreign islands, June 7, I 787 ; letter from the colonial agent, Feb. 6,1788 , giving an account of a joint interview of himself and the agent for Barbados with Pitt, on the subject of the African slave-trade, together with subsequent letters and other papers on the same topic; much information on slavery and the sugar industry, the most important items being long letters from the colonial agent in which he states that the government was trying to investigate profits on sugar under cover of queries on slavery, and his account of why France sold sugar cheaper on the continent than England.

Aug. 7 , I788-July 22, I795.

This book has several proclamations permitting the temporary importation of American provisions and lumber in British ships from foreign islands.

Aug. I7, I795-Mar. I9, I799.

Sept. I7, I799-Dec. I0, I807.

Ian. 27, I $808-J$ une 23, I 814 .

When news of the American embargo arrived a communication from the assembly was recorded, stating that "it was from the Produce of America that the Inhabitants of St. Christopher obtained threefourths of her food upon which they subsisted themselves their families and their slaves".

British orders in Council of Feb. 7, I8Io, and Nov. 30, I8I3, are entered. There is some material on measures of defense at the opening of the War of $18 \mathrm{I} 2$. 


\section{MINUTES OF PRIVY COUNCIL.}

June 23, I790-Jan. 3, I8I7. (Unpaged.)

Many documents are entered on these minutes. There are frequent a plications for opening the port for the importation of provisions and lumber in British bottoms, some of which were granted.

A letter from Capt. Riou of H. M. S. Rose, Basseterre, Mar. 8, I794, speaks of "privateers fitting out and cruizing in the neighborhood of St. Thomas owned by the French Danes Americans and others and manned in Succession by the different Prisoners released and escaped from our Island".

In the minutes of Apr. I0, I80I, is copied a printed "Address of the General Conference of the Methodist Episcopal Church to all their Brethren and Friends in the United States" on slavery, and a proclamation of the council thereon follows. The address was said to have been published in the New York Spectator, and also in the Providence Journal of June II, I8oo.

The British order in Council of Apr. I2, I809, on the importation of provisions and lumber, is entered. Certain passages show the effect of the American embargo.

Various proclamations, permitting the importation of specified commodities, are entered or noted. In I8L I great reluctance was shown to placing a bounty on salt fish from Br. N. Am.

Aug. 28, I8I7-Oct. 6, I837.

Occasional items were noticed dealing with trade relations.

MINUTES OF THE GENERAL COUNCIL OF THE LEEWARD ISLANDS.

Mar. I-Apr. 23, I798. (Unpaged.)

This volume includes St. Kitts, Nevis, Antigua, and Montserrat. The contents relate mainly to slavery. The assembly sat at the same time, and many of its addresses, resolutions, etc., are entered here.

MINUTES OF ASSEMBLY.

These have been bound and repaired in recent years. In some cases the paper is very brittle. This series is on the whole less valuable than council minutes, and documents copied therein are fewer in number. Some volumes are incomplete.

Sept. 26, I745-Aug. I0, I753.

Report on "the Late Attempt on the Island of St. Bartholomew and the Depredations committed there". Feb. I3, I746/7.

Feb. 3, I756-Apr. I5, I761.

There is some material on defense, privateers, control of the export of provisions, and the reduction in the amount coming from the northern colonies.

Apr. 30, 1761-Sept. 7; 1769.

At the beginning of this book are a few references to French prisoners in the island, and to the expedition against Martinique.

Correspondence of council and assembly over the Stamp Act riot of Oct. 3I, I765, is entered in the minutes for Dec. I7, I765, and Jan. 2I, I766. On the last date the council asked the assembly to appoint a committee for the purpose of drawing up a joint address to the king on the riot, and destruction of stamped paper. The assembly's reply ended, "This House will readily appoint a Committee to join a 
Committee of your Board in representing to His Majesty the extreme grievances and heavy burthen of the Stamp Act in order if possible to obtain a repeal of the said Act".

Oct. 24, 1769-Feb. 29, 1776.

Apr. 4, I776-Sept. 25, I778.

Some items relate to defense.

Oct. I, I778-May 7, I78I.

Some items relate to defense; naval and military intelligence; congested state of St. Kitts following the capture of St. Eustatius, there being upwards of I 400 prisoners of war in the island; and efforts to have them removed.

June 7, I78I-Oct. $3 \mathrm{I}, \mathrm{I} 785$.

A letter of Adm. Rodney, June I9, I78I, deals with naval movements, and criticizes severely the surrender of Tobago. Another letter from the same source is dated the following day, and one from Prescott, July 4, I78I, both on naval and military affairs.

Defense of the island is a prominent topic. Much material on the dispute between St. Kitts and Nevis duplicates that in the minutes of council.

Oct. 8, I790-Aug. 28, I794.

Sept. I6, I794-June II, I799.

July I2, I799-Sept. 20, I802.

In I800 measures were taken to prevent disease reaching the isiand through American ships attached to the convoy. "The Sickness prevalent at Grenada is generally attributed to the American Vessels." Landing of French prisoners by American men-of-war is mentioned in the same year.

Oct. I8, I802-Feb. I2, I806.

Apr. 3, I806-Oct. I8, I8I I.

The records show in 1806 a local readiness to pay a bounty on fish from $\mathrm{Br}$. N. Am., and also a reluctance to impose any duty on the same product from the U. S.

Resolutions of the next year state that famine was imminent and that American traders had almost abandoned the island, as it was impossible to pay them in bills or specie. The consequent need of permitting the exportation of sugar was urged.

Nov. 25, I8I I-Aug. I0, I8I6.

A few items deal with the regulation of trade.

LETTER-BOOKS.

These contain despatches from the governor to the Secretary of State, local and intercolonial letters.

July I5, I8I6-Sept. 8, I8I9.

Gov. Probyn to Bathurst: "A great and serious scarcity of provisions certainly prevails among these Islands, there being no vessel in the British American Trade, and a want of Capital to establish such; and unless the Merchants from Great Britain will embark in a Commerce of this description, every Calamity is to be feared from the want of the accustomed resources." Aug. 8, I8I6.

rieh. 4,1823 -Oct. 20,1825 .

A despatch to Bathurst under date of Apr. 4, I825, states that no colonial duties have been 'evied on American produce imported under 3 Geo IV. c. 44 and 45 , during 1824 . 


\section{ST. LUCIA.}

The records listed below are at Castries, in the office of the administrator, to whom any application relating to them should be made. They are stored in a vault, situated on the ground floor, that would not put up a strong defense against fire. Apart from some traces of mildew they are in good condition.

A search of the registrar's office yielded nothing for our purpose.

Local conditions at the treasury, described below, made impossible an examination of in-letters of the governor's office and of the privy council.

Though St. Lucia well deserves her title of cockpit of the West Indies, and Castries has been the scene of repeated battles, fires, and hurricanes, yet her archives have suffered less from such causes than one might expect. During the English assault on Morne Fortuné in I796 a fire ravaged the town beneath and destroyed all government records. Notarial études were in the hands of their owners, and most of them survived. In I8I7 a terrific hurricane blew down Government House, burying the governor in the ruins, and injuring him so severely that he survived only a few hours. Yet apparently the despatches were not harmed, for a credible witness wrote about thirty years later, "The public records are only complete since July 1800 -all those of a previous date having been destroyed by fire in I796".

During the last generation government offices in Castries have been moved several times. About twenty-five years ago the loft above the present treasury was used as a general dumping-place, to relieve congestion elsewhere. At length the trap-door was nailed down, and finally the existence of these records nearly passed from memory. At the time of our visit carpenters removed the trap-door. Mere physical conditions made a thorough examination of this room impossible. Nearly two tons of manuscript volumes and files lay in confusion, scattered at random from one end of the garret to the other, where they had been carelessly thrown years before. Mingled with them were old blue-books, newspapers, odds and ends of every description, the whole heavily carpeted with dust, and with evidences of bats and other unlovely denizens of the place; while at every move to examine the documents sundry varieties of spiders and numerous specimens of the insect known locally as "ciseaux" scuttled to fresh cover. The effect of sunshine upon a metal roof made approach to the sides almost impossible. An hour's rail brought to light nearly all the old letter-books, entry-books, and minutes of council listed below. Permission was granted to remove them to the administrator's office, where they now are. Many other volumes having no relation to American history still remain, and also a large quantity of loose papers. Most of the latter are in bundles, and lie in irregular heaps of varying area and depth. A brief examination revealed files of the governor's office which form the counterpart of the letter-books, and also council papers. Some of the letters are dated I820. Occasional despatches from the Colonial Office were noted. There are also despatches from the governor general at Barbados, but these of course are of a later period.

It will be seen that between the date mentioned by Mr. Breen and the opening date of the archives as constituted at present there is a gap of about eighteen years. For that period we lack at the least the original despatches from England, letter-books of the governor, and the first volume of "Public Acts of Government" with its ordinances and proclamations. The earliest

${ }^{1}$ St. Lucia, by Henry Breen, F. S. A. ( 1844 ), p. 372, note. The author resided for several years in the island, and had held responsible positions there. The quotation bears out the local tradition that Mr. Breen was of Irish descent. 
minutes of privy council were taken from the garret, and the legislative council clates only from 1832 . No custom-house papers or records of a court of vice-admiralty for the early years are known to survive. Whether despatches, etc., between I800 and I8I8 are buried under one of the dusty piles above the treasury it is at present impossible to tell. Official excavations by the aid of a prison gang would soon settle the matter; but until some such action is taken one can only wonder whether these early records of the English régime in St. Lucia still exist or if perchance they have been lost by some manifestation of that spirit of indifference towards old archives which is so apparent in the islands at the present time.

It is clear that a large part of the items bearing on commercial relations with the United States follow the main lines already noted in other islands. Two features, however, seem worthy of notice. The first is the series of despatches from the Colonial Office, which give the official British account of difficulties arising from certain duties and tonnage dues on British vessels in ports of the United States, that for a time excluded American shipping from the British West Indies. The second does not relate to the United States at all. Among students of various colonial problems, however, there may well be some for whom the results of concessions as to language, law, and religion to the "new subjects" of a conquered colony are matters of interest. For any such the archives of St. Lucia are of especial value.

\section{DESPATCHES FROM THE COLONIAL OFFICE.}

The series of original despatches starts with I8I8. There are a few gaps. The entry-book for such despatches begins a year sooner. Strangely enough the copies yield better material for our purpose than the originals, for not only are there no gaps, but while many enclosures have been lost from the despatches they are usually copied in the entry-books. The latter are therefore selected for presentation, but original despatches were also examined, and unless there is a note to the contrary the material is present in both series. Original despatches are sewn in sections about an inch thick, which have paper covers but are not numbered.

\section{ENTRY-BOOKS OF DESPATCHES.}

May 8, 1817-Sept. 24, 1825. (268 pp.) Indexed.

Circular, giving tables of fees of customs officers in the Br. W. I., divided into lists for American, European, and island vessels. Downing Street, May 8, I8I7. (In entry-book only.)

Despatch, enclosing note from Thomas Lack to Henry Goulburn on export of sugar from the W. I. by vessels importing provisions and lumber. The Committee of Privy Council for Trade refused their consent. Downing Street, Feb. 25, 1818. The enclosure is entered, dated Feb. Io.

Bathurst to Sir John Keane. Discusses the temporary permission at times given to import lumber from foreign islands in British vessels, and approves of the governor's refusal to allow such importation by foreign ships. Downing Street, Feb. 8, I821.

Same to the officer administering the government. Circular despatch on duties levied in the U. S. on British tonnage and goods from the W. I. Downing Street, Dec. 30, I823. Enclosed is a letter from the Board of Trade which recommends that diplomatic negotiations should be initiated, and states that the British government is ready 
to adopt a policy of equality as regards tonnage dues and duties on goods imported in foreign bottoms. (In entry-book only.)

Id. Circular despatch relating to heavy charges on English commerce and navigation in the Br. W. I. and Br. N. Am., and which were proving a serious factor in the competition with merchants and shipowners of other countries. Downing Street, June 4, I824. One enclosure from the Board of Trade is present.

Sept. 30, I825-Dec. 3I, I83I. (Unpaged.) Indexed.

Bathurst to Maj.-Gen. Mainwaring. As the U. S. have not placed British commerce and navigation on the footing of that of the most favored nation, the provisions of section 4 of the act $6 \mathrm{Geo}$. IV. c. I I4, closing ports in the Br. W. I. to American shipping, are to be enforced. Downing Street, Aug. I2, I826. One enclosure from the Treasury present.

Id. Circular despatch, tracing the course of negotiations since I820 regarding duties on British shipping and commerce in American ports, and reiterating instructions to close all ports of the $\mathrm{Br}$. W. I., New foundland, etc, to American shipping after Dec. I next. Downing Street, Aug. I9, I826.

Id. Circular despatch, forwarding a report from the Board of Trade dealing with queries from some of the W. I. on the interpretation of recent regulations affecting their trade with the U. S. Downing Street, Apr. I8, I827. Enclosure present.

Huskisson to same. Circular despatch, which treats in detail the principles underlying the statutes 6 Geo. IV. c. I I4, 7 Geo. IV. c. 56 , and sundry orders in Council, and describes the problems that have arisen from their practical application. The course adopted by the U. S. and other nations is described, and instructions are given on the enclosed order in Council of July I6, I827. Downing Street, Sept. 8, I827. (In entry-book only. The order in Council is not copied here, but in the volume entitled "Public Acts of Government".)

Murray to Maj.-Gen. Mackie. Circular despatch, forwarding, with comments, an order in Council of Nov. 5, I830, "authorizing the admission into all His Majesty's Possessions abroad of American Ships arriving from the United States with Goods the Growth, produce or manufacture of that Country". Downing Street, Nov. IO, I830. (Enclosed are correspondence of the Foreign Office, Pres. Jackson's proclamation of Oct. 5 , I 830 , circular instructions to collectors of customs in the U. S., and three papers from the British Board of Trade. No enclosures remain with the original despatch. The order in Council is not copied.)

\section{"HOME CORRESPONDENCE."}

This series of letter-books has indexes and also marginal summaries.

"Vol. I." June 28, I818-May I3, I824. (274 pp.)

Maj.-Gen. Sir John Keane to Bathurst, no. 3. Describes state of the colony following the late hurricane, and gives reasons for opening the port temporarily to vessels of all friendly nations. July 27, I8I8.

Id., no. 36. Despatch similar to the previous one, in consequence of another severe storm. Oct. 27, I8I9.

$I d .$, no. 55. Importation of lumber in British vessels. Only 29 American vessels of small tonnage have entered in the past twelve months. Nov. 26, I8I9. 
Maj-Gen. Mainwaring to same, no. 6. Details of the importation of provisions, lumber, etc., by various channels. Sept. 7, I82 r.

I3.. no. 4I. Forwards, with comments, an ordinance entitled "An Ordinance imposing certain Colonial duties on Articles imported under authority of an Act of Parliament passed in the third year of His Majesty's reign intituled 'An Act to regulate the Trade between $\mathrm{H}$ is Majesty's possessions in America and the West Indies"'. Dec. 20, 1822. (Enclosure not found. Before this time such documents had ceased to be copied in minutes of the privy council, and the first volume of "Public Acts of Government" is missing.)

Id. no. I8. Sends ordinance entitled "An Ordinance imposing a Tonnage duty upon Vessels of the United States . . . and an additional Io per cent upon the duties established upon Articles imported therein". Nov. 3, I823. (Enclosure not copied.)

July 20, 1829-Mar. 12, 1831 . Unpaged. Nothing found.

\section{MINUTES OF PRIVY COUNCIL.}

Nov. 25, 1816-Jan. 3, 1822. 412 pp.

This volume, which has some pages missing at the end, contains the first minutes of the council under Pritish rule. It begins with procès vorbant of the nomination and summons of the privy council, and commissions of Maj.-Gen. Richard Seymour as governor, commander-in-chief, and vice-admiral. At first, except for some documents entered, French is used exclusively. A governmental order soon made English the language of the minutes, but a diminishing proportion of ordinances and proclamations are entered in French for some years. The material for American history in this series is confined to commercial lines.

Proclamation permitting for two months the importation of certain provisions in British ressels from neighboring islands, and the exportation of rum and molasses. Jan. 3, I8I 7 . This was at the instance of a local petition.

Proclamation opening the port of Castries for three months for the importation of certain specified provisions, lumber, and live stock in the vessels of all nations in amity with G. B., in order to mitigate the disastrous effects of the hurricane of the previous day. Oct. 22, I8I7. A subsequent proclamation of Oct. 25 allowed the exportation of rum and molasses, and also fixed import, export, and tonnage duties.

Proclanation extending that of last October until Apr. 22, I818, in order to allow time for the crops to mature, and thus permit payment in produce. Nor. 19, I8I7.

Proclamation reducing duties on neutral vessels and their goods, in order to "Encourage a greater infux of Foreign Vessels". Jan. I6, ISIS.

Ninute and proclamation adding sugar to the list of articles that may be exported in foreign vessels as payment for imports. Jan. 26 , 18 I 8.

Proclamation keeping open the port to foreign vessels importing certain articles of provisions, lumber, and live stock until Oct. 21. Mar. 26, I8I8.

Minute stating that the port had been closed to foreign vessels in consequence of instructions from the Colonial Office, followed 
by a proclamation allowing the importation of certain articles of provisions, live stock, and lumber in British ships, and the exportation of rum and molasses in the said vessels. May I, I8r8.

Minute on the alarming economic situation, followed by a proclamation opening the port for three months to foreign ships importing certain articles, and allowing them to export rum and molasses. May 21 , I8I8.

Minute of a proclamation ordered, to keep the port open until Feb. 20, I8I9. July 28, I8I8. (Not entered.)

Minutes relating to a tax on transient traders, and discussion as to advisability of opening the port to foreign ships for the importation of provisions, etc., and the exportation of rum and molasses. Oct. 28, 1820 .

Deliberations of council upon a petition of merchants, etc., and an order for a proclamation opening the port until June 30,1821 , for the importation in British ressels of certain articles of lumber from other parts of the W. I. under European domination. Nov. I4, I820.

Apr. II, I822-Dec. 20, I83o. (Unpaged.)

There is little for our purpose in the second volume of privy council minutes. On Aug. 21, I822, there was discussion of the Intercourse Bill, regulating trade of the Br. IV. I. with foreign islands and with the U.S. A local ordinance on this subject was drawn up on Sept. 4 .

"PUBLIC ACTS OF GOVERN MENT."

"Vol. 2." I826-1830.

The first volume of this series of entry-books was not found, but it is clear that some of the material is in the minutes of privy council. The chief classes of documents entered are ordinances, proclamations, orders in Council, and governmental orders. There is some material on shipping, taxes on transient traders, etc., most of which is of an indirect nature for our subject, and a British order in Council of July 16 , 1827 , relating to trade.

\section{LETTER-BOOKS OF LOCAL CORRESPONDENCE.}

These contain no direct material beyond occasional instructions from the governor to the collector and comptroller of customs to allow certain articles from the cargoes of American ships to be landed, or notifying them that proclamations relating to the importation of American produce had been extended. "A." June 26, I8I8-Mar. 24, I820. (260 pp.) Indexed.

"B." Mar. 28, I820-Oct. 5, I82 I.

Oct. 5, I82I-Aug. I9, I823.

Aug. 23, I823-Jan. 21, I825.

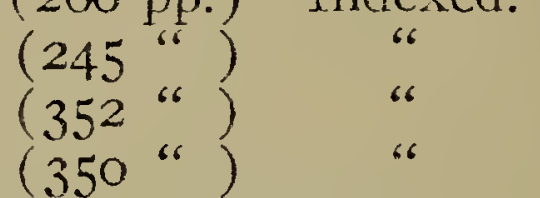

No other volumes were found of a prior date to $183 \mathrm{I}$.

DUPLICATE DESPATCHES.

Five volumes of duplicate despatches sent from St. Lucia to the Colonial Office have recently been presented by the latter to the colony. They cover the period I8I4-I840. 


\section{ST. VINCENT.}

Political records at Kingstown, St. Vincent, are scanty, and it was with some difficulty that they were found at all. Certain books of council minutes are in very poor condition, the paper being dark and very brittle. Wanuscript volumes of old laws are in the vault of the registrar, who is under the supervision of the chief justice. The remaining books were found at the administrator's office, in a room on the ground floor.

It should be noted that these records cover not only St. Vincent lut also Bequia and the Gremadines north of Carriacou.

Anministrator's Ofmice.

MTXUTES OF PRIVY COUNCIL.

Feb. 4. 1784-Dec. 5, 1789. (Lnpaged.)

Minutes of July 4, Ang. 25, Sept. 25, Nov. 13, I787, Fel). 3, May 23, July 30 , r 789 , deal in part with the question of opening the ports for importation of certain specified articles of provisions and lumber. Proclamations to that effect are at times recommended, but these were not entered, and could not be discovered in loose form.

Dec. Io, I789-June 8, 1805 . (Unpaged.) End missing.

The same kind of material as in the preceding volume is found in the following sessions: June 4. 1790; May 26, Oct. 25, I791 ; Apr. Io, 1792; Jan. 23, Aug. 5, Oct. r, 1793; Jan. I, Mar. 25, Nor. 18, 1795 ; Jan. 24,1796 ; Oct. 25, 1797. In the later dates mention is made of allowing American ships to enter, and in 1798 there are the cases fumished by arrival of the schooner Sea. Flower from Portland and the brig Hamall from Boston.

Lient.-Gov. Wentworth to Gov. Bentinck. Discusses the trade of Nova Scotia with St. Vincent, and refers to the transient duty of three per cent. imposed upon traders from this British colony but not upon those from the U. S. Halifax, Mar. 3, I803.

Circular despatch from the Colonial Office on the question of opening ports of the island to articles from the U. S. Downing Street, Sept. 5 , I804. An address of the council to the governor, dated Nov. I, 1804 , and read at a meeting on Nov. 20, treats this matter in detail, gives statistics of recent imports from G. B.. Ireland, and Br. N. Am., and argues the necessity of allowing the importation of salt provisions from the U.S.

May 2, I8o6-Feb. I, I820. (Unpaged.)

The British orders in Council of Sept. I7 and Oct. I, ISo6, dealing with the regulation of the IV. I. import trade, are entered. Subsequently there is correspondence and other material on the importation of provisions and lumber in neutral vessels. The question of placing a bounty on Newfoundland fish is also brought up for discussion.

The case of the American brig Alert appears under date of Aug. I2, i 808.

Circular despatch from the Colonial Office, enclosing an act, etc., on trade between Bermuda and the U. S. Downing Street, Sept. I4, I8Iz. (Two enclosures also entered.)

MINLTES OF LEGISLATIVE COUNCIL.

Mar. 3, I $784-F e b .5$, I 785 . ( ( 63 pp.)

Feb. $15,1785-J a n .17,1787$. (Unpaged.) 
Feb. T. I -87-July 20, 1792. (Unpaged.)

Also has despatch of July 20, I791. with enclosure from Quelec merchants. Vide minutes of assembly.

Sept. 4. 1792-Dec. 30. 1796. (Unpaged.) This rolume is too fragile to be eximined in detail.

An address of council and assembly to the governor sets forth the alarming scarcity of provisions, and prays that the ports may be opened to ressels of every nation (France excepted) importing foodstuffs. June 26, 1793 .

Tan. 25. I797-Jan. Io. 1799. (Unpaged.) This volume is also too fragile to permit a full examination.

Jan. I. 1799-June 12, 1802. (Unpaged.)

Oct. 4. Isog-Dec. I, Isis. (Unpaged.)

There are notes of acts imposing tonnage duties on American ressels. ISI 2.

\section{MINUTES OF ASSEMBLY.}

Oct. 4: 1786-June 5, I793. (Unpaged. Beginning and end missing.)

Regulation of trade with the U. S. Oct. $23,17 S_{7}$.

Circular from Dundas, enclosing copy of memorial from merchants of Quebec. Whitehall, July 20, 1791. (The enclosure, dated Quebec, Dec. 9. I 789. deals with the importation of rum and molasses, and suggests preferential treatment of return trade as compared with that of the U.S.)

\section{MISCELLANTOUS.}

Nov. 17, 1808-Aug. 22, 181 I. (186 pp.)

This is an entry-book of local and English letters. There are a few petitions and other material on the landing of cargoes.

Jan. 23, 1809-Feb. 25, 1812. (132 pp.)

This letter-book of local and English letters has nothing for American history.

\section{Registrak's OFitce.}

\section{LAWS.}

1767-1772. This volume is imperfect.

An act for preventing abuses in the lumber-trade with America and to $1784-1787$. regulate local trade in grains, etc. Jan. Ir, 1768 .

I 7 - -1793 . Imperfect. Partly duplicates the next rolume.

$178,-1796$. Proclamations and acts.

There are'a few proclamations of the usual character, to open the ports for the importation of certain specified items of provisions and lumber.

I797-ISO9. This volume has a table of contents.

An act for laying a tax on transient traders. Oct. 22, 1799. (Traders from Br. N. Am. and the U.S. were exempted from certain provisions in case they sold their cargoes wholesale. This act was altered by another of Nor. 21, 1808, in favor of traders from Br. N. Am.) 
TOBAGO.

When Tobago became a ward of Trinidad (q.v.) in I8g9 some records were brought from Scarborough to the government buildings in Port of Spain. These were lost in the fire of I903. In I9I 5 further transfers were made, chiefly of land records and registers of vital statistics. In a vault attached to the office of the colonial secretary of Trinidad are two letter-books of despatches from the governor of Tobago to the Colonial Office, of which the earliest begins in I829, and the two volumes of minutes noted below.

Considering the fire of $\mathrm{I}_{903}$, the evidence of existing despatches and minutes, and verbal information offered, it was judged useless to make a trip to Tobago. Records still at Scarborough are said to be scanty and comparatively recent in clate.

$$
\text { "MinUtes of THE HOUSE OF ASSEMbly, TOBAGo." }
$$

Nov. 1, 1797-Aug. 4, I799. (370 pp.)

During this period Stephen DeLancey was governor, and his relations with the assembly were at times very strained. The bulk of the material is of course local in its nature, but there is some relating to W. I. currency, trade with Spanish colonies, and a long, important report in Oct., I798, on "the increase of Negroes and the amelioration of their state", in answer to a resolution of the House of Commons of Apr. 6, I797. It is a good description of slavery in Tobago.

A minute of 1798 says that some documents were destroyed by a fire at Scarborough in 1790 . A note at the end of this book states it to have been volume "fourth of fair minutes".

Aug. 13, 1799-June 26, 1802. (Unpaged.)

Among local items is material on trade with Spanish colonies, a bill to ameliorate the condition of the negroes, desire of the colony to remain under British rule, importation of salt provisions from the U. S., and a petition to the king by council and assembly, Nov. I7, ISoo, setting forth the economic history of the island under British rule, including the effect of the American Revolution.

\section{TRINIDAD.}

On March 23, 1903, a mob set fire to the building in which government offices were housed in Port of Spain. In a few moments the building and all its records were destroyed. Archives of the registrar general were not harmed, but they deal only with land titles and vital statistics. Minutes of the Cabildo and a volume of proclamations escaped because for many years they had been out of government hands.

$A$ few volumes of diplicate despatches from Trinidad to the Colonial Office have since been given by the latter. The earliest is for I8I4. They of course simply duplicate material at the Public Record Office in London.

\section{Town HaLl.}

By the articles of capitulation, as printed in L. M. Traser's History of Trinidad, all recordis were to be left in the island. In $18 \mathrm{r}_{3}$ the records of the Cabildo were extant from 1733. For many years this body continued to exist, and in $18+0$ it finally became the town council of Port of Spain. The governor acted as president, and the minutes of meetings are signed by all members present. With a mixture of executive, legislative, and judicial functions, in 
its early days under british rule, before it was shorn of much of its power, the Cabildo had a close resemblance to the council of mainland colonies.

Under Sir Ralph Woodford early minutes of the Cabildo (I $733^{-18 \text { I3 }) ~}$ were copied and translated. Fraser used them in his history, the first volume of which was published in I89I. Now there is no trace of either copies or originals. One theory is that they may have perished in the fire of 5903 . along with the manuscript of Fraser"s third volume. The first volume of the existing set covers the period June 2I, I8I3-July I5, I8I6. The material is largely local in character, and a brief search among its brittle pages revealed nothing for American history. For the first few years English and Spanish are on opposite pages; then the Spanish version stops. The rolume has ISo sheets, written on both sides.

A topical index, arranged alphabetically, is in a separate book. It covers the minutes for I8I3-1837.

These minutes are in the office of the town clerk, Port of Spain, to whom any application regarding them should be made.

\section{Port of Spajn Peblic Librari.}

"Proclamations. I8I3-IS33." This volume of 500 pages contains both manuscript and printed proclamations for the period June 17, i $8_{1} 3^{-}$ Dec. $3^{\mathrm{J}}, \mathrm{I} 833$.

On Aug. Io, I8 3 , was published an imperial proclamation of June ro on the importation of provisions. This is the only item within the radius of United States history.

\section{Registrar Gineral's Opitce.}

\section{(Port of Spain.)}

Contains conveyances, deeds, wills, etc., from early times, including Tohago material. A book of Tobago conveyances of 1717 was seen. Tobago paper: are in Spanish, English, or French, according to (late. Ohl Spanish deeds of Trinidad can no longer he handlerl. 


\section{INDEX.}

Abaco Island, 32, 33

Abdy, Robert, IO, I5

Abigail, 374

Absentees, debts, 277 ; Leeward Islands, 235, 248; tax, 164, 171, 177, 178, 213, 215, 244, 259, 272,275

Accounts, see Public accounts

Achilles, 374

Acteon, 374

Active, 374

Acts, authority of president of Council, 72; colonies and royal review, 138 ; consideration in England, delays, 58, 170, 178, 244: in Colonial Office Papers, 2 ; limitation, 157 ; period of unconfirmed, 5I; policy of disallowance, $2 \mathrm{II}$; representations and disallowances, 42, 69-74, 92, I12-I I5, 124, 138, 139, 156, 170, 172, 173, 175-177, 179, 180, 193, 194, 208-216, 232, 233, 238-240, 24.3$245,248,249,257,272-277$; riclers, 159,163 , I 80, 190, 2 I I ; suspending clause, 29, 4I, 52, $70,72,91,112,113,125,165,172-175,177$, I 78, 184, 192, 193, 210, 213,214, 244, 273, 275; sce also Privy Council; islands by name Acts of Assembly in Bermuda, I 5

Acts of Assembiy in Charibbee Leeward Islands, $28,3,286$

Acts of Assembly in Leeward Islands, 278

Acts of A ssembly of Jamaica, 218,367

Acts of Assembly of Montserrat, 283

Acts of A ssembly of Nevis, 286

Acts of A ssembly of St. Christopher, 292

Acts of trade, act of 17 I I, 208; African trade, 70; and colonial manufactures, 125, 126; and French trade edicts, 241, 242, 252; British islands and mainland colonies, I82, 230, 234, 275; British registers for American ships, 10.4, 217; British trade with islands, 168; colonial acts on enforcement, 177,215 , $24 \mathrm{I}, 246,272$; conflicting jurisdiction, 59, $95,164,165,179$; enforcement, 17, 48, 64. $72,143,161,162,172,188,214,216,276$, 327; enforcement in mainland colonies $(1767), 337$; forcible rescue of seized ship, Ior; foreign islands and British mainland colonies, $46-50,57,59,60,62,71,90,99$. I00, 164, 268, I 7 I-I73, 190, 19I, 213, 215 , $239-243,253,256,325,337,393,394$; foreign islands and England, 394; international islanc trade, $46,47,53,56,59,60,63,69,70$, $72,88,9 \mathrm{I}, 93,125,127,135,136,14 \mathrm{I}, 145$, $146,163,164,165,168,179,180,182,183$, $184,211,214,233,241,242,252,253,255$, $272,274-276,313,405$; Irish violation, 47, 5.3; island charges on English trade, 349; island trade with Europe, 24.0; Madeira trade, 234; naval officers as of hicials, 53; New England retaliation (1785), 323; reve- nue, diversion, 163; Scottish violation, 174: ship frames, 95: suggested liberalization, 51 . 142; troops and enforcement, 188; United States peace-time trade (before 1804 ), 33 . $34,65,74,104-106,123,127,128,140,141$, $153,197,198,203,217,230,265,266,268$, $277,301,313,315,323,326,337,339,357$, $359,392,395,403,404$; (after War of 1812 ), retaliations, III, I I 5, I 23, I55, 208, 2 I 8, $270,304,327,346,349,350,353,354,360$, $387,392,396,397,399-402$; violation by men-of-war, 52; violations, seizures, 25-27. $29,30,45,50,62,87-89,94,95,97-99$, IOI , I I $3,114,136,137,140,147,161,164-$ I66, I 82, I $84,189,234,235,241,252,27$ I, $275,344,349$; see also Customs; Free ports: Neutral trade; Trade with the enemy; products by name

Acts passed in Barbados, 74, 75

Adams, John, letter to, 260

Adams, John, of Barbados, 55, 73

Adams, John, privateer, 30

Adams, Samuel, letter to, 260

Adams, 3 II

Addison, Joseph, letters, 233, 272; letters to, $40,69,27 \mathrm{I}$; reference, 2 IO

A. Desnordescho Low, 377

Adjournment, see Assembly

Administration of estate, see Probate

Admiralty, agent and collection of dues, 88 ; appeals, 357 ; colonial jurisdiction, 180; fees, I5I; proprietary jurisdiction, I5; regula. tions, I5I; trade-with-enemy case, 19; see also Prizes; islands by name

Adriana, 374

Adriance, H. M. S., 65

Adrenture, $259.37 t$

Advice boat of King of Spain, seizure, 247, 255 , 276

Adye, Pres. A. C., letters, I 54, I 55

"Affair of the Jamaica Embargo," 184

Africa, trade, 393; see also Slave trade

African Company, see Royal African Company

Agents, see Colonial agents

Agriculture, new products for West Indies, 63 ; produce as legal tender, I 84 ; see also "con. ditions" and "produce" under names of islands; products by name

Aikman, Alexander, notes, 388 ; printer, 279,22 r, $223,225-228$

Aikman, Alexander, and Son, 22 I

Ainslie, Gov. George Robert, letter, I55; letter to, 349

Aix-la-Chapelle, treaty of, 297

Alert, 403

Alexander, Capt. Charles (called Hallock), 30

Alexander, William, see Stirling

Aifred, U. S. S., 30, 152 
Algiers, American consul, 108

Alida, 250

Alligator, 303

Almanack for the Year I807. Antigua, 260

American Antiquarian Society, Proccedings, 369 American Historical Association, Annual Report, 3 American Historical Review, 26I

American Revolution, Americans and Lord North ( 1783$)$, I40; attitude of British islands, 30, 3I, 56, 64, 96, 98, 102-105, 110, I39, I49-15I, 19I, 192, 194, 248, 260, 298, $3 \mathrm{I} 6,325,357,358,36 \mathrm{I}, 392,395$; attitude of Ireland, 264; British impressment from prizes, 197; British negro regiment, Quakers, I 30; British seizure in New York City, I23: British transports, 197; British troops, 299, 316 ; conditions, 31 , 1.53, 195; convoys, I51, $153,263,264,318$; course of war, I95; Declaratory Act, I 89; effect on Tobago, 405; enforcement of acts of trade $(1767) 337$; English opinion (1775), 260; flag, 298; fleets and forces in West Indies, $65,150,15 I, 153$, 196, 326; Florida, I50, 195, 196; French preparations in West Indies, 65, 74, 263; French war, 126; German troops, 300; intercepted letters, 260; Massachusetts Coercive Acts, $19.3,260,318,357$; munitions from British islands, 64, 102, I0.3, I I0, I52, 194, 260, 394; neutral islands and trade, I03, I26, I95, 25I, 26I-264, 3I6; operations in West Indies, 20, 21, 29-32, 195-197, 251, 265, $298,315,316,329,354,392,395,397$; plan against $\mathrm{New}$ Orleans, I95; prisoners of war, $31,32,65,152,196,264,326,342 n .344$, 395,397 ; privateers, $30,65,74,97,103$, I04, I IO, I 26, I 27, I $51-153$, I $55,195,197,261$, $262,299-301,337,339,358,359,374,375$ prizes, $21,32,33.97,103,104,127,151,152$, $197,300,326,355,359,374,375$; siege of Boston, supplies from islards, $29,30,64$, y 02 , 394; Stamp Act in islands, 25, 56, 95, I00, I42, 179, I $89,256,39$ I, 392, 394, 396; trade with British islands, provisions, 20, $2 \mathrm{I}, 3 \mathrm{I}$, $32,64,65,97,98,102-104,126,133,152$, I97. $251,260-265,292,299,300,318,337$, $339,391,392,395$; West Indian records, $323,3.34,337,339$; see also Loyalists

Amherst, Sir Jeffery, 26r

Amherst, Capt. (?) Jeffery, letter, I 96

Amitié, 88

Ancient Journals of A ssembly of Bermucia, 120

Anderson, Rew. , of St. Kitts, 239

Andrew Doria, U. S. S., 30

Andrews, C. M., Guide to Materials in British Museum. iii; Guide to Materials in Britis? Record Office, iii

Anguilla, and acts of trade, 256; and St. Croix, 232 ; governor, 274; popalation, 232-234; see also Leeward Islands

Ann, 322

Anne, 374

Annotto Bay, $20 \%$

Anstruther, Maj. William, letters, 98

Antelope, H. M. S., 185

Antigua, absentees, 244,275 ; acts, 4, 9, 328 ; acts in force, 234,241 ; admiraliy, $24,32,32$, 323,355 ; agent, $23.5,238,247,276$; archives on island: condition and character, 321,322 , 324 ; in arsenal, $32 \mathrm{I}-324$; in court-house, 324-328; in sccretary's office, 328 ; assembly rights, I 43, 233-236, 246, 254, 278-273, 276; chancery, 23I, 232, 238, 239, 245, 254, 276; church, 272; correspondence of Secretary of State, 4; council membership, 72, 230, $243,244,254$; courts, $23-233,235,272$, 273,324 ; currency, $235,241,324,327$; customs, $233,235,236,24 I, 272,273,325,326$, 328; debts, collection, interest, $238,243,275$; defense, $230,231,239,246,247,249-251$, $258,325,326$; during American Revolution, $65,248,262,325,326,395$; during War of $1812,326,327$; during War of the Spanish Succession, $23 \mathrm{I}$; fees, 230, 23I, 239, 240 ; fire at St. John's, 257; iree ports, 249; governor in residence, 252 ; governor's letterbook, 323; hurricane, 248; land affairs, 233 , $235,272,328$; Leeward. Islands, government, vi; liquor imports, 239, 272; Loyalists, 197 ; maps, 234, 240; militia, 23I; misgovernment, 244 ; negro insurrections, $7,238,242$, 252 ; non-residents, 238 ; pirates, 149 ; polriical conditions, $235,236,238$; population, $231,238,246$; possesion, powder-duty, 248,249 ; privateers, $65.247,262$; produce records, 328 ; public acconme, $\div$ ? 230,237 , $239,240,246$; quarterise sidtic, 324 ; Roman Catholics, $233,24,245,=72,275$; sessional papers, 4-II, 252, 266-269, 27,8, $28 \mathrm{x}, 324,396$; shipping returus, I I, 2\%, 265,326 ; slave trade, $237,239,249 ;$ Stan Act, 256 ; suffrage, $233,235,273$; taxs, 241 , 328 ; trade, neutral, United States, violation $:$ $50,230,23 I, 233,235,239,245,246,266$, $269,272,275,323-328$; vital records, 231 , $237,239,240,242,244,249$; wrecks, 249 , 252 ; see also Leeward Islands

Antigua Squadron, 152

Autin, Marquis d', letter to, 186

Apollo, 39

Arbaud, Count d', letter, 262

Archer, Edward, indenture, 344

Archives of British West Indies, in Colonial Office Papers, $\mathrm{I}-4$; in general series of Public Record Office, 2 ; in the islands, condition, iv, 320; materials and purpose of present guide, iii-v; other guides, purpose, iii; see also islands by name

Argent, $M \cdot \mathrm{d}^{i}$, correspondence, 126

Argo, 374

Ariel, I23

Arlington, Henry Bennet, Ist earl of, letter to, I 82

Arny, British, in West Indies, and colonial military laws, Ioo; and enforcement of ac1s of trade, I88; and promotion of settlement, 182; Bermuda company in Bahanas, $14-16$, 22,89 , I 13 ; bounty lands, I48, I 50 ; conspiracy, 98 ; distress, 17 , I 44 ; firing on rioters, trial, 258; franchise, 15 ; ncgro troops, 41 , I71, 186, 188; pay, I82; quartering, 324; recruting, character, $213,258,299$; regilars from rnainland colonies, I4I; rotation, 141 , I48, I.9, I9.3-195, 256, 316; subsistence controversy, $165-167$, I89-!91, 209-211, 
$2 \mathrm{I}_{3}$; see also "defense" and "negro insurrections" under islands by name; wars by name

Arnold, Capt. William, deposition, 336

Arthur, Lt.-Col. George, letter, 123

Ashley, John, 52

Asiento, agent detained, I86; complaint of company, 182; Jamaica and, 160, 162, 163, 165, 167-169, 208; monopoly, 181; new Spanish, 56,63 ; operation, 163 ; see also Slave trade; South Sea Company

Aspinall, Algernon, 318; acknowledgment to, vi Assemblies, adjournment and dissolution, $7 \mathrm{I}$, I $14,150,16 \mathrm{I}, 183,208-2 \mathrm{IO}, 258,259$; and addresses to king, 210 ; and appointment of treasurer, 46, 143, 148, I81; and Board of Trade, I78; and chancery, I89; and impeachment, 258,259 ; as court, 53, I89; barrister members, 64; choice of speaker, $7 \mathrm{r}$, II3; clerk, choice, secrecy, II3, II4, 2 I5; control over finances, 46, 53, 71, 72, 94, 96, 99-102, I I 4, I I $5,125,143,148$, I 50, I 56, I59, I61, I63, I64, I 66, I 68, I 7 I-175, I 81 , I89-192, 209-2II, 2 I3, 2I4, 234, 246, 254, 275,276 ; councillors and franchise for, 248 , $249,257^{-259}, 277$; exclusion of officers, 173 , 2 I4; inspection of minutes, I78; Jamaican declacation of rights, 178 ; number and pay, 74, I 12 ; presents to governor, 70 ; privileges, I81, 189, 209, 210, 216; qualifications, 96, IOI , 143, 2IO, 2II, 2I3, 273; term, I7 I, I72, 2I3, 2 I6, 270; see also Acts; Colonial agents; Councils; Elections; Governors; Legislature; Sessional papers; islands by name

Attainder, 125

Attorney general, colonial, dismissal, 174

Atwood, Thomas, complaint, 137

Atwood, Ch. J. Thomas, letter, 30

Auchinleck, Pres. Andrew, letter, 90

Auld, Allan, memorial, I9o

Austrian Succession, War of the, Georgia-Florida, $18,90,185,186 ;$ in West Indies, 17,18 , $24,53,54,58,60,61,167,168,170-172,182$, I $83,185,186,187,213,244,253,305,325$, 393; naval operations, 182,183 ; neutral trade, 91, 99; prisoners of war, 18, 53, 92, 186; privateers, 24, 53, 54, 60, 91, 92, 170, I $86,253,315,322$; prizes, I 8,24 ; trading with the enemy, flags of truce, 92, 93, 99, I I4, 182, 244, 253, 393; Vernon's expedition, $252,253,315,393$

Ayscough, Pres. John, letters, 166, 167; letter to, $2 \mathrm{I}_{3}$

Ayscough, Samuel, 389

Bahama Gazetie, 332

Bahama Society, 23

Bahamas, acts, 15, 16, 42, 331, 332; admiralty, 333; American capture of New Providence, 20, 21, 29-3I, 329; and Turks Islands, 17-19, 25-29, 42, 9I; archives at London: correspondence of Board of Trade, II-2I ; correspondence of Secretary of State, 2I40; entry-books, 40-42; archives on islands: character and condition, $329,330,332,333$; in legislative libraries, 332,333 ; in offices, $330-332$; in supreme court, 333 ; in vestry room, 33I; assembly, character, $43-4,22$, 40, 4I; chancery, 33I; charter, 16; church. tithes, 22, 23, 4I, 33I ; commissioners of correspondence, 332 ; commissions and instructions, 40-42, 3I7; conditions, I I-I7, $21,22,24,26,28,29,40,97$; cotton, 34; council, character, expense, 23,40 ; courts, 333; Craven's title, I3; criminal cases, 20, 22 ; currency, legal tender, I3, 20, 4I; customs, $17,24,45$; defense, soldiers from Bermuda, 12-1 7, 19, 21-23, 25-27, 29, 3I, 32, 39-4I, 89, I I 3; descriptions, I3, I5; during American Revolution, prizes, 20, $21,29-$ 33, 329; during Seven Years' War, 19, 20; during Spanish and French War (1740-48), $17,18,24$; during War of $1812,39,40$; tees, 14, 23; formation of royal government, I I; free port, 25, 26; French and Spanish designs and attacks, II I I2, I4, I6, I7, 22-25, 32, 40, 329; Genet's privateers, 35; governors, abstracts of letters, 21 ; land system, $13-16$, $23,26,28,29,34,35,37-39,41,42,330,331$ Loyalists, 24, 3I-35, 42, 97, 30I, 33I; misgovernment, I4, 16, I7, 23, 24, 28-30, 41; mutiny, 17; negro insurrections, 16,23 : negroes, regulations, 20; pirates, II-14, 21 . $22,24,28,40,87,162$; population, list ot families, I6, I7; possession, $\mathrm{v}$; produce, I5, 29; proprietors and copartners, $I I-16,2 I-23$, $28,29,40-42$; public accounts, $13-19,22$. 23, 45; Public Lot records, 332; public ship, I 2, 40; salaries, 28; sale of American slaves, 40; salt, I 2, 15, I7, I 8, 20; seal, 330; sessional papers, I2, I3, 22, 23, 33-39, 42$45,330-333$; settlement, $12,13,21,22,40$, 46; shipbuilding, I 5, I6, 29; shipping returns, 22, 23, 45, 369; slave and emancipation records, 331 ; Stamp Act, 25 ; sufrage, 15, 23; trade, neutral, United States, violations, $12,15,17,25,26,29,30,33-38,87$. $88,90,330,333$; Trott's claim, 13; vital records, I4, I5, 19, 23, 331; war ships, 17 , 22 ; war-time prosperity, 29; whaling, 12; wrecking, 29; see also West Indies

Bain, Capt. James, instructions, 196; letter, 196 Baker, Samuel, letters, $3^{89}$

Balcarres, Gov. Alexander Lindsay, 6th earl of, letters, r98-200; letters to, 199, 200, 217. 305

Balfour, Pres. John, letter, 308 ; petition, 306 Ballahoe, 262

Ballot, use, $172,173,214$

Bultimore Hero, $26 \mathrm{I}$

Bancroft, Edward, 264

Barbados, acts, 74-76, 339, 340; acts collected, 63,$72 ;$ acts unprinted, $55 ;$ admiralty, 46, 59 . 60,85 ; agents, correspondence, $76,338,3,39$; and Leeward Islands, 231 ; and other Mindward Islands, 70, 74; archives at London: correspondence of Board of Trade, 45-47: correspondence of Secretary of State, 5968; entry-books, 69-74; miscellaneous records, 57-59, 86; archives on island, character and condition, 334-340; assembly, demands, power, 46, 48, 49, 53, 54, 61, 64, $71,72,74,76$; attorney general, 61, 62, 79: 
bounty, 74; chancery, 54, 334; church, Barnett, William, 193

churchwardens, ecclesiastical cotrt, 45, 47, Barrington, Gen. John, letters, 159

$55,57,59,60,62,69,70,73,340$; colonial Barristcrs, in assembly, 64

secretary, 69; conditions, 51, 52, 54, 55, 57- Barrow, Thomas, letters, 123

$60,63,337$; constitutional history, 51 ; council, official members, suspension, $51,54,56$, $62,63,72,76$; courts and lega! matters, 47 , $48,52,54-56,59,60,62,63,64,69,73,76$, 87 ; currency, paper money, $45,47,48,52$, 59, 69-7 I ; customs, farming, $47,48,56,59$, $60,69,74,86,23^{2}, 339,340$; debts, intcrest, recovery, $49,5 \mathrm{I}-53,60,74$; defensc, 45,47 , $48,5 \mathrm{I}-58,60-63,65,67,69,7 \mathrm{I}, 72,252$; disorders, 209; during American Revolution, prisoners, provisions, $56,64,65,74,337$, 339; during Frencl Revolution war, 58; during King William's War, 76 ; during Seven Years' War, prisoners, trade, 55, 6I, 62, 283, 339; during Spanish and French War ( $1740-48)$, prisoners, privateering, 53, $54,60,61$; during War of $1812,68,339$; during War of the Spanish Succession, prisoners, prizes, 45, 46, 59; embargo, 30.3; escheats, 60 ; exchequer, $55,6 \mathrm{I}$; fees, 45,47 , $5 \mathrm{I}, 55,56,60,69,72,8 \mathrm{I}$; fire companies and local corporation, 56; fish imports, 68; free port, 339; governors: commissions and instructions, $55,59,69-74,317$; salary and perquisites, $49-53,57,60,70-72,76$; imprcssment, 60, 69; insurance, 59; John Adams case, 73 ; labor, 76 ; land, 48, 52, 340 lieutenant governor, 56, 70; liquor dutics, 70, 7 I , 340; lotteries, 63, 74; loyalty ( 760 ), 63; military appointments, 331 ; militia, 314 ; misgovernment, complaints, quarrels, 46 , $47,49,54-57,59,60,63,236$; negro tax, 47; offices, 48 , 60 ; packet boat, 55 ; pirates, $46-$ $48,60,69,336,337,340$; poll tax 47,49 ; population, $46-48,52,54,55,58,63,314$; possession, - ; powder duty, $54-56,63,64$; prices, 59; probate records, $340 ;$ produce, new products, 48, 54, 63: provost marshal, 55, 73; public accounts, $49,50,52,53,55,57-59$, 87; public debt, 59; Quakers, 48; revenue, $54,59,87$; schoolmaster $, 58,70$; sessional papers, $54,61-63,65-68,75,335$; shipping returns, $34,36-38,65,68,85-87$; shipping returns not rnade, 56; slaves, manumission, slaveholders, 49,339 ; slave trade, 45,46 , 48-50, 54-56, 62-6t, 87, 395; Stamp Act, 56; taxes, 50, 5I, 54, 60; "Taylor's Laws," 340; trade, neutral, United States, violations, $46-48,50-59,6 x-70,230,315,3.37$ 340 ; vital records, $45,46,48,53-56,62-64$, 87; wrecking, 249; see also West Indies; Windward Islands

Barbados Gazette, 53, 61, 62

Barbados Mercury, 56, 339

Barbados Planter, "Sugar Trade," 58

Barbuda, grant, 230, 247. 276; see also Virgin Islands

Barclay, James, 224

Barclay, Thomas, letter, 206

Barnard, Thomas, letters, 164,165

Barnes, Lt.-Gov. Edward, letter, 132 ; letter to, 349

Barnes, J., letter, I 2

Baskett, Jolin, printer, 75, II $5,218,278,283$, 286,292

Bassetcrre, records at, 392-397; trade, 269

Basto, 374

Bath, Earl of, see Puiteney

Bath, Jamaica, 175

Bathsheba, 22 I

Bathurst, Henry, $3 d$ earl, letters, 349, 350, 399 , 400 ; letters to, 207, 208, 350, 397, 400, 401

Bay of Campeachy, affairs, 232, 387; England and possession, $164 ; \log w o 0 d, 168,181,182$, 210,213

Bayer, Bastian, letter, 325

Beak, Thomas, agent, memorial, 239

Beard, Lt. Arthur, 99

Beaufort, Henry Somerset, $3 d$ duke of, I 5

Beaufort, N. C., 2 I

Beaujon, Gor. Anthony, letters, I 2 I

Beaver, H. M. S., 65

Beckford, Peter, 164

Beckford, William, letter to, 2 I 5

Beckwith, Sir (Gov.) George, letters, 68, 107, 108 , 303,316 ; letters to, 68, 107

Bedford, John Russell, 4th duke of, letters, 54. I 71 , 191; letters to, $73,250,253,254,276$, 306

Beeston, Sir William, letters, 387,390

Belhaven, John Hamilton, $3 d$ baron, commission and instructions, $47,59,70$; memorial, 70

Belize, see British Honduras

Bell, Herbert C., work on present volume, vi

Bell, Winslow, 34til.

Benbow, Adm. John, correspondence, 314

Bennet, Henry, see Arlington

Bennett, Lt.-Gov. Benjamin, acts, II5; charges against, 97; commission and instructions, Ii 2 ; letters, 87,98 ; testimonial, 23

Bennett, M. S., 371,372

Bentinck, Goi. William Henry, address to, 40,3: lecter to, 403; letters, I 2 I, I 22, 302, 303; see also Portland, $3 \mathrm{~d}$ dukc of

Bequia, records, 403

Berbice, correspondence, 317; see also British Guiana

Berkeley, George, 89, 97, 98, I 12

Berkeley, James, $3 d$ earl of, I 5

Bermuda, acreage, I02; acts, I I $5,346,346 \mathrm{n}$.; acts in force $(1768), 100 ;$ administration and guardianship records, 342,343 ; admiralty, $87-89,93,107,112,344$; adventurers, list. 345 ; aflidavits and bonds, 344; agent, payment, 96: Americans in, I I ; and Bahama tracie restrictions, 90 ; and Caicos Islands, 94 ; and Turks Islands, I9, 28, 90, 97, 100, 101; archives at London: correspondence of Board of Trade, $87-97$; correspondence of Secretary of Statc, 97-112; entry books, I12I 15 ; index of correspondence, I I 5 ; archives on islands: condition and character, in Public Building, 34-346; family papers, 347; parish records, 346,347 ; assembly, character, disputes, financiai control, 87, 89, $91 \cdots 06$. 99-102, I10, II2-I15, 119; chancery, 345; 
church, 97, 98, I 1 2, 345, 346; circular trade, 90 ; collegc, S9, 97, 98, i 12 ; colonial records (Lefroy), 345, 346; conditions, 87-90, 93, 95, IOI, IO2; conspiracy of soldiers, 98 ; corporation records, 347 ; council and appointmients, official members, 5 I , 72, 93, I I 3, I I 4 ; courts and legal matter's, 88,99 , I I 4 , I I $6,342,344^{-}$ 346 ; culrency, 90-92, 98, 346; customs, 88 90,94 , I I 2, I I $3,342,346$; deeds, 343,344 ; defense, 87-9 I, 94, 95, 98-I 00, I05, 106, I I I, I1 $3,344,346$; descriptions, 88 , 95; during American Revolution, 96-98, I02-I05, I Io, 264, 300; during French Revolution and Napoleonic wars, 106, $110,342,344$; during Seven Years' War, 94, 95, 99, 25.3, 342, 344; during Spanish and French wars (I 739-48), 9I-93, 99, I I 4, 253; during War of I 81 2, I I I; during War of the Spanish Succession, 97, 98; entry books, I I2-I I5; estimates, I02; excise, 96; factions, 10o; fees, 94; fishing, 93-95; forcible rescue of seized ship, Ior; foreign tonnage, I I I free ports, 98, I Io; governors: abstracts of lettcrs, 97 ; commissions and instructions, 90, 94, I I 2 -I I 5, 3 I 7 ; salary and allowances, 89, 92, 93, 95, I00, II2-II4; grand jury presentment, 94; habeas corpus, 98 , I I 3 ; inventories, 34.3 ; Jews, I I 4; jury system, 9.3; "King's Slaves," 88; land, rent, revenue, 88-90, 96, 98, I oo, I OI , I08, I I 4, 344; liquor duties, 89 , 94, roo, 346n.; local trade and manufacture, 89; Loyalists, I Io; magazine ship, 98, 346; map, 34I; military laws, I oo; misgovernment, complaints, $93,9.5,97,98 ;$ mortgages, 3+3; neg10 crimes and insurrections, 89, 9.5, 99; non-conformists, 98 ; officers, conmissions, lists, $94,95,342,345,346$; orders in Council, 345 ; pirates, 88 , 99, I I 2,344 ; population, $88,89,94-96,100,102,314,342$, 344, 347; ports, 99, I00, I 04, I I 5, 217 ; possession, v; powder duty, I I3, 170, 344; privateers, $87,95,97$, 106, I I $0,25.3,300$, 344 ; prize records, 346 ; proclamations, 342 , 343,345 ; public acconints, revenue, 87-92, 96, 99, I or ; Quakers, 345; salt, 93; schools, 345,346 ; sessional papers, 93,99, I03-I Io, I I $5,343-345$; ship protests, 34 I, 344, 345; shipbuilding and frames, $95,103,345$; shipping returns, 91, 97, 99, I09, 344; sletves, records, result of oversupply, $95,342-344$, 346 ; slave trade, $89,90,94,98,342$; soldiers for Bahamas, I4-16, 22, 89, I I.3; Spanish trade seizures, 87, 89, 97-IO0, I I 2, II3; Stamp Act, 96, Ioo; strategic inportance, 88-9I, 99; survey, 34 I ; taxes, 89, 90, 93, 96, I 00, IO I, I I 4, I I 5 ; timber sales, 94; tobacco, Sy, 90, 95, 344-346; trade, neutral, United States, violations, I7,87-9I, 93-99, I OI-I I I, I I $3, \quad$ I I $4,207,25.3,3$ I $5,342,34 t, 403$; turtles, 93; vital records, $94,34.3,347$; whaling, 89-93, I or, I I 3-I I 5, 345: wills, 342; wire, 92, 98 , I 4 ; wrecking, $87,93,94$, I02; writs and forms, 3+2; see a!so West Indies

"Bermuda Newspaper," 87

Bernaeri, Betsey, .374 (4)
Betsy Orrick, 374

Belly, 177

Bevan, Michael, trial, $I_{4}$

Beverley, Capt. Harry, 163

Bibliographia Jamaicensis, $38 \mathrm{I}$; Supplement, 38r

Bickwood, J., letter, I07

Biddle, Capt. Nicholas, 30

Bills of credit, see Paper money

Bingham, William, I5I, I52, 262, 264, 300

Births, see Vital records

Bishop, John, 20, 25

Bishop, Pres. William, letter to, 66

Black River, Mosquito Coast, trade, 192, 195

Blackett, Capt. William, 29

Bladen, Martin, 54; letter, I 82

Blakency, Col. William, 315 ; report, 253

Blanco, Augustine, 23

Blathwayt, William, 390 ; lettcrs to, 389 , 390

Blcnman, Jonathan, opinion, 51

Blockade, War of I 8 I 2 , I I I

Bloodworth, Capt. Joseph, deportation, 337

Bluefields, squadron at, 183 ; see also Mosquito Coast

Board of Trade, and appointment of councillors, $7 \mathrm{I}$; and colonial acts, $2 \mathrm{II}$; papers, scope, 1-4; papers from colonies, 272, 273; see also Correspondencc; Entry-books

Bogle and Co., 207

Bolingbroke, Henry St. John, Ist viscount, letters, 46, I6r, 209; letters to, 69, 209,

Bompar, Gov. - de, letter, 6I

Bond, Phineas, letters, 35, 207

Bonds, see Shipping returns

Boston, privateer, 322 ; siege, supplies, $29,30,64$, I 02,394 ; trade, 27, 89

Boston Milssacre, similar case on islands, 258 , 259

Boston Port Bill, 193, 260, 318, 357

Bouillé, François, marquis de, and American pitivateers, I5I, I52; correspondence, I26, 300,301 ; operations, 316,354

Bounty, land for troops, I 48 , I 50 ; to Barbados. 74; see also Fish

Bowles, William A., 37

Boyle, G., letter, 198

Bradford, James, 20

Bradley, William, inemorial, I 82

Bradshaw, Richard. letters to, 253

Braxton, Carter, letter, 26I

Brecknock, 'Timothy, letter, I fo

Breen, Henry, St. Lacia, $398 n$.

Brereton, Gov. Robert, letters, 297

Brett, Curtis, and Co., 225

Bridgetown, fire, 61,339 ; 10cords at, $334-340$

Bridgetown Cazelte, 3.39

Bridgetown Public Library, records in, 335

Brigs, Capt. William, 96

Brimage, William, letter, I03; memorial, Iof

Brisbanc, Sir Charles, letter-book, r 24; letters, 303,304

Bristol, Eng., see Merchant Adventurers

Bristol, 254

Bristol Gally, $23 \mathrm{I}$

Bristow, John, 266

Brituin, ryI

Brilannia, 374 
Britannicus, "Miserable Case of British Sugar Plantations," 52

British Empire, guides to archives, iii

British Guiana, archives at London, I21, I22; archives in colony, 347; defense, 121, 122; exports, I2I; lumber, I $2 \mathrm{I}$; neutral trade, $12 \mathrm{I}$, I22, I55; possession, vi; Spanish encroachment, 63; vital records, 347; War of 1812, I2 I, I22; see also Essequibo; Surinam

British Honduras, affairs, 203, 3I7; archives at London, 122, 123; archives in colony, 348; British activities, 182, 195; complaint against Spanish, 190; conditions, 123, I79, 198; evaciation, I88; shipping returns, I23; trade (mahogany), neutral, United States, $123,192,198-200,203-206,217$

British North America, see Canada; Colonies, British-American

British West Indies, see West Indies

Bromley, Willian, letter, 209

Brooke, Thomas, 97

Brown, Lt.-Gov. Alexander, ${ }_{3} 6$

Brown, Campbell, letter to, 323

Brown, Pres. John, letters, 33

Brown, Capt. William, letter to, 260

Brown, William Sturges, letter to, 268

Browne, Anthony, agent, letter, 327

Browne, Gov. Montfort, and capture of New Providence, 20, 21, 30, 3I; and trade with the enemy, 20, 2I; as prisoner, 31; cartel, 32; commission and instructions, 42 ; exchange, $3 \mathrm{I}$; letters, 29-32; letters to, 2 I, 29

Browne, Gov. William, commission and instructions, II 5 ; letters, IO4, I05

Brownfield, Henry, letter to, 260

Bruce, Lt.-Gov. James, letters, I28, I29; letters to, 129,351

Bruce, Gen. Thomas, letter, 58

Brudenell Montagu, George, see Cardigan

Bruere, Gov. George J., and trade, 95; commission and instructions, I I 4 ; complaint against, 98 ; letters, 95-97, 99-104, II9; letters to, 99IOI, I04; memorial, 104

Buchanan, -196

Buchanan, Thomas, petition, 192

Buck, (?) Samuel, memorials, 12, I3, 40

Buckingham, H. M. S., 255

Buenos Ayres, plan against, 192; privateers, 350

Bull, Lt.-Gov. William, correspondence, 24, 186

Buller, James, letter, iII

Bullock, Thomas, 177,226

Bunbury, Sir Henry E., letters to, III, II 2

Bunel, $M ., 2$ or

Burch, M., of Antigua, 264

Burchett, Josiah, letters, 17,163

Burge, George, agent, 3861 .

Burke, J., letter, 266

Burke, Richard, letter, 158 ; letters to, 124,158

Burke, William, 248

Burr Conspiracy, 205

Burrow, J., letter, in

Burt, Gov. William Mathew, commission and instructions, 277,278 ; letters, $261-26 \%$; letter to, 263 ; proclamation, 392

Byan, Edward, 323

Bylandt, Count de, 263,264
Byng, Gov. Robert, commission and instructions, 72 ; letter, 53; letters to, 72

Byron, Adm. John, 264

Cable, Samuel, 292

Cabot, U. S. S., 30

Caicos Islands, 37, 268; French seizure. 94

Calder, Henry, letters, 316

Calendar of State Papers, Colonial, America and West Indies, V.

Calendars, see Registers

Califf, Dr. John, letter to, 260

Camden, John J. Pratt, 2d earl, letters, 74, 109

Cameron, Gov. Charles, and privateering, 217; letters, 38,39 ; letter to, 39 ; license, 330

Campbell, Pres.

Campbell, Maj. Alexander, journal, 196

Campbell, Sir (Gen., Gov.) Archibald, instructions, 216; letters, 195-197

Campeachy, see Bay of Campeachy

Canada and British North America, istand trade, fish bounty, $154,155,230,268,269,297,308$, $311,313,318,338,349-352,359-361,396$, $397,400,403,404$; see also New France

Candler, Capt. Bartholomew, report, 232

Canso, claims, 250

Cap Français, 195, 199, 203

Cape Breton, 92

Cape Cod, pirates, 87

Cape St. Nicholas, see St. Nicholas Mole

Carbery, John Vaughan, earl of, see Vaughan, John, lord

Cardigan, George Brudenell Montagu, ath earl of, letters to, 282

Cardonnel, Adam, I5

Caribbeana, 365

Caribbee Islands, map, 254

Caribs, see St. Vincent

Carkesse, Charles, letters, $47,232,233,235,272$; letter to, 15

Carleton, town, 32

Carlisle, Charles Howard, yst earl of, commission and instructions, 389 ; letter, 389

Carmarthen, Francis G. Osborne, marquis of, letter to, 98

Carmichael, Gen. Hugh L., letters, 12I, 206

Carolina, and pirates, II; see also North Carolina; South Carolina

Carriacou Island, fugitive slaves, 148; population, I 43, 314; slaves, I43

Cartagena, correspondence of governor, 1 8.3, 191, 192; expedition, I86, 315; privateers from (1777), 195; trade centre, 46

Carteret, 186

Carteret, John, 2d baron, letter, 13; letters to, $40,59,70,98,140,236,25 \mathrm{I}$

Cary, Richard, letter, 325

Case of the British Northern Colonies, 50

Castle Harbor, port, 95

Castries, open port, 297, 401, 402; records at, $398-402$

Cat Island, 32,33

Cathcart, Charles, 8th baron, experlition, 186, $252,253,315$

Cathcart, Hugh, letter, 199

Catherine, $87,252,374$

Catholics, see Roman Catholics 
Cayenne, Hench activities, 62 ; settlement, 56 , 256; trade with English colonics, 62, 256

Caylus, Marduis de, 253

Census, sec Pupulation

Chalmers, George, 3I3; at Grenada, I4I; correspondence, 140,313 ; Opinions, I5

Chance, $39,62,256,374$

Chancery, and assembly, 189 ; see also islands by name

Chandos, 165,184

Churles Toun, 102

Charleston, 35

Charlolic: 374

Charmiss Molly, 24

Charming Polly, 374

Charter, Baharnas, I6; see also Proprietors

Cliarts, Antigua, 234

Chatham, William Pitt, Ist earl of, letter, I76; letters to, 255, 306

Chatham, 374

Chesapeake-Leopard affair, 38, 206

Chester, 374

Chetwynd, Join, letters to, I64, 165

Chetwynd, William, 13, I5

Chowan, 374

Christie, Ger. Gabriel, letters, 316

Chrystie, Arlam, letter, 35

Church of England, appointments and removals, 73: ecclesiastical courts in West Indies, 47, $56,57,60,60,73$; see also London, bishop of, and islands by name

Churchwardens, 57

Clarendon Parish, Jamaica, records, 364, 390

Clark, George Rogers, 35

Clarke, Lt.Gor. (Gen.) Alured, letters, 197, I98; letter to. 106

Clarke, Sir Charles, 33.5

Clarke, Go\%. George, correspondence, 393

Clarke, Sir \$. H., letter to, 202

Cleland, Col. William, 77

Clerke and Parke, letters, 389

Clerks of assembly and council, appointment, secrecy, II 3, II 4, I 77, 2 I 5

Clifford, Jerconimy, memorial, 305

Clifton, $D_{\%} \ldots, 264$

Clinton, Sit Henry, letter, 316

Clugny, Baron de, correspondence, 127

Coal, as ballast. 322

Cochrane, Sir Alexander, I I I

Cockbum, Sir (Gor.) James, letters, I I I ; letter to, $\mathbb{1 1} 5$

Cockran, Cop?. Philip, 250

Cocoa, British excise, I 50

Codrington, Gov. Christopher, and courts, 324

Codringtos, Sir William, commission and instructions, 271; grant, $230,247,276$

Coffee, cuiture, 20, 126, 167, 212 ; English duty, I 50, 194 ; trade, I $21,122,193,194,352,389$

College, Bermuda, 89, 97, 98, r 12

Colleton, Sir John, 15, 46, 60

Collow, William, 313

Colonial agents, appointment and control over, $95,164,167,179,215,216$; correspondence, $338,339.386,387$; cxpcnses, subscription, 76, 163, 181, 210; see also Committee of correspondence
Colonial Office Papers, classification, 1 ; on West Indies, described, $1-4$; open dates, r; reference aids, 3,4 .

Colonial secretaries, appointment, 46; Jamaica dispute, 163 ; records at Antigua, 328; records at Bahamas, 330; registry and other offices, $60,69,2+5,273,275$

Colonies, English-American mainland, and West Indies, iv, 2, 335; army regulars from, $1+1$; counterfeiting in, 180 ; powers of legislatures, 41 ; representation in, 26 ; situation in. address on, 168 ; trade with British islands, iv, $2,125,126,16+230,3+4$; see also Acts of trade; Trade with the eneny; colonics and wars by name

Colquhoun, Patrick, letters, 268

Columbus, 65

Columbus, U. S. S., 30

Commerce, see Communications; Trade

Commissioners of correspondence, Bahamas, 332

Commissions of governors, see "governors" under islands by name

Committee for Trade, 67

Committee of correspondence, Jamaica, 194,216 , 386,387

Communications, colonial post office, 176,215 ; neutral despatches on seized vessels, 107, 108; packet service, 55, I 38, I 47, I 60,193 , $208,257,259,260,314$; postal rates, 147 ; routes, 92, IOI, I02; seizure of Spanish advice boat, 247,276 ; to Board of Trade, 272 , 273; to Secretary of State, I83, 214,248

Compere, L., letter, 390

Congreve, William, I63

Connecticut, and Bermuda (1779), rof: Ber. muda trade (1786), 105; during American Revolution, Loyalist recruiting, 31; Mohegan petition, I 85; trade with the enemy, 2 I 5 ; see also New England

Connor, -

Constant Love, 98

Convicts, immigrant, $163,164,168$

Convoys, American Revolution, I51, I 53, 263 , 264, 3 r 8; salt trade, roo; Seven Years' War, 188; War of Austrian Succession, 39.3; War of $1812,318,349$; War of Spanish Succession, 208

Conway, Henry Seymour, letters, 189 ; letters to, 42, $100,189,256$

Cooke, Edward, leiter to, 67

Cooke, Edward E., memorial, $2 \$ 8$

Coope (Cooper), Richard, agent, letters, 240, 24I, 250

Cooper, - - of Carolina, ro5

Cooper, Thomas Mansfield, 177

Coote, Sir Eyre, letters, 205, 206

Copartners of Bahamas, I $2-14$

Corbet, Edward, correspondence, 200-202; recall, 2 or

Corlet, Pres. —, letter to, 349

Cornewall, Henry, report, 253

Coroners, appointment, 166

Corporations in West Indies, 56, 347

Correspondence, in Colonial Office Papers, registers and abstracts, $2-4$; of Board of Trade: Bahamas, II-2I; abstracts, 2 I t table of contents, 42 ; Barbados, 45-57; abstracts, 57. 
in lex, 74; Bermuda, 87-97; abstracts, 97; index, $x_{5}$; Dominica, I 24; Grenada, I35... I4I; Jamaica, I59-I80; abstracts, I80; index, 216; Leeward Islands, 230-249; abstracts, 249; index, 277; Tobago, 306; West Indies, 313, 314; of Secretary of State: Antigua, 4; Bahamas, 2 I-40; Barbados, 59-68; Bermuda, 97-I I2; British Guiana, I2 I, I22; British Honduras, I 22-I24; Dominica, 124I33, 349, 350; Grenada, I40-I55; Guadeloupe, I 59; Havana, I59; Jamaica, I80-208; Leeward Islands, 249-270; Martinique, 282 , 283; Montserrat, 283; Nevis, 286; St. Croix, 291 ; St. Eustatius, 292 ; St. Kitts, 292; St. Lucia, 297, 399-402; St. Vincent, 298-304; Santo Domingo, 304, 305; Surinam, 305, 306; Tobago, 306-308; Trinidad, 310-312; Virgin Islands, 312; West Indies, 3I4-3I6; see also Entry-books

Cosby, Gov. William, commission, 274

Cotes, $A d m$. Thomas, 226

Cotton, culture, 15,20 , 125 ; trade, 34, 72, I21, 122, 339

Cottrell, Stephen, corespondence, 67, I41, 268

Councils, and chancery, 334; and colonial agent, $164,167,179$; and term of officials, 72 ; appointment of clerk, 177 ; confirmatory power, 93. I I 4; expense, 4o; for new islands, I 56; for Windward Islands, 136 ; franchise of councillors, $248,249,257-259,277$; functions, 39I; martial law and sitting, I 76, 214 ; membership, appointments, Catholics, official members, $7,51,54,62,63,71,72,90$, I I $3,139,147,156,173,183,190,192,193$, $214,230,239,275$; power over officials, I 89 ; precedence in, 62,238 ; president, remuneration, 48,178 ; president and approval of acts, 72 ; president and lieutenant governor, 56 ; privi,eges of councillors, I79, I8I, 210,2 I 5 , 216; removal of councillor to collect debt, 179; right of mecting, I26; suspension, 2 10; see also Assemblies; Governors; Sessional papers; islands by name

Councils of war, 160, 167, 216, 219, 278, 380,388

Count de Paix, 87

Counterfeiting, I 80

Counties, Jamaica, 176

Courland, William Kettler, duke of, 7 I

Court of policy, British Guiana, 12 I, 122

Court-martial in colonies, 95, 190

Courts, appeal to Privy founcil, 52, II3; appointment and tenure of judges, I7I-I73; colonial, I 14, 276, 3I6; see also Acmirally; Chancery; Exchequer; islands by name

Cox, Samuel, quarrels and letters, 47

Crab Island, claims, 246, 248, 254, 259, 260; settlement, 233; Spanish attack, 236; see also Virgin Islands

Crachen, - - of Belfast, I Io

Craggs, Jaines, letters, I2, 234; letters to, 40, 70, I I 2,272

Craven, William, 3 dearl of, and Bahamas, $13,15,40$ Crawford, - - letter, 235

Crawford, Gov. James, correspondence, I07

Credit, in colonies, 173

Creek (Muskogee) Indians, 37

Cressy, H. M. S., 349
Crime, accused sent to England, $22,69,73,160$, $183,187,208,271$; cases, 20, 22; colonial jurisdiction, $190,216,236,254$; firing on rioters, 258,259 ; free negro murder of slave, I 40; murder triais, 20, 88; mutinies, 17,23 , 28; see also Negro insurrections; Pirates

Crisp, Joseph, petition, 278

Crooke, Samuel, petition, 277

Crooked Island, 37, 268

Crow Lane, Bermuda, port, i I 5

Crowninshield, George, complaint, 20

Cruger, J. W. H., petition, I92

Cuba, conditions, Dennis's mission, 22, 164; emigration to New Orleans, 203; see also Havana; Spanish West Indies

Cumberland, Richard, memorial, 26

Cumine, Alexander, letter, 195

Cundall, Frank, acknowledgment to, vi; Bibliographia Jamaicensis, 381 ; Historic Jamaica, 386; "Press and Printers of Jamaica," 369 ; West-India Committee Circular, 389

Cunningham, Gov. Henry, instructions, 212 ; letter to, 212; memorials, 168; "Queries concerning Troops," I 85

Cunningham, Robert, letters, 231

Cunninghame, Go\%. James, commission and instructions, 74 ; letter, 65

Curaçao, attack, 197; British archives, 124; negro insurrection, $254 ;$ possession, $v$; prizes from, 87; sessional papers, I24; shipping returns, 124; trade, 198; see also Dutch West Indies

Curphey, Rev. -, 22

Currency, light coin, 192, 193; New York and West Indies, 130, 316; produce as, 20, 324; see also Money; islands by name

Curzon and Gouverneur, letter to, 292

Cushing, Thomas, letter to, 260

Cust, Savile, 249

Customs, charges against English commerce, 400; collector and governor, 95; English, r 50, 235, 243, 3I3, 3I4, 386, 394; English objections to colonial, I I2, I I3, 346; fees after I8I7, 399; jurisdiction over colonial, $36 \mathrm{I}$; officers as councillors, $5 \mathrm{I}, 72,90,113$; on goods of non-residents, II 3,354 ; status of naval officer, 60; Swedish, for St. Bartholomew, 265; see also Acts of trade; Powder duty; Slave trade; Tonnage; islands by name

Dalling, Gov. John, commission and instructions, 216; letters, 180, 193-197; letters to, 193, 195,196

Dalrymple, Campbell, letters, I35, I41, 159; letter to, 148

Dalzell, Robert, regiment, 253

Danbury, Conn., 3 I

Daniell, William, 224

Danish West Indies, and American privateers, 152; beginning, 72; British immigration, 242; British trade, 394; claim to St. Croix, St. John, and St. Thomas, 232, 239, 240, $242,249^{-25}$; international island trade, 253 , 255; neutral trade, 24, 108, 255, 26I-263; settlement, 233, 236; Spanish threats, 233; trade with English mainland colonies, 245 ; see also Virgin Islands; islands by name 
Darcy, Robert, see Holderness

Daricn Indians, 58, 17 I

Dart, 305

Dartmouth. William Legge, Ist earl of, letters, 133, I60, 208; letters to, 59, I I 2, I 83,

Dartmouth, William Legge, $2 d$ earl of, letters, 29, I 26, I 48, 149, 192-194, 259; letters to, 29, I 26, I 39, 148, I49, I92, I94, 248, 249, $258-260$

Dartmouth, proposed town, 29

Davenport, Frances G., Guide to Materials in British Museum, iii

Davidson, Capt. - 9 I, 99

Davis, N. Dainell, on records, 320,347

Davis, Nathaniel, 177

Dean, John, 388

Deane, Silas, 264

Deaths, see Vital records

Debts, collection and privilege of legislators, 179 , 2 I5; see also Public debts; islands by name

Declaratory Act, I 89

Deeds, records, 33I, 343, 344

Defense, attitude of islands, 334 ; see also "defense" and "powder duty" under islands by name

Defiance, $177,374(2)$

Delafaye, Charles, lettcrs, I2, 23.5; lettcr to, 98

DeLancey, $L t$.-Gov. James, correspondence, 188

DeLancey, Gov. Stephen, 37, 337, 405; letters, 188, 307

Dclap, Thornas, 187

Delaplaine,,- 300

Delicia, 12, 40

Delmage, Adam, 377

Demerara, correspondence, 317 ; see also British Guiana

Denmark, sec Danish West Indies

Dennis, Capt. - 22, 164

Dent, Pres. Samuel, letter, I 54

Derby, Richard, complaint, 20

Deshayes, Robert, 248

Despard, Edward M., letters, I23, I98; narrative, 123

Despatches, see Communications

Dessalines, Jean J., 204

Diable, 322

Dicker, Samuel, letter, 176

Dillon, Comte, commissions, 392, 395

Dinwiddie, Robert, 88, 90, I 3 ; complaint, 97 ; letter, 90; memorial, 52

Dispatch, 374

Divorce, colonial bills, I 57, 2 I 6

Docminicque, Paul, I3

Doger, Capt. P. L., 305

Dolly, $177(2)$

Dolphin, 374(3)

Dominica, acts, 133,354 ; acts, suspending clause, 125; admiralty, 354, 355; and Barbados, 74; archives at London: correspondence, I24I.33; entry-books, I33, 157, 317; archives on island: character and condition, 348 ; in administrator's office, 349-352; in courthouse, 35.3-355; assembly, disputes, 125,126 , I38; attainder, I25; British occupation, I4I, 142; chancery, I 45 ; church, I38, I 45 ; claims, ncutralization, $49-55,58,60-62,7 \mathrm{I}-73$, I24, $24 \mathrm{I}, 242,250,252-254,298$; coffee culture,
126; conditions, 124, 126, I27, 135-137; cotton culture, 125 ; council rights, 126; courts, 124, I26, I.37, I43, 355; currency, 35I, 352 ; customs, $126,133,134,138,145,352$, 354; defense, I25, I 26, I35, I39, I42, I44I 47; during American Revolution, capture, provisions, $126,354,355,395$; during War of 1812 , provisions, 349 ; election, 144; fees, 125; free negroes, I24; free port, I 25, 126, 128, I 29, I 35, 142, 314; French émigrés, I 29; Frcnch landing (I793), I4I; government, separate, I24, I 33, I 36-139, I 42-I44, I 46, I56, 25I; governor: commissions and instructions, I24, I33, 3I7 ; compensation, I24I26, I33; impressment, I25; land, French holdings, I25, I26, I28, I $37,139,140,143$, I46, I 5.5, 314; Loyalists, 124, I28; misgovernment, $125,137,138$; narrative, 125 ; officers, list, pay, I25; packet service, 208 ; pirates, I33, I38; population, I.37, 314; possession, v; prices current, I25; produce and export, 137; proprietors, 156; restoration, 127; sessional papers, $127-134,350-$ 353,358 ; settlement, $62,124,125,135$, 136 , I42; shipping returns, I25, I27, 130132 , I 34; slave trade, I26, I35; trade, neutral, United States, violations, I25-133, 135I37, I $4 \mathrm{I}-\mathrm{I} 43,230,3 \mathrm{I} 4,349-354$; see also West Indies

Dominicans, on ceded islands, I37, I4I

Donaldson, - $-262,263$

Dottin, Pres. James, letters, 52, 53, 60; letter to, 72

Dougan, John, 39

Douglas, Charles, agent, letters, I99

Douglas, George Hamilton, see Orkney

Douglas, George (James George), agent, memorial, 244

Douglas, J. C. S., trial, I79, I89, 192

Douglas, $A d m$. (Sir) James, I 88 ; letter, I 78

Douglas, Gov. Walter, instructions, 27o; letters, $23 I$; lctter to, 270

Dove, 374

Dowdeswell, Gov. William, Ictters, 36

Downes, Richard, 78

Downshire, Marquis of, see Hillsborough

D'Oyly, Christian, 299n.

Droghing passports, 202

Druid, H. M. S., I9I

Drummond, John, memorial, 25 I

Ducasse, $A d m$. Jean, I 83

Duckworth, $A d m$. (Sir) John Thomas, letter, 282

Duke, Henry, 64

Dummer, Edmond, I60, 314

Dumbar, Charles, surveyor general, and membership in councils, $7,5 \mathrm{I}, 72,90,113$; charges against, $24.3,246,253$; memorial, 235 ; on trade of mainland colonies, 239

Dundas, Henry, letters, 66, I98, 404; letter to, $3 \mathrm{I} 3$

Dundas, Maj. William, letter, 259

Dummore, Gov. John Murray, 4th earl of, letters, $33-36$

Duport, Stephen, agent, memorial, 23 I

Durnford, Lt.-Gov. Elias, letters, I9I

Dutch West India Company, slave trade, 237 
Dutch West Indies, affairs, 234; American Revolution, neutral tradc, 64, 103, 126, I5I, 152, 261-264, 316; and British privateers (I74I), 186; and Buenos Ayres privatecrs, 350; and United States trade with British islands, I98, 265; British archives, I24; British immigrants, 242; British trade seizures, 58, 87, 99. $242,252,275$; Fronch treaty, 240; fugitive slaves, I87; international island 1.5ade, 95, 93, 168, 242; St. Bartholomew and St. Martin, 250, 274; Scven Years' War, neutral trade, $24,55,247,255,394$; slave trade, $128,233,234,237$; Spanish and Fronch wars ( $1739-48)$, trade, 9I-93, 244, 253; trade with English mainland colonies, 49, 239, 240, $245,253,393$; see also islands by name

Dyc wood, see Logwood

Dyer, H. M., lcttcr, 38

Eagle, 250,374

Earthquake, Jamaica, 160

East Florida, Loyalists, 32, I23, 150, 301, 339; settlers for Dominica, I25

East India Company, and American trade, 31 ; and West Indies, $63,70,3 \mathrm{II}$

Ecclesiastical courts, see Church of England

Eden, J., opinion, I6

Education, Bahama act, 20

Edwards, Bryan, and council, 192; West Indies, 194; transcripts, 387

Egleton, Henry, 378

Egremont, Charles Wyndham, ad earl of, letters, 141 , I88, 256; lcttcr's to, 99, I4I, I88, 256

Elections, colonial, $144,145,276,277$; see also Suffrage; islands by name

Eleuthera Island, 2, 33

Elisabeth, 374

Elletson, $\mathbb{L}_{i_{0}}$-Gov. Richard Hope, letters, I79, 180,190

Elletson, Roger, 388

Elliot, Goo. Hugh, letters, 269,270

Elliot, Grey, letter to, 97

Ellis, John, agent, petitions, I24, I26

Ely's Harbor, Bermuda, i I5

Emancipation records, Bahamas, 33I; see also Slaves

Embargo, American (1794), 106, I07, 153, 351; (1807), 39, I10, 3II, 395, 396; (I8I2), 68, 269; island, $181,184,195,260,357,35^{8}$

English Harbor, 257

Enterprize, I7I

Entry-books, at Dominica, 350, 354; at St. Lucia, 399, 400; in Colonial Office Papers, 2; of Board of Trade: Bahamas, 40-42; Barbados, 65-74; Bermuda, I12-1 15; Grenada, 155I57; Jamaica, 208-216; Leeward Islands, $270-277$; St. Vincent, 304 ; of Secretary of State: Bahamas, 42; Barbados, 74; Bermuds, I15; British Guiana, 122: Curaçao, I24; Dominica, I33; Grenada, 155-157; Janaica, 217, 218; Leeward Islands, 277, 278; St. Vincent, 304; Tobago, 308, 309; Trinidad, 312 ; West Indies, 316, 317 ; see also Correspondence

Equipage money, 60

Equity, see Chancery

Escheats, see islands by name
Espanola, see Santo Domingo

Esperance, 165. I84. 374

Essequibo, correspondence, 317 ; see also British Guiana; Dutch West Indies

Estaing, Charles Hcctor, comie d', 25, 99, I00

Estwick, Samuel, agent, lctter, 56

European Magazine, 390

Evans, - 70

Evans, Thomas, deposition, 337

Exchange, bills, $323,327,351,352$; rates, 298, 299

Exchequer, colonial court, 69,275 ; see also islands by name

Excise, 50, 96; see also Taxcs

Expenditures, see "control over finance" under Assembly; "public accounts" under islands by name

Experiment, $374(2)$

Exports, see Trade

Exuma Island, trade, 32-34, 36-38, 268

Eyre, John, letters to, 389

Eyre, Thomas, letters to, 389

Eyres, - letters to, 2 I 5

Fahic, James, correspondence, $26 \mathrm{I}$

Fair American, 377

Fair Lady, 177

Fairchild, Judge - -55

Families, list of Bahama, 16 ; see also Population

Family papers, Bermuda, 347

Fandino (Vandeño), Capt. Juan de Leon, I 8

Fane, Francis, letter, $5 \mathrm{I}$; opinions and reports, I $5,18,49,92,236,239-241,244$; testimonial, 23

Fanny, 140, 374

Farrell, Dominick, letter, 247

Farrill, —, letter, I2

Fawkener, William, letters, 67, 204

Fayette, 374

Fees, list of colonial acts, 2 10; see also islands by name

Ferrall, Lt. - - , I 4

Finances, see Currency; Exchange; Land; Public accounts; Revenue; Taxcs; "control over finances" under Assemblies

Finch, Daniei, see Nottingham

Finch, Edward, lettcrs, 7 I

Fines, Barbados, 60

Finlay, - - in British Honduras, 123

Fire companies, Barbados, 56

Firewood, governor's allowance, 93, 95

Fish, American and Canadian trade, bounty and duties, 68, I 54, I 55, 205, 207, 268, 269, 297 , $308,338,352,353,357,359-362,396,397$, 403 ; see also Provisions

Fisher, Capt. John, 30 I

Fisher, Ruth A., work on prescnt volume, vi

Fishing, Bermuda, 94, 95; illegal, 93; seal, I3; turtlc, 59, 93; see also Salt; Whaling

Fitzgerald, - , lettcr, 203

Fitzmaurice, Lt.-Gov. Ulysses, and council, I39, I 47 ; lettcrs, I 38 , I 45 ; letters to, I44, I45; proclamation, 145

Fitzwilliam, Gov. Richard, commission and in. structions, 4I ; complaint against, I6, 17, 24, $4 \mathrm{I}$; lettcrs, I5-I7, 23; letter to, 24

Flag. American, 298 
Flags of truce, and trade, 92, 99, I I4, I60, I6I, I 78, I 82, 253, 299

Fleming, $L t$.-Gov. Gilbert, letters, 243, 245, 246, 252,254 ; letters to, $254,275,276$

Fleuron, 24I, 275

Florida, shipwrecks, I2; see also East Florida; West Florida

Floyd, Com., 9 I

Fly, U. S. S., 30

Flying Fish, 374

Forbes, Lt.-Gov. John, letter, 36

Ford, Gilbert, 2 I 5

Foreigners, admission, I 44, 207, 303, 308, 3 I I

Forfeitures, Barbados, 60

Forms, see Writs

Forrest, Com. Arthur, letters, I90, I9I

Fort Nassau, plan, I 5, 23; seizure, 20

Fort Royal, Grenada, map, I 4 I

Fort St. John's, Nicaragua, capture, I96

Fort St. Louis, Santo Domingo, capture, plan, I87

Fortifications, in Windward Islands, I45; on foreign islands, I92; see also "defense" under islands by name

Fortitude, 3I I

Fortune, 24I, 275, 374

Fox, Henry, see Holland

Frampton, Charles, report, 253

France, treaty of 1686,59 ; war (I720) in West Indies, 12; see also French Revolution; French West Indies; Navy; wars by name

Franchise, see Suffrage

Franco-American War, in West Indies, prisoners and privateers, 305, 397

Frankland, $A d m$. (Sir) Thomas, 247

Franklin, Benjamin, I40, 300

Franklin, Samuel and Walter, petition, 192

Franklin, Thomas, jr., petition, 192

Fraser, Major —, letters, 98

Fraser, Capt. George, 250

Fraser, L. M., Trinidad, 405

Free American, 374

Free ports, effect of acts, 193; French, 190, 325; French and British, I50; in West Indies, $58,313,314$; see also islands by name

Free ships, free goods, $87,92,99,264$

Freelove, F., letter, 57

Freeman, Constant, I 77

Freeman, Thomas, 388

Freeport Gazette, 137

French, Joseph, affirmation, 322

French, in Bahamas, 22; in ceded islands, I35I37, I 4I-I 47, I 50, I 55, I 56; see also "land" under Dominica

French and Indian War, see Seven Years' War

French Guiana, see Cayenne

French Revolution, American attitude, ro6; British privateers, 106, 283, 396; émigrés in West Indies, I29; Genet's privateers and projects, 35, 36, Io6; war in West Indies, 58, I 4I, 25I, 282, 396; see also Neutral trade

French West Indies, African trade, 393; American-built privateers (1806), 67; and American Revolution: as neutrals, 74, I26, I5 I, I 52, I95, 26I-263, 299-30I, 358, 359; as participants, 65,74 , I26, I95, 25 I, 265, 298, $316,354,395$; and British free ports, I50; and Caribs, I47, I48; and Darien Indians,
58; and neutral trade (1793-99), I08, 263, 267; British navy's trade, I 83; British trade seizures, I 27, I 65, I 69, I 82, I 84, I 85, I 89 , $233,241,250,252,254$; claims to islands, raids, II, I 2 , I 8-20, 46-55, 57-62, 7 I-73, 94, 99, IOO, I 88, 235, 239-242, 247, 249-254, $273,274,297,298,306,392,395,397$; conditions, information on, 135, 145, 190, 257 , 258; during War of Jenkins's Ear, r86, 253; during War of Spanish Succession, 45, 46; Dutch treaty, 240; émigrés, 129; expected war (1724), 236; fortifications and troops, 146, I83, I92-194; fugitives in, I9I ; international island trade, $46,47,53,59,60,69$, I 10, I25, I27, I 36, I4 I, I42, I62-I65, I68, I82, I 83, I 93, 233, 24I, 242, 252, 274, 275, 3I 5 ; militia, 240; negotiations, 250, 297, 3 I 5 ; officers, 232; pirates, 47; plans against (1793), 25I ; privateers and Santo Domingo trade (I804), 203; produce, sugar, and trade, 69, 3I3; shipping, I92; slave trade, 237; trade seizures by, 52, I 69, I 72, I 73, I 86, 232, 238, 24I, 243, 249, 250, 252, 253, 256; trade with English mainland colonies, 48-50, 57, $59,60,62,71,90,99,100,168,171,190,194$, $239-243,245,256,325,337,393,394$; trade with the enemy, I88, 330; treatment of English in, 125, 235; treaty of 1686,59 ; United States trade, 30I; wreck, 87; see also Austrian Succession; Cayenne; Guadeloupe; Martinique; Santo Domingo; Seven Years' War

Fresne, Chevalier de, commissions, 392, 395; correspondence, 392,395

Frey, Bruner, and Co., letter, 124

Friderici, Gov. Juriaan François de, letter, 306

Friend, Capt. Charles, 187

Friendship, 87, 336, 374(2)

Fugitive slaves, British sale of American, 40, I I I, I 12, 217 ; in French islands, I9I; in Spanish islands, 25, 27, I40, I48, I 7 I, I87, I90, I 91 , 246, 254, 260; see also Maroons

Fuller, Rose, agent, letters, I76, I79

Fuller, Stephen, agent, 386n.; letters, I79, I82, I 94 ; letter to, I95; memorials, I80, I9I, I95

Furnell, Peter, petition, 2 I 5

Gage, Gen. Thomas, 29, 30; letter, Ioo

Galathea, French frigate, 254

Gale, (?) Christopher, letter, 12

Galleons, plan to capture, I 83

Gambier, Lt.-Gov. John, complaint against, 3I ; letters, 20, 25, 3I, 197

Gambier, Judge Samuel, I9, 4I

Garnier, Capt. William, letters, $25^{8}$

Gauld, $\longrightarrow, 29$

Genet, Edmond C., privateers and projects, 35 . 36, 106

George and Elizabeth, 88, 89, 97, 98

Georgetown, British Guiana, records at, 347

Georgia, conditions (1778), I95; Spanish menace and attacks, I $8,24,90,185$, I 86

Germain, Lord George, letters, 2 I, 65, 102, 133, I95, I96, 25I, 260, 263, 298, 299, 391 ; letters to, I39, I94

Gerrard, James, letter, 174

Ghent, peace of, news, 39, 122, 133 
Gibraltar, siege as war (1727), 252

Giuseppi, M. S., Guide to MSS. in Public Record Office, in.

Glasgow, H. M. S., 30

Glencairn, Isabella, countess, memorial, 25 I

Gloster, Archibald, agent, memorial, 3 I I

Godet, Millicent, 347

Godet family, papers, 347

Godolphin, Sir. William, letter, I 82

Gohier, - , I3, 40

Gold mines, I 70

Goodrich, Bridger, and American Revolution, I03, I04, I06, I07; and council, I05; letters, 105, 107

Gordon, -263

Gordon, David, letter, 204

Gordon, Maj. (?) Harry, reports, 145,149

Gordon, Gov. Robert, letters, 122

Gordon, Rev. William, 47, 69

Gordon, William, merchant, letters, 47, 250

Gordon, William, of Massachusetts, letter to, 260

Gore, Gov. Francis, of Bermuda, letters, 109

Gore, Lt.-Gov. Francis, of Grenada, I36

Gosling, F. G., acknowledgment to, vi

Goulburn, Henry, letters, 327, 349; letters to, I I I, 346, 399

Gould, James, 3 I

Governors, and admiralty, 93; and clergy, 73; and collector, 95; and colonial agent, 95; and navy, 45, I60, I6I, I78, 181, 183, 186, I 88, 2 10, 273, 274; and prize money, 234; correspondence in Colonal Office Papers, registers, abstracts, 2-4; devolution of power, 274; equipage money, 60 ; procedure of complaints against, 236; whale royalty, ior; see also Assemblies; Councils; and islands by name

Graaff, Gov. Johannes de, and Americans, correspondence, $26 \mathrm{I}-263$

Graham, - 104

Graham, Pres. John, letters, I38, I45

Grame, Hugh, I59

Granby, John Manners, marquis of, report to, I 45

Grand Anse, Jamaica, 198

Grand jury, 94

Grant, Ger. James, I53, 25 I, 264; letters, 315

Granville, John Carteret, earl, see Carteret

Gray, R., Chronological Table, 346n.

Greathead, Pres. Craister, letters, 260, 26I; letter to, 260; office, 312

Green, Gov. (Sir) Charles, letters, I41, I53, I54, 306; letters to, I4I

Green, John, of Bahamas, case, 28-30; memorial, 30

Green, John, of Bermuda, letters, I04, I07

Green, Joseph, letter, 29

Greg, John, 62; letter, I 39

Gregory, Pres. John, letters, 169

Grenada and dependencies, absenteeism, I43; acts, 157,362 ; acts printed, I37; admiralty, 140, I51, 362; and American Revolution, I39, I 50-I 52, 3I 5, 316, 357-359, 36I ; appropriations, 143; archives at London: correspondence of Board of Trade, 135-141; correspondence of Secretary of State, I40-
155; entry books, I55-157, 3I7; archives on island: character and condition, 355 , 356 ; in Registrar's Office, 361, 362 ; in Secretary's Office, 356-36I ; assembly, establishment, rights, I36-140, 142-144, 147, I48, I50, I56, I58; British excise on products, I 50; British occupation, I4I, I42; chancery, I38; church, I37, I38, I45; conditions, 135-137, I40, I 41, I44, I46, I48, I50, 361 ; council, membership, suspensions, I39, 145, I 47, I5I, I56, I57; courts and legal matters, I 37, I39, I40, 142, I 56; customs, I38, I45, I5 I, I58; defense, 136, 138, 139, I41, 142, I 44-I 47, I 49, I 52, I 53, I 57, 358; disease, 398; elections, 144, I45; exchequer, 145; fees, 138, 151; foreigners, 144; free port, I 54; French inhabitants, 135-137, 141-146, I 50 , I55, I56; French rule and cession, 135, 136, I40; fugitive slaves, I40, I48; government, I36, I37, 142, I 44; governors: commissions and instructions, 140, I55-157, 317, 359; letter books, 360, 36I ; salary, 156,359 ; in Leeward Islands, 25I; land, I35-143, I46, I5I, I53, I55; misgovernment, complaints, 142, I43, I45, 146; narrative of British control (1775), I 50; negro (maroon) trouble, I46-I 48; non-residents, 362; offices, lists, values, I35, I50; pirates, I38, I49; population, I35, I43, 314; possession, v; privateers, I52, 358, 359; proclamations, 356-358; produce returns, I4I; Roman Catholics, I 37-I39, I4 I, I43, I 44, 147, 156; sessional papers, I 43, I 44, I 5 I, I 53-1 55, I 57-1 59, $358-362$; settlement, $62,136,137,142$; shipping returns, I35, I36, I41, I54, I 55 , I 59; slaves, records, $135,143,361$; slave trade, 137, 141, 159; sugar industry, 361; taxes, 135, I38; trade, neutral, United States, violations, 140, I41, 143, I5 I, 153I 55, I 58, 230, 356-362; see also West Indies; Windward Islands

Grenadines, assembly, 136, 137; conditions, 146; land, 137 ; records, 403; settlement, 62, 136; see also Carriacou; Grenada

Grenville, Gov., Henry, commission and instructions, 72; letters, $54,55,306$; letter to, 73 ; proclamation, $6 \mathbf{I}$

Grenville, Grenada, port, I 54, I55

Grenville Packet, 126

Grey, Sir Charles, letter, 58

Greyhound, 322

Grey-Wilson, Sir William, 330

Grushy, Capt. James, 322

Guadeloupe, archives of English occupation, 159; capture and occupation, $247,248,255$, 394; evacuation, 14I; possession, v; see also French West Indies

Guadelquiver, 374

Guarda costas, Cuban, 12, 14; see also "trade seizures" under Spanish West Indies

Guatemala, memorandum on, 203

Guise, John, report, 253

Gumbs, —, 256

Habeas corpus, in colonies, $73,89,98,113,165$, 184, I88, 189

Hacker, Capt. Hoysted, 30 
Haggett, Othniel, 49

Haiti, see Santo Domingo

Haldane, Gov. George, commission and instructions, 215 ; letter, 177

Hales, Robert, complaint, 59, 60

Halifax, George Montagu, 2d earl of, 27 I

Halifax, George Montagu Dunk, $3 d$ earl of, letters, 25, 42, 99, I 35, I 41, I 42, I 78, I 88, 256, 306; letters to, $96,99,100,188,256$

Halkett, Gov. John, letters, 37 ; letter to, 42

Hall, Hubert, I $7 \mathrm{n}$.

Hall, Richard [I], 74

Hall, Richard [2], 63, 75

Hall, William, letter to, 158

Hallock, Capt. Charles Alexander, 30

Hamilton, $\longrightarrow$, death, 270

Hamilton, Lt.-Col. Alexander M. K., letters, 205 , 206

Hamilton, Lord Archibald, charges against, case, I6I-I63, 209, 210, 390; disputes, I6I, I8I, I 83 ; instructions, 2 Io let-pass, 221 ; letters, I60, I6I, 209, 2 I0; letters to, 208-210

Hamilton, Capt. David, letters to, 389

Hamilton, Gov. Henry, letters, 97, 98, 105-107, I29; letter to, I25

Hamilton, John, consul, letter, 38

Hamilton, John, see Belhaven

Hamilton, W., letter to, 2 I 8

Hamilton, Gov. Walter, and councils, 230; commissions and instructions, $27 \mathrm{I}$; letters, I6I, I62, 232-235; letters to, 272

Hamilton, William Leslie, 25I

Hamilton, Bermuda, archives at, 34I-346; corporation records, 347 ; port, 2 I 7

Hammond, George, letters, 35, 106, 204; letters to, 106

Hancock, John, letter to, 260

Handasyd, Gov. Thomas, letters, I 59, I82, I 83 ; regiment, 209

Handbook of Jamaica, $38 \mathrm{I}$

Hannah, 362, 374, 403

Hannah and Elizabeth, 374

Hanover Parish, Jamaica, records, 364

Happy Couple, 374

Harbor Island, clains, I2

Harcourt, Lt.-Gov. (Col.) George W. R., 199, 379; letter, $29 \mathrm{I}$

Harley, Thomas, letter, 46

Harper, -

Harriett, 374 (2)

Harrington, William Stanhope, Ist earl of, letters, 239, 240; letters to, 274

Harris, R. S., letter, 209

Harris, Richard, letter, 234

Harris, Rev. Thomas, 73

Harrison, Richard, I5I

Harry, David, 8I

Hart, Gov. John, commission and instructions, 235, 273; disputes, 236, 237, 249; letters, $235^{-238}, 249-25 \mathrm{I}$; letters to, $249,25 \mathrm{I}$; salary, 249

Harvey, Pres. John, letters, I 55

Hasell and Tasker, letter, 292

Hastings, Hans F., see Huntingdon

Havana, archives on English occupation, I59; attacks, I 86, I 88, 282; nission to, I 64,

Havannah, 374
Haward, 265

Hay, Gov. Edward, commission, 74; disputes, 64,65 ; letters, 56, 63-65

Hazard, Capt. John, 30

Heathcote, (?) Sir Gilbert, testimonial, 23,

Hebburn, J., letter, 33

Hector, 374

Henderson, Alexander, letter, I26

Herbert, John Richardson, 39 I

Herbert, Joseph, 391, 392

Hewitt, W., letter, I27

Heywood, Gov. Peter, and revenue, I64; letters, I62, I63, I 81; letter to, I62

Hibbert, George, agent, letters, 202, 208, 386n.; letters to, 2 I 7

Hibernica, 374

Hickmann, J. L., 389

Higginson, 1 at Dominica, 35 I

Hill, Wills, see Hillsborough

Hills, Henry, 75, I I 5

Hillsborough, Wills Hill, earl of, letters, 26, 27, $56,63,101,133,137,138,143,145^{-147}$, I90, I92, 257-259; letters to, 28, I38, I45I 47, I90-I92, 248, 257-259

Hiram, 68, 270; 374

Hirondelle, 374

Hislop, Lt.-Gov. Thomas, letters, 3Io, 3 I I

Hispaniola, see Santo Domingo

Hodges, Thomas, 79

Hodges, Thomas, jr., 59, 60

Hodgson, Gov. John, letters, I09-I I I ; letters to, I Io

Hodgson, Robert, and Mosquito Coast, 192, I93, I97; correspondence, I88, I9 I-I93

Hodgson, Capt. Thomas, 27

Hodgson, Thomas, cartel, 32

Hog Island, plans, 22, 332

Holderness, Robert Darcy, 4th earl of, letters, I72, 246; letters to, I73, I 76, 255, 276

Holland, Henry Fox, Ist baron, letter, I75; letter to, 255

Holmes, $A d m$. Charles, I88; letter, 188

Home, Lt.-Gov. Niman, letters, 153

Honduras, see British Honduras

Hope, Lt.-Gov. John, I I5; commission and instructions, II2; complaint against, 89; letters, 87-89, 98; letters to, I I2, I I3

Hope, 374 (2)

Hopervell, 87, 374

Hopkins, Esek, in West Indies, 20, 21, 30, 298

Hopkins, Capt. John B., 30

Hopson, Gen. Peregrine Thomas, letters, I59

Hornet, 374

Horses, and sugar trade, 69; neutral trade, 350, 351 ; prices, 59

Horsford, Gen. George, letters, I I I ; letter to, I I I

Hosier, $A d m$. Francis, 166, I 81

Hotham, Com. William, Ist baron, I 53

Houstoun, Lt.-Gov. Alexander, letter, I53

Howard, Charles, see Carlisle

Howard, Sir Esmé, acknowledgement to, vii

Howard, Henry, see Suffolk

Howe, Emanuel Scrope, zd viscount, commission and instructions, 7I, 72; letters, 5I, 60; letter to, 72

Howe, Richard, viscount, correspondence, 195

Howe, Sir William, 64, 394; correspondence, I95

Howe, 359 
Howell, John, letter, I 89

Howell, Pres. John, letters, 17, 24

Hubbard, Charles Hobby, 260, 26I

Hudson, Israel, 79

Huguenots, in West Indies, $27 \mathrm{I}$

Hull, Charles H., report on West Indian archives, vii, $320,336,369$

Humberston, Francis M., see Seaforth

Humphreys, Francis, letter, 24

Hunt, Pres. Robert, letters, 36, 37

Hunter, Gov. (Gen.) Robert, commission and instructions, I66, $2 \mathrm{I} 2$; dispute, I85; letters, I67, I68, I8I, I84, I85; letters to, I8I, I84, I 86,212

Huntingdon, Hans F. Hastings, IIth earl of, letter, 350 ; letter to, 349

Hurricanes, I60, I65, I66, 248, 394, 398, 400, $40 \mathrm{I}$

Huskisson, William, letters, 350, 400

Hutchins, Thomas, 29

Hutchinson, William, letter, 265

Hyde, Edmund, I 73

Hyde, John, I5; letter, I 5

Hyde, Laurence, see Rochester

Iberville, - d', memorial, 234

Ice, trade, 20.5, 269

Immigration, from French-controlled Europe, 349; Irish, to United States, I Io; of aliens from United States, 42; see also Slave trade; White servants; "immigration" and "settlement" under islands by name

Impeachment, at Montserrat, 258, 259

Impressment, American papers, 58, I99; Chesapeake-Leopard affair, 38; desertion to American vessels, I Io; French, of British subjects, I25; in West Indies, 53, 60, 69, 91, 170, 181, I86, 2 I 3; of American seamen, 283; seduction of British seamen, 39, 217

Indexes of Board of Trade correspondence, Bahamas, 42; Barbados, 74; Bermudas, I I5; Jamaica, 2 I6; Leeward Islands, 277

Indianer, 108

Indians, Creeks, 37, 218; Darien, 58, I7 I; kidnapped for slavery, 185 ; Mohegan petition, I 85; slaves, I85; southern, in War of I8I2, 39; war (1792), I06; see also "Caribs" under St. Vincent

Indigo, trade, I64-I66, 245, 389

Industry, 102

Ingram, Peter, letter, 195

Ingram, Richard, see Irwin

Institute of Jamaica, records in, 38I-390

Insurance, 55, 59, 323

Interest rate, acts, 49, 52, 60, I73, I74, 243, 275

Interruptet, 374

Ireland, trade; linen, 47; sugar, 57; with the enemy, 55, 62, I 88, 247, 253, 255, 264, 300, 395 ; with the islands, illegal, 49, 53, 234, 243 , 269,393

Irish, emigrants to United States, I Io; in islands, convicts, papists, servants, 102, I67, I68, I 83, 21 2; party, I 47

Irving, Alexander, 30

Irving, Sir Paulus Aemilius, letter, 35

Irwin, Andrew, I 39

Irwin, Richard Ingram, 5 th viscount, commission and instructions, $47,70,306$
Jackson, Chaloner, I6, I7; letter, 4 I

Jackson, Cuthbert, memorial, I4

Jackson, Richard, opinions and reports, 20, 56, I 24, I 38, I 39, I79, 249

Jacmel (Jeremie), trade, 198, 200, 201

Jacobitism, in Jamaica, 184

Jamaica, absentees, tax, I64, I7 I, I77, I78, 213 , 215 ; acts: lists, 218,388 ; manuscript, I90, 218,367 ; printed, 169, 170, 216, 218, 269; representations and disallowances, I70, I72, I 73, I75-I77, I 79, I 80, 193, I94, 208-2 I6; suspending clause, I65, I 72-I75, I77, I 78, I 84, I92, I93, 2IO, 2I3, 2I4; acts of trade, conflicts, enforcement, violations, $16 \mathrm{I}-\mathrm{I} 67$, I 7 I, I 72, I 74, I 77, I 79, I 83, I 88, I 89, I 93, 2 I4-216; admiralty, I77, 373-377; agent, 163, I64, I67, I79, I 81, 2 I 0, 215,2 I6, 386, 387 ; and British imports, I79, 3I4; and Free Port Act, I93; and Molasses Act, I 85; and threatened Spanish war (I729), I67, I68, I 8I, I 82, I84; appropriations, I 74; archives at London: correspondence of Board of Trade, I59-I80; correspondence of Secretary of State, I80-208; entry books, 208$2 \mathrm{I} 8$; indexes, $2 \mathrm{I} 7$; archives on island: condition and character, 362-364, 370, 373, 377, 381 ; at Court House, 370 ; at Headquarters House, $377-380$; at Institute of Jamaica, 381-390; Edwards Transcripts, 387, 389; Livingston Manuscripts, 390; assembly, privileges, qualifications, rights, term, I 59I64, I68, I 7 I-I 75, I 78, I 79, I 81, I 83, I 84, I 86, I 88-I 92, 208-2I I , 2I 3-2I6, 388; attorney general, dismissal, I74; bonds, I 74; chancery, I7I, I73, 210, 213, 37I, 372; church, I62, I 7 I, 2 I0, 2 I I , 369, 384, 385; coffee culture, 167, I94, 212 ; committee of correspondence, I94, 2I6, 386, 387; conditions, reports, I64, I67, I68, I72, I73, I75, I 78, I 87, I94, 2 I3-2 I 5, 387-390; contingent expenses, I74; convoys, 208; council, appointment, clerk, privileges, suspension, I64, 167, I 73, I 76-179, I 83, I 84, I 88-190, I 92, I93, 210, 214-216, 388; councils of war, I6o, I67, $216,219,380,388$; counterfeiting, I80; counties, I76; courts and legal matters, controversies, records, I72-I 76, I79, I80, I 87, I 90, 2 I 4-216, 370-373, 386; currency, I62, I68, I 7 I-I 74, I 76, I 77, I 80, I84, I88, I 92, I93, I98, 2 I 5 ; customs, I64, I67-I70, I 84, I 92, I 93, 2 I 4; debts, recovery, I64, I72, I 77, I8I, 210, 215, 2 I6; defense, fortifications, troops, I60-162, I65-168, I 70-I76, I 79-1 84, I 87, I 89-I96, 206, 207, 209-2 I 3, 252,380 ; development of government, I 82 ; disorders, causes, 209, 210 ; divorce, 216; during American Revolution, attitude, privateers, trade, I9I-I97, 216, 374, 375; during King William's War, 2 I 9, 380, 387, 388; during Seven Years' War, I 76, I 77, I 88; during Spanish and French war (I739-48), I70$172,182,183,185^{-1} 87$; during War of I812, $207,208,217,218$; during War of the Spanish Succession, I60, I61, I82-184, 208; earthquakes and hurricanes, I6o, I65, I66; elections, ballot, poll-books, I 72, I 73, I 75, I 76, I80, 2 I 4, 369; embargoes, I 8I, I 84, 
I95; emigration, 214; emporium, I70; English laws, I65; enlistment, 2 I 3 ; escheats, I60, 209, 2 Io; fees, I 78, I 79, 2 I0, 2 I 5, 2 I6; foreign island trade, I63-I65, I68, I79, I 80, I 82, I83, I94, 2II, 2I4; foreigners, 207; free negroes, grants, increase, privileges, I67, I68, I78, I79, 203, 205, 2 I 2, 2 I 5, 227; fugitive slaves and maroons, I64, I7 I, I87, I90, I9I, I98, I99, 209; governors: abstracts of letters, I80; addresses, 387-389; and navy, I60, I6I, I78, I8I, I 83, I86, I88, 2 I0; commissions and instructions, 40, 47, I65, I66, I68-I 70, 2 I0-2 I 4, 2 I6, 3I7, 388, 389; letters, 217,387 ; salary, I65, 213 ; immigrants from other islands, 246; imports and exports, I60, I67; imposts on mainland products, I 84; impressment, 9I, 2I3; Indian slaves, I 85 ; internal politics, I7 I, I75, I 84 , I87, 2 Io; Jacobitism, I 84; Jews, I69-I 7 I, I 85, 2 I 3 ; land, grants, rent, I6o, I6I, I68I 72, I 75, 2 I0, 2 I 2, 2 I 4, 2 I6, 230, 365; legal tender, produce, I84, 2 I 2 ; lieutenant governor, 209; liquor duties, I69, I73; local records, 369, 384-386; Loyalists, I97, 2 I 7 ; martial law and council, I76, 214 ; militia, I60, I6I, I67, I7 I, I76, I77, I85, I9I; mine grants, I70, 2I3; misgovernment, I6I, I62, 209, 210, 390; missionaries to slaves, 206; naturalization, I70, I7 I, I90, 2 I6; negro (maroon) insurrections, I6I, I64, I67-I70, I 74, I77, I82, I84, I85, I 88, I9I, I93, 209; negro troops, I7I, I86, I88; neutral trade, I93, I98, 200, 202, 204-207, $217,376,377$; non-residents, tax, 384,385 ; officers: appointment and control, I64, I77, I79, I8I, I83, I 89, 2 I 4, 2 I5; exclusion from legislature, I73, 2 I4; patent duties, I60, I63; pluralism, 209, 2 I I ; salaries, I67, I78; packet service, 208; pirates, I2, I6I-I63, I65, I 8 I, I 84, I87, 2 I I, 375, 388; planting and trading interests, I 77; population, white and black ratio, 167 , I68, I70, I 75, I78, I93, I94, 209, 2 I 4, 227, 3I 4; ports, I64, I 76, I 77, 2 I I, 2 I 4; post office, I76, 2 I 5 ; poverty, I 88; powder duty, I 69, I 70, I 73, I 78, 2 I6; printed journals, 2 I 8 , $224,227,228,38 \mathrm{I}$; privateers, records, I 86 , 375,376 ; prizes, duties, records, I83, 208, 209, 2 I 5, 373-377; produce, I74, I75, I 84; property, records, I 73,365 ; provost marshal, I 73, 2 I5; public accounts, I6o, I65-I67, I69, I 70, I 74, I 78, I 79, 224, 379, 388, 390; quieting possession, 208-2 I0, 2 I6; religious liberty, 218; revenue: amount, I60, I69, I70, I73, 212, 2 I4; decrease, I68; diversion, I63; perpetual, I64-I66, I 8I, I84, 2 I I, 2 I 2 ; surplus, I80, I9I-I94, 2 I6; Santo Domingo trade under blacks, I99-204, 2 I 7, 305, 379; Scottish illicit trade, I74; seat of government, I 74-I76, I 84, I87, 2 I4, 363n.; secretary's office, dispute, I63; sessional papers, I63, I 74, I 98, I99, 202, 204, 205, 2 I 8-228, $332,368,369,378,38 \mathrm{I}-384$; settlement, I 70, I 72, I 74-I 76, I 8I, I 82, 209-2 I 4, 2 I 8, 390; shipping returns, I98, 228-230; slave trade, duties, I60-I63, I65-I69, I 7 I, I 75, I 79-I 8 I, I84, I 85, I 87, I 94, I 98, 208, 2 I02 I 3,2 I6, 230, 3 I 4 ; slavery, abolition, 387 ; slaves, prices, records, taxes, I60, I67, I69, I73, I75, 206, 366, 367, 384-386; Spanish trade and Asiento, I60-I64, I68, I69, I72, I 79, I 80, I 83, I 85, I 88, I93, 2 I I, 2 I6, 227 Spanish treasure ship, I84, I85; Stamp Act, I79, I89; suffrage, I6I; sugar trade, I98; taxes, I69, I70, 384-386; test act, $21 \mathrm{I}$; trade, I60, I66-I68, I 75-I77, I79, I 80, I98, 206, 2 I4, 230, 389; trade with mainland colonies, I 82; trade with United States, peace-time, I 97, 203, 2I 7, 3 I 5, 387; vessels registered at, 229, 230; vital records, 364; white servants, I63, I64, I67, I68, I75, I86, 2 I2; see also West Indies

Jamaica Courant, I 74

Jamaica Gazette, 364

James, 263, 374

Jameson, J. F., "St. Eustatius in the American Revolution," 26I

Jane, I 55, 270, 395

Jaspar, 374

Jay, John, 2 I

Jeany, 374

Jefferson, Thomas, Chesapeake-Leopard proclamation, 38

Jeffrey, Capt. Richard, 322

Jeffries, $D r . \longrightarrow$, letter to, 260

Jenkins, Maj. Edward, instructions, I96

Jenkins, John, petition, $5^{8}$

Jenkins's Ear, War of, see Austrian Succession

Jenkinson, Robert B., see Liverpool

Jennings, Capt. Henry, 22 I

Jennings, Richard Downing, 262, 263

Jeremie, see Jacme1

Jervis, Sir John, letter, 58 ; letter to, I06

Jessup, Col. —, of St. Kitts, 244

Jessup, Edward, petition, 275

Jews, affairs in islands, I I 4, I69-I7 I, I85, 2 I 3, 335,340

Johnson, James, 198

Johnson, Walter, "Progress of a Planter," 390

Johnston, - of Nassau, 33

Johnston, Pres. Anthony, letter, 264

Johnstone, Col. Alexander, I 42

Johnstone, Gov. Cochrane, letters, I3O, I3 I ; letter to, I 30

Jones, - , at Bluefields, I9I

Jones, Edward, 88

Jones, Pres. Francis, letters, 92, 94

Joubert, - , at Martinique, I 52

Journal of General Assembly of Leeward Islands, 267

Journal of General Council of Leeward Islands, 267

Journal of the Council of Jamaica, 227

Journals of Assembly [Jamaica], 2I9, 22 I, 223, 225-228, 332, 388

Julian (Juliana), 374

Julius, Pres. John, letters, 269, 270

Jupiter, 374

Juries, 49, 93; fines, I9o

Justices of peace, I73, 275

Keane, Sir John, letters, 400; letter to, 399

Keene, Henry, letter to, 299

Keith, Sir Basil, commission and instructions, 2 I6; disputes, I6I; letter, I93, I94

Kelley, - letter, I64. 
Kemble, Col. _ instructions, I95, 196

Kennedy, Robert, letter, I Io

Kennedy, Capt. Walter, 337

Keppel, Adm. Augustus, viscount, I 88

Kettey, 374

King, Benjamin, 244, 275 .

King, John, letters to, 107, 14I

King, Rufus, letter, 2 I7

King George's War, see Austrian Succession; Jenkins's Ear

King William's War, in West Indies, 76, 219, 325, $338,380,387-389$

"King's Slaves," 88

Kingston, Jamaica, freeholders, 207; hurricanes, I60, I65; information on, 209; parish and city records, $364,384-386$; port, 177 ; records at, $370-390$; seat of government, $174-176$, $184,187,214,363 n$.

Kingstown, St. Vincent, open port, 303; records at, 403,404

Kinnicutt (Kenneckett), Capt. - - of Rhode Island, I 00

Kitty, 374 (2)

Knill,

Knowles; Capt.

Knowles, Sir (Adm., Gov.) Charles, commission and instructions, I 87, 213, 214; disputes, I 74, I75, 2 I 4; Ft. St. Louis, I87; letters, 24, 53, I 72-I 75, I87, letter to, 2 I 4 ; petition, 2 I 5

Knox, William, letters, 21, 97, 195; letter to, 299

Labor, Barbados act, 76; see also Slaves; White servants

Lack, Thomas, letters, I I I, 346, 399

Lady Caroline, 374

Lady Catherine, 102

Laforey, Sir Francis, letter, 349

La Galissonnière, Michel, comte de, commissioner, memorials, 297

La Guaira, S. Am., 308

La Guira, Tobago, 308

Lamb, Matthew, opinions, I8, I 7 I, I77, I80, I90, 245,246

Lanarge, - , letter, 305

Land, alien holdings, 157 ; bounty for troops, 148 , I50; control over revenue, 95 ; mine grants, I 70, 213; title, 3I6; see also islands by name

Lansdowne, see Shelburne

Larkin, George, 97

Laroche, Daniel, I 9

La Varenne, Marquis de, 232

Lavington, Gov. Ralph Payne, Ist baron, commission, 277, 278; letters, 248, 249, 259, 260, $268,269,277$; letters to, 259, 269

Lawes, Capt. Joseph, letter, I 84

Lawes, Sir Nicholas, instructions, 40, 210,2 II; letters, I63-165; letter to, 2 I I

Lawford, George, deputations to, 355

Lawrie, James, letters, 195, I98

Laws, see Acts

Laws of Grenada, I 57

Laws of Saint Christopher, 292

L'Cholet, _—, correspondence, I 7 I

Leak, John, 266

Lear, Tobias, letters to, 201, 202, 260

Lee, Arthur, and Lord North, I40

Lee, Gen. Charles, letter to, 260
Lee, Gregory V. 120

Lee, Henry, correspondence, 68

Lee, Thomas, letter to, 260

Lee, William, letter, 260

Leeds, Francis, 5th duke of, see Carmarthen

Leeward Islands, absenteeism, 235, 239; acts, representations, suspending clause, 23I, 234, $244,249,272,273,278$; admiralty, 265,266 , 278; agents, 240, 27I; archives at London: correspondence of Board of Trade, 230-249; correspondence of Secretary of State, 249270; entry-books, 270-278, 3I7; indexes, 277; assemblies, rights, 246, 271, 274, 277; chancery, 259, 260; church, 245; complaint of Barbados, 45 ; conditions, $234-236,240$, $244,246,260$; councils: officers as members, $5 \mathrm{I}, 54,72$; precedence, suffrage, suspension, $237,242,244,248,257,258,273$; courts, 240, 275; currency, 232, 24I, 243, 249, 254; customs, 25, 232, 233, 243, 271, 273; defense, $58,23 I-234,237,239,240,243,244,246,247$, $250-252,255^{-258}, 272,274,276,277,318$; disorders, 209; during American Revolution, attitude, 248, 25I, 260, 3I8; during Seven Years' War, 247, 248, 255; during Spanish War (1740), 45, 252; during War of 1812 , 269, 270; during War of the Spanish Succession, 78 ; emigration, 242,246 ; exchequer, 23I ; fees, 234, 236, 237, 24I, 243, 249; free ports, 266, 268; fugitive slaves, 254, 260; government, vi; governors: and navy, 273, 274; commissions and instructions, 235,243 , $245,248,270,27$ I, 273, 274, 276-278; correspondence, $249,277,278$; residence, 252 ; salary and grants, 235, 238, 239, 243, 249, 25I, 252, 27I-274; Huguenots, 27I ; indigo, 245; islands included, 25I, 257n.; land, 233, 239, 27I; loyalty (1769), 257; lumber, 122; militia, 235, 244; misgovernment, complaints, 236, 243; negro insurrections, 242, 243, 257; officers, lists, powers, 234, 237, 239; ordinary, 245,275 ; packet boats, 55,257 , 259, 260; pirates, $232-236,249,251,271$, 272,276 ; political conditions, 235, 238; population, white, decrease, $234,247,258$; powder duty, 231, 240, 241, 243, 274; prices, 140; produce, 234; recruiting in, 258; registry offices, 245 ; revenue acts, 235 ; slaves, 242 ; slave trade, $231,233,234,237,25^{8}$; sessional papers, $23 I, 267,279$; settlement, 232 ; taxes, 249; trade, French edict, neutral, United States, 234, 238, 24I, 242, 252, 265269 , 3I5; trial of soldiers for killing rioters, 258, 259; vital records, 244; white servants, 235; see also Antigua; Montserrat; Nevis; St. Kitts; Virgin Islands; West Indies

Lefroy, Sir John Henry, Memorials of Bermuda, 34 In. ; records, 345,346

Legal tender, produce as, 20, I84, 2 I 2

Legge, Com. Edward, 54

Legge, William, see Dartmouth

Legislature, powers of colonial, 26, 4I; see also Assemblies; Councils

Leheup, Peter, agent, letter, 50

Lennox, Charles, see Richmond

Let-passes, see Ship passes

Letter to the People [Jamaica], I80 
Letters of marque, see Privateering

Lettres Patentes concernant le Commerce Estranger, 24 I

Leyborne, Gov. William L., and Caribs, I47; commission and instructions, I56; letters, I 39, I47-I 50; memorial, I 39

Liberté, 377

Liberty, 374

Lieutenant-governors, commission and instructions, I 12; in West Indies, 56, 209; salary, 70,178

Lightfoot, (?) Richard, letter, 49

Lillie, Samuel, 322

Lillington, George, 78

Lilly, Christian, letter, 59

Lincoln, Gov. Edmund, instructions, 298, 304; letter, 301 ; letter to, 298

Lindsay, Alexander, see Balcarres

Lindsay, Gov. William, letters, 307

Linens, trade, 47

Liquor, duties, 48, 60, 70, 71, 89, 94, I69, I73, 239-241, 272, 273, 340, 346n.; license, I00

List of Colonial Office Records, In.

Liston, Robert, 267; account, 206; information, I07; letter, 201

Lists and Indexes, no. XXXVI, In., 309n.

Liverpool, Robert B. Jenkinson, $2 d$ earl of, letter, 349

Liverpool, Jamaica trade, I67-I69, I 75, 194

Livingston, Noel B., manuscript, 390 ; on records, $365 \mathrm{n}$.

Livingston, 374

Lloyd, Sir Nathaniel, opinion, 27 I

Logwood, cutting and trade, 58, I23, I68, I8I, I 82,187, I $88,203,2$ I, 2 I $3,252,254,387$, 389

London, Bishop of, colonial jurisdiction, 55,60 , 62, I I2, I 71

London, treaty of (1686), 59

Londonderry, Thomas Pitt, 5 th ( $I s t$ ) earl of, and Bahamas, I3; and records, 287; commission and instructions, 273 ; letters, 238, 25I ; letters to, 273

Long, Beeston, (?) $36 \mathrm{I}$; letter, 203

Long, Charles, letter, 3 I 4

Long, Edward, letter, I 88

Long Island, 33

Losack, Gen. Richard Hawkshaw, letters, 248, 258,$277 ;$ ? ztters to, 258,259

Lotteries, 63, 74, 2 I6, 277

Louisa, 88

Louisiana, Genet's project, 35; see also New Orleans

Lowndes, Charles, letter to, 73

Lowndes, William, letters, 23 I, 232

Lowther, Gov. Robert, and truce, 45; cartel, 59; commission and instructions, 69, 70; complaints against, disputes, 46, 47; letters, $45^{-47}, 59$; letters to, 69

Loyalists, in British Honduras, distress, 123; in East Florida, 30I, 339; in Mosquito Shore, 197, I98; in West Indies, I97; relief, I Io, I95, 217 ; troops, 3I, I50, I95-I97, 326; see also islands by name

Lubin,, 202

Lucas, Judge - 335

Lucas, George, narrative, 253
Lucas, Pres. William, letter, I53; letter to, 349

Lucretia, 374

Lumber trade, American Revolution and island,

64, 318; British Guiana, I 2 i ; customs, 354; intercolonial, 358, 404; neutral, I54, I98, $204-206,267,291,297,303,308,3$ II , 349$35 \mathrm{I}, 357-36 \mathrm{I}, 392,394,396,404$; price, I98; United States peace-time, 128, 129, 304, 339, $357,358,360,395,399-401,403$; see also British Honduras

Lushington, R., letter, I I I

Lyde, Byfield, letter to, 260

Lydia, 374

Lynch, Sir Thomas, report, 388; rules, 389

Lyon, Edmund Pusey, agent, $386 \mathrm{n}$.

Lyttelton, Sir Charles, 390

Lyttelton, Rev. Thomas, letter, Io2

Lyttelton, Gov. William Henry, commission and instructions, 215; disputes, I78, I88, I89; letters, I78, I79, I88, I89; letters to, I78, I 79, I 88, I 89, 2 I 6

McAdam, William, petition, 192

McArthur, Gen: - letter, 32

Macartney, Sir George, commission and instructions, I57; letters, I39, I 5 I-I 53, I 55; memorial to, I39

McEvoy, Capt. - journal, I96

Mackay, William, letter to, 260

Mackenzie, Francis H., see Seaforth

Mackenzie, Pres. Kenneth, letter, I 53

Mackie, Gov. (Gen.) George, letter to, 400

McNeill, John, petition, I4 I

Maddison, Lt.-Gov. George, I 36

Madeira, West Indian trade, 234

Madrid, manifesto, 177

Magazine ships, 98, 346

Mahogany, see British Honduras; Lumber trade

Mahomet, Indian, petition, I85

Mail, see Communications

Mainwaring, Gov. (Gen.) John M., letters, 40I; letter to, 400

Maitland, Gov. Frederick, letters, I54, I 55

Maitland, Richard, agent, letter, $36 \mathrm{I}$

Maitland, Gen.(Sir) Thomas, and Santo Domingo, letter, 199, 379; convention, 2 I 7

Malcolm, Harcourt, and Votes of Assembly, 44

Man-of-War Bay, Tobago, foray, I 53

Manchester, William Montagu, 5 th duke of, letters, 206-208; letters to, 217

Manchester Parish, Jamaica, records, 364

Mann, Adm. Robert, letters, $25^{8}$

Manners, John, see Granby

Manners, 260

Manufactures, colonial, 7 I, 89, 125, 126, I64

Manumission records, 366,386

Maps, I4I, 240, 254, 34I

Margaret, 98, 344

Margarita, and fugitive slaves, I40, I48; see also Spanish West Indies

Marianne, 374

Maroons, trouble in Grenada, I46-I48; see also "fugitive slaves" and "negro insurrections" under Jamaica

Marquis de Bouillé, 374

Marquis of Rockingham, 262 
Marriages, see Vital records

Marryat, Joseph, agent, letter, 3 I I

Marsh's Harbor, Bahamas, 32

Martha and Mary, 374

Martial law, and legislature, I76, 2 I 4; in islands, I 84, I 85 , I9 I

Martin, Thomas, letter to, 260

Martindale, Capt. William, journal, 87

Martinique, captures, occupation, $282,283,317$, 396; conditions, 59, 282 ; defeat of royalists, I 29; English records, 76, 282, 283; hostages, 23I; negroes and slaves, 282 ; possession, $v$; property, 282; treatment of English, 249; see also French West Indies

Martinique Gazette, I 52

Martyn, Joseph, letter, 325

Mary, 338, 374

Mary Ann, 92

Maryland, tobacco trade, I8, 89, 292

Massachusetts, coercive acts, 193, 318, 357; illegal trade, Ioo; trade with the enemy, I77; see also New England

Master, Gov. Richard, letters, 307

Mathew, Gov. (Gen.) Edward, forces under, I40; instructions, I40, I 57, 359; letters, I4I, I 53, 316; letters to, I4I

Mathew, Gov. (Lt.-Gov.) William, affidavit, 253; commission and instructions, 274; disputes, 237; letters, 237-245, 252, 253, 287; letters to, $252,274,275,393$; vessel, complaints against, $24 \mathrm{I}-243,250-252$

Mathias, Vincent, agent, letter to, 93

Matson, Pres. John, letters, I29, I30

Matty, 28

Maud, Joseph, letter, I79

Maurepas, Comte de, letter, I 86; letters to, 305, 3 I 5

Maurice, 374

Maxwell, James, 68

Maxwell, Gov. John, instructions, 42 ; letters, 2 I, 32

Maxwell, Gen. Thomas, 45

Maynard, John, memorial, 58

Mays, Simeon, letter to, 260

Meikle, John Philip, 26I

Melville, Gov. Robert, charges against, I45, I46; commission and instructions, I42, I 55, I 56 ; letters, I 35-I38, I 42, I 43, I 45, I 46; letters to, I42, I43, I46, I56; memorial, I36; petition to, I 58 ; proclamation, I44; return, I46; salary, 142

Meng, Wollere, letter, I9I

Merchant Adventurers of Bristol, West Indian trade, I37, I56, I67-169, I75, I 94, 24I

Merry, Anthony, letters, 204, 205

Metcalf Parish, Jamaica, records, 364

Metcalfe, Pres. - letters, I 32

Methodist Episcopal Church, 396

Methuen, John, letters, 46, I62, 2 Io

Mexico, letter to viceroy, I92

Middleton, $\longrightarrow$, I 47

Mildmay, William, commissioner, memorials, 250,297

Milford, 374

Military, control over, in islands, I 46, I 49, I60, I86, 33I ; see also Army; Defense; Militia; Navy; wars by name

Militia, French, 240; see also isiands by name

Mil?enium, 323
Miller, John, letter, I9I

Miller, William, letter, 34

Mills, - inspector general, 64

Mills, — $\longrightarrow$, of Salem, 299

Mills, Luke, 322

Mine grants, I 70, 213

Minerva, 374

Minerva, H. M. S., I95

Minutes of Assembly of Tobago, 308

Miquelon, private sale, $342 \mathrm{n}$.

Miranda, Francisco de, I 2 I

Missionaries to slaves, 206

Mississippi River, settlement, 29, I95

Missive van Repraesentant, 26I.

Modyford, Sir Thomas, 390

Mohegan Indians, petition, I 85

Molasses, see Rum; Sugar

Mole-Head Act, 64, 74

Molesworth, Lt.-Gov. Hender, articles of war, 2 I9; letters, 389

Monckton, Gen. Robert, I4I, I50; correspondence, 282

Money, counterfeiting, I80; light, I92; on prizes and seized vessels, I09, I 2I, I 55, 207, 208, 304; Spanish trade and importation, I89; see also Currency; "currency" under islands by name

Monro, Gen. (Gov.) William, letters, 3 I I

Monroe, James, letter, Io7

Montagu, Lord Charles, corps, I97; letter, I96; narrative, I97

Montagu, George, Ist ( $3 d)$ duke of, see Cardigan Montagu, John, $2 d$ duke of, grant, 47-49, 70, 7I, $235,249,252,306$; testimonial, 23

Montagu, $A d m$. Robert, 20 I

Montagu, William, see Manchester

Monte Cristi, trade, I9, 20, 25, 26, I 76, I77, I 88,2 I 5

Montego Bay, Jamaica, port, I 77, I94, 229

Montresor, Gen. Henry T., letter, I23

Montserrat, absentees, 248, 277; acts, 234, 283; acts in force, 240 ; archives at London, correspondence, 283 ; archives on island, character and condition, 390, 39I ; assembly, rights, $245,258,259,276$; assembly sitting thirty years, 270; council, functions, 391; courts, 238, 391 ; customs, 235, 24I, 273; defense, 237, 239, 258; during American Revolution, $39 \mathrm{I}$; during War of the Spanish Succession, 23I, 234, 237, 25I ; elections, 245, 276; fees, 239, 240; impeachment, 258, 259; indigo, 245; land, 233; Leeward Islands government, vi; negro insurrection, 248, 257 ; political conditions, 235; population, 239, 257; possession, v; powder duty, 248; price regulation, 277; produce, 239; property, 272; public accounts, 234, 237, 239-24I, 246; records burnt, 236; Roman Catholics, 244; sessional papers, 266-268, 279-286, 39 I, 396; shipping returns, 265,286 ; slave trade, $237-$ 239; slaves, 239; taxes, 234; trade, enforcement acts, neutral, 230, 241, 242, 246, 268, $269,275,39$ I ; vital records, 239; see also Leeward Islands

Moodie, Edith, work on present volume, vi

Moore, Lt.-Gov. (Sir) Henry, dispute, I76; letters, I76, I77, I88; letter to, 2 I 5 
Moore, Com. (Sir) John, letters, I 59

Morgan, Lt.-Gov. (Sir) Henry, letters, 389

Moriarty, G. Andrews, jr., "Barbadian Notes," 340

Morne Fortuné, assault, 398

Morne Ver-pré, battle, I29

Morris, Charles, I 40

Morris, Dep. Gov. Robert Hunter, 94

Morris, Gov. Valentine, letters, I49, I50, 263, 298-30 I ; letter to, 298; memorials, 298; report, 149

Morrison, Miss - acknowledgment to, vi

Morrison, Lt.-Gov. Edward, letters, 207, 208; letters to, $2 \mathrm{I} 7$

Morse, Capt. Robert, report, I53

Mortgages, Bermuda, 343

Mosquito, 65

Mosquito Coast, accounts, 187; affairs, I 77, I79, I 80, I 82-I84, I87, I88, I90-I96; American settlement, 206; attack, I86; events, I73; expedition, I96; government for, I7 I ; insurrection, I90; Loyalists, I97, I98; material on history, 122, 123; settlement, 186

Mosquito Indians, assistance by, I 64

Mostyn, Roger, 2 I

Moth (Motte), Gov. Frederick, 250

Mowat, William, declaration, I9

Mules, trade, 35I

Mumford, Capt. Richard, I 7 I

Munnings, Pres. W. Vesey, letters, 39

Munro, see Monro

Murder, see Crime

Mure, Hutchinson, petition, 3 I 5

Murray, Alexander, letters, 34

Murray, Sir George, letters, 350, 400

Murray, John, see Dunmore

Murray, Lt.-Gov. John, letters, I 22

Murray, John, of New York, petition, 192

Murray, William, solicitor general, opinion, 93

Muskogee Indians, see Creek

Mutinies, $17,23,28$

Nancy, 374

Napoleonic Wars, navy in West Indies, 340; privateering, 67, 203, 204, 269, 376, 377; Santo Domingo, 199-20 ; see also Neutral trade.

Nassau, plans, 33I; prisoners of war at, 32; Public Lot records, 332 ; public meeting, I2; records at, 329-334; see also New Providence

Naturalization, as issue in War of 1812,68 ; colonial bills, 157,216 ; in Jamaica, 170, $17 \mathrm{I}$, I90; refusal in United States, 42

Nautilus, H. M. S., 103

Naval office, governor's control, 2I4; for lists, see Shipping returns

Navy, American, in West Indies, American Revolution, 20, 2I, 29-3I, I03, I52, 298, 329; French War, 397

Navy, British, in West Indies, American Revolution, I03, I52, I95, 25I, 299, 3I5, 397; American sailors (I8I4), 39; and civil authorities, $45, \mathrm{I} 60, \mathrm{I} 6 \mathrm{I}, \mathrm{I} 78, \mathrm{I} 8 \mathrm{I}, \mathrm{I} 83, \mathrm{I} 85$, I86, I 88,2 I0, 273, 274; and pirates, I63, 235; and settlement of ceded island's, I 35 ; and trade enforcements, 53, IOO, IOI, IO8, I64, I8I ; at Bahamas, I7; dependence on, 25 ;
King William's War, 389; list (1756), I88; method of recruiting, I 7 ; movements (I 726 ), 166; Napoleonic wars, 340; officers as councillors, 54; Seven Year's' War, I88, 247, 255; trade by, I00, I60, I63, I83, I84, 209; violation of acts of war, 52; War of the Austrian Succession, I8, 91, 21 3, 252, 253, 393; War of the Spanish Succession, 78, I82, I83, 23I, 3I4; see also Convoys; Impressment

Navy, French, in West Indies, American Revolution, I95, I96, 265, 397; list (I756), I88; Seven Years' War, 247, 255; War of the Austrian Succession, 393

Navy, Spanish, in West Indies, I89, 192; American Revolution, I96; list (1739), I 85

Neale, J. E., work on present volume, vi

Negro insurrections, fear, 314; see also islands by name

Negroes, from Jamaica to United States, 203; from United States at Trinidad, 312; murder of slave by free, I40; proportional increase, I93, I94; trades abandoned to, I02; treatment, 340; troops, I30, I4I, I7 I, I86, I 88; see also Slaves; "free negroes" and "negroes" under islands by name

Nelson, Horatio, viscount, 25I ; letters, 265

Nepean, Sir Evan, letters to, 58, 265

Neptune, 374

Netherlands, see Dutch West Indies

Neutral trade, and American-built privateers, 67; and undesired immigrants, 349; Bahamas, 38 , 333; Barbados, 338,340 ; Bermuda, ro8I I I, 342; British Guiana, I2 I, I22; British Honduras, 123, 199, 200, 204-206, 217 ; crisis of 1794, 106, 35I; despatches, I07, I08; detained seamen, I29, 35I; discriminating duties, $68,154,155,205,207,217,268$, $269,291,297,308,338,352-354,357,359$, $362,396,397,403,404$; Dominican needs, 350-353; during American Revolution, I03, I26, I 95, 25I, 26I-264, 3I6; during Seven Years' War, 55, 247, 255, 394; during Spanish and French Wars (I7.39-48), 87, $9 \mathrm{I}-93,99,244,253,393$; during War of 1812, 270, 327, 349, 353, 358, 360; French decrees, I I0; Grenada, I53-I 55; Leeward Islands, 267-269, 283, 284, 29I, 39 I, 392, 395-397; money on seized ships, I09, I55; neutral crew, ro9; permitted and illicit, 36$39,66-68,74,198,200,202,217,323,326-$ 328, 356-362; St. Lucia, 297; St. Vincent, 302, 303, 404; Santo Domingo under blacks, 199-204, 21 7, 305, 330, 379; seizures, 36, 106-108, I 55, 3I I , 323, 35I, 376, 377; Tobago, 306-308, 405; Trinidad, 3I I ; with Spanish West Indies, 36; see also Acts of trade; Free ports; Jamaica; Lumber; Provisions; Trade with the enemy

Neutrality, Genet's projects, 35,36

Nevell, $A d m$. John, journal, 389

Nevine, William, see Nivine

Nevis, acts, 4, 278, 286, 287; agent, 247; archives at London, correspondence of Secretary of State, 286; archives on island, character and condition, 39I; assembly, rights, 246; conditions, $235,236,238$; council, membership, 230; defense, 237, 239, 249, 258, 278, 
392; disorders, Rebel Club, 246; during American Revolution, capture, 265, 392, 395, 397 ; during War of the Spanish Succession, capture, 230, 23I , 233, 234, 27I, 272; fees, 239; free ports, 266; indigo, 245; land, 234; Leeward Islands government, vi; negro insurrection, 236; population, 238, 239, 257; possession, v; powder duty, 249; public accounts, 234, 237, 239, 240, 246; registry, 275; Roman Catholics, 246, 276; sessional papers, 252, 266, 267, 278-282, 287-291, 39 I, 392, 396; shipping returns, 26r, 265, 29I; slave trade, 237, 249; Stamp Act, 256, 391, 392; trade, enforcement, neutral, United States, 230, 246, 266, 268-270, 392; vital records, 237, 239, 240, 249; see also Leeward Islands

New Amsterdam, British Guiana, records at, 347

New Constellation, 374

New England, and island despatches, 92; and Turks Islands, IOI; French complaint, 254 ; lumber trade, 394; retaliation on acts of trade, 323; Surinam trade, 46; see also states by name

New England Historical and Genealogical Register, 340

New France, plans against, 58

New Hampshire, powder duty, r 7o; see also New England

New Jersey, loyal commissioners, 3 I

New Orleans, garrison, I9I; negro refugees to Trinidad, 312; plan to attack, 195; refugees from Santo Domingo, 203

New Providence, capture, 20, 2 I, 29-3I, 329; free port, 25, 26; landholders, I3; pirates, 12 ; plan of harbor, 22; see also Bahamas

New Spain, letter of viceroy, $\mathrm{x} 83$; see also Mexico; Spanish West Indies

New York, currency, I30; Honduras trade, I92; trade with the enemy, 253

New York City, 27, 123, 322

New York Spectator, 396

Newbury, Ioo

Newcastle, Thomas Pelham-Holles, duke of, letters, $48,50,54,57,89$, I68, I 81 , I 84, I 86 , $237,238,240-243,252$; letters to, 53, 58$60,7 \mathrm{I}, 72,98,99,182,2 \mathrm{II}, 2 \mathrm{I} 2,250,252$, 273-275; testimonial to, 23

Newcomb, Thomas, 75 , x I 5

Newfoundland, journal to, 59 ; see also Canada

Newport, R. I., 24, 25

Newspapers, files, $53,56,61,137,164,174,184$, 26I, 306, 332, 339

Newton, Thomas, 91

Nicaragua, expedition, 195-197

Nicholson, - letter, 12

Nicholson, Lt.-Gov. Robert, letter, I 2 I

Nicolay, Gov. (Gen.) William, letters to, 350

Nicoll, Capt. W. Z., 305

Nicols, - of Rhode Island, correspondence, I 7 I

Nisbet, Pres. - correspondence, 392

Nivine, William, agent, memorial, 235, 27 I

Noden, Charles, agent, petition, 89

Noden, R., letter, I7

Non-conformity, 98

Non-intercourse acts, $269,303,308$
Non-residents, tax, 238, 384, 385, 402; see also Absentees

Norman Island, treasure trove, 245, 254

North, Frederick, lord, American threat against, I40; and patron of office-seeker, I40; letters to, 98,140

North Carolina, conditions, 195; see also Carolina

Northam, John, 177

Northey, Sir Edward, attorney general, opinions, 40, 47, 69, 208-210, 23I-233, 272

Norton, Sir Fletcher, attorney general, opinion, 138

Norwood, Richard, survey and map, 34I

Nostra Signora de Bethleem, 163

Nottingham, Daniel Finch, $2 d$ earl of, letters to, 57,314

Nova Scotia, limits, 250; South Sea Company grant, 234; see al.so Canada

Nuestra Señora, 245, 254, 276

Nuestra Señora de la Soledad, 20, 25

Nugent, Lt.-Gov. (Gen.) George, letters, 200, 201, 203, 204; letters to, 201, 202, 217

Nugent, Lt.-Gov. John, letters, 266

Odell, Col., letters, 196

Officers, absenteeism, I43; appointment and removal, 46, 70, 72, 93, I 14, I74, I76, I77, 214, 215; conformity, I62; in council and legislatures, $51,54,72,90,113,173,212$, $2 \mathrm{I} 4$; of colonial secretary, 6o, 69, 245, 273, 275; patent, $x 84,212$; pluralism, 209, 211 ; see also Fees; islands and offices by name

Oglethorpe, Gen. James Edward, letter to, 27; report, 253

Oliver Cromwell, 65, I5I

Onslow, (?) Thomas, letter to, 162

Orange, 359

Ord, Capt. George, 102

Orde, Gov. John, complaint against, 125; instructions, 124; letters, 125, 127, I28

Orders in council, see Privy Council

Ordinance for A ssembly in St. Vincent, 144

Ordinary, office, 245

Ordnance, see Defense

Orkney, George Hamilton Douglas, earl of, letters to, I6I, 210

Osborne, Francis G., see Carmarthen

Otway, - correspondence, I79, I 88

Oxenford, John, letters, 50, I68

Oxford, 45,69

Pacifique, 374

Packet service, see Communications

Packett Boat, 87

Page, Samuel, deposition, 22 I; petition, 22 I

Paine, Capt. -, 64

Paine, Sir Charles, petition, 242

Palatines, 22

Pall Mall, 241, 243

Panama, 18, 46, 186, 242

Paper money, act, 47 ; bills of credit, $48,69,71$; parliamentary inquiry, 52

Pareja, Gov. Agustin, correspondence, 254

Parham, Antigua, port, 249, 269

Paris, Peace of ( 1763$), 62$, I4 I

Parish, see Church of England 
Parke, Gov. Daniel, complaint against, 249; death, 270 ; letter, 4

Parker, David W., work on present volume, vi

Parker, Sir Hyde, letter, I99; letter to, 199

Parker, Adm. (Sir) Peter, 264

Parker, T., letter, 2 Io

Parliament, and colonial assemblies, I9I; and West Indies, 7I, I79, 208, 209, 2 I I, 2I4, $215,237,243$

Parris, Alexander, indenture, 344

Parry, Gov. David, commission, 74 ; letters, 58 , 65,66 ; letters to, 66,74

Parry, $A d m$. William, correspondence, 259, 277

Partridge, Capt. Joseph, letter, I36; memorial to, I I I

Paul, Pres. - letter, 303

Paul, Capt. Robert, letter, I 36

Paullin, Charles O., Guide to Materials in London Archives, iii

Paxson, Frederic L., Guide to Materials in London Archives, iii

Payne, Gov. Ralph, see Lavington

Peisby, Francis, letter to, 247

Pelham-Holles, Thomas, see Newcastle

Pembroke Parish, Bermuda, records, 347

Penguin, I77

Peniston family, papers, 347

Pennsylvania, trade with the enemy, 253

Pensacola, I95, I96

Pensez-y-bien, plantation, 237, 27 I

Penson, Lillian M., work on present volume, vi Perceval, (?) Spencer, 25 I

Pérez, Luis M., work on present volume, vi, 374n.

Perry, Micajah, testimonial, 23

Peru, conditions, I 8; conspiracy, I 86

Petty, William, see Shelburne

Phebe, 374

Phenny, Gov. George, commission and instructions, 40; letters, I3-I5, 22, 23; letter to, 4I; memorial, 22; misgovernment and wife, I4, I5, 23, 4I

Philadelphia, and Mosquito Coast, I9I; coal as ballast to, 322; illicit trade, I9, I72; privateer, 30

Philafricanus, "Progress of a Planter," 390

Philippo Quinto, 87

Philips, Gov. Richard, 342n.

Phillip, - , report, 253

Phillipps Collection, 389,390

Pickles, William, 255

Picton, Gen. Thomas, letter, 310 ; letter to, 305

Pierce, Córnelia M., work on present volume, vi

Pigott, John, memorial, 98

Pilotage, cost, 24

Pindars River Estate, 390

Pinfold, Gov. Charles, commission and instructions, 73 ; letters, $55,56,6 \mathrm{I}, 62$, 306; letters to, 62,73

Pink Pheasant, 238

Pinnock, Ch. J., I 88

Pinnock, Philip, 2 I 5

Pirates, courts and trials, I2, I $3,20,22,25,28$, 69,89, I 38, I 49, I 56, I63, I 65, I 87, 276; description, I64; experiences with, I2; infestation, 87, I63; pardon, 3I5; Spanish West Indies, 62, 63, 189, 242, 252; Virginia, 163; see also islands by name
Pitman, Frank W., British West Indies, 180

Pitt, Lt.-Gov. John, II 5 ; commission and instructions, 90, II 3 ; letters, 89 , 98; letter to, II 3 ; salary, 89

Pitt, Thomas [I], Bahama lease, I5; letter to, 12 ; memoranda, I 81,210

Pitt, Thomas [2] see Londonderry

Pitt, William [I], see Chatham

Pitt, William [2], 395

Pluralism, 209, 2 I I

Poisson Volant, 201

Poll taxes, 20, 47, 49, 384-386

Polly, 374

Popple, Gov. (Sec.) Alured, commission and instructions, I I 3 ; letters, 90-92, 99, I I 5; letters to, 88,99 , II 3,24 I; memorial, 90

Popple, Henry, memorial, I 7

Popple, Sec. William [r], grant, 237, $27 \mathrm{I}$; letter to, I63

Popple, Gov. William [2], commission and instructions, 94, I I 3, I I 4; complaint against, 93; deposition, 93; letters, 92-95, 99; letters to, 9I, 94, I I 4; memorial, 99; salary, 92, 93

Popplewell, George, 75

Population, sée islands by name

Port Antonio, Jamaica, as port, I77, 229, 230; defense, plan, 192

Port au Prince, capture, 305; occurrences, 202

Port de Paix, I99

Port Island, 348

Port Louis, capture, 24, I 7 I

Port of Spain, records at, 405, 406

Port Royal, Jamaica, hurricane, I60, I65; parish records, $347,364,384-386$

Port Royal Harbor, Ruatán, plan, I 86

Portland, Henry Bentinck, Ist duke of, commission and instructions, $70,165,212$; letters, I66, I 84; letters to, I84, 2 I I, 212

Portland, William H. C. Bentinck, $3 d$ duke of, correspondence, 66, I4I, I99; see also Bentinck, Gov. William Henry

Portland Parish, Jamaica, records, 364

Porto Bello, attack, I86; trade, 46, I67, I 83

Porto Plata, 9 I

Porto Rico, correspondence of governor, 246, 254, 259; information on, 258; plans against, 250 , 3I 5; see also Spanish West Indies

Ports, see Free ports; islands by name

Post office, see Communications

Postillion, 322

Potter, Capt. Simeon, 322

Powder, island trade during American Revolution, 64, I02, I03, I I0, I 94

Powder duty, enforcement, I70; see also islands by name

Powell, Lt.-Gov. James Edward, letters, 33

Powell, Rowland, 389

Pownall, John, 2I 4 ; letter, 73 ; letters to, 95. 96, I 35,192

Pratt, John J., see Camden

Prescott, Robert, letters, 316, 397

Prevost, Gov. (Lt.-Gov.) George, letters, I3 I, 297

Prices, current, 24, 59, I25, 204-208, 298, 398; regulation, 277 ; rum, 387 ; slaves, 160

Prince Charles of Lorraine, 322

Prince Regent, 68

Prince Rupert's Head, Dominica, 28 
Princess Amelia, 60

Pringle, Pres. Walter, letter to, 138

Prisoners, see Crime

Prisoners of war, Bermuda cartels, 342, 344; recruiting among, 196, 217; Scottish servants, 186; see also wars by name

Privateering, American vessels for French (I 806), 67; Buenos Ayres, 350; colonial letters of marque, 126, 315; crews of captured, 197; crown claim to prize money, $9 \mathrm{I}$; depredations by Spanish (I728), I84; ignoring flags of truce, 92; land forays, 9I, I53; records, $333,344,375,376$; ships built for enemy, 253; without commission, 270; see also Pirates; wars by name

Privy Council, judicial appeals to, 52, II 3,2 IO, 212, 273; orders: absentees, I7I, I78, 243, 244, 248; assemblies, 136, I 72, 235, 245, 248 ; Bahama proprietors, I3, I5, I6; bills of credit, 48; chancery, 245,248 ; correspondence, I55; councils, 5 I, 54, I77, I79; courts, $20,235,272$; defense, 18, 53, 89, 90, 232, 244 , 247; Dominica, I24, I38; entry books of, to governors, 278; Gov. Hart, 236; governor's instructions, 47, 94, I65, 235, 243; Guadeloupe, 248; land grants, I68, I69; new islands, I 36, I39; ordinary, 245; petitions from sugar colonies, 50; powder duty, I70; privateers, I70, 345; prizes, 23I; Quaker affirmation, 48; Roman Catholics, 233, 245; salaries, 50, 53, 89, 92, 235, 238, 239; slave trade, I66, I68, I69; South Sea Company, 234; trade, 46, I04, I65, 242, 250, 326, 327, $345,349,352$; white servants, 167

Prizes, appeal in cases, 107, I08; by Genet's privateers, 35 ; duties on goods, I $83,208,209$, 2I 5; prize money, governor and, 234, 3II ; records, $88,346,373-377$; royal share, 88 , 9I, 97; specie on, 12 I, 207, 208, 304; with neutral crew, ro9; see also Admiralty; wars by name

Probate and administration, records, I73, 33I, $333,340,342,343,355,365$

Probyn, Gov. Thomas, letter, 397

Proceedings of Jamaica Assembly, 198

Proclamations, see islands by name

Produce, see Agriculture

Property, Barbados, 49; British West Indies, 3I3; colonial laws and conditions, I73; escheats, I7, 60; free negro holdings, I79; Jamaica records, 365,366 ; quieting possession, I72, I73, I83, 208-210, 216, 233, 239, 272, 274; see also Debts; Probate; Taxes

Proprietors, see Bahamas

Providence, U. S. S., 30

Providence Journal, 396

Provisions for West Indies, American Revolution and, $21,64,65,98,102-104,126,133$, 260, 263, 318, 337, 339, 391, 392; Dominican customs, 354, during Seven Years' War, 394, 396; for British Honduras, and acts of trade, I23, from Spanish colonies, I4I; island acts on trade, 275; neutral trade, 35, I09-III, I2 I, I22, I 29-133, I 54, I 55, I99, $204,206,267-269,297,303,307,308,3 I I$, $3 \mathrm{I} 8,35 \mathrm{I}-353,357-362,392,395-397,403-$ 405; price regulation, 277 ; scarcity in $\mathrm{Ba}$ - hamas, I7; United States peace-time trade' I 28, 339, 395, 397, 399, 40I-403; War of I 812 and, 68, 349, 406; see also Acts of trade; Fish; Neutral trade; Trade with the enemy Provost marshal, fees and regulations, 55, 173, 215 ; office, 73 ; proceedings, 169 ; tenure and power, 2I2, 214

Public accounts, see islands by name

Public Acts in Force, Barbados, 340

Public debts, 49, 59, 243

Public Record Office, "General Catalogue," 3 ; West Indian material in general series, 2; see also Colonial Office Papers

Public vessel, Bahamas, I2

Puerto Cabello, 253

Pullein, Lt.-Gov. Henry, commission and instructions, I I2; letters, 87

Pulteney, Sir William, 54

Pulteney, William, letter to, $\mathbf{1 4 8}$

Purcell, Lt.-Gov. John, letters, 246; letters to, 246,276

Putnam, Israel, letter to, 260

Pye, Adm. (Sir) Thomas, letter, roI

Quadruple Alliance, War of the, in West Indies, I2, 87

Quakers, affirmation, 48, 70; and negro regiment, I 30 ; Barbados, 335, 340; Bermuda, 345

Quartering, regulations, 324

Queen Anne's War, see Spanish Succession

Queen of Hungary, 322

Quieting possession, see Property

Quit-rents in West Indies, 314; see also" lands" under islands by name

Rainbow, 374

Randolph, Edmund, letter to, 107

Ranger, 20, 42

Ranger, H. M. S., 145

Rattan, see Ruatán

Rattlesnake, 300

Rawlins, Gov. Henry, letter, 270

Reade, Gen. - , report, 253

Rebecca, 24, 89, 359

Rebel Club, Nevis, 246

Receiver general, IOI, I8I, 2 I0

Recovery, 374

Redhead, Samuel, 9

Rédonet, Capt. Etienne, 377

Reference aids, to Colonial Office Papers, 3, 4; see also Indexes

Registers, ship, British, for American vessels, I04; flag without, IO9; lack, I4

Registers of Board of Trade correspondence, 3

Registry, archives in office, Bahamas, 330, 33I; Barbados, 340; established, 245; colonial secretary and, 245, 273; Nevis, 275

Religious liberty, declaration, 218

Remsen, John, letters, 62, 256

Report of Jamaica Assembly as to Trade, 200

Representation, British theory, 26

Reprisal, 326

Reprizal, 26I

Reserve, 377

Resolute, 374

Revenge, 359 
Revenue, use of surplus, 180, 191, 194, 216; see also "public accounts" and "revenue" under islands by name

Reynolds, James Joshua, deposition, 264, 395

Rhode Island, cartel, $342 \mathrm{n}$; colonial privateers, 91, 99, 322; island trade, 90, 99, I7 I, 253, 393; light coinage, I92; salt trade, seizure, Ioo; trade with the enemy, I77, 21 5; see also New England

Rice, war-time trade, 103

Richards, Capt. Nathaniel, 322

Richardson, Rev. Alexander, diary, 347

Riche, 374

Richie, - of Philadelphia, 256

Richmond, Charles Lennox, 3 rd duke of, letter to, 189

Ricketts, Gov. George P., commission, 74; letters, $66,306,351$; proclamation, 306

Ricouart, Louis B., Chevalier de, intendant, 232

Riders to bills, 159, 163, 180, 190, 2 I I

Rigaud, 267

Riots, soldiers and suppression, 258, 259

Riou, Capt. Edward, letter, 396

River-master, 318

Road Harbor, 268

Robertson, James, letter, 268

Robinson, E., letters, 200

Robinson, John, letter, I92

Robinson, Gov. (Lt.-Gov.) Richard, on public papers, I 16

Robinson, Sir Thomas, commission and instructions, 72; complaints against, 54; letters, $53,54,60,81$; memorial to, 58

Robinson, William Davis, petition, I54

Robley, Pres. — , letters, 307

Robley, Joseph, letter, I $5^{8}$

Rochester, Laurence Hyde, Ist earl of, letter to, I 83

Rochford, William Henry Zuylestein, 4th earl of, letters, I93, 248

Rodney, $A d m$. George B., baron, r93; letters, $266,282,316,397$

Rodney dit Rédonet, Capt. Etienne, 377

Roger, 374

Rogers, Capt. - letter to, 107

Rogers, Gov. Woodes, and Bahamas, 13, 15, 16, $2 \mathrm{I}-24$; commission and instructions, $40,4 \mathrm{I}$; death, I6; letters, II-I 3, I5, I6, 22; letters to, I2, 40, 4I; petition, 22

Roman Catholics, colonial legislation, I67, I83, 233i in ceded islands, rights, $137-139,141$, $143-145,147,156$; in Leeward Islands, 244$246,272,275,276$; servants, I83, 2 I 2

Rose, Joseph Warner, 269

Rose, H. M. S., I 8, 396

Roseau, Dominica, 126, 395; archives at, 348-355

Rosencrantz, - memorial, 246

Ross, Daniel, 262, 263

Ross, Thomas, letter, 24

Ross, William, letter, 203

Rous, Pres. Samuel, letters, 56, 62

Rover, 374

Royal African Company, 46, 48, 59, 70, I65, I66, 229n., 230; agreement, 3 I 5

Royal American Regiment, 326

Royal British Asiento Company, 165; see also Asiento
Royal Commission on Public Records, Second Report, 320

Royal Rover, 337

Royall, Isaac, 322

Royalties of Bahama proprietors, I3-I5

Ruatán (Rattan) attack, 186; plan, 186; settlement, 186, 196; troops, 98

Ruddach, Charles, letters, 390

Rufane, Gen. William, letter, I 35

Rules and Articles of War, I9I

Rum, prices, 386; trade, 46, I03, I21, I22, I69, $230,269,303,325,328,351,352,357,358$, $393,401,402,404$

Russell, Capt. - , letter, $5^{8}$

Russell, John, see Bedford

Russell, Thomas, letter to, 260

Rutherford, John, memorial, 3 Io

Rutledge, John, 32

Ryder, Sir Dudley, attorney general, opinions, 58,93

Sail Cloth Act, 9I, 93

St. Andrew Parish, Grenada, port, 158

St. Andrew Parish, Jamaica, records, 175, 364

St. Ann Parish, Jamaica, records, 364, 386

St. Bartholomew, and War of 1812,270 ; attacks and capture, $244,245,247,248,253,396$; neutrality, 250; Swedish tariff, 265

St. Catherine's, Jamaica, I69; parish records, 364

St. Christopher, see St. Kitts

St. Christopher Gazette, 26I

St. Croix, affairs, 238; archives at London, 291 ; British trade, 393; claims, 49, 52, 71, 237240, 249, 252, 273, 274; Danish purchase, 72 ; immigration from other islands, 246; neutral trade, 29I; settlement, 232, 233, 272; Spanish seizures at, 58; see also Danish West Indies; Virgin Islands

St. David Parish, Jamaica, records, 364, 369

St. Dorothy Parish, Jamaica, records, 364

St. Elizabeth Parish, Jamaica, records, 364

St. Eustatius, and American Revolution, captures, 25I, 252, 316, 397; English archives, 292; possession, v; see also Dutch West Indies

St. George, 186

St. George Basseterre Parish, St. Christopher, 239

St. George Parish, Jamaica, records, 364

St. George's, Bermuda, as port, 95, 99, 100, 104; corporation and parish records, 347

St. George's, Grenada, archives at, 355-362; fire, 147; free port, I 54; town lots, 137

St. James, 98

St. James Parish, Jamaica, records, 364

St. John, Henry, see Bolingbroke

St. John Island, claims, 242, 249, 274; see also Danish West Indies; Virgin Islands

St. John Parish, Jamaica, records, 364

St. John's, Antigua, fire, 257; records at, 32 I328; trade, 249, 269

St. Kitts, absentees, tax, 244, 272, 275; acts, 292; acts in force, 24I; admiralty, 263; agents, 239, 240, 244, 247, 394, 395; archives at London, correspondence, 292 ; archives on island, character and condition, 392; assembly rights, $237,238,243,248,257,275$, 
277; chancery, 248, 257, 274, 277; church, 239; council, franchise of councillors, membership, 239, 248, 249, 258, 259, 275, 277; courts, 236, 272, 274; customs, 237, 24I ; defense, 230, 249, 25I, 254, 258, 3 I6, 393397; during American Revolution, attitude, French occupation, 251, 260, 262, 264, 265, 316, 394, 395, 397; during Seven Years' War, privateers, 247, 255, 394, 396; during War of I8I2, 395; during War of the Austrian Succession, privateers, 253, 393; during War of the Spanish Succession, invasion, 230, 23I, 233; elections, suffrage, 238, 248, $249,258,259,273,277$; fees, 238-240; fire and hurricane, 394 ; free ports, 266 ; internal affairs, disorders, 25I, 258; licenses, 240; liquor duties, 240, 24I; land, French holdings, 23I-237, 27I-273; Leeward Islands, government, vi; map, 240; militia, 23I ; negro insurrection, 254; population, 230, 238, 257; possession, v; powder duty, 240$242,248,249$; property, acts, 239, 272; public accounts, 240-242, 246; pubiic debt, 243; Roman Catholics, 244, 275; sessional papers, $252,266-269,278,280-282,292-296,393^{-}$ 397; settlement, 23I, 272; shipping returns, 261, 296; slave trade, 237, 240, 245, 249, 395; South Sea Company grant, 234; Stamp Act, 256, 394, 396; taxes, 242; trade, enforcement, neutral, United States, violations, 50, 230, $244^{-246}, 255,266,268,269,275,393,395^{-}$ 397 ; vital records, 238, 24I-243, 249; see also Leeward Islands

St. Leger, Anthony, letter, 3 I 6

St. Leger, Sir John, letter, 23 I

St. Lucia, and American Revolution, attack, 316, 3I8; and Caribs of St. Vincent, I45; archives at London: correspondence, 297; entry books, 3 I 7; miscellaneous, 297; archives on island: character and conditions, 398, 399; despatches and entry-books, 399-402; local correspondence, 402 ; claims, neutralization, $46,47,49-55,57-62,7 \mathrm{I}-73,235,24 \mathrm{I}, 242$, 249-254, 297, 298; defense, 3I6, 3 I 8; free ports, 297, 325, 401, 402; French occupation, 247 ; governors, commissions, $40 \mathrm{I}$; grant, $47-49$, 70; hurricanes, 398, 400; non-residents, tax, 402; possession, v; sessional papers, 40I, 402; settlement, 47; Spanish seizures at, 58; trade, illega1, neutral, United States, 50, 297, 325, 399-402; uninhabited, 88; see also French West Indies; West Indies; Windward Islands

St. Martin, captures, 248, 25I, 253, 254, 316; neutrality, $240,250,274$

St. Mary Parish, Jamaica, records, 364

St. Michael, Barbados, 63

St. Nicholas Mole (Cape St. Nicholas), trade, 26, I09, I90, I9I

St. Paul's Parish, Nevis, records, 239

St. Peter's Church, Bermuda, records, 347

St. Philip's Parish, Antigua, records, 242

St. Thomas Island, claims, 232, 249, 272; correspondence of governor, $249,25 \mathrm{I}$; free port, 268; illicit English trade, 394; settlement 233, 236; see also Danish West Indies; Virgin Islands
St. Thomas the East Parish, Jamaica, records, 364

St. Thomas the Vale Parish, Jamaica, records, 364

St. Toolie Estate, 390

St. Vincent, acts, 304, 404; and American Revolution, capture, 298-300, 3I5; and Barbados, 74 ; archives at London: correspondence, 298-304; entry-books, I 57, 304; archives on island, character and condition, 403, 404; assembly rights, I36, I38, I 43, I 44, I49, I 50, I 56, 298, 299; botanical garden, I48; Caribs, I25, I38, I39, I 45-I48, I 50, I 56, 300; chancery, I 45, 298; church, I 38, I 45, I 56 ; claims, neutralization, $47,49-55,57-62$, $7 \mathrm{I}-73,24 \mathrm{I}, 242,250,252-254,298$; conditions, I 36, I 37, I 49; council, membership, 298, 358; customs, I 38, I 45, 298, 300; defense, I 35, I 39, I 4I, I 44-I 47, 299; elections, 298; exchange, 298, 300; exchequer, 300; foreigners, 303; free ports, 303; French in, I46; government, separate, I 36, I 37, I 42I 44, I56, 298; governors: commissions and instructions, 298, 304, 3I7; salary, 298; grant, 47, 70; in Leeward Islands, $25 \mathrm{I}$; land grants, rent, I37, I 40 , I 43, I46, I 50, I 55 , 298-300, 3I4; occupation, I 4I, I 42; political unrest, I49, I50; population, 3 I 4 ; possession, $\mathrm{v}$ : prices, 298; proposal (I 762), 282; sessional papers, $282,30 \mathrm{I}-304,358,403,404$; settlement, 62 , I 36 , I 42 ; shipping returns, 30I, 304; slaves, I 36 ; town regulations, I 38 , I 39, I 56; trade, neutral, United States, 230, 30I-303, 403, 404; see also West Indies; Windward Islands

Salamander, 89, 97, I I 3

Salaries of officials, 28,48, I25, I 35, I 78 ; see also "governor" under islands by name

Salem, Mass., 20

Salt, export in foreign vessels, 37 ; method of collecting, IOo; naval interference with trade, IOO, IOI; proposed monopoly, 94; trade during American Revolution, 31, 32, I 03, 265; see also Bahamas; Turks Islands

Saltonstall, Capt. Dudley, 30

Salvage, claims, 323

San Pedro, attack, I97

Sancta Reta, 252

Sandy Point, St. Kitts, 269

Santa Cruz, see St. Croix

Santa Rita, 9

Santiago de Cuba, attack, I7 I, I82, I87; trade, I 85

Santiago de la Vega, Jamaica, see Spanish Town Santo Domingo (Hispaniola), American ordnance purchases (I799), I99; and Bahamas, I 2 ; attack (I 748), I 7 I ; baptisms, 305; British occupation, 305; British records, 205, 206, 304,305 ; British trade seizures, I82; capture of governor, I 83 ; conditions ( 1807 ), 205; exports, 304; forces, 82; French designs against British trade, 42; French plans to retake, 20I ; French trade captures, 203, 204; governors, instructions, 3I7; in War of the Austrian Succession, 305; Jamaica trade, 2 I I n neutral trade, 357 ; plan against (I779), I95; plantations, 305 ; refugees, 203 ; 
settlement, 209; trade negotiations under blacks, 199-204, 217, 305; trade with English mainland colonies, I72, I73, I94; see also Monte Cristi; St. Nicholas Mole

Santo Domingo (city), plan, 206

Sargent, Diamond, 342n.

Saunders, Robert, petition, 209

Savanna de la Mar, I77, 205, 229, 230

Savannah Packet, I02

Savy, John, 24

Scarborough, Tobago, records at, 405

Scarborough, H. M. S., I OO, IOI, 258

Schools and schoolmasters, 58, 70, I 12, 345, 346

Scorpion, H. M. S., IO2

Scotland, emigration to Trinidad, 3ro; illicit trade, I75; military prisoner-servants from, I 86

Scott, Lt.-Gov. George, I 36; complaints against, I 42 ; land grants by, I37; letters, - 135, I36, I 4 I ; letters to, I 37, I 4 I, I 55

Sea Flower, 403

Seaforth, Gov. Francis Humberston Mackenzie, baron, letters, 67 ; letter to, 74

Seal fishery, I3

Seals, 72, 330

Search, see Impressment; Neutral trade

Secretaries, see Colonial secretaries

Secretary of State, character of letters to, 183 , 2 I4, 248; papers, scope, I, 2; see also Correspondence

Sedgwick, Edward, letter, I35; patent, I 58

Selwyn, William, letter, $5^{8}$

Sessional papers, in Colonial Office Papers, 3; see also islands by name

Seton, Lt.-Gov. James, commission, 298; letters, 301,302

Seven Plantations Estate, 390

Seven Years' War, in West Indies, and peace, cessions, 62, I4I ; convoys, I 88; neutral trade, $55,247,255,394$; preparations and operations, I9, $55,94,95,99$, I 76, I 77, I 88, $247,248,255,282,283,394,396$; prisoners of war, 20, 6I, I76, I 88, 247, 394; privateering, I9, 20, 24, 95, I 76, I $83,247,248,255$, 394,396 ; prizes, 55 ; records, 334,339 ; trade with the enemy, flags of truce, I9, 20, 25, 55,6 I, I 76-I 78, I88, 2 I 5, 247, 255, 394

Sewell, Robert, agent, 386n.

Seymour, Lord Hugh, 200

Seymour, Gov. Richard, commissions, $40 \mathrm{I}$

Shark, H. M. S., I7, 298

Sharpe, Charles, 299

Sharpe, John, agent, letters, 50, I 70, I82, 242, 276; letters to, 58; petitions, I70, 247

Sharpe, Pres. William, letter, 46; letter to, 69; testimonial, 59

Shee, Sir George, letter to, 67

Sheffield, John Baker Holroyd, Ist earl of, correspondence, 3 I 3

Shelburne, William Petty, 2d earl of, letters, 25, I00, 137; letters to, I00, I42, I43, 189, I90

Shelton, Richard, letter, I 5

Sheppard, Capt. Thomas, 62

Sherlock and Lowry, 227

Shettlewood, William, letters, 389

Shingles, price, 59
Shipbuilding, Bahamas, 15, 16, 29; Bermuda, $90,95,345$; details, 322

Shipley, Gov. (Sir) Charles, letter, I 55

Shipping, Bahamas, regulations, 16, 20; Barbados, 48; Bermuda, forms, 342; cases, 9, 14; coal as ballast, 322 ; damages by hurricanes, I60, I65, I66; French and Spanish, I92; in distress, 156; insurance, 323 ; lists, registers, 9 I, I 59, I 75, 229, 230, 323, 344; passes, I 45, I 46, 342; protests, 34I, 344, 345; requisitioned, 24; taxes, I69, I79; see also Shipbuilding; Shipping returns; Shipwrecks; Trade

Shipping returns, in Colonial Office Papers, character, 3 ; see also islands by name

Shipwrecks, on Florida coast, 12; records, 333; salvage, I6; Spanish, treasure ships, I63, I84, I $85,245,249,252,254,276$; wrecking, 23, $29,87,93,94$, IOI, IO2

Shirley, Gov. Thomas, and command of troops, 27; and Turks Island, 26-28, I02; commissions and instructions, 42 , I33, 277; complaints against, disputes, 28-30, 126; letters, $26-29$, 126, 265, 266; letters to, 26, 27, 29, 126, I33, 277; memorial, 26; proclamation, 395; promotion, 29

Shirley, Gov. William, and trade with the enemy, I 9, 20; commissioner, memorials, 250, 297; commissions and instructions, 4I; letters, I9, 20, 25, I 89; letters to, 25, 42; salary, 25 Shoes, trade, I 25

Shute, Gov. Samuel, testimonial, 23

Shuttleworth, I., letter, 58

Silhouette, $\longrightarrow$, commissioner, memorials, 297

Silver mines, r 70

Simcoe, Gen. John Graves, letters, 305

Skene, Sec. Alexander, 47, 69

Slave trade, English objection to colonial duties, 56; French absorption, 393; general statistics, 314 ; in foreign bottoms, 128; instructions, 305; monopoly, I60, I6r; movement to abolish, 318, 3I9; opposition and negro unrest, 314 ; private, 166,315 ; requirement of returns, II3; smallpox, 258; see also Asiento; Royal African Company; South Sea Company; islands by name

Slavery, abolition, 386; Methodist Church missionaries, 396; see also Slaves; Slave trade; islands by name

Slaves, governor's allowance, 93, 95; Indians from Spanish possessions, I 85; see also Fugitive slaves; Negro insurrections; Slavery; islands by name

Sloane, Hans, testimonial, 23

Smith, - 263

Smith, Capt. Benjamin, 253

Smith, Capt. James, petition, 338

Smith, Resolve, intercepted letters, trial, 299, 300 Smith, Thomas, letter, 94

Smith, Sec. Wavel, and council, 239; disputes, 236, 237, 249; letters, 238, 254, 273

Smith, Pres. William, letter, I I I

Smuggling, inter-island, I7; prevalence, I93; see also Trade

Snow, Capt. George, 186

Soldiers, see Army

Some Observations on Exportation of Sugar, 52 
Somerset, Henry, see Beaufort

South America, trade (1824), 350

South Carolina, and island despatches, 92, ror, I02; and Spanish plan (1742), I86; Barbados relief, 339; cartel, 32; conditions (I778), 195; Irish servants for, I Io; land indenture, 344; Loyalist recruiting, 196; privateers, I03; see also Carolina

South Sea Company, and Campeachy, 213; and colonial duties on slaves, I63, I65, I67-169, I8I, 210-2 I2, 230; damage to Spanish trade, I64; factors, 24; illegal aid of Spanish, I85; land grants, 234, 235; memorial, I6I ; operations, trade, I67, I82, I84; stock for sufferers $23 \mathrm{I}$

Southampton Parish, Bermuda, records, 347

Southwell, Edward, testimonial, 23

Spain, war threats, 60, 139, 184, 252; see also Austrian Succession, War of, and other wars by name; Spanish West Indies

Spanish Asiento Company, 63

Spanish Succession, War of, in West Indies, convoys, 277; flags of truce, I60; Leeward Islands, $45,78,230,23 \mathrm{I}, 233,234,237,25 \mathrm{I}$, 271, 272; movements and defense, 98, I82, I 83, 3I4, 315, 325; prisoners of war, 45,59 , I83, 25I, 3I6; privateers, I 84, 23I; prizes, $45,46,59,97,182,231,316$; trade with the enemy, flags of truce, I6o, I6I, I83, 315; truce, 59, I 84

Spanish Town, Jamaica, I69; and seat of government, I74-176, 184, 187, 214, 363n.; pirate trial, 187; records at, $363-370,372 n$.

Spanish Town, Virgin Islands, government, 274 Spanish War of 1739 , see Austrian Succession, War of

Spanish West Indies and mainland, advice boat seizure, 247, 255, 276; and American Revolution, 32, 195-197, 263, 264, 329; and fugitive slaves, 25, 27, I40, I48, I7 I, I87, I90, I9I, 246, 254, 260; and Seven Years' War, 24, I88, 274; Bahamas, I I, I2, I4, I 7, 22-25, 32, 40, 329; British Honduras, I90; British kidnapping of Indians, I 85; British navy's trade, I60, I63, I84; British trade seizures, $56,62,63,162,163,174,178,179,233,243$, $247,250,255,276$; 315; Campeachy, 232; conditions, description and information, I83, I90, I92, 258; Crab Island, 236, 248, 259, 260; Georgia, 24; Guiana, 6I, 63; international island trade, $30,46,47,69,70$, I35, I4I, I45, I46, I6I, I64, I68, I69, I72, I 79, I $80,182,183, x 85$, I 88, I $93,216,276$, 3I5; land attacks by privateers, 9I; light coin, 193; Mosquito Coast, I87, 188, I9I, I93; piracy, I2, I3, I64, I 89, 242, 252, shipping in distress, 156; shipping movements, I92; shipwrecks, treasure, I84, I85, $245,254,276$; slave trade, I28, I6I; trade, regulations, I8I, I83, 193; trade seizures by guarda costas, I 2, I 4, I6, I8, 26, 49, 5I, 58, 60, 87, 89, 97, I00, I I2, II, 163 , I69, I $82,184,185,187$, I $91,195,2$ I0, 233 , $237,238,242,243,248-250,253,254,259$, $272,315,387$; trade with the enemy, 3I5; threats and war preparations, I 8I, I82, I9I, I92, 233, 250; troops and defenses, I89, I92,
193, 195, 196, 315; Turks Islands, 94, 98; United States trade (I799), 36; Virgin Islands, 237, 24I, 245, 249, 252, 272; see also Asiento; colonies and wars by name

Speaker of assembly, royal confirmation, II 3 Speedwell, I77, 346n.

Spooner, Pres. John, letters, 67, 68

Spotswood, Alexander, I63; certificate, 87 ; letter, 2I; military instructions, 3I5; testimonial, 23

Spry, Gov. William, commission and instructions, 74 ; letters, 56, 63

Stamp Act in West Indies, $25,56,96,100,179$, $\mathrm{I} 89,256,391,392,394,396$; lists of documents, $99,142,189,256$

Stanhope, James, Ist earl, 2I; letters, 46, I62, 27 i ; letters to, I6I, 2 IO

Stanhope, Lovel, agent, letters, I76, I78

Stanhope, William, see Harrington

Stanley, Pres. John, letters, 267

Stanton, George Leonard, I39, 15I, 157

Stanyan, Temple, letter, 50

Stapleton, Sir William, orders, 278

Statesman, $25 \mathrm{I}$

Staves, scarcity, 339

Steele, Capt. John, I9I

Stephens, W., 6I

Stevens, Edward, 199, 20I ; letters, 201, 202, 305

Stevenson, Cornelius, 262, 263

Stewart, Charles, letters to, 390

Stewart, John, letter, $\mathbf{I}^{2} 2$

Stiles, John, letter to, I I9

Stirling, William Alexander, lord, 3 I

Stokes, Anthony, letter, 33

Stone, Andrew, letter to, 99

Stone, M., letter, I 40

Stone, William, letter to, 99

Storer, Mrs.—, letter to, 260

Strahan (William Strachan), report, 88

Strickland, Sir William, letter to, I6

Stuart, Lt.-Gov. William, capitulation, 354; letters, $125^{-127}$

Suffolk, Henry Howard, I2th earl of, letter, I50 Suffrage, 15, 23, I37, I44, I45, I61, 273; see also Elections.

Sugar, as currency and standard of value, 235 , 324; British and foreign trade, 46, 47; direct foreign trade, I69, 243; duties, 235, 243, 3I4, 386,394 ; expected effect of sugar act, 72 ; hogsheads, 259; illegal trade, 50, 71, 95, 136, I4I, I 54, 2 I 4, 325, 362; industry, I 5, 95, 272, 328, 361, 390; Molasses Act, approval, enforcement, 185, 213; neutral and war-time trade, $68,269,35^{2}, 357,35^{8}$; pest, I49, I5O; prices, I $7 \mathrm{I}, 3 \mathrm{I} 3$; report on trade, 50; trade, 46, 52, 57, 58, 69, I03, I2I, I22, I98, 230, 238, 31 3, 337, 339, 389, 395; see also Trade

Sullivan, John, letter to, 268

Superb, IO3

Surinam, and American Revolution, 64; and Spanish (1754), 6I; British archives, I22, 305, 306; capture, 45; history, 305; trade, 46, 306; see also Dutch West Indies.

Surveyor general, colonial, and council, 5I, 90; charges against, 243; term, 72

Surveyor's department, records, 33 I 
Surveys, 34I

Suspending clause, see Acts

Sutton, Edmund, 59, 60

Swansea, I 4

Sweden, American trade under flag, 3I6; and Tobago, 7I ; tariff at St. Bartholomew, 265

Swift, 301

Sydney, Thomas Townshend, Ist viscount, letters, 74, I25, I4I ; letters to, 58, 265

Symmes, Andrew, and Turks Islands, correspondence, 25-29, 42

Symonds, Capt. Richard, I7

Symson (Symon), Alexander, I5I ; letter to, I 58

Taggart, William, deposition, 25

Talbot, Sharington, letter, $25^{\circ}$

Tallow, trade, 234

Taxes, see Customs; Excise; "control over finances" under Assemblies; islands by name

Taylor, Richard, deposition, I2

Taylor, William, case, 28, 30; memorial, 30

Taylor's Laws, 340

Tea, smuggling, I4I

Temple, Sir John, 58

Tenant (Tennent), - $, 262,263$

Tenier,,- 263

Thomas, Gov. George, commission and instructions, 276; dispute, 243; letters, 246, 247, 255, 256,276 ; letters to, 256,276

Thomas, 36

Thomas and Waddle, r9

Thompson, Benjamin, letter to, I03

Thompson, Pres. Robert, letter, 267

Thornton, Edward, I08; letters, 200-202

Three Friends, 374

Three Sisters, 23I, 271

Thurston, John, letter, 209; letter to, 209

Thynne, Thomas, see Weymouth

Till, James; letter, I I I

Tinker, Gov. John, commission and instructions, 4I ; letters, I7n., I 8, I9, 24, I86; letters to, $24,41,186$

Tithes, 16, 23, 4 I

Tobacco, as standard of value, 324 ; Bermuda and, 89, 90, 95, 344-346; smuggling, I $4 \mathrm{I}$; war-time trade, 292

Tobago, acts, 309; and Barbados, 70, 74; archives at London: correspondence, 306-308; entry-books, I57, 308, 309; archives on island, character and condition, 405; assembly, I36; capture, 397; chancery, I 45; church, I 38, I45, I49; claims, neutralization, 46, 48-51, 53-55, 57-59, 61, 62, 73, $249,250,252-254,298,306$; conditions, 58 , I 37, I 42, I 46, I47, I 49, I 5I, 306; council, I 38, I45, I56, 358; Courland's offer to sell, $7 \mathrm{I}$; currency, 405; customs, I38, I 45; defense, I 35, I39, I4I, I 44-I 47, I 49, I 52, 306, 359; distress, sugar-cane pest, I49; economic history, 405; French in, I46; government, separate, I36, I37, I44, I 56; governors, instructions, 3I 7 grant, 48, 49, 7 I, I 42, I44; in Leeward Islands, 25I ; land, acreage, system, I37, I 40, I43, I46, I 47, I 55; log-wood cutting, 58,6I ; military power in, I 46; negro insurrections, $56,63,146,148$; occupation, I4I, I 42; offices, 306 ; papers on,
47; population, I46, I47; possession, v; privateer foray, I 53; produce statistics, I46, I 47; sessional papers, I 45, 307-310, 358, 405; settlement, $47,62,70,135$, I 36,142 , 306; shipping returns, 308, 3 I0; slavery, 405; trade, neutral, violations, I $47,306-308,405$; turtle fishing, 59; white fatality, I42; see also West Indies; Windward Islands

Tobago Gazette, 306

Tonnage, 74, 90, I I i defense levy, 325; see also "customs" under islands by name

Tonyn, Gov. Patrick, letter, I 97

Tortoise shell trade, 387

Tortola, affairs, 232; government, 274; population, 233, 234; settlement, 233; trade, 268, 269; treasure trove, 245, 254; see also Virgin Islands

Tortuga, Spanish seizures at, 96, Ioo

Tothill, Thomas, 390

Toussaint L'Ouverture, Pierre Dominique, letters to, 305; trade negotiations, I99-203, $217,305,379$

Townshend, $\frac{379}{}$, letter, I 4

Townshend, Charles, 2d viscount, letter, I84; letters to, $46,70,250,306$

Townshend, Thomas, see Sydney

Townshend, Thomas, narrative, I 50

Trade, by British navy, I00, I60, I63, I 83, I 84, 209; South American (1824), 350; West Indian statistics, 3I3, 3I4; see also Acts of trade; Admiralty; Canada; Convoys; Customs; Embargo; Neutral trade; Non-residents; Privateers; Shipping; Slave trade; United States; products by name

Trade with the enemy, see wars by name

Traill, Robert, 342n; letters, 98, 104

Treason, 56, I 25, I 83

Treasure ships, plundering of wrecked, I 84, I 85 , $245,254,276$

Treasure trove, I $7,245,254$

Treasurer, appointment, 46, I43, I 48, I 81; see also "public accounts" under islands by name

Trelawney, Gov. Edward, commission and instructions, 2I3; letters, I70-I72, I85-I 87; letters to, I86, 21 3, 2 I 4

Trelawney, Gov. William, commission and instructions, 216; death and popularity, I93; letters, I80, I90-192; letters to, I90-I93

Trelawney Parish, Jamaica, records, 364

Triennial act, 2 I 3

Trigge, Gen. Thomas, correspondence, I4I

Trinidad, agents, 3I I; American negroes, 3I2; American surgeon, 312 ; archives at London: correspondence, 3IO-3I2; entry books, 3I2; archives on island, character and condition, 405, 406; commission for government, 3IO; conditions, I 45; customs, 3 IO; during War of I8I2, 3II, 3I2, 406; foreigners, 3II ; immigration, 3IO; Loyalists, 3IO; neutral trade, 3 II ; possession, $v$; sessional papers, 3IO; shipping reports, 3IO, 3 I I ; slave trade, 305

Trinity College, Dublin, and college for Bermuda, 89, 97, 98, I 12

Trott, Nicholas, memorial, I3

Trumbull, John, 3 I

Tryon, Rowland, memorial, 27 I 
Tryon, Gov. William, petition to, 192

Tucker, Benjamin, I77

Tucker, Henry, agent, and records, 34I ; letters, 94, 103, 109; memorial, 98

Tucker, James, I Io

Tucker, Richard, 97

Tuckett, William, letter, 256

Tudor, William, 269

Tufts, Peter, deposition, 322

Turks Islands, agent, 20; and American Revolution, 32; Bahamas and Bermuda and, 17,19 , 25-29, 42, 90, 91, 97, 100, 102; claims, 18-20, 25, 42; description, 19; disorders, 28, 29, embargo, 37; French raids, 99, 100, 188; fugitive slaves, 25, 27; importance and conditions, 25-27, 29; impositions at, 102; misgovernment, 27-29; papers on, 314; pirates, 87; salt-making, trade, violations, $20,25-27,29,33,34,37-39,90,96,100-102$, 191, 218, 268; Spanish depredations, 94, 98; wrecking, IOI

Turtles, fishing, 59, 93

Two Brothers, 374

Tyler, J., letters, 389

Tyrrell, Sir John, I5

Tyrrell, Adm. Richard, correspondence, 256

United States, and British West Indies, iv, 2; and Santo Domingo under blacks, 199-204, 217 , 305, 379; as foreign, 265; Chinese and East Indian trade, 311 ; dissentions, 106, 266; hostility (1808), 308; see also Acts of trade; Colonies; Indians; Navy; Neutral trade; wars by name

Uring, Nathaniel, 235, 249

Ury, - - letter to, 21 I

Ushant, 374

Values, in terms of produce, 324

Van Bibber, Abraham, 262

Van Norden, John, map, 34I

Vandeño, Capt., see Fandiño

Varenne, Marquis de 1a, 232

Vaughan, David, 344

Vaughan, John, lord, commission and instructions, 388 ; letters, 388

Vaughan, Sir John, 251; letters, 283, 315, 316; letter to, 315

Veillon, French warship, 305

Venezuela, Miranda, I2 I

Vera Cruz, Asiento agents, r86; letter to governor, 192; plan against, 192

Verchild, Pres. James, letters, 248, 256, 277

Vere, Mrs. - memorial, I4

Vere Parish, Jamaica, records, 364

Vernon, Adm. Edward, expedition, $186,252,253$; letters, 182, 393; quarrel, 186; seizure by, I 82 ; testimonial, 23

Vernon, James, letter, 50

Vernon, 322

Vickers, John, deposition, 21

Viper, H. M. S., I 77

Virgin Islands, acts, 312; affairs, 231-234, 236, $240,241,243,246,249,259,260,271,273$; archives at London, correspondence, 312 ; assembly, 249, 259; claims, 236, 245, 252; court; 238 ; customs, 259 ; defense, 247 ; dur- ing Spanish War (1740), 252; fugitive slaves, 246; government, 241, 251, 275, 276; grant, 230; land, 242; loyalty, 261; negro insurrection, 242; population, 232, 247; report, 232; sessional papers, 268, 289, 312 ; settlement, 259; Spanish wreck, 252; see also Danish West Indies; Leeward Islands; islands by name

Virgin Queen, 91

Virginia, Beverley's voyage, 163; complaints against governors, 236 ; pirates, 163 ; powder duty, 170

Vital records, see islands by name

Votes of the Assembly of Bahama Islands, 36, 44

Votes of the Assembly of Grenada, 143, 153, 158

Votes of the Assembly of Jamaica, 381

Wager, Sir Charles, 15

Waldegrave, James, Ist earl, 54, 73; hetter, 242; letters to, 298, 315

Walden, William, 322

Walker, George, agent, 63; memorials, 63, 65

Walker, Adm. (Sir) Hovenden, I61, 209

Walpole, Edward, proposal, 23

Walpole, Horatio, letter, 246; letter to, 70

Walpole, Sir Robert, letters to, 23, 57

Walton, John, petition, 230

War of 1812 , blockade, I1 ; British Guiana and, 121, 122; British detention order, 349; British sale of American slaves, 40, I I I, I 12 , 2 I 7 ; causes, 68 , 349; convoys, 318,349 ; defensive measures in islands, 39, 395; Jamaica, 207,208 ; naval fight, 68 ; news of declaration, 39 , III, 316; passports, 217 ; peace and resumption of trade, 39, III, I15, 122, 123, $133,155,208,218,270,304,308,312,346$, 353,360 ; prisoners of war, 40, 217, 270; privateers, 39, 121, 122, 217, 270, 316, 339; prizes, seizures in port, 39, 68, 121, 207, 208, $217,218,269,270,297,303,311,326,327$; seduction of British sailors, 217; southern Indians, aid, 39; specie from United States, I I I t trade during, 68, I I I 270, $316,327,349$, $353,358,360,406$

Ward, Artemas, letter to, 260

Warren, Thomas, 48

Warwick, H. M. S., 255

Washington, George, 31, 140; letter to, 260

Wasp, U. S. S., 30

Waterlow and Sons, 120

Watson, Sir Francis, 388

Watts, Dr. Edward, letter to, 260

Wayland, William, $143,157,158$

Weekes, Nathaniel, petitions, 85

Weekes, Pres. Ralph, letters, $55,6 \mathrm{I}$; letters to, $6 \mathrm{I}$

Weekly Jamaica Courant, 164, 184

Weltden, Anthony, correspondence, 24

Wendell, John, letter to, 260

Wentworth, Lt.-Gov. (Sir) John, letter, 403

Wentworth, Gen. Thomas, 186; instructions, 315

Wescomb, Daniel, letters, 163, 166

West, Richard, correspondence, 48,70 ; opinions and reports, $46,48,88,165,233,235,240$, 244,272

West Florida, in American Revolution, 195, 196

West India Committee, papers, 318,319

West India Merchants, minutes, 313, 318, 319 
West Indies, British, and continental America, iv, 2; archives at London: correspondence of Board of Trade, 313, 314; correspondence of Secretary of State, 314-316; entry-books, 316, 317; charges on English trade, 349; chronology of possession, v; conditions, depression, 314, 319; courts, 316; currency, 316 ; disorders, 16I; fear of negro insurrections, 3I4; land titles, 316 ; letters of marque, 315; military and naval papers, 314-317; negotiations on, 315 ; property, 313; quitrents, 314; slave trade, 314, 315; see also Archives; Army; Communication; Danish; Dutch; French; Navy; Spanish; Trade; islands and wars by name

Westmorland Parish, Jamaica, records, 364

Weston, Edward, letter, I 40

Weymouth, Thomas Thynne, $3 d$ viscount, letters, I 45,146

Whaling, American, 301; Bahamas, 12; see also under Bermuda

Whipple, Capt. Abraham, 30

Whitcomb, Thomas, 217

White, Capt. —, executed, 255

White, Capt.

White, Michael, correspondence, 258

White, Robert, letters, 123

White servants, from Ireland, convicts, 102; Leeward Islands act, 235; see also under Jamaica

Whitfield, - at Santo Domingo, 202

Whitmore, Gen. William, 99

Whittingham, Gov. (Sir) Samuel Ford, letter to, 349

Whitworth, Francis, 60

Whole Proceedings of Captain Dennis's Expedition, 164

Wild Cat, 374

Wilkinson, James, letter, 205

William, 89, 322

Williamson, Lt.-Gov. Adam, letters, 198

Willing and Francis, letter, 323

Willing and Morris, 26r

Wills, see Probate

Wilmot, Henry, agent, complaint, 247 ; letter, 394

Winchelsea, H. M. S., 232

Windward (Caribbee) Islands, assembly, 136; contingent charges, 137; force, 140, 150, 151; general council, minutes, 143, 156,
358; government, 135-137; governor's salary, I42; lumber trade, I22; see also islands by name

Windward Passage, pirates, 163

Wine, Bermuda, 92, 98, 114

Winiet, - at Grenada, 139, 150

Witter, Norwood, 215

Wolmer, John, 387

Wolmer's Free School, 387

Wood, Gov. Alexander, letters, 297

Wood, Robert, letter, 247

Wood, Gov. Roger, letter-book, 345; will, 342

Wood, William, letter, 169; letters to, 57, 114, 275

Wood, Zachariah, letter, 34

Wood, in Bermuda, 94, 95; tithe, 16; see also Logwood; Lumber

Woodford, Sir Ralph, 406; letters, 312

Woodley, Lt.-Gov. William, commission and instructions, 277; letters, 122, 248, 257, 258, 277; letters to, 257

Woodley, Pres. William, letter, 269

Worsley, Gov. Henry, commission and instructions, 70,71 ; complaints against, 49, 57; hearing before, 47 ; letters, 47-50, 59, 60, 250 ; letters to, $60,70,71$; orders to, 250 ; salary controversy, 49-52, 57, 60, 71, 72

Wright, James M., Bahama Islands, 329n.; aid to present volume, vi, 329n.

Wright, Miss Irene A., 381

Writs and forms, 342

Wyndham, Charles, see Egremont

Yeamans, John, agent, 239, 243, 252; letter to, 253; memorials, 238-24I

Yonge, Sir William, letter to, 16

Yorke, Sir Philip, solicitor general, opinions, 46 , 252

Young, Adm. James, correspondence, 64, 337

Young, Sir (Gov., Lt.-Gov.) William, and land grants, 139, 140; commission, 133; letters, 125, 139, 150, 151, 306, 308; letters to, 133. I50, 151

Young Cezar, 31

Yucatan, trade, 387

Zubiaur, Joseph de, 9

Zuylestein, William Henry, see Rochford 


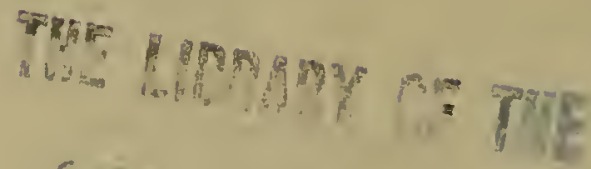 CLT 191932}

WWHESTIY of ILWOIS 


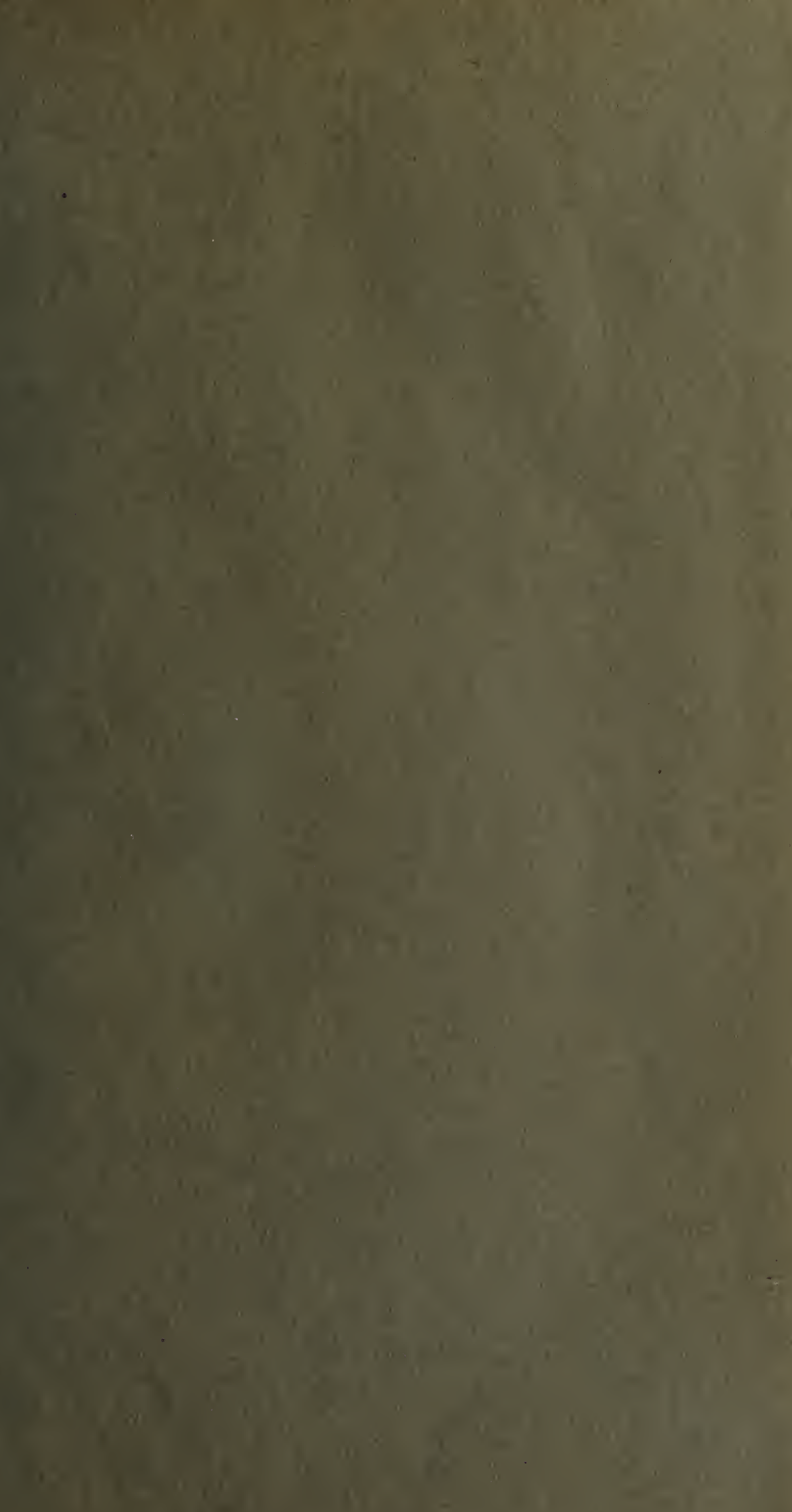



in

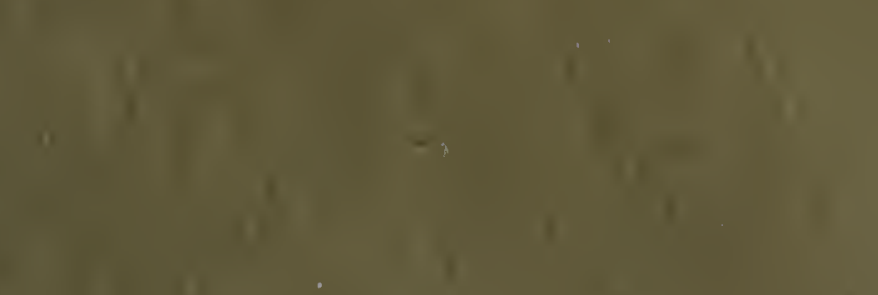

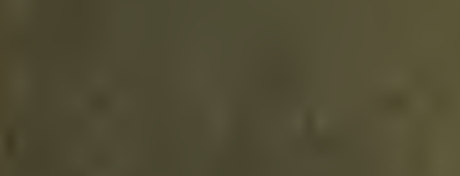

i 120
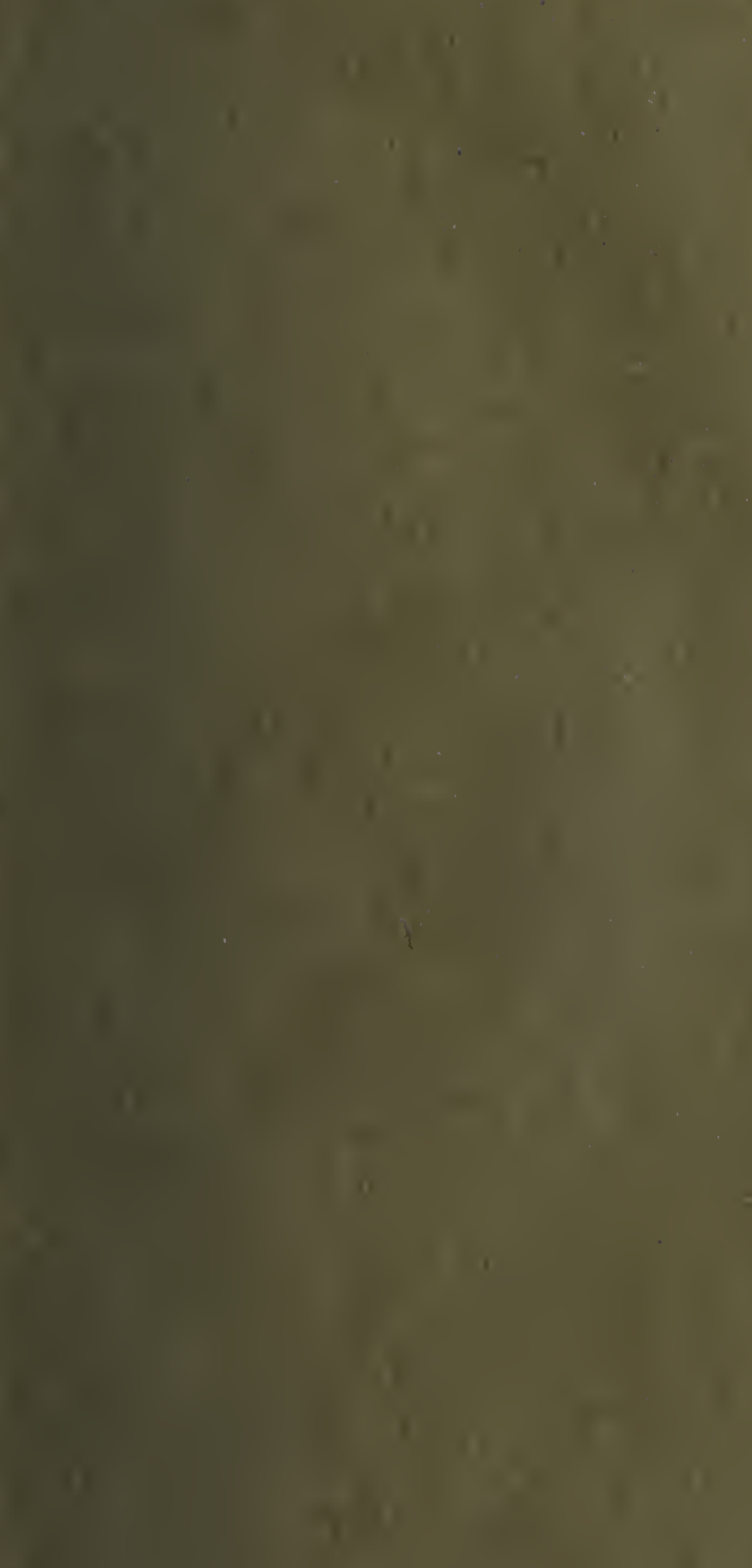


